UNIVERSIDADE DE SÃO PAULO

FACULDADE DE DIREITO

PROGRAMA DE PÓS-GRADUAÇ̃̃O EM DIREITO

ÁREA DE FILOSOFIA E TEORIA GERAL DO DIREITO

LEONARDO GOMES PENTEADO ROSA

\title{
O LIBERALISMO IGUALITÁRIO DE RONALD DWORKIN: O CASO DA LIBERDADE DE EXPRESSÃO
}

\author{
DISSERTAÇÃO DE MESTRADO \\ PROFESSOR ORIENTADOR: PROFESSOR ASSOCIADO RONALDO PORTO MACEDO \\ JUNIOR
}

FACULDADE DE DIREITO DA UNIVERSIDADE DE SÃO PAULO

SÃO PAULO

2014 
LEONARDO GOMES PENTEADO ROSA

\section{O LIBERALISMO IGUALITÁRIO DE RONALD DWORKIN: O CASO DA LIBERDADE DE EXPRESSÃO}

Dissertação apresentada à Faculdade de Direito da Universidade de São Paulo, Programa de Pós-Graduação em Direito, como requisito parcial para obtenção do título de mestre em Direito

Área de Concentração: Filosofia e Teoria Geral do Direito

Orientador: professor Associado Ronaldo Porto Macedo Junior 
ROSA, Leonardo Gomes Penteado. O liberalismo igualitário de Ronald Dworkin: o caso da liberdade de expressão. 254f, 2014. Dissertação apresentada à Faculdade de Direito da Universidade de São Paulo, área de Filosofia e Teoria Geral do Direito, como requisito parcial para obtenção do título de mestre em Direito.

Aprovado em:

Banca Examinadora.

Presidente: Prof. Dr. Associado Ronaldo Porto Macedo Junior (orientador)

Instituição: Departamento de Filosofia e Teoria Geral do Direito da Faculdade de Direito da Universidade de São Paulo

Julgamento:

Assinatura:

Membro(a): Prof.(a) Dr.(a)

Instituição:

Julgamento:

Assinatura:

Membro(a): Prof.(a) Dr.(a)

Instituição:

Julgamento:

Assinatura: 


\section{AGRADECIMENTOS}

Ao professor Ronaldo Porto Macedo Junior, meu orientador, pelas oportunidades, pelos anos de dedicação à minha pesquisa e à minha formação e pelas lições prestadas - pelas que creio ter absorvido mas também pelas que eu ainda não soube incorporar.

Ao professor Samuel Rodrigues Barbosa, pelo encorajamento e abertura. Ao professor José Reinaldo de Lima Lopes, pela sinceridade e pelas críticas.

À minha mãe, Maria Antonieta, pelo amor, cuidado e pela cultura ofertada.

Ao meu pai, Francisco, pelo carinho, pelo apoio e por me fazer corinthiano.

Ao meu irmão, Pedro, pelo exemplo e amizade.

Às minhas avós Adelina (in memoriam) e Maria, por terem sabido fazer sozinhas.

Às minhas tias Alice, Eva e Maria, pelo afeto e pela presença.

Ao Felipe, pela amizade engolidora de décadas.

À Luciana, pela amizade paciente e perseverante.

À Tamara, pelas lições sobre o significado e valor das coisas.

Ao Yuri, pelas lições de humildade e de coragem.

Ao Guilherme, que me ajuda.

Aos meus novos amigos Pablo e Danilo agradeço pela companhia neste período de pós-graduação. Em especial, agradeço ao Danilo pelo exemplo de batalhador da vocação e ao Pablo pelo exemplo de resiliência frente às dificuldades da vida e do trabalho.

À Renata, minha parceira de apequenamento do mundo, agradeço pelo amor, pelo aconchego e pela casa.

Agradeço à Renata do Vale Elias, à Luciana Silva Reis, ao Pablo Antonio Lago, ao Yuri Corrêa da Luz e ao Arthur Péricles pelas discussões e conversas sobre os temas desta 
dissertação e sobre muitos outros. À Renata agradeço ainda pela leitura e pelas sugestões sobre como corrigir erros do meu trabalho e sobre como formatá-lo.

Agradeço aos funcionários e às funcionárias que trabalham na Universidade de São Paulo, em especial às senhoras Ana Lima Batista e Beatriz dos Santos, da secretaria do Departamento de Filosofia e Teoria Geral do Direito da Faculdade de Direito, pelo esforço na organização e condução dos afazeres indispensáveis ao ambiente onde, já há quase uma década, tenho a oportunidade e privilégio de estudar.

À Fundação de Amparo à Pesquisa do Estado de São Paulo (FAPESP) agradeço pelo apoio por meio de financiamento na modalidade de bolsa de mestrado concedido à realização desta pesquisa. Agradeço também pelo financiamento anterior, em nível de iniciação científica, e sem o qual este trabalho seria muito inferior.

Este trabalho foi concebido muito aos poucos ao longo de bastante tempo. Gostaria de agradecer, pela influência e encorajamento, desde estágios bastante precoces, anteriores ao fim da minha graduação, ao Caio Moysés de Lima, ao Paul Yowell, e aos participantes do grupo de estudos do professor Ronaldo nos primeiros semestres de 2010 e de 2011 (leituras, respectivamente, de capítulos de Sovereign Virtue e de Taking Rights Seriously, ambos de Dworkin) e do curso do professor na Pós-Graduação da FDUSP (leituras de Justice for Hedgehogs, também de Dworkin). 
"Quero inventar o meu próprio pecado (Cale-se!) Quero morrer do meu próprio veneno (Cale-se!)" Chico Buarque e Gilberto Gil, Cálice. 


\section{Resumo em Português}

ROSA, Leonardo Gomes Penteado. O liberalismo igualitário de Ronald Dworkin: o caso da liberdade de expressão. Dissertação. Universidade de São Paulo, Faculdade de Direito, 2014, $254 f$.

Esta dissertação é dedicada à interpretação do direito à liberdade de expressão disponível na obra do filósofo Ronald Dworkin. No primeiro capítulo, abordo o sentido em que o autor fala de direitos, o significado das liberdades no seu pensamento, e o esforço por ele feito de integrá-las à sua concepção de justiça distributiva, a saber, a igualdade de recursos. O capítulo segundo é dedicado a aspecto importante da teoria do autor: a continuidade entre ética e moral, em especial à sua teoria da dignidade, seja na forma do que chama de "modelo do desafio", seja na forma de dois princípios (do respeito-próprio e da autenticidade). Ele também explora consequências da teoria ética de Dworkin às liberdades e a integração entre ela e o valor da igualdade. O terceiro capítulo, então, é dedicado mais diretamente ao direito à liberdade de expressão como Dworkin o concebe: integrado à justiça distributiva e fundamentado no que chama de "independência ética" e na autenticidade que marca a igualdade de recursos, bem como a uma concepção de democracia, de que fazem parte, a depender da terminologia que adota em diferentes trabalhos, "agência", e os princípios ou dimensões da sua concepção de democracia como parceria. Também faz parte do terceiro capítulo discussão de casos concretos, em que a generosidade de Dworkin em relação ao direito objeto da dissertação se evidencia. Discuto por que Dworkin inclui na liberdade de expressão o discurso de ódios e pornografia- mas também por que, justamente pelo seu fundamento na dignidade do emissor, não inclui a liberdade de imprensa, a liberdade acadêmica, e os atos de expressão por empresas. A conclusão da dissertação é dedicada às suas ideias de "cultura de liberdade" e de "cultura de independência".

Palavras-Chave: 1. Ronald Dworkin. 2. Liberdade de expressão. 3. Igualdade. 4. Democracia. 5. Ética. 6. Dignidade. 7. Liberalismo. 


\begin{abstract}
ROSA, Leonardo Gomes Penteado. The egalitarian liberalism of Ronald Dworkin: the case of freedom of speech. Dissertation. University of São Paulo, Faculty of Law: 2014, 254f.

This dissertation is dedicated to the interpretation of the right to free speech available in the work of philosopher Ronald Dworkin. In the first chapter, I dwell with the sense in which the author speaks of rights, with the meaning of liberties in his thought, and his effort to integrate them to his conception of distributive justice, namely, equality of resources. The second chapter is dedicated to an important aspect of the author's theory: the continuity between ethics and morals, especially his theory of dignity, either in the form o what he calls "the model of challenge" or in the form of two principles (of self-respect and authenticity). It also explores the consequences of Dworkin's ethical theory to the liberties and integration between it and the value of equality. Then, the third chapter is dedicated more directly to the right of free speech as Dworkin conceives it: integrated to distributive justice and founded in what he calls "ethical independence" and in the authenticity that marks equality of resources, as well as in a conception of democracy, formed, depending on the terminology he adopts at different works, "agency" and the principles or dimensions of his partnership conception of democracy. It is also part of the third chapter discussion of concrete cases, where Dworkin's generosity towards the right which is the object of the dissertation makes itself evident. I discuss why Dworkin includes in free speech hate speech and pornography - but also why, precisely because of its foundation in the dignity of the speaker, does not include freedom of the press, academic freedom and expressive acts by companies. The conclusion of the dissertation is dedicated to his ideas of "culture of liberty" and "culture of independence".
\end{abstract}

Keywords: 1. Ronald Dworkin. 2. Freedom of Speech. 3. Equality. 4. Democracy. 5. Ethics. 6. Dignity. 7. Liberalism. 


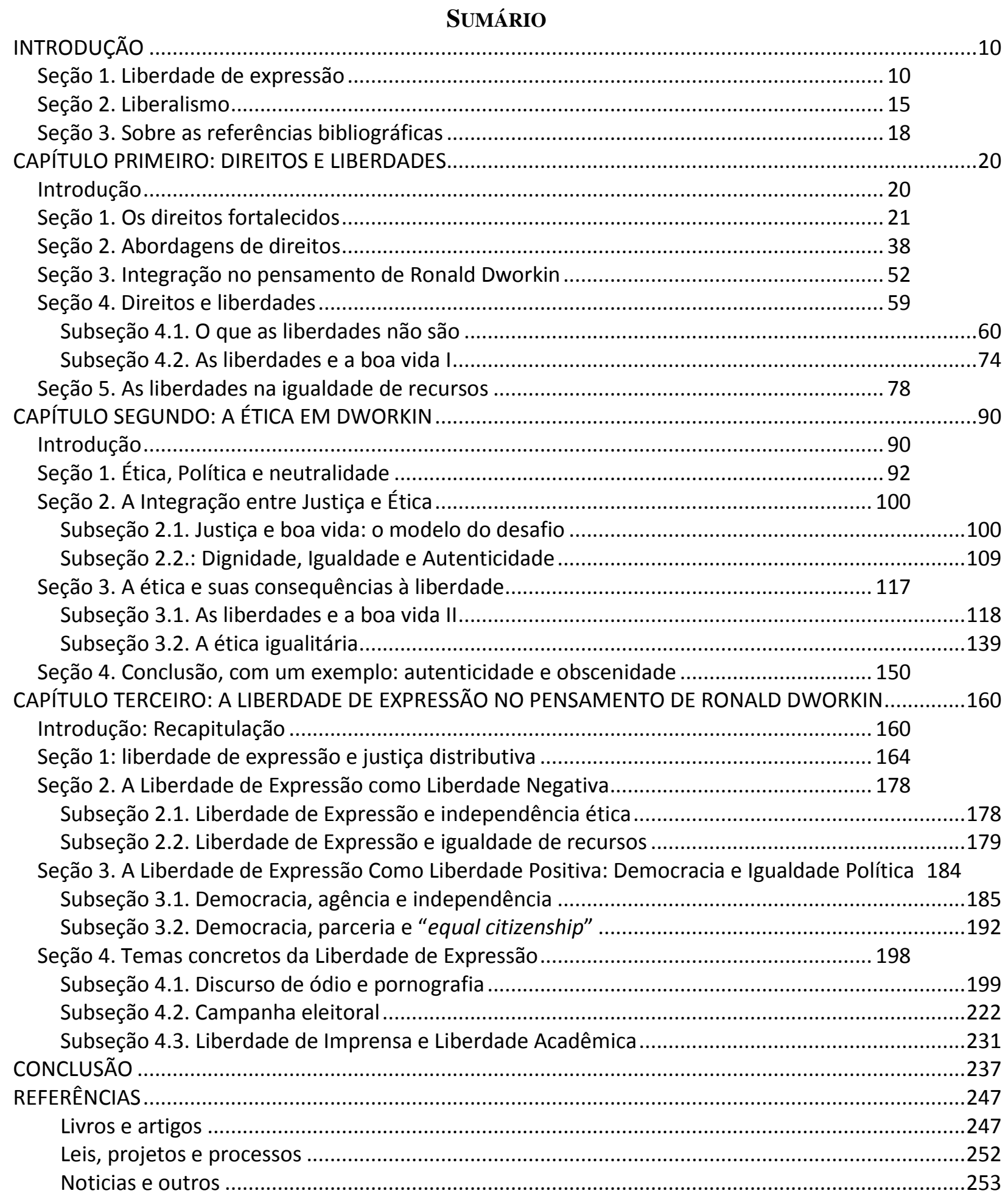




\section{INTRODUÇÃO}

\section{Seção 1. Liberdade de expressão}

A liberdade de expressão é daqueles conceitos políticos de tratamento oscilante na política contemporânea. Ora celebrada, ora limitada de maneira mais ou menos responsável, é direito que não escapa à atenção nem de cientistas e filósofos políticos, nem de jornalistas, leitores de jornais e tampouco, é claro, de juristas. Esta dissertação é dedicada à liberdade de expressão e aposta na cogência da interpretação deste direito na obra do filósofo Ronald Dworkin.

Dworkin escreveu extensamente sobre o tema e, de fato, liberdade de expressão é provavelmente o direito mais discutido pelo autor. Se é verdade que ele escreveu inúmeros trabalhos sobre ação afirmativa e aborto, é a liberdade de expressão o seu exemplo preferido na exposição de aspecto importantíssimo de seu pensamento sobre polêmicas envolvendo direitos: a noção de direitos no sentido forte. Portanto, e em primeiro lugar, isto significa que o leitor encontra a liberdade de expressão na obra de Dworkin mesmo quando o texto não é dedicado especificamente ao tema.

Em segundo lugar, Dworkin interveio, sobretudo nos EUA, em diversos debates sobre liberdade de expressão próprios (ainda que não exclusivamente) do nosso tempo: posicionouse contra a proibição do discurso de ódio, inclusive negacionista do Holocausto, e de certas formas de pornografia, procurou entender o que significam a liberdade de expressão e a liberdade de imprensa de modo a oferecer solução a casos envolvendo privilégios da mídia, bem como criticou fortemente o caminho que a seu ver a Suprema Corte dos EUA toma ao restringir limites de doações a campanhas eleitorais a partir de interpretação das demandas da Primeira Emenda à Constituição dos EUA (que, entre outros, garante a liberdade de expressão).

Mas se ao leitor está disponível muito material escrito por Dworkin sobre liberdade de expressão, é também verdade que nem sempre é evidente como as diferentes partes deste conjunto de escritos se articulam entre si. Por exemplo, o princípio da autenticidade que, como trabalhado abaixo no capítulo primeiro, faz parte da linha de base do leilão imaginário que Dworkin elabora ao defender a sua teoria da justiça distributiva, oferece um argumento a favor da ideia de que uma sociedade igualitária respeita a liberdade de expressão. Mas é possível 
perguntar como a liberdade de expressão assim defendida se relaciona com este direito concebido como próprio da independência que, segundo Dworkin, os cidadãos guardam em relação ao Estado num regime democrático. Em outras palavras, Dworkin defende o direito à liberdade de expressão ao discutir diferentes aspectos da sua teoria política - no caso, justiça distributiva e democracia - e cabe ao leitor tentar articulá-las.

É claro que, dentre os trabalhos de Dworkin, Justice for Hedgehogs ${ }^{1}$, livro publicado em 2011, tem justamente esta função de articulação da imensa produção intelectual do autor, e nesta dissertação procuro seguir o modo que Dworkin encontrou para unir os diferentes aspectos do seu pensamento. Mas há mais sobre liberdade de expressão na sua obra do que explicitado neste livro recente, e pretendo neste trabalho identificar e articular as reflexões do autor, inclusive aquelas disponíveis somente em outros pontos de sua produção. Se uma metáfora espacial me é permitida, podemos entender os diferentes trabalhos de Dworkin como diversos prédios geminados, consistindo o esforço desta dissertação na descoberta e ocasional construção de passagens entre eles em diferentes andares, mas sempre em vias de mão dupla.

Esta dissertação é dividida em três capítulos. O primeiro introduz a questão dos direitos/liberdades na obra de Ronald Dworkin e, ao explorar de que modo o autor justifica as liberdades, procura discutir qual o valor servido pela autorização da prática de condutas que, por hipótese, prejudicam o interesse coletivo, como é o caso do discurso de ódio, da pornografia pesada e outros tipos de discurso detestável que caracterizam casos talvez questionáveis de exercício da liberdade de expressão. Em Dworkin, esta pergunta convida a compreensão do sentido das liberdades concebidas como "direitos no sentido forte". O capítulo serve, portanto, de introdução à análise do tema à luz do direito à liberdade de expressão na obra de Ronald Dworkin, objeto da dissertação. Já o objetivo do segundo capítulo é de, após apresentar no capítulo anterior que tipo de justificação das liberdades Dworkin entende adequada, explorar qual justificação deste tipo é apresentada pelo autor aos direitos, especialmente à liberdade de expressão. Assim, se no primeiro capítulo indicou-se que as liberdades em Dworkin se integram à ética, agora se analisa a ética de Dworkin, isto é, a concepção de bem apresentada pelo autor e a partir da qual se constrói justificação de direitos, como o direito à liberdade de expressão.

\footnotetext{
${ }^{1}$ Dworkin. Justice for Hedgehogs, London/Cambridge: The Belknap Press of Harvard University Press, 2011.
} 
O terceiro capítulo, por sua vez, é o capítulo central da dissertação, em que apresento de maneira mais acabada e articulada a justificação da liberdade de expressão elaborada por Ronald Dworkin, a saber, uma justificação da liberdade de expressão enquanto direito exigido pela igualdade e pela democracia lidas a partir de uma teoria ética. É crucial que se compreendam as especificidades desta concepção para que se compreenda a defesa oferecida pelo autor à ampla liberdade de expressão concebida enquanto um direito. Ainda neste capítulo, discuto casos concretos e elaboro os argumentos oferecidos pelo autor às soluções que defende. Ao contrário do que alguns críticos parecem supor, Dworkin admite restrições a direitos - discuto algumas delas no último capítulo. É de se imaginar que inúmeras políticas públicas defendidas nestas questões sejam aceitáveis a partir da teoria da liberdade de expressão de Dworkin, o que certamente torna a concepção deste direito defendida pelo autor mais palatável aos leitores contemporâneos sem que caia ela nas armadilhas conceituais comumente empregadas para defender regulamentações de certos tipos de discurso. Em especial, o capítulo terceiro é oportunidade para explorar as consequências à liberdade de expressão do esforço do autor de integrar liberdades à boa vida e à justiça distributiva enquanto igualdade de recursos. Por outro lado, a intepretação dworkiniana da liberdade de expressão fornece crítica bem acabada e a meu ver convincente a proibições inaceitáveis à liberdade de expressão, entre elas vedações baseadas no conteúdo de certas manifestações ditas violadoras da igualdade e da dignidade. As concepções dworkinianas destes conceitos políticos se comprometem com (e o autor efetivamente desenvolve) argumento convincente contras estas vedações, que cada vez mais fazem escola no direito brasileiro, contando com importante apoio da academia ${ }^{2}$ e da jurisprudência. Temos aqui, portanto, a oportunidade de

\footnotetext{
${ }^{2}$ Entre nós, não são poucos os trabalhos recentes sobre liberdade de expressão. Veja, por exemplo, Alex Lobato Potiguar, Igualdade e Liberdade: a luta pelo reconhecimento da igualdade como direito à diferença no discurso de ódio. 155f. Dissertação de Mestrado, Faculdade de Direito, Universidade de Brasília. Orientador: Alexandre Bernardino Costa. Brasília, 2009.; Samantha Ribeiro Meyer-Pflug. Liberdade de expressão e discurso de ódio. Prefácio de Ives Gandra da Silva Martins e apresentação de Ney Prado. São Paulo: Editora Revista dos Tribunais, 2009 e José Emílio Medauar Ommati. Liberdade de Expressão e discurso de ódio na Constituição de 1988. Editora Lumen Juris: Rio de Janeiro, 2012. Em especial, Dworkin figura no trabalho de Potiguar pela sua ideia de "integridade". Ommati também apresenta como sua referência teórica o direito como integridade de Dworkin (p. 43 e cap. 3; veja ainda p. xii, para menção a Meyer-Pflug como autora que adota o mesmo marco mas com conclusões distintas, criticadas por Ommati). Ommati discute ainda diversos aspectos do pensamento do autor, entre eles a igualdade, sua integração com a liberdade, sua concepção de democracia como parceria, sua crítica ao "balancing" de direitos e a sua defesa do direito ao discurso de ódio, aspecto que Ommati, em crítica a MeyerPflug, julga incompatível com a integridade aplicada ao direito brasileiro (esp. pp. 96-103, embora deixe claro que é contra qualquer restrição prévia à emissão do discurso). Ao que parece, portanto, Meyer-Pflug não compartilha da defesa comum da proibição do discurso de ódio (veja relato de Ives Gandra no "Prefácio", pp. 12-
} 
observar no detalhe tema relevante ao Brasil e que mereceu bastante atenção de Dworkin, mas que recebeu do autor solução fundamentalmente distinta da adotada por nós, ainda que nem todas as soluções concretas encontradas no direito brasileiro doestoem das disponíveis na obra dworkiniana.

É possível afirmar que o liberalismo igualitário de Dworkin, em suas diferentes formulações, tem oferecido defesa generosa da liberdade de expressão. A defesa é deste tipo por um motivo e em dois sentidos. O motivo é que Dworkin se concentra na liberdade de expressão enquanto direito, e não enquanto instituição política capaz de gerar benefícios gerais, por exemplo, capaz de aprimorar nossas práticas democráticas ${ }^{3}$ (isso não significa que, para Dworkin, a liberdade de expressão como instituição pública presente nos regimes políticos contemporâneos seja exclusivamente uma questão de direito individual ${ }^{4}$ ). Como veremos no primeiro capítulo, liberdades, para autor, são direitos, isto é, questão de princípio. O primeiro sentido é o de que, por se fundar num direito, é de difícil exceção, pois a consideração que aponta para que não se preserve determinada liberdade deve ser também um direito $^{5}$. O segundo sentido é de que a liberdade de expressão em Dworkin se estende a práticas cuja permissão é controversa nas democracias ocidentais contemporâneas. Para

3 e a posição da autora na p. 264 de seu livro, em especial o parágrafo em que está o trecho citado por Gandra na p. 13) Meu trabalho se concentra na liberdade de expressão como direito moral e não discuto a teoria do direito de Dworkin. Trabalho, entretanto, diversos dos pontos da obra de Dworkin que chamaram a atenção de Ommati, mas tiro outra conclusão. Também faço menor seleção de questões concretas do que a feita por Meyer-Pflug, cujo trabalho é tematicamente bastante abrangente. Não é meu objetivo resenhar a bibliografia brasileira sobre liberdade de expressão e sobre Dworkin, mas vale perceber que meu trabalho se ocupa de tema e autor contemporâneos que têm merecido bastante atenção da academia nacional.

${ }^{3}$ Dworkin, "The Place of Liberty" in Sovereign Virtue, Sovereign Virtue: The Theory and Practice of Equality, Cambridge/London: 2001; Dworkin, "Why Must Speech be Free?" in Freedom's Law, Freedom's law: the moral reading of the American Constitution. Cambridge (Mass.): Harvard University Press, 1996, pp. 199 e ss.; veja ainda Dworkin, "Taking Rights Seriously" in Taking Rights Seriously. London: Gerald Duckworth \& Co. Ltd, 20052005 (terceira impressão), publicado inicialmente em 1977 e Dworkin, "Do We Have a Right to Pornography?" in A Matter of Principle. London/Cambridge(Massachusetts): Harvard University Press, 1985.

${ }^{4}$ Veja Dworkin, "Ronald Dworkin replies" in Frederick F. Schauer, Virginia Held e John L. Hess, "The Rights of M. A. Farber: An Exchange", The New York Review of Books, edição de 7 de dezembro de 1978 e, de Schauer,. "[Sem título]" in Frederick F. Schauer, Virginia Held, and John L. Hess, The Rights of M.A. Farber: An Exchange, reply by Ronald Dworkin, The New York Review of Book, edição de 7 de dezembro de 1978.

${ }^{5}$ Dworkin, "Taking Rights Seriously" in Taking Rights Seriously, op. cit., por exemplo, e Dworkin, "Why Must Speech be Free?" op. cit., esp. pp. 200 e ss. 
Dworkin, erra-se ao proibir o discurso de ódio ${ }^{6}$, como a negação do holocausto ${ }^{7}$, ou a pornografia $^{8}$.

Tomemos dois exemplos nacionais. Em maio de 2013 dois jornalistas foram condenados por uma charge considerada racista ${ }^{9}$. Ela foi descrita nos seguintes termos:

"O fato consistiu na publicação de charge que, a pretexto de discutir a menoridade penal, apresentava uma mulher afrodescendente em sala de parto e quatro bebês da mesma etnia, com tarjas nos olhos, em retirada do local. Para completar, a ilustração mostrava um médico que, ao telefone, bradava 'Segurança!!! É uma fuga em massa!!!'. ${ }^{10}$

Outro caso que também culminou em condenação criminal, mas que teve mais repercussão, foram as mensagens publicadas no Twitter por uma jovem após a eleição de Dilma Rousseff para a presidência da República em 2010, entre elas “'Nordestisto (sic) não é gente. Faça um favor a SP: mate um nordestino afogado!",11.

A solução que o sistema de persecução penal tem encontrado no direito brasileiro é clara: trata-se de manifestações proibidas. Esta resposta é intuitiva porque atrela a percepção do absurdo das opiniões - a associação entre criminalidade e negritude ${ }^{12}$ e entre desumanidade e procedência regional nordestina - à indisponibilidade de suas manifestações. Por que poder dizer esses absurdos? Em particular, por que poder dizer absurdos que promovem ideias não só incorretas, mas representativas de passado e de presente de discriminação que queremos - ou

\footnotetext{
${ }^{6}$ Dworkin, "Free Speech, Politics, and the Dimensions of Democracy" in Sovereign Virtue, op. cit.

${ }^{7}$ Dworkin, "Addendum: A Compelling Case for Censorship?" em "Pornography and Hate" in Freedom's Law, op. cit. (pp. 223-226).

${ }^{8}$ Dworkin, "Why Must Speech be Free?", "Pornography and Hate", "MacKinnon's Words", os três em Freedom's Law, op. cit.; veja ainda, para discurso de ódio e pornografia, Justice for Hedgehogs, op. cit., cap. 17.

${ }^{9}$ Acórdão na Apelação Criminal N. 2012.016841-9, Lages, TJ/SC, Des. Jorge Schaefer Martins, $4^{\mathrm{a}}$ Câmara Criminal, julgado em 23/05/2013.

${ }^{10}$ TRIBUNAL DE JUSTIÇA DE SANTA CATARINA, "JORNALISTAS SÃO CONDENADOS POR CHARGE QUE INCORRE EM DISCRIMINAÇÃO RACIAL", disponível em http://app.tjsc.jus.br/noticias/listanoticia!viewNoticia.action?cdnoticia=28062, último acesso em 17.12.2013. Veja ainda, da mesma notícia, o seguinte trecho "O chargista foi condenado à pena de dois anos de reclusão, enquanto o editor-chefe, por ter sua atuação considerada como de menor importância, recebeu pena de um ano e quatro meses de reclusão. Ambos foram beneficiados com o regime aberto e a substituição da pena de prisão por restritivas de direitos." Veja, do Conjur, Consultor Jurídico TJ-SC condena jornalistas por racismo em charge, $1^{\circ}$ de junho de 2013, disponível em http://www.conjur.com.br/2013-jun-01/tj-sc-condena-jornalistas-racismocharge-maioridade-penal, último acesso em 04.13.2013.

"Terra, "SP: estudante é condenada por ofensas a nordestinos no Twitter", 17 de maio de 2012, disponível em http://noticias.terra.com.br/brasil/sp-estudante-e-condenada-por-ofensas-a-nordestinos-no-

twitter,133cdc840f0da310VgnCLD200000bbcceb0aRCRD.html, último acesso em 04.12.2013, “(sic)" do original.

${ }^{12}$ Veja Acórdão na Apelação Criminal N. 2012.016841-9, op. cit.: o Relator atribui à acusação a tese, que acata no acórdão, de que a charge é racista porque associa o nascimento de pessoas negras à ocorrência de ilícitos penais. Neste parágrafo, descrevo modo de pensar a meu ver adotado, entre outros, neste julgado.
} 
devemos querer - ver, respectivamente, superado e eliminado? Ainda, em especial às manifestações no Twitter, como permitir discurso que não simplesmente promove ideia discriminatória em abstrato, mas incita a efetivação desta discriminação por meio de subtração de direito tão fundamental quanto o direito à vida? As nossas intuições parecem apontar inequivocadamente para a opção proibitiva porque se trata os dois casos de discursos absurdos que, julga-se, contribuem para a discriminação e a violência, que são sérias violações de direitos humanos. Ainda que por ventura se reconheçam as manifestações como exercício da liberdade de expressão, parecem ser estes casos adequados à restrição desta liberdade frente a outros valores e direitos ${ }^{13}$. Estes casos sequer são "casos difíceis", em que polêmica - às vezes mais, às vezes menos justificadamente - se instaura acerca da solução a ser dada sobre questão jurídica. Parece ser bem simples: ninguém tem direito a dizer essas coisas e a sua proibição, ainda que talvez não a sua criminalização, é perfeitamente adequada.

Esta dissertação é dedicada, entre outros, à busca, no pensamento de Ronald Dworkin, de razões contra estas intuições e conclusões. Não se trata de defesa da moralidade deste tipo de discurso, mas de defesa do direito ao discurso, mesmo ele sendo evidentemente imoral. Como discuto abaixo, temos razões para concordar com Dworkin que o ponto da liberdade de expressão não é saber se o discurso deve ser praticado, mas se há um direito de praticá-lo. Começo, no primeiro capítulo, pela ideia mais fundamental: o que é um direito. Antes, porém, gostaria de fazer alguns breves comentários sobre a literatura em que esta pesquisa se insere.

\section{Seção 2. Liberalismo}

O título desta pesquisa faz referência à defesa, por parte de Dworkin, de um tipo específico de liberalismo. Por "liberalismo igualitário" a literatura de filosofia política contemporânea se refere a autores comprometidos com teses liberais sem descuidar do valor da igualdade. A definição é ampla, talvez desprovida de conteúdo filosófico apreciável. No caso de Dworkin, seu "liberalismo igualitário", expressão comum na literatura dedicada à sua obra, consiste no esforço de defender teses liberais de modo não só compatível com uma teoria da igualdade, mas verdadeiramente derivada da sua concepção de igualdade. Ao que parece,

\footnotetext{
${ }^{13}$ Parece ser esta a opinião acatada pelo Relator no Acórdão na Apelação Criminal N. 2012.016841-9, op. cit.
} 
autores falam em "liberalismo igualitário" (Christopher Wolfe ${ }^{14}$ ) ou "igualitarismo liberal" (Darlei Dall'Agnol) ${ }^{15}$ em razão da defesa que Dworkin faz da sua teoria política nos termos do que chama "igualdade liberal"16 (embora a expressão tenha sido empregada em discussões sobre outros aspectos da teoria do autor, como em trabalhos de Abigail Levin ${ }^{17}$ ).

Talvez não haja, nesta dissertação, nada que justifique a eleição da igualdade como valor político "soberano" em detrimento de outros nas discussões sobre liberdade de expressão, pois embora eu ressalte em diversos pontos a necessidade de compreensão das liberdades no pensamento de Dworkin como parte da justiça distributiva e, portanto, da igualdade, é verdade que para o autor também não se pode prescindir do outro sentido da relação, isto é, não é possível compreender a igualdade sem referência às liberdades. Se me fosse dada a oportunidade, talvez o título deste trabalho fosse outro. Mas é também verdade que, num esforço de integração entre liberdade e igualdade, e entre política e ética, talvez a própria referência de Dworkin à igualdade como "Virtude Soberana" mereça desconfianças,

${ }^{14}$ Christopher Wolfe é um crítico de Dworkin que apresentou ampla revisão das obras de Dworkin em "The Egalitarian Liberalism of Ronald Dworkin" in Christopher Wolfe (Ed.) Liberalism at Crossroads: An Introduction to Contemporary Liberal Political Theory and Its Critics. $2^{\text {nd }}$ Ed. Oxford: Rowman \& Littlefield Publishers, Inc., 2003. Neste artigo, o autor expôe a teoria do direito de Dworkin como expressa em Law's Empire, a teoria ética do autor, desenvolvida em "Foundations of Liberal Equality" (e que exponho amplamente no capítulo segundo desta dissertação), bem como os artigos que Dworkin publicou como capítulos de Sovereign Virtue e outros trabalhos, dentre eles Life's Dominion, sobre aborto e eutanásia. As contribuiçãoes de Wolfe são muito valiosas, e especialmente as suas críticas merecem resposta em separado, o que fica para outra ocasião. O que se pode questionar em trabalho dedicado à liberdade de expressão no liberalismo igualitário de Dworkin é a inclusão do aspecto construtivo da interpretação no direito no "liberalismo igualitário" do autor (embora talvez Wolfe não pretenda incluir a teoria do direito do Dworkin no seu liberalismo apesar de discuti-la neste texto). De Wolfe, veja também Natural Law Liberalism. New York: Cambridge University Press, 2009, edição paperback (inicialmente publicado em 2006), esp. o cap. 4, que é dedicado a Dworkin.

${ }^{15}$ Fala, por sua vez, em "igualitarismo liberal" em artigo intitulado "O igualitarismo liberal de Ronald Dworkin". (KRITERION, Belo Horizonte, $\mathrm{n}^{\circ}$ 111, Jun/2005, p. 55-69) e dedicado a revisão de seu pensamentoe à apresentação da teoria política de Dworkin, inclusive dos direitos, como fundada na igualdade e, inclusive com comentários a "Foundations of Liberal Equality". A expressão também aparece em Macleod (Liberalism, Justice, and Markets, op. cit., p. 115 para "liberal egalitarianism", p. 187, n. 1 para "liberal egalitarian" e pp. 201, 203, 207 para "egalitarian liberalism"). Kymlicka fala em "igualdade liberal" para se referir a Dworkin e a Rawls (Will Kymlicka. Contemporary Political Philosophy. Oxford: Oxford University Press, 2002, 2a edição, cap. 3), enquanto Dall'Agnol fala em "igualitarismo liberal de Dworkin" justamente para diferenciá-lo de Rawls.

${ }^{16}$ Dworkin, "Foundations of Liberal Equality" in DARWALL, Stephen (Ed.) Equal Freedom: Selected Tanner Lectures on Human Values. Ann Arbor: The University of Michigan Press, 1995 (aulas dadas em 1988).

${ }^{17}$ Que fala em "liberalismo igualitário" para se referir, entre outros, a Ronald Dworkin em trabalho em que critica o esforço dworkiniano de defender interpretação da liberdade de expressão que inclua o direito de publicar e de consumir pornografia: Abigail Levin, The Cost of Free Speech: Pornography, Hate Speech, and their Challenge to Liberalism. Basingstoke: PALGRAVE MACMILLAN, 2010, pp. 28, 36, 38, 42, p. 240 (n.1 à p. 7)..Agradeço a Levin por responder a email sobre a publicação de seu artigo e livro. Veja Roberto Gargarella As teorias da justiça depois de Rawls: um breve manual de filosofia política. Trad. Alonso Reis Freire, revisão da tradução Elza Maria Gasparatto, revisão técnica Eduardo Appio. São Paulo: WMF Martins Fontes, 2008, pp. 91-2 para defesa da posição do "liberalismo igualitário" contra a proibição da pornografia (veja ainda p. 115, n. 27). 
salvo se entendida como um privilégio expositivo sem consequências teóricas. Em defesa da atenção à igualdade em um trabalho sobre a liberdade de expressão pode-se dizer, como elaboro no capítulo terceiro, que, se a integração das liberdades na igualdade não é mais fundamental que outras integrações, é ela particularmente importante à compreensão do sentido e da extensão das liberdades de expressão nos temas polêmicos que discuto, entre eles o discurso de ódio. O uso da expressão "liberalismo igualitário" reflete bem os objetivos do autor sobretudo quando busca defender teses liberais polêmicas, como a extensão da liberdade de expressão a casos complexos como uma demanda da igualdade devidamente interpretada.

Ao longo deste trabalho, faço diversas referências a comentadores de Dworkin e a intérpretes da liberdade de expressão, ou os dois. Importantes são a dissertação de Caio Moysés de Lima $^{18}$, a tese de Júlio César Casarin Barroso Silva ${ }^{19}$, os livros de Kent Greenawalt $^{20}$, Eric Barendt ${ }^{21}$, Jeremy Waldron ${ }^{22}$, Stephen Guest ${ }^{23}$, Stephen Mulhall e Adam Swift $^{24}$ e Colin MacLeod ${ }^{25}$ bem como os artigos de Paul Yowell ${ }^{26}$ e de Arthur Ripstein (este último, aliás, recomendado pelo próprio Dworkin) ${ }^{27}$. Muitos destes autores são críticos de Dworkin e/ou representativos de abordagem da liberdade de expressão de que discordo, e que cito seja porque são referência de determinada passagem, porque elaboram tema que menciono mas não discuto, porque citam e comentam trecho de Dworkin que trabalho, porque trazem opinião diferente dele ou por outros motivos.

\footnotetext{
${ }^{18}$ Caio Moysés de Lima. O Império dos Direitos: Lei e Autoridade Política em Ronald Dworkin. 184f. Dissertação de Mestrado - Departamento de Filosofia, Faculdade de Filosofia, Letras e Ciências Humanas, Universidade de São Paulo. Orientador: Rolf Nelson Kuntz. São Paulo, 2011.. O autor oferece na p. 99 representação esquemática do pensamento de Ronald Dworkin e da sua defesa dos direitos. Ainda, nas pp. 32-4, oferece explicação analítica do direito à livre manifestação do pensamento no direito brasileiro.

19 Júlio César Casarin Barroso Silva. Democracia e Liberdade de Expressão: Contribuições para uma interpretação política da liberdade de palavra. Tese de Doutorado. Faculdade de Filosofia, Letras e Ciências Humanas, Universidade de São Paulo. Orientador: Álvaro de Vita. São Paulo, 2009.

${ }^{20}$ Kent Greenawalt. Fighting Words - Individuals, Communities, and Liberties of Speech. Princeton: Princeton University Press, 1995.

${ }^{21}$ Eric Barendt. Freedom of Speech. $2^{\text {nd }}$ Ed. OUP: Oxford, 2007.

22 Jeremy Waldron, The Harm in Hate Speech. Cambridge (Mass.): Harvard University Press, 2012.

${ }^{23}$ Stephen Guest. Ronald Dworkin. $3^{\text {rd }}$ Ed. Stanford: Stanford Law Books, 2012.

${ }^{24}$ Stephen Mulhal e Adam Swift. Liberals and Communitarians. 2nd Ed. Oxford: Blackwell Publishers Ltd., 1996.

${ }^{25}$ Colin Macleod. Liberalism, Justice, and Markets: a Critique of Liberal Equality. Oxford: Clarendon Press, 1998.

${ }^{26}$ Paul Yowell. "A Critical Examination of Dworkin's Theory of Rights". The American Journal of Jurisprudence, Vol. 52, pp. 93-137, 2007.

${ }^{27}$ Arthur Ripstein "Liberty and Equality" in Arthur Ripstein (Ed.). Ronald Dworkin. New York: Cambridge University Press, 2007. Dworkin o recomenda em Justice for Hedgehogs: "I recommend Ripstein's account of my views about distributive justice" (p. 479, n. 12 à p. 361).
} 


\section{Seção 3. Sobre as referências bibliográficas}

São necessárias algumas observações sobre as referências bibliográficas neste trabalho.

1) Salvo indicação em contrário, todos os trabalhos citados são de autoria de Ronald Dworkin;

2) Salvo indicação em contrário, as páginas indicadas se referem ao original, e não à tradução dos trabalhos citados;

3) Por vezes, promovo alterações nas citações extraídas das traduções brasileiras para, creio, aprimorá-las. Quando o faço, informo que as modifiquei;

4) Há dificuldades em citar artigos do The New York Review of Book, cuja versão online não é dividida em páginas. Em razão disso, cito de maneira mais detalhada possível, que, no caso, é a indicação do item do artigo. Sempre que possível, prefiro consultar e citar o artigo como publicado em livro de Dworkin;

5) Nas referências, ao fim da dissertação, inseri a indicação bibliográfica das traduções entre parêntesis no mesmo item dos originais, ou seja, a ordem das obras segue a ordem cronológica das publicações dos originais, e não da publicação das traduções;

6) Especificamente sobre "Foundations of Liberal Equality" ${ }^{28}$ : trata-se de trabalho que, salvo melhor juízo, não foi traduzido para o português com exceção da versão mais enxuta publicada como capítulo 6 de Sovereign Virtue ("Equality and the Good Life"), e publicada portanto na tradução brasileira pela Ed. Martins Fontes (Virtude Soberana). Trabalhei com base na versão mais longa, sem tradução completa, mas sempre que possível cito a versão já traduzida para o português, indicando a página de Virtude Soberana em que se encontra.

7) Opto por citação do título do trabalho em detrimendo do sistema autor-data porque, pela quantidade de trabalhos do autor, e em razão da minha própria experiência, o sistema autor-data dificulta a condução do leitor pelo pensamento de autor que se espalha por diversas obras, como é o caso de Dworkin.

8) Existem disponíveis alguns levantamentos sobre as publicações de Dworkin. O leitor encontra listas nos seguintes trabalhos:

- Justine Burley (Ed.). Dworkin and His Critics - with replies by Dworkin. Malden: Blackwell Publishing, 2005, pp. 396 e ss.

\footnotetext{
${ }^{28}$ Dworkin, "Foundations of Liberal Equality", op. cit.
} 
- Stephen Guest, Ronald Dworkin. $3^{\text {rd }}$ Ed. Stanford: Stanford Law Books, 2012, pp. 271 e ss. e também p. 236, n. 16 à p. 153 para lista de trabalhos de Dworkin sobre liberdade de expressão.

- Ronaldo Porto Macedo Junior, Do xadrez à cortesia: Dworkin e a teoria do direito contemporânea. São Paulo: Saraiva, 2013, pp. 326 e ss. (veja especialmente a lista de vídeos de palestras de Dworkin nas pp. 326-7).

Sobre liberdade de expressão em geral, o livro de Eric Barendt, Freedom of Speech. $2^{\text {nd }}$ Ed. OUP: Oxford, 2007 faz indicações bibliográficas por tema e local (veja pp. 507 e ss.). 


\section{CAPÍTULO PRIMEIRO: DIREITOS E LIBERDADES}

\section{Introdução}

A teoria política de Ronald Dworkin tem lugar de destaque aos direitos, compreendidos como uma defesa dos indivíduos frente ao interesse coletivo. O objetivo deste capítulo é apresentar tanto os aspectos gerais da concepção de direitos defendida pelo autor quanto os delineamentos da interpretação das liberdades disponível na obra de Dworkin, defesa esta a ser pormenorizada nos capítulos seguintes, quando discuto mais especificamente a liberdade de expressão como interpretada por ele.

Explicações da ideia de direitos tem grande valor em um tempo que, como o nosso, é testemunha, simultaneamente, de defesas arraigadas de "direitos humanos" e de desrespeito aos direitos civis higienizado por meio de retórica mais ou menos rigorosa. A concepção de direitos de Dworkin permite que se compreenda o que significa afirmar que determinada pessoa tem direito a determinado recurso, ação etc. e que tipos de considerações devem ser levados em consideração - e, também, quais não devem ser consideradas - no exercício interpretativo de definição de direitos. Estudo da obra de Dworkin, portanto, é oportunidade de análise de uma interpretação da prática de direitos capaz de orientar a difícil tarefa de adjudicar casos complexos envolvendo (real ou de maneira somente aparente) conflitos de direitos.

Para tanto, e seguindo a própria estrutura da reflexão do autor, é preciso entender o que são direitos. A resposta a esta indagação reside na noção de "direito em sentido forte", oferecida já em “Taking Rights Seriously”, artigo de 1970 publicado no livro homônimo”. Este e outros aspectos da resposta do autor a esta questão são analisados na próxima seção deste capítulo, em que seguirei de perto a obra do autor de modo a apresentar os aspectos desta noção de direitos. Na seção seguinte, apresento as consequências do fortalecimento de direitos. Em especial, analiso a crítica de Dworkin ao que ele chama de "balancing model" e às atitudes em relação aos direitos que, na sua opinião, precisam ser abandonadas. Ainda nesta seção, introduzo o que o autor oferece como modo de tratamento dos direitos, em especial das situações em que existe genuíno conflito entre eles.

Na terceira seção, deixo de lado brevemente a concepção dworkiniana de direitos para discutir aspecto da obra do autor indispensável à compreensão das liberdades em sua obra, em 
especial da liberdade de expressão, objeto deste trabalho. Trata-se da noção de que conceitos políticos são integrados entre si. É que, como se verá nos capítulos seguintes, é nestes termos que Dworkin defende a liberdade de expressão - ou seja, por meio de recurso a outros conceitos, como igualdade, ética etc.

Discutida a integração de conceitos defendida por Dworkin, é possível, na quarta seção, apresentar a defesa geral dos direitos às liberdades elaborada pelo autor. Embora ter um direito signifique tê-lo no sentido forte descrito na primeira seção, nem por isso se pode concluir (e Dworkin é cuidadoso ao rejeitar esta inferência falaciosa) pela existência de determinado direito. Ou seja, do significado de direitos, caso existam, não decorre que algum exista: como reconhece o próprio autor, é ainda preciso defender a existência específica de cada um deles. É necessário então apresentar a defesa das liberdades disponível na obra do autor: Dworkin defende as liberdades de modo a integrá-las à ética, entendida como a reflexão sobre a boa vida. Este é o objeto da quarta seção, em que também apresentarei aquilo que, para Dworkin, as liberdades não são.

$\mathrm{Na}$ quinta seção, exploro outra integração na obra de Dworkin, desta vez entre igualdade e liberdade, valores políticos comumente tratados como conflitantes entre si. Mais especificamente, apresento o intrincado argumento oferecido pelo autor em defesa da integração da liberdade (na forma de direitos a liberdades) na justiça distributiva (na forma da concepção de igualdade que ele chama de igualdade de recursos). Este argumento será recuperado no capítulo terceiro, quando apresentarei os passos seguidos pelo autor para delimitar a liberdade de expressão longe do ambiente ideal em que constrói inicialmente a sua teoria da justiça. Antes disso, no segundo capítulo, elaborarei a ética de Dworkin, que pelo menos em uma de suas formulações inclui valor ético que faz parte da integração entre liberdades e igualdade de recursos, a saber, a autenticidade. Por ora, vale começar pela política.

\section{Seção 1. Os direitos fortalecidos}

Dialogar com a existência de direitos é condição necessária à plena participação nos debates políticos contemporâneos: direitos são reclamados por minorias mas também por maiorias, são utilizados para criticar o direito positivo e advogar sua reforma, bem como para 
defendê-lo e preservá-lo, entre outros ${ }^{29}$. Disso entretanto não decorre que os atores políticos guardem noção idêntica ou sequer que o mesmo ator utilize a mesma ideia de direitos em diferentes circunstâncias. Ou seja, "direitos" é palavra dotada de "ambiguidade" 30 . Ao menos no caso de Ronald Dworkin, entretanto, a compreensão das suas posições a respeito de temas controversos, entre eles os relacionados à liberdade de expressão, é dependente de devida atenção àquilo que Dworkin quer dizer quando diz que alguém tem um direito a algo.

É, portanto, importante entender a noção dworkiniana de "direito no sentido forte", que é a definição empregada por ele para discutir "direitos políticos", isto é, aqueles direitos que são de titularidade dos cidadãos e que são dirigidos contra o Estado ${ }^{31}$. Para apresentá-la, Dworkin reconhece a diversidade de sentidos da noção de "direitos" no discurso político e diferencia "duas forças" ou "sentidos" da palavra:

"(...) a palavra 'direito' tem força diferente em diferentes contextos. Na maioria dos casos, quando dizemos que alguém tem o 'direito' de fazer alguma coisa, subentendemos que seria errado interferir com a realização daquela ação ou, pelo menos, que necessitamos de razões especiais [special grounds] para justificar qualquer interferência. Uso esse sentido forte da palavra 'direito' quando afirmo que o leitor tem o direito de gastar seu dinheiro no jogo, se assim o desejar, embora devesse [ought to] gastá-lo de maneira mais meritória"32

O autor pretende diferenciar esta ideia de direitos da noção de que determinada ação é correta. Utilizando o exemplo do jogo, Dworkin diz: "Alguém pode ter o direito de fazer algo que seja a coisa errada a fazer, como no caso do jogo" ${ }^{33}$.

${ }^{29}$ Veja observação de Dworkin sobre a importância do valor da liberdade no debate político: Justice for Hedgehogs, op. cit., p. 364 . Veja ainda Caio Moysés de Lima, O Império dos Direitos: Lei e Autoridade Política em Ronald Dworkin, op. cit., pp. 4 e ss., 10 e ss. Por fim, veja o que Waldron diz sobre dignidade em The Harm in Hate Speech, op. cit., pp.136-143.

${ }^{30}$ Para Dworkin, há "ambiguity in the language of rights", "Taking Rights Seriusly", op. cit., p. 194.

${ }^{31}$ Sobre "the idea of political right itself" Dworkin pergunta o seguinte: "What kind of rights do we each as individuals have against our state - against ourselves collectively?", Justice for Hedgehogs, op. cit., p. 328 (veja em geral cap. 15 e "Hard Cases", op. cit., p. 91); ver ainda "Principle, Policy, Procedure", in A Matter of Principle, p. 80 e "Do We Have a Right to Pornography?" in A Matter of Principle, op. cit., p. 353. Faço estas referências ao significado de direito político em Dworkin como resposta a indagação feita pelo professor Samuel Rodrigues Barbosa na minha banca de qualificação. Agradeço ao professor pelo tempo dedicado à minha pesquisa e pelas críticas e sugestões à condução deste trabalho.

32 Dworkin, "Levando os Direitos a Sério" in Levando os Direitos a Sério. Tradução Nelson Boeira, Revisão da Tradução Silvana Vieira, São Paulo: Martins Fontes, 2002, pp. 289-90 (acrescentei entre colchetes expressões do original em inglês; no original, veja "Taking Rights Seriously", op. cit., p. 188. Veja ainda "The Model of Rules II" in Taking Rights Seriously, op. cit., p. 48 e "Principle, Policy, Procedure" in A Matter of Principle, op. cit., esp. pp. 76, 79, 80, Justice for Hedgehogs, op. cit., pp. 327 e ss., entre outros.

${ }^{33}$ Dworkin, "Levando os Direitos a Sério", op. cit., p. 290; no original, "Taking Rights Seriously", op. cit., p. 188. Dworkin afirma ainda que também é possível ser permissível que se impeça alguém de fazer algo que julgamos correto, isto é, que alguém não tenha o direito de fazer algo que é certo: o exemplo do autor é a fuga do prisioneiro de guerra, que pode ser impedida pelos carcereiros, mas que é a coisa que o prisioneiro deve fazer (veja pp. 188-9). Dworkin apresenta a distinção ao discutir desobediência civil e o "paradox" de que tanto 
A distinção é bastante intuitiva pois representa juízos que não necessariamente coincidem em determinada teoria política ${ }^{34}$. Ou seja, é possível que uma teoria admita que determinada ação não deva ser praticada sem que defenda que isto baste a que seja proibida pelo Estado; poderão ser necessários os "special grounds" (ou "razões especiais") ${ }^{35}$ de que fala Dworkin ao definir direitos no sentido forte. Mas mesmo que determinada teoria pretenda aproximar os dois juízos, será preciso oferecer argumento que os conecte, isto é, que indique por que ninguém pode ter direito a fazer algo errado, ou por que direitos são a faculdade de fazer somente o que é certo. ${ }^{36}$

"conservatives" quanto "liberals" têm a mesma opinião sobre a "question of principle" envolvida na desobediência civil (ambos creem "that men have a duty to obey the law but have the right to follow their consciences when it conflicts with that duty", p. 187), embora apresentem em diferentes casos concretos opiniões que contradizem essa opinião (conservadores defendem que se puna quem foge do alistamento militar em razão de - admitem eles - objeção de consciência enquanto liberais defendem a punição de quem se recusa - também por questão de consciência - a executar as ordens de dessegregação racial nas escolas, pp. 187-8). Em outras palavras, diz Dworkin, aqueles que em tese discordam entre si na verdade concordam quanto ao tema fundamental da desobediência civil, mas contradizem a si mesmos quando chamados a opinar sobre questões polêmicas. A distinção entre sentidos de direitos apaga o paradoxo e a contradição pois permite perceber que liberais e conservadores concordam que um indivíduo tem por vezes o direito de desobedecer o direito no sentido de que ele faz a coisa correta ao desobedecê-lo, mas que discordam quanto a ter ele o direito forte de não ser impedido de desobedecer (pp. 190 e ss.). Isso leva Dworkin a rejeitar a pertinência da noção de "right to conscience", já que, para ele, ela é relevante para saber o que é certo, mas não é crucial à discussão sobre quais direitos (no sentido forte) os indivíduos têm (p. 190). Sobre o tema, veja Caio Moysés de Lima, O Império dos Direitos: Lei e Autoridade Política em Ronald Dworkin, op. cit., pp. 106 e ss.,

${ }^{34}$ Veja, por exemplo, "Introduction: The Moral Reading and the Majoritarian Premise" in Freedom's Law, op. cit., p. 36. A respeito desta questão do "right to do wrong", veja Caio Moysés de Lima, O Império dos Direitos: Lei e Autoridade Política em Ronald Dworkin, op. cit., pp. 100 e ss., sobre a estrutura das "liberdades clássicas", entre elas a liberdade de expressão. Moysés de Lima trabalha a partir de livro de Edmundson sobre Waldron e Galston, e cita também George. Veja também p. 113 e o seguinte trecho de de Lima: "No vocabulário de Dworkin, os direitos genuínos, que incluem a liberdade de praticar condutas imorais, são direitos em 'sentido forte'. Dizemos que uma pessoa tem o direito de gastar o seu direito como quiser justamente porque admitimos que ela possa fazê-lo mesmo que perca tudo 'nos cavalos'.

"Jeremy Waldron defende a mesma tese no ensaio A Right to Do Wrong. A existência de um direito moral, segundo ele, justifica-se precisamente pela importância que o poder de escolha adquire em certos casos. Poder escolher entre o certo e o errado é uma condição para a autoconstituição da personalidade individual e para a integridade pessoal. Essa justificativa guarda paralelo com a tese dworkiniana de que os direitos fundamentais apoiam-se, em última análise, na dignidade humana, sob a forma do ideal de igualdade de consideração e respeito. Se apenas as ações moralmente corretas ou moralmente indiferentes pudessem ser objeto dos direitos morais, não haveria razão para a existência desses direitos; a noção de deveres daria conta do recado", pp. 102-3, notas omitidas (com citacões de Taking Rights Seriously, op. cit, pp. 188-9, páginas de "Taking Rights Seriously", op. cit. e de texto de Waldron. De Lima, numa dessas notas, também menciona "Do We Have a Right to Pornography", op. cit. - veja pp. 335-6). Veja Waldron em the Hart in Hate Speech, op. cit., p. 126, para aplicação do "right to do wrong" à liberdade de expressão e ao caso da publicação dos "Danish cartoons", inclusive com referência elogiosa à visão de Dworkin de que a imprensa fez bem em não republicar os "cartoons" mesmo tendo direito de reproduzi-los. Veja ainda Guest, Ronald Dworkin, op. cit., pp. 208 e ss..

${ }^{35}$ Dworkin, "Levando os Direitos a Sério", op. cit., p. 289; no original, "Taking Rights Seriously", op. cit., p. 188.

${ }^{36}$ Ver referências na nota anterior. 
Mas mais que isso, a distinção apresenta importante, digamos, ordenação da linguagem de direitos, embora cada sentido de direitos tenha legitimidade no seu contexto ${ }^{37}$. Falar de direitos no sentido forte não é simplesmente falar do que é certo ou errado: é falar de algo diferente, a saber, de uma prerrogativa de fazer algo independentemente de ser certo ou errado ${ }^{38}$. A percepção desta característica dos direitos no sentido forte é especialmente relevante ao direito à liberdade de expressão, que, na obra de Dworkin, se estende a diversas condutas que - podem crer mesmo aqueles que divergem de sua proibição - não devem ser praticadas, como o discurso de ódio ${ }^{39}$. Ela é também relevante à defesa oferecida pelo autor da ideia de que o valor da vida de um indivíduo não pode ser aprimorado pela mudança desprovida de seu endosso ou (o que é distinto mas decorre desta ideia) de que, apesar de determinada decisão ética poder ser avaliada como incorreta, há uma razão política na forma de um direito para não interferir na vida de um indivíduo mesmo que a interferência corrigisse decisões incorretas (veja o capítulo segundo desta dissertação para mais detalhes sobre a crítica de Dworkin ao paternalismo e a sua defesa do que chama de "prioridade da integridade ética" 40 ).

Como visto, Dworkin apresenta a noção de direitos fortes ao analisar os direitos que os cidadãos possuem contra o Estado; ele também descreve esta noção ao oferecer análise das justificativas existentes ao constrangimento das ações dos indivíduos por meio de atos estatais. É neste ponto que entra a conhecida distinção dworkiniana entre princípios e políticas (policies). ${ }^{41}$ Para o autor, princípios são considerações sobre distribuição de bens, recursos,

\footnotetext{
${ }^{37}$ Dworkin, "Taking Rights Seriously", op. cit., pp. 188 e ss.

${ }^{38}$ Dworkin, "Taking Rights Seriously", op. cit., pp. 190-1.

39 "Do We Have a Right to Pornography?", op. cit. "Pornography and Hate", op. cit., esp. pp. 218-9, "MacKinnon's Words", op. cit. (por exemplo, "Liberals defend pornography, though most of them despise it", p. 238), "The Right to Ridicule", "The Right to Ridicule", The New York Review of Books, Volume 53, número 5, 23 de março de 2006.

${ }^{40}$ Ainda, veja Caio Moysés de Lima, O Império dos Direitos: Lei e Autoridade Política em Ronald Dworkin, op. cit., p. 105 para a ideia de que os direitos em sentido forte são manifestações da autenticidade, segundo princípio da concepção dworkiniana de dignidade, entendida que "A igualdade de consideração e respeito exigiria, em outras palavras, admitir que os indivíduos possam ter opiniões divergentes sobre o que é moral ou imoral", p. 105

${ }^{41}$ Dworkin, "O Modelo de regras I" em Levando os Direitos a Sério, op. cit., pp. 36-7; no original,"The Model of Rules I" in Taking Rights Seriously, op. cit., pp. 22-3. Veja ainda "Hard Cases", op. cit., pp. 90 e ss. Veja Caio Moysés de Lima, O Império dos Direitos: Lei e Autoridade Política em Ronald Dworkin, op. cit., esp. p. 7 para a importância da distinção ao pensamento de Dworkin e pp. 39 e ss. e cap. II, seção 4, esp. pp. 44 e ss. e p. 45, n. 96 para menção a distinção trabalhada por Thomas Nagel que Caio julga bastante semelhante à distinção entre princípios e políticas e n. 97 para referências a diversos trabalhos de Dworkin. Veja Yowell, "A Critical Examination of Dworkin's Theory of Rights", op. cit., p. 108, p. 99 (n. 37) e pp. 125-6.
} 
oportunidades etc. que apontam para a existência de um "direito",42, sendo "direito político" um "objetivo político individualizado" (individuated political aim) ${ }^{43}$, enquanto políticas são considerações deste mesmo tipo, mas que apontam para uma "meta" (goal) ${ }^{44}$, que é um “objetivo político não-individualizado" (non-indiduated political aim) ${ }^{45}$; princípios e políticas são considerações que justificam "decisões políticas". 46 Ao distinguir princípios de políticas, Dworkin entende

“(...) um objetivo político [political aim] como uma justificação política genérica. Uma teoria política considera um determinado estado de coisas como um objetivo político se, para essa teoria, ele conta a favor de uma decisão política que ela tem a probabilidade de promover ou proteger tal estado de coisas, e conta contra esta decisão que ela irá retardar sua ocorrência ou colocá-lo em perigo. Um direito político é um objetivo político individualizado. Um indivíduo tem direito a uma oportunidade, a um recurso ou a uma liberdade se conta a favor de uma decisão política que a decisão provavelmente promove ou protege o estado de coisas no qual ele desfruta tal direito, mesmo que com isso nenhum outro objetivo político seja servido e algum objetivo político seja desservido, e conta contra a decisão que ela retardará ou colocará em perigo esse estado de coisas, mesmo que com isso algum outro objetivo político possa ser atingido. Uma meta [goal] é um objetivo político não-individualizado, isto é, um estado de coisas cuja especificação não requer a concessão e nenhuma oportunidade particular, nenhum recurso ou liberdade para indivíduos determinados". ${ }^{47}$

Em outras palavras, para Dworkin, o Estado necessita de justificativas para tomar decisões que visam a alcançar objetivos políticos (political aims) por ele adotados, e esses objetivos políticos são de dois tipos: individualizados (ou seja, direitos) ou não individualizado (isto é, metas - goals). Dworkin oferece como exemplo do primeiro o direito à liberdade de expressão e, como exemplo do segundo, um contrato firmado entre o Estado e um fabricante de

42 "Casos Difíceis" em Levando os Direitos a Sério, op. cit., pp. 141 e ss.; no original, "Hard Cases" in Taking Rights Seriously, op. cit., pp. 90 e ss.

43 "Casos Difíceis" em Levando os Direitos a Sério, op. cit., p. 142, no original, "Hard Cases", op. cit., p. 91.

44 "Hard Cases", op. cit., p. 90; veja nota abaixo sobre a tradução de "goal" por "meta". Dworkin utiliza a expressão "meta coletiva" (collective goal) ("Casos Difíceis" op. cit., p. 143; no original, "Hard Cases", op. cit., p. 91) no que parecer ser um uso redundante, pois toda meta, enquanto espécie de objetivo, é coletiva segundo a própria definição oferecida pelo autor.

45 "Casos Difíceis" em Levando os Direitos a Sério, op. cit., pp. 142-3, no original, "Hard Cases", op. cit. p. 91. A tradução brasileira ("Casos Difíceis", op. cit.) traduz tanto "goal" (pp. 141 e 142) quanto "aim" (pp. 142 e 143) por "objetivo" (veja em geral pp. 141 e ss.), embora também traduza "goal" por "meta" (p. 143; todas as páginas são da tradução). Sigo a tradução de "goal" por "meta" e a tradução de "aim" por "objetivo"; é importante não misturar as expressões pois Dworkin utiliza "aim" genericamente ao discutir tanto políticas quanto princípios, enquanto utilizada a expressão "goal" somente para designar políticas - meta é um tipo de objetivo ("Casos Difíceis", op. cit., p. 143; no original, "Hard Cases", op. cit., p. 91).

46 "Principle are propositions that describe rights; policies are propositions that describe goals", "Hard Cases", op. cit., p. 90. Veja Caio Moysés de Lima, O Império dos Direitos: Lei e Autoridade Política em Ronald Dworkin, op. cit., p. 45 (texto junto à nota n. 98); Veja Yowell, "A Critical Examination of Dworkin's Theory of Rights", op. cit., p. 108, entre outros.

47 "Casos Difíceis", op. cit., pp. 142-4, nota omitida (alterei a tradução para, creio, aperfeiçoá-la e acrescentei entre colchetes palavras do original em inglês); no original, "Hard Cases", op. cit., p. 91, nota omitida. 
munição. ${ }^{48}$ A liberdade de expressão para o autor é um direito porque respeitá-lo significa atribuir liberdade a indivíduos determinados; é claro que, no caso do contrato administrativo, há uma parte específica, mas se a meta é obter munição em prol do "bem-estar coletivo" (collective welfare) $^{49}$ (por exemplo, aprimorar a capacidade das forças armadas do país de reagir a ameaça externa), quem figura no outro polo da relação contratual é "acidental"50, relevante instrumentalmente à consecução do objetivo político (no caso, uma meta). Daí ele ser não-individualizado, enquanto a liberdade de expressão é individualizada. Isto fica claro ao observarmos que suprimir o direito à manifestação política de uma pessoa não é descaracterizado como violação de um direito se (e ainda que) este direito de expressão for (seja) estendido a outro a quem a manifestação era anteriormente vedada; ou seja, deixar de violar um direito violando outro corrige uma violação mas não a outra. E mais: essa correção é desconectada do cometimento da outra, isto é, ocorreria ainda que ninguém tivesse sido privado do direito. Se uma indústria bélica, entretanto, oferece o melhor e mais barato produto disponível no mercado, celebrar o contrato com ela e não com o concorrente é ação política justificável, não tendo o concorrente nenhuma consideração política a recorrer contra a decisão política tomada. (É importante observar que esta caracterização da liberdade de expressão é particular de Dworkin, ainda que ele entenda que a liberdade de expressão também é uma questão de policy $^{51}$. Como ele mesmo observa inúmeras vezes, e como será exposto neste trabalho, existem justificativas de liberdades baseadas em policies, e naturalmente todas as consequências de conceber a preservação da liberdade de expressão enquanto meta e não direito se aplicam. ${ }^{52}$ ).

\footnotetext{
48 "Hard Cases", op. cit., p. 90.

49 "Casos Difíceis", op. cit., p. 142; no original, "Hard Cases", op. cit., p. 90.

${ }^{50}$ Dworkin diz, em resposta a crítica de Frederick Schauer: "Arguments of policy are collective justifications, which point to some overall benefit for the community as a whole, and concede that the special benefits that particular individuals received are accidental", Dworkin, "Ronald Dworkin replies" in Frederick F. Schauer, Virginia Held e John L. Hess, "The Rights of M. A. Farber: An Exchange", op. cit.. Os dois autores e a autora com quem Dworkin se corresponde nesta publicação são responsáveis por trechos diferentes da compilação de críticas a que o autor respondeu conjuntamente. O artigo de Dworkin que desencadeou este exchange foi publicado posteriormente em livro: "The Farber Case: Reporters and Informers" in A Matter of Principle, op. cit.. Veja capítulo terceiro desta dissertação, abaixo.

${ }^{51}$ Dworkin, "Ronald Dworkin replies", op. cit. Veja nota à introdução do capítulo terceiro para mais detalhes.

${ }^{52}$ Veja Dworkin em "Is the Press Losing the First Amendment?" e "The Farber Case: Reporters and Informers" (ambos) in A Matter of Principle. op. cit., "Ronald Dworkin replies", op. cit., e em "Why Must Speech be Free?" in Freedom's Law, op. cit..
} 
Essas observações sobre os exemplos dados por Dworkin se prestam a ilustrar uma característica que, segundo o autor, políticas, mas não direitos, têm, a saber: "As metas coletivas estimulam as trocas de benefícios e encargos no seio de uma comunidade, tendo em vista a produção de algum benefício geral para a comunidade como um todo."53. Imaginemos que o produto oferecido pela indústria bélica do parágrafo anterior seja superior em qualidade mas que também seja mais caro. Isto faz com que o Estado precise comparar os benefícios de adquirir a munição por ela fabricada com os benefícios obtidos por utilizar em outro ponto do orçamento os recursos que seriam economizados se outro fornecedor fosse escolhido. Se o contrato é uma decisão política cujo objetivo não é individualizado, ou seja, é uma meta, o fato de que escolher este e não aquele contratante atinge melhor a meta é suficiente à justificação da decisão, novamente não tendo o fabricante preterido nenhuma consideração política contra a decisão política tomada. Dworkin imagina dois exemplos de objetivos políticos, a saber, eficiência econômica (que pode justificar subsídio a determinada indústria e não a outra) e uma concepção de igualdade que indique, por exemplo, que ninguém tenha riqueza superior ao dobro daquele que tiver menos riqueza (o que pode exigir drásticas medidas de redistribuição de renda), e em seguida diz que "Em cada caso, princípios distributivos estão subordinados a uma certa concepção de bem coletivo agregado, de modo que uma oferta menor de algum benefício a um homem possa ser justificada simplesmente mostrando que isso levará a um maior benefício geral" ${ }^{54}$. O que se vê é que, no caso das políticas, a ligação entre o recurso e seu titular é "contingente" "55, enquanto no caso dos princípios esta ligação é caracterizadora da titularidade do direito.

É possível, naturalmente, que uma decisão política tenha que lidar com duas ou mais políticas, dois ou mais princípios, ou políticas e princípios. ${ }^{56}$ Nesta articulação, diferentes teorias políticas podem atribuir diferentes pesos, inclusive peso absoluto, a determinada

\footnotetext{
53 “Casos Difíceis", op. cit., p. 143; no original, "Hard Cases”, op. cit., p. 91 . O autor, entretanto, faz questão de dizer, mais à frente, que a linguagem econômica não é completamente alheia à interpretação de princípios, sobretudo quando há conflito entre eles: veja pp. 98-9 e também "Taking Rights Seriously", op. cit., pp. 195 e ss.

54،"Casos Difíceis", op. cit., p. 143; no original, "Hard Cases", op. cit., p. 91; veja ainda pp. 91-2 para a consideração de como a associação de duas ou mais políticas aumenta ainda mais a necessidade de trade-offs (na tradução, "trocas": "Casos Difíceis", op. cit., p. 144).

${ }^{55}$ Dworkin usa o termo em "Temos direito à pornografia?", op. cit., p. 523; no original, "Do We Have a Right to Pornography?", op. cit., p. 352. Veja também "Why Academic Freedom?", op. cit., pp. 259-60.

56 "Hard Cases", op. cit., pp. 91 e ss.
} 
política ou princípio ${ }^{57}$. Como visto, a noção de direitos que Dworkin desenvolve restringe as justificações admissíveis à sua limitação. Assim, além de diferenciar direitos e políticas, o autor oferece uma visão sobre a relação entre os dois tipos de considerações capazes de justificar decisões políticas. Para ele, salvo exceções, princípios não perdem para políticas. Princípios, em Dworkin, são fortes mas não absolutos:

“(...) um princípio pode ter de capitular diante de outro, ou mesmo diante de uma política urgente com a qual esteja em competição a propósito de determinados fatos. Podemos definir o peso de um direito, admitindo que ele não é absoluto, como sua capacidade de suportar tal competição. Segue-se, da definição de um direito, que ele não ser menos importante (outweighed) que todas as metas sociais (all social goals). Para simplificar, podemos estipular que não chamaremos de direito qualquer objetivo político a menos que ele tenha um certo peso contra as metas coletivas em geral; a menos que, por exemplo, que ele não possa ser derrotado mediante o apelo a qualquer das metas rotineiras da administração política, mas somente por uma meta de urgência especial",58

Essa definição de direitos também oferece ordenação da linguagem política. Imediatamente após o fim do trecho citado acima, Dworkin diz o seguinte:

"Suponhamos, por exemplo, que um homem diga que reconhece o direito à liberdade de expressão, mas acrescente que tal liberdade deve ficar em segundo plano [yield] sempre que seu exercício possa ser inconveniente para o público. Ele quer dizer, imagino, que reconhece a meta amplamente disseminada do bem-estar coletivo, mas reconhece a distribuição da liberdade de expressão apenas nos termos recomendados por essa meta coletiva para circunstâncias específicas. Sua posição política é exaurida pela meta coletiva; o direito putativo nada acrescenta e não há nenhuma razão para reconhecê-lo como um direito" 59

É que, para o autor, ideias como a liberdade de expressão, a depender da teoria política adotada, são consideradas direitos ou metas, bem como direitos ou metas de diferentes pesos. ${ }^{60}$ A ordenação da linguagem é propiciada porque, fortalecidos os direitos, não faz sentido falar em um direito se a justificativa da adoção da proteção da liberdade de expressão, por exemplo, é subordinada ao atendimento de meta, o que "desindividualiza" o objetivo ao torná-lo dependente da sua capacidade de agregar à meta, no caso, de contribuir ao "bem-estar

\footnotetext{
57 "Hard Cases", op. cit., pp. 91 e ss.

58 "Casos Difíceis", op. cit., pp. 144-5 (alterei a tradução: substituí "conflito" por "competição" para traduzir "competes", "concorrência" por "competição" para traduzir "competition", "intransigente" por "urgente" para traduzir "urgent" e "invalidado" por "derrotado" para traduzir "defeated" - mas o "urgência" está na tradução, p. 145; acrescentei entre colchetes palavras do original em inglês); no original, "Hard Cases", op. cit., p. 92. Veja ainda, por exemplo, "The Farber Case: Reporters and Informers", op. cit., pp. 375-6, "Is the Press Losing the First Amendment?", op. cit., p. 387.

59 "Casos Difíceis", op. cit., p. 145 (acrescentei palavra entre colchetes, que é do original em inglês); para o original, veja "Hard Cases", op. cit., p. 92.

60 "Hard Cases", op. cit., pp. 92-3.
} 
coletivo" (collective welfare). ${ }^{61}$ No mínimo, a noção de direito forte mostra que o homem imaginado por Dworkin não trata a liberdade de expressão enquanto um direito no sentido relevante, que é o forte.

Em conclusão, pode-se dizer que, para Dworkin, dizer que alguém tem um direito - por exemplo, à liberdade de expressão - significa que o indivíduo pode exercê-lo mesmo que seja errado fazê-lo, independentemente de o exercício contribuir a um objetivo não individualizado e, com efeito, ainda que prejudique meta(s):

“A afirmação de que cidadãos têm direito à liberdade de expressão deve implicar (imply) que seria errado, por parte do governo, impedi-los de se expressarem, mesmo acreditando que o que vão dizer causará mais mal do que bem. A afirmação não pode significar, com base na analogia do prisioneiro de guerra, apenas que os cidadãos nada fazem de errado ao dizer o que pensam, embora o governo se reserve o direito de impedir que o digam" ${ }^{62}$

É neste ponto de "Taking Rights Seriously" que Dworkin discute os "special grounds" necessários à "interference" de um direito. O autor defende que restrições às ações dos cidadãos são justificadas em geral se atendem a um benefício coletivo - aquilo que anos depois Dworkin chamaria, em "Hard Cases", de política ou objetivo não-individualizado (ou em "What Right Do We Have?" de "interesse geral"63). Mas se a restrição toca direitos, diz o autor, essa justificação não é o suficiente, e a ideia de direito no sentido forte se presta

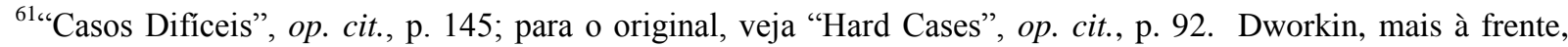
esclarece que uma teoria que, como o "utilitarismo de regras" ("Casos Difíceis", op. cit., p. 149) "unite rights and goals (...) by making the force of a right contingent upon its power, as a right, to promote some collective goal" ("Hard Cases", op. cit., p. 95) é capaz de adotar a noção de "direito institucional", isto é, o direito a que uma instituição política tome certa decisão (p. 93). É que, esclarece o autor, esta teoria pode defender que as decisões políticas sejam tomadas para preservar o direito de determinada pessoa (o exemplo, novamente, é a liberdade de expressão) independentemente das consequências ao objetivo coletivo eleito, e pode fazê-lo na crença de que se todos os agentes políticos assim agirem o objetivo coletivo será mais bem preservado do que se cada ação individual for orientada ao seu atendimento (pp. 95-6); veja nota abaixo. Nesta dissertação entretanto discuto mais o que Dworkin chama de "background rights", a saber "rights that provide a justification for political decisions by society in the abstract" (p. 93), e não direitos institucionais. Veja Dworkin em "Devaluing Liberty", Index on Censorship, 1988 17:7, pp. 7-8. Veja Caio Moysés de Lima, O Império dos Direitos: Lei e Autoridade Política em Ronald Dworkin, op. cit., pp. 87 e ss. para discussão do que Dworkin chama de "institutional" e "background rights", entre outras distinções. Veja ainda "Do We Have a Right to Pornography?", op. cit., pp. 353 e ss., em especial p. 357.

62 "Levando os Direitos a Sério", op. cit., p. 293 (acrescentei palavra entre colchetes, que é do original em inglês); para o original, veja "Taking Rights Seriously", op. cit., pp. 190-1.

63 "If someone has a right to something, then it is wrong for the government to deny it to him even though it would be in the general interest to do so", "What Rights Do We Have?", in Taking Rights Seriously, op. cit., p. 269. A expressão também aparece em "Taking Rights Seriously" ("If I have a right to speak my mind on political issues, then the government does wrong to make it illegal for me to do so, even if it thinks this is in the general interest", op. cit., p. 192 (veja ainda p. 194 para "general benefit") e em "The Farber Case: Reporters and Informers" op. cit., p. 375.
} 
justamente a distinguir as ações protegidas contra este tipo de restrição justificada de maneira mais simples daquelas não protegidas: ele diz que

\begin{abstract}
"Em geral (...) é uma justificação suficiente, mesmo para um ato que limita a liberdade, que esse ato seja calculado de modo que aumente aquilo que os filósofos chamam de utilidade geral - ou seja, calculado de modo que, no cômputo geral, produza mais benefícios que danos. Assim, embora o governo da cidade de Nova York necessite de uma justificativa para proibir que os motoristas dirijam pela Lexington Avenue acima [drive up], está suficientemente justificado se os funcionários competentes acreditarem, a partir de comprovação substantiva, que as vantagens para a maioria irão superar os inconvenientes para uns poucos. Contudo, quando se diz que cidadãos individuais têm direitos contra o governo, como o direito à liberdade de expressão, tal afirmação deve significar que esse tipo de justificação não é suficiente. Caso contrário, a alegação não se sustentaria no argumento de que [would not argue that] os indivíduos têm proteção especial contra a lei quando os seus direitos estão em jogo, mas é este precisamente o cerne da alegação". ${ }^{64}$
\end{abstract}

O sentido de direitos adotado por Dworkin tem importantes consequências à concepção de liberdade de expressão defendida pelo autor e que exploro em outros pontos deste trabalho. E este sentido tem também importantes consequências à atitude que deve ser adotada na difícil tarefa de arbitrar situações de conflito de direitos. Este é o tema da próxima seção, mas gostaria de, ainda nesta seção, ressaltar um aspecto da noção de direitos fortes salientada acima ao apresentar a noção dworkiniana de princípio, isto é, o fato de que princípios são, para o autor, objetivos políticos individualizados.

Como visto, a discussão sobre direitos em "Taking Rights Seriously” se dá pelo esforço de distinguir sentidos de direitos, e ao fazê-lo Dworkin aborda não só a liberdade de expressão, mas também o tema da desobediência civil, isto é, à questão de haver direito de desobedecer ao direito. A solução proposta pelo autor a este último tema é bastante simples: há um direito (subjetivo) de desobedecer ao direito (objetivo) quando este desrespeita aquele, e este direito (subjetivo) de desobedecer não é distinto do direito (subjetivo) desrespeitado. ${ }^{65}$ Dworkin então imagina objeções. Uma delas consiste em formular um "princípio de respeito pelo direito",66

\footnotetext{
64 “Levando os Direitos a Sério", op. cit., p. 293 (acrescentei entre colchetes palavras do original em inglês); para o original, veja "Taking Rights Seriously", op. cit., pp. 191. Veja ainda "What Rights Do We Have?", op. cit., pp. 268-9. Para crítica à ideia de Dworkin de "rights as trumps" no contexto da liberdade de expressão, veja Waldron em The Harm in Hate Speech, op. cit., pp. 157-161 e ss. Veja ainda Abigail Levin, The Cost of Free Speech: Pornography, Hate Speech, and their Challenge to Liberalism, op. cit., pp. 39 e ss.

65 "Taking Rights Seriously", op. cit., p. 192; veja em geral pp. 192 e ss.

66 "Taking Rights Seriously", op. cit., p. 193; na tradução, "respeito à lei”: "Levando os Direitos a Sério", op. cit., p. 296.
} 
em termos de "direitos em competição, a saber, o direito moral da maioria de ter suas leis aplicadas, ou o direito da sociedade de manter o grau de ordem e segurança que deseja". 67

Não é difícil perceber que esse expediente argumentativo não está disponível uma vez assumida a noção de direitos no sentido forte. Contra este argumento, Dworkin apresenta as seguintes considerações. Para ele, a maioria ou "a sociedade" não podem ter direitos neste sentido porque, se tiverem, não fará sentido dizer que alguém possa opor interesses ao seu interesse mais geral. Disso não decorre, é claro, que os membros da maioria não possam ter direitos. Mas significa que subordinar a existência do direito, por exemplo, à liberdade de expressão, a que a sua existência e exercício beneficiem a maioria significa, como diz Dworkin, "aniquilá-lo" ${ }^{68}$. Citei há pouco trecho do autor em que ele imagina indivíduo que defende a liberdade de expressão até o ponto em que for "conveniente" para a sociedade ${ }^{69}$; da mesma forma que, para Dworkin, este indivíduo não toma a liberdade de expressão como um direito, aquele que subordina um direito à chancela da maioria ou de seus interesses gerais na verdade não trata o direito em questão em seu sentido forte. ${ }^{70}$

A conclusão desta reflexão de Dworkin é que direitos no sentido forte são sempre pessoais. Ele diz:

"Para preservá-los, precisamos reconhecer como direitos em competição somente aqueles pertencentes a outros membros da sociedade, tomados enquanto indivíduos. Precisamos diferenciar entre os 'direitos' da maioria enquanto tal, que não podem valer como justificação para invalidar [overruling] os direitos individuais, e os direitos pessoais dos membros da maioria, que podem ser levados em conta" ${ }^{\text {"71 }}$.

Dworkin então oferece um teste para saber se existe um direito de que seja aplicada uma norma que puna um ato de desobediência civil: há o direito se o indivíduo tiver o direito a que

\footnotetext{
67 "Levando os Direitos a Sério", op. cit., p. 297 (substituí "direitos concorrentes" por "direitos em competição" para traduzir "competing rights", e "sobretudo para" por "a saber" para traduzir "namely"), "Taking Rights Seriously", op. cit., p. 194; veja pp. 192 e ss. para as objeções.

68 "Taking Rights Seriously", op. cit., p. 194.

${ }^{69} \mathrm{O}$ trecho está em "Hard Cases", op. cit., p. 92.

70 "The existence of rights against the Government would be jeopardized if the Government were able to defeat such a right by appealing to the right of a democratic majority to work its will. A right against the Government must be a right to do something even when the majority thinks it would be wrong to do it, and even when the majority would be worse off for having it done. If we now say that society has a right to do whatever is in the general benefit, or the right to preserve whatever sort of environment the majority wishes to live in, and we mean that these are the sort of rights that provide justification for overruling any rights against the Government that may conflict, then we have annihilated the latter rights", "Taking Rights Seriously", op. cit., p. 194.

71 "Levando os Direitos a Sério", op. cit., p. 298 (substituí "direitos concorrentes" por "direitos em competição" para traduzir "competing rights") e acrescentei "dos membros" para adequar a tradução ao original, bem como acrescentei a palavra entre colchetes, que é do original em inglês; para o original, "Taking Rights Seriously", op. cit., p. 194, em trecho que segue imediatamente o fim do citado na última nota.
} 
a norma a ser aplicada fosse promulgada caso ela inexistisse ${ }^{72}$. Dworkin conclui que há o direito de que normas, por exemplo, que proíbem violência física sejam aplicadas, mas não há o direito correspondente em relação a normas que obrigam o alistamento militar. É que, sustenta o autor, indivíduos têm o direito, independentemente de comporem maioria, de que sejam promulgadas normas proibindo lesões corporais mas não têm o direito, independente de comporem maioria, de que sejam promulgadas normas obrigando o alistamento necessário a que se travem guerras ${ }^{73}$. É por isso que, para ele, não há um direito ao "princípio de respeito pelo direito" na extensão discutida acima, isto é, a ponto de se opor ao direito de desobediência civil que existe na hipótese de violação de direitos pessoais.

Há um exemplo na obra de Dworkin que ilustra o direito pessoal de membro da maioria que entra em conflito com direito pessoal de membro de minoria. Em "Hard Cases" Dworkin formula e responde a objeções à distinção entre princípios e políticas ${ }^{74}$. Uma das objeções consideradas pelo autor consiste em dizer que é possível construir um princípio em termos de uma política e vice-versa, o que apagaria a distinção ou pelo menos prejudicaria a sua utilidade $^{75}$. O exemplo imaginado pelo autor é de um defensor da segregação racial nas escolas norte-americanas que utiliza tanto um "argumento de política de que, em termos gerais, a mistura das raças provoca mais mal-estar geral do que satisfação",76, quanto um argumento de princípio que menciona ao risco à saúde e à integridade física daqueles que podem sofrer com os "conflitos" (riots) ${ }^{77}$ decorrentes do processo de dessegregação. ${ }^{78}$ Dworkin sustenta que, se um argumento puder ser substituído por outro, pouco significaria entender que o direito à igualdade dos negros segregados é forte a ponto de derrotar salvo os mais urgentes argumentos de política e de ceder somente contra argumentos de princípio. ${ }^{79} \mathrm{O}$ ponto do autor é que se

\footnotetext{
72 “Taking Rights Seriously”, op. cit., pp. 194-5

73 “Taking Rights Seriously", op. cit., pp. 194-5

74 "Hard Cases", op. cit., pp. 94 e ss.

75 "Hard Cases", op. cit., p. 96.

76 “Levando os Direitos a Sério", op.cit, p. 150 (substituí “argumento político" por "argumento de política” para traduzir "policy argument"), para o original, veja "Hard Cases", op. cit., p. 96.

77 "Levando os Direitos a Sério", op.cit., p. 150; no original, "Hard Cases", op. cit., p. 96.

78 “Casos Difíceis", op.cit., p. 151; para o original, veja "Hard Cases", op. cit., p. 96.

79 A tradução brasileira traduz "yield” por “ceder”, expressão que por vezes utilizo nesta dissertação para descrever a relação entre princípios e políticas em Dworkin: veja "O caso Farber: reporteres e informantes" in Uma questão de princípio. $2^{a}$ Ed. Tradução Luís Carlos Borges. Revisão técnica Gildo Sá Leitão Rios. São Paulo: Martins Fontes, 2005, p. 562; no original, “The Farber Case: Reporters and Informers" in A Matter of Principle, op. cit., p. 377 (em trecho citado no capítulo terceiro, abaixo). Veja ainda: "Suppose it is conceded that the right to equality between races is sufficiently strong that it must prevail over all but the most pressing argument of policy, and be compromised only as required by competing arguments of principle. That would be an empty
} 
frente ao direito à igualdade compreendido enquanto direito forte não puder ser oferecido argumento de política, mas puder ser formulado argumento de princípio que substitua o de política, talvez a distinção entre princípios e políticas precise ser repensada.

A resposta de Dworkin à objeção consiste em apontar para o seguinte: embora o argumento de princípio baseado em igualdade racial possa entrar em conflito com o argumento também de princípio baseado na segurança física dos indivíduos, isso não significa que este argumento seja tão forte quanto seria o argumento de política que lhe substituísse caso a dessegregação fosse recomendada por um argumento também de política, e não de princípio. Em outras palavras, se a dessegregação fosse uma questão de política, o objetor talvez tivesse maior sucesso pois o seu argumento de política talvez fosse mais convincente; mas a dessegregação é uma questão de princípio (é exigida pelo direito à igualdade racial), e embora ele também tenha um argumento de princípio (baseado nos riscos que a dessegregação traz à integridade física dos indivíduos), isso não significa que o sucesso seja o mesmo que ele alcançaria se à dessegregação opusesse argumentos de política, e não de princípio. O autor conclui:

"Podemos, portanto, admitir que o direito em competição à vida apresenta um argumento que se coloca contra o direito à igualdade, e ainda assim afirmar que o peso desse argumento é insignificante [of negligible weight]; forte o bastante, talvez, para retardar o avanço da dessegregação, mas não suficientemente forte para retardá-la muito". ${ }^{80}$

Os argumentos de política e de princípio que Dworkin atribui ao objetor imaginário ilustram, respectivamente, “direito" não-pessoal, isto é, interesse coletivo ou objetivo nãoindividualizado e direito pessoal, no sentido forte ou objetivo individualizado. O direito à vida possivelmente prejudicado pelos conflitos ocasionados pela dessegregação é possuído por

concession if arguments of principle could always be found to substitute for an argument of policy that might otherwise be made.", "Hard Cases", op. cit., p. 96.

80 "Casos Difíceis", op. cit., p. 151, acrescentei as palavras entre colchetes para indicar como constam no original; no original, "Hard Cases", op. cit., p. 96. O ponto de Dworkin é que uma questão de princípio não é transformada em questão de política mesmo que seja possível conceber argumento de política "transformável" em argumento de princípio, pois esta transformação não necessariamente mantém a cogência do argumento no cenário de política; ou seja, num cenário deste tipo, o argumento contra a dessegregação talvez fosse forte, mas sendo a dessegregação uma questão de princípio, apresentar o argumento de princípio análogo ao de política não tem o mesmo sucesso que apresentar o de política caso a questão não fosse de princípio.

Compare o exemplo da desegregação com a narrativa de Leon Tolstói, War and Peace. Trad. Louise Maude e Aylmer Maude, Foreword de Christopher Hong, Cambridge World Classics (edição kindle), 2010, Livro Onze, capítulo XXV, sobre discurso feito pelo personagem Rostopchin, governador de Moscou às vésperas da entrada do exércio comandado por Napoleão na cidade; o governador se dirige a uma turba ordenando a morte de um indivíduo condenado por traição. A meu ver, é hipótese em que a liberdade de expressão pode ser restrita justamente porque o argumento de princípio que apela à segurança e à vida aqui é muito forte, ao contrário do que ocorre no caso da dessegregação. Compare com "Why Academic Freedom?", op. cit., p. 259. Agradeço à Renata do Vale Elias por me ajudar a melhorar a exposição deste exemplo. 
todos os indivíduos independentemente de fazerem parte da maioria. No caso concreto, cedem frente ao direito à igualdade que exige a dessegregação. Por sua vez, o argumento de política baseado no desconforto da maioria é baseado, para usar uma expressão do autor, no "desejo comum de uma vasta maioria" ${ }^{\prime}$. Ou seja, para Dworkin, membros de maioria evidentemente têm direitos, mas a maioria ela mesma nunca os tem.

Outro ponto relevante à compreensão do significado de direitos em Dworkin diz respeito ao significado da sua violação. Em artigo intitulado "Principle, Policy, Procedure" e publicado em A Matter of Principle, Dworkin elabora a noção de direito em sentido forte de maneira interessante e relevante aos meus propósitos neste capítulo. $\mathrm{O}$ autor, neste trabalho, tem o objetivo de apresentar interpretação dos direitos processuais. Este ponto não é especificamente importante a esta pesquisa. Mas é relevante compreender a explicação que Dworkin dá à ideia de direito no sentido forte a partir do que chama de "fator de injustiça" ou "moral harm" (expressão que prefiro não traduzir ${ }^{82}$ ). Esta ideia é utilizada pelo autor para explicar o tipo específico de "harm" que sofre um indivíduo quando um direito seu é violado. Dworkin diz:

\begin{abstract}
"Os direitos politicos, como o de não ser condenado se inocente, funcionam principalmente como instruções ao governo, e podemos ser tentados a pensar que não há nada de errado quando o governo observa a instrução e comete um erro sem culpa. Mas isso é falso, pois a violação de um direito constitui um tipo especial de dano [harm], e as pessoas podem sofrer esse dano mesmo quando a violação é acidental. Devemos distinguir entre o que podemos chamar de dano simples [bare harm] que uma pessoa sofre por meio da punição, seja essa punição justa ou injusta - por exemplo, sofrimento, frustração, dor ou insatisfação de desejos que ela sofre só por perder sua liberdade, ser espancada ou morta -, e os danos adicionais que se pode dizer que ela sofre sempre que sua punição é injusta, pelo simples fato dessa injustiça. Chamarei estes últimos de 'fator de injustiça' em sua punição ou seu dano 'moral'[ 'moral' harm]. O dano que alguém sofre pela punição pode incluir ressentimento, escândalo [outrage] ou alguma emoção similar, e é mais provável que inclua alguma emoção desse tipo quando a pessoa punida acredita que a punição é injusta, quer seja quer não. Qualquer emoção desse tipo é parte do dano simples, não [d]o fator de injustiça. Esta é uma noção objetiva que pressupõe que alguém sofre um dano especial [special injury] quando tratado injustamente, quer tenha conhecimento disso ou se importe com isso ou não, mas que não sofre esse dano quando não é tratado injustamente, mesmo acreditando que está sendo e realmente se importe com isso. É uma questão empírica se alguém que é punido injustamente sofre mais danos simples quando sabe que as autoridades cometeram um erro do que quando sabe que
\end{abstract}

\footnotetext{
81 “Levando os Direitos a Sério", op. cit., p. 199; para o original, veja "Taking Rights Seriously", op. cit., p. 195: trata-se de trecho em que o autor discute a distinção dos direitos pessoais e não pessoais em relação à desobediência (veja pp. 195-6).

${ }^{82}$ A tradução brasileira fala em "fator de injustiça” para traduzir "injustice factor" (opção que adoto) e "dano moral": "Princípio, política, processo", in Uma questão de princípio, op. cit., p. 117. Esta última é expressão que, na dogmática do direito brasileiro, designa noção distinta daquela que Dworkin pretende expressar por "moral harm" e que, suspeito, cada vez mais se distancia da ideia de injustiça que, para o autor, está pressuposta na violação de um direito. Também por isso prefiro utilizar a expressão em inglês mesmo.
} 
elas deliberadamente armaram-lhe uma cilada. Mas é um fato moral, se a suposição do último parágrafo estiver certa, que ofator de injustiça em seu dano é maior no segundo caso" ${ }^{\text {"83 }}$.

O que se vê é que, para Dworkin, a violação de um direito dispensa conhecimento, incômodo ou queixa por parte de seu titular, e - e aqui temos um ponto bastante relevante dispensa o tipo de resultado sensível que muitas vezes se espera, seja na forma de dano físico, seja na forma de sofrimento psíquico efetivo ou potencial. Estas são características próprias do que Dworkin chama de "bare harm”, desnecessárias à violação de um direito no sentido forte, noção normativa cuja violação é uma categoria objetiva ${ }^{84}$, moral, irredutível a aspectos subjetivos eventualmente presentes em razão da violação do direito. Estes aspectos não são necessários à violação de um direito e, portanto, quando ocorrem não são eles que a caracterizam $^{85}$.

Talvez o leitor familiarizado com os trabalhos de Ronald Dworkin sinta falta de maior atenção à natureza antiutilitarista dos direitos no pensamento do autor. Afinal, ao definir direitos em “Taking Rights Seriously”, Dworkin menciona que "utilidade geral” é em geral justificação suficiente a restrições de liberdade, mas insuficiente justamente quando há direito a ser considerado ${ }^{86}$, e posteriormente diz que o sentido forte de direito "pode ser chamado de

\footnotetext{
83 "Princípio, política, processo", op. cit., p. 117, acrescentei entre colchetes as palavras do original para indicar como constam no original (veja em especial o "'moral' harm", como se traduz "dano "moral"; veja nota anterior para minha preferência por não traduzir a expressão), acrescentei o "[d]" e inseri os itálicos; no original, Principle, Policy, Procedure", op. cit., p. 80, acrescentei os itálicos. Na p. 76, Dworkin define "right in the strong sense" como o direito no sentido que "would provide an argument of principle requiring disclosure" (no caso, ele discute o suposto "right to know" do público acerca de informações sobre companhias de propriedade do Estado e, nesta página, Dworkin cita páginas de "Taking Rights Seriously", op. cit.) ou, depois, como o direito que "acts as a trump over the balance of bare gains and losses that forms na ordinary utilitarian calculation" (p. 89). Direitos políticos da citação da p. 80 são, naturalmente, direitos no sentido forte, e exigem, portanto, a noção de fator de injustiça ou de moral harm que, para o autor, não estão disponíveis numa sociedade que explique direitos processuais de maneira utilitarista (o que Dworkin chama de "cost-efficient society", veja pp. 79 e ss, esp. 79, pp. 81, 87 etc.). A ideia de "moral harm" recebe referência de Dworkin em pelo menos uma obra posterior: veja "Why Academic Freedom?" in Freedom's Law, op. cit., p. 251 (veja n. 5, p. 380) (o artigo anterior é citado em Justice for Hedgehogs, op. cit., p. 372, n. 8 na p. 482, com referência a Robert Bone, comentador do artigo de $A$ Matter of Principle). Compare com "Do We Have a Right to Pornography?", op. cit., pp. 346-7.

${ }^{84}$ Dworkin diz: “(...) moral harm is an objective notion, and if someone is harmed (or, in the alternative language, if there is a moral loss in the situation) when he is punished though innocent, then his moral harm occurs even when no one knows or suspects it, and even when - perhaps especially when - very few people very much care", "Principle, Policy, Procedure", op. cit., p. 81 (veja ainda o trecho da p. 80 citado acima).

${ }^{85}$ Compare com a defesa da proibição de discurso de ódio não como uma questão de prevenção de ofensa, mas de dignidade em Waldron, The Harm in Hate Speech, op. cit., esp. cap. 5, esp. pp. 105-116, 118 e ss.

86"Levando os Direitos a Sério", op. cit., p. 293, em trecho citado acima (para o original, veja "Taking Rights Seriously", op. cit., p. 191).
} 
conceito antiutilitarista de um direito" ${ }^{\sharp 7}$. Inclusive, logo em seguida, Dworkin parece supor que "interesse geral" ou outras expressões necessariamente caracterizam referência a visão utilitarista. ${ }^{88}$ Que direitos em Dworkin são “anti-utilitaristas" não pode ser negado, mas fato é que em outros pontos a noção de direitos fortes para o autor se contrapõe a considerações de benefício coletivo que não são necessariamente utilitaristas. Direitos em Dworkin são mais amplos: “(...) direitos politicos são trunfos sobre outras justificações que, de outro modo, seriam adequadas para a ação política" ${ }^{89}$. Essas justificações podem, mas não precisam, ser utilitaristas. ${ }^{90}$ Efetivamente, direitos em Dworkin são anti-utilitaristas, mas, por serem muito mais que isto, é preciso tomar cuidado para não tomar uma característica da categoria como

87 “Que Direitos Temos?", in Levando os Direitos a Sério, op. cit., p. 414; para o original, veja "What Rights Do We Have?", op. cit., p. 269.

${ }^{88}$ Ele diz: "The vast bulk of the laws which diminish my liberty are justified on utilitarian grounds, as being in the general interest or for the general welfare (...)","What Rights Do We Have?", op. cit., p. 269.

${ }^{89}$ Dworkin, Justiça para Ouriços. Tradução Pedro Elói Duarte, Revião Joana Portela, Coimbra: Almedina, 2012, p. 337, nota omitida; Justice for Hedgehogs, p. 329, nota omitida. Pouco antes, após mencionar outros usos de "direitos", Dworkin diz: "Sometimes (...) people use the idea of a political right in a stronger and more discriminating way: to declare that some interests particular people have are so important that these interests must be protected even from policies that would indeed make people as a whole better off", p. 329, nota omitida. Veja ainda o seguinte trecho sobre "direitos humanos" e seus variados usos: "I use the phrase in a stronger way that matches the strong sense of a political right: to designate a trump". p. 332. Anteriormente, ao defender interpretação do valor da igualdade que não exclui ações de discriminação reversa em universidades, Dworkin ofereceu pelo menos dois sentidos em que a comunidade pode ser "better off", a saber, um sentido utilitarista e outro ideal. ("Reverse Discrimination", in Taking Rights Seriously, op. cit., p. 232, por exemplo. "[A community] (...) may be better off in a utilitarian sense, that is, because the average or collective level of welfare in the community is improved even though the welfare of some individuals falls. Or it may be better off in an ideal sense, that is, because it is more just, or in some other way closer to an ideal society, whether or not average welfare is improved", p. 232. Veja ainda "What Rights Do We Have?" (op. cit., p. 274) em que o autor entende direitos como trunfos: "Rights, I have argued elsewhere, are best understood as trumps over some background justification for political decisions that states a goal for the community as a whole", "Do We Have a Right to Pornography?", in A Matter of Principle, op. cit., p. 359, nota omitida (a nota - n. 15, p. 414 - faz referência a Taking Rights Seriously, op. cit.). Veja Caio Moysés de Lima, O Império dos Direitos: Lei e Autoridade Política em Ronald Dworkin, op. cit., p. 27, n. 49 para levantamento dos pontos dos diferentes trabalhos em que Dworkin defende esta ideia (veja ainda pp. 39 e ss., pp. 63-8 e pp. 155, 171). Veja Yowell em"A Critical Examination of Dworkin's Theory of Rights", op. cit., esp. pp. 93 e ss., 130-1, 133 (o autor susenta que Dworkin defendeu duas teorias diferentes dos direitos nas suas primeiras publicações).

${ }^{90}$ Ele diz claramente: “(...) not every claim about general interest appeals to an utilitarian argument. We might think, for example, that even if capital punishment decreases murder, and therefore contribute to the net gain in happiness, it is still unjustified because the moral blight that official killings imposes on the community outweighs the suffering caused by a small increase in murders", Justice for Hedgehogs, op. cit., p. 329. Veja ainda "Do We Have a Right to Pornography?", op. cit., pp. 359 e ss. (em especial, "There are many different theories in the field about what makes a community better of on the whole; many different theories, that is, about what the goal of political action should be. One prominent theory (or rather group of theories) is utilitarianism in its familiar forms, which suppose what the community is better off if its members are on average happier or have more of their preferences satisfied.", p. 359). 
sua definição: direitos são mais que antiutilitaristas na teoria de Dworkin e, de fato, não é aí que reside seu conceito fundamental ${ }^{91}$.

Assim, eu gostaria de concluir esta seção ressaltando o aspecto pessoal da ideia de direitos defendida por Dworkin, a meu ver característica mais fundamental ao sentido forte de direitos do que o fato de que, salvo exceções, sobrevivem a considerações utilitaristas que se lhe oponham. É que, para Dworkin, como visto, direitos são descritos por princípios, que são objetivos individualizados, enquanto objetivos não-individualizados são políticas, que não se reduzem a padrões utilitaristas. Em qualquer hipótese, trata-se de justificações não individualizadas que, salvo exceções, não sobrevivem a conflitos com direito(s). A meu ver, a característica fundamental da noção dworkiniana de direitos, e que precisa ser considerada na análise da defesa proposta por Dworkin à liberdade de expressão enquanto um direito, é que direitos em seu sentido forte são individuais, possuídos pelo seu titular contra o Estado independentemente do tipo da consideração não-individual que se lhe contraponha. ${ }^{92}$

É claro que esta interpretação dos direitos não se fundamenta a si própria. Ou seja, não é porque esse é um sentido em que se fala em direitos que existem direitos neste sentido. Como veremos mais à frente neste capítulo, Dworkin está ciente disto e naturalmente oferece justificações aos direitos que inclui em sua teoria política. Esta dissertação se concentra justamente nas defesas que o autor oferece a um desses direitos, a saber, ao direito à liberdade de expressão.

\footnotetext{
${ }^{91}$ Compare com Yowell, “A Critical Examination of Dworkin's Theory of Rights”, op. cit., pp. 94-5 e itens I e II.

${ }^{92}$ Sobre direitos de grupo, Dworkin diz o seguinte ao discutir a ideia de "direito político": "It is controversial among political philosophers, moreover, whether groups of individuals have political rights - whether we can properly speak of the right of an ethnic minority within a larger political community, for instance. See e.g., Will Kymlicka, Liberalism, Community, and Culture (Oxford: Oxford University Press, 1989). My own view is that only individuals have political rights, though these rights include a right not to be discriminated against because they are members of some group and may also include a right to benefits in common with other members of their group - a right for instance, that legal proceedings be available in their group's language. However, I shall not pursue this question here. My argument holds equally for group political rights if there are any.", Justice for Hedgehogs, op. cit., pp. 473-4, texto da nota 1 à p. 329, itálicos no original (veja ainda "Hard Cases", op. cit., p. 91, n. 1 e "The Farber Case: Reporters and Informers", op. cit., p. 375). Compare com "Equality of Resources", op. cit., pp. 113-117 e "Is the Press Losing the First Amendment?", op. cit., pp. 387-9. Veja ainda Waldron em The Harm in Hate Speech, op. cit., pp. 56-7, 60-1, 122-3.
} 


\section{Seção 2. Abordagens de direitos}

As observações sobre direitos fortes feitas por Dworkin e expostas na seção anterior não são compreendidas pelo autor como argumentos a favor de direitos específicos ${ }^{93}$. Ou seja, são considerações "hipotéticas", pois consistem em dizer que, se houver determinado direito, possuí-lo significa ser seu titular no sentido forte, e disso então seguem as consequências apontadas pelo autor, entre elas não ser possível que se lhe oponham "direitos da maioria"94. Entretanto, se não oferecem uma teoria de quais direitos existem, estas considerações ao menos oferecem guia sobre como tratar direitos. Na seção anterior, apontei, por exemplo, o argumento formulado por Dworkin segundo o qual falar em direito da maioria é incompatível com o reconhecimento de direitos no sentido forte. Se é verdade que a noção dworkiniana de direitos, bem como a distinção oferecida pelo autor entre princípios e políticas, é "formal" dado seu propósito explícito, declarado pelo próprio Dworkin, de compreender se determinada teoria política adota certo direito e não de defender a existência de determinado direito ${ }^{95}$, é também verdade que entender direitos no sentido forte, individualizado, exclui diversas considerações da linguagem aceitável ao debate em torno de quais direitos existem.

Nesta seção analiso as consequências da noção dworkiniana de direito no sentido forte às situações de conflitos entre direitos e de restrições a direitos em geral. Para tanto, naturalmente, é necessário entender quais são as situações em que existem efetivamente direitos em conflito, e não somente considerações que se contrapõem a determinado direito, mas que, à luz da noção de direito no sentido forte, não são capazes de limitá-lo.

A hipótese de "direito da maioria", segundo Dworkin, é uma dessas situações de falso conflito. Outras são, segundo o autor, situações em que, por exemplo, há especulação sobre as consequências de reconhecimento de direitos. Dworkin discute o tema também em "Taking

\footnotetext{
93 “Taking Rights Seriously”, op. cit., p. 197, pp. 190-1; veja também "Hard Cases”, op. cit., pp. 90-1.

${ }^{94} \mathrm{O}$ autor diz: "The argument so far has been hypothetical: if a man has a particular moral right against the Government, that rights survives contrary legislation or adjudication", "Taking Rights Seriously", op. cit., p. 197. Veja outras referências na nota acima. Compare com Caio Moysés de Lima, O Império dos Direitos: Lei e Autoridade Política em Ronald Dworkin, op. cit., pp. 91-9, esp. p. 95. Veja ainda Yowell, “A Critical Examination of Dworkin's Theory of Rights", op. cit., pp. 95-6.

${ }^{95}$ Dworkin, em "Hard Cases", op. cit., ao distinguir direitos e "goals", diz que "I shall make, that is, a formal distinction that does not attempt to show which rights men and women actually have, or indeed that they have any at all. It rather provides a guide for discovering which rights a particular political theory supposes men and women to have. The formal distinction does suggest, of course, an approach to the moral fundamental question: it suggests that we discover what rights people actually have by looking for arguments that would justify claims having the appropriate distributional character. But the distinction does not itself supply any such arguments", pp. 90-1. Veja ainda Yowell, “A Critical Examination of Dworkin's Theory of Rights”, op. cit., pp. 94-5.
} 
Rights Seriously": ele imagina o argumento segundo o qual o reconhecimento do direito à desobediência “(...) não levará simplesmente a um declínio marginal do respeito à lei, mas a uma crise de ordem. Os cidadãos podem optar por obedecer somente àquelas leis que eles pessoalmente aprovão e isso é anarquia." 96

Existe uma irracionalidade particularmente desesperadora (e talvez ocasionalmente patológica) na antecipação do futuro caracterizada pela ação baseada no possível. É que há tantos eventos possíveis que é impossível agir exclusivamente de acordo com possibilidades: distintos eventos, ambos ou todos possíveis, indicarão cursos de conduta incompatíveis entre si. O que fazer? Quem quer que se baseie por tudo aquilo que é possível deixa de agir. À ação alguma seletividade é indispensável, e neste ponto reside aspecto de arbitrariedade que, para usar a expressão de Dworkin, "aniquila” direitos ${ }^{97}$. E esta arbitrariedade é insuperável se tudo o que importa é aquilo que é possível porque a simples ideia de possibilidade é incapaz de oferecer qualquer discriminação. Não é a simples possibilidade da ocorrência de evento que se pretende evitar que justifica a restrição de direito, mas a seleção deste evento possível entre tantos outros, muitos deles, supõe-se, que não se pretendem evitar ou, ao menos, cujo acontecimento não é tão trágico a ponto de justificar limitação de direito. A instituição de direitos no sentido forte é incompatível com a especulação sobre o futuro ${ }^{98}$; algo mais limitado precisa ser oferecido como critério de limitação dos direitos. Como diz Dworkin, o argumento por ele imaginado (citado cima) “(...) ignora a distinção primitiva entre o que pode acontecer e o que irá acontecer" ${ }^{\prime \prime 9}$.

O critério oferecido por Dworkin é baseado na obra de um importante juiz norteamericano: "Como disse Learned Hand, devemos descontar a gravidade do mal que nos ameaça da probabilidade de sua concretização" ${ }^{100}$. Assim, quanto mais grave o evento, menor precisa ser a probabilidade de sua ocorrência para que se justifique (alguma) restrição de direito. Ocorre que pouco antes deste trecho Dworkin faz observação um pouco distinta e a

\footnotetext{
96 "Levando os direitos a sério", op. cit., pp. 299-300; no original,“Taking Rights Seriously”, op. cit., p. 195. Veja ainda "Appendix: A Reply to Critics", op. cit., pp. 354-5.

97 "Taking Rights Seriously", op. cit., pp. 194, 195.

98 "Levando os direitos a sério", op. cit., p. 300; no original, “Taking Rights Seriously”, op. cit., pp. 194 e ss., 201 e ss.

99 "Levando os direitos a sério", op. cit., p. 300; no original, "Taking Rights Seriously", op. cit., pp. 195.

100 "Levando os direitos a sério", op. cit., p. 300, nota do tradutor omitida; no original, "Taking Rights Seriously", op. cit., pp. 195. Veja Yowell, "A Critical Examination of Dworkin's Theory of Rights”, op. cit., pp. 96-7.
} 
meu ver mais cogente. Ao sustentar que, como visto acima, ao objetor da desobediência não é dado apresentar sua visão em termos de direitos da maioria, o autor diz o seguinte:

“(...) o conservador não pode levar adiante seu argumento com base nos direitos concorrentes, mas talvez ele queira recorrer a um outro tipo de fundamento. Um governo, poderia ele argumentar, pode ter razão em restringir os direitos pessoais dos cidadãos numa situação de emergência, ou quando uma grande perda puder ser evitada, ou talvez quando algum benefício de grande importância puder ser realmente assegurado. Se a nação estiver em guerra, uma política de censura pode justificar-se mesmo que infrinja o direito de dizer o que se pensa em questões politicamente controversas. A emergência, porém, deve ser genuína. Deve existir aquilo que Oliver Wendell Holmes descreveu como um perigo claro e iminente, [clear and present danger], e esse perigo deve ser de vulto [of magnitude]. ${ }^{101}$

Este critério me parece mais cogente porque é intuitivo que, levados os direitos a sério, é preciso que o cenário cuja prevenção justifique restrição seja grave, e não somente provável ainda que não grave. O critério oferecido por Dworkin baseado em Learned Hand se compromete com a compensação da suavidade por alta probabilidade; o critério oferecido por Dworkin baseado em Oliver Holmes, entretanto, acentua o fato de que a restrição de um direito com base em evento que se pretenda evitar deve incluir ocorrência grave, uma "emergência", que seja, além disso, "claro e iminente"102. Não existe compensação possível:

101 "Levando os direitos a sério", op. cit., p. 299, acrescentei entre colchetes as palavras do original; o original, "Taking Rights Seriously", op. cit., pp. 195; veja ainda Life's Dominion, an Argument about Abortion, Euthanasia, and Individual Freedom. New York: Vintage Books, edição vintage, 1994, pp. 104-5. Observação importante: como relata Kent Greenawalt, "The famous language of 'clear and presente danger' was first used in Justice Oliver Wendell Holmes's 1919 opinion for the Supreme Court in Schenk v. United States, which upheld a conviction under the Espionage Act. He said, 'The question in every case is whether the words used are used in such circumstances and are of such a nature as to create a clear and present danger that they will bring about the substantive evils that Congress has a right to prevent.' For most of the Supreme Court Justices who then accepted this language, and perhaps for Holmes himself, the formula was not very protective of speech.", Fighting Words: Individuals, Communities, and Liberties of Speech,. Princeton: Princeton University Press, 1995, p. 17, notas omitidas, itálicos no original. Greenawalt em seguida relata as mudanças neste padrão promovidas pelo próprio Holmes e por Louis Brandeis e que garantiram maior proteção à liberdade de expressão (veja pp. 17 e ss.). Importante desenvolvimento é a seguinte ideia, adotada, como explica Greenawalt, pela Suprema Corte dos EUA na década de 1960: "According to this Brandenburg test, iminente lawless action must be the speaker's objective and be actually likely to happen" (p. 18, itálicos no original). Veja ainda Barent, Freedom of Speech, op. cit., p. 50, pp. 157 -8 para o caso de 1919 (veja p. 158 para a mesma citação selecionada por Greenawalt) e pp. 50, 1656, 171-2, 183-4, para o caso Brandenburg. Veja também Anthony Lewis, Freedom for the Thought that we Hate, op. cit., cap. 3, esp. pp. 26 e ss. para o teste de Holmes e p. 124 para o caso Brandenburg. Entre nós, veja Júlio César Casarin Barroso Silva. Democracia e Liberdade de Expressão: Contribuições para uma interpretação política da liberdade de palavra. Tese de Doutorado. Faculdade de Filosofia, Letras e Ciências Humanas, Universidade de São Paulo. Orientador: Álvaro de Vita. São Paulo, 2009, esp. pp. 72 e ss., pp. 94 e ss. Veja ainda a Nota do Tradutor em Dworkin, "O Modelo de Regras I, op. cit., p. 44. Para crítica, veja Waldron em The Harm in Hate Speech, op. cit., pp. 96-7. Veja, por fim, a resposta de Dworkin a críticos "Ronald Dworkin replies", op. cit., e "Devaluing Liberty", p. 7 (terceira coluna da página). Veja "Why Must Speech be Free?", op. cit., p. 198, "Pornography and Hate", op. cit., p. 219, "Why Academic Freedom?", op. cit., p. 259.

102 "Levando os direitos a sério", op. cit., p. 299, em trecho citado acima; no original, "Taking Rights Seriously", op. cit., pp. 195. 
nem o evento provável mas suave nem o grave mas improvável justificam restrição de direito. $^{103}$

O critério dworkiniano-homesiano de restrição de direitos é mais fiel ao sentido forte de direitos não somente por ser mais demandante, mas também porque o dworkiniano-handiano é muito frouxo e leva a restrições que Dworkin claramente pretende rejeitar, como aquelas segundo a qual “(...) a comunidade ficaria marginalmente melhor com a aplicação estrita da lei (...) ${ }^{\prime 104}$, por exemplo. O ponto é que o primeiro critério explica melhor a rejeição de Dworkin aos argumentos por ele mencionados; e também explica melhor a interpretação que Dworkin dá ao direito à liberdade de expressão, como exponho no capítulo terceiro, abaixo. (Quanto ao tema da desobediência civil, Dworkin sustenta ser bem possível "que a tolerância aumentará o respeito pelas autoridades e pelo conjunto das leis que elas promulgam ou que pelo menos retardará a taxa de crescente desrespeito". ${ }^{105}$ A conclusão do autor é que, sendo ambos os cenários possíveis, a simples menção à possibilidade de "anarquia" não é o bastante para restringir eventual direito à desobediência civil).

A apresentação da incompatibilidade entre especulação sobre as consequências do exercício de direitos e leva-los a sério é extremamente importante ao direito à liberdade de expressão no pensamento de Ronald Dworkin. É corriqueiro que se pretendam proibir o

\footnotetext{
${ }^{103}$ Greenawalt relata o seguinte: "During the 1930s and 1940s 'clear and present danger' emerged as the critical test for subversive advocacy and as the standard for a wide range of free speech problems. Its 'reformulation' by a plurality in Dennis v. United States, a post-war prosecution of leaders of the American Communist Party, represented a severe setback for free speech. Under this standard, a court was to ask if 'the gravity of the 'evil,' discounted by its improbability, justifies such invasion of free speech as is necessary to avoid the danger.' This language allowed speech to be punished if it posed some threat of a very great danger in a rather distant future. As other Justices pointed out, American courts were hardly in a position to estimate how likely it was that domestic Communist speech would contribute to a violent revolution many years hence. Justice Feliz Frankfurther, concurring in the result, urged a 'candid and informed weighing of the competing intersts' in free speech and national security. But any potention this 'ad hoc' balancing approach might have had to provide serious judicial scrutiny was surrendered by a later part of the opinion, which said that Congress's judgment in adjusting the interests should be set aise 'only if there is no reasonable basis for it', Fighting Words: Individuals, Communities, and Liberties of Speech, op. cit., p. 18, notas omitidas, itálicos no original. Em outras palavras, algo parecido com o teste de Hand foi utilizado para interpretar o teste de Holmes. Barendt, por exemplo, aponta que o teste do "clear and present" danger é justamente um mecanismo de diminuir os riscos trazidos pelo "balancing process" (veja Freedom of Speech, p. 50). Trata-se não de motivo para indistingui-los: pelo contrário, justamente pelos problemas apontados por Greenawalt e pelas razões formuladas por Dworkin contra o que chama de "balancing model", o teste de Holmes é preferível, ainda que ele mesmo, como mencionado em nota acima, tenha inicialmente servido para restringir a liberdade de expressão e ainda que, como aponta Barendt, alguns pretendam utilizá-lo não para abandonar, mas para aplicar uma espécie de "balancing".

104 "Levando os direitos a sério", op. cit., p. 300; para o original, "Taking Rights Seriously", op. cit., pp. 196.

105 "Levando os direitos a sério", op. cit., p. 300; para o original, "Taking Rights Seriously", op. cit., pp. 196; veja pp. 195-6.
} 
discurso de ódio, a pornografia pesada e outros exemplos em razão da contribuição que supostamente são capazes de dar a ações violentas. Este, é claro, é um tema que legitimamente faz parte do debate. Por ora vale apontar a limitação, própria do respeito aos direitos no sentido forte, à imaginação de situação futura que contemple esses tipos de discurso: neste ponto, o critério dworkiniano-holmesiano fornece esta limitação.

Dworkin, entretanto, não oferece simplesmente considerações que, além de hipotéticas, são negativas, isto é, indicam quais atitudes frente a direitos os “aniquilam” e que, portanto, não devem ser adotadas. É que ele, além de ser especialmente avesso a um modelo de direitos que chama de "balancing", propõe um modelo diferente ao salientar os defeitos de lidar com direito nos termos defendidos pelo modelo que critica. Exponho estes modelos a seguir.

Dworkin expõe o modelo de "balancing", traduzido como "modelo do balanceamento""106, como uma elaboração a partir da “(...) confusão entre direitos da sociedade e direitos dos membros da sociedade" ${ }^{\text {107, }}$, confusão esta exposta na seção anterior, e que consiste em considerar a própria maioria, ou outro grupo ele mesmo, como possuidor de direitos $^{108}$. Para Dworkin, somente indivíduos, membros de grupos ou não, podem ser considerados direitos no sentido forte. ${ }^{109} \mathrm{O}$ modelo do balanceamento é caracterizado pela visão segundo a qual qualquer equívoco na adjudicação de direitos - tanto para "infringir" quanto para "inflar um direito" - é de mesma gravidade ${ }^{110}$. Se a maioria tem direitos, é natural que o exercício de qualquer direito pessoal que a prejudique seja sopesado com os interesses coletivos representados pelos direitos da maioria: segundo o autor, este modelo

“(...) recomenda que se busque o equilíbrio [striking a balance] entre os direitos do indivíduo e as exigências da sociedade como um todo. Se o Governo infringir um direito moral (por exemplo, ao definir o direito à liberdade de expressão de forma mais restrita do que o exigido pela justiça), terá cometido um erro contra o indivíduo. Por outro lado, se o governo inflar um direito (definindo-o mais amplamente do que o exigido pela justiça), estará privando a sociedade de algum benefício geral, como o da segurança nas ruas, pois não há razão para negar-lhes isso. Assim, um engano em uma direção é tão

\footnotetext{
106 “Taking Rights Seriously”, op. cit., pp. 302 e ss.. A tradução ("Levando os direitos a sério”, op. cit.) fala em "equilíbrio" (p. 303, por exemplo). Prefiro "balanceamento" ou análogo, como consta em "Liberdade de expressão, política e as dimensões da democracia”, in Virtude Soberana, op. cit., p. 516 (por exemplo). Veja ainda "Devaluing Liberty", op. cit., e "It is absurd to calculate human rights according to a cost-benefit analysis" op. cit.. Veja ainda capítulo terceiro desta dissertação. Veja ainda "It is absurd to calculate human rights according to cost-benefit analysis", The Guardian, 24 de maio de 2006, disponível em http://www.theguardian.com/commentisfree/2006/may/24/comment.politics, último acesso em 02.11.2013.. Em Waldron, The Harm in Hate Speech, op. cit., veja pp. 145-6.

107 "Levando os direitos a sério”, op. cit., p. 306; no original, “Taking Rights Seriously”, op. cit., p. 199.

108 "Taking Rights Seriously", op. cit., p. 194.

109 “Taking Rights Seriously”, op. cit., p. 194-5.

110 "Levando os direitos a sério", op. cit., p. 303; no original, "Taking Rights Seriously", op. cit., p. $197-8$.
} 
sério quanto um engano em outra. $\mathrm{O}$ governo deve buscar o meio-termo: equilibrar [to balance] os direitos gerais e pessoais, concedendo a cada um o que lhe é devido"111

Deste definição do modelo decorre que o custo de um direito seja levado em consideração na decisão sobre seu reconhecimento de modo tal que, no exemplo do autor, debates políticos não-barulhentos gozem de maior proteção do que protestos incômodos. ${ }^{112}$ É intuitivo que o custo da prática de determinada conduta seja incluído no cálculo necessário à decisão sobre sua permissão. Por que tolerar os congestionamentos provocados pelos protestos em grandes avenidas ou rodovias ou o incômodo provocado por espetáculos musicais ${ }^{113}$ Por que tratar da mesma maneira o debate civilizado, republicano e educado e a grosseria capaz de ofender?

Em razão dos fundamentos que enxerga na prática de direitos, Dworkin rejeita o modelo do balanceamento. As demandas da sociedade caracterizadas como direitos no modelo do balanceamento são interesse coletivo caracterizados, na linguagem de "Hard Cases"114, como objetivos políticos não-individualizados (políticas) e, portanto, não são capazes de restringir direitos, objetivos individualizados. ${ }^{115}$ Os "custos" de direitos no sentido forte só serão relevantes à fixação de sua extensão se eles mesmos forem corretamente caracterizados como direitos no sentido forte; um objetivo individualizado só cederá frente a outro objetivo individualizado, e não frente a objetivo não-individualizado. A posição do autor quanto à caracterização destes “custos” é, portanto, consequência da noção de direito adotada por

\footnotetext{
${ }^{111}$ Levando os direitos a sério", op. cit., p. 303, itálicos da tradução, inseri as palavras do original entre colchetes e substituí "equilibrar o bem-estar geral e os direitos individuais" como tradução de "to balance the general and personal rights" pela opção que consta na citação; no original, "Taking Rights Seriously", op. cit., p. 197-8, itálicos no original. Veja também O Império dos Direitos: Lei e Autoridade Política em Ronald Dworkin, op. cit., esp. pp. 91 e ss. e Yowell, "A Critical Examination of Dworkin's Theory of Rights", op. cit., pp. 96 e ss. sobre o modelo rejeitado por Dworkin e a liberdade de expressão - Yowell concluí que a posição de Dworkin sobre direitos "is a balancing test", p. 98, itálico no original (veja ainda p. 105). Waldron defende aplicação do que chama de "balancing approach" à questão do discurso de ódio (The Harm in Hate Speech, op. cit., p. 145, entre outros).

112 "Taking Rights Seriously, op. cit., p. 198 (Dworkin fala em "noisy demonstrations" e em "calm political discussion", p. 198).

${ }^{113}$ BRASIL, Câmara Municipal de São Paulo. Projeto de Lei 01-00002/2013 do Vereador Conte Lopes (PTB), Publicado DOC 06/02/2013, p. 75. O projeto tem a seguinte descrição: "Proíbe a utilização de vias públicas, praças, parques e jardins e demais logradouros públicos para realização de bailes funks, ou de quaisquer eventos musicais não autorizados e dá outras providências". A demanda de autorização para realização de "quaisquer eventos musicais" é, a meu ver, violação da liberdade de expressão que só é explicável pelo tipo de raciocínio que Dworkin critica sob a ideia de "balancing model" porque é absurdo supor que a maioria tem o direito de decidir, por meio da administração pública, as hipóteses em se pode produzir música em público (o que é diferente de dizer que qualquer evento, independentemente das suas características, possa se realizar em qualquer luga e a qualquer hora, independentemente de autorização).

${ }_{114}^{114}$ Dworkin, op. cit.

115 "Hard Cases", op. cit., pp. 90 e ss.; veja seção anterior.
} 
Dworkin. A adoção de um modelo em detrimento de outro não significa somente optar por uma atitude frente a direitos cuja existência se supõe: significa também uma atitude quanto ao que significam direitos, qual a sua importância e, particularmente relevante, o que é devidamente caracterizado como um direito. Se maiorias não têm direitos, e se o simples "custo" de um direito não é ele mesmo outro direito, é natural que o modelo do balanceamento seja rejeitado.

$\mathrm{O}$ autor discute o modelo que rejeita e aquele que defende junto de situação prática, real e extrema. Parece plausível aplicar o modelo do balanceamento sobretudo a casos complexos, em que considerações apontam para soluções distintas; é que, como Dworkin diz,

"Há ampla concordância quanto a certos casos cristalinos [clear cut cases]. Quase todos os que acreditam nos direitos admitiriam, por exemplo, que um homem tem o direito moral de expressar suas idéias, de modo não provocativo, sobre questões relativas à política e que esse é um direito importante que o Estado deve empenhar-se ao máximo em proteger. Mas há grande controversia quanto aos limites de tais direitos paradigmáticos." $" 116$.

Dworkin apresenta como exemplo um caso nos EUA que trata da liberdade de expressão: “(...) o célebre processo contra Os Sete de Chicago (...)"117. Neste caso, explica o autor, indivíduos foram acusados de ir de um estado a outro para provocar "distúrbios públicos"118; ele acrescenta ainda: “ (...) os réus no processo de Chicago não foram acuados de violência direta; o argumento corrente era de que os atos de fala que eles planejaram tornaram possível que outros cometessem atos de violência, seja em apoio, seja como reação hostil ao que disseram."119. Em que pese a concepção de direitos oferecida pelo autor seja "hipotética", a defesa do segundo modelo em detrimento do modelo do balanceamento leva Dworkin a concluir que viola a liberdade de expressão a restrição que se pretende impor aos réus no caso em questão ${ }^{120}$.

Dworkin defende um modelo distinto apontando para o fundamento dos direitos no sentido forte. Como visto, a sua teoria é "formal" no sentido de que não diz exatamente quais direitos existem. Mas, admite o autor, é preciso justificá-los, e essa justificação é

\footnotetext{
116 "Levando os Direitos a Sério", op. cit. p. 302, acrescentei as palavras do original entre colchetes; no original, “Taking Rights Seriously", op. cit., p. 197.

117 "Levando os Direitos a Sério", op. cit. p. 302; no original, "Taking Rights Seriously”, op. cit., p. 197.

${ }^{118} \mathrm{Na}$ tradução brasileira, "Os réus eram acusados de conspirar para cruzar as fronteiras estaduais com a intenção de provocar distúrbios públicos", Dworkin, "Levando os Direitos a Sério", op. cit., p. 303; no original, Dworkin fala em "riot", "Taking Rights Seriously", op. cit., p. 197.

119 "Levando os Direitos a Sério", op. cit. pp. 309-10; "Taking Rights Seriously", op. cit., p. 202.

120 "Taking Rights Seriously", op. cit., pp. 201 e ss.
} 
particularmente demandante dado o fato de que se trata de uma instituição "forte", com todas as consequências e custos de sua adoção ${ }^{121}$ : “A instituição dos direitos (...) é uma prática complexa e problemática que torna mais difícil e mais cara a tarefa governamental de assegurar o bem-estar geral. Ela seria uma prática frívola e enganosa, caso não servisse a algum objetivo [point]." ${ }^{, 22}$. Mais especificamente, para o autor, a justificação dos direitos reside em pelo menos uma dentre duas ideias: "dignidade humana" e "igualdade política"123. O sentido da prática de direitos é dependente destes valores. ${ }^{124}$ Assim caracterizados os direitos, violá-los, diz Dworkin, é particularmente grave e, portanto, tratar a "inflação" de direitos como

121 “Taking Rights Seriously", op. cit., p. 198.

122 "Levando os Direitos a Sério", op. cit. p. 304, incluí entre colchetes palavra do original; para o original, “Taking Rights Seriously”, op. cit., pp. 198. Depois de comentar teorias da liberdade de expressão que buscam proteger o público, Dworkin diz: “(...) other theories of free speech - in the broad sense including free press hold that the right is directed at the protection of the speaker, that is, that individuals have the right to speak, not in order that others benefit, but because they would themselves suffer some unacceptable injury or insult if censored. Anyone who holds this theory must, of course, show why censorship is a more serious injury than other forms of regulation. He must show why someone who is forbidden to speak his mind on politics suffers harm that is greater than when he is forbidden, for example, to drive at high speeds or trespass on others' property or combine to restrain trade", p. 386. Veja seção 4, abaixo, para discussão de exemplo parecido em "Why Rights do We Have?", op. cit. Waldron discute a visão dworkiniana de "rights as trumps" em trabalho sobre liberdade de expressão e diz The Harm in Hate Speech, op. cit., pp. 159-61.

123 "Levando os Direitos a Sério", op. cit. pp. 304-5; para o original, “Taking Rights Seriously", op. cit., pp. 1989; a primeira "supposes that there are ways of treating a man that are inconsistent with recognizing him as a full member of a the human community, and holds that such treatment is profoundly unjust" (p. 198), enquanto a segunda "supposes that the weaker members of a political community are entitled to the same concern and respect of their government as the more powerful members have secured for themselves" (pp. 198-9). Segundo Caio Moysés de Lima, estas duas ideias foram posteriormente unificadas no pensamento de Dworkin: $O$ Império dos Direitos: Lei e Autoridade Política em Ronald Dworkin, op. cit., p. 74, n. 154 e p. 103, n. 206. Concordo com a leitura. Veja Justice for Hedgehogs, op. cit., pp. 329-31. Vale apontar que aquilo que Dworkin chama neste artigo de "igualdade política" é mais abrangente do que o autor entende posteriormente por esta expressão (como ela figura em "Political Equality", in Sovereign Virtue, op. cit. e Justice for Hedgehogs, op. cit., pp. 388 e ss. - veja capítulo terceiro, abaixo).

124 "It makes sense to say that a man has a fundamental right against the Government, in the strong sense, like free speech, if that right is necessary to protect his dignity, or his standing as equally entitled to concern and respect, or some other personal value of like consequence. It does not make sense otherwise", "Taking Rights Seriously", op. cit., p. 199. O que se percebe é que, em "Taking Rights Seriously" Dworkin diz o que são direitos no sentido forte, enquanto em outros trabalhos o autor defende quais são estes direitos; esta dissertação segue a mesma estrutura: veja os próximos capítulos para a exposição da defesa dworkiniana do direito forte à liberdade de expressão. Veja o comentário de Eleftheriadis sobre direitos em Dworkin: "Dworkin's views are (...) based on a substantive argument about morality developed fully in Dworkin's Sovereign Virtue and recently in Is Democracy Possible Here? and not in the earlier Taking Rights Seriously that Griffin exclusively relies on.", "Human Rights for Liberals" (October 9, 2009). Global Justice, Forthcoming; Oxford Legal Studies Research Paper No. 41/2009. Available at SSRN: http://papers.ssrn.com/sol3/papers.cfm?abstract id=1486080. p. 6, itálicos no original. Compare com Abigail Levin, The Cost of Free Speech: Pornography, Hate Speech, and their Challenge to Liberalism, op. cit., pp. 38 e ss. 
injustiça tão grave quanto a sua "invasão" é equívoco que condena o modelo do balanceamento. ${ }^{125}$

Um caso prático de direito brasileiro ilustra o tema. Tem sido recentemente aventada a possibilidade de o instituto jurídico da reincidência não ter sido recepcionado pela Constituição Federal de 1988. A Defensoria Pública e outros levaram o tema ao Supremo Tribunal Federal com a argumentação de que a reincidência viola a proporcionalidade e o direito à individualização da pena ${ }^{126}$. O plenário do Supremo Tribunal Federal enfrentou a questão e, por unanimidade, rejeitou a tese em julgamento com repercussão geral em Recurso Extraordinário $^{127}$. Não pretendo entrar no mérito da questão, mas somente analisar um argumento oferecido pelo Ministro Luiz Fux sobre questão específica do julgamento conforme consta no Informativo STF $700^{128}$. A análise é válida porque o argumento do Ministro ilustra um tipo de atitude em relação aos direitos estranha ao conceito forte de direitos em Ronald Dworkin.

Segundo parece, para o Ministro o argumento de que a reincidência é incompatível com a Constituição porque pune com maior gravidade aquele que já delinquiu e em relação a quem o sistema punitivo falhou ao deixar de ressocializá-lo não procede porque não é possível saber (ou, pelo menos, não se sabe) se a reincidência deriva do fracasso do sistema ou de outra circunstância, como uma qualquer do sujeito. Consta no Informativo: “O Min. Luiz Fux acresceu não se poder saber o motivo de o agente ter voltado a delinquir depois de punido se isso decorreria de eventual falibilidade do sistema carcerário, da personalidade do indivíduo

\footnotetext{
125 "Taking Rights Seriously", op. cit., p. 199. Mas Dworkin admite que, em casos de conflito entre direitos, "'Balancing' is appropriate", p. 199. Veja "The Place of Liberty" in Sovereign Virtue, op. cit., pp. 128 e ss. para defesa da ideia de que a igualdade não admite exceções (esta ideia precisa ser lida, como fica claro neste artigo, à luz da tese dworkiniana de que valores políticos, devidamente compreendidos, não entram em conflito entre si: veja próxima seção deste capítulo).

${ }^{126}$ Consta que foi "alegado que o instituto configuraria bis in idem, bem como ofenderia os princípios da proporcionalidade e da individualização da pena." Brasil, Supremo Tribunal Federal. "Reincidência e Recepção pela CF/88 1" in Informativo 700. Secretaria de Documentação (SDO), Coordenadoria de Jurisprudência Comparada e Divulgação de Julgados - CJCD, Brasília: abril de 2013, p. 2, itálicos no original.

${ }^{127}$ Brasil, Supremo Tribunal Federal. RE 453000/RS, rel. Min. Marco Aurélio, Plenário, julgado em 4.4.2013. O STF julgou, junto deste RE, alguns habeas corpus (veja "Reincidência: agravamento de pena e recepção pela CF/88 - 2" in Informativo 700, op. cit., p. 3).

${ }^{128}$ Supremo Tribunal Federal. "Reincidência e Recepção pela CF/88 1-3" e "Reincidência: agravamento de pena e recepção pela CF/88 - 2" in Informativo 700, op. cit.
} 
ou de outros fatores."129. Independentemente do mérito do argumento favorável à nãorecepção da reincidência, o contra-argumento de Fux dialoga, ainda que para efeitos de argumentação, com a veracidade da tese da não-recepção defendida pelo recorrente. Mas então oferece contra-argumento que não leva os direitos a sério, para utilizar expressão de Dworkin.

Se não é possível saber o motivo da reincidência, e se, suponha-se, há um direito constitucionalmente reconhecido de não ter a pena majorada se a segunda condenação decorre de fracasso da função ressocializante de punição anterior, a dúvida recomenda declaração de não-recepção da reincidência, e não a manutenção da aplicação do instituto. A abordagem de Fux, ainda que não seja exatamente uma versão do modelo de balanceamento criticado por Dworkin, é incompatível com a instituição de direitos, pois violar o direito de não ter a pena majorada é algo grave de tal modo que, em caso de dúvida, é melhor declarar a incompatibilidade do instituto ainda que alguns indivíduos reincidentes deixem de ter a sua pena majorada sem que tenham direito a tanto (aqueles que reiterem conduta delituosa, na hipótese aventada pelo Ministro Fux, por personalidade e não por falha do sistema). A opção de somente garantir direito em caso de certeza de sua titularidade é incompatível com a atitude que vê na inflação de direitos injustiça menor do que na sua infração ${ }^{130}$.

129 "Reincidência e recepção pela $\mathrm{CF} / 88$ - 3" in Informativo 700, op. cit. p. 3. Veja o voto do ministro no Acórdão no Recurso Extraordinário 453.000-RS. Inteiro Teor. Relator Min. Marco Aurélio, Plenário do Supremo Tribunal Federal, 04/04/2013, pp. 18 a 20 do "Inteiro Teor do acórdão". Em especial,

"A matéria, aqui, senhor Presidente, no meu modo de ver, foi muito bem colocada tanto pelo Relator quanto pelo Ministério Público. Ela é uma matéria principiológica, quer dizer, vai-se ao princípio específico da individualização da pena, olvidando-se o princípio maior: a promessa constitucional é a de criar uma sociedade justa e, além de justa, uma sociedade igualitária.

"Bom, se a sociedade é justa, a defesa da sociedade prepondera sobre eventuais direitos reflexos do imputado, em primeiro lugar.

"Em segundo lugar, se é uma sociedade igualitária, não se pode, como destacou o Ministro Marco Aurélio, colocar, na mesma vala comum, o reincidente e aquele que atendeu aos reclamos dos antecedentes das virtualidades da lei e não cometeu mais nenhum crime, sinalizado que lhe foi, que a reincidência poderia torná-lo, digamos assim, um criminoso numa situação mais prejudicial.

(...)"

Nós não temos condições de saber da personalidade do agente, o porquê ele voltou a delinquir, se isso pode ser efetivamente imputável ao sistema carcerário. Nós não podemos esquecer que Lombroso, de há muito, afirmava a existência, é certo, do criminoso nato. Então, nós não temos capacidade institucional para verificarmos se efetivamente isso é uma imputação diretamente vinculada ao Estado, pelo seu fracasso do sistema carcerário.", pp. 18-9.

${ }^{130}$ É verdade que, ao defender que uma "violação" é mais grave que uma "inflação", Dworkin parece não cogitar dúvidas empíricas, como são as razões que motivam a prática de um crime. Parece-me entretanto que a gravidade apontada pelo autor na violação de um direito recomenda cautela também quando a dúvida é desta natureza e, além disso, mais à frente neste mesmo artigo Dworkin, ao analisar o caso "Chicago", elabora restrições à atuação do Estado quando há dúvidas sobre fato (veja "Taking Rights Seriously", op. cit., pp. 202 e ss., para a ideia de que direitos limitam a ação em situações de incerteza sobre fatos). Veja ainda discussão abaixo sobre garantias 
Isto, entretanto, não significa que para Dworkin direitos não possam sofrer restrição com justiça. Significa porém que, se um direito é reconhecido, deixar de estendê-lo a um caso limite precisa de justificativa mais demandante do que aquela tolerada por um modelo que considere inflação erro tão grave quanto invasão. ${ }^{131}$ Esta reflexão leva Dworkin à seguinte conclusão:

"Só posso pensar em três tipos de fundamentos que podem ser coerentemente utilizados para restringir a definição de um determinado direito. Primeiro, o governo poderia mostrar que os valores protegidos pelo direito original não estão realmente em jogo no caso marginal, ou que estão em jogo apensar de uma forma atenuada. Segundo, poderia mostrar que, se o direito for definido de modo a incluir o caso marginal, algum direito concorrente [competing right], no sentido forte que descrevi anteriormente, verse-á então restringido. Terceiro, poderia mostrar que, se o direito fosse assim definido, o custo para a sociedade não seria simplesmente adicional, mas de grau muito superior ao custo pago no caso da concessão do direito original; um grau suficientemente alto para justificar qualquer atentado à dignidade ou à igualdade que possa estar aqui envolvido"132

Dworkin oferece interpretação destes critérios ao discutir, no mesmo artigo, o já mencionado caso do "Chicago Seven Trial". Outros exemplos oferecidos pelo autor em artigo publicado em livro posterior elucidam a distinção entre as duas primeiras hipóteses de restrição. Para Dworkin, o direito à liberdade de expressão inclui as condutas realizadas pelos réus no caso "Chicago". Em primeiro lugar, diz o autor, é necessário estender o direito ao discurso calmo e civilizado ("não provocativo"133) aos casos mais extremos pois - e aqui temos um dos trechos mais inspiradores que já li em Dworkin - "Um homem não pode se expressar livremente quando não pode adequar sua retórica ao seu ultraje [match his rhetoric to his outrage], ou quando deve conter-se para proteger valores que para ele nada são quando

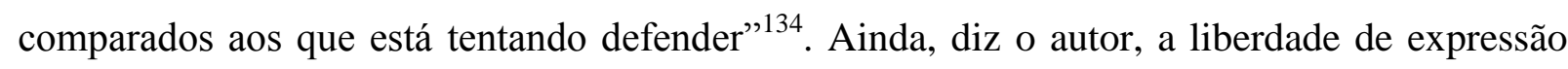
serve de proteção à dignidade de quem protesta, e é, portanto, incorreto lançar mão de critérios

processuais penais conforme "Taking Rights Seriously", op. cit., pp. 203-4 e "The Farber Case: Reporters and Informers", op. cit., pp. 375-6.

131 "Taking Rights Seriously", op. cit., p. 199. Veja Caio Moysés de Lima, O Império dos Direitos: Lei e Autoridade Política em Ronald Dworkin, op. cit., pp. 107-8.

132 "Levando os Direitos a Sério", op. cit. p. 307; no original, "Taking Rights Seriously", op. cit., p. 200. Veja ainda "Why Academic Freedom?", op. cit., pp. 354 e ss. e, de Waldron, The Harm in Hate Speech, op. cit., pp. $145-7$.

133 "Levando os Direitos a Sério”, op. cit. p. 309; no original, “Taking Rights Seriously”, op. cit., p. 201

134 "Levando os Direitos a Sério", op. cit. p. 309, inseri entre colchetes as palavras do original; no original, "Taking Rights Seriously", op. cit., p. 201; veja em geral pp. 201-2. Veja o seguinte trecho sobre ridicularização: "Ridicule is a distinct kind of expression; its substance cannot be repackaged in a less offensive rhetorical form without expressing something very different from what was intended. That is why cartoons and other forms of ridicule have for centuries, even when illegal, been among the most important weapon of both noble and wicked political movements", "The Right to Ridicule" in The New York Review of Books, 23 de março de 2006. Veja ainda "Do We Have a Right to Pornography?" in A Matter of Principle, op. cit., p. 342 e, de Waldron, The Harm in Hate Speech, op. cit., p. 149-50, 182-3, pp. 189 e ss., pp. 197-9. 
adequados àqueles cuja conveniência se pretenda defender restringindo as hipóteses de protesto permitidas. ${ }^{135}$ A conclusão dele é que tanto no caso de protesto mais calmo quanto no mais extremo está em jogo o mesmo valor, e, portanto, não é hipótese do primeiro tipo de fundamento ("ground") a restrição de direito. ${ }^{136}$

Ainda sobre este primeiro fundamento, o autor, em artigo de 1996, dá exemplo em que, diz ele, o que se pretende proteger num caso claro não se estende a outra situação, ou, em outras palavras, “(...) segundo a melhor interpretação, seu objetivo [point] ou sua justificativa não se aplicam no caso em questão". ${ }^{137}$ Trata-se do contraste entre matar alguém deliberadamente ("ato deliberado de matança""138) e a situação em que "um médico administra uma injeção letal a um doente em estado terminal que expressou sinceramente o desejo de morrer" 139 . O ponto do autor é que enquanto o primeiro ato viola a "santidade da vida", isto não ocorre no segundo ${ }^{140}$.

Dworkin discute conjuntamente os dois outros fundamentos, isto é, a existência de direito em conflito ou de situação de emergência ou de grande dano à sociedade. $O$ autor o faz considerando o caso de Chicago e conclui que nenhuma destas hipóteses de restrição se

135 "If the point of the right is to protect the dignity of dissenters, then we must make judgments about appropriate speech with the personalities of the dissenters in mind, not the personality of the 'silent' majority for whom the anti-riot law is no restraint at all", "Taking Rights Seriously", op. cit., p. 201.

136 "Levando os Direitos a Sério", op. cit. p. 307; no original, "Taking Rights Seriously", op. cit., p. 201.

137 "Por que a liberdade acadêmica?", in $O$ direito da liberdade: a leitura moral da Constituição norteamericana. Tradução Marcelo Brandão Cipolla, revisão técnica Alberto Alonso Muñoz. São Paulo: Martins Fontes, 2006, p. 406, acrescentei entre colchetes a palavra do original; no original, "Why Academic Freedom?" in Freedom's Law, op. cit., p. 254.

138 "Por que a liberdade acadêmica?", in $O$ direito da liberdade, op. cit., p. 406; no original, "Why Academic Freedom?" in Freedom's Law, op. cit., p. 254.

139 "Por que a liberdade acadêmica?", in $O$ direito da liberdade, op. cit., p. 406 (substituí "de veneno" pela opção que consta na tradução para traduzir "lethal"). "Why Academic Freedom?" in Freedom's Law, op. cit., p. 254. Veja ainda p. 254 e "Equality of Welfare", in Sovereign Virtue, op. cit., pp. 48-9.

140“"Por que a liberdade acadêmica?", in $O$ direito da liberdade, op. cit., p. 406; no original, "Why Academic Freedom?" in Freedom's Law, op. cit., p. 254. Nesta página, Dworkin inclui a nota 6 (texto na p. 380), em que cita Life's Dominion, op. cit. O leitor, naturalmente, não precisa concordar com a adequação de exemplificar o primeiro fundamento de restrição por meio da distinção oferecida por Dworkin. Ou seja, ainda que o leitor discorde do exemplo dado, pode ser válido restringir direitos quando o seu valor não seja atendido no caso concreto. Cumpre observar, ainda, que Dworkin, neste texto, discute liberdade acadêmica, distinguida da liberdade de expressão, entre outros, porque "is less clearly a right" ("Why Academic Freedom?" in Freedom's Law, op. cit., p. 247; veja em geral pp. 247-8). Em outras palavras, aquilo que em "Taking Rights Seriously" figura como hipóteses de restrição a direito em "Why Academic Freedom?" figura como hipóteses de restrição de valor (no exemplo mencionado, a santidade da vida). Outro exemplo oferecido pelo autor é o de "insulto deliberado" que, para ele, em contraste com um "insulto negligente", não é protegido pelo valor da liberdade acadêmica ("Deliberate insults - by which I mean statements or displays whose principal motive is to cause injury or distress or some other kind of harm - are not even in principle covered by the idea of academic freedom (...) though intentional insult is not covered by academic freedom, negligent insult must be", "What is Academic Freedom", op. cit., p. 255; veja em geral pp. 255 e ss.). Veja capítulo terceiro para discussão. 
vislumbra. O aspecto crucial desta interpretação de Dworkin reside na rejeição, mencionada acima, de especulação sobre consequências do exercício de direitos. O autor indaga: quanto em vida ou em propriedade seria salvo se os discursos inflamados não tivessem ocorrido? ${ }^{141} \mathrm{E}$ responde: não se sabe, tanto porque não se domina a relação entre protesto e "riot" quanto porque há muitas outras causas à violência (ex. pobreza, violência policial etc.) ${ }^{142}$ A conclusão de Dworkin é que qualquer ação do governo com o objetivo de lidar com esse processo é "um exercício de especulação, tentativa e erro. O governo deve tomar suas decisões sob condições de extrema incerteza, e a instituição dos direitos, quando levados a sério, limita sua liberdade de experimentar sob tais circunstâncias". ${ }^{143}$.

Novamente, os fundamentos dos direitos - em Dworkin, dignidade ou igualdade - são importantes ao argumento do autor: restringir um direito (no caso, à liberdade de expressão) “(...) equivale a insultá-lo de forma incontestável e profunda, em troca de benefícios especulativos (...)"144, e só pode ser justificado em situações em que haja verdadeiro risco de violação de outro direito ou para prevenir uma tragédia (o exemplo é de quem grita "Fogo!" num teatro lotado sem que haja de fato um incêndio). ${ }^{145}$ Estas considerações levam o autor a concluir que punição aos réus no caso "Chicago" caracteriza violação do direito à liberdade de expressão. $^{146}$

O que se percebe é o esforço do autor em distinguir restrições a direitos aceitáveis das inaceitáveis. Como visto, para ele, dado os fundamentos de direitos, não se pode tolerar a facilidade com que o modelo do balanceamento restringe direitos. Dworkin costuma mencionar área da moralidade e do direito particularmente hostil a este tipo de raciocínio restritivo de direitos: as garantias processuais penais ${ }^{147}$, que aumentam "marginalmente" a chance de determinado indivíduo sofrer violência provocada por indivíduo culpado

\footnotetext{
141 “Taking Rights Seriously", op. cit., p. 202.

142 "Taking Rights Seriously", op. cit., p. 202.

143 "Levando os Direitos a Sério", op. cit. p. 310; no original, “Taking Rights Seriously”, op. cit., p. 202. Veja acima discussão sobre reincidência no STF.

144 “Levando os Direitos a Sério”, op. cit. p. 310; no original, “Taking Rights Seriously”, op. cit., p. 202 (veja ainda pp. 203-4).

145 “Taking Rights Seriously”, op. cit., pp. 202, 204. Outro exemplo de Dworkin são segredos militares durante guerras: "Government may properly punish the publication of military secrets in time of war", Forked Tongues, Faked Doctrines, op. cit, p. 149. Veja ainda A Harmful Precedent, op. cit. e "Hard Cases", op. cit., pp. 93-4. Para críticas, veja MacKinnon em Only Words, op. cit., pp. 103-4, esp. p. 104.

146 “Taking Rights Seriously", op. cit., pp. 202-3.

${ }^{147}$ Veja "Taking Rights Seriously", op. cit., pp. 203-4, "Principle, Policy, Procedure", op. cit. e "The Farber Case: Reporters and Informers", op. cit., pp. 375-6, 377.
} 
equivocadamente absolvido. ${ }^{148}$ Ocorre que este risco marginal não pode ser corretamente caracterizado como fonte de um direito possuído pela sua vítima eventual, pois, como visto acima, para Dworkin nem a maioria tem direitos nem pode a especulação sobre o possível ser tolerada na distribuição de direitos ${ }^{149}$; o benefício social propiciado pela restrição às garantias processuais penais caracteriza-se como consideração de política que defende benefício coletivo e é, portanto, incapaz de justificar tal limitação. ${ }^{150}$ Dado o fundamento dos direitos, “(...) seria desrespeitoso se o Estado dissesse a um homem que ele deve sofrer tal dano em vista da possibilidade de que venha a reduzir marginalmente o risco de perdas por parte de outros homens". ${ }^{151}$ Riscos "especulativos" ou ganhos "marginais" não justificam restrições a direitos no sentido forte. ${ }^{152}$

Mas as reflexões de Dworkin não se limitam à racionalização das restrições a direitos. Embora o autor expresse a sua crítica ao modelo do balanceamento em termos de modelo de conflito de direitos, as suas considerações sobre o tema, se lidas conjuntamente, caracterizam não somente um modelo de como arbitrar choques de direitos, mas mais precisamente uma atitude que, se de um lado demanda justificação específica aos direitos supostamente existentes, de modo que nem toda consideração se qualifique enquanto tal, de outro oferece defesa contundente aos direitos, nos termos do sentido forte descrito na seção anterior. Ou seja, a proposta de Dworkin caracteriza atitude em relação aos direitos dos cidadãos contra o Estado, e não somente um modelo de como resolver conflitos. Trata-se de atitude de valorização e de preservação de direitos enquanto instituição que protege o indivíduo contra atuações do Estado justificadas por considerações de interesse coletivo. As reflexões de

148 "Levando os Direitos a Sério", op. cit. p. 312; no original, "Taking Rights Seriously", op. cit., p. 203. Comentando a jurisprudência da Suprema Corte dos EUA sobre "police procedure" Dworkin diz: "These rulings increase the chance that a guilty man will go free, and therefore marginally increase the risk that any particular member of the community will be murdered, raped, or robbed.", p. 203.

${ }^{149}$ É claro que há um sentido em que se pode formular um argumento de princípio a favor da vítima; ele, entretanto, não será um argumento cogente: veja "Hard Cases" (op. cit., p. 96) para o exemplo (discutido acima) do direito do indivíduo contra ameaça à sua vida provocada pela desegregação racial.

${ }^{150}$ Dworkin diz: "It is widely thought, for example, that crime would decrease, trials be less expensive, and the community better off as a whole if strict rules of criminal procedure that guard against the conviction of the innocent, at the inevitable cost of some acquittal of the guilty, were abandoned. But that is an argument of policy against those procedural rules, and so it would not justify relaxing the rules if those who are accused of crime have a right (as most liberals think they do) to the protection the rules provide", "The Farber Case: Reporters and Informers", op. cit., p. 376

151 "Levando os Direitos a Sério", op. cit. p. 312; no original, "Taking Rights Seriously", op. cit., pp. 203. O "damage" a que o autor faz referência na citação são a proibição de falar e "damage" ao direito contra autoincriminação (p. 203).

152 “Taking Rights Seriously", op. cit., pp. 204. 
Dworkin oferecem fundamento e preservação das "liberdades", que para o autor são, como veremos, direitos; com efeito, a noção de direitos no sentido forte contém elementos da "atitude" que Dworkin posteriormente chamaria de "cultura de liberdade"153, como a discuto na conclusão desta dissertação.

Por hora, gostaria de discutir tese importante ao pensamento do autor, a saber, a tese de que valores não entram em conflito entre si. Trata-se de ideia essencial à compreensão do que são e o que significam as liberdades para o autor.

\section{Seção 3. Integração no pensamento de Ronald Dworkin}

Ronald Dworkin tem defendido que valores não conflitam entre $\mathrm{si}^{154}$, isto é, que é sempre possível seguir, por exemplo, o que exige a igualdade sem com isso violar a liberdade. Mas alguns aspectos desta tese precisam ser ressaltados para que se seja possível compreendêla sem anacronismos.

Em especial, é preciso ler Dworkin tendo em mente a concepção de igualdade defendida pelo autor, pois fazê-lo é essencial para o teste da tese sob análise. É que Dworkin não defende abstratamente a tese de que valores não conflitam entre si, isto é, de maneira independente de concepções específicas de igualdade e liberdade, por exemplo. Dworkin defende que, corretamente compreendida, é possível atender a igualdade sem que se viole a liberdade, também corretamente compreendida ${ }^{155}$. Dworkin não pretende defender que, independentemente das definições dadas aos valores, entre eles não há conflito. Diz Dworkin:

"É claro que podemos definer as várias virtudes políticas de maneira tal que conflito seja de fato inevitável. Suponha que definamos igualdade da maneira que certos socialistas definiram: igualdade significa todos terem a mesma riqueza independentemente das escolhar que façam sobre trabalho ou lazer ou consumo ou investimento. Podemos definir a liberdade [liberty] da maneira que John Stuart Mill e Isaiah Berlin definiram: a liberdade [liberty] de uma pessoa é a sua liberdade [freedom] de fazer o que quer que queira fazer livre de interferências de terceiros. Então certamente teremos um conflito entre liberdade e igualdade. Para proteger a igual distribuição de riqueza, teremos que proibir o furto [theft], o que é uma negação da liberdade. Se permitirmos às pessoas que produzam e negociem bens, então

\footnotetext{
153 "Devaluing Liberty". Index on Censorship, 1988, 17: 7.

${ }^{154}$ Veja, por exemplo, "What Rights Do We Have?", op. cit., "The Place of Liberty" in Sovereign Virtue, op. cit., "Do Values Conflict? A Hedgehog's Approach", 43, Arizona Law Review, 251, 2001, e "Do Liberty and Equality Conflict?", In Paul Baker(Ed.) Living As Equals. Oxford: Oxford University Press, 1996. Mais recentemente, veja Justice for Hedgehogs, op. cit.. e também "It is absurd to calculate human rights according to cost-benefit analysis", op. cit.

${ }^{155}$ Esta também é a leitura de Macleod: veja seus comentários a Dworkin, em especial o seguinte trecho: “(...) we can see that liberty is only diminished by equality if the particular valued liberties which constitute the most attractive normative conception of liberty are threatened by the best especification of a normative conception of equality", Liberalism, Justice, and Markets, op. cit., p. 158 (veja ainda p. 159, por exemplo, e cap. 6 em geral).
} 
desigualdade aparecerá, porque alguns serão mais talentosos na produção que outros, independentemente de quão frequentemente reunamos os recursos para redistribuição. Então se queremos garantir a igualdade termos que proibir o comércio, o que é uma grande interferência na liberdade. A primeira destas cessões [compromises] de liberdade parece justificada; devemos proibir o furto. A segunda não parece justificada: não devemos proibir o comércio. Mas os dois casos são similares pois em ambos temos de escolher entre proteger a igualdade e proteger a liberdade: não podemos proteger os dois ao mesmo tempo." 156

Dworkin chama estas definições de liberdade e igualdade, que inevitavelmente geram conflito entre os valores, de definições "flat", e põe-se a compreender os valores de outra maneira, que chama de "dinâmica". ${ }^{157}$ Assim, para o autor, no sentido flat dos valores, evidentemente há conflito; o tratamento igual, expressão empregada por Dworkin em Taking Rights Seriously ${ }^{158}$ nem sempre é compatível com a ausência de restrição pois muitas vezes é preciso proibir determinada ação desejada (ex. gastar integralmente a renda auferida, algo obstado pela tributação da renda ${ }^{159}$ ) para que pessoas estejam em situações iguais (ambas tenham acesso a determinado serviço público). Mas este sentido que Dworkin chama de flat, não-intepretativo, não é relevante à filosofia política e ao direito: para o autor, o crucial é o sentido valorativo, "normativo"160, que demanda interpretação, isto é, indagação do sentido, por exemplo, da titularidade de determinada liberdade ${ }^{161}$. Isto leva Dworkin a dizer que a igualdade é aquela de igual tratamento, o que não necessariamente implica tratamento igual

${ }^{156}$ Dworkin, "Do Values Conflict? A Hedgehog's Approach", op. cit., p. 253, traduzi, mantive palavras do original entre colchetes. Veja Maria Beatriz Inkis. O Exercício da Cidadania segundo as Teorias Política e Jurídica Propostas por Ronald Dworkin. 107f. Dissertação de Mestrado, Universidade Presbiteriana MacKenzie, orientador: Gianpaolo Poggio Smanio. São Paulo: 2009, pp. 25 e ss. (Inkis também traduz "liberty" e "freedom" por "liberdade" e indica, ao citar Dworkin, quando o original traz uma ou outra palavra. Desconheço opção, e é por isso que faço a mesma escolha). Veja ainda a crítica de Bernard Williams a Dworkin em "Conflicts of Liberty and Equality" in. In the Beginning Was the Deed. Princeton: Princeton University Press, 2005.

${ }^{157}$ Dworkin, Do Values Conflict? A Hedgehog's Approach, pp. 253 e ss.; veja em especial: "I shall call the first set - the traditional definitions under which conflict is apparent and inevitable - the flat conceptions of equality and liberty. I shall call the second set - the different conceptions under which equality and liberty do not conflict, at least obviously, the dynamic conceptions", p. 254. Dworkin também contrapõe a concepção "flat" a uma "normativa": "We use the words 'liberty' and 'equality' in two senses. We use each as a flat description that carries, in itself, no suggestion or endorsement or complaint, and we also use each normatively to identify a political virtue or ideal that we do endorse. We use 'liberty' in its flat sense to indicate the absence of constraint. Someone may say using that sense, that liberty is reduced by laws prohibiting murder and theft, without implying that he opposes these laws. We use 'liberty' in its normative sense, on the other hand, to describe the ways in which we believe people ought to be free", "The Place of Liberty", op. cit., p. 125 (veja ainda pp. 132-3).

158 "Reverse Discrimination", op. cit., e "What Rights Do We Have", op. cit. (respectivamente, caps. 9 e 12 de Taking Rights Seriously, op. cit.).

${ }^{159}$ Exemplo do autor, em trecho citado abaixo retirado de "Do Liberty and Equality Conflict?", op. cit.., p. 40; veja ainda pp. 45 e ss.

160 "O lugar da liberdade" in Virtude Soberana, op. cit., pp. 165-6 (nesta edição, traduz-se "flat" por "simples"); no original, "The Place of Liberty", op. cit., pp. 125-6.

161 "The Place of Liberty", op. cit., p. 126. Veja Macleod, Liberalism, Justice, and Markets, op. cit, pp. 157 e ss. 
(i.e., idêntico): não é paradoxal que a igualdade por vezes exija distinto tratamento para pessoas diferentes ${ }^{162}$. Também, o autor não vê violação da liberdade na regulamentação do sentido de uma via urbana ${ }^{163}$, ou na proibição do furto $^{164}$ : a liberdade existente não é aquela caracterizada pela completa falta de restrições à ação. Segundo Dworkin,

"É claro que alguns valores ou ideais políticos conflitam uns com os outros, no sentido de que uma política [policy] que serve a um frequentemente compromete [compromises] o outro. A liberdade às vezes conflita com a segurança, por exemplo: uma comunidade pode ser forçada a escolher entre banir um grupo político impopular e correr um risco aumentado de prejuízo violento [violent injury] aos indivíduos. Será que a igualdade também conflita com a liberdade de maneira similar, de modo que tenhamos por vezes de desistir de uma para proteger a outra? Não há dúvida de que os termos 'liberdade' e 'igualdade' podem ser definidos de maneira tal que, assim definidas, elas de fato entrem em conflito, contínua e incansavelmente [steadily and relentlessly]. Suponha que definamos igualdade, por exemplo, como a situação em que todos de uma dada comunidade política tenham a mesma riqueza, independentemente de quanto cada um tenha consumido, quão duro tenha trabalhado ou em que atividade Suponha que então definamos liberdade como a situação em que o governo não impede ninguém de fazer absolutamente [at all] qualquer coisa que ele ou ela queira, e então que não tome nenhuma parcela da renda de ninguém como tributo. Então é claro que igualdade e liberdade conflitariam.

"Estas são explicações desesperançosas [hopeless] de liberdade e de igualdade por uma razão que agora devo explicar. 'Liberdade' e 'Igualdade' dão nome a ideais políticos abstratos, que devem ser interpretados antes de poderem ser aplicados a temas políticos concretos. Políticos e cidadãos discordão sobre se a tributação é uma invasão da liberdade, ou se a discriminação reversa [reverse discrimination] ofende a igualdade não porque falam línguas diferentes, mas porque são atraídos por interpretações diferentes e competitivas destes dois ideais. Eles têm diferentes entendimentos sobre como melhor definir ou expressar os valores mais fundamentais que estes ideais políticos corporificam ou protegem. Devemos julgar qualquer teoria da liberdade e da igualdade sob esta luz. Devemos perguntar se ela é uma interpretação bem sucedida, isto é, se ela é bem sucedida em expressar o que é bom no ideal que pretende explicar" 165 .

Em Do Values Conflict? A Hedgehog's Approach, Dworkin compreende este ônus de oferecer uma definição bem sucedida dos valores ao defender o que chama de definições

162 "Reverse Discrimination", op. cit., p. 227 e "What Rights Do We Have", op. cit. Veja ainda "Equality of Welfare" in Sovereign Virtue, op. cit., p. 11 e também "Equality of Resources", in Sovereign Virtue, op. cit., pp. 108-9, em especial o seguinte trecho: ao considerar e rejeitar um "flat statement" sobre fatos que a igualdade de recursos supostamente deve ignorar (p. 108), ele conclui que "Equality of resources is a complex ideal. It is probably (as the various arguments we have canvassed here suggest) an indeterminate ideal that accepts, within a certain range, a variety of distributions. But this much seems clear: any defensible conception of that ideal must attend to its different dimensions, and not reject out of hand the requirement that it be sensitive to the cost of one person's life to other people. The present suggestion, that genuine theories of equality must be concerned only with the quantity of disposable goods or liquids assets people command at a particular time, is a piece of preanalytic dogma that does not, in fact, protect the boundaries of the concept of equality from confusion with other concepts, but rather thwarts the attempt to picture equality as an independent and powerful political ideal", pp. 108-9. Veja Guest, Ronald Dworkin, op. cit., p. 147.

163 "What Rights Do We Have?", op. cit..

164 "Do Values Conflict? A Hedgehog's Approach", op. cit., p. 253, por exemplo. Veja ainda Justice for Hedgehogs, op. cit., pp. 345-6.

${ }^{165}$ Ronald Dworkin. "Do Liberty and Equality Conflict?", op. cit., p. 40, traduzi, mantive entre colchetes as palavras do original, itálicos no original. Veja a mesma ideia em "The Place of Liberty", op. cit., pp. 126-7. Entre nós, veja os comentários de José Emílio Medauar Ommati à relação entre igualdade e liberdade em Dworkin. Liberdade de Expressão e discurso de ódio na Constituição de 1988, op. cit., pp. 91 e ss.. 
dinâmicas; a definição dinâmica de igualdade defendida por Dworkin é aquela elaborada em Sovereign Virtue sob a rubrica de "igualdade de recursos"166, e a definição dinâmica de liberdade é a seguinte: "A sua liberdade [liberty] é a sua liberdade [freedom] de dispor como quiser da propriedade ou dos recursos que lhe foram atribuídos sob um sistema razoavelmente justo [reasonably fair] de propriedade e de outras leis, livre de interferência de outros, desde que você não viole os direitos de ninguém"167.

Eu gostaria de salientar dois pontos acerca da apresentação da tese do conflito entre valores em termos de "definições dinâmicas". Em primeiro lugar, o argumento oferecido pelo autor contra a tese de que a igualdade e a liberdade conflitam entre si é especificamente orientado à sua concepção de igualdade, a saber, a igualdade de recursos e o espaço existente nesta teoria para as liberdades. ${ }^{168}$ A tese de que não existe tal conflito é dependente da atratividade desta concepção de igualdade enquanto concepção da justiça distributiva. Isto obviamente não significa que o conflito exista caso a concepção seja questionável; mas, se as concepções de Dworkin estiverem corretas, significa que o conflito inexiste. Esta relação é discutida ainda neste capítulo, quando exponho o esforço dworkiniano de situar as liberdades, entre elas a liberdade de expressão, na igualdade de recursos. ${ }^{169}$

${ }^{166}$ Dworkin, "Do Values Conflict? A Hedgehog's Approach”, op. cit., p. 253; veja Dworkin, "Equality of Resources", in Sovereign Virtue, op. cit..

${ }^{167}$ Dworkin, "Do Values Conflict? A Hedgehog's Approach", op. cit., p. 254, traduzi e mantive entre colchetes as palavras do original; veja a quinta seção deste capítulo e a primeira seção do capítulo terceiro desta dissertação. Veja Maria Betriz Inkis, O Exercício da Cidadania segundo as Teorias Política e Jurídica Propostas por Ronald Dworkin, op. cit., p. 26 (em trecho citado abaixo no capítulo três), em geral pp. 25 e ss..

${ }^{168}$ Ao caracterizar os seus propósitos no texto que discute este tema, Dworkin diz o seguinte: "I try to defend (...) that if we accept equality of resources as the best conception of distributional equality, liberty becomes an aspect of equality rather than, as it is often thought to be, an independent political ideal potentially in conflict with it", "The Place of Liberty", op. cit., p. 121 (veja ainda pp. 128, 132, 133-4). Veja também Ripstein, "Liberty and Equality", op. cit., pp. 83-4.

${ }^{169}$ Isto não impede que um argumento a favor de uma concepção se inicie na hipótese de que valores não conflitam entre si, tampouco obsta a existência de um argumento que critique a tese da existência de conflitos sem ser completamente dependente de uma concepção específica. Dworkin diz, após apresentar posições extremas sobre o valor da liberdade: "A more plausible conception of liberty will emerge from the argument later. Since the case for that conception will begin in the hypothesis that liberty and equality do not conflict, however, we must not rely on it when we are considering, in the earlier parts of this chapter, whether to accept or reject that hypothesis.", "The Place of Liberty", op. cit., p. 127. Ou seja, Dworkin discute o conflito entre valores, conclui que não há motivo para supor que haja conflitos, e se põe a defender concepções de igualdade e de liberdade integradas uma à outra. Ao discutir o conflito, o autor oferece razões para rejeitá-lo, mas o faz ao defender o que chama de "abstract egalitarian principle" (veja p. 128) como um princípio compartilhado "among us" (p. 129). Em seguida, ele defende a ideia de liberdade como desprovida de valor que independa das suas consequências às vidas de seus titulares (veja seção 4 deste capítulo, abaixo), e argumenta que, se a liberdade tem valor porque contribui à vida dos indivíduos, e se a igualdade exige que o governo cuide das vidas das pessoas, o conflito entre liberdade e igualdade é improvável, ainda que possível na hipótese que ele menciona (veja pp. 129-130). O ponto é que este é um argumento contrário à existência do conflito entre igualdade e liberdade que não é dependente da 
Em segundo lugar, esta apresentação da questão é decorrente da teoria da interpretação defendida por Dworkin, para quem igualdade e liberdade são valores, o que demanda elaboração do seu sentido: ao discutir conceitos "de tipo natural" 170 , Dworkin os contrasta com conceitos como igualdade e liberdade:

"Acreditamos que o ouro é o que é bastante independentemente de preocupações, ambições ou necessidades humanas. Mas isso não é sequer remotamente plausível sobre uma virtude política como a igualdade ou a liberdade. Não podemos olhar nelas e encontrar uma composição química ou uma gravidade específica. Elas são o que são porque somos o que somos: nós acreditamos que um governo que respeite a liberdade e a igualdade de alguma maneira aprimora a vida daqueles a quem governa.

"Liberdade de igualdade não são tipos naturais, como ouro ou cachorros, mas valores, e não podemos entender um valor a não ser que entendamos por que é importantante que respeitemos ou busquemos este valor, a não ser que entendamos o que é bom neles. De fato, toda a ideia de conflito entre valores pressupõe, como enfatizei, não somente que escolhas são necessárias, mas que algo de valor se perde sempre que uma escolha é feita. Então devemos ser guiados por essa premissa. As nossas interpretações da liberdade, igualdade e do resto deve visar a mostrar o que é bom na virtude em questão. Deve visar a mostrar por que, se a virtude for comprometida [compromised], algo ruim aconteceu, algo de valor foi perdido, pessoas não foram tratadas como têm um direito de ser." 171

Em outras palavras, valores como igualdade e liberdade são conceitos cuja compreensão exige indagação sobre o seu sentido, de modo que sua interpretação convida o desenvolvimento, para utilizar a terminologia exposta acima, de definições dinâmicas, e não flat, isto é, exige que os valores sejam elaborados politicamente ${ }^{172}$. Na próxima seção, apresento a interpretação do valor da liberdade oferecida pelo autor - interpretação que, como

igualdade de recursos: o argumento dependente é oferecido pelo autor em outro ponto deste artigo e, apesar de não ser contraditório com o primeiro, é distinto dele. Mas isto não descaracteriza o fato de que no pensamento de Dworkin o conflito entre valores é uma questão dependente das distintas concepções porque pelo menos o princípio de igualdade por ele defendido, ainda que compartilhado, pode ser rejeitado ou qualificado mesmo que fazê-lo seja absurdo (pp. 128-9; após discutir possibilidades, o autor diz: "The abstract egalitarian principle can theoretically be rejected outright or qualified in all these diferente ways.”, p. 129). Daí ser possível concluir que este argumento crítico da tese do conflito entre valores não é completamente independente das concepções de igualdade possíveis de serem formuladas pelo menos no sentido de que rejeita algumas e, portanto, seleciona outras (as demais) ao fazê-lo. A natureza da visão sobre liberdade defendida por Dworkin não é tão clara, mas, pelas observações do autor, me parece que é também dependente de concepções nos mesmos termos que o valor da igualdade porque a igualdade, na definição do autor, leva à liberdade, e vice-versa (veja pp. 129-131).

${ }^{170}$ A tradução de Justice in Robes (Justiça de toga, Tradução Jefferson Luiz Camargo, Revisão da tradução Fernando Santos e Revisão técnica Alonso Reis Freire. São Paulo: WMF Martins Fontes, 2010) fala em "espécie natural": por exemplo, "Introdução: direito e moral" in Justiça de toga, Cambridge/London: Cambridge University Press, 2006, pp. 16-7 (no original, "natural kind", "Introduction: Law and Morals", in Justice in Robes, op. cit., p. 10). A tradução de Justice for Hedgehogs (Justiça para para ouriços, op. cit.), para traduzir a mesma expressão, fala em "tipo natural", p. 167 (para o original, Justice for Hedgehogs, op. cit., p. 159). Sigo a opção de Justiça para ouriços na tradução do trecho abaixo e, portanto, falo em "tipo natural".

${ }^{171}$ Dworkin, "Do Values Conflict? A Hedgehog's Approach", op. cit., p. 255, itálicos no original, traduzi; veja ainda "Do Liberty and Equality Conflict?", op. cit., pp. 41 e ss., esp. p. 41 para o exemplo do "cometa". Para discussão sobre conceitos em Dworkin, veja "Introduction: Law and Morals", op. cit., e Justice for Hedgehogs, op. cit., cap. 8. Veja ainda"Hart's Poscript and the Point of Political Philosophy", in Justice in Robes, op. cit., op. cit., para o valor das liberdades em Dworkin, discutido na próxima seção.

172 "The Place of Liberty", op. cit., pp. 126-7 (veja trecho citado abaixo). 
visto, rejeita o sentido flat e assume as responsabilidades indissociáveis da formulação de uma concepção de um valor político. Especificamente, aponto a integração entre as liberdades e a boa vida, ideia que ecoa a dependência entre valores políticos e os indivíduos por eles beneficiados explícita no trecho de Dworkin citado.

Em conclusão, pode-se dizer que para Dworkin a questão do conflito entre valores é parte interpretação dos valores, e não anterior a ela, ou seja, que, entre outras, o intérprete dos valores deve se perguntar, ao interpretar e não antes de começar a fazê-lo, se os valores conflitam entre si. Indagar se valores entram em conflito não é fazer pergunta de natureza distinta de indagar se determinado ato (para usar o exemplo do autor), como o furto, é justo ou injusto: são ambas questões interpretativas das práticas de justiça, liberdade e direito e precisam ser respondidas na interpretação dessas práticas. ${ }^{173}$

A percepção de que as relações entre valores como igualdade e liberdade, valores importantes à liberdade de expressão em Dworkin, são temas internos às concepções de justiça distributiva, igualdade e liberdade aponta para a necessidade de compreensão ampla das concepções desenvolvidas pelo autor. Em outras palavras, não é possível compreender o argumento dworkiniano de que o fundamento das liberdades é a igualdade sem que antes se indague "o que é igualdade para o autor?". Ao leitor não é dado indagar simplesmente se, na sua própria concepção de igualdade, a liberdade de expressão é uma liberdade de fundamento igualitário; esta não é uma questão irrelevante, mas à apreciação dos méritos da defesa

\footnotetext{
${ }^{173}$ Veja "Do Liberty and Equality Conflict?", op. cit., sobre pessoas que trabalharam terem a mesma riqueza das que não trabalharam, e sobre a proibição do furto ou roubo: "Our objection to these states of affairs is not that though they are desirable in themselves they conflict with other values we want to promote. It is rather that they are bad in themselves. We sacrifice nothing of value by not rewarding the purposefully idle or by thwarting the murderous. So we must reject these interpretations [dos valores da igualdade e da liberdade] and search for other, better ones, before we can decide whether, on the best interpretations of liberty and equaliy, the conservatives are right that minimum-wage laws and high taxes invade liberty and the radicals are right who say that freedom of speech is an obstacle to equality", p. 41, itálico no original (veja pp. 39 e 55 sobre liberdade de expressão e discurso racista e de sexualidade explícita como um problem para igualdade, tema abordado no capítulo terceiro desta dissertação). Veja Ripstein sobre Dworkin, cuja "broader interpretive approach to political philosophy (...) views ideas of liberty, equality, and responsibility as all interpretive concepts that must be understood in terms of substantive views about what is valuable", "Liberty and Equality", op. cit., p. 96. Sobre o tema da integração entre liberdade e igualdade e liberdade de expressão, sobretudo a respeito de regulação eleitoral, inclusive com críticas à integração de valores em Dworkin a partir de "The Place of Liberty", veja Yasmin Dawood, "Democracy and the Freedom of Speech: Rethinking the Conflict between Liberty and Equality" in Canadian Journal of Law and Jurisprudence Vol. XXVI, No. 2 (July 2013).
} 
dworkiniana da liberdade de expressão é indispensável discussão sobre a teoria da igualdade de Dworkin. ${ }^{174}$

Pode-se explicar este ponto por meio das ideias de conceito e concepções, noções utilizadas por Dworkin para designar, respectivamente, os aspectos de uma prática sobre os quais há consenso entre os intérpretes e os aspectos sobre os quais há divergência. Para ele, a necessidade de elaboração de concepções de conceitos políticos como igualdade e liberdade exclui o sentido "flat" das expressões ${ }^{175}$. Diz o autor, ao relatar o esforço do intérprete da prática de cortesia de oferecer um "conceito de cortesia" que

"O contraste entre conceito e concepção é aqui um contraste entre níveis de abstração nos quais se pode estudar a interpretação da práica. No primeiro nível, o acordo tem bor base idéias distintas que são incontestavelmente utilizadas em todas as interpretações; no segundo, a controvérsia latente nesta abstração é identificada e assumida." 176

Para Dworkin, indivíduos que compartilham um conceito e que oferecem diferentes concepções deste conceito são capazes de divergir com sentido ${ }^{177}$. Ele afirma o seguinte:

"Qualquer pesoa que adote a liberdade ou a igualdade como ideal normativo deve ter alguma opinião sobre os modos como as pessoas deveriam ser livres e os aspectos nos quais deveriam ser iguais ou tratadas como iguais, e cada pessoa terá uma opinião diferente. A liberdade e a igualdade, em outras palavras, são conceitos que admitem diversas interpretações ou concepções. Se achamos que a liberdade e a igualdade entram em conflito como ideias dependerá, indubitavelmente, de quais concepções de cada adotamos." 178

${ }^{174}$ Veja, para "confusões" causadas pelos diferentes sentidos de igualdade e liberdade, "The Place of Liberty", op. cit., pp. 132-3. Nestas páginas, o autor aponta para mal-entendidos provocados pelo fato de que indivíduos aparentam divergir politicamente sobre primazia de um valor em relação a outro quando na verdade divergem sobre o valor da igualdade ele mesmo (p. 133). Pouco antes, após expor os três casos discutidos neste artigo (pp. 123-5), Dworkin diz: "Most of the people who seem to reject equality, in cases like our examples, do not actually reject it. They think equality very importand indeed, but they do not think that the form in which equality is at stake in these cases is the important or genuine form of that virtue.”, p. 125. Isso esclarece o equívoco de máleitura de Dworkin que desconsidere o contexto teórico da sua defesa das liberdades. Como diz Ripstein, “(...) Dworkin advocates a standpoint from which disagreements about the respective importance of liberty and equality can be assessed. He contends that they are not actually disagreements about the weight to be attached to competing and opposed values, with libertarians at one extreme and egalitarians at the opposite one, but rather competing interpretations of equality", "Liberty and Equality", op. cit., p. 84 (veja em geral pp. 84-5).

175 "The Place of Liberty", op. cit., pp. 125-6.

${ }^{176}$ Dworkin, $O$ império do direito, Tradução Jefferson Luiz Camargo, revisão técnica Gildo Sá Leitão Rios. $2^{\text {a }}$ Ed. São Paulo: Martins Fontes, 2007, p. 87 (agradeço à Renata do Vale Elias por me emprestar este livro); no original, Law's Empire, Oxford/Portland: Hart Publishing, 2008; publicado inicialmente em 1986., p. 71 (veja em geral pp. 70 e ss.) Veja ainda "The Place of Liberty", op. cit., pp. 126-7. Entre nós, veja Ronaldo Porto Macedo Junior, Do xadrez à cortesia: Dworkin e a teoria do direito contemporânea. São Paulo: Saraiva, 2013. Veja também Caio Moysés de Lima em O Império dos Direitos: Lei e Autoridade Política em Ronald Dworkin, op. cit., pp. 20-1 (na n. 40, p. 20 ele cita a mesma definição de Law's Empire, op. cit. que selecionei), 78-9.

177 "The Place of Liberty", op. cit., pp. 126-7.

178 "O lugar da liberdade", op. cit., p. 166; no original, "The Place of Liberty", op. cit., p. 126 (veja ainda pp. 129133). O autor continua imediatamente a seguir, ecoando ideias mencionadas há pouco: "We can easily construct a conception of liberty such that liberty must obviously and inevitably conflict with any plausible conception of equality", p. 126. Ele exemplifica: fala da concepção anarquista que defina liberdade como tudo o que indivíduos 
Em outras palavras, que igualdade e liberdade são conceitos políticos significa que interpretá-los exige abandonar o sentido "flat" e elaborá-los politicamente por meio de concepções destes conceitos. Mas, em uma divergência entre estas concepções, a compreensão do argumento do adversário exige que se perceba que não há compartilhamento de concepção - isto é, que quando fala em "igualdade" não tem Dworkin em mente a noção abstrata, compartilhada, de igualdade, ou o sentido flat do valor, mas a sua concepção específica do valor, isto é, a igualdade de recursos. Se de um lado a distinção entre conceitos e concepções acentua o compartilhamento de algo entre indivíduos que divergem entre si, de outro aponta para divergências, algo inexistente quando se fala no sentido "flat" criticado por Dworkin.

Faço estas observações porque não é raro que críticos de Dworkin ofereçam interpretações absurdas, ou simplesmente completamente estranhas, como se não falassem do texto que citam, justamente por acreditarem que Dworkin fala daquilo que eles têm em mente. É sempre preciso indagar: "do que fala Dworkin quando se diz que a proibição do discurso de ódio ou da pornografia violenta ofende a igualdade?”. Em que pese na política haja sempre algo compartilhado ${ }^{179}$, concepções são variáveis, e discutir as consequências ou fundamentos (não-?)igualitários da liberdade de expressão sem explicitar a concepção de igualdade do autor sob análise é receita para confusões e más-leituras. Acredito que a compreensão da concepção dworkiniana de interpretação e da sua posição sobre o conflito de valores é capaz de evitar este tipo de engano.

\section{Seção 4. Direitos e liberdades}

Neste capítulo, apresentei a ideia fundamental de direitos no pensamento de Dworkin, bem como algumas de suas consequências à postura que tal instituição política demanda. Discuti ainda brevemente a tese defendida pelo autor de que valores, como igualdade e liberdade, não conflitam entre si, e apontei para a necessidade de ter em mente as concepções do autor destes valores ao analisar as opiniões por ele defendidas sobre, por exemplo, a

quiserem fazer, o que necessariamente geraria conflitos entre liberdade e igualdade, e a concepção segundo a qual liberdade somente incluísse aquilo que acarretasse igualdade entre os cidadãos, o que naturalmente faria com que liberdade e igualdade jamais entrassem em conflito entre si (pp. 126-7).

${ }^{179}$ Dworkin acredita que a igualdade é o valor politico fundamental: veja, por exemplo, "Introduction: Does Equality Matter" in Sovereign Virtue, op. cit., "The Place of Liberty", op. cit. (esp. p. 128), "Reverse Discrimination" e "What Rights Do We Have" in Taking Rights Seriously, op. cit. 
liberdade de expressão. Apresentei ainda o reconhecimento, por parte de Dworkin, da necessidade de apresentar concepções interpretativas dos valores políticos. Nesta seção, chamo a atenção para a interpretação da liberdade oferecida pelo autor.

Muito brevemente, para ele, não há que se falar em liberdade enquanto valor genérico: o que há são direitos às liberdades. Naturalmente, estes direitos carregam o sentido forte exposto na primeira seção. Isto significa dizer: o valor político da "liberdade" são direitos políticos fortes a liberdades, entre eles o direito à liberdade de expressão. Isso não significa que a única justificação possível ao reconhecimento ou à concessão de uma liberdade seja um direito, mas significa que existe uma relação importante, a ser oportunamente pormenorizada, entre o valor da liberdade e direitos individuais. Ainda, o autor rejeita a ideia de que as liberdades tenham valor intrínseco - como é o caso da arte - e sustenta que elas se fundamentam pela sua integração com a ética.

Para apresentar estes temas, exploro na primeira seção aquilo que, para Dworkin, a(s) liberdade(s) não é(são). Para tanto, será necessário recorrer a trabalhos diferentes em que o autor defende as mesmas ideias em contextos distintos, de modo que a exposição inevitavelmente adquire pelo menos alguma aparência de colcha de retalhos. Em seguida, trabalho brevemente a justificação das liberdades para o autor: a sua integração à boa vida enquanto fundamento de diversos direitos, entre eles a liberdade de expressão.

Subseção 4.1. O que as liberdades não são

Não há direito geral à liberdade enquanto não restrição: o que há são direitos a liberdades

O sentido forte de direito defendido por Ronald Dworkin em "Taking Rights Seriously" é, para o autor, motivo para a rejeição de uma tese algo intuitiva e bastante "popular" acerca da "liberdade", a saber, que a não interferência do Estado na ação ou omissão do sujeito é sempre algo de valor, ainda que este direito possa eventualmente ceder frente a outro que lhe supere. ${ }^{180}$ Em outras palavras, o autor rejeita que se defina liberdade em termos

\footnotetext{
180 “What Rights Do We Have?" in Taking Rights Seriously, op. cit. p. 266 (veja em geral pp. 266 e ss.). Ele diz: "Liberty gave its name to the most influential political movement in the last century, and many of those who now despise liberals do so on the ground that they are not sufficiently libertarian. Of course, almost everyone concedes that the right to liberty is not the only political right, and that therefore claims to freedom must be limited, for example, by restraints that protect the security or property of others. Nevertheless the consensus in favor of some right to liberty is a vast one, though it is, as I shall argue in this chapter, misguided.
} 
de ausência de restrição e nega que haja um direito geral à liberdade. Como visto na seção anterior, esta noção de liberdade é o "sentido flat" por ele criticado e que inevitavelmente entra em conflito com outros valores, entre eles a igualdade.

Em “What Rights Do We Have?”, Dworkin diz:

“(...) parece-me absurdo supor que homens e mulheres tenham qualquer direito geral à liberdade, pelo menos do modo como a liberdade tem sido tradicionalmente concebida por seus defensores.

"Tenho em mente a definição tradicional de liberdade como ausência de restrições impostas pelo governo ao que um hoem poderia fazer, se desejasse.". ${ }^{181}$

Esta concepção, ressalta o autor, não seleciona grupo de ações específico cuja proibição viola a liberdade (é, neste sentido, "neutra"): "A liberdade de um homem diminui quando o impedimos de falar ou fazer amor como deseja, mas também diminui quando o impedimos de assassinar ou difamar outras pessoas" ${ }^{182}$. Embora as duas ideias - de liberdade como ausência de restrição e de direito à liberdade - sejam apresentadas pelo autor como distintas embora conectadas ${ }^{183}$, a crítica por ele formulada é uma só e dirigida à concepção que as associa: àquela segundo a qual existe um direito à liberdade compreendida como ausência de restrição.

O problema fundamental apontado por Dworkin nesta concepção é que, se o direito à liberdade é concebido de modo a incluir qualquer ação, é tão enfraquecido que não desempenha mais o papel que se espera de um direito ${ }^{184}$. Talvez seja direito em outro sentido, mas não naquele forte, reconhecível a partir da nossa experiência política, pois, segundo este sentido, nem tudo pode ser direito ${ }^{185}$. Isto, para o autor, afasta a noção de liberdade como ausência de restrição ${ }^{186}$. Lembremos que direitos para Dworkin são caracterizados justamente

"The right to liberty is popular all over this political spectrum.", p. 266.

181 "Que direitos temos?" in Levando os direitos a sério, op. cit., p. 411; no original, "What Rights Do We Have?" in Taking Rights Seriously, op. cit. p. 267. Dworkin atribui esta concepção a Isaiah Berlin e a Jeremy Bentham (veja p. 267). Veja ainda Justice for Hedgehogs, op. cit., pp. 345-6 e cap. 17. Veja "The Place of Liberty" (op. cit.), p. 125, em trecho citado em nota acima.

182 “Que direitos temos?”, op. cit., p. 411; no original, "What Rights Do We Have”, op. cit. p. 267.

183 Ele diz que "the neutral sense of liberty seems to me to have caused more confusion than it has cured, particularly when it is joined to the popular and inspiring idea that men and women have a right to liberty", "What Rights Do We Have" in Taking Rights Seriously, op. cit. p. 268. Ou seja, ao que tudo indica, uma ideia pode ser concebida sem a outra. Dworkin, entretanto, as critica conjuntamente - nesta versão em que uma "is joined" pela outra.

184 “What Rights Do We Have?”, op. cit., pp. 268 e ss. Compare com a opinião de Waldron, como exposta por Caio Moysés de Lima: O Império dos Direitos: Lei e Autoridade Política em Ronald Dworkin, op. cit., pp. 102-3 (trecho citado em nota acima).

185 "What Rights Do We Have?", op. cit., pp. 268 e ss.

186 "What Rights Do We Have?", op. cit., pp. 268 e ss. 
pela limitação ao tipo de justificação possível à sua restrição: se há direito a determinada conduta, ela só pode ser restrita se presentes justificações específicas, enquanto em situações distintas a restrição é admissível mesmo que ausente a justificação especial (veja as duas primeiras seções deste capítulo). Dworkin oferece neste ponto um exemplo conhecido: dirigir num sentido em uma avenida é conduta que pode ser proibida pelo estado simplesmente por atender ao interesse coletivo, e este é o caso justamente porque não há um direito no sentido forte em consideração. ${ }^{187}$

Em outras palavras, para Dworkin a seletividade da ação a ser preservada faz parte daquilo que se espera de um direito, pelo menos no sentido forte da expressão. Num exemplo dado pelo autor, a crítica que se fazia nos EUA ao "busing" e à tentativa de proibi-lo por meio de Emenda à Constituição eram dependentes de, por alguma razão, esta prática ser tão condenável quanto outras que são constitucionalmente vedadas ${ }^{188}$. Para Dworkin, dizer que faz parte do "meu direito" dirigir neste ou naquele sentido de uma via até que tem algum significado - expressa talvez um desejo ou algo que seja bom para mim $^{189}$ - mas trata-se de

\footnotetext{
187،"What Rights Do We Have?”, op. cit., p. 269 (“the government needs no special justification - but only a justification - for this sort of legislation", p. 269, itálico no original). Na p. 267, Dworkin havia citado Berlin dando exemplo similar: para ele "freedom" incluiria "absense of obstructions on roads along which a man can decide to walk" (Isaiah Berlin apud Dworkin, p. 267). Dworkin diz que se trata de trecho do "most famous modern essay on liberty" (p. 267), mas não diz o título nem dá outras informações. Veja "Pornography and Hate", in Freedom's Law, op. cit., artigo, entre outros, sobre Berlin, esp. p. 215 para exemplos similares ao de "What Rights do We Have?", op. cit. Veja ainda "Is the Press Losing the First Amendment?", in A Matter of Principle, op. cit., p. 386 e "Do Liberty and Equality Conflict?", op. cit., p. 49. Veja Pavlos Eleftheriadis em Legal Rights, op. cit., p. 1: após citar Taking Rights Seriously (op. cit., p. xi), ele diz: "Dworkin's own particular account of the special weight of rights is contested, but this statement of the general role of rights is not".

${ }^{188}$ Dworkin comenta a controvérsia: "The suggestion, that neighborhood schools somehow rank with jury trials as constitutional values, would seem silly but for the sense many Americans have that forcing school children into buses is somehow as much an interference with the fundamental right to liberty as segregated schooling was an insult to equality. But that seems to me absurd (...)", "What Right Do We Have", op. cit., p. 267 (logo em seguida vem o trecho citado no início do segundo parágrafo desta subseção).

189 "The term 'right' is used in politics and philosophy in many different senses, some of which I have tried to disentangle elsewhere. In order sensibly to ask whether we have a right to liberty in the neutral sense, we must fix on some one meaning of 'right'. It would not be difficult to find a sense of the term in which we could say with some confidence that men have a right to liberty. We might say, for example, that someone has a right to liberty if it is in his interest to have liberty, that is, if he wants it or if it would be good for him to have it. In this sense, I would be prepared to concede that citizens have a right to liberty. But in this sense I would also have to concede that they have a right, at least generally, to vanilla ice cream", "What Right Do We Have?", op. cit., p. 268, nota omitida (a nota reside no fim do primeiro periodo e faz referência ao capítulo 7 de Taking Rights Seriously, que é o artigo homônimo discutido acima neste capítulo).
} 
direito em sentido que não entra em conflito com direitos existentes no sentido forte da expressão, entre eles o direito à igualdade. ${ }^{190}$

(É aliás o valor da igualdade, na interpretação do que chama de "concepção liberal da igualdade"191, que Dworkin apresenta, neste artigo, como o fundamento dos direitos às liberdades. Entretanto, não é adequado apresentar as liberdades em geral como "direitos à igualdade" como defendidos em "What Rights Do We Have?" ou como direitos de independência como exposto em “Do We Have a Right to Pornography?”. Em primeiro lugar, porque, como o próprio autor indica, o argumento que apresenta é um dentre outros tantos possíveis de serem formulados a favor de direitos ${ }^{192}$. Em segundo lugar, porque estes direitos figuram em crítica sobretudo ao utilitarismo ${ }^{193}$, fato que, se acentua aspecto importante a ideia de direitos do autor - que direitos são dependentes do contexto político em que são defendidos ${ }^{194}$ - ressalta, pelo mesmo motivo, que em outra circunstâncias existem outros direitos. Em outras palavras, não é adequado discutir esta tentativa de fundar direitos na igualdade neste ponto da dissertação porque aqui discuto aspectos mais gerais das liberdades, características estas não circunscritas a um argumento em especial dirigido a considerações específicas (no caso, utilitaristas) ${ }^{195}$. Isto, é claro, não significa que, para Dworkin, direitos não se fundamentem na igualdade ou na independência ${ }^{196}$; isto somente significa que esta fundamentação é mais complexa e rica do que o argumento igualitário específico oferecido em "What Rights Do We Have?". Esta complexidade ficará mais clara quando os fundamentos da liberdade de expressão em Dworkin forem discutidos no capítulo terceiro, abaixo).

Anos depois de Taking Rights Seriously, Dworkin voltou a criticar a ideia de que liberdade é ausência de restrição, desta vez sob a rubrica de que liberdade é licença ${ }^{197}$.

\footnotetext{
190 “What Right Do We Have?”, op. cit., pp. 268-9. Dworkin então passa a discutir objeções que imagina: veja pp. 269 e ss. Exploro abaixo as consequências do tratamento dado pelo autor a uma dessas objeções às liberdades em seu pensamento.

191 “Que direitos temos?” op. cit., p. 420; no original, “What Rights Do We Have?”, op. cit., p. 273.

192 "What Rights Do We Have?", op. cit., pp. 272 (veja ainda pp. 277-8 e "The Forum of Principle" in A Matter of Principle, op. cit., p. 403, n. 42 à p.66.)

193 “What Rights Do We Have?”, op. cit., e “Do We Have a Right to Pornography?”, op. cit.. Veja Yowell, “A Critical Examination of Dworkin's Theory of Rights", op. cit., esp. pp. 93, 98-9, 106-8, 110-20.

194 “The Place of Liberty", op. cit., n. 9, p. 481 à p. 134. Veja ainda "Do We Have a Right to Pornography?", op. cit. e Yowell, “A Critical Examination of Dworkin's Theory of Rights”, op. cit., pp. 130, 131.

${ }^{195}$ Veja, para este ponto, Darlei Dall'Agnol,“O igualitarismo liberal de Dworkin”, op. cit., esp. pp. 59 e ss.

${ }^{196}$ Veja "The Place of Liberty”, op. cit., pp. 128 e ss., e Justice for Hedgehogs, op. cit., pp. 329 e ss.

197 "The Place of Liberty", op. cit., pp. 126 e ss.
} 
Novamente, ele defende a ideia de que liberdades são direitos. ${ }^{198}$ Para o autor, como visto acima, liberdade e igualdade são conceitos interpretativos cuja compreensão se dá por meio de concepções interpretativas. ${ }^{199}$ Como também vimos, entretanto, o autor defende que o conflito entre valores políticos depende das concepções adotadas, o que o leva a ser cauteloso na definição de liberdade, que deverá decorrer da concepção de igualdade por ele defendida. ${ }^{200}$ Dworkin não apresenta nenhum argumento elaborado em favor da compreensão da liberdade enquanto direitos: e se limita a descrever a realidade das principais concepções do valor e a "assumir" a identificação entre liberdade e direitos a liberdades: ele diz que qualquer concepção deverá rejeitar a identificação da liberdade com "license" (ou "permissividade",201) de modo que nem toda restrição a ação desejada pelos cidadãos caracterize violação da liberdade $^{202}$ - e defende que

“(...) qualquer concepção aceitável (...) identificará direitos a certas liberdades designadas como essenciais à liberdade e estipulará que o governo não deve limitar essas liberdades sem uma justificativa especial mais poderosa ou irresistível [compelling] do que a justificativa que requer para outras decisões políticas, inclusive restrições a outras liberdades não protegidas por tais direitos." 203

Entre estes direitos se encontra a liberdade de expressão. ${ }^{204}$ Ela é, portanto, identificada, no pensamento de Ronald Dworkin, como um direito neste sentido que exige justificação especial. Este sentido, naturalmente, é o forte de direitos apresentado pelo autor em "Taking Rights Seriously" e explorado na primeira seção deste capítulo: é o sentido segundo o qual ter um direito a determinada liberdade significa que o estado só pode restringilo se presentes determinadas circunstâncias, circunstâncias estas mais demandantes do que as normalmente necessárias a uma restrição. É assim que, no pensamento de Dworkin, o autor dá um passo importante na construção de defesa contundente das liberdades: a liberdade não é

\footnotetext{
198 "The Place of Liberty", op. cit., pp. 126 e ss.

199 "The Place of Liberty", op. cit., pp. 126-7; veja seção 3, acima.

200 "The Place of Liberty", op. cit., p. 127.

201 "O lugar da liberdade", op. cit., pp. 166-7; no original, "The Place of Liberty", op. cit., pp. 126-7

202 "The Place of Liberty", op. cit., p. 127.

203 "O lugar da liberdade", op. cit., pp. 167 (inseri entre colchetes a palavra como consta no original); no original, "The Place of Liberty", op. cit., p. 127.

${ }^{204}$ Outros são as "freedom of conscience, commitment, speech, and religion, and to freedom of choice in matters touching central or important aspects of an agent's personal life like employment, family arrangements, sexual privacy, and medical treatment", "The Place of Liberty", op. cit. p. 127 (o autor diz que esses são "at minimum" os direitos incluídos na lista, p. 127). Estes exemplos são importantes porque neste artigo Dworkin discute casos concretos relacionados à campanha política (que toca liberdade de expressão), saúde pública e regulamentação de relações de trabalho (veja pp. 123-5; veja ainda capítulo terceiro, abaixo). Veja Macleod, Libralism, Justice, and Markets, op. cit., pp. 158-9. Veja ainda, de Dworkin, "Foreword", op. cit., p. v em trecho citado na seção 4 do capítulo segundo, abaixo
} 
fazer qualquer coisa que se queira, pois liberdade são direitos a liberdades. Esta defesa é forte porque, justamente ao selecionar dentre diversas condutas aquelas que devem ser protegidas, abre espaço para justificar politicamente o que há de especial nas liberdades - Dworkin faz isso em "Taking Rights Seriously", como visto, ao sustentar que direitos se fundamentam na dignidade e na igualdade e que, portanto, sua violação é especialmente danosa. Esta especialidade dos direitos, se de um lado exige a rejeição de concepções supostamente "neutras" que enxergam em qualquer "restrição" uma violação da liberdade, de outro lado abre espaço para a interpretação dos valores da igualdade e da liberdade como conceitos políticos que admitem diferentes concepções. A exposição das justificações ao direito à liberdade de expressão oferecidas pelo autor é objeto dos próximos capítulos. Por hora, vale discutir mais alguns aspectos gerais das liberdades no pensamento de Dworkin que são importantes para o restante desta dissertação.

\section{As liberdades não são (somente) instrumento de interesse coletivo}

A exposição desta característica negativa das liberdades em Dworkin (isto é, daquilo que elas não são) admite maior brevidade porque decorre de reflexões do autor expostas em outros pontos, em especial da associação entre liberdades e direitos e da distinção entre princípios e políticas.

Para o autor, as liberdades podem, mas não necessariamente são e, de fato, crucialmente não são, instrumentos de interesse coletivo. Elas podem ser instrumentos deste tipo porque é compreensível que interesses coletivos sejam promovidos pelo reconhecimento e preservação de liberdades. Elas não necessariamente são porque é imaginável outra justificativa das liberdades; elas crucialmente não são instrumentos de interesse coletivo porque as liberdades comumente reconhecidas pela política e pelo direito são mais corretamente compreendidas e justificadas como protetivas de direitos (no sentido forte já discutido).

Em outras palavras, Dworkin diz que a liberdade pode "ter valor instrumental para alguma outra meta, como a arte ou o saber (...)"205, embora defenda que não reside aí a sua

205 "O lugar da liberdade”, op. cit., p. 170, n. 6; no original, "The Place of Liberty”, op. cit., p. 480, nota 6 à p.129. 
justificativa fundamental ${ }^{206}$. Mais relevante aos propósitos desta pesquisa, a liberdade de expressão é comumente utilizada por Dworkin para ilustrar a diferença entre princípio e política: para o autor, reside no primeiro, e não na segunda, a fundamentação do direito objeto desta pesquisa ainda que a liberdade de expressão possa ter benefícios coletivos ${ }^{207}$. Estes e outros temas são trabalhados no capítulo terceiro, em que discuto especificamente a liberdade de expressão e exploro os diferentes argumentos em defesa deste direito disponíveis no pensamento de Dworkin. Daí esta discussão neste momento ser mais sumária.

Mas desde já o tema merece breve ilustração. Como visto, a distinção entre princípios e políticas marca a distinção entre justificações políticas baseadas em direitos (objetivos individualizados) e em políticas (objetivos não-individualizados) ${ }^{208}$. Como diz o autor, isso não impede que a distinção caracterize diferentes maneiras pelas quais um direito a uma liberdade pode ser justificada, pois o reconhecimento de uma liberdade pode se dar tanto em razão de haver um direito moral a ela quanto em razão de este reconhecimento ser capaz de atender a um objetivo não individualizado ${ }^{209}$.

O exemplo dado por ele sobre pena de morte ${ }^{210}$ esclarece a distinção. Dworkin imagina argumento utilitarista de política a favor da medida e um argumento não-utilitarista de política contrário a ela: segundo o primeiro, a pena capital previne mortes enquanto, para o segundo,

206 "The Place of Liberty", op. cit., pp. 129 e ss. Veja próxima subseção.

${ }^{207}$ Veja "The Farber Case: Reporters and Informers" e "Is the Press Losing the First Amendment", ambos in A Matter of Principle, op. cit..Veja ainda "Why Must Speech Be Free?" op. cit. Veja ainda, para justificações da liberdade de expressão baseadas em "policy" ou em "liberty", Justice for Hedgehogs, op. cit., pp. 373-4 (veja ainda p. 329). O direito de consumo da pornografia é contexto de extensa discussão sobre a distinção entre "goals" e "rights": "Do We Have a Right to Pornography" op. cit. Veja ainda a primeira seção deste capítulo para discussão sobre princípios e políticas, com referência à troca de artigos entre Dworkin e Frederick Schauer.

208 "Hard Cases", op. cit., pp. 90 e ss. (veja seção 1 deste capítulo, acima).

${ }^{209}$ Dworkin exemplifica esta possibilidade ao imaginar a possível justificação da liberdade de expressão sob um "rule utilitarianism":

"Once popular form of that theory, for example, holds that an act is right if the general acceptance of a rule requiring that act would improve the average welfare of members of the community. A political theory might provide for a right to free speech, for example, on the hypothesis that the general acceptance of that right by courts and other political institutions would promote the highest average utility of the community in the long run.

"But we may nevertheless distinguish institutional rights, at least, from collective goals in such a theory. If the theory provides that an official of a particular institution is justified in making a political decision, and not justified in refusing to make it, whenever that decision is necessary to protect the freedom to speak of any individual, the theory provides free speech as a right. It does not matter that the theory stipulates this right on the hypothesis that if all political institutions do enforce the right in what way an important collective goal will in fact be promoted. What is important is the commitment to a scheme of government that makes an appeal to the right decisive in particular cases.", "Hard Cases", op. cit. pp. 95-6, nota omitida. Veja ainda "Taking Rights Seriously", op. cit., p. 199, n. 1 e "Devaluing Liberty", op. cit. (este ultimo é discutido na conclusão desta dissertação).

${ }^{210} \mathrm{O}$ exemplo foi brevemente mencionado e o trecho citado acima: veja nota na primeira seção deste capítulo. Veja Guest, Ronald Dworkin, op. cit., p. 169. 
mesmo isto sendo verdade, homicídios sancionados pelo estado geram mais prejuízos que benefícios à comunidade. ${ }^{211} \mathrm{O}$ que Dworkin monta é divergência entre argumentos de política a respeito do reconhecimento de determinado direito: ambas as justificações dizem respeito a um objetivo não individualizado, pois não fazem referência a consideração pertinente exclusivamente a indivíduos específicos, sejam eles as vítimas (direito de ver o condenado morto) ou os condenados (direito de não receber pena de morte). A exposição deste debate hipotético é interessante porque a vedação da pena capital é em geral concebida como um direito do condenado, e, sendo possível defendê-la por meio de argumentos de política, fica ilustrado o reconhecimento de um direito em razão de argumento que se refere a objetivo nãoindividualizado $^{212}$.

Por ora, eu gostaria de acentuar que não é de política o tipo de justificação às liberdades que o leitor normalmente encontra na obra de Dworkin. Para o autor, as liberdades são questão de princípio. Assim como para ele direitos são liberdades, liberdades são justificadas por direitos. Os argumentos em defesa destas visões serão expostos nos próximos capítulos.

\section{As liberdades não dependem do interesse de seu titular}

Além de contrapor à defesa instrumental das liberdades a sua justificação por meio de direitos, Dworkin contrasta justificação instrumental a justificação constitutiva das liberdades ao defender a ausência de conflito, por exemplo, entre igualdade e liberdade ${ }^{213}$. Dizer que a liberdade é "constitutiva" entretanto carece de esclarecimento em pelo menos dois sentidos: o que significa "constituir" e o que é "constituído".

Em "The Place of Liberty", Dworkin, como visto, procura fornecer um argumento a favor da integração entre liberdade e igualdade situando as liberdades na sua teoria da justiça distributiva, a igualdade de recursos. Discuto este argumento em maior detalhe na próxima

\footnotetext{
${ }^{211}$ Justice for Hedgehogs op. cit., p. 329. Veja ainda Life's Dominion, op. cit., p. 182.

${ }^{212}$ Veja "Hard Cases", op. cit. pp. 95-6, e trecho citado em nota acima.

213 "The Place of Liberty", op. cit., pp. 134 e ss. Ainda, em "Why Must Speech be Free?", op. cit., Dworkin apresenta duas justificações da liberdade de expressão: uma instrumental e outra constitutiva (pp. 199 e ss.). Dworkin ressalta que cada tipo de justificação marca de maneira diferente os limites da liberdade de expressão (p. 199), e que a instrumental "is both more fragile and more limited" (p. 201; veja ainda a última seção do próximo capítulo e o capítulo terceiro, ambos abaixo). O autor diz a mesma coisa ao contrastas argumentos baseados em liberdade a argumentos baseados em policy: Justice for Hedgehogs, op. cit., pp. 373-4. "It is commonplace that no political right is absolute and that even free speech has its limits. But the character and justification of these limits differs, depending on which of the justifications for the right I mentioned is in play", p. 373.
} 
seção. Por enquanto vale apontar que, neste esforço, o autor critica a tentativa de articular os dois valores por meio do que chama de "estratégia do interesse", segundo a qual as liberdades existentes são aquelas "instrumentalmente" necessárias à "satisfação" dos interesses das pessoas corretamente recolhidos ${ }^{214}$ (e aqui, versões desta estratégia, Dworkin aponta, podem divergir: se distinguem pela diferente interpretação que têm sobre como recolher estes interesses ${ }^{215}$ ). Dworkin indica que teorias deste tipo são a "concepção utilitarista de igualdade"216 (mencionada acima ainda nesta subseção) e teorias contratualistas ${ }^{217}$ (embora a versão de John Rawls também tenha aspectos da estratégia que Dworkin prefere, a saber, constitutiva e seja, portanto, "um misto"218 das duas).

Dworkin defende visão não instrumental das liberdades e, portanto, para integrar liberdade e igualdade, procura optar por estratégia distinta: trata-se do que o que chama de "estratégia constitutiva", que integra, desde o início, a liberdade na definição de justiça distributiva $^{219}$. Que a liberdade é "constitutiva" significa portanto que ela se define por ser necessária à interpretação de outro valor; e o que ela constitui é exatamente este outro valor: no caso, a igualdade. Trata-se, entretanto, somente de um exemplo de como um valor constitui outro na obra de Dworkin; as próprias liberdades, na opinião do autor, são integradas à boa vida (veja abaixo).

Não é o caso de esmiuçar a estratégia constitutiva pois isso nos levaria à exposição do próprio argumento do autor a favor da defesa de certas liberdades na igualdade de recursos. Mas agora é bom momento de discutir as críticas do autor à estratégia do interesse.

\footnotetext{
214 “O lugar da liberdade”, op. cit., p. 179; no original, “The Place of Liberty”, op. cit., pp. 134-5 (em especial, "(...) as things fall out, certain liberties are instrumentally connected to the satisfaction of interests so that protecting interests in the right proportion or according to the right formula requires establishing and respecting right to these liberties.", p. 134-5). Veja Macleod, Liberalism, Justice, and Markets, op. cit., pp. 159 e ss.

215 "Each version of that strategy stipulates a particular account of how people's interests are to be identified, and what function of different people's interests an ideal distribution aim to satisfy." "The Place of Liberty", op. cit., p. 134

216 “'O lugar da liberdade”, op. cit., p. 179; para o original, “The Place of Liberty”, op. cit., p. 135.

217 "The Place of Liberty”, op. cit., pp. 135-6.

218 “O lugar da liberdade", op. cit., p. 179; no original, “The Place of Liberty”, op. cit., pp. 136 (veja ainda p. 138 e o seguinte trecho: "Rawls strategy for reconciling liberty and equality appears to be a mixed interest and constitutive strategy", p. 136, nota omitida). Veja resumo destas teorias criticadas por Dworkin em Macleod, Liberalism, Justice, and Markets, op. cit., p. 160, n. 3.

219 "O lugar da liberdade", op. cit., p. 179; no original, "The Place of Liberty", op. cit., p. 135 (veja em especial "The constitutive strategy (...) builds liberty into the structure of its chosen conception of equality from the start", p. 135).
} 
O problema desta estratégia, segundo Dworkin, é a fraqueza com que reconhece liberdades: submeter as liberdades, sobretudo na "margem"220, ao interesse dos indivíduos dificilmente acarreta no seu reconhecimento em oposição ao seu abandono porque embora indivíduos se beneficiem de que se lhes reconheçam liberdades, pode passar longe do seu interesse que essas liberdades sejam generalizadas dados os custos de fazê-lo. O autor diz, após mencionar liberdade de expressão política, entre outros ${ }^{221}$, citando Hart:

“Como H. L. A. Hart assinalou, porém, posso muito bem achar que estou em pior situação devido a essas liberdades serem generalizadas em minha sociedade, isto é, porque outras pessoas têm direitos deste tipo. Estou especialmente propenso a pensar assim com relação ao que poderíamos chamar de margem desses direitos. Com certeza eu estaria em pior situação se ninguém em minha comunidade tivesse permissão para discutir política, mesmo em particular. Mas não se segue que eu estaria em pior situação se as grandes e impopulares manifestações políticas, que muitos cidadãos achassem muito agressivas [deeply offensive], fossem proibidas em áreas públicas; eu talvez acreditasse estar em situação melhor, em média [on balance], se a verba pública necessária para policiar tais manifestações fosse gasta na prevenção do crime, ou na criação de melhores hospitais". ${ }^{222}$

O que se percebe é que, para Dworkin, a estratégia do interesse fracassa justamente por submeter as liberdades à capacidade que têm de servirem instrumentalmente aos interesses dos indivíduos, o que não lhes garante a proteção necessária ${ }^{223}$. Pouco antes da discussão sobre estratégia instrumental, o autor havia comentado o "igualitário-utilitarista" 224 de modo a

220 "O lugar da liberdade", op. cit., p. 183; no original, "The Place of Liberty”, op. cit., p. 137:

221 "(...) I can be no worse off just for having the right to speak in unpopular demonstrations (...)", "The Place of Liberty", op. cit., p. 137. Veja "Taking Rights Seriously", op. cit., p. 197, esp. trecho citado acima.

222 "O lugar da liberdade", op. cit., p. 183, nota omitida, acrescentei entre colchetes palavras do original; para o original, "The Place of Liberty", op. cit., p. 137, nota omitida (na nota, Dworkin cita trabalho de Hart: veja n. 13, p. 481). Na próxima seção, discuto o argumento dworkiniano que integra liberdade e igualdade tornando as liberdades como aspectos definidores, e não objeto, do leilão imaginário que caracteriza a igualdade de recursos (pp. 139 e ss.). Tratar as liberdades como objeto do leilão é equívoco que seria cometido pela igualdade de recursos se ela utilizasse a estratégia do interesse, e não a estratégia constitutiva (pp. 139-143). Leiloar as liberdades é transformá-las em bens de modo que as submete aos interesses dos indivíduos e, portanto, ao tipo de fragilidade encontrada pelo autor, por exemplo, no utilitarismo igualitário (pp. 139-143): ele diz que "If the depressing suspicion I expressed earlier is accurate - that most people are indifferent about at least some of the basis liberties our constitutional traditions celebrate - liberty would not survive the auction in any robust form. Some people would pay the price necessary to guarantee the basic liberties for themselves, but not many would, and that fact alone would increase the price of liberty for those anxious to secure it", p. 142. O autor entretanto aponta que a igualdade de recursos é incompatível com a estratégia do interesse (pp. 143, 145), e que ela utiliza a estratégia constitutiva (pp. 143 e ss., esp. pp. 145-7; veja ainda p. 122). Compare esta ideia com a noção de "injustice factor" ou "moral harm" como indicativa do significado da violação de um direito em "Principle, Policy, Procedure", op. cit., p. 80 (entre outras). Para crítica a este argumento de Dworkin contra a "interest strategy", veja Macleod, Liberalism, Justice, and Markets, op. cit., pp. 163 e ss. (veja também pp. 182 e ss.)

223 "The Place of Liberty", op. cit., p. 132, 134-5, p. 139 (veja em geral pp. 131-147). Veja ainda "What Rights Do We Have", op. cit., pp. 270, 271-2.

224 "O lugar da liberdade", op. cit., p. 175; para o original, "The Place of Liberty", op. cit., p. 131. Para o autor, trata-se de quem defende "that a government show equal concern when it takes the welfare of each member of the 
criticá-lo pelo mesmo defeito, a saber, por fundamentar as liberdades, por exemplo, na utilidade produzida "a longo prazo",225: trata-se, diz Dworkin, de é um "ato de fé cega com o único intuito de reconciliar a liberdade com o credo utilitarista". ${ }^{226}$ Em especial, como visto no trecho citado acima, o problema reside nos direitos "marginais"; inclusive, diversos direitos à liberdade de expressão por ele defendidos, entre eles o direito ao discurso de ódio e à pornografia pesada, não são justificáveis por argumentos instrumentais ${ }^{227}$, como são os argumentos de política discutido acima neste capítulo, bem como aqueles pelos quais a estratégia do interesse pretende integrar liberdade e igualdade. Estes direitos "marginais", entretanto, encontram abrigo na justificação de princípio que o autor oferece. Naturalmente, isto per se não é argumento. Será preciso analisar os argumentos de Dworkin não só em defesa destes direitos mais polêmicos, mas do fundamento mais geral das liberdades, entre elas a liberdade de expressão.

\section{As liberdades não são mercadoria ${ }^{228}$ (commodity)}

Como visto acima, Dworkin rejeita a visão de que existe um direito no sentido forte à liberdade entendida enquanto ausência de restrição. Em “What Rights Do We Have?”, o autor entretanto imagina objeções à sua crítica unidas pela tentativa de distinguir as liberdades “importantes" - que seriam incluídas pelo direito à liberdade - das não importantes ${ }^{229}$. Assim,

community into account in the same way, by identifying and pursuing policies that promise the greatest average welfare in the long run", p. 131.

225 "O lugar da liberdade", op. cit., p. 174; para o original, "The Place of Liberty", op. cit., p. 131. Veja ainda "What Rights Do We Have?", op. cit., p. 271.

226 "O lugar da liberdade", op. cit., p. 175; para o original, "The Place of Liberty", op. cit., p. 132 (veja ainda pp. 137-8) e Justice for Hegdehogs, op. cit., pp. 294-5. Para crítica, veja Macleod, Liberalism, Justice, and Markets, op. cit., esp. pp. 164-5, com citação deste trecho de "The Place of Liberty", op. cit. (veja ainda p. 168 sobre o argumento de Dworkin neste artigo: "The extremely complex argument which Dworkin develops is designed to give liberty na invulnerable and noncontingent place in the egalitarian ideal"). Veja, de Dworkin "Why Academic Freedom" in Freedom's Law, op. cit., pp. 249-50. Sobre justificações "goal-based' da liberdade de expressão, Dworkin diz: "This argument has the weakness of providing contingent reasons for convictions we do not hold contingently", "Do We Have a Right to Pornography?", op. cit., p. 352 (mesmo trecho citado por Stephen Guest, Ronald Dworkin, p. 264, n. 23 à p.157 - veja ainda p. 169 para citação de Justice for Hedgehogs similar a essa de "The Place of Liberty" - Guest não diz a página, mas acredito que seja as que menciono acima nesta nota, i.e., pp. 294-5).

${ }^{227}$ Veja, por exemplo, "Why Must Speech Be Free?", op. cit., pp. 199 e ss. e "Do We Have a Right to Pornography?", op. cit., pp. 351-2. Veja ainda "Equality of Resources", op. cit., pp. 75-6 e referências na nota anterior.

228 "Que Direitos Temos?”, op. cit., p. 416; no original, “What Rights Do We Have?", op. cit., p. 270.

229 "What Rights Do We Have?", op. cit., pp. 269 e ss. "It may now be said that I have misunderstood the claim that there is a right to liberty. It does not mean to argue, it will be said, that there is a right to all liberty, but 
somente as liberdades "importantes" seriam protegidas por direitos, o que caracterizaria contra argumento a Dworkin porque estes direitos poderiam entrar em conflito com o valor da igualdade, o que não ocorre, como visto, com os "direitos" à liberdade enquanto ausência de restrição ${ }^{230}$. A primeira versão deste contra argumento considerada pelo autor é interessante aos meus propósitos porque oferece oportunidade para Dworkin rechaçar a ideia de que liberdades são "commodity” (mercadoria), isto é, que podem ser vendidas e compradas.

Dworkin constrói esta versão como uma teoria que consiste em distinguir as liberdades "importantes" das não importantes pela medida de liberdade perdida em cada caso, isto é, o caso em que a restrição da liberdade de um indivíduo viola um direito é diferenciado do caso em que isso não ocorre porque “(...) no primeiro caso a quantidade da mercadoria [commodity] de que foi privado é, por alguma razão, maior em termos de quantidade ou de impacto do que no segundo caso". ${ }^{231}$ Dworkin sustenta que esta medida dificilmente especifica as liberdades a serem protegidas de modo que “(...) se ajuste ao nosso sentido [sense] intuitivo sobre quais liberdades são básicas e quais não são" ${ }^{232}$. Se o critério é "frustração", diz ele, proibir o furto ou regulamentar o trânsito violam mais a liberdade do que limitações ao discurso político ${ }^{233}$; se a medida da restrição à liberdade são as suas consequências às escolhas futuras do indivíduo que a sofre, nada é pior do que as penas trazidas normalmente pelo direito penal. ${ }^{234}$ Intuitivamente, entretanto, aponta o autor, os direitos às liberdades não impedem o furto, nem as leis de trânsito, embora estejam crucialmente implicadas na liberdade de expressão. O defeito desta teoria que Dworkin expõe e rechaça consiste no tipo de equívoco de submeter as liberdades às escolhas de seus titulares, equívoco que, como visto acima, coloca em risco as liberdades. Em outras palavras, submetê-las a uma métrica própria de mercadorias, cujo preço os indivíduos são capazes de estimar da mesma forma que são capazes de dizer o quanto se

simply to important or basic liberties. Every law is, as Bentham said, an infraction of liberty, but we have a right to be protected against only or serious infractions.", p. 269.

230 "What Rights Do We Have?", op. cit., p. 270.

231 "Que direitos temos?", op. cit., p. 416; no original, "What Rights Do We Have?", op. cit., p. 270. A segunda teoria consiste em apontar para o "special character" (pp. 270-1) das liberdades protegidas por direitos. Dwokin acredita que esta formulação da distinção abandona a noção de direito geral à liberdade (p. 271).

232 "Que direitos temos?", op. cit., p. 416, acrescentei entre colchetes palavra do original; no original, "What Rights Do We Have?", op. cit., p. 270.

233 Que direitos temos?", op. cit., p. 416; no original, "What Rights Do We Have?", op. cit., p. 270. Compare com "Do Liberty and Equality Conflict?", op. cit., p. 41.

234 “What Rights Do We Have?", op. cit., p. 270. 
incomodam com determinada restrição, é se equivocar quanto à natureza das liberdades e o tipo de proteção que oferecem aos indivíduos.

Que liberdades não são "propriedade" é defendido pelo autor ao discutir um caso real ocorrido nos EUA, em que um ex-agente do serviço de inteligência (CIA) havia assinado contrato por meio do qual se comprometia a submeter eventual publicação sobre a agência à sua autorização antes de publicá-1o ${ }^{235}$. Mas o réu publicou livro sobre a atuação da CIA na Guerra do Vietnã sem esta autorização, foi processado e condenado a devolver o dinheiro lucrado com sua obra. ${ }^{236}$ A punição, após ser reformada por um tribunal, foi reinstaurada pela Suprema Corte dos EUA. ${ }^{237}$ Ao trabalhar o caso, Dworkin assume alguns fatos: (i) que o agente não teria obtido o emprego caso houvesse se recusado a assinar o acordo que o obrigava a pedir a autorização; (ii) que, não fosse o acordo, ele estaria livre para publicar o livro; (iii) que o livro não continua "informação confidencial" 238 e que (iv) seria inconstitucional uma lei que obrigasse qualquer indivíduo a pedir autorização para publicar livro sobre a CIA. ${ }^{239}$ Dworkin analisa o caso longamente e sob mais de uma perspectiva ${ }^{240}$, mas o que importa para os meus propósitos é a sua crítica ao argumento segundo o qual o acordo deve ser aplicado porque o agente o assinou por meio de “(...) uma escolha livre e informada" ${ }^{241}$; em suma: se ele “(...) barganhou livremente os seus direitos plenos da Primeira Emenda ao concordar com um exame prévio, por que os tribunais deverial agora liberá-lo da barganha quando ela se mostra inconveniente?",242.

\section{A resposta de Dworkin:}

"Esse foi o argumento da CIA e ele prevaleceu. Mas não é tão forte quanto parece porque se baseia numa analogia equivocada entre um direito constitucional e um pedaço de propriedade. A Primeira Emenda não distribui direitos como marcas comerciais, cujo objetivo é aumentar a riqueza total de cada cidadão. A Constituição como um todo afirma, como disse, as condições sob as quais os cidadãos serão

\footnotetext{
235 "Is The Press Losing the First Amendment" in A Matter of Principle, op. cit., p. 381 (veja ainda p. 393). O caso é United States v. Snepp (p. 381).

236 "Is The Press Losing the First Amendment", op. cit., pp. 381-2.

237 "Is The Press Losing the First Amendment", op. cit., p. 382. Veja também pp. 393-7.

238 “A imprensa está perdendo a Primeira Emenda?" in Uma questão de princípio, op. cit., p. 586; no original. "Is The Press Losing the First Amendment", op. cit., p. 393.

239 “A imprensa está perdendo a Primeira Emenda?" op. cit., pp. 585-6; no original. "Is The Press Losing the First Amendment", op. cit., p. 393.

${ }^{240}$ Veja, por exemplo, a discussão sobre "right to listen", "Is The Press Losing the First Amendment", op. cit., p. 395-6. Minha análise se concentra nos argumentos de Dworkin a respeito do direito do autor de publicar (pp. 3967).

241 "Is The Press Losing the First Amendment", op. cit., p. 396.

242 “A imprensa está perdendo a Primeira Emenda?", op. cit., p. 591; no original, "Is The Press Losing the First Amendment", op. cit., p. 396.
} 
considerados parte de uma comunidade de iguais. Um cidadão individual não é mais capaz de redefinir essas condições do que a maioria. A Constituição não permite que ele se venda como escravo ou que ceda seu direito de escolher sua própria religião. Não porque nunca seja do interesse dele fazer tal troca, mas porque é intolerável que algum cidadão seja escravo ou que hipoteque sua consciência". ${ }^{243}$

A pergunta oferecida pelo autor como teste da constitucionalidade de acordo é a seguinte: a medida impõe a quem o assina uma situação “(..) considerada uma negação da igualdade pela Constituição?"244 Dworkin conclui que acordos relativos à liberdade de expressão podem violar a proteção que a Constituição dos EUA lhe oferece, da mesma forma que podem violar a liberdade de religião, o que não exclui que alguns acordos sejam válidos $^{245}$. No caso do ex-agente, na opinião de Dworkin o acordo viola a liberdade de expressão $^{246}$. Em especial, o argumento que trata direitos constitucionais como propriedade, como algo que pode ser negociado, vendido e comprado, é um equívoco, pois trata a liberdade de expressão como uma propriedade que se pode perder por meio de um contrato que depois se mostra desvantajoso ${ }^{247}$. O equívoco desta visão, segundo Dworkin, reside em tratar o "equal standing" (ou "igualdade de condições" ${ }^{248}$ ) protegido pela Primeira Emenda algo que se pode perder: para ele, isso nunca acontece ${ }^{249}$.

Em outras palavras, para Dworkin as liberdades não podem nem ser medidas a partir da experiência subjetiva do indivíduo frustrado pela restrição, nem abandonadas em troca do valor em dinheiro ou outro recurso que as partes de um contrato considerem que vale. $\mathrm{O}$ valor da liberdade é portanto outro.

243 “A imprensa está perdendo a Primeira Emenda?”, op. cit., p. 591; no original, "Is The Press Losing the First Amendment", op. cit., p. 396

244 "Is The Press Losing the First Amendment", op. cit., p. 396, traduzi - no original: "deemed a denial of equality by the Constitution?"; a tradução brasileira é a seguinte: “(...) que se considera negar a igualdade pela Constituição?", “A imprensa está perdendo a Primeira Emenda?”, op. cit., p. 592.

245 "Is The Press Losing the First Amendment" in A Matter of Principle, op. cit., p. 397.

246 "Is The Press Losing the First Amendment" in A Matter of Principle, op. cit., p. 397.

247 "Is The Press Losing the First Amendment" in A Matter of Principle, op. cit., p. 397.

248 “A imprensa está perdendo a Primeira Emenda?”, op. cit., p. 592.

249 "Is The Press Losing the First Amendment" op. cit., p. 397 (compare com Justice for Hedgehogs, op. cit., pp. 390-2). Mas o autor é claro ao dizer que nem todo contrato pelo qual um indivíduo concorda em deixar de publicar algo é inaceitável ("Is The Press Losing the First Amendment", op. cit., p. 397); o problema, diz ele, é a conclusão irrestrita adotada pela Suprema Corte dos EUA: "The Court assumed that anyone who is employed by a government agency might waive his First Amendment rights even without specific congressional authorization. That assumption makes the mistake of supposing that a constitutional right is simply a piece of personal property", p. 397. 


\section{Subseção 4.2. As liberdades e a boa vida I}

Talvez o leitor tenha se incomodado pela ausência de fundamento aos direitos, entre eles ao direito à liberdade de expressão, na discussão até agora realizada sobre a obra de Dworkin. Lembremo-nos do exemplo de política enquanto objetivo não-individualizado oferecido pelo autor: o contrato celebrado entre o Estado e indústria bélica para fornecimento de munição atende a algum valor, ainda que eventualmente discutível. Mas parece carecer de justificação a liberdade de expressão supostamente justificada por princípio. Recordemos também diversas considerações do autor sobre direitos são explicitamente "hipotéticas", isto é, não se dirigem a identificar direitos efetivamente existentes ${ }^{250}$. Ainda assim, fica a pergunta: a que serviria a liberdade de expressão, objeto desta dissertação, bem como outras liberdades?

Apontei até agora neste capítulo aspectos das liberdades na obra de Ronald Dworkin. Em primeiro lugar, as liberdades são para o autor um direito forte, isto é, não cedem, salvo em situações extremas, a considerações de benefício coletivo, tampouco exigem de seu titular que faça aquilo é certo: os direitos não se limitam ao que é correto, e não há contradição em criticar alguém por exercer liberdade cuja existência não se questione. Em segundo lugar, as liberdades não são exclusivamente interesse coletivo, pois são mais devidamente justificadas por direitos; tampouco as liberdades são propriedade, ou seja, não podem ser vendidas e compradas, e tratá-las desta forma, portanto, implica descaracterizá-las.

Estas visões rejeitadas pelo autor podem parecer extremas, mas lamentavelmente têm confortável lugar em parte do discurso político mais ordinário, sobretudo naquele ressentido pelos supostos excessos de direitos concedidos aos sujeitos. Isso é comum especialmente em relação à liberdade de expressão, direito que comumente se pretende limitar sob pretexto de que seu uso "abusivo" não pode ser tolerado, que sua interpretação - como a de qualquer direito fundamental, acrescenta-se - precisa ser limitada (ou sopesada, na terminologia mais ilustrada) por outros direitos. Ou ainda, em clara falácia, que, justamente por não ser ilimitado, o direito à liberdade de expressão deve ceder no caso que estiver em questão. Há quem ainda acrescente, neste cálculo de preferências, os custos de determinadas hipóteses de exercício da liberdade de expressão, notadamente daquelas que causam "transtornos", como as de protestos e manifestações em vias públicas normalmente ocupadas por motoristas em seus veículos. Como visto, Dworkin oferece razões para que se abandone esse modo de pensar. Mas o que o

250 “Taking Rights Seriously”, op. cit., p. 197 (veja discussão acima). 
autor oferece no seu lugar? Ou seja, como pensar as liberdades se não desta forma que lhes oferece um lugar ao lado de considerações tão distintas entre si quanto o interesse em não ser ofendido e de não chegar tarde em casa após o expediente?

É claro que, se entendida a demanda por justificação das liberdades, especialmente das mais custosas, em termos de qual o ganho das liberdades a outro bem como o aprimoramento da economia por meio de regime de propriedade privada, etc., incorre-se no erro de assumir que o reconhecimento de liberdades é sempre decisão política justificada por política. Como visto, não é aí que Dworkin encontra a fundamentação das liberdades. É preciso, entretanto, dar uma chance à pressuposição de que existem direitos no sentido forte defendido por Dworkin. É preciso buscar na obra do autor as justificativas possíveis desses direitos. Se bem sucedidas, elas apontam para a existência de liberdades que não podem ser limitadas por simples recurso a argumentos capazes de forçar a reconsideração de decisões justificadas por políticas. Esta dissertação aposta na cogência destas justificações e procura apresentá-las da maneira mais convincente possível.

Em Dworkin, em contraste à noção de que as liberdades são instituto social que se presta a promover objetivo coletivamente positivo, as liberdades são constitutivas da boa vida, da igualdade e da democracia. Em outras palavras, as liberdades são importantes a que seus detentores, ainda que não as exerçam, vivam bem, sejam tratados com igualdade (ou "igual consideração e respeito", expressão comum na obra do autor ${ }^{251}$ ), e possam julgar como genuína a natureza democrática do regime político sob os quais vivem. Por enquanto, gostaria de explorar a integração entre igualdade e boa vida; na próxima seção, apresento a integração entre as liberdades e a teoria da justiça defendida por Dworkin, a saber, a igualdade de recursos. (A integração entre liberdades e democracia fica para o capítulo terceiro).

\section{As liberdades não têm valor intrínseco: são direitos constitutivos da boa vida}

Para Dworkin, as liberdades, não têm valor intrínseco: seu valor depende da capacidade que têm de contribuir à boa vida. Isto é, o autor enxerga as liberdades de maneira integrada à ética.

\footnotetext{
${ }^{251}$ Por exemplo "Que direitos temos?", op. cit., p. 419; para o original, "What Rights Do We Have?", op. cit., p. 273.
} 
Dworkin, em sua resposta ao Pós-Escrito publicado na segunda edição de The Concept of Law, de Hart, elabora duas explicações acerca da “(...) relação entre entender um valor e viver melhor em consequência disso" 252 : pode-se elaborar explicação integradora ou autônoma ${ }^{253}$ (integrated ou detached). $\mathrm{O}$ autor oferece um contraste para explicar a distinção entre as explicações (ou "visões", como diz ${ }^{254}$ ). Dworkin contrasta virtudes pessoais e arte: sobre a segunda, diz que.

“(...) podemos dizer que uma pintura não teria valor se não tivesse nenhum significado nem exercesse qualquer impacto sobre qualquer sensibilidade, sem presumir também que seu valor depende do impacto que ela realmente exerce, ou do valor independente desse impacto para qualquer criatura" ${ }^{255}$.

O ponto é que para ele é correto entender que o valor da arte depende, em certo sentido, de ser capaz de gerar impacto na sensibilidade dos indivíduos afortunados o suficiente para dela gozarem. Mas isso não significa que o valor seja medido nos termos desse impacto. Essa ideia é coerente com outra, defendida anteriormente por Dworkin, de que a arte tem valor intrínseco $^{256}$. Mas não faz sentido dizer o mesmo acerca das virtudes pessoais, pois “(...)

252 "O pós-escrito de Hart e a questão da filosofia política" in Justiça de toga, Tradução Jefferson Luiz Camargo, Revisão da tradução Fernando Santos e Revisão técnica Alonso Reis Freire. São Paulo: WMF Martins Fontes, 2010, p. 221; no original, "Hart's Poscript and the Point of Political Philosophy", in Justice in Robes, op. cit., p. 156 (veja pp. 156 e ss. em geral).

${ }^{253}$ A tradução brasileira traz "integrado" para traduzir integrated e "autônomo" para traduzir "detached": veja "O pós-escrito de Hart e a Questão da Filosofia Política", op. cit., p. 221, por exemplo. Caio Moysés de Lima traduz "detached" como "desvinculada": veja O Império dos Direitos: Lei e Autoridade Política em Ronald Dworkin, op. cit., p. 131.

254 "Hart's Poscript and the Point of Political Philosophy", op. cit., p. 156 (na tradução, "concepções": "O pósescrito de Hart e a questão da filosofia Política", op. cit., p. 221).

255 "O pós-escrito de Hart e a Questão da Filosofia Política", op. cit., p. 223; no original, "Hart's Poscript and the Point of Political Philosophy", op. cit., p. 157 (veja em geral pp. 156 e ss.). Neste ponto, Dworkin defende que o valor da arte é detached, mas rejeita a ideia que atribui a G. E. Moore de que "art would retain its full value even if all creatures that could appreciate it perished never to return", p. 157. Para o autor, portanto, não há arte sem impacto, mas isso não significa que o valor da arte se defina pelo seu impacto. É interessante observar que Dworkin, ao discutir arte neste texto, utiliza a ideia de "impacto", própria do "modelo de impacto", ética por ele rejeitada em prol da ética de desafio por ele defendida em "Foundations of Liberal Equality", op. cit. (ou "Equality and the Good life" in Sovereign Virtue, op. cit.,): veja o próximo capítulo para mais detalhes. Veja Controle de Constitucionalidade e Democracia no debate entre Ronald Dworkin e Jeremy Waldron, 130f. Trabalho de Conclusão de Curso, Orientador: prof. Ronaldo Porto Macedo Junior. Faculdade de Direito da Universidade de São Paulo: São Paulo, 2013 p. 35, por exemplo.

${ }^{256}$ Dworkin, Life's Dominion, op. cit., pp. 71 e ss, em especial: Para Dworkin, "something is instrinsically valuable (...) if its value is independent of what people happen to enjoy or want or need or what is good for them" (p. 71, italic no original). Nas pp. 71-2, Dworkin fala que consideramos intrinsecamente valiosas "great paitings" (p. 72). Veja também "The Place of Liberty", op. cit.,: "If liberty were valuable in the way some people think art can be valuable - for its own sake, quite apart from its impact on those who enjoy it - then we might be able to understand, if not to approve, the view that liberty is such fundamental metaphysical importance that it must be protected whatever the consequences for people. But liberty seems valuable to us only because of the consequences for people: we think lives led under circumstances of liberty are better lives just for that reason.”, p. 121 (segue trecho das pp. 129-30 citado abaixo). 
consideramos esses valores como aspectos ou componentes de uma vida atraente e plenamente bem-sucedida, e não como recursos instrumentais para vir a tê-la.". ${ }^{257}$ Dworkin trata as liberdades de maneira similar, o que lhes nega o caráter intrínseco: a sua existência caracteriza a boa vida, e, não o fizessem, as liberdades não teriam valor. Segundo ele,

"Algumas pessoas tratam a arte como valor fundamental independente e rival da igualdade abstrata. Mas só podem sensatamente pensar assim porque acham que a arte tem valor por motivos independentes da contribuição que faz à vida daqueles que a produzem, dela desfrutam ou dela se beneficiam. Isto é, as pessoas acreditam na arte pela própria arte. Todavia a liberdade não pode, da mesma forma, ter valor intrínseco fora do papel que a liberdade desempenha na vida daqueles que a possuem (6), pois parece estranho que o fato de as pessoas terem algum direito em especial, como o direito à liberdade de expressão, tenha valor objetivo, intrínseco [in and of itself], independentemente das conseqüências desse direito para elas. (...) ninguém poderia ser entusiasta da liberdade, como algo de valor intrínseco, se não achasse que a vida levada em certas condições de liberdade fosse, exatamente por esse motivo, mais valiosa, por ser uma vida mais autônoma ou mais autêntica, ou ter mais dignidade, ou melhor em qualquer outro aspecto. Assim, embora possa parecer plausível que não se esgote o valor da arte nas diversas maneiras em que torna melhor a vida pelo menos de algumas pessoas, uma afirmação paralela não parece plausível para direitos como a liberdade de escolha em expressão, tratamento médico ou trabalho" 258

Assim, pode-se dizer, a partir de leitura destes textos de Dworkin ${ }^{259}$, que na sua teoria a liberdade e as virtudes pessoais são integradas na definição de boa vida de maneira similar, sendo seu valor dependente da contribuição que são capazes de dar à qualidade da vida, enquanto a arte, por ter valor intrínseco mesurável independentemente do impacto que tem, é autônoma $^{260}$ em relação ao do viver bem. ${ }^{261}$

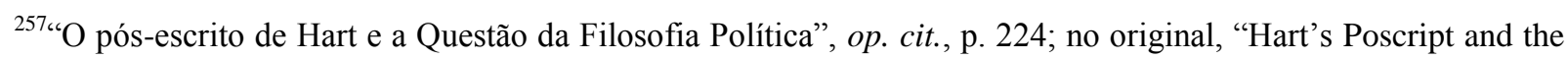
Point of Political Philosophy", op. cit., p. 158.

258“"O lugar da liberdade", op. cit., pp. 170-1, modifiquei (substitui "aderem" por "acreditam" e acrescentei o trecho entre colchetes para indicar como consta no original) e mantive acentuação conforme regras gramaticais aplicáveis ao tempo da publicação da tradução; no original, "The Place of Liberty", op. cit. pp. 129-30, nota 6 omitida no lugar de (6) (veja ainda pp. 121, 130); a nota tem a seguinte redação: "I mean to doubt that liberty can have inherent or fundamental value independent of its contribution to the values of life. It can, of course, have instrumental value toward some other goal, like art or knowledge, that is itself thought to be inherently valuable for reasons that make its value independent of its contribution to the value of lives", p. 480.

${ }^{259}$ Isto é, da leitura de "The Place of Liberty", op. cit., Life's Dominion, op. cit., e de "Hart's Poscript and the Point of Political Philosophy", op. cit.. Compare com a leitura que Macleod faz do significado da "estratégia do interesse", defendida em Liberalism, Justice, and Markets, op. cit., cap. 7, esp. pp. 182 e ss. contra as críticas de Dworkin. Macleod diz que a opção de Dworkin pela "estratégia constitutiva" e pelos princípios do leilão (veja discussão na próxima seção) na verdade reflete aspectos da estratégia dos interesses, e o motivo para dizê-lo me parece que reside em percepção de que as liberdades se integram à boa vida em Dworkin. Isso não significa que o argumento de Macleod sobre as estratégias do interesse e constitutivas está correto, mas significa que talvez ele tenha alguma razão na sua descrição da relação entre liberdades e ética em Dworkin.

260 "O pós-escrito de Hart e a Questão da Filosofia Política", op. cit., p. 221.

${ }^{261}$ Mas observe que o a analogia preferida de Dworkin para explicar a boa vida é aquela com arte: veja "Foundations of Liberal Equality", op. cit., pp. 250 e ss. - veja o próximo capítulo. Não vejo razões para crer que essa analogia contrarie as teses defendidas pelo autor sobre o contraste entre arte e liberdades.
} 
Que as liberdades são integradas à boa vida significa que é com base na ética que o autor justifica diversas liberdades, entre elas o direito à liberdade de expressão. No próximo capítulo, exploro a ética do autor - a concepção de bem que chama de "modelo de desafio" bem como a concepção de dignidade por ele formulada mais recentemente. Ao fazê-lo, procuro mostrar as consequências que o próprio Dworkin traça entre essas visões sobre a boa vida e as liberdades, entre elas a liberdade de expressão, direito cuja configuração no pensamento do autor é objeto específico do capítulo terceiro. Por enquanto, gostaria de apresentar o complexo argumento oferecido pelo autor para integrar liberdade e igualdade, o que ele faz ao procurar integrar a liberdade como direitos a liberdades na sua teoria da justiça distributiva, a igualdade de recursos.

\section{Seção 5. As liberdades na igualdade de recursos}

No pensamento de Ronald Dworkin, a liberdade objeto desta pesquisa, em especial o direito ao consumo, à produção de pornografia, ainda que pesada, e a manifestações de ódio, deve ser abordada de maneiras diferentes a depender dos argumentos contra os quais o direito questionado possa ou deva ser defendido ${ }^{262}$. Estes argumentos podem ser paternalistas ou de justiça distributiva. $^{263}$

Dworkin é quem oferece a distinção, algo intuitiva, ao discutir o "lugar da liberdade" e o suposto conflito entre igualdade e liberdade na sua teoria da igualdade, a saber, a igualdade recursos. O autor, no capítulo terceiro de Sovereign Virtue, se diz preocupado com a defesa liberal de liberdades relevantes "somente contra as refutações fundamentadas em argumentos distributivos. Não contemplarei as refutações moralistas ou paternalistas ao liberalismo."264. Ainda que descontemos a crueza e extravagância do exemplo dado por Dworkin de desafio paternalista (fim da liberdade de religião para garantir a salvação geral ${ }^{265}$ ), as objeções de

\footnotetext{
${ }^{262}$ Ver Dworkin, "The Place of Liberty”, op. cit., primeira seção.

263 "The Place of Liberty", op. cit., primeira seção, p. 120.

264“'O lugar da liberdade”, in A virtude soberana: teoria e prática da igualdade. Tradução Jussara Simões; revisão técnica e da tradução Cícero Araújo e Luiz Moreira. São Paulo: Martins Fontes, 2005, p. 157 (fiz breve alteração na tradução retirando um "seus" no que era "seus argumentos distributivos"). No original, veja "The Place of Liberty", op. cit., s. 1, p. 120; a preocupação de Dworkin com as liberdades se expressa em objetivo de "defend a characteristic thesis of liberalism, that people's liberty over matters of great personal concern should not be infringed", "The Place of Liberty", op. cit., p. 120.

265 “The Place of Liberty", op. cit., p. 120. Veja a definição de paternalismo de Christopher Wolfe: é "the idea that government can legitimately engage in regulation of individual activity for the sake of preventing individuals
} 
justiça distributiva são muito mais interessantes e cogentes e são elas que preocupam o autor em "The Place of Liberty".

A questão da liberdade de expressão deve ser compreendida em Dworkin não só como uma relação entre as autoridades públicas e a qualidade da vida do sujeito sancionado por medidas paternalistas, mas que também se compreenda o eventual direito ao discurso de ódio, por exemplo, em termos de liberdade aparentemente violadora da igualdade. $\mathrm{O}$ direito ao consumo de pornografia ou à manifestação de ódio na igualdade de recursos precisa ser compreendido próximo a outros direitos aparentemente envolvidos neste conflito entre igualdade e liberdade: por exemplo, o direito de escolha de escola, que alguns querem ver limitado "para que se alcance a verdadeira igualdade econômica" 266 . O conflito intuitivo aqui é o seguinte: "Será mesmo mais importante que a liberdade de algumas pessoas seja protegida para melhorar a vida que essas pessoas levam, do que outras pessoas, que já estão na pior situação, disponham dos diversos recursos e de outras oportunidades de que elas precisam para levar uma vida decente? Como poderíamos defender esta tese?"267. Por que proteger as liberdades garantidoras dessas práticas se há prejuízo à igualdade? Antes, é claro, é preciso indagar: há prejuízo à igualdade?

Esta formulação compra alguns pressupostos das críticas feministas, por exemplo, de Rae Langton e de Catharine MacKinnon ${ }^{268}$ ao direito à pornografia e à defesa deste direito feita por Dworkin, pois dialoga com a hipótese de que há algo que demanda especial justificação na defesa de uma liberdade aparentemente causadora de desigualdades. Ao apresentar o problema, tenho utilizado "aparentemente" para descrever a inserção da liberdade de expressão no conflito entre liberdade e igualdade. É que Dworkin nega importante

from harming themselves, apart from any direct impact such activity may have on others", Natural Law Liberalism, op. cit., p. 58.

266 "O lugar da liberdade", op. cit., p. 158; no original, veja "The Place of Liberty", op. cit., p. 120; trata-se de um exemplo de desafio a liberdade baseado em justiça distributiva. Outro exemplo é a medicina privada, p. 123. Entre os casos discutidos por Dworkin neste capítulo de Sovereign Virtue está um caso julgando pela Suprema Corte dos Estados Unidos sobre financiamento privado de campanha (veja pp. 176-7 e "Free Speech, Politics, and the Dimensions of Democracy" in Sovereign Virtue sop. cit., discutido no capítulo terceiro, abaixo).

${ }^{267}$ "O lugar da liberdade", op. cit., p. 159, itálico do Dworkin; no original, veja "The Place of Liberty", op. cit., p. 121, itálicos no original. Veja ainda "Political Equality", op. cit., pp. 195-198.

${ }^{268}$ Catharine MacKINNON. Only Words. Cambridge (Mass.): Harvard University Press, 1993 e Rae Langton. Sexual Solipisism: Philosophical Essays on Pornography and Objectification. Oxford: Oxford University Press, 2009. Veja, de Langton, em especial "Whose Right? Ronald Dworkin, Women, and Pornographers". Philosophy \& Public Affairs, Vol. 19, No. 4 (Autumn, 1990), pp. 311-359 (publicado como um dos capítulos de Sexual Solipsism). 
pressuposto da acusação de que o direito contra a pornografia é um direito à igualdade que se contrapõe e se sobrepõe ao direito à liberdade dos pornógrafos: que haja um conflito entre igualdade e liberdade tal que a questão possa ser colocada nesses termos.

E é justamente neste ponto que se insere o complexo argumento desenvolvido por Dworkin para expor o lugar ocupado pela liberdade na igualdade de recursos. Dworkin utiliza a ideia de um leilão entre indivíduos cujo objeto são os recursos disponíveis na ilha em que se acham $^{269}$. Segundo ele, a liberdade é essencial à constituição dos termos em que se dá o leilão imaginário capaz de indicar a justa distribuição de recursos ${ }^{270}$. Isso significa que as liberdades na igualdade de recursos não são objeto do leilão, i.e., não podem ser negociadas e, portanto, que sua importância independe do interesse que os participantes tenham nelas e que poderia ser expresso em recursos que estariam dispostos a empenhar para tê-las ${ }^{271}$. Para Dworkin, a titularidade de recursos implica liberdades em relação a estes recursos, o que leva o autor a formular alguns princípios indicadores de extensas liberdades, entre elas a liberdade de expressão (discutida no contexto de financiamento de campanha, por exemplo). Para efeito dos exemplos de escolha educacional ou médica, a consequência é que restrições a tais escolhas ou caracterizam promoção da igualdade de recursos, hipótese em que as liberdades sequer existem, ou deixam de fazê-lo, hipótese em que é a própria igualdade de recursos que impede as restrições: não há conflito entre liberdades e igualdade na igualdade de recursos de modo que se pudesse afirmar que vale a pena sacrificar, por exemplo, a liberdade de escolher onde estudar em nome dos ganhos igualitários de tal medida ${ }^{272}$.

A seguir, exponho de que modo as liberdades constituem o pressuposto do leilão imaginário caracterizador da igualdade de recursos, bem como os princípios defendidos por Dworkin como próprios da "baseline" (linha de base ${ }^{273}$ ) do leilão imaginário,isto é, "um

\footnotetext{
269 "Equality of resources", op. cit., esp. pp. 66 e ss.

270 "The Place of Liberty", op. cit.; veja ainda "Equality of Resources", op. cit., pp. 70-1.

${ }^{271}$ Trata-se da crítica de Dworkin à "interest strategy": "The Place of Liberty", op. cit., pp. 136 e ss. Entre nós, veja Ommati. Liberdade de Expressão e discurso de ódio na Constituição de 1988. op. cit., pp. 94 e ss. Veja Macleod, Liberalism, Justice, and Markets, op. cit., cap. 7, esp. “(...) Dworkin's commitment to lberty is not independently derived from an egalitarian account of justice. Rather a conception of liberty plays a direct and fundamental role in the very definition of distributive equality supplied by equality of resources", p. 168 (veja pp. 168 e ss. em geral).

272 "The Place of Liberty", op. cit., p. 123.

273 "The Place of Liberty", op. cit., p. 143 (na tradução brasileira, "O lugar da liberdade" in A virtude soberana, op. cit., traduz-se "baseline" por "parâmetro": veja p. 193, por exemplo).
} 
sistema de liberdade/restrição para tal leilão" ${ }^{274}$. Retorno ao argumento no capítulo terceiro, em que exploro a passagem do que Dworkin chama de "ideal mundo ideal" ao "mundo real ideal" e, em seguida, ao "real mundo real" 275 , que apresenta proposta da igualdade de recursos à questão política da liberdade de expressão, em especial à a pornografia pesada e do discurso de ódio.

Dworkin, em “Equality of Resources”, capítulo segundo de Sovereign Virtue, defende a sua concepção de igualdade segundo a qual a medida deste valor político é uma questão de recursos, e não de bem estar ${ }^{276}$. No capítulo 3, "The Place of Liberty", Dworkin se dá a tarefa de encontrar lugar seguro à liberdade na igualdade de recursos, versão de teoria da igualdade por ele explicada nos seguintes termos: "ela estipula que a distribuição igualitária ideal satisfaz uma versão apropriadamente complexa do teste da 'inveja': ninguém desejará a propriedade atribuída a qualquer outra pessoa, ou por ela controlada" ${ }^{277}$. Ele continua, explorando a ideia de leilão imaginário para explicar o teste da inveja:

274 "O lugar da liberdade", op. cit., p. 192; no original, "The Place of Liberty", op. cit., p. 143.

275 "O lugar da liberdade", op. cit., pp. 235 e ss.; no original, "The Place of Liberty", op. cit., pp. 172 e ss.

${ }^{276}$ Veja Ripstein em "Liberty and Equality", op. cit.., esp. pp. 89 e ss., Yowell, "A Critical Examination of Dworkin's Theory of Rights", op. cit., pp. 116 e ss., Kymlicka, Contemporary Political Philosophy, op. cit., cap. 3, pp. 75 e ss. e Roberto Gargarella, As teorias da justiça depois de Rawls: um breve manual de filosofia política, op. cit., pp. 68 e ss.

277 "O lugar da liberdade", op. cit., p. 187; neste trecho, abandono, em prol de "teste da inveja" etc., a opção feita na tradução brasileira de traduzir "envy test" por "teste da cobiça"; no original, "The Place of Liberty", op. cit., p. 139. Veja "Equality of Resources", op. cit., esp. pp. 66 e ss. e 81 e ss., e este trecho em particular: "Under equality of resources (...) people decide what sorts of lives to pursue against a background of information about the actual cost their choices impose on other people and hence on the total stock of resources that may fairly be used by them. The information left to an independent political level under equality of welfare is therefore brought to the initial level of individual choice under equality of resources. The elements of luck in the auction just described are in fact pieces of information of a crucial sort; information that is acquired and used in that process of choice.

"So the contingent facts of raw material and the distribution of tastes are not grounds on which someone might challenge a distribution as unequal. They are rather background facts that determine what equality of resources, in these circumstances, is. Under equality of resources, no test for calculating what equality requires can be abstracted from these backgrounds fact and used to test them. The market character of the auction is not simply a convenient or ad hoc device for resolving technical problems that arise for equality of resources in very simple exercises like our desert island case. It is an institutionalized form of the process of discovery and adaptation that is at the center of the ethics of that ideal. Equality of resources supposes that the resources devoted to each person's life should be equal. That goal needs a metric. The auction proposes what the envy test in fact assumes, that the true measure of the social resources devoted to the life of one person is fixed by asking how important, in fact, that resource is for others. It insists that the cost, measured in that way, figures in each person's sense of what is rightly his and in each person's judgment of what life he should lead, given that command of justice. Anyone who insists that equality is violated by any particular profile of initial tastes, therefore, must reject equality of resources and fall back on equality of welfare", pp. 69-70. A referência de Dworkin em "Equality of Resources" ao enunciar o "envy test" são as seguintes: "D. Foley, "Resource Allocation and the Public Sector," Yale Economic Essays 7 (Spring 1967); H. Varian, "Equity, Energy and Efficienty," Journal of Economic Theory, 
"Compreendemos melhor o teste da inveja em ação ao imaginar um mecanismo artificial que pudesse alcançar uma distribuição que passasse no teste. Pessoas em uma ilha deserta fariam lances por diversos grupos de recursos físicos lá encontrados, com um estoque inicial de recursos para os lances (conchas, por exemplo), e o leilão se repete diversas vezes, até que todos concordem com seu término. Se terminar, passou no teste da inveja, pois ninguém inveja o quinhão de recursos que outro adquiriu, embora cada pessoa esteja satisfeita ou bem sucedida em graus diferentes"278

A igualdade de recursos, além do leilão, lança mão de seguros hipotéticos capazes de mitigar as diferenças de talento entre os indivíduos. ${ }^{279}$ (Este ponto é mencionado brevemente no segundo capítulo, abaixo). Outra categoria essencial à igualdade de recursos é a de custos de oportunidade:

"Se aceitarmos a igualdade de recursos como a melhor concepção do princípio igualitário abstrato, queremos, então, que as instituições que tornam disponíveis os recursos para qualquer pessoa sejam dependentes, tanto quanto possível, dos custos de oportunidade desses recursos para outrem, à maneira como o leilão imaginário e as transações pós-leilão fazem que dependam ${ }^{280}$

Esta é a concepção de igualdade de Dworkin: há igualdade quando indivíduos não invejam os recursos de que gozam os outros, e este é um estado que se alcança, num mundo ideal, por meio de um leilão imaginário capaz de estabelecer o preço dos recursos por meio de custos de oportunidade. Onde se situa a liberdade nesta concepção de igualdade? Segundo Dworkin, num lugar bastante seguro. É que, na igualdade de recursos, defendida por Dworkin,

“(...) a liberdade é necessária à igualdade, segundo essa concepção de igualdade, não na duvidosa e frágil hipótese de que as pessoas realmente dão mais valor às liberdades importantes do que aos outros recursos, mas porque a liberdade, quer as pessoas lhe dêem ou não mais valor do que a todo o resto, é essencial a qualquer processo no qual a igualdade seja definida e garantida. Isso não transforma a liberdade em instrumento da igualdade distributiva mais do que esta em instrumento da liberdade: as

September 1974, pp. 63-91.”, p. 478, n. 1 à p. 67, itálicos no original. Veja Ripstein, "Liberty and Equality”, op. cit., Macleod, Liberalism, Justice, and Markets, op. cit.. e Guest, Ronald Dworkin, op. cit., cap. 10.

278 "O lugar da liberdade", op. cit., p. 187; neste trecho, novamente faço opção por "inveja" em vez de "cobiça" (veja nota acima). Para o original, veja "The Place of Liberty", op. cit., p. 140. A opção por "teste da inveja" consta, por exemplo, em Roberto Gargarella. As teorias da justiça depois de Rawls: um breve manual de filosofia política. Op. cit., p. 69 (para descrição da igualdade de recursos, veja em geral pp. 68 e ss.). Veja ainda: "Envy, in this context, is an economic, not psychological, phenomenon. Someone envies the resources of another when he would prefer those resources, and the pattern of work and consumption that produces them, to his own resources and choices", "Do Liberty and Equality Conflict?", op. cit., p. 47 (veja em geral pp. 44-8). Veja Guest, Ronald Dworkin, op. cit., pp. 189 e ss.

279 "The Place of Liberty", op. cit., p. 140. Veja Ripstein, "Liberty and Equality”, op. cit., pp. 98 e ss.

280“"O lugar da liberdade", op. cit., p. 188: neste trecho, fiz breve alteração da tradução, que, na edição brasileira, traz no fim do trecho citado a seguinte opção: "à maneira como o leilão imaginário e o pós-leilão o fazem" para traduzir "in the way the imaginary auction and post-auction transactions make them so depend". Para o original, veja "The Place of Liberty", op. cit., p. 140; veja pp. 149 e ss. Veja Ripstein, "Liberty and Equality", op. cit., pp. 89 e ss., Macleod, Liberalism, Justice, and Markets, op. cit., cap. 7, esp. pp. 175 e ss. e Guest, Ronald Dworkin, op. cit., pp. 188-9. 
duas idéias, pelo contrário, fundem-se em uma tese mais completa sobre quando a lei que governa a distribuição e o uso dos recursos trata a todos com igual consideração" ${ }^{281}$.

$\mathrm{O}$ argumento que o autor desenvolve em defesa da segurança da liberdade na igualdade de recursos é extremamente complexo, mas a ideia fundamental é bastante simples e algo intuitiva. Dworkin sustenta que ter um recurso e ter algumas liberdades ligadas a esse recurso não são coisas distintas. Esta ideia é intuitiva porque a noção de "ter um recurso" parece exigir desde já alguma liberdade ou algumas liberdades, isto é, alguns direitos que deem significado a "ter um recurso". Ou seja, Dworkin explora a ideia bastante plausível de que a distribuição igualitária de recursos assume um regime de liberdades que regulamenta o acesso aos recursos distribuídos. Esta formulação da questão integra liberdade e igualdade porque a dimensão igualitária do acesso a um recurso só é inteligível se compreendida em termos de liberdades explicativas deste acesso. Imaginemos uma pessoa em situação de desigualdade e que se lha atribua um recurso de modo a melhorar a sua posição. Por que atribuir-lhe um recurso implica tratá-lo com maior consideração e respeito do que não lhe atribuir o recurso se negar a liberdade de usufruir do bem atribuído não significar tratá-lo com menor consideração e respeito? Daí a integração entre igualdade e a liberdade na forma de um grupo de direitos, de liberdades. $^{282}$

Esse grupo de direitos é chamado por Dworkin de "o sistema de liberdade/restrição" que é pressuposto em qualquer tipo de leilão ${ }^{283}$; é que, sem saber o que poderá ser feito com determinado recurso é impossível estabelecer seu preço porque é impossível ao sujeito decidir se adquire o recurso ${ }^{284}$. Dworkin dá o exemplo de argila, produto de interesse de um escultor: é preciso que se estabeleçam, antes do leilão, quais direitos estão associados a esta matéria-

\footnotetext{
281 "O lugar da liberdade”, op. cit., pp. 160-1; neste trecho, mantenho os acentos obrigatórios segundo as regras gramaticais aplicáveis na data de publicação da tradução brasileira, mas desde então alteradas. Para o original, veja "The Place of Liberty", op. cit., pp. 122-3; veja ainda pp. 180-3. A integração da igualdade e da liberdade em Dworkin tem sido ressaltada em trabalhos brasileiros sobre liberdade de expressão: veja José Emílio Medauar Ommati. Liberdade de Expressão e discurso de ódio na Constituição de 1988. op. cit., pp. 94 e ss. e Alex Lobato Potiguar, Igualdade e Liberdade: a luta pelo reconhecimento da igualdade como direito à diferença no discurso de ódio. op. cit. pp. 34-5 (veja texto da n. 93 para citação de parte do trecho de "O lugar da liberdade", op. cit., pp. 160-1 que cito). Veja Yowell, “A Critical Examination of Dworkin's Theory of Rights”, op. cit., pp. 118 e ss. e Macleod, Liberalism, Justice, and Markets, pp. 156 e ss.

282 Como diz Darlei Dall'Agnol sobre Dworkin:"(...) a questão básica da sua filosofia política não é 'quanta igualdade deve-se deixar de lado para respeitar um direito?', mas sim 'é este direito necessário para proteger a igualdade?”, “O igualitarismo liberal de Dworkin”, op. cit., p. 59.

283 "O lugar da liberdade", op. cit., p. 192; no original, "The Place of Liberty", op. cit., p. 143.

284 “The Place of Liberty”, op. cit., p. 143.
} 
prima de seu trabalho, pois só assim será possível julgar seu preço ${ }^{285}$. Ao escultor é eventualmente bem menos interessante a argila se com ela não puder fazer uma escultura satírica dado o fato de que a linha de base (baseline) do leilão não contém tal direito à liberdade de expressão, do que se a linha de base incluísse tal direito e ele pudesse portanto se expressar com maior liberdade ${ }^{286}$. Outro exemplo dado por Dworkin é o do mastro: ele afirma que “(...) possuir um maestro e ter um conjunto de direitos para controlar seu uso são, em essência, apenas descrições diferentes da mesma coisa"287.

Ao leitor do capítulo terceiro de Sovereign Virtue pode soar supérfluo que Dworkin tenha construído arcabouço teórico intrincado, com estratégias, princípios, e métricas de déficits para defender uma tese apresentável por meio da discussão de exemplos tão simples (veremos alguns destes conceitos no próximo capítulo). E a tal leitor talvez não convença dizer que se trata de tentativa de explorar não se liberdade e igualdade entram em conflito, mas se tais valores conflitam entre si numa teoria da igualdade específica, a saber, a igualdade de recursos. É que parece que Dworkin construiu um labirinto chamado de igualdade de recursos de modo a ter, como liberal, de tornar tal labirinto ainda mais complicado para provar que a liberdade é bem-vinda na confusão conceitual apresentada por ele sob a forma de teoria da igualdade - prova esta disponível por meio de argumentos muito mais simples, ausente o labirinto. Não pretendo enfrentar tal indignação (que, diga-se brevemente, ignora de que modo a igualdade de recursos talvez seja capaz não só de tolerar, mas de fortalecer a liberdade ${ }^{288}$ ). É que os conceitos trazidos por Dworkin na sua tentativa de situar a liberdade na igualdade de recursos são de interesse à compreensão das liberdades na sua obra. A este objetivo a ideia intuitiva expressa acima não basta. Por outro lado, tentarei expor o argumento de Dworkin de modo mais sintético possível, sem entrar em detalhes e categorias que não sejam estritamente necessárias aos meus propósitos.

\footnotetext{
285 "The Place of Liberty", op. cit., pp. 143-4.

286 "The Place of Liberty", op. cit., p. 144 para o exemplo da argila e da escultura satírica. Yowell, "A Critical Examination of Dworkin's Theory of Rights", op. cit., p. 118 e Macleod, Liberalism, Justice, and Markets, op. cit., p. 169 (e veja o exemplo que Macleod constrói nas pp. 179 e ss.). Veja Guest, Ronald Dworkin, op. cit., pp. 203-4, p. 205.

287 "O lugar da liberdade", op. cit., p. 194; no original, "The Place of Liberty", op. cit., p. 144.

288 "The Place of Liberty", op. cit., pp. 180-183. Veja a crítica de Yowell, Liberalism, Justice, and Markets, op. cit., pp. 156-7 (veja cap. 6 em geral) e, em especial, de Macleod em, Liberalism, Justice, and Markets, op. cit., esp. pp. 185-6 (“(...) the bridge strategy provides a needlessly circuitous route for defendind liberty and it cannot be divorced from the potentially thorny issues surrounding the connection between human interestes and liberty", p. 186).
} 
De volta ao "labirinto". Para situar a liberdade na igualdade de recursos, Dworkin recorre a uma estratégia que chama de "estratégia constitutiva", que "insiste que a liberdade deve figurar na própria definição de distribuição ideal" ${ }^{289}$. Dworkin opta por uma versão específica desta estratégia, a saber, a versão da ponte ${ }^{290}$ (“bridge version”), que estabelece uma ligação entre o princípio abstrato da igualdade, de um lado, e o leilão imaginário e o teste da inveja, de outro lado. ${ }^{291}$ A linha de base do leilão a ser escolhida é aquela "que oferece mais plausibilidade à afirmação de que o leilão realizado a partir desse parâmetro [i.e., desta linha de base] trata as pessoas com igual consideração"292. Dworkin em seguida apresenta diversos “princípios” componentes da linha de base. Os mais relevantes são o princípio da abstração, da segurança e da autenticidade. Passo a explorá-los.

Em primeiro lugar, Dworkin discute o princípio da abstração, que estabelece uma "uma forte presunção a favor da liberdade de escolha" ${ }^{\text {293 }}$, e que inclui o princípio da segurança, que autoriza restrições à liberdades necessárias a que tenham as pessoas "segurança física e controle suficiente sobre a sua própria propriedade para permitir-lhes levar adiante seus planos e projetos" 294 . A importância do princípio da abstração à versão da ponte é que é capaz de interpretar de maneira adequada o ideal igualitário porque permite que o leilão ofereça mais

\footnotetext{
289 "O lugar da liberdade", op. cit., p. 135; no original, "The Place of Liberty", op. cit., p. 135. Dworkin contrasta a estratégia constitutiva com a "interest strategy", empregada por diversas teorias, como a utilitarista, e que consiste em identificar os interesses dos indivíduos e, então, apontar quais liberdades contribuem à satisfação desses interesses: veja pp. 134-5, pp. 136 e ss. Veja seção quatro deste capítulo, acima.

290 "O lugar da liberdade", op. cit., pp. 199 e ss.; no original, "The Place of Liberty", op. cit., pp. 147 e ss. Veja Guest, Ronald Dworkin, op. cit., pp. 199 e ss. para discussão da estratégia da ponte e comentários sobre os princípios do leilão.

291 "The Place of Liberty", op. cit., pp. 147 e ss., pp. 148 e 149 em especial.

292 "O lugar da liberdade", op. cit., p. 200 (inseri o conteúdo entre colchetes); no original, "The Place of Liberty", op. cit., p. 148. Veja Macleod, Liberalism, Justice, and Markets, op. cit., cap. 7, esp. pp. 170 e ss.

293 "The Place of Liberty", op. cit., p. 148, traduzi (a tradução brasileira faz a seguinte opção: "um forte pressuposto a favor da liberdade de escolha", "O lugar da liberdade", op. cit., p. 200); veja em geral "The Place of Liberty", op. cit., pp. 147-158.

294 "The Place of Liberty", op. cit., p. 149, traduzi (a tradução brasileira faz a seguinte opção: "segurança física suficiente às pessoas e controle suficiente sobre suas próprias propriedades para lhes permitir elaborar planos e projetos, e realizá-los", "O lugar da liberdade", op. cit., p. 201). Dworkin diz que o princípio da abstração "embrace" o princípio da segurança: "The Place of Liberty", op. cit., p. 152. Veja Macleod, Liberalism, Justice, and Markets, op. cit., pp. 172 e ss. para discussão dos princípios, em especial pp. 173-4, 177-8 para o princípio da abstração e da segurança, em especial o seguinte trecho: "The principle of abstraction provides the key to securing na attractive conception of liberty within equality of resources because it grounds our convictions about true opportunity costs while at the same time establishing a basis for a liberal conception of liberty. As we have seen, the principle of abstraction seems to establish a presumption of freedom of choice. People whouls be free to use the resources they acquire in whatever way they see fit, subject to the limits imposed by the principle of security. The liberal conception of liberty built into equality of resources does not appear ad hoc or dogmatic because it can be grounded in the principle of abstraction", p. 178 (veja pp. 178 e ss. para crítica a este argumento de Dworkin com aplicação dele ao tema da liberdade e expressão).
} 
opções aos indivíduos, o que por sua vez torna o leilão mais sensível aos planos e projetos aos participantes $^{295}$. É por isso que, para Dworkin, os terrenos (exemplo do autor) no leilão imaginário não devem ser divididos em partes muito grandes, caso contrário falham em "flexibilidade" por deixarem de se adequar aos interesses daqueles que precisam de áreas menores, o que, por sua vez, distorce os custos de oportunidade ao diminuir artificialmente o preço que teria que ser pago por terrenos maiores caso a linha de base incluísse o princípio da abstração $^{296}$. Dworkin, ao comentar o princípio da abstração, sustenta que

“O princípio reconhece que o custo de oportunidade verdadeiro de qualquer recurso transferível é o preço que os outros pagariam por ele em um leilão cujos recursos fossem oferecidos da forma mais abstrata possível, isto é, na forma que permita a maior flexibilidade de adaptação a planos e preferências. Insiste, portanto, que o leilão deve oferecer recursos nessa forma abstrata se o leilão houver de ser reconhecido como identificador de uma distribuição igualitária" ${ }^{297}$.

Para os propósitos desta pesquisa, é importante observar que o princípio da abstração, em Dworkin, oferece um argumento contra a "imposição da moral" ("enforcement of morals ${ }^{, 298}$ ). É que, dado o fato de que a igualdade de recursos emprega a ideia de custos de oportunidade para estabelecer os preços dos recursos no leilão imaginário, e dado o fato de que a flexibilidade oferecida pelo princípio da abstração é importante à identificação dos custos reais, os recursos a que um indivíduo tem acesso dependem do preço desses mesmos recursos a terceiros, e não de julgamento sobre a destinação que o indivíduo pretenda dar aos recursos a que tem direito segundo o do leilão ${ }^{299}$. Isso faz com que um indivíduo que pretenda impor intolerância religiosa, por exemplo, se veja impossibilitado de fazê-lo por não gozar, numa situação inicial de igualdade, de recursos que bastem à aquisição do ambiente intolerante - e isso é impossível porque o preço deste ambiente leva em consideração o fato de que indivíduos de outras religiões têm recursos à sua disposição para impedir o estabelecimento do ambiente intolerante $^{300}$. O ponto de Dworkin é que a ideia de custos de oportunidade oferece um

\footnotetext{
295 “The Place of Liberty", op. cit., pp. 150-1.

${ }^{296}$ Para o exemplo do terreno, no caso de Dworkin utilizado para construir um estádio de futebol, veja "The Place of Liberty", op. cit., p. 150; para o argumento do autor, veja pp. 150-1, veja em geral pp. 149-152. Veja ainda Ripstein em "Liberty and Equality", op. cit., p. 91.

297 "O lugar da liberdade", op. cit., p. 205, com alterações (alterei "verdadeiro custo de oportunidade" para "custo de oportunidade verdadeiro", e modifiquei o último período, que, na tradução, consta da seguinte forma: “(...) o leilão deve oferecer recursos nessa forma abstrata se for para reconhecer o leilão como identificador de uma distribuição igualitária"); no original, "The Place of Liberty", op. cit., p. 151.

298 "The Place of Liberty", op. cit., pp. 153 e ss. (a tradução brasileira faz opção por "vigência da moral", A virtude soberana, op. cit., pp. 207 e ss.).

299 "The Place of Liberty", op. cit., p. 154. Veja Macleod, Liberalism, Justice, and Markets, op. cit., pp. 191-2.

300 "The Place of Liberty", op. cit., pp. 154-5.
} 
julgamento neutro do custo dos recursos ${ }^{301}$. Isso permite que a versão da ponte, por ele defendida, desemboque na "tese liberal de que o sistema de linha de base de liberdades/restrições seja absolvido de quaisquer restrições com base em verdade religiosa ou virtude moral" 302 .

Vimos acima que as liberdades para Dworkin não gozam de valor intrínseco. Esta ideia é defendida pelo autor em "The Place of Liberty" justamente porque para ele as liberdades se prestam a preservar, nos termos dos princípios da abstração, entre outros, os pressupostos do leilão, que garantem o emprego dos recursos distribuídos com justiça e que podem ser empregados livremente por cada indivíduo na interpretação do desafio posto pelas circunstâncias e na consequente condução da vida.

O ultimo princípio que gostaria de discutir com mais $\operatorname{vagar}^{303}$ é o da autenticidade. Segundo Dworkin, a igualdade de recursos precisa indicar as circunstâncias em que os indivíduos estão prontos para participar do leilão imaginário ${ }^{304}$; o autor nos diz que

${ }^{301}$ Ao comentar os direitos das minorias nesta situação, Dworkin diz que o número de indivíduos conta, porque quanto mais numerosa maior a capacidade da minoria de comprar recursos, e sustenta sobre seus membros: "Their prospects, too (...) will depend on the opportunity costs to others, neutrally judged, of what they want", p. 155. Veja ainda "Equality of Resources", op. cit., p. 69.

302 "O lugar da liberdade", op. cit., p. 211 (alterei “o sistema paramétrico de liberdades/restrições” para a opção que consta na citação); no original, "The Place of Liberty”, op. cit. p. 155. Mas o autor é claro que a neutralidade por ele defendida não é uma "equally easy form of neutrality" (p. 154), isto é, que permite que quaisquer tipos de vida sejam igualmente fáceis de se levarem . O exemplo do religioso intolerante, bem como o exemplo do homem que pretende colecionar obras-primas mas que, dada a igualdade de recursos, não tem dinheiro para pagá-las, são casos de estilos de vida inviabilizados pela teoria de Dworkin - veja pp. 154-5 e "Foundations of Liberal Equality", op. cit., p. 301 para exemplo similar, bem como pp. 297-305 para discussões sobre neutralidade e tolerância (compare com "Equality of Resources", op. cit. p. 75 e veja comentários de Macleod em Liberalism, Justice, and Markets, op. cit, pp. 190-2). Ainda de "Foundations of Liberal Equality", veja o seguinte trecho: "The analysis of distributional justice suggests how liberal equality connects equality and liberty. Since liberal equality depends on economic and political devices that review the true opportunity costs of impersonal resources, an egalitarian society must be a free society (26). Invasions of liberty - criminal laws prohibiting activities or ways of life some people might wish to take up, for example - are invasions of equality as well, unless they can be justified as necessary to protect an egalitarian distribution of resources and opportunities by providing security of person and property or in some other way (27). No laws prohibiting activities on grounds of personal morality could pass that test, and so liberal equality supports one of the strongest of the instinctive principles of liberalism identified at the outset: its tolerance in matters of personal morality (28)", "Foundations of Liberal Equality", op. cit., pp. 224-5; veja ainda 196-7, esp. pp. 197, 290 e ss.; (26), (27) e (28) marcam as posições das notas de rodapé, com referências ao artigo republicado como "The Place of Liberty", op. cit., justamente artigo sob análise neste item. Veja discussão sobre tolerância liberal e liberdades em Dworkin no próximo capítulo.

${ }^{303}$ Dworkin apresenta outros princípios, entre eles o da (i) "correction” ("The Place of Liberty”, op. cit., pp. 155 e ss.), que recorre a um pré-leilão perfeito de modo a corrigir externalidades e custos de transação inevitáveis num leilão imperfeito, e o princípio da (ii) "independence” (pp. 161 e ss.), que corrige preconceitos permitidos pelos princípios da abstração e da "correction".

304 “The Place of Liberty”, op. cit. p. 159. Veja ainda "Equality of Resources”, op. cit., pp. 70-71. 
"A personalidade não é fixa: as convicções e as preferências mudam e podem ser influenciadas ou manipuladas. Uma explicação completa da igualdade de recursos deve incluir, portanto, como uma característica da sua linha de base, alguma descrição das circunstâncias nas quais as personalidades das pessoas serão tomadas como devidamente desenvolvidas de modo que os cálculos do leilão possam ser realizados. A linha de base precisa de algum princípio que defina autenticidade. (27)"305

Autenticidade, para Dworkin, envolve uma dimensão passiva, de revisão, bem como uma dimensão ativa, de influência ${ }^{306}$; o princípio da autenticidade na linha de base do leilão não iria "permitir restrições, tanto antes do leilão inicial quanto depois dele, às oportunidades de formar, ponderar ou advogar convicções, apegos ou preferências"307. Novamente, a ideia de custos de oportunidade explica a relevância de um princípio à qualidade igualitária do leilão hipotético: sem autenticidade, os preços são distorcidos porque se distorce o que os participantes do leilão gostariam de comprar ${ }^{308}$. É assim que Dworkin justifica o princípio da autenticidade como um dos componentes da linha de base do leilão imaginário.

Não é difícil imaginar a relevância deste princípio a esta pesquisa. Em primeiro lugar, a conexão entre autenticidade e liberdade de expressão é evidente e o próprio Dworkin a menciona $^{309}$. Em segundo lugar, a ideia de autenticidade figura como princípio ético de

\footnotetext{
305 "O lugar da liberdade”, op. cit., p. 217, com modificações (a versão brasileira tem o seguinte texto: “(...) Uma teoria completa da igualdade de recursos deve incluir, portanto, como parâmetro, alguma descrição das circunstâncias nas quais se interpretará que a personalidade está devidamente desenvolvida para que se possa efetuar os cálculos do leilão. Isto é, o parâmetro precisa de um princípio que defina autenticidade (27)" omito trecho em que nada modifiquei); no original, "The Place of Liberty", op. cit., p. 159. Na citação, o (27) marca a posição da nota 27 , em que Dworkins sustenta que "personality is authentic for our purposes, when they have been formed under circumstances appropriate to using an auction among personalities so formed as a test of distributive equality", p. 483. Compare com o que Macleod chama de "circumstances of authenticity" e sua crítica ao princípio da autenticidade, Liberalism, Justice, and Markets, op. cit., pp. 37-45, pp. 172-3, 184.

306 "The Place of Liberty", op. cit., p. 160.

307 "O lugar da liberdade”, op. cit., 218; no original, “The Place of Liberty”, op. cit., p. 160.

308 "The Place of Liberty", op. cit., p. 160; veja próxima nota.

${ }^{309}$ Ao comentar os custos de oportunidade e, em seguida, a autenticidade e a liberdade de expressão, Dworkin diz que: "violations of the principle of authenticity are likely to distort prices more fundamentally, because they affect what people decide they want, and therefore change the entire bidding program they decide to pursue. We have that special reason, within the structure of equality of resources, for insisting that authenticity be weighted more heavily than abstraction in any contest between these principles and the requirements of security - for insisting, for example, that free speech be protected except in the case of undeniable and overhanging danger", "The Place of Liberty", op. cit., p. 160. Veja Guest, Ronald Dworkin, op. cit., p. 201 (sobre autenticidade, liberdade de expressão e o teste norte-americano do "clear and presente danger"). Veja comentário de Yowell em "A Critical Examination of Dworkin's Theory of Rights", op. cit., p. 119, com citação de parte deste trecho e de outro que também cito acima. Veja em especial o seguinte comentário: "It should be noted that Dworkin does not propound the principles of abstraction, independence, and authenticity as part of the general theory of rights. The principles are consistent with the shielded-interest and excluded-grounds theories and they are evidence of Dworkin's general thinking about rights in his later work: 'The Place of Liberty' was published in 1987 (one year after Law's Empire) and republished in 2000. But despite the broad implications of some of its claims, the argument is formally presented only as a defense agasinst the claim that resource egalitarianism is a threat to liberty. Several disclaimers state that it does not counter all arguments for restricting liberty; that it is not an
} 
dignidade dotado de diversas consequências à política liberal de Dworkin. É este último ponto - a ética dworkiniana e as suas consequências à política em geral e às liberdades em especial o objeto do próximo capítulo.

exhaustive account of the rights we have; that for the rights it supports there may be other, better arguments; and that it is not even the only arguments for rights on equality of resources. Dworkin's essencial aim is to rebut the contention that resource egalitarianism conflicts with liberty by showing that certain assumptions about liberty are necessary in order to avoid distorting prices in the initial auction of resources and to preserve the integrity of the desert island scenario as a model for redistribution. The argument provides philosophical grounds for a theory of rights only for the theorist who accepts Dworkin's resource egalitarianism", p. 120, itálicos no original, notas omitidas (veja ainda pp. 125, 133). A meu ver, o argumento de "The Place of Liberty" é que a defesa das liberdades é frequentemente dependente de uma teoria da justiça, e que, portanto, uma "general theory of rights" de que fala Yowell precisa passar por uma teoria do que significa uma distribuição justa. Yowell está certo ao apontar que o argumento de Dworkin depende da adesão à igualdade de recursos e, embora de fato não haja uma teoria completa dos direitos neste artigo, julgo possível encontrar nele diversos aspectos essenciais de uma teoria geral dos direitos, como procuro apontar ao discutir a defesa dworkinaina da liberdade de expressão. 


\section{CAPÍTULO SEGUNDO: A ÉTICA EM DWORKIN}

\section{Introdução}

Este capítulo cuida do esforço de Ronald Dworkin em oferecer o que chama de "foundations" à sua teoria política, mais especificamente, de oferecer fundamentação ética ao seu liberalismo. Dworkin explicitamente rejeita a tentativa de outros autores de separar a ética da política, e, em "Foundations of Liberal Equality", artigo que sigo mais de perto neste capítulo e que apresento extensamente, explora as razões que têm aqueles que adotam concepção específica de boa vida para também adotar a concepção de política defendida pelo autor (são o que chama de "ethical liberals"). Para ele, ética e política são "contínuas" entre si: daí o autor defender a "estratégia da continuidade" em "Foundations of Liberal Equality"310 e o "princípio de Kant" em Justice for Hedgehogs (veremos abaixo de que se trata cada uma dessas ideias). A conexão entre a ética de Dworkin e a política por ele defendida é importante a este trabalho porque a liberdade de expressão é defendida em seu liberalismo igualitário por meio de ideias éticas como "autenticidade" ou "independência". A liberdade de expressão no pensamento de Ronald Dworkin é portanto caso particular da sua tentativa mais ampla de fundar uma concepção política liberal em uma concepção de bem específica.

Não faz parte do objetivo deste capítulo abordar todos os aspectos do complexo argumento do autor, que, no mais, foi exposto mais de uma vez através de terminologias variáveis $^{311}$. Este capítulo apresenta e discute aquilo que nestes argumentos é importante à compreensão da defesa dworkiniana das liberdades, em especial da liberdade de expressão. A primeira seção deste capítulo é dedicada à compreensão de algumas consequências do projeto

\footnotetext{
${ }^{310}$ Veja comentários de Guest em Ronald Dworkin, op. cit., cap. 11, esp. pp. 212 e ss.

${ }^{311}$ Veja Lilian Furquim, O Liberalismo Abrangente de Ronald Dworkin. 235f. Tese de Doutorado, Faculdade de Filosofia, Letras e Ciências Humanas, Universidade de São Paulo. Orientador: Cícero Araújo. São Paulo, 2010 e Stephen Mulhal e Adam Swift. Liberals and Communitarians. 2nd Ed. Oxford: Blackwell Publishers Ltd., 1996, esp. pp. 249 e ss. e cap. 9 (que é dedicado sobretudo a "Foundations of Liberal Equality", op. cit.). Veja também uma objeção de Finnis: Dworkin acaba tendo concepção de bem (Natural Law and Natural Rights, Oxford: Clarendon Press, Oxford University Press, 1980, pp. 221 e ss., p. 230). Embora devamos observar que Finnis escreveu antes das obras mais recentes de Dworkin (em que ele elabora a sua concepção de bem), esta crítica não me parece promissora se dirigida a autor que explicitamente desenvolveu teoria ética. Veja, do livro de Mulhal e Swift, pp. 296-7 sobre não ser disponível a Dworkin defender-se da mesma forma que Rawls de críticas comunitaristas acerca da relação entre concepção de bem e política; isto é verdade, é claro, mas pelo mesmo motivo que esta defesa não lhe é disponível não se pode criticá-lo por ter teoria do bem implícita ou oculta.
} 
ético-político de Dworkin, especificamente da ressignificação que a neutralidade sofre quando o autor a substitui pela igualdade como base da sua teoria.

A segunda seção, por sua vez, é dedicada especificamente à ética de Dworkin: em primeiro lugar, ao que ele chama de "modelo do desafio" como exposto em "Foundations of Liberal Equality" e, em segundo, os dois princípios éticos de dignidade - "respeito próprio" e "autenticidade" - que figuram como sua concepção de bem no mais recente Justice for Hedgehogs. A terceira seção, então, é dedicada à análise das consequências destas visões éticas ao tópico das liberdades e à sua conexão com o valor da igualdade, central ao liberalismo do autor. É que um dos “enigmas" "312, como Dworkin diz, a que ele submete o seu modelo do desafio é saber se o endosso por parte do titular da vida é aditivo ou constitutivo do valor da $v i^{313}$. A resposta do modelo - é constitutivo - leva à adoção do que o autor chama de "prioridade da integridade ética", noção que tem consequências interessantes ao valor da vida daqueles que produzem e consomem certos tipos de discursos, e, assim, sobre a viabilidade ética de suas proibições. Ainda, o modelo do desafio e a integração entre ética e justiça levam Dworkin a defender a tese de que a justiça dos recursos disponíveis a um indivíduo é um parâmetro do valor de sua vida. Como vimos no capítulo primeiro e pormenorizarei no próximo capítulo desta dissertação, a integração entre igualdade e liberdade no pensamento do autor oferece fundamentação da liberdade de expressão na concepção de justiça distributiva defendida por Dworkin, a saber, a igualdade de recursos. Conclui Dworkin: sendo a liberdade uma questão de justiça distributiva, e sendo a justiça distributiva parâmetro do valor da vida, a violação da liberdade de expressão prejudica a vida de quem a viola ou goza de benefício decorrente da violação.

Análise desta consequência da continuidade entre ética e política em Dworkin é seguida por outra, que é importante dada a insistência do autor em defender o valor político da igualdade: a integração entre ética e igualdade. Neste capítulo, ofereço análise de argumentos formulados por Dworkin em "Foundations of Liberal Equality" e em Justice for Hedgehogs segundo o qual os defensores da concepção de bem preferida pelo autor têm razão para adotar

\footnotetext{
312 "A igualdade e a vida boa", op. cit., p. 343; no original, "Equality and the Good Life", op. cit., p. 245. Veja "Foundations of Liberal Equality", op. cit., p. 234.

313 "Foundations of Liberal Equality", op. cit., pp. 262-273. George discute a distinção em Making Men Moral, op. cit., cap. 3, pp.103-4 (veja pp. 102-108 em geral). Em "A igualdade e a vida boa", in A Virtude Soberana, op. cit, traduz-se "additive" por "cumulativo": veja p. 373, por exemplo. Veja ainda críticas de Christopher Wolfe a Dworkin em, Natural Law Liberalism, op. cit., capítulo 4, esp. pp. 74-75, 76-8 e 80-81.
} 
visão igualitária de política e, segundo alguns desses argumentos, para adotar especificamente a igualdade de recursos como concepção de igualdade.

Como será detalhado no próximo capítulo, Dworkin oferece defesa generosa da liberdade de expressão: fundada numa concepção de dignidade, inclui (i) direito ao (ii) discurso de ódio e à pornografia, entre outros. Mas os fundamentos do direito à liberdade de expressão, embora constantes em substância na obra do autor, mais recentemente culminaram em interpretação mais explicitamente generosa dos direitos ao discurso de ódio do que à pornografia. Em conclusão deste capítulo, e de modo a conectá-lo ao próximo, exploro brevemente o recurso que Dworkin faz a aspectos de sua ética (ou à sua teoria da dignidade) para justificar o direito à liberdade de expressão. Farei isso com atenção especial aos casoslimite da obscenidade e do discurso de ódio e à natureza dupla - ativa e passiva - do que Dworkin chama de "autenticidade", noção importante às concepções de democracia e igualdade utilizadas pelo autor para justificar a liberdade de expressão.

\section{Seção 1. Ética, Política e neutralidade}

Se é difícil imaginar uma definição de liberalismo contemporâneo que não inclua entre seus defensores a figura de Ronald Dworkin, é certamente mais difícil elaborar uma definição de liberalismo que capte as nuances da relação entre esta vertente de teoria política e os temas complexos do paternalismo e do perfeccionismo. Dworkin, em geral, é considerado um autor anti-perfeccionista $^{314}$; ele se considera um autor deste tipo ${ }^{315}$. Mas existem definições de perfeccionismo que não parecem excluir o liberalismo igualitário de Dworkin, que é um liberalismo que defende a continuidade entre ética e moral ${ }^{316}$. Já quanto ao paternalismo, se é possível encontrar em sua teoria um viés contrário a medidas deste tipo, a preocupação analítica presente em obras de Dworkin como "Foundations of Liberal Equality" demanda

\footnotetext{
314 É a opinião de George: Making Men Moral: Civil Liberties and Public Morality. Oxford: Clarendon Press, 1993 cap. 3, p. 84. Veja ainda Mulhall e Swift, Liberals and Communitarians, op. cit., pp. 251 e ss.: os autores consideram Dworkin um liberal "comprehensive" mas "anti-perfectionist".

${ }^{315}$ Em "Equality and the Good Life", in Sovereign Virtue, op. cit., cap. 6, pp. 241-2, Dworkin apresenta o perfeccionismo como um dos "rivals" da igualdade liberal, por ele defendida. Para a complexidade da questão na teoria igualitária de Dworkin, veja Macleod, Liberalism, Justice, and Markets, op. cit., cap. 8 ("Dworkin's egalitarian framework is, prima facie, compatible with the justification of a wide array of perfectionist policies (...) I argue that the best reconstruction of Dworkin's liberalism is one which rejects the comprenehsively antiperfectionist ideal of liberty neutrality. Liberal tolerance is a more attractive ideal and is more compatible with the egalitarianism that animates much modern liberalism", p. 190; veja ainda, por exemplo, pp. 186, 187-8, 190, 1957, 200-3, 217) e Mulhal e Swift, Liberals and Communitarians, op. cit., 251 e ss. e cap. 9, (esp. pp. 300 e ss.).

${ }^{316}$ Dworkin, "Foundations of Liberal Equality", op. cit.. Veja referências na nota anterior ao livro de Macleod.
} 
tratamento cuidadoso e detalhado, deixando claro que algumas delas são admissíveis na "igualdade liberal" (liberal equality), como o autor chama a sua teoria política ${ }^{317}$.

O objetivo desta seção é de explorar modificações na teoria política de Dworkin acerca da questão da neutralidade liberal. A ideia não é investigar se Dworkin é ou não um perfeccionista ou paternalista. Estas questões talvez sejam importante em outros contextos, mas para efeitos do que interessa a esta pesquisa vale mais investigar a evolução da teoria política do autor no que diz respeito a ser ou não dado ao Estado, e, se for, de que modo, intervir na vida dos cidadãos.

Aquilo que Dworkin chama em "Foundations of Liberal Equality" de modelo de continuidade entre ética e moralidade revela o fundamento último da organização política (o que inclui o direito) no pensamento do autor: a ética. É claro que a unidade do valor caracterizadora do mundo moral é marcada pelo recurso mútuo entre a ética e a moral; ou seja, para Dworkin, só se conhece a justiça se conhecermos a boa vida e só se sabe qual a boa vida se conhecemos a justiça ${ }^{318}$. Mas Dworkin também diz, ao compreender a posição do direito em relação à moral em termos de uma imagem de árvore, que o direito é um galho da moral, que, por sua vez, é um galho da ética ${ }^{319}$. Não acredito que entre as duas ideias (de reforço/recurso mútuo e de árvore) haja contradições. De qualquer modo, o dividendo do modelo da continuidade é a percepção abstrata, a demandar ulterior especificação, de que a política deve servir à boa vida. Como diz Dworkin, o liberalismo precisa mostrar por que os liberais podem viver bem: se não é possível viver bem em determinado regime político (ou se é muito difícil fazê-lo), temos um motivo bastante à rejeição da teoria defensora do regime hipotético ${ }^{320}$.

Em "Liberalism", artigo republicado como capítulo oitavo de A Matter of Principle, Dworkin procura mostrar como é possível compreender a teoria política do liberalismo em termos de compromisso constitutivo na forma de uma interpretação específica do princípio da

\footnotetext{
${ }^{317}$ Tratamento deste tipo foi dado por George (Making Men Moral, op. cit., cap. 3) e por Christopher Wolfe, Natural Law Liberalism, op. cit., cap. 4 e "Egalitarian Liberalism of Ronald Dworkin", op. cit. .

318 "Foundations of Liberal Equality", op. cit. esp. p. 194 ou "Equality and the Good Life" op. cit., esp. p. 237. Veja Mulhall e Swift, Liberals and Communitarians, op. cit., pp. 279, 293.

${ }^{319}$ Justice for Hedgehogs, op. cit., cap. 19, pp. 405 e ss. (veja Justiça para ouriços, op. cit., para tradução de "branch" por "ramo", pp. 414 e ss.); veja ainda "Hart's Postscript and the Point of Political Philosophy" in Justice in Robes, op. cit., esp. pp. 156 e ss.

320 "Equality and the Good Life", op. cit., esp. p. 238 (principalmente as duas primeira acusações que Dworkin considera).
} 
igualdade que gera, a depender das circunstâncias práticas, diferentes medidas derivadas ${ }^{321}$. $\mathrm{O}$ autor, neste artigo de 1978, posterior portanto ao seu livro Taking Rights Seriously (que é de 1977), mas anterior à versão mais acabada da sua teoria da igualdade (exposta em Sovereign Virtue, coletânea de 2000 - a maior parte dos textos havia sido publicada anterioemente), entende o liberalismo como uma interpretação do valor da igualdade compreendido como neutralidade entre concepções da boa vida. Como veremos, a compreensão da igualdade como neutralidade é estranha à neutralidade defendida pela visão mais acabada do pensamento dworkiniano, a saber, aquele defendido em "Foundations of Liberal Equality" (do qual o capítulo sexto de Sovereign Virtue é versão). Ocorre que, em Liberalism, Dworkin já defende o mercado e ideia bastante próxima à de custos de oportunidade ${ }^{322}$ como caracterizadores da igualdade liberal, a exemplo do que fará em Sovereign Virtue na defesa do que chamaria de igualdade de recursos. De fato, ao discutir o mercado, Dworkin o compreende como uma instituição fundamental à igualdade, mas que justamente em nome de tal valor precisa ser corrigida $^{323}$. Simultaneamente, Dworkin se mostra atrelado a arcabouço conceitual que marcou Taking Rights Seriously: ao discutir democracia, o autor aponta para a violação da igualdade no cômputo do que chama de preferências externas ${ }^{324}$.

Naturalmente relevante ao propósito desta subseção, vale observar que, no fim do artigo sob análise, Dworkin considera algumas críticas ao liberalismo. Interessa mais a quarta, a saber, aquela segundo a qual o liberalismo “(...)priva a sociedade política de sua função mais elevada e justificativa final, de que a sociedade deve ajudar seus membros a conseguir o que é, na verdade, bom"325. Esta definição é bastante semelhante à apresentação do que Dworkin posteriormente chama de princípio igualitário abstrato ${ }^{326}$. Dworkin não enfrenta o tema: ele o

\footnotetext{
321 "Liberalismo" in Uma questão de princípio, op. cit..

${ }^{322}$ Veja "Liberalism" in A Matter of Principle, op. cit., pp. 193 e ss., esp. p. 194. Para elaboração da ideia de custos de oportunidade em "The Place of Liberty", op. cit., veja a última seção do capítulo primeiro, acima.

323 "Liberalism", op. cit., pp. 194 e ss.; a mesma ideia aparece em "Equality of Resources" in Sovereign Virtue, e também "The Place of Liberty", no mesmo livro, op. cit. (pp. 155 e ss., por exemplo).

${ }^{324}$ Ponto salientado por Yowell: "A Critical Examination of Dworkin's Theory of Rights", op. cit., p. 99, n. 37. Dworkin em "Liberalism", op. cit., cita explicitamente Taking Rights Seriously, pp. 234 e ss. (capítulo nono, "Reverse Discrimination", op. cit.), 275 ("What Rights do We Have?", op. cit.): "Liberalism", op. cit., n. 6, p. 410 à p.196. Veja "Do We Have a Right to Pornography?", op. cit., artigo sobre pornografia inicialmente publicado em 1981.

325 "Liberalismo" in Uma questão de princípio, op. cit., p. 303 (suprimi vírgula antes de "justificativa final" para, julgo, aprimorar a tradução; no original, "Liberalism", op. cit., p. 203 ((..) denies to political society the highest function and ultimate justification, which is that society must help its members to achieve what is in fact good").

326 “The Place of Liberty", op. cit., p. 130. Veja Macleod, Liberalism, Justice, and Markets, op. cit., esp. cap. 7.
} 
dispensa. Parece que o autor escolheu avaliar a objeção posteriormente; e pode (itálicos propositais) ser que, ao fazê-lo, tenha decidido reconsiderar a sua visão sobre neutralidade (o que, como veremos, não significa rejeitar que haja um sentido no qual sua teoria liberal é neutra entre concepções de bem).

Num sentido, portanto, este artigo de Dworkin, ao conter, de um lado, análise da democracia em termos de limitação de preferências e associação entre igualdade e neutralidade e, de outro, elaboração do mercado como instrumento fundamental da justiça e reconhecimento de algum mérito na crítica de que o liberalismo ignora, como ele diz, a "função mais elevada e justificativa final" da "sociedade política" ${ }^{327}$, aparenta ser um meio termo entre seus escritos iniciais e a forma mais elaborada de sua filosofia política liberal de matriz igualitária. Não pretendo aqui discutir se os dois modelos são compatíveis; suspeito que sejam, e que o modelo de Taking Rights Seriously caracterize parte não-central do arcabouço teórico da igualdade liberal defendida posteriormente por Dworkin ${ }^{328}$. Basta-me apontar mudanças que o próprio Dworkin, como veremos, reconheceu posteriormente. Passemos ao próximo artigo de A Matter of Principle.

Em 1983, Dworkin publicou "Why Should Liberals Care About Equality?", republicado como capítulo nono de A Matter of Principle. Nele, Dworkin constrasta um liberalismo baseado em igualdade com aquele baseado em neutralidade, sendo que "Ambas combatem a imposição legal da moralidade privada [legal enforcement of private morality]" 329 . Dworkin defende o primeiro em detrimento do segundo. O autor portanto, defende a neutralidade de maneira diferente daquela defendida anteriormente (i.e., em

\footnotetext{
327 "Liberalismo" op. cit., p. 303 (suprimi vírgula antes de "justificativa final" para, julgo, aprimorar a tradução; no original, "Liberalism", op. cit., p. 203.

${ }^{328}$ É claro, a diferença entre os momentos da obra de Dworkin é objeto de comentário na literatura: veja Veja nota de rodapé de Rae Langton: "My concern in this article is almost exclusively with Dworkin's theory as it appears in Taking Rights Seriously and A Matter of Principle. Since then Dworkin's views have undergone some changes (e.g., in "What is Equality?"), but these are not, I think, changes that substantially affect the points I want to make here. It seems to me that both Dworkin's arguments in "Reverse Discrimination" and the "Dworkinian" antipornography arguments presented in this article are compatible with the equality of resources scheme presented by Dworkin in his latter work.", "Whose Right? Ronald Dworkin, Women, and Pornographers", op. cit., pp. 311-359, p. 317, n. 18, itálicos no original. Veja ainda Yowell, "A Critical Examination of Dworkin's Theory of Rights", op. cit., pp. 110-20, e também pp. 121, 122125 e ss. para discussão da distinção entre princípio e política após a formulação da igualdade de recursos.

329 "Por que os liberais devem prezar a igualdade?", op. cit., p. 305 (acrescentei as palavras entre colchetes, que são do original); no original, "Why Should Liberals Care About Equality?", op. cit., p. 205.
} 
Liberalism, de 1978) ${ }^{330}$. O liberalismo não é mais baseado em neutralidade, mas em igualdade somente ${ }^{331}$. Mas há um sentido em que este liberalismo é neutro; é que isto deriva da igualdade $^{332}$ :

"Essa forma de liberalismo [i.e., o "liberalismo baseado na igualdade"] insiste em que o governo deve tratar as pessoas como iguais no seguinte sentido. Não deve impor sacrifícios nem restrições a nenhum cidadão com base em um argumento que o cidadão não poderia aceitar sem abandonar seu senso de igual valor" 333 .

${ }^{330}$ Vale apontar, entretanto, que a oposição à "enforcement of private morality", oposição esta que une as duas versões de liberalismo enunciadas por Dworkin em 1983, pode ser interpretada de modo a abranger a modelo do desafio, ética abstrata defendida por Dworkin em "Foundations of Liberal Equality", op. cit. (ou seja, esta ética, mesmo abstrata, talvez possa ser compreendida como uma "private morality" para efeitos da oposição). Neste caso, haveria uma demarcação entre, de um lado, os capítulos oitavo ("Liberalism", op. cit.) e nono ("Why Should Liberals Care About Equality?", op. cit.) de A Matter of Principle pelo menos, bem como Taking Rights Seriously, e, de outro, Sovereign Virtue (cujo capítulo 6 é versão alterada de "Foundations of Liberal Equality"). Mas esta não é uma opção a meu ver defensável pois já no capítulo nono de A Matter of Princple a neutralidade perde papel fundamental (no sentido mesmo de inicial, e não de importante) no liberalismo de Dworkin, conforme auto-interpretação do próprio autor em "Foundations of Liberal Equality" (veja abaixo para elaboração).

${ }^{331}$ O que evidentemente não é dizer que Dworkin se tornou um igualitário neste artigo: seu compromisso com a igualdade é, à evidência, fundamental desde sempre: veja Taking Rights Seriously, op. cit., e discussão acima.

${ }^{332}$ Veja Abigail Levin, The Cost of Free Speech: Pornography, Hate Speech, and their Challenge to Liberalism, op. cit., pp. 28 e ss., esp. pp. 30-3.

333 "Por que os liberais devem prezar a igualdade?", op. cit., p. 305 (acrescentei o trecho entre colchetes, mas o trecho entre aspas consta logo antes do início da citação, na mesma página, e dele omito nota); no original, "Why Should Liberals Care About Equality?", op. cit., p. 205. Este trecho de Dworkin é comumente citado e questionado por críticos: veja, por exemplo, George em Making Men Moral, op. cit., pp. 97-8, especialmente a seguinte passagem: "Whether the individual whose preferred conduct is proscribed or restricted accepts or rejects the argument grounding the limitation - or even thinks about the matter at all - is simply irrelevant to whether those exercising authority over that conduct are in fact treating the individual with equal concern and respect", $p$. 97, itálico no original (George cita versão mais extensa do trecho de Dworkin que selecionei na p. 97; veja ainda, de Finnis, "Liberalism and Natural Law Theory", 45 Mercer L. Rev. 687 1993-1994, pp. 700 e ss. e, de Guest, Ronald Dworkin, op. cit., p. 119). Este argumento de Dworkin é pouco desenvolvido, mas a terminologia foi retomada em Justice for Hedgehogs, op. cit., quando ele fala em "respeito próprio" como um dos aspectos da dignidade humana, sendo o outro a "autenticidade". Em trabalho sobre Dworkin, Macleod parece unir as duas ideias ao discutir o que chama de "endorsement constraint argument": "a self-respecting person must lead her life by her own lights and have the conviction that her commitments are the rights one for her", Liberalism, Justice and Markets, op. cit., p. 205 (veja em geral pp. 205-207 e também p. 162). Este sentido de respeito-próprio sobrevive à crítica de George porque esclarece que o "não poderia aceitar" do famoso trecho de Dworkin não é (puramente) demanda de concordância do sujeito, mas condição normativa da sua dignidade (compare esta visão com a que George atribui a Wojciech Sadusrki em Making Men Moral, pp. 100-2: ao que parece, Sadurski defende que "respeito" exige que certas ações de um indivíduo sejam livres de interferência, ideia que é, a meu ver, pelo menos convergente com a defendida por Dworkin). Na minha opinião, este sentido também resiste bem às críticas de que legislações paternalistas se dirigem às condutas julgadas equivocadas, e não às pessoas que as realizam: veja Paul Yowell, A Critical Examination of Dworkin's Theory of Rights, op. cit., pp. 122-4, pp. 135-6, para endosso desta visão em Finnis (Yowell cita Natural Law and Natural Rights, op. cit., p. 223). George também segue Finnis (Making Men Moral, op. cit. pp. 95-7). O argumento é importante, entre outros, porque é bastante difundido: entre nós, veja a seguinte manifestação de Silas Malafaia: "PR SILAS MALAFAIA FALA SOBRE A MARCHA PARA JESUS E A PARADA GAY / PT 1", disponível em http://www.youtube.com/watch?v=vy5VIxQwlcM\&feature=player_embedded, último acesso em 11.12.2013. A distinção entre rejeição das condutas e rejeição das pessoas talvez faça sentido enquanto opinião sobre a adequação, propriedade ou moralidade de uma conduta, mas, quando orienta ação política que subtrai escolha por parte do cidadão, potencialmente afeta a sua dignidade mesmo que não seja especificamente motivada a 
O elo das duas etapas da filosofia política de Ronald Dworkin reside nos capítulos oitavo e nono de A Matter of Principle. A sugestão aqui é que em o capítulo nono de $A$ Matter of Principle marca uma mudança importante no local ocupado pela ideia de neutralidade no liberalismo de Dworkin se o contrastarmos com o capítulo oitavo do mesmo livro; e quem faz esta sugestão é o próprio Ronald Dworkin. Ao definir liberalismo em Foundations of Liberal Equality, ele o caracteriza como a compreensão da liberdade, da igualdade e da igualdade como aspectos de um só valor político ${ }^{334}$. Em nota (de número 2) ao texto desta definição, ele diz:

"Contraste esta afirmação sobre a essência do liberalismo com a minha afirmação anterior de que o coração do liberalismo é a neutralidade entre teorias do bem. Veja Ronald Dworkin, A Matter of Principle (Cambridge, Mass: Harvard University Press, 1985), chap. 8. Abandonei em seguida esta explicação por tomar equivocadamente um teorema por um axioma. Veja Dworkin, A Matter of Principle, chap. 9. Nessas aulas elaboro substancialmente a segunda visão, ${ }^{\text {335. }}$.

Dworkin diz neste trecho que a interpretação integradora dos valores da liberdade, da igualdade e da comunidade é um ou o axioma do liberalismo. Dworkin não diz que

prejudicá-la. Que talvez seja possível, como quer Malafaia, criticar a homossexualidade sem odiar os homossexuais não decorre que seja possível, por exemplo, proibir a prática sexual homossexual sem violar a dignidade de seus praticantes (o exemplo é de Dworkin, discutido abaixo, e não de Malafaia, que discute outras polêmicas, como a "lei da homofobia"). O ponto de autores que, como Dworkin (e, parece, Sadurski), defendem proteção de indivíduos contra ações intrusivas do Estado não é proteger especificamente os caminhos escolhidos, quaisquer que seja, pelos indivíduos, mas o direito de escolhê-los. O fato de que a política intrusiva é dirigida à ação e não à pessoa pode não fazer diferença porque pode afetar a escolha de qualquer maneira - se houver direito à escolha, é plausível dizer que houve prejuízo à dignidade do indivíduo.

334 "Foundations of Liberal Equality", op. cit., p. 194; o "(2)" marca a posição da nota de rodapé 2, citada a seguir. Este trecho se repete, com algumas alterações, em "Equality and the Good Life", op. cit., p. 237 (para a tradução brasileira, veja "A igualdade e a vida boa", op. cit., p. 331. Observe entretanto que a relação nãoconflituosa entre valores não é novidade em Dworkin: veja por exemplo "What Rights Do We Have?", op. cit. para a defesa de que liberdade e igualdade não conflitam entre si; veja discussão acima (terceira seção do capítulo primeiro) sobre integração dos valores em Dworkin.

335 "Foundations of Liberal Equality", op. cit., nota. 2, p. 194, traduzi, itálicos no original; as "aulas" (lectures) de que fala Dworkin são "Foundations of Liberal Equality", suas Tanner Lectures on Human Values. (Talvez um esclarecimento se faça necessário: o "última" (latter) refere-se à visão defendida em "Why Should Liberals Care About Equality?", op. cit. (cap. 9 de A Matter of Principle, op. cit.) e elaborada em "Foundations of Liberal Equality", e não à ideia de que a neutralidade é axioma do liberalismo). Veja Mulhall e Swift, Liberals and Communitarians, op. cit., capítulo nono em geral, especialmente “(...) it is notable that, in the more recent exposition of his liberalism that we focus on here, he [Dworkin] admits to having abandoned his earlier claim that neutrality among theories of the good is essential to it. Rather than being an axiom, he says, such neutrality should rather be regarded as a theorem, something derivable from more basic propositions", p. 276; veja ainda pp. 300-8. Veja também Macleod, Liberalism, Justice, and Markets, op. cit., pp. 188-9 (comentando Kymlicka sobre ser preferível tratar a neutralidade "(...) as a derivative and perhaps contingent commitment (...)" do liberalismo, p. 189); veja também p. 190 (“(...) Dworkin's endorsement of neutrality is contingent on its compatibility with equality", p. 190, nota omitida (a nota faz referência às mudanças no pensamento de Dworkin a respeito da neutralidade e da igualdade detectáveis nos diferentes capítulos de A Matter of Principle; mas veja p. 200, n. 12 para defesa da presença do ideal de "tolerância liberal" - defendido por Macleod - em trabalho publicado por Dworkin na década de 1980). 
neutralidade não faz parte do seu liberalismo ${ }^{336}$. A igualdade liberal, defendida por Dworkin, é neutra, tanto no sentido de que contempla diversas concepções de bem quanto no sentido de que impede recurso a concepções de bem na tomada de decisões políticas. ${ }^{337}$. A questão é que esta neutralidade não ocupa lugar fundamental nestes escritos posteriores do autor: ela decorre da igualdade somente (como dizem Mulhall e Swift, é "derivável de proposições mais básicas" ${ }^{, 338}$ ). O ponto é que o recurso a razões éticas como fundamento de decisões políticas é vedado em virtude de razões éticas ${ }^{339}$, isto é, a igualdade liberal, caracterizada por Dworkin como dotada de estratégia de continuidade entre ética e moral, tem uma teoria ética nos seus fundamentos que veda o recurso à ética no processo de tomada de decisões políticas ${ }^{340}$.

Vê-se que o abandono da neutralidade enquanto axioma e a sua adoção enquanto teorema é caracterizadora da estratégia da continuidade defendida por Dworkin; comparando as estratégias da continuidade e da descontinuidade (aquela que separa ética e política) no que se refere à "liberal tolerance or neutrality",341, o autor diz que:

"a estratégia contratual da descontinuidade constrói a neutralidade no início da história que conta (...) A estratégia a continuidade, pelo contrário, espera chegar à neutralidade no curso em vez de no começo do argumento, como um teorema em vez de como um axioma metodológico (...) embora ambas as estratégias defendam a tolerância, chegam a diferentes interpretações desta virtude, e portanto a diferentes concepções de liberalismo (...) o projeto de procurar fundações para as nossas convicções políticas é reflexivo. Quando escolhemos entre contrato e continuidade, como estratégias para basear a nossa política liberal na ética pessoal, escolhemos também entre duas formas de liberalismo" ${ }^{342}$.

Isso significa que a realocação da neutralidade na obra de Dworkin de axioma a teorema, como ele diz, é provocada pela adoção de uma ética enquanto fundamento da filosofia política

\footnotetext{
${ }^{336}$ Macleod, Liberalism, Justice, and Markets, op. cit., p. 190 (trecho que segue o excerto citado na nota anterior).

${ }^{337}$ Dworkin, em "Foundations of Liberal Equality", op. cit., chama o primeiro sentido de "neutrality of appeal", e o segundo de "tolerance": veja pp. 297-305. Veja primeira subseção da terceira seção deste capítulo, abaixo. Veja Mulhall e Swift, Liberals and Communitarians, op. cit., pp. 300 e ss., esp. pp. 306-7.

${ }^{338}$ Mulhall e Swift, Liberals and Communitarians, op. cit., p. 276, traduzi.

339 "Foundations of Liberal Equality", op. cit., sobre tolerância, pp. 297-305, esp. pp. 300-305; veja Justice for Hedgehogs, op. cit., esp. cap. 17.

${ }^{340} \mathrm{Como}$ diz o autor, "Our continuity strategy must come upon neutrality of both kinds, as I said earlier, in the course of the argument, as theorems. The strategy begins in ethics, and so it can achieve neutrality of appeal only if it can show that the ethical foundations to which appeals are already very generally accepted, or at least that these could be widely accepted without people having to abandon convictions they are unlikely to give up. It draws political principles from these ethical foundations, and so it can achieve neutrality in operation only if these ethical foundations have that consequence.". "Foundations of Liberal Equality", op. cit., p. 298. Veja em nota acima referências a Mulhal e Swift e a Macleod.

341 "Foundations of Liberal Equality", op. cit.,pp. 208-9, traduzi; a estratégia da descontinuidade é atribuída por Dworkin a John Rawls, pp. 203 e ss., esp. pp. 204 , entre outros. Veja em geral p. 208 para contrastes entre as duas estratégias. Veja Mulhall e Swift, Liberals and Communitarians, op. cit., pp. 277 e ss. para a estratégia da descontinuidade e pp. 282 para a da continuidade.

342 "Foundations of Liberal Equality", op. cit., p. 209, traduzi.
} 
do autor ${ }^{343}$. Para efeitos desta subseção, é relevante observar que a viabilidade de uma teoria política que atribua à autoridade política a responsabilidade de cuidar da vida dos cidadãos mas que lhe nega acesso, salvo exceções, a políticas paternalistas, é dependente da viabilidade da neutralidade enquanto teorema, e não axioma. Em grande parte, portanto, a questão é identificar os méritos da ética de Dworkin, a saber, do modelo do desafio, tarefa que não faz parte desta dissertação. O temor latente é identificado por Dworkin: trata-se do medo de que seja inevitável que o recurso à ética provoque posturas paternalistas ${ }^{344}$. A meu ver, entretanto, este medo precisa ser enfrentado na interpretação dos valores éticos, e não na discussão mais abstrata sobre as vantagens e desvantagens entre modelos de continuidade, como o defendido por Dworkin, e de descontinuidade.

Na próxima seção, discuto a ética de Dworkin. O autor não apresentou a sua concepção de bem com terminologia uniforme. Inicialmente, a apresentou em termos do que chamou de "modelo de desafio"; em seguida, em termos de princípios éticos de dignidade. Em cada uma das subseções da seção seguinte, exponho brevemente estes dois modos encontrados pelo autor para expor sua ética. Em seguida, passo às consequências destas visões sobre o valor da vida às liberdades.

\footnotetext{
${ }^{343}$ Veja Mulhal e Swift: "We are calling a state anti-perfectionist, or neutral, if it does snot act upon judgements as to the relative merits of the different ways of life espoused by its citizens. But we are conceding that the reasons for it not do so may lie, as we will see that they do for Dworkin, in a comprehensive doctrine about the nature of well-being", Liberals and Communitarians, op. cit., p. 253.

344 Ao discutir, em "Foundations of Liberal Equality", op. cit., de que modo aquilo que Dworkin chama de "personal perspective" impacta a "political perspective", o autor aborda a questão: veja pp. 201-2, pp. 207-9. Dworkin diz que "Government must be neutral in ethics in the following sense. It must not forbid or reward any private activity on the ground that one set of substantive ethical values, one set of opinions about the best way to lead a life, is superior or inferior to others. This version of neutrality seems particularly problematic from the ethical perspective", "Foundations of Liberal Equality", op. cit., p. 228; o ponto é que a perspectiva pessoal, do que fazer na vida, parece indistinguível da política no modelo da continuidade, de modo que se pode indagar que motivo há para não se fazer política baseado nas suas convicções éticas (veja pp. 228-9, 201-2, 207-9). "The strategy of continuity rejects this distinction [a distinção feita pela estratégia da discontinuidade entre compromisso com uma perspectiva pessoal e compromisso com uma perspectiva política], and so must explain how political neutrality grows out of ethical commitment directly, without an intervening contract or joint social construction. I have already suggested the main line of the explanation I shall offer: it rests on a distinction between the philosophical level of ethics, where liberalism takes sides, and more substantive levels, where the side it takes at the philosophical level dictates neutrality", p. 229. Ou seja, o ponto em que a ética liberal serve de fundamento à política é abstrato, e não específico (veja pp. 207-9). Veja Mulhal e Swift, Liberals and Communitarians, op. cit., cap. 9.
} 


\section{Seção 2. A Integração entre Justiça e Ética}

\section{$\underline{\text { Subseção 2.1. Justiça e boa vida: o modelo do desafio }}$}

Em "Foundations of Liberal Equality", Dworkin faz diversas reflexões sobre o que chama de "ética filosófica" ao promover o esforço de encontrar fundamentos éticos à sua concepção de política ${ }^{345}$, conforme o que chama de "estragégia da continuidade", própria, segundo o autor, de quem pretende integrar visões sobre política e sobre viver bem ${ }^{346}$.

A pergunta fundamental que o autor se faz ao elaborar a sua concepção de ética diz respeito à "ideia de uma boa vida. Que tipo de bondade [goodness] uma boa vida tem?"347. A partir desta pergunta, Dworkin contrasta dois tipos de bem estar, a saber, o bem-estar crítico (critical well-being), e o bem-estar volitivo (volitional well-being) ${ }^{348}$. Ele distingue as duas ideias nos seguintes termos: "O bem-estar volitivo de uma pessoa aumenta, somente por este motivo, quando ela tem ou alcança o que de fato quer. Seu bem-estar critico aumenta quando ela tem ou adquire o que torna sua vida melhor de ter ou alcançar" ${ }^{\text {"349 }}$. Em outra definição, Dworkin diz que este aumento ocorre quando a pessoa tem ou adquire "o que deve querer, isto é, as realizações ou experiências que fariam sua vida pior não querer" ${ }^{\text {"350 }}$. Como exemplo do primeiro, Dworkin menciona velejar bem e, como exemplo do segundo, manter uma relação próxima com os filhos ${ }^{351}$; os exemplos esclarecem a distinção porque indicam que saber velejar bem é algo que contribui ao bem-estar se houver desejo de posse de tal habilidade, enquanto deseja-se relação próxima com os filhos porque a ausência desta relação piora a vida per se, ou seja, que a presença da relação compõe o bem estar é o que gera o desejo, e não o contrário (isto é, o desejo que faz a relação aprimorar o bem-estar). Isso significa que o juízo

\footnotetext{
345 "Foundations of Liberal Equality", op. cit., pp. 229 e ss.

346 "Foundations of Liberal Equality", op. cit., p. 207, veja ainda pp. 207 e ss.

347 "Foundations of Liberal Equality", op. cit., p. 229, itálico no original, traduzi, mantive entre colchetes palavra do original. Mulhal e Swift dizem que esta é a "philosophical or structural question that Dworkin wants to address", Liberals and Communitarians, op. cit., p. 283 (veja pp. 283 e ss.)

348 "A igualdade e a vida boa", op. cit., pp. 338 e ss.; no original, "Equality and the Good Life", op. cit., pp. 242 e ss. Veja "Foundations of Liberal Equality", op. cit., 230 e ss. Veja Guest, Ronald Dworkin, op. cit., pp. 220 e ss.

349 "A igualdade e a vida boa", op. cit., p. 338, nota omitida, acrescentei o "volitivo" para adequar a tradução ao original e modifiquei a tradução para optar por "somente" no lugar de "exatamente" para traduzir "just"; no original, "Equality and the Good Life", op. cit., p. 242.

350 "Foundations of Liberal Equality", op. cit., p. 230, itálicos no original, nota omitida, traduzi. Veja Mulhal e Swift, Liberals and Communitarians, op. cit., p. 283

351 "Foundations of Liberal Equality", op. cit., p. 230.
} 
sobre o valor da vida, neste caso, é crítico, isto é, diz respeito ao que deve ser desejado independentemente de presença anterior do desejo ${ }^{352}$.

O objetivo de Dworkin é alcançar continuidade entre a sua teoria política e a ética, e dada a ideia de "motivação" que emprega ao afirmar que pessoas que adotem determinadas visões sobre ética têm razões para adotar certas visões sobre política, a noção de bem-estar a ser trabalhada é a crítica, e não a volitiva ${ }^{353}$. Esta ideia de motivação, diz ele, é normativa e filosófica ${ }^{354}$ pois caracteriza o projeto de “(...) construir uma imagem atraente dos objetivos e das ambições que acreditamos que as pessoas devem ter, e então mostrar como a política liberal de certa maneira segue da e é coerente com esta imagem"355. Em contraste, ele menciona o projeto de apontar que “(...) as políticas liberais, pode-se entender, servem ou atendem [fulfilling] o que consideramos ser objetivos ou ambições pessoais bastante difundidos"356; trata-se de questão que conecta política e psicologia e que “(...) se preocupa com a motivação descritivamente" 357 , em oposição àquela por ele enfrentada, que, por ser normativa, conecta política e ética, entre outros ${ }^{358}$.

Assim, para Dworkin, interesses críticos e princípios políticos são normativos no sentido que permite a busca de "integridade normativa" entre ambos ${ }^{359}$. No caso do artigo sob análise, o autor percorre o caminho que começa na ética e termina na política: ele formula um "thought experiment" que consiste em imaginar "liberais éticos", isto é, aqueles que adotam o modelo de ética defendido pelo autor, unidos pelo compromisso de discutir e definir quais padrões políticos devem ser por eles adotados ${ }^{360}$. O objetivo de Dworkin é mostrar que

\footnotetext{
352 "Foundations of Liberal Equality", op. cit., pp. 230-1. E ainda: "I do not think that having a close relationship with my children is important just because I happen to want it; on the contrary, I want it because I believe a life without such a relationship is a worse one", p. 231. Veja ainda "Equality of Welfare", op. cit., pp. 43-44, em especial "Even when we do enjoy what we have or have done, we often enjoy it because we think it valuable, not vice versa", p. 43.

353 "Foundations of Liberal Equality", op. cit., p. 233. Veja ainda: "I shall form this point on assume that our project of finding a liberal ethics as a foundation for liberal politics must concentrate on critical as distinct from volitional well-being. We need an account of what people's critical interests are that will show why people who accept that account and care about their own and other people's critical well-being will be led naturally toward some form of liberal polity and practice", p. 233.

354 "Foundations of Liberal Equality", op. cit., p. 192, n. 1.

355 "Foundations of Liberal Equality", op. cit., p. 192, n. 1, itálico no original, traduzi.

356 "Foundations of Liberal Equality", op. cit., p. 192, n. 1, traduzi, mantive entre colchetes palavra do original.

357 "Foundations of Liberal Equality", op. cit., p. 192, n.1, traduzi.

358 "Foundations of Liberal Equality", op. cit., p. 192, n.1.

359 "Foundations of Liberal Equality", op. cit., p. 233.

360 "Foundations of Liberal Equality", op. cit., pp. 275 e ss., esp. pp. 276-7. Veja Mulhall e Swift, Liberals and Communitarians, op. cit., p. 291.
} 
"liberais éticos têm boa razão para se tornarem liberais políticos, e, em particular, para adotar a

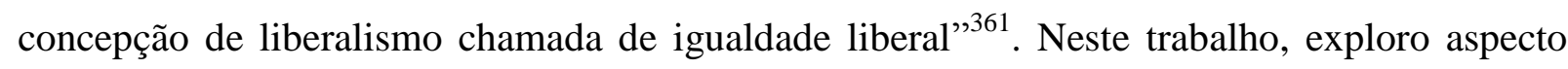
específico da teoria política de Dworkin, a saber, o tema das liberdades. Não é o caso portanto de analisar em detalhes o que chama de "igualdade liberal", teoria que, entre outros, defende interpretação da igualdade enquanto igualdade de recursos e tolerância nos termos do que o autor caracteriza de "liberal" 362 . Estes são tema para a próxima seção e para o próximo capítulo. Por enquanto, apresento somente a ética de Dworkin, bem como algumas de suas consequências à sua teoria política.

Como visto, para ele, a questão ética a ser enfrentada quando se buscam fundamentos éticos ao liberalismo como teoria normativa é a do valor ético enquanto bem estar crítico. Este entretanto é o início, e não o fim, de diversas complicações que Dworkin diagnostica e busca solucionar. Ele observa que as nossas convicções sobre interesses críticos "expressam-se de maneiras diferentes e, em alguns aspectos, antagônicas de conceber a métrica do valor ético ${ }^{363}$. Estes conflitos culminam em alguns problemas éticos ${ }^{364}$, entre eles dois que serão analisados na próxima seção, a saber, a importância do "endosso" do indivíduo ao valor da vida que vive 365 e a relação entre justiça e boa vida ${ }^{366}$.

Nossas convicções sobre bem-estar critico oscilam, diz o autor, entre dois modelos: o do impacto e o do desafio, cada qual sobre o valor em geral aplicado à questão do valor da vida $^{367}$; esta oscilação gera os “preocupações e enigmas"368 e um liberal a resolve adotando o modelo do desafio ${ }^{369}$, definido como aquele que vê o valor da vida como uma questão da habilidade na sua performance ${ }^{370}$. O modelo do impacto, em contraste, "afirma que o valor

\footnotetext{
361 "Foundations of Liberal Equality", op. cit., p. 277, traduzi.

362 "Foundations of Liberal Equality", op. cit., pp. 277-8. Veja Veja Mulhall e Swift, Liberals and Communitarians, op. cit., pp. 291-2.

363 "A igualdade e a vida boa", op. cit., p. 350; no original, "Equality and the Good Life", op. cit., pp. 250-1. Veja "Foundations of Liberal Equality", op. cit., p. 240 ("Foundations of Liberal Equality", op. cit., p. 240 ("(...) our ethical instincts and impulses reflect two different and in some respect antagonistic ways of conceiving the source and nature of the value a life can have for the person whose life it is").

364 "Foundations of Liberal Equality", op. cit., p. 240.

365 "Foundations of Liberal Equality", op. cit., pp. 237-8, 262-273.

366 "Foundations of Liberal Equality", op. cit., pp. 235-7, 253-62.

367 "Foundations of Liberal Equality", op. cit., pp. 240-1, pp. 275-6.

368 "A igualdade e a vida boa", op. cit., p. 343; no original, "Equality and the Good Life", op. cit., p. 245. Veja "Foundations of Liberal Equality", op. cit., p. 234.

369 "Foundations of Liberal Equality", op. cit., pp. 241, 276 e ss.

370 "A igualdade e a vida boa", op. cit., pp. 351, 354; no original, "Equality and the Good Life", op. cit., pp. 251, 253 "Foundations of Liberal Equality", op. cit., pp. 241, 244.
} 
ético da vida - seu êxito no sentido crítico - é parasitário e medido pelo valor de suas consequências para o resto do mundo." ${ }^{371}$. Neste modelo, quanto maiores as contribuições da vida de uma pessoa ao "valor objetivo do mundo" "372, melhor é a sua vida. Dworkin apresenta a percepção de que as vidas de pessoas como Alexander Fleming, Mozart e Martin Luther King foram boas como visão que reforça o modelo do impacto ${ }^{373}$. Mas a adoção do modelo per se não implica a adesão a nenhuma posição específica sobre quais consequências de determinada vida são boas ou más: o indivíduo que adota o modelo do impacto entende que boa vida é aquela que gera as consequências por ele consideradas boas, quaisquer que sejam, isto é, independentemente da sua adesão ao modelo ${ }^{374}$.

Dworkin diz que o modelo do desafio, por sua vez, "Adota a tese aristotélica de que a vida boa tem o valor inerente de uma performance habilidosa"375. O autor apresenta como consequência deste enunciado que a vida tenha um valor inerente, independente das consequências que a extrapolem ${ }^{376}$. Após oferecer "um mergulho complexo e elegante”377 como exemplo de algo que possui o tipo de valor que o modelo do desafio encontra na vida, o autor completa:

"O modelo do desafio afirma que viver uma vida é, em si, uma performance que requer habilidade, que é o desafio mais abrangente e importante que enfrentamos, e que os nossos interesses críticos consistem nas realizações, eventos, e nas experiências que significam que enfrentamos bem o desafio"378.

Dworkin faz algumas advertências sobre os modelos do desafio e do impacto. Em primeiro lugar, os modelos são “(...) interpretações da experiência ética, tentativas de organizar as convicções ou intimations do valor ético que a maioria de nós temos em uma

\footnotetext{
371 "A igualdade e a vida boa", op. cit., p. 352; no original, "Equality and the Good Life", op. cit., p. 252; para "Foundations of Liberal Equality", op. cit., veja p. 242("The model of impact (...) holds that the ethical value of a life - its success in the critical sense - is entirely dependent on and measured by the value of its consequences for the rest of the world").

372 "A igualdade e a vida boa", op. cit., p. 352; no original, "Equality and the Good Life", op. cit., p. 252; para "Foundations of Liberal Equality", op. cit., veja p. 242.

373 "Foundations of Liberal Equality", op. cit., p. 242.

374 "Foundations of Liberal Equality", op. cit., p. 243, pp. 275-6. Veja Mulhall e Swift, Liberals and Communitarians, op. cit., pp. 283 e ss.

375“"A igualdade e a vida boa", op. cit., p. 354, alterei a tradução para substituir "ação" por "performance" para traduzir "performance"; no original, "Equality and the Good Life", op. cit., p. 253; para "Foundations of Liberal Equality", op. cit., veja p. 244. Veja Guest, Ronald Dworkin, op. cit, pp. 220 e ss.

376 "Foundations of Liberal Equality", op. cit., p. 244.

377 "A igualdade e a vida boa", op. cit., p. 354; no original, "Equality and the Good Life", op. cit., p. 253; para "Foundations of Liberal Equality", op. cit., veja p. 244.

378 "A igualdade e a vida boa", op. cit., p. 354, alterei a tradução para substituir "ação" por "performance" para traduzir "performance"; no original, "Equality and the Good Life", op. cit., p. 253; para "Foundations of Liberal Equality", op. cit., veja p. 244.
} 
imagem coerente" ${ }^{, 379}$. Isto significa que os modelos oferecem solução a problemas internos à ética, e não a questões externas ao esforço de encontrar valor na vida ${ }^{380}$.

Esta advertência é importante à apreciação das razões do autor para a sua preferência por um modelo em detrimento de outro. Para Dworkin, o modelo do impacto negligencia convicções éticas extremamente importantes: trata-se de convicções a que o modelo do desafio dá sentido, como aquelas que apontam para o valor de aquisição de conhecimento desprovido de grandes consequências para o mundo (por exemplo, obter algum conhecimento sobre a arte desenvolvida contemporaneamente à vida do indivíduo $)^{381}$. O modelo do desafio tem lugar para convicções adverbiais, isto é, convicções de que o importante é como a vida é vivida (seu exemplo é a vida com integridade), e não somente sobre as suas consequências ${ }^{382}$. Dworkin ainda aponta que a intuição de que ter bom impacto no mundo contribui ao valor da vida não é estranha ao modelo do desafio, pois faz sentido dizer que é uma excelente maneira de enfrentar o desafio da vida encontrar a cura de uma doença ${ }^{383}$. O autor não nega que, à luz do modelo do desafio, determinadas convicções éticas sejam "estranhas", mas diz que "as convicções que o modelo do desafio torna estranhas são, afinal, convicções que pouca gente teria de fato, se é que alguém as teria." ${ }^{384}$. Por isso, o modelo do desafio é superior como interpretação "das nossas práticas e dos nossos instintos éticos" ${ }^{385}$.

Em segundo lugar, os modelos são formais, o que significa que não são exaustivos quanto às questões éticas, isto é, indivíduos com diferentes convicções podem igualmente aderir a este ou aquele modelo. Sobre este aspecto dos modelos o autor diz o seguinte:

"Temos convicções sobre nossos interesses éticos, sobre que tipos de vidas são boas no sentido crítico, e elas geram enigmas e problemas. Podemos estruturar estas convicções em torno de diferentes modelos.

\footnotetext{
379 "Foundations of Liberal Equality", op. cit., p. 241, itálico de "interpretações" no original, traduzi, mantive "intimations" como consta no original por falta de palavra adequada em português.

${ }^{380}$ Dworkin afirma que o ceticismo a que os modelos se contrapõem é interno, e não externo: "Foundations of Liberal Equality", op. cit., p. 242, veja pp. 241-2 em geral e também p. 245.

381 "Foundations of Liberal Equality", op. cit. pp. 244-5. Veja ainda "the value of a performance as an exercise of skill in the face of a challenge, is complete in itself in a way that does not depend on anything we might call objective value or value to everyone.", p. 247 (trata-se de excerto de ponto do texto em que Dworkin elabora a maneira pela qual o modelo do desafio rejeita o "puzzle" caracterizado pela aparente insignificância dos seres humanos frente à enormidade do universo: veja pp. 246-249). Veja Mulhal e Swift, Liberals and Communitarians, op. cit., p. 284.

382 "Foundations of Liberal Equality", op. cit., p. 243; veja Justice for Hedgehogs, op. cit., p. 13 e p. 197 e discussão na próxima subseção para ideia de que o valor da vida é adverbial.

383 "Foundations of Liberal Equality", op. cit., p. 245, pp. 248-9.

384 "A igualdade e a vida boa", op. cit., p. 355; no original, "Equality and the Good Life”, op. cit., p. 254; para "Foundations of Liberal Equality", op. cit., veja p. 245. Dworkin não dá exemplos destas convicções.

385 "Foundations of Liberal Equality", op. cit., p. 276, traduzi.
} 
O primeiro atrela a bondade de uma vida ao valor objetivo de seu produto independente. $\mathrm{O}$ segundo atrela a bondade de uma vida à habilidade com que é vivida, valorizada como uma performance. Estes são ambos modelos formais: nenhum deles pretende definir quais produtos são valiosos ou quais performances são habilidosas.". ${ }^{386}$

Isto fica claro no caso do modelo do impacto, pois, como visto, diferentes visões sobre o que caracterizam boas consequências levam a diferentes opiniões sobre quais vidas são boas $^{387}$.

No caso do modelo do desafio, que é a ética liberal, Dworkin explicitamente o apresenta como, além de formal, abstrato $^{388}$. Este ponto é importante porque diz respeito a um ônus assumido pelo autor ao pretender justificar uma política liberal através de uma concepção ética. É que a neutralidade do liberalismo em relação às concepções de bem impede que a ética liberal seja excessivamente detalhada ${ }^{389}$. Dworkin descreve a sua expectativa quanto à ética liberal nos seguintes termos:

"Uma ética deve ter uma natureza estrutural e filosófica em vez de substantiva. Ela deve conter proposições como as que descrevi na Introdução, que apoiam uma concepção do valor ético como performance em vez de produto, por exemplo, que não pode ser descartada nenhuma concepção substantiva e detalhada de boa vida que provavelmente seja popular na nossa comunidade política. Uma ética liberal deve ser mais do que esta virtude negativa, entretanto. Deve ser suficientemente muscular para formar uma ética liberal distinta, de modo que qualquer um que abrace as visões que oferece mais provavelmente abraçaria a política liberal. Será preciso saber, depois, se a ética liberal que descreverei passa nestes testes gêmeos: o teste negativo de abstração e o teste positivo de poder discriminador., ${ }^{390}$

Há, portanto, diz Dworkin, dois níveis na ética: o filosófico e o substantivo ${ }^{391}$; e a ética liberal "adota um lado" (takes sides) ${ }^{392}$ somente no primeiro e, justamente por fazê-lo, é neutra no substantivo, ou seja, a neutralidade substantiva do modelo do desafio é demanda do seu significado filosófico ${ }^{393}$. Daí o autor, ao conceber o seu "thought experiment", apresentar os "liberais éticos" como comprometidos tanto com o modelo do desafio quanto com outras

\footnotetext{
386،Foundations of Liberal Equality”, op. cit., pp. 275-6, itálicos acrescentados, traduzi (sigo a tradução de "puzzle" por "enigma": veja, por exemplo, "A igualdade e a vida boa", op. cit., p. 343 - no original, "Equality and the Good Life", op. cit., p. 245). Veja ainda, de "Foundations of Liberal Equality", op. cit., pp. 207-8, p. 249, 254-5, 285, 301-2, entre outros.

387 "Foundations of Liberal Equality", op. cit., p. 253.

388 "Foundations of Liberal Equality", op. cit. pp. pp. 207, 223, 229, 248, 249, 253, 277, 279, 285, 298. Veja Mulhal e Swift, Liberals and Communitarians, op. cit., cap. 9, esp. 282-3 e pp. 300 e ss.

389 "Foundations of Liberal Equality", op. cit., pp. 207-8; veja ainda p. 229.

390 "Foundations of Liberal Equality", op. cit.,pp. 207-8, itálicos no original, traduzi. Veja Mulhall e Swift, Liberals and Communitarians, op. cit., pp. 253 e ss. (esp. pp. 254-5) e pp. 282-3.

391 "Foundations of Liberal Equality", op. cit., p. 229.

392 "Foundations of Liberal Equality", op. cit., p. 229 (veja trecho citado em nota acima).

393 "Foundations of Liberal Equality", op. cit., p. 229.
} 
visões sobre como conduzir suas vidas ${ }^{394}$. Como visto anteriormente neste capítulo, temos neste ponto um reposicionamento da neutralidade na reflexão política de Dworkin. Nesta subseção, percebemos como este reposicionamento é permitido pelo nível em que o modelo do desafio atua e pela limitação das suas exigências àquelas mais filosóficas, por exemplo, sobre o tipo de valor que a vida tem.

Há ainda uma característica desenvolvida por Dworkin e cujo esclarecimento é importante à compreensão da ética liberal e de seu significado filosófico: a analogia elaborada pelo autor entre arte e ética na compreensão do tipo de valor que uma vida e uma obra de arte têm. A analogia também é importante porque é utilizada pelo autor para indicar que, para o modelo do desafio, o valor ético, a exemplo do valor estético, é indexado às circunstâncias do indivíduo que vive a vida. ${ }^{395}$ Procedamos por partes.

Para o autor, existe uma analogia estrutural entre valor ético e valor estético ${ }^{396}$ (o que não significa que, para o modelo do desafio, a vida seja arte ${ }^{397}$ ). Esta analogia é explorada a partir da distinção entre valor de produto ${ }^{398}$ (product value) e valor artístico ${ }^{399}$ (artistic value), por exemplo, de uma pintura: enquanto o primeiro é "o poder que ele tem de despertar a sensação estética e outras formas de experiências valiosas"

394 "Their comprehensive convictions about the good life are very different one from another, and taken together these convictions represent the range of opinions people in our world actually have. But this is a group of people each of whom is assumed to hold a certain ethical position. They all understand their different ethical convictions in the fashion of a challenge conception. They endorse the very abstract implications of that conception that I described in the last section.", "Foundations of Liberal Equality", op. cit.p. 277; veja em geral pp. 276-7 e 301-2. 395 "Foundations of Liberal Equality", op. cit., pp. 249-253. Veja Guest, Ronald Dworkin, op. cit, pp. 221 e ss.

396 "Foundations of Liberal Equality", op. cit., pp. 250 e ss. Em especial, sobre "the injuction that we should try to make our life a work of art", Dworkin diz: "the injunction makes sense only if understood in the structural sense I mean the analogy between art and ethics to reveal: we make our lives works of art by treating ethical value in the challenge way, and therefore as having the same structure as artistic value.”, p. 252, n. 39.

397 "Foundations of Liberal Equality", op. cit., pp. 251-1, n. 39 : "The model of challenge (...) makes room for the romantic ideal that one should make of one's life a work of art (...). But it does not require it".

398 Justiça para ouriços, op. cit., p. 205, para traduzir "product value" (Justice for Hedgehogs, op. cit., p. 197) adoto a opção da tradução. Mas neste texto Dworkin distingue o "product value" ("the value it has just as an object, independently of the process through which it was created or of any other feature of his history", p. 197), que é "subjective or objective", do "performance value", que é "(...) the value of having been manufacture through a creative act that has performance value", p. 197). As ideias me parecem as mesmas das elaboradas em "Foundations of Liberal Equality", op. cit. Veja ainda, "A igualdade e a vida boa", op. cit., p. 360 para "valor do produto" e "valor artístico"; para o original, "Equality and the Good Life", op. cit., p. 258.

399 "A igualdade e a vida boa", op. cit., p. 360 (nestra tradução, traduz-se "product value" por "valor do produto", p. 360).

400 "A igualdade e a vida boa", op. cit., p. 360 (modifiquei a tradução para substituir "sensações" por "experiências" para traduzir "experiencies"); para o original, "Equality and the Good Life", op. cit., p. 258.. Para "Foundations of Liberal Equality", op. cit., ver p. 250. 
possui, não independentemente, mas devido a como foi produzido"401. A distinção, diz ele, é demandada para que possamos diferenciar o valor de uma obra de arte original e de um produto cópia que não seja percebido como tal ${ }^{402}$ e guarda espaço ao "nosso respeito pela performance que o produziu, considerada como resposta habilidosa a um desafio artístico bem avaliado" 403 .

Analogamente, para Dworkin o valor da vida não reside no seu produto somente exclusivamente nas suas consequências ao mundo, como quereria um defensor do modelo do impacto - mas no modo pelo qual é vivida, isto é, no modo pelo qual o desafio da vida é enfrentado $^{404}$. Com efeito, para o modelo do desafio, este desafio inclui a sua própria definição, isto é, compõe o desafio de viver identificar qual exatamente é o desafio a ser vivido $^{405}$; como ele diz, “(...) se viver bem for considerado um desafio, definir o que é viver bem deve fazer parte desse desafio também"406. Dworkin explora a inexistência de uma "visão estabelecida" 407 para a arte tal qual, para ele, inexiste um padrão de boa vida anterior à ocorrência da própria vida que, em razão disso, pode "alargar" a nossa compreensão de quais casos devem ser caracterizados como vida bem vivida ${ }^{408}$. O valor ético (da vida) e o estético

401 "A igualdade e a vida boa", op. cit., p. 360; para o original, "Equality and the Good Life", op. cit., p. 258.. Para "Foundations of Liberal Equality", op. cit., ver p. 251.

402 "Foundations of Liberal Equality", op. cit., p. 251. Mesmo objetivo da distincão feita em Justice for Hedgehogs, op. cit., p. 197 (veja nota acima).

403 "A igualdade e a vida boa", op. cit., p. 360 (modifiquei a tradução para substituir "empreendimento" por "performance" para traduzir "performance" e adequei a flexão de gênero de palavras para adequar o trecho à modificação); para o original, "Equality and the Good Life", op. cit., p. 258.. Para "Foundations of Liberal Equality", op. cit., ver p. 251.

"Foundations of Liberal Equality", op. cit., p. 251.

404 "Foundations of Liberal Equality", op. cit., pp. 250 e ss.

405 "Foundations of Liberal Equality", op. cit., p. 251.

406 "A igualdade e a vida boa", op. cit., p. 361; no original, "Equality and the Good Life", op. cit., p. 258; para "Foundations of Liberal Equality", op. cit., veja p. 251.

"Foundations of Liberal Equality", op. cit., p. 251.

407 "Foundations of Liberal Equality", op. cit., p. 251, traduzi (veja citação em nota abaixo), no original: "settled view". "A igualdade e a vida boa", op. cit., p. 361 ("tese consolidada"); no original, "Equality and the Good Life", op. cit., p. 258

408 "Foundations of Liberal Equality", op. cit., p. 251. Em especial, veja o seguinte trecho: "There is no settled view about what artistic achievement is, as there is (I imagine) about achievement in diving. We expect artists to make claims that, if successful, might expand or at least change what the tradition counts as artistic achievement. These claims (we might say) offer to make something of nothing, to make value out of a kind of performance in which none was recognized before. If we treat ethical value as the value of a performance rather than the independent value of a product, then we shall have to take the same view of what a skillful performance of living is. There is no settled cannon of skill in living, and some people's lives, at least, make claims about a skilfull performance that is widely accepted would change prevailing views on the subject and might even launch what would seem a new mode of living well, making, once again, ethical value from nothing", p. 251, nota omitida. Compare com Justice for Hedgehogs, op. cit., pp. 211 e ss. 
(da arte) são, para o autor, indexados às “circunstâncias" temporais, geográficas, pessoais etc. enfrentadas pelo sujeito ou pelo artista ${ }^{409}$. Estas circunstâncias são, diz Dworkin, "parâmetros" ("parameters") utilizados para avaliar a qualidade da vida ou da arte, e não "limitações" (“limitations") ${ }^{410}$ à capacidade de um indivíduo ou de um artista de alcançar a vida ou a obra cuja qualidade seja "transcendente" a estas circumstâncias" ${ }^{411}$ (veja próxima seção para mais detalhes). O seguinte parágrafo conclui a reflexão do autor e, por captar bem tanto a analogia entre arte e ética quanto a característica de abstração d padrões intelectuais o modelo do desafio, vale ser citado na sua inteireza:

"A analogia artística nos lembra que o valor da performance pode ser indexado sem ser subjetivo, pois a indexação pode ser fornecida pelos parâmetros do desafio que mudam com o tempo e a situação, mas que, não obstante, apresentam exigências categóricas. Viver bem, assim como pintar bem, significa responder [responding] de maneira apropriada à situação, embora, é claro, o desafio ético de determinada época e lugar seja bem diferente de seu desafio artístico. A arte e a ética, nesta perspectiva, estão indexadas da mesma maneira. Ambas requerem decisão, fazendo parte do desafio que apresentam acerca da reação certa às circunstâncias complexas nas quais é preciso tomar tal decisão. Em ambos os casos, é uma questão adicional qual é realmente a resposta ética certa para qualquer pessoa em quaisquer circunstâncias em especial, ou se existe uma única resposta correta, mesmo que somente para uma pessoa ou circunstância, ou apenas um conjunto delas. O modelo do desafio, no nível de abstração que estamos explorando, não tenta responder a essas perguntas. Salienta apenas que tipo de perguntas - que elas requerem uma resposta pessoal à particularidade da situação, e não da aplicação, a tal situação, de um ideal eterno de vida". 412

Para concluir esta subseção, gostaria de chamar a atenção para uma característica da indexação do valor da vida presente neste trecho citado: a resposta ao desafio posto pelas circunstâncias é pessoal ${ }^{413}$. Como vimos no capítulo anterior, direitos no sentido forte, para Dworkin, são pessoais, e não instrumentos de benefício coletivo. Como veremos, que o tipo de valor da vida é ligado à performance de resposta pessoal a um desafio tem consequências a quais direitos existem, pelo menos em uma teoria que, como a de Dworkin, se põe a fundamentar uma teoria política em uma concepção ética. Guardemos ainda esta característica

\footnotetext{
409"Foundations of Liberal Equality", op. cit., pp. 249-253. Em especial, "It seems irresistible that living well, judged as a performance, means among other things living in a way responsive and appropriate to one's culture and other circumstances", p. 250.

${ }^{410}$ Para esta tradução, veja "A igualdade e a vida boa", op. cit., p. 363; para o original, "Equality and the Good Life", op. cit., p. 260.

${ }^{411}$ Em "Foundations of Liberal Equality", op. cit., veja pp. 252-3.

412 "A igualdade e a vida boa", op. cit., pp 362-3, modifiquei a tradução ao substituir "ação" por "performance" para traduzir "performance", "reagir" por "responder" para traduzir "responding" (e "reação" por "resposta" para traduzir "response") e "vinculadas" por "indexadas" para traduzir "indexed; no original, "Equality and the Good Life", pp. 259-60; "Foundations of Liberal Equality", op. cit., p. 253

${ }^{413}$ Justice for Hedgehogs, op. cit., p. 204, trecho citado abaixo.
} 
da indexação do valor da vida para a próxima subseção, em que analisarei a elaboração da concepção de bem de Dworkin em termos de dois princípios éticos de dignidade.

Em seguida, na seção 3 deste capítulo, retornarei ao modelo do desafio e às suas respostas aos problemas éticos identificados por Dworkin. Os liberais éticos do "thought experiment" do autor adotam a ética do desafio e, ao resolverem os diferentes temas nos termos desde modelo, obtêm razões para a adoção de determinadas teses políticas ${ }^{414}$. Alguns destes caminhos são objeto da próxima seção. Antes disso, gostaria de apresentar outra formulação da ética de Dworkin, a saber, aquela em termos de dois princípios éticos de dignidade ou "individualismo ético".

\section{Subseção 2.2.: Dignidade, Igualdade e Autenticidade}

Os temas analisados até agora nesta seção foram tratados em artigo publicado em Sovereign Virtue a partir de "Foundations of Liberal Equality. Como visto, Dworkin defende um modelo liberal de ética que chama de "modelo do desafio". O projeto dworkiniano de integrar ética e moral e de fundamentar uma teoria política liberal numa concepção de bem recebeu formulação mais abrangente e com outra terminologia em livro mais recente de Dworkin, a saber, em Justice for Hedgehogs (2011). A formulação é mais abrangente porque o autor discutiu desta vez temas outrora não abordados, como as consequências da sua ética aos temas do "auxílio" (Capítulo 12, “Aid”), "Dano” (Capítulo 13, "Harm”) e obrigações,e entre elas promessas (Capítulo 14 "Obligations") ${ }^{415}$, além de ter situado neste projeto aspectos de sua teoria política anteriormente expostos em termos não-éticos ${ }^{416}$, entre outros.

A terminologia é nova porque Dworkin não mais fala em "modelo do desafio" ou "do impacto", embora a expressão "desafio" não esteja completamente ausente do livro

\footnotetext{
414 "Foundations of Liberal Equality", op. cit., pp. 275 e ss, veja ainda p. 241.

${ }^{415}$ Veja a tradução portuguesa de Justice for Hedgehogs, Justiça para Ouriços, op. cit., caps. 12 e 14 (pp. 279 332). Isso não significa que tudo nestes capítulos seja novo. Tomemos um exemplo: igualdade e suas consequências às nossas condutas quanto a terceiros. Compare, por exemplo, o cap. 12 de Justice for Hedgehogs, op. cit. (esp. pp. 273-5) com "Foundations of Liberal Equality", op. cit., pp. 291 e ss.: no primeiro trecho, Dworkin busca mostrar como a igual importância objetiva das vidas não exige que tratemos terceiros como tratamos, por exemplo, nossos familiares, exigência que, como o autor expõe no segundo trecho, a igualdade de recursos também não faz.

${ }^{416}$ Como a ideia de obrigação política enquanto obrigação associativa tem justificação ética: veja Capítulo 13 , "Obligations", esp. pp. 311 e ss. e compare com Law's Empire, op. cit., caps. 5-6. Para comentários, veja Caio Moysés de Lima em O Império dos Direitos: Lei e Autoridade Política em Ronald Dworkin, op. cit., pp. 79 e ss. (veja em especial p. 99 para quadro representativo da teoria de Dworkin). Guest resume diversos pontos de Justice for Hedgehogs: veja Ronald Dworkin, op. cit., cap. 9.
} 
mencionado, e o autor continue a rejeitar a ideia de que as consequências de uma vida são tudo o que basta à medida de seu valor ${ }^{417}$. Não é claro o motivo da mudança. Talvez isso tenha ocorrido para evitar um tipo de mal-entendido contra o qual Dworkin advertiu, a saber, o erro de ler no modelo do desafio a defesa de que vidas de valor são somente aquelas "cheias de desafio interno" "418. É que a ideia do modelo, como visto, é que “(...) a própria vida deve ser encarada como desafio" 419 , e pode perfeitamente ser o caso que a melhor resposta a este desafio exclua determinadas atividades desafiantes ${ }^{420}$. Não é objeto deste trabalho oferecer comparação sistemática entre as duas execuções do projeto, que penso serem convergentes no que têm de principal, embora no restante deste capítulo eu ocasionalmente aponte aspectos em que o autor talvez tenha mudado de opinião. Seria o caso de análise mais minuciosa de possíveis alterações se elas tivessem consequências ao tema desta pesquisa, coisa que não me parece ocorrer. Discuto na conclusão deste capítulo possível consequência deste tipo ao contrastar diferentes trabalhos de Dworkin no que diz respeito aos fundamentos dos direitos relacionados à obscenidade. Em geral, entretanto, julgo que eventuais alterações nas opiniões do autor de entre "Foundations of Liberal Equality" e Justice for Hedgehogs não tenham relevância ao objeto deste trabalho, a saber, à defesa do autor ao direito à liberdade de expressão.

Em especial, a vida continua sendo tratada como um desafio ${ }^{421}$, pois "Temos de tratar a construção das nossas vidas como um desafio, que pode ser bem ou mal enfrentado" ${ }^{422}$; o valor da vida é "adverbial"

\footnotetext{
${ }^{417}$ Justice for Hedgehogs, op. cit., pp. 198 e ss. Ele diz, num dos trechos em que retoma a terminologia anteriormente utilizada: "On any plausible view of what is truly wonderful in almost any human life, impact hardly comes into history at all", p. 198.

418 "Foundations of Liberal Equality", op. cit., p. 249, traduzi, no original: "full of internal challenge". "A igualdade e a vida boa", op. cit., p. 358 ("repletas de desafios interiores"); no original, "Equality and the Good Life", op. cit., p. 256.

419 "A igualdade e a vida boa", op. cit., p. 358; no original, "Equality and the Good Life", p. 256; "Foundations of Liberal Equality", op. cit., p. 249.

420 "Foundations of Liberal Equality", op. cit., p. 249; compare com Justice for Hedgehogs, op. cit., pp. 209-10 e "Introduction: Does Equality Matter?" in Sovereign Virtue, op. cit., p. 6.

${ }^{421}$ Justice for Hedgehogs, op. cit., p. 13.

${ }_{422}$ Justiça para ouriços, op. cit., p. 25; no original, Justice for Hedgehogs, op. cit., p. 13.

${ }^{423}$ Justiça para ouriços, op. cit., p. 25; no original, Justice for Hedgehogs, op. cit., p. 13 (veja ainda p. 197).

${ }^{424}$ Dworkin parece tratar "valor adverbial" como sinônimo de "valor de performance" ao discutir o valor da vida e a sua relação com o universo: "the value we think we find in our connection with the universe must be adverbial, performance value. Recognizing our tiny role is part of living well", Justice for Hedgehogs, op. cit, p. 216. A tradução deste livro (Justiça para ouriços, op. cit., p. 223) fala em "desempenho" para traduzir
} 
"Temos de encontrar o valor de viver - o sentido da vida - no viver bem, tal como encontramos valor em amar, pintar, escrever, cantar ou mergulhar bem." ${ }^{\text {,25 }}$. Naturalmente, são ideias (vida como desafio, valor adverbial, analogia com arte ${ }^{426}$ e mergulho, entre outros) que ecoam, quando não repetem, o modelo ético do desafio.

Fato, entretanto, é que em meio aos trechos citados no parágrafo anterior, Dworkin insere nova terminologia. Logo após a primeira citação acima (sobre a vida como desafio), ele diz, em passagem com palavras por mim italicizadas: "Devemos reconhecer, como fundamental entre os nossos interesses privados, uma ambição para tornar boas as nossas vidas: autênticas e válidas, em vez de más ou degradantes. Em particular, temos de acarinhar [cherish] a nossa dignidade." ${ }^{427}$. Dworkin apresenta a sua concepção de ética em termos de “dois princípios de dignidade", a saber, os princípios do respeito próprio e da autenticidade ${ }^{428}$; ou seja, os dois princípios éticos formam uma "concepção de dignidade humana" ${ }^{429} . \mathrm{O}$ primeiro diz que "Cada pessoa deve levar sua própria vida a sério: tem de aceitar que é importante que a sua vida seja uma realização bem sucedida e não uma oportunidade perdida"430; este princípio reconhece a "atitude" ${ }^{431}$ (crítica, isto é, não somente subjetiva,

"performance". A tradução de Sovereign Virtue, por sua vez, traduz "performance" por "ação" (veja "A igualdade e a vida boa", op. cit., p. 354, por exemplo).

${ }^{425}$ Justiça para ouriços, op. cit., p. 25; no original, Justice for Hedgehogs, op. cit., p. 13.

${ }^{426}$ A analogia aparece também no capítulo 9: veja Justice for Hedgehogs, op. cit., pp. 196 e ss., pp. 213 e ss., inclusive a ideia de que o valor da vida é o valor de uma "performance" e a distinção entre valor de produto e valor artístico (pp. 197 e ss.). É interessante que, ao distinguir os dois tipos de valor - de produto e artístico -, Dworkin associe o primeiro às ideias de valor subjetivo e de impacto, e o segundo a valor objetivo e às visões de boa vida de Platão e Aristóteles (veja pp. 197-8). Trata-se, claramente, de convergência com obra anterior de Dworkin, pois, para usar a terminologia de "Foundations of Liberal Equality", em Justice for Hedgehogs ele associa valor de produto ao valor encontrado na vida pelo modelo do impacto e o valor artístico (de performance) ao valor ético ressaltado pelo modelo do desafio. Veja Guest, Ronald Dworkin, op. cit., p. 220, para associação da ideia de "performance" (em "Foundations of Liberal Equality", op. cit.) à noção de "valor adverbial" (em Justice for Hedgehogs, op. cit.).

${ }_{427}$ Justiça para ouriços, op. cit., p. 25, acrescentei os itálicos e coloquei entre colchetes a palavra do original em inglês traduzida como "acarinhar" na edição portuguesa; para o original, Justice for Hedgehogs, op. cit., p. 13. Veja Guest, Ronald Dworkin, op. cit., pp. 160 e ss.

${ }^{428}$ Justiça para ouriços, op. cit., cap. 9; no original, Justice for Hedgehogs, op. cit., cap. 9. De rigor, na p. 13, há alguma confusão: o autor fala, por exemplo, em "Dignity and self-respect" (p. 13), como se respeito próprio não compusesse a dignidade e/ou fosse sinônimo de autenticidade. Emprego entretanto a formulação da dignidade em termos de respeito próprio e autenticidade presente no capítulo 9 do livro de Dworkin (bem como esclarecida já na p. 14) por ser esta a formulação mais acabada da concepção de ética do autor presente em Justice for Hedgehogs. Veja Yowell, “A Critical Examination of Dworkin's Theory of Rights”, op. cit., pp. 127-8 para a relação entre estes dois princípios e direitos humanos e políticos. Veja Caio Moysés de Lima. O Império dos Direitos: Lei e Autoridade Política em Ronald Dworkin, p. 75, n. 158.

${ }^{429}$ Justice for Hedgehogs, op. cit., p. 204; veja Caio Moysés de Lima, O Império dos Direitos: Lei e Autoridade Política em Ronald Dworkin, op. cit., pp. 74 e ss.

${ }^{430}$ Justiça para ouriços, op. cit., p. 211; no original, Justice for Hedgehogs, op. cit., p. 203. 
amparada num desejo ${ }^{432}$ ) de reconhecer a "importância objetiva" em viver bem ${ }^{433}$. O segundo princípio de dignidade, por sua vez, diz que "Cada pessoa tem a responsabilidade especial e pessoal de criar essa vida por meio de uma narrativa ou de um estilo coerente que ela própria aprova" 434 . Os princípios relacionam-se entre si nos seguintes termos: "A autenticidade é o outro lado do respeito próprio. Porque uma pessoa se leva a sério, pensa que viver bem significa exprimir-se na sua vida, procurando uma forma de vida [way to live] que considere certa para si e para as suas circunstâncias". ${ }^{435}$

Os dois princípios de dignidade humana são apresentados por Dworkin como “análogos éticos" dos dois princípios de política por ele defendidos, que exigem do Estado, respectivamente, que trate os cidadãos com igual consideraçào e que respeite suas "responsabilidades éticas" "436. Assim, o princípio ético do respeito-próprio corresponde à igualdade política e o princípio ético da autenticidade corresponde à exigência de respeito pelo estado às escolhas dos indivíduos ${ }^{437}$. A integração entre ética e moral propiciada pela integração entre os princípios de dignidade e os princípios políticos elaborados por Dworkin serão objeto da próxima seção. Por hora, vale aprofundar a análise dos princípios éticos.

O princípio do respeito próprio aponta para o "importância objetiva" do sucesso da vida $^{438}$. Dworkin por vezes fala em "interesses críticos"439, "vida criticamente boa"440, e

\footnotetext{
${ }^{431}$ Justiça para ouriços, op. cit., p. 213; no original, Justice for Hedgehogs, op. cit., p. 205.

${ }^{432}$ Veja discussão abaixo e Justice for Hedgehogs, op. cit., pp. 206-9; veja p. 208 para a expressão "critical atitudes".

433 Justiça para ouriços, op. cit., p. 212; no original, Justice for Hedgehogs, op. cit., p. 205. Compare com "Equality of Welfare", op. cit., pp. 30 e ss.

${ }^{434}$ Justiça para ouriços, op. cit., p. 211; no original. Justice for Hedgehogs, op. cit., p. 204. Compare com a defesa da natureza constitutivea do endosso do indivíduo quanto à sua vida e à prioridade da integridade ética, ideias defendidas por Dworkin em "Foundations of Liberal Equality" e discutidas na subseção 3.1., abaixo

435 Justiça para ouriços, op. cit., p. 217 (substituí "Como" por "Porque" para traduzir "Because" e inseri as palavras do original entre colchetes); no original, Justice for Hedgehogs, op. cit., p. 209. Veja Guest, Ronald Dworkin, op. cit., p. 163.

${ }^{436}$ Justiça para ouriços, op. cit., p. 25; no original, Justice for Hedgehogs, op. cit., p. 14. Para o autor, são os seguintes os "two fundamental principles of politics: a requirement that government treat those it governs with equal concern, and a further requirement that it respect [sic], as we may now put it, its subjects' ethical responsibilities. In Chapter 9 I construct the ethical analogues of these two political principles. People must thake their own lives seriously: they must accept that it is objectively important how they live. People must take their ethical responsibility as well they must insist on the right - and exercise that right - to make ethical decision finally for themselves", Justice for Hedgehogs, op. cit., p. 14 (veja ainda pp. 203 e ss.). Veja abaixo na próxima seção discussão sobre o primeiro princípio de dignidade e a igualdade.

${ }^{437}$ Justice for Hedgehogs, op. cit., p. 14.

${ }^{438}$ Justiça para ouriços, op. cit., p. 204; no original, Justice for Hedgehogs, op. cit., pp. 196 (veja ainda pp. 202 e ss., 256).

${ }^{439}$ Justice for Hedgehogs, op. cit., p. 195, traduzi; na tradução, "interesses fundamentais", Justiça para ouriços, op. cit., p. 203.
} 
"atitudes críticas" 441 , o que nos remete à noção de bem-estar crítico como apresentada pelo autor em "Foundations of Liberal Equality". Pode-se dizer que o valor objetivo da vida para o autor reflete o reconhecimento de que o valor da vida é dependente daquilo que nós devemos querer $^{442}$, e que é caracterizador de um valor objetivo, portanto, independente do valor subjetivo de desejarmos viver bem ${ }^{443}$. Dworkin utiliza categorias propostas por Stephen Darwall para dizer que o princípio do respeito próprio caracteriza o respeito que temos em relação a nós mesmos em razão do "reconhecimento" do nosso "estatuto [status] como pessoas" ${ }^{444}$.

Já a autenticidade, para o autor, caracteriza a vida que, sendo ou não em conformidade com padrões socialmente disponíveis, é vivida “(...) segundo, e não contra, a nossa situação e os valores que consideramos adequados" ${ }^{\$ 45}$. Para Dworkin, a autenticidade tem duas dimensões $^{446}$ : responsabilidade $\mathrm{e}$ independência ética. A primeira dimensão oferece interpretação da dignidade como demanda de “(...) ser responsável por aquilo que se faz [owning up to what one has done]"447, e, quando interpretada, enfrenta questões sobre as

\footnotetext{
${ }^{440}$ Justice for Hedgehogs, op. cit., p. 196, traduzi; na tradução, "vida fundamentalmente boa”, Justiça para ouriços, op. cit., p. 204.

${ }^{441}$ Justiça para ouriços, op. cit., p. 215; no original, Justice for Hedgehogs, op. cit., p. 208

${ }^{442}$ Justice for Hedgehogs, op. cit., p. 13, por exemplo, especialmente p. 195, entre outros. Veja ainda "Do Liberty and Equality Conflict?", op. cit., pp. 42-3 e "Is Democracy Possible Here?", sobre o primeiro princípio de dignidade: "The success or failure of any human life is importante in itself, something we all have reason to want or to deplore", pp. 9-10, itálico no original.

${ }^{443}$ Justice for Hedgehogs, op. cit., 206-8; veja em especial p. 208 para "critical judgments" e "critical atitudes", que estabelecem critérios que oferecem "panic" ou "pride" quanto às escolhas da vida: veja os exemplos de Dworkin na p. 208. Veja ainda pp. 206-8 para a discussão sobre prazer (“(...) this meaning-of-life hedonism, as we might call it, is not an alternative to thinking it importante to live well. It is only a sadly popular answer to the question of what living well means", p. 207) e a compare com a discussão sobre interpretação e intenção em "How Law is Like Literature" in A Matter of Principle, op. cit., e Law's Empire, op cit., cap.2. A associação entre bem estar critico e valor objetivo é autorizada ainda pela resposta análoga oferecida por Dworkin à ameaça do ceticismo: ele precisa ser interno - veja "Foundations of Liberal Equality", op. cit., pp. 241-2, p. 245 e Justice for Hedgehogs, op. cit., pp. 208-9.

${ }^{444}$ Justiça para ouriços, op. cit., p. 213 (acrescentei entre colchetes palavra do original); no original, Justice for Hedgehogs, op. cit., pp. 205-6. O "recognition respect" é contrasto ao "appraisal respect", que se dispensa a indivíduos "in virtue of his character or achievements", p. 205. Na n. 14 (à p. 205), na p. 458, Dworkin faz referência a artigo de "Stephen L. Darwall: "Two Kinds of Respects", Ethics 88, No. I (October 1977): 36-49." (itálico no original). Veja Waldron em The Harm in Hate Speech, op. cit., pp. 86-7.

${ }^{445}$ Justiça para ouriços, op. cit., p. 217; para o original, Justice for Hedgehogs, op. cit., p. 210 (veja em geral pp. 209-10).

${ }^{446}$ Justiça para ouriços, op. cit., p. 219; no original, Dworkin usa a expressão "dimension" para descrever responsabilidade e independência ética: veja Justice for Hedgehogs, op. cit., p. 211.

${ }^{447}$ Justiça para ouriços, op. cit , p. 218 (acrescentei entre colchetes as palavras do original); para o original, Justice for Hedgehogs, op. cit., p. 210.
} 
hipóteses em que é aceitável demandar da sociedade recursos para $\mathrm{si}^{448}$. Ao entender a responsabilidade nestes termos, Dworkin evidencia a importância de questões éticas a temas políticos, como a justiça distributiva, pois saber se um indivíduo tem direito a determinados recursos depende de distinguir demandas eticamente inaceitáveis porque de responsabilidade do indivíduo daquelas aceitáveis, pelas quais o indivíduo não responde ${ }^{449}$.

A segunda dimensão da autenticidade, por sua vez, diz respeito às demandas de dignidade no nosso trato com outras pessoas ${ }^{450}$ : para Dworkin, a dignidade demanda independência, mas não ausência de "(...) influência ou (...) persuasão",451 pois, embora muito das nossas vidas possa ser elaborado por nós, “(...) limitações de natureza ou de circunstância(...)"452, como aspectos de tempo, espaço, bem como circunstâncias políticas ou pessoais naturalmente restringem como podemos conduzir as nossas vidas ${ }^{453}$. A independência ética para Dworkin, portanto, não exige que cada um de nós nos ponhamos a individualizar completamente nossas existências ${ }^{454}$, e o autor não considera necessariamente inautêntica a vida de indivíduos que se "sujeitam" à "autoridade ética" de uma entidade religiosa, desde que isso se dê "de modo voluntário". 455 A analogia da arte esclarece a relação entre limites à vida e a sua autenticidade: para Dworkin, a autenticidade é violada não quando, por exemplo, a

${ }^{448}$ Justice for Hedgehogs, op. cit., p. 211.

${ }^{449}$ Justice for Hedgehogs, op. cit., p. 211. Compare com "Equality of Welfare", op. cit., pp. 30 e ss., esp. pp. 3842. Veja Ripstein em "Liberty and Equality", op. cit., em especial p. 92 para o sentido "constitutivo" em que a "responsabilidade" entre na igualdade de recursos.

${ }^{450}$ Justice for Hedgehogs, op. cit., p. 211.

${ }^{451}$ Justiça para ouriços, op. cit., p. 219; no original, Justice for Hedgehogs, op. cit., p. 211.

${ }^{452}$ Justiça para ouriços, op. cit., p. 219; no original, Justice for Hedgehogs, op. cit., p. 212. Veja Guest, Ronald Dworkin, op. cit. p. 163

${ }^{453}$ Justice for Hedgehogs, op. cit., pp. 211-2.

454 Justice for Hedgehogs, op. cit., pp. 211-2.

${ }^{455}$ Justiça para ouriços, op. cit., p. 220; para o original, Justice for Hedgehogs, op. cit., pp. 211-3, especialmente o seguinte trecho: "Theocratic communities that impose an ethical regime by coercion compromise their subjects' authenticity. In liberal political communities, in contrast, those who subject themselves to the ethical authority of their church do so voluntarily. They are nevertheless inauthentic if their adherence is so mechanical and unthinking that it does not flow into and shape the rest of their lives, if their religion is dutiful or social or selfcongratulatory rather than a source of narrative energy. Fundamentalist Christians who denounce unbelievers and vote as they are told by televangelists, but who seem otherwise untouched by Christian charity, lead inauthentic lives even though their religion is not coerced", p. 213. O importante neste exemplo para os meus propósitos é perceber que o tipo de adesão "mecânica" à religião não é própria da natureza eventualmente coercitiva da experiência religiosa, e pode estar presente em outras atividades, inclusive não religiosas, que por vezes poderiam ser equivocadamente consideradas mais livres do que o exercício da vida espiritual sob uma comunidade liberal descrito por Dworkin. Para ele, o ponto da independência enquanto dimensão da vida autêntica, portanto, não reside no tipo de experiência - religiosa ou não - mas no modo pelo qual o indivíduo a vive (ou é obrigado a vivê-la). Veja ainda "Introduction: Does Equality Matter?" in Sovereign Virtue, op. cit., p. 6. 
ausência de tecnologia ou a presença de tributação ${ }^{456}$ (desde que justa ${ }^{457}$ ) limita as vidas disponíveis da mesma forma que a indisponibilidade de certas cores a um artista não torna a sua obra menos autêntica ${ }^{458}$. A "limitação" das opções, portanto, precisa ser distinguida da sua "usurpação": determinado indivíduo

“(...) não vive autenticamente, por muitas opções que lhe sejam oferecidas, se os outros lhe proibirem algumas opções, que, de outro modo, estariam disponíveis, porque as consideram inválidas [unworthy]. A indignidade reside na usurpação e não na limitação. A autenticidade exige que, na medida em que se devem tomar decisões sobre a melhor utilização a dar à vida de uma pessoa, as decisões devam ser tomadas pela pessoa cuja vida está em causa" ${ }^{, 45}$.

A questão, sustenta Dworkin, diz respeito ao “(...) caráter bem como à existência de obstáculos à escolha"460. Em outras palavras, para Dworkin não é simplesmente a indisponibilidade de caminhos éticos que caracterizam a violação da autenticidade, mas a razão pelo qual essa indisponibilidade existe.

São aquilo que Dworkin chama de "implicações políticas" desta dimensão da autenticidade que mais me interessam nesta pesquisa, ou seja, as limitações que impõe à atuação do Estado ${ }^{461}$ : a sua atuação em nome da justiça não tem o mesmo efeito sobre a autenticidade na sua dimensão de independência ética que a sua atuação por razões éticas, o que reflete a distinção entre "limitação e "usurpação" e a preocupação com a natureza, e não somente o fato da restrição às opções disponíveis ao indivíduo ${ }^{462}$. Em outras palavras, o que se enxerga na obra de Dworkin é uma concepção de bem expressa, entre outros, pela ideia de vida autêntica como vida independente, a partir da qual Dworkin justifica um direito político à independência ética.

\footnotetext{
${ }^{456}$ Esses são exemplos de "circumstances" dados por Dworkin: veja Justice for Hedgehogs, op. cit., p. 212

${ }^{457}$ Veja discussão de Maria Beatriz Inkis em O Exercício da Cidadania segundo as Teorias Política e Jurídica Propostas por Ronald Dworkin, op. cit. (a partir de Is Democracy Possible Here?), em especial o seguinte trecho: "Como explica Dworkin, a liberty não é prejudicada quando o governo restringe a freedom, se houver uma 'razão distributiva' plausível para tanto.

"Essa 'razão distributiva' baseia-se na justa alocação de recursos e oportunidade à disposição da comunidade como um todo. Deste modo, seguinto o exemplo de Dworkin, a tributação injusta compromete a liberdade (liberty), a justa, não", p. 26, nota omitida, itálicos no original (veja em geral pp. 26-7).

458 Justice for Hedgehogs, op. cit., p. 212.

459 Justiça para ouriços, op. cit., p. 219; para o original, Justice for Hedgehogs, op. cit., p. 212, traduzi. No original: "Authenticity demands that, so far as decisions are to be made about the best use to which a person's life should be put, these must be made by the person whose life it is". Veja também "Introduction: Does Equality Matter?", op. cit., p. 6.

${ }^{460}$ Justiça para ouriços, op. cit., p. 220; para o original, Justice for Hedgehogs, op. cit., p. 212.

461 Justice for Hedgehogs, op. cit., p. 212 - o autor remete ao cap. 17 de seu livro para elaboração dessas "implicações políticas".

${ }^{462}$ Justice for Hedgehogs, op. cit., p. 212. Veja ainda “Do Liberty and Equality Conflict?”, op. cit., pp. 50-1.
} 
Isso significa que nem toda intervenção do estado na vida do cidadão deve ser rechaçada. Ações de grande impacto no tipo de vida que as pessoas podem ter mas que não impedem os indivíduos de tomarem decisões cruciais para as suas vidas nem se amparam em razões éticas não violam a independência ética porque não "visam [a] usurpar a minha responsabilidade de identificar uma vida de sucesso" ${ }^{\text {463 }}$. O ponto que eu gostaria de destacar é que é a própria ética, no caso, a concepção de bem dworkiniana, formulada em termos de dignidade, sobretudo no segundo princípio acima descrito, que, em muitos casos, proíbe o estado de recorrer a concepções de bem ao restringir liberdades. Em outras palavras, "O segundo princípio da dignidade torna especial a ética, limita o alcance [range] aceitável da decisão coletiva" ${ }^{464}$. Se o liberalismo de Dworkin impede o Estado de recorrer a concepções de bem ao restringir determinada liberdade, é porque esse impedimento é ele próprio fundado em uma concepção de bem, que é aquela segundo a qual uma vida bem vivida tem autenticidade. Esta e outras consequências políticas da ética do autor são objeto da próxima seção.

A ideia de que "todos temos uma responsabilidade ética soberana de fazer das nossas vidas algo de válido [of value ]"465 resume a concepção de ética enquanto dignidade defendida por Dworkin ao reconhecer o valor objetivo da vida e a atribuição ao indivíduo que a vive a responsabilidade de conduzi-la. Existe ainda outra terminologia empregada pelo autor que vale a pena ser, ainda que brevemente, mencionada: por vezes, em vez de apresentar os dois princípios éticos como princípios de dignidade, Dworkin os concebe como princípios do que

\footnotetext{
463 Justiça para ouriços, op. cit., p. 378 (acrescentei a palavra entre colchetes; para o original, Justice for Hedgehogs, op. cit., p. 369. E ainda: "When government forbids conspiring with confederates in crime, it does not constrain a foundational right. Nor does it act to vindicate some collective judgment of worthy behavior or to impose some uniform orthodoxy in ethics. It acts to improve safety; its motives, like its motives in taxation or economic regulation, are moral, not ethical." (p. 374).

${ }^{464}$ Justiça para ouriços, op. cit., p. 378, acrescentei a palavra do original entre colchetes; para o original, Justice for Hedgehogs, op. cit., p. 371 (veja o mesmo trecho citado em Guest, Ronald Dworkin, op. cit., p. 176). O autor continua: "We cannot escape influence o four ethical environment: we are subject to the examples, exhortations, and celebrations of other people's ideas about how to live. But we must insist that the environment be created under the aegis of ethical independence: that it be created organically by the decisions of millions of people with the freedom to make their own choices, not through political majorities imposing their decisions on everyone", p. 371, nota omitida. Veja a conclusão desta dissertação e também "Foundations of Liberal Equality", op. cit., pp. 297-305, esp. pp. 300-5, e breve discussão na próxima seção.

${ }^{465}$ Justiça para ouriços, op. cit., p. 25, acrescentei entre colchetes palavra do original; no original, Justice for Hedgehogs, op. cit., p. 13 ("we each have a sovereign ethical responsibility to make something of value of our own lives").
} 
chama de "individualismo ético". ${ }^{466}$ Num dos artigos em que apresenta esta versão de ética, Dworkin remete o leitor a "Foundations of Liberal Equality", dizendo que neste artigo havia elaborado o individualismo ético "o qual, porém, não é chamado por esse nome no texto em questão". ${ }^{467}$ Como visto, neste trabalho Dworkin desenvolve e defende o que chama de "modelo do desafio". Apesar das modificações de terminologia, e não somente pelas autoreferências, acredito que a concepção de ética de Dworkin, salvo detalhes que, se relevantes, apontarei oportunamente, é bem representada por qualquer uma das nomenclaturas acima elaboradas. Nas próximas seções deste capítulo, procuro apontar e elaborar algumas das consequências desta concepção às liberdades, em especial à liberdade de expressão.

\section{Seção 3. A ética e suas consequências à liberdade}

O objeto desta seção é a análise de algumas das consequências da ética de Dworkin à sua teoria política de acordo como uso que o autor faz de seu modelo liberal para solucionar alguns problemas. Na primeira subseção, apresento a visão do autor sobre a natureza constitutiva do endosso do indivíduo às escolhas de sua vida e as importantes consequências desta posição à adequação de medidas políticas intrusivas. Discuto ainda a opinião de Dworkin de que a justiça é um parâmetro normativo do valor da vida, bem como a relevância desta ideia ao argumento oferecido pelo autor de que, sendo as liberdades fundadas na justiça, sua violação prejudica a vida dos violadores ou de quem se beneficia do ambiente produzido pela violação. Em cada uma destas subseções, procuro conectar estes temas à liberdade de expressão, especialmente seus aspectos mais polêmicos, como o discurso de ódio.

A conexão é importante porque a ideia dworkiniana - apresentada no primeiro capítulo - de que as liberdades se integram à boa vida e a ela contribuem parece implicar, caso se defenda que o discurso de ódio faz parte da liberdade de expressão, que fazer afirmações racistas contribui à qualidade da vida de seu emissor. Ainda, outra questão merece

\footnotetext{
${ }^{466}$ Veja Yowell, "A Critical Examination of Dworkin's Theory of Rights", op. cit., p. 127, n. 236. Veja, de Dworkin "Why Academic Freedom?" op. cit., esp. pp. 250 e ss., "Do Liberty and Equality Conflict?" op. cit., esp. pp. 42-44 e "Introduction: Does Equality Matter?" in Sovereign Virtue, op. cit., esp. pp. 5. Existe breve modificação da nomenclatura na designação do segundo princípio: como visto, em Justice for Hedgehogs Dworkin o denomina "autenticidade", mas em outros pontos o chama, por exemplo, de "principle of special responsibility" ("Do Liberty and Equality Conflict?", op. cit., p. 43 e "Introduction: Does Equality Matter?", op. cit., p. 6).

467 "Por que a liberdade acadêmica?", op. cit., p. 400, n. 86; para o original, "Why Academic Freedom?" in Freedom's Law, op. cit., p. 380, n. 3 à p. 250: "For a description of ethical individualism (though not under that name) see my Foundations of Liberal Equality (University of Utah Press, 1990)".
} 
enfrentamento: a busca da proibição deste tipo de discurso pode parecer um imperativo ético dadas suas consequências ofensivas às suas vítimas. A solução de Dworkin aos problemas éticos que enfrenta oferece resposta complexa à primeira questão e aponta para bons motivos para repensar a conclusão da segunda. Estes são temas relevantes, pois esclarecem o sentido em que Dworkin integra justiça e ética, especialmente liberdades, entre elas a liberdade de expressão, e a sua concepção de bem.

Por fim, na segunda subseção, exploro o esforço do autor de mostrar as consequências igualitárias da sua visão de boa vida à política. Que o seu modelo de ética é igualitário é importante a esta pesquisa porque aspectos da ética de Dworkin bem como a sua interpretação do valor da igualdade figuram nos argumentos formulados pelo autor em defesa da liberdade de expressão. Estes argumentos serão expostos no próximo capítulo, e, portanto, agora é hora de expor tais antecedentes, em especial a conexão pretendida pelo autor entre a sua ética e a política igualitária por ele defendida.

\section{Subseção 3.1. As liberdades e a boa vida II}

Apresentei no capítulo anterior a visão dworkiniana sobre o valor das liberdades: ao contrário da arte, elas não gozam de valor intrínseco pois o que têm de bom é decorrente da sua integração à vida de seus titulares. Vimos neste capítulo que a concepção de ética do autor, apresentada seja em termos do modelo do desafio ou dos dois princípios éticos de dignidade do respeito próprio e da autenticidade, se caracteriza como um modelo filosófico e abstrato do valor da vida que tem consequências à política. Alguns aspectos desta tese merecem pormenorização num trabalho sobre a liberdade de expressão em Dworkin. É que o autor é conhecido pela defesa da inclusão de discursos de conteúdo de aceitabilidade questionável, ao menos no contexto político de diversas democracias contemporâneas, inclusive a brasileira. Em especial, Dworkin defende o direito à expressão de ódio e, também, de consumo e publicação de pornografia. As justificações destas inclusões serão estudadas no próximo capítulo.

Desde já, entretanto, pode-se perguntar o seguinte: dadas estas opiniões sobre o valor das liberdades e o conteúdo da liberdade de expressão, o exercício da liberdade de expressão na forma de manifestações racistas, misóginas ou de qualquer modo dotadas de conteúdo discriminatório contribuem à qualidade da vida de seus emissores? A integração das liberdades 
à boa vida também permite que se levante outra questão: quais as consequências das restrições às liberdades não àqueles que as sofrem especificamente, isto é, que têm proibidas condutas que exerceriam, mas a terceiros que não sofren restrições a condutas que gostariam de praticar? Existe diferença, para efeitos da questão sob análise, entre o valor da vida deste indivíduo e o valor da vida de um racista? Por fim, quais as consequências destas restrições à qualidade da vida dos que desejam o fim dessas manifestações, isto é, àqueles que gostariam de viver em ambiente desprovido de manifestações preconceituosas e que efetivamente vivem neste tipo de ambiente, se ele é produto de proibições ao exercício da liberdade de expressão?

Em outras palavras, nesta subseção procuro explorar as respostas de Dworkin às perguntas sobre a relação entre as liberdades e qualidade da vida de diferentes sujeitos. Entre eles, aqueles que exercem a liberdade de expressão na sua forma extrema que Dworkin vê incluída nas liberdades a serem defendidas; não se trata somente daqueles que têm ideias preconceituosas, mas daqueles que efetivamente as expressam. Para resumir e feita a advertência, os chamarei de preconceituosos manifestos. Procuro também elaborar a relação disponível na obra de Dworkin entre as liberdades e a qualidade da vida de terceiros, isto é, aqueles cujas condutas não sofrem restrições de instituições ofensivas à liberdade de expressão. Entre estes terceiros estão, por exemplo, os liberais, notadamente os dworkinianos: que não manifestam nem têm opiniões racistas (são incompatíveis com a igualdade em geral e com a igualdade de recursos em especial). Há por fim aqueles que gozam efetivamente da institucionalização de proibições à liberdade de expressão porque o ambiente assim resultante favorece as suas escolhas éticas: são os beneficiados. A análise destas questões me leva a texto discutido na seção anterior.

Dworkin discute em "Foundations of Liberal Equality" o "puzzle" a respeito da natureza do endosso do indivíduo em relação aos aspectos de sua vida ${ }^{468}$. A questão consiste em saber se o valor de "vivências, relacionamentos, fatos ou realizações"469 que consideramos valiosos no sentido crítico é dependente do reconhecimento por parte do indivíduo que vive a vida, ou se esse reconhecimento acrescenta ao valor destes aspectos, mas não os condiciona ${ }^{470}$.

\footnotetext{
468 "Foundations of Liberal Equality", op. cit., pp. 237-8, 262-73. Para este e outros "puzzles", veja Mulhal e Swift, Liberals and Communitarians, op. cit., 285-88.

469 "A igualdade e a vida boa", op. cit., p. 347; no original, "Equality and the Good Life", op. cit., p. 248. Em "Foundations of Liberal Equality", op. cit., veja p. 237.

470 "Foundations of Liberal Equality", op. cit., pp. 237 e ss.
} 
Dworkin delineia duas opções: o endosso é aditivo ao ou constitutivo do valor da vida do indivíduo $^{471}$. Para a primeira visão, "podemos julgar a vida dele boa ou ruim sem consultar as opiniões dele a respeito do valor de sua vida"472, para a segunda, “(...) nenhum componente contribuirá para o valor da vida da pessoa sem o endosso dela (...) A perspectiva constitutiva nega apenas que algum evento possa tornar melhor a vida de uma pessoa contra sua própria opinião contrária"473.

O tema é um "enigma" ético porque nossas convicções apontam para soluções distintas: se parece equivocado submeter o valor crítico da vida a um ato subjetivo de endosso, também parece sem sentido enxergar valor numa vida forçada ${ }^{474}$. Dworkin atribui ao modelo ético do impacto opção pela visão aditiva, pois para este modelo "o valor ético é uma questão do valor objetivo que uma vida acrescenta ao universo" ${ }^{475}$. Para o modelo do impacto, o máximo que pode ocorrer é o endosso do indivíduo agregar ao valor de sua vida, o que significa que o valor não depende deste endosso ${ }^{476}$. O exemplo apresentado pelo autor é da vida de Hitler: ela teria sido muito melhor se ele tivesse sido trancafiado ou morto jovem em vez de mantido livre e vivo para praticar o mal que praticou, ou seja, é possível julgar a qualidade de sua vida independentemente do desejo ou das opiniões de quem a vive $e^{477}$.

O modelo do desafio, preferido por Dworkin e adotado pelos liberais éticos, opta pela visão constitutiva do endosso em relação ao valor da vida porque, como visto, para este modelo o valor ético é adverbial, ligado à performance representada pela própria vida, e a esta

\footnotetext{
471 "Foundations of Liberal Equality", op. cit., pp. 237 e ss. Veja "A igualdade e a vida boa", op. cit., pp. 373 e ss. para tradução como "comulativo" (additive) e "constitutivo" (constitutive). Veja Mulhal e Swift, Liberals and Communitarians, op. cit., pp. 288 e ss., 299-300 e Macleod, Liberalism, Justice, and Markets, op. cit., pp. 205-7.

472 "A igualdade e a vida boa", op. cit., p. 347; no original, "Equality and the Good Life", op. cit., p. 248. Em "Foundations of Liberal Equality", op. cit., veja p. 237.

473 "A igualdade e a vida boa", op. cit., p. 347; no original, "Equality and the Good Life", op. cit., pp. 248-9. Em "Foundations of Liberal Equality", op. cit., veja p. 237; veja ainda pp. 265, 272, 303, 304 e 305. O "only" do trecho ("apensar", na tradução) fica por conta de Dworkin, neste parágrafo, negar que a visão constitutiva seja equivalente à "skeptical view that someone's life is good or bad in the critical sense only when and because he thinks it good or bad", p. 237. O ponto é que a visão constitutiva nega que a vida do indivíduo possa ser aprimorada sem o seu endosso, o que não impede que o indivíduo esteja equivocado sobre um aspecto de sua vida ser valioso ou desprovido de valor (p. 237).

474 "Foundations of Liberal Equality", op. cit., pp. 238, 262-3.

475 "Foundations of Liberal Equality", op. cit., p. 263, traduzi; Dworkin imagina "bizarre views" que justificaria opção do modelo do impacto pela visão constitutiva - que o valor objetivo da vida depende de agradar a Deus, que só se agrada se a vida é endossada. Mas justamente por serem bizarras, o autor as rejeita.

476 "Foundations of Liberal Equality", op. cit., p. 263.

477 "Foundations of Liberal Equality", op. cit., p. 263.
} 
ideia é essencial a intenção do sujeito de praticá-la ${ }^{478}$. O autor diz, a respeito do modelo do desafio:

"Mesmo em sua forma mais abstrata o modelo pressiona na direção da perspectiva constitutiva, pois a intenção faz parte da ação: não damos crédito ao agente [performer] por alguma característica de sua performance que ele se esforçava para evitar, ou que não reconheceria, mesmo em retrospectiva, como boa ou desejável»"479.

O exemplo aqui é o do misantropo, cuja opinião sobre amizades impede que elas aprimorem a sua vida ${ }^{480}$. Quanto ao exemplo de Hitler, que apoia as convicções aditivas, Dworkin afirma que para outros o assassinato precoce de Hitler teria sido nitidamente melhor, mas isso não pode ser dito, segundo o modelo do desafio, sobre "a sua própria vida"481.

Neste ponto, Dworkin assume a distinção entre ética de primeira pessoa e ética de terceira pessoa, central a "Foundations of Liberal Equality" 482 mas de aceitabilidade duvidosa em Justice for Hedgehogs ${ }^{483}$. Outro ponto que merece atenção, mas somente de passagem, são as consequências da visão constitutiva à viabilidade do que Dworkin chama de "paternalismo crítico coercivo" ${ }^{484}$, que diz respeito à seguinte questão: é "apropriado o Estado tentar melhorar a vida das pessoas obrigando-as a agir de maneira que elas achem que vai piorar suas vidas?" ${ }^{485}$. O modelo do desafio não rejeita todo tipo de paternalismo, pois enxerga a possibilidade de certas formas serem posteriormente endossadas, ainda que no momento de

\footnotetext{
478 "Foundations of Liberal Equality", op. cit., p. 264.

479 "A igualdade e a vida boa”, op. cit., p. 374, acrescentei a palavra em inglês entre colchetes, que é do original, alterei a tradução para substituir "se esforçasse por evitar, nem reconheceríamos" por "se esforçava para evitar, ou que não reconheceria" para traduzir "he was struggling to avoid, or would not recognize" (também substituí "desempenho" por "performance" para traduzir "performance"; para o original, "Equality and the Good Life", $o p$. cit., p. 268; em "Foundations of Liberal Equality", op. cit., veja p. 264.

480 "Foundations of Liberal Equality", op. cit., p. 264. Veja Guest, Ronald Dworkin, op. cit, p. 221.

481 "Foundations of Liberal Equality", op. cit., p. 264, traduzi expressão retirada do seguinte trecho: "Ou course it would have been better for everyone else if Hitler had died in the cradle. But on the challenge view it makes no sense to say that his own life would have been better, as distinct from no worse, if that had happened. There is nothing comparable under that model to a negative impact on the world", p. 264 (veja ainda pp. 266-7). Veja a tradução: "A igualdade e a vida boa", op. cit., p. 374 ("a vida dele") e "Equality and the Good Life", op. cit., p. 268. Veja as críticas de Wolfe a Dworkin em Natural Law Liberalism, op. cit., cap. 4, esp. p. 69. George parece supor que, para Dworkin, o endosso da vida por parte daquele que a vive é questão de satisfação: Making Men Moral, op. cit., pp. 105-6. Não é boa interpretação do argumento de Dworkin, que apresenta a convicção que associa endosso a satisfação, mas a rejeita: veja "Foundations of Liberal Equality", op. cit., pp. 262-3.

482 "Foundations of Liberal Equality", op. cit., veja pp. 199- 203

${ }^{483}$ Justice for Hedgehogs, op. cit., pp. 255, 260-4.

484 "A igualdade e a vida boa", op. cit., p. 374; no original, "Equality and the Good Life", op. cit., p. 268; para "Foundations of Liberal Equality", op. cit., ver p. 264 (veja em geral pp. 264 e ss.).

485 "A igualdade e a vida boa", op. cit., p. 374; no original, "Equality and the Good Life", op. cit., p. 268; para "Foundations of Liberal Equality", op. cit., ver p. 264.
} 
sua prática serem contrárias às "convicções" ponto do paternalismo ético" $" 488$ porque, ao adotar a visão constitutiva, rejeita a tese de que a vida do indivíduo afetado pelo paternalismo seja aprimorada pela medida ${ }^{489}$. O exemplo do tipo de paternalismo que Dworkin chama de "paternalismo cirúrgico"490 é aquele voltado contra homossexualidade: a abstinência sexual imposta pelo paternalismo não aprimora a vida do homossexual mesmo que se entenda (ou se entendesse) que a prática de relações sexuais homossexuais piora a vida de seus praticantes pois a ação imposta é desprovida da intencionalidade essencial à caracterização do ato valioso enquanto performance, isto é, “(...) no modelo do desafio é a performance que conta, e não o mero resultado externo, e é preciso ter a motivação certa para a performance" ${ }^{\wedge 91}$. Por óbvio isto não significa que o modelo do desafio implique a aceitação de uma teoria minuciosa sobre o valor de determinadas práticas sexuais $^{492}$; significa somente que, independentemente das opiniões guardadas pelos aderentes ao modelo do desafio - que, relembremos, é abstrato, e não intervém em todas as questões éticas - o valor depende de endosso, que é inexistente em prática coagida. Acredite o aderente

\footnotetext{
486 "Foundations of Liberal Equality", op. cit., p. 264.

487 "Foundations of Liberal Equality", op. cit., p. 265 (veja ainda p. 273); "It overstates the point to say that the challenge model rules any form of paternalism, however, because the defect it finds in paternalism can be cured by endorsement if the paternalism is sufficiently short-term and limited that it does not significantly constrict choices if the endorsement never comes", p. 265; o exemplo é da criança obrigada a estudar música. Crítica minuciosa, e que mereceria abordagem em separado, é dirigida por George e por Wolfe a Dworkin: veja, de George, Making Men Moral, op. cit., pp. 106 e ss. George cita Christopher Wolfe, 'Dworkin on Liberalism and Paternalism' artigo que, como relata, foi apresentado em um encontro nos EUA em 1991("1991 Annual Meeting of the American Public Philosophy Institute": veja George, Making Men Moral, op. cit., p. 107, nota 64). George informa que o artigo ainda não havia sido publicado. Acredito que seja o capítulo 4 de Christopher Wolfe, Natural Law Liberalism. op. cit..

488 "Foundations of Liberal Equality", op. cit., p. 265, itálico no original, traduzi. Para "Igualdade e a vida boa", op. cit., veja p. 375 ("entenderiam o paternalismo ético"); para o original, "Equality and the Good Life", op. cit., p. 269.

489 "Foundations of Liberal Equality", op. cit., p. 265. Como diz Yowell, “(...) one of Dworkin's key contentions in this chapter [i.e., cap. 6 de Sovereign Virtue] is that a person's life can be truly improved ony when he is living in accordance with his genuine convictions. This argument seeks to show that certain types of paternalism are self-defeating", "A Critical Examination of Dworkin's Theory of Rights", p. 136, itálicos no original, notas omitidas.

490 "A igualdade e a vid boa", op. cit., p. 376, itálico no original; no original, "Equality and the Good Life", op. cit., p. 269. Para "Foundations of Liberal Equality", op. cit., veja p. 266; para este tipo de paternalismo, "coercion is justified on the ground that the behavior implanted is good or the behavior excised is bad for people", p. 266.

491 "A igualdade e a vid boa", op. cit., p. 376, modifiquei a tradução para substituir "desempenho" e "ação" por "performance" para traduzir "performance"; no original, "Equality and the Good Life", op. cit., p. 269. Para "Foundations of Liberal Equality", op. cit., p. 265.

492 "Foundations of Liberal Equality", op. cit., 297-305, esp. pp. 297- 302 para discussão sobre a variedade de visões sobre ética que liberais éticos podem adotar.
} 
ou não que a prática sexual homossexual piora a vida de seus praticantes, ele acredita que a imposição de abstinência é incapaz de corrigi-la ou aprimorá-la.

Outro exemplo dado por Dworkin, desta vez de "paternalismo de substituição"493 diz respeito ao "ranking" 494 do valor das possíveis vidas de um indivíduo: se adota uma vida religiosa monástica endossada, uma vida política endossada ou uma vida política não endossada $^{495}$. Dworkin imagina uma sociedade que proíba a vida monástica em razão da opinião segundo a qual joga sua vida fora quem opta por ela, e imagina um indivíduo que, vivendo nesta sociedade e desejando a vida proibida, torna-se um político ${ }^{496}$. O ponto é o seguinte. Este indivíduo não é responsável pela adoção da vida de político, mas é responsável pelos atos valiosos praticados nesta vida, o que gera a pergunta: esta é uma vida melhor do que a vida religiosa monástica que ele teria vivido ausente a proibição ${ }^{497}$

Dworkin apresenta a noção de "prioridade da integridade ética"498 para resolver a questão:

"Se aceitarmos o modelo do desafio, podemos insistir na prioridade da integridade ética em quaisquer de nossos juízos sobre a bondade da vida de alguém. A pessoa alcançou a integridade ética, pode-se dizer, quando vive com a convicção de que sua vida, em suas características principais, é apropriada, que nenhuma outra vida que poderia viver seria uma reação [response] nitidamente melhor aos parâmetros dessa situação ética corretamente julgada. A prioridade da integridade faz uma declaração mais forte do que simplesmente afirmar que a decepção [disappointment] e a lástima [regret] destroem [mar] a life, que essas são características de uma vida que pro tanto torna pior. Se isso fosse tudo, então esses componentes negativos poderiam ser facilmente superados pelas características positivas da vida substituta. Estaríamos à vontade para dizer que, muito embora o político tivesse preferido muito mais a vida em ordens religiosas, sua carreira estava, contudo, em media [on balance], mesmo considerando seus próprios sentimentos, uma vida melhor do que a vida desperdiçada que teria tido.Se dermos prioridade à integridade ética, transformamos a fusão [merger] de vida e convicção em parâmetro de êxito ético, e estipulamos que a vida que jamais atinge tal tipo de integridade não pode ser criticamente melhor para alguém do que a vida que já leva". ${ }^{999}$

\footnotetext{
493 "A igualdade e a vid boa", op. cit., p. 376, itálicos no original; no original, "Equality and the Good Life", op. cit., p. 269. Para "Foundations of Liberal Equality", op. cit., veja p. 266; este tipo de paternalismo "justified a prohibition not by pointing to the badness of what it prohibits but to the positive value of the substitute lives it makes available", p. 266.

494 "Foundations of Liberal Equality", op. cit., p. 269.

495 "Foundations of Liberal Equality", op. cit., p. 266 e ss., em especial pp. 268-9. Veja Mulhal e Swift, Liberals and Communitarians, op. cit., pp. 289-90.

496 "Foundations of Liberal Equality", op. cit., p. 266.

497 "Foundations of Liberal Equality", op. cit., p. 266-7.

498 "A igualdade e a vida boa", op. cit., p. 378, por ex..

499 "A igualdade a a vida boa", op. cit., pp. 378-9, tálicos no original, inseri entre colchetes as palavras do original, e alterei a tradução para substituir "equilibrada" por "em media" para traduzir "on balance" e para substituir "essencialmente" por "criticamente" para traduzir "critically"; para o original, veja "Equality and the Good Life", op. cit., p. 270; para "Foundations of Liberal Equality", op. cit., veja p. 267. Veja, e trecho citado em Mulhall e Swift, Liberals and Communitarians, op. cit., p. 289.
} 
Em outras palavras, Dworkin sustenta que o modelo do desafio adota a prioridade da integridade ética, que exige que se valorize o julgamento do indivíduo sobre a pertinência das suas escolhas de modo que mesmo aqueles que julguem a vida monástica inferior à política saibam identificar que, uma vez tendo o indivíduo escolhido a primeira, este rumo é eticamente melhor que o segundo, ainda que nem tudo na vida de político seja imposto. ${ }^{500} \mathrm{~A}$ melhor vida possível ao indivíduo é, na hipótese, a vida política íntegra, mas ausente o endosso necessário à integridade ética, a melhor vida é a vida religiosa íntegra, e não a vida política não-endossada ${ }^{501}$. Dworkin aqui insiste no tratamento dado à integridade ética do ponto de vista de terceira pessoa: as convicções do indivíduo devem ser tratadas "simplesmente como fatos" 502 , ou seja, "dadas suas convicções inabaláveis, é a única vida que ele pode levar em paz consigo mesmo, e é, portanto, o melhor que ele pode fazer para resolver o desafio de sua situação, agora contendo esse fato". 503

Apresentada esta solução da ética dworkiniana ao problema da natureza do endosso ao valor da vida, é possível apreciar as consequências destas ideias, sobretudo da prioridade da integridade ética em terceira pessoa, à questão das consequências das liberdades, em especial da liberdade de expressão, à vida daqueles que exercem seus direitos de modo que não é certo (veja "Taking Rights Seriously"). Assumamos que este é o caso dos preconceituosos manifestos mencionados acima, isto é, daqueles que utilizam a liberdade de expressão para manifestar opiniões racistas, homofóbicas, misóginas etc. Imaginemos ainda que a vida sem estas condutas seja melhor do que a vida com elas. Quais as consequências, ao valor da vida dos indivíduos que as praticam, da proibição de manifestações deste tipo?

A meu ver, a este caso deve ser aplicada a mesma solução dada por Dworkin aos exemplos das proibições de práticas sexuais homossexuais e da vida monástica. A proibição do discurso de ódio preconceituoso não melhora a vida de seus emissores, pois a natureza imposta da abstenção da prática do discurso preconceituoso a priva de aprimorar a vida. É que a abstenção coagida não caracteriza performance que tenha origem em ato do próprio

\footnotetext{
500 "Foundations of Liberal Equality", op. cit., p. 269.

501 "Foundations of Liberal Equality", op. cit., p. 269.

502 "Foundations of Liberal Equality", op. cit., p. 268, traduzi.

503 "A igualdade e a vida boa", op. cit., p. 379; para o original, "Equality and the Good Life", op. cit., p. 272; para "Foundations of Liberal Equality", op. cit., veja p. 269. Dworkin também elabora a relevância da prioridade da integridade ética para a ética em primeira pessoa, isto é, do ponto de vista do sujeito cuja visa está em análise: veja p. 268.
} 
indivíduo. Impedi-lo de exercer liberdade não aprimora a sua vida porque se dá contra a sua convicção sobre o que é uma vida melhor.

Algunas observações são importantes. Em primeiro lugar, Dworkin, ao analisar o problema da natureza do endosso, enfrenta argumentos paternalistas, isto é, argumentos que pretendem restringir ou proibir condutas em benefício do próprio indivíduo ${ }^{504}$. Não estão em análise aspectos das condutas mencionadas que eventualmente violem direitos de terceiros ou diminuam o valor da vida que levam. Não é pertinente discutir neste momento eventuais direitos de negros, mulheres e homossexuais, tampouco eventual dificuldade que tenham em viver suas vidas em razão da ocorrência de manifestações preconceituosas porque, na obra de Dworkin, estas questões não são distintas das questões envolvidas na fixação dos limites da liberdade de expressão, tarefa para o próximo capítulo. Em outras palavras, esta questão, que não enfrento agora, não é distinta de uma das questões de justiça subjacentes à própria dissertação: há direito ao discurso de ódio? Há direito contra o discurso de ódio? Apesar disso, não deixa de ser relevante observar que restrições, por exemplo, ao discurso de ódio, não aprimoram a vida dos preconceituosos manifestos.

Em segundo lugar, a comparação entre manifestações racistas e práticas sexuais homossexuais poderá parecer impertinente a quem reprove as primeiras e nada tenha a censurar às segundas. De minha parte, compartilho estas visões. A questão, entretanto, é que este não é o ponto: o modelo do desafio é abstrato, não inclui nem proíbe estas opiniões, e a discussão sobre a natureza do endosso diz respeito à atitude necessária inclusive (e, portanto, não só) a quem desaprove as condutas exemplificadas. $O$ argumento aqui é hipotético, e o ponto é justamente que as eventuais verdades morais sobre sexo e igualdade (envolvidas no julgamento sobre a vida sexual homossexual e a expressão de racismo serem condutas certas) não são relevantes a partir da terceira pessoa, que é a analisada por Dworkin ao discutir as consequências do modelo ético do desafio ao paternalismo. Levantá-las, portanto, seria profunda incompreensão do objetivo do autor e do argumento que pretendo extrair de sua obra para aplicar a certos casos de exercício de liberdade de expressão.

Em terceiro lugar, as reflexões feitas até aqui não excluem a ideia de que o racismo e o sexismo contribuam à piora da vida. O ponto, entretanto, é que esta piora pode ser inevitável

\footnotetext{
${ }^{504} \mathrm{O}$ autor distingue estes argumentos daqueles "distributivos", analisados em outro texto: veja "The Place of Liberty”, op. cit., pp. 120-1. Mencionei a distinção feita por Dworkin no primeiro capítulo.
} 
ou, pelo menos, impossível de ser solucionada pelos mecanismos coercitivos de uma prática paternalista, capazes de piorar ainda mais a vida do preconceituoso manifesto (no exemplo de Dworkin, se é verdade que a vida política íntegra é superior à vida monástica íntegra, é verdade que esta é superior à vida política forçada).

Por outro lado, a insistência na capacidade que preconceitos têm de piorar a vida do indivíduo que os manifesta talvez assuma interpretação equivocada da titularidade de um direito. Ter direito à liberdade de expressão no sentido forte defendido por Dworkin significa poder exercer os atos de expressão desta forma protegidos, mas disso não decorre que devam ser ou que sejam necessariamente exercidos. A integração dworkiniana das liberdades à boa vida reside, antes de tudo, na etapa de titularidade de um direito. A afirmação de Dworkin de que a autenticidade exige a liberdade de expressão que inclua, por exemplo, a expressão de discurso de ódio ${ }^{505}$ não significa que a vida autêntica seja necessariamente a vida de expressão racista, mas que a vida autêntica é a vida de titularidade do direito de expressão racista. Não é a pornografia que contribui à boa vida, mas o direito de possui-la e de distribui-la. $\mathrm{O}$ direito a uma conduta e o exercício desta conduta são coisas diferentes, e nada na defesa do primeiro exige ou compromete o defensor com a defesa do segundo, embora a titularidade de um direito obviamente signifique que o sujeito não pode ser turbado no seu exercício, o que é diferente de dizer que deve ou que é certo exercê-10 ${ }^{506}$.

Com isso não quero dizer que no pensamento de Dworkin a autenticidade, a prioridade da integridade ética e a integração entre liberdades e boa vida nada tenham a ver com o exercício de liberdades. A depender das convicções do indivíduo, manifestações racistas podem ser atos de integridade e de autenticidade. Há um sentido em que manifestações racistas são perfeitamente autênticas. Mas se este é o caso é um assunto que cabe ao indivíduo. A proibição das manifestações preconceituosas simplesmente piora ainda mais a vida do indivíduo porque lhe priva de possível integridade ética. Isso não contradiz a ideia de que estas manifestações pioram a vida do indivíduo, mas condiciona a compreensão desta afirmação ao entendimento de que pior ainda é proibi-las, e que, como cabe ao indivíduo endossar os aspectos de sua vida, a única forma de correção aceitável é aquela que parte dele mesmo ${ }^{507}$.

\footnotetext{
${ }^{505}$ Veja próxima seção e, por exemplo, Justice for Hedgehogs, op. cit., cap 17.

${ }^{506}$ Veja discussão no capítulo primeiro.

507 "Foundations of Liberal Equality", op. cit., p. 303.
} 
Esta última observação permite responder a pergunta sobre a relação entre restrições às liberdades e a qualidade da vida de terceiros, isto é, de indivíduos cujas convicções não exigem manifestações preconceituosas, que não promovem as suas proibições. Imaginei acima um "liberal dworkiniano" nestas condições, isto é, alguém que adote a igualdade de recursos como teoria da justiça. Que a integração entre liberdades e boa vida opera em primeiro lugar, mas não só, na titularidade de direitos significa que estes liberais sofrem com proibições ainda que estas não afetem condutas que eles queiram praticar, e, na verdade, cuja prática seria uma violação da integridade ética, como a manifestação discurso de ódio (a integridade ética exige do igualitário que não manifeste discurso racista, por exemplo). No caso da liberdade de expressão, existe um “insulto" particular na proibição de acesso a ideias, bem como na sua publicação, que independente do efetivo exercício das liberdades de consumo e de expressão. ${ }^{508}$

Em outras palavras, mesmo aqueles que não pretendem e não devem praticar determinada conduta sofrem com a restrição a práticas a que tem direito. O ponto é que ter direito a uma liberdade independe de sofrer restrição que faça a diferença, isto é, ter exercício efetivamente turbado por proibição. Isso não significa que o preconceituoso manifesto, que sofre esta restrição prática, tenha sua vida piorada menos ou em igual medida que a do terceiro; significa apenas que violar a liberdade de expressão é "insulto" tanto aos que a exercem quanto a quem não a exerce. Lembremo-nos daquilo que as liberdades, para Dworkin, não são: não podem ser alienadas e não dependem de interesses concretos dos indivíduos, pois são constitutivas de suas vidas, da igualdade e da democracia. Isto significa que pouco importa nosso desintesse em hipóteses específicas de exercício da liberdade de expressão (caso do liberal, que valoriza sua liberdade, mas não quer nem deve exercê-la por meio de manifestação racista), ou mesmo o eventual desinteresse mais geral em relação a qualquer liberdade (próprio de quem gostaria de vendê-las todas, algo que a igualdade de recursos não admite, pois elas são pressupostos do leilão imaginário, e não o seu objeto).

Por último, é importante discutir a integração das liberdades à ética quanto à vida daqueles que são beneficiados pelas restrições das liberdades por terem a sua vida facilitada por ambiente desprovido das opiniões que os preconceituosos manifestos gostariam de expressar. Mas por que a restrição das liberdades afetaria a qualidade da vida destes

\footnotetext{
508 “Why Must Speech be Free?”, op. cit., pp. 200-1 (veja próxima seção para citação e próximo capítulo).
} 
indivíduos? A resposta a esta pergunta se encontra, na obra de Dworkin, na solução encontrada pelo autor no modelo do desafio à questão da relação entre justiça e ética, ou, colocado o tema em outros termos, sobre o prejuízo à boa vida do gozo de recursos distintos dos justos, sejam elas superiores ou inferiores ao estabelecidos pela justiça distributiva.

Dworkin expressa a integração da justiça à ética sustentando o valor da vida é dependente da medida da justa distribuição de recursos porque a justiça é um parâmetro normativo do desafio a ser enfrentado na vida. A compreensão desta definição exige o delineamento de alguns pares de categorias. A primeira distinção pertinente é aquela que separa as circunstâncias da vida entre parâmetros e limitações ${ }^{509}$. Como visto acima, Dworkin introduz a distinção ao explorar a analogia entre arte e ética: ele entende que as especificidades das circunstâncias em que os artistas produzem suas obras caracterizam o desafio por eles enfrentado $^{510}$. Ele diz que "as suas circunstâncias afetam o que para eles é uma performance habilidosa de definir e estender e executar arte" ${ }^{, 11}$. Isso faz com que o valor artistico seja indexado a essas circunstâncias, e não transcendente do tempo e lugar em que a obra é produzida ${ }^{512}$. A ideia aplica-se analogamente à ética: “A arte e a ética, nessa perspectiva, estão indexadas da mesma maneira. Ambas requerem decisão, fazendo parte do desafio que apresentam acerca da resposta certa às circunstâncias complexas nas quais é preciso tomar tal decisão" ${ }^{513}$. Dworkin dá diversos exemplos das variadas circunstâncias da vida:

"Entre essas circunstâncias figuram nossa saúde, nossa força física, a duração de nossa vida, nossos recursos materiais, nossas amizades e associações, nossos compromissos e tradições de família, raça e nação, o sistema constitucional e jurídico no qual vivemos, as oportunidades e os padrões intelectuais, literários e filosóficos oferecidos por nossa língua e por nossa cultura, e milhares de outros aspectos de nosso mundo também.".514.

Essas circunstâncias, além de parâmetros, isto é, padrões que caracterizam o desafio a ser enfrentado, podem ser também limitações, isto é, obstáculos ao enfrentamento do desafio.

\footnotetext{
509 "Foundations of Liberal Equality", op. cit., pp. 252 e ss. Veja Mulhal e Swift, Liberals and Communitarians, op. cit., pp. 285 e ss. para exposição deste "puzzle".

510 "Foundations of Liberal Equality", op. cit., p. 252.

511 "Foundations of Liberal Equality", op. cit., p. 252, itálico no original, traduzi; o trecho continua: "An artist's situation in the history of art, and the political, technological, and social conditions of his age, enter we might say into the parameters of the challenge he faces" (p. 252, italic no original). Veja "A igualdade e a vida boa", op. cit., p. 362; no original, "Equality and the Good Life", op. cit., p. 259.

512 "Foundations of Liberal Equality", op. cit., 249 e ss. em geral, pp. 252-3 em especial.

513 "A igualdade e a vida boa", op. cit., p. 362, modifiquei a tradução para substituir "vinculadas" por "indexadas" para traduzir "indexed" e "reação" por "resposta" para traduzir "response"; no original, "Equality and the Good Life", op. cit., p. 359; para "Foundations of Liberal Equality", op. cit., ver p. 253.

514 "A igualdade e a vida boa", op. cit., p. 365; no original, "Equality and the Good Life", op. cit., p. 260; para "Foundations of Liberal Equality", op. cit., ver p. 254.
} 
Não é objetivo do modelo do desafio dizer detalhadamente quais circunstâncias são limitações ou parâmetros, pois faz parte da tarefa de viver bem discriminar as circunstâncias entre parâmetros ou limitações ${ }^{515}$. Faz parte do desafio refletir, no exemplo, se a nacionalidade do indivíduo é um parâmetro, algo que contribui à caracterização do desafio específico que ele enfrenta e que caracteriza um bom desempenho no enfrentamento deste desafio, ou uma limitação, um obstáculo que dificulta o alcance de maior valor ético ${ }^{516}$. Dworkin, num momento de reflexão mais concreta e pessoal, diz que o fato de ser norte-americano é para ele um parâmetro, e não uma limitação, pois ele "estabelece uma condição da boa vida para mim: é a vida apropriada à pessoa cuja situação inclui esta conexão". ${ }^{117}$

Ocorre que parâmetros nem sempre são como a circunstância da nacionalidade, que, se interpretada como parâmetro e não como limitação, indica que, sendo um indivíduo, por exemplo, norte-americano, a sua vida deve atender a tal fato. É que esta definição de parâmetro, exemplificado pela ideia de nacionalidade, não indica qual deve ser a circunstância, mas qual deve ser a vida dada determinada circunstância. Dworkin, por outro lado, identifica o que chama de "parâmetros normativos", que

"não definem nossa ética segundo nossa situação real, mas segundo nossa situação como presumimos
que deveria ser. Em outras palavras, nossa vida pode ir mal, não só porque não estamos dispostos ou
somos incapazes de responder às nossas circunstâncias, mas porque temos as circunstâncias
equivocadas. Nem ao menos encaramos o desafio que identificamos como o correto. Mesmo que
façamos o melhor possível nas circunstâncias que enfrentamos, erramos ao medir nosso êxito em
comparação com a oportunidade que acreditamos ser merecedores, e é esta última que define a boa vida
para nós.".

Um exemplo de parâmetro normativo dado por Dworkin é o número de anos de uma vida: um indivíduo cuja vida foi muito curta não tem a sua vida avaliada somente segundo sua resposta ao breve tempo que teve para viver, mas também segundo a ideia de que sequer

\footnotetext{
515“"Foundations of Liberal Equality", op. cit., pp. 254-5

516 "Foundations of Liberal Equality", op. cit., pp. 254-5.

517 "Foundations of Liberal Equality", op. cit., p. 255, traduzi. Mas o autor é claro ao dizer que nem tudo pode ser limitações, caso contrário não haveria indexação possível a circunstâncias, que seriam todas problemas a serem enfrentados, e não critérios a serem atendidos: na terminologia de Dworkin, o valor da vida se tornaria "transcendente", o que é incorreto porque o valor ético é indexado. (Não é o caso de discutir este ponto em detalhes, mas se trata de um "puzzle" ético, e a opção pelo valor indexado decorre, diz o autor, da opção pelo modelo do desafio, veja pp. 250 e ss.) Ainda, nem tudo podem ser parâmetros, caso contrário a indexação seria tão completa que a vida adequada seria justamente aquela vivida, o que impediria o enfrentamento da vida como um desafio. Veja "Foundations of Liberal Equality", op. cit., p. 255 (veja ainda p. 259).

518 "A igualdade e a vida boa", op. cit., pp. 365-6 (modifiquei a tradução para substituir "vida boa" por "boa vida" para traduzir "good life" e "reagir" por "responder" para trazudir "respond"); no original, "Equality and the Good Life", op. cit., pp. 261-2; para "Foundations of Liberal Equality", op. cit., ver p. 254.

"Foundations of Liberal Equality", op. cit., p. 256.
} 
enfrenta o desafio que se espera de um ser humano ${ }^{519}$. A justiça, para Dworkin, é parâmetro deste tipo: ela estabelece as circunstâncias que o indivíduo deve enfrentar, quanto dos recursos da sociedade deve ter, e, em razão disso, que um indivíduo tenha mais ou menos recursos do que aqueles definidos pela justiça é algo que prejudica o valor da sua vida ${ }^{520}$.

É importante perceber que a questão não diz respeito à quantidade de recursos per se, mas à justiça da quantidade (ou seja, mais recursos não necessariamente é algo bom ${ }^{521}$ ). Dworkin atribui ao modelo do impacto a visão de que a vida de uma pessoa pobre, que tem menos recursos do que a justiça determina, seria beneficiada por maior quantidade de recursos independentemente de mudarmos de ideia sobre esta nova fatia ser justa ${ }^{522}$. Isto é esperado no modelo do impacto, pois, quanto mais recursos distribuídos a um indivíduo, maior a capacidade que tem de gerar alterações positivas em estados objetivos do mundo de que depende o valor de sua vida ${ }^{523}$, desde que, é claro, a injustiça na distribuição não seja de sua responsabilidade, pois isso precisaria ser contabilizado no cálculo do impacto da sua vida ${ }^{524}$. Dworkin atribui ao modelo do desafio visão mais complexa sobre a relação entre qualidade da vida e justiça:

"Decerto os recursos precisam figurar como parâmetros, de alguma maneira. Não podem figurar somente como limitações, porque não podemos pensar que a melhor vida ideal é a de quem tem a seu dispor todos os recursos que se possa imaginar. Isto é, não podemos descrever o desafio de viver bem sem formular algumas hipóteses sobre os recursos de que a boa vida deve dispor. Devemos, portanto, procurar alguma opinião adequada sobre o modo como os recursos entram na ética como parâmetros da boa vida, e acho que não temos alternativa senão inserir a justiça nessa história, estipulando que a boa vida é adaptada às circunstâncias que a justiça exige."525.

O argumento fundamental de Dworkin neste ponto é rejeitar a própria cisão do mundo normativo em ética e moral ${ }^{526}$, pois pois, diz ele,

"Seria estranho declarar, como juízo moral de nossa preferência, que seja apropriado a cada pessoa tenha sua parcela justa de recursos, definidos de determinada maneira, e não pensar também, ao fazer um juízo

\footnotetext{
519 "Foundations of Liberal Equality", op. cit., p. 256.

520 "Foundations of Liberal Equality", op. cit., pp. 258 e ss.

521 "Foundations of Liberal Equality", op. cit., pp. 279-80, p. 181, n. 49 e pp. 285-291. Veja Veja Mulhall e Swift, Liberals and Communitarians, op. cit., pp. 291, 293, 298-9.

522 "Foundations of Liberal Equality", op. cit., p. 259.

523 "Foundations of Liberal Equality", op. cit., pp. 258-9.

524 "Foundations of Liberal Equality", op. cit., p. 258.

525 "A igualdade e a vida boa", op. cit., p. 369 (modifiquei a tradução para substituir "vida boa" por "boa vida" para traduzir "good life"); no original, "Equality and the Good Life", op. cit., pp. 264; para "Foundations of Liberal Equality”, op. cit., ver p. 259. Veja Guest, Ronald Dworkin, op. cit, pp. 223-4.

526 "Foundations of Liberal Equality", op. cit., p. 260.
} 
ético sobre quais circunstâncias devemos tratar como apropriadas na decisão de qual vida seria boa para nós, que as circunstâncias justas, assim definidas, sejam as apropriadas. ${ }^{, 527}$.

Lembremos que a ética, para Dworkin, diz respeito aos interesses críticos, normativos por definição tal qual a moral, que diz respeito ao modo pelo qual devemos tratar os outros ${ }^{528}$. A ideia de que seria possível estabelecer critérios "eticamente" correto distintos dos "moralmente" é o objeto fundamental da desconfiança de Dworkin ${ }^{529}$. Para ele, se temos uma noção de justiça, normativa que é, é impossível desconectá-la da empreitada, também normativa, de buscar a boa vida, de modo que afirmar o que a justiça exige significa afirmar as circunstâncias adequadas ao desafio de viver a vida, e vice-versa ${ }^{530}$.

O que temos, portanto, é uma exceção ao silêncio geral dos modelos éticos filosóficos sobre quais circunstâncias são parâmetros e quais são limitações: para o modelo do desafio, a justiça é necessariamente um parâmetro normativo da boa vida ${ }^{531}$. Isto significa que prejudica a qualidade da vida agir com injustiça ou mesmo dispor de recursos superiores ou inferiores aos distribuídos pela justiça ${ }^{532}$. Ou seja, para Dworkin, a justiça distributiva identifica quais recursos devem ser atribuídos a determinado indivíduo e, ao fazê-lo, estabelece parte das circunstâncias que caracterizam o desafio que o indivíduo deve enfrentar em sua vida.

Assim, para o modelo do desafio, "uma vida piora quando o desafio certo não pode ser enfrentado"533 e, para o autor, se determinada situação é injusta, ela prejudica a qualidade da vida por impedir o enfrentamento do desafio correto. Fica uma pergunta, entretanto: quão mal vai a vida se o desafio correto está indisponível? Para responder à questão da relevância da justiça à ética é necessária outra distinção oferecida por Dworkin: parâmetros, além de normativos ou não-normativos (Dworkin não nomeia a alternativa), podem ser suaves (“soft”)

\footnotetext{
527 "A igualdade e a vida boa", op. cit., pp. 369-70; no original, "Equality and the Good Life", op. cit., pp. 264-5; para "Foundations of Liberal Equality", op. cit., ver p. 260 (veja pp. 259-60 em geral). Veja Mulhal e Swift: "If we think that people should only have their fair share of rosources, we cannot also think that the circumstances that are appropriate in deciding how to live well can be ones in which we have an unfair share. Here, the distinction between the moral (other-regarding) and the ethical (self-regarding) requirements of human well-being simply breaks down.”, Liberals and Communitarians, op. cit., p. 287 (veja pp. 285 e ss. em geral).

${ }_{528}$ Justice for Hedgehogs, op. cit., p. 13, por exemplo.

529 "Foundations of Liberal Equality", op. cit., p. 260.

530 "Foundations of Liberal Equality", op. cit., p. 261 e Justice for Hedgehogs, op. cit., p. 255. Compare com "Equality of Welfare", op. cit., pp. 30-42, esp. p. 38.

531 "Foundations of Liberal Equality", op. cit., pp. 255, 259.

532 "Foundations of Liberal Equality", op. cit., pp. 258 e ss.

533 "Foundations of Liberal Equality", op. cit., p. 260, traduzi. Veja "A igualdade e a vida boa", op. cit., pp. 370; no original, "Equality and the Good Life", op. cit., pp. 270.
} 
ou rígidos ("hard") ${ }^{534}$ conforme a consequência da desobediência da condição que impõem à avaliação da performance. Se a desobediência é fatal, e traz prejuízo completo à vida, o parâmetro é rígido, mas, se pode ser compensada por outro aspecto, o parâmetro é suave ${ }^{535}$. Dworkin dá novos exemplos artísticos: a estrutura de um soneto é um parâmetro rígido, enquanto as manobras obrigatórias de uma apresentação de skate são suaves pois sua ausência pode ser compensada por outras manobras ${ }^{536}$. Um exemplo ético dado pelo autor de parâmetro normativo suave é a duração da vida, e o exemplo concreto de quem teve uma vida curta mas soube compensar sua brevidade é Mozart ${ }^{537}$.

Resta estabelecer com maiores detalhes as consequencias da violação deste parâmetro, seja pela prática de ato injusto, seja pelo acesso a quantidade de recursos inferior ou superior ao designado pela justiça. Dworkin enfrenta esta questão distinguindo parâmetros suave e rígido, e defendendo que a justiça é um parâmetro suave, isto é, a sua violação per se caracteriza desvalor da vida, mas não caracteriza ruína, pois o indivíduo cujas circunstâncias destoam das demandadas pela justiça pode compensar este prejuízo de outras maneiras ${ }^{538}$. Dworkin defende a ideia de que a justiça é um parâmetro normativo suave da boa vida, e aponta a possibilidade de enxergar em Platão a visão contrária, de que a justiça é parâmetro rígido $^{539}$. O motivo da opção de Dworkin reside na atratibilidade da visão de que pelo menos algumas vezes uma vida injusta pode ser melhor do que seria não fosse a injustiça ${ }^{540}$. Os exemplos são Michelângelo, cuja arte teve financiamento injusto, e uma pessoa cuja vida seja salva de doença na infância pelo cuidado médico pago pela riqueza injusta de seus pais ${ }^{541}$. Dworkin julga estes casos "estatisticamente insignificantes" ${ }^{542}$; mas são possíveis, e isto basta à rejeição da tese atribuída a Platão, que "estava quase certo",543.

\footnotetext{
534 "A igualdade e a vida boa", op. cit., p. 366; para o original, "Equality and the Good Life", op. cit., p. 262.

535 "Foundations of Liberal Equality", op. cit., pp. 257-8

536 "Foundations of Liberal Equality", op. cit., p. 257 (veja 260-2 em geral).

537 "Foundations of Liberal Equality", op. cit., p. 257.

538 "Foundations of Liberal Equality", op. cit., p. 259-62.

${ }^{539}$ Veja "Foundations of Liberal Equality", op. cit., pp. 260 e ss. Veja ainda "Principle, Policy, Procedure", op. cit., p. 86 e Justice for Hedgehogs, op. cit, pp. 195 e ss., 259-262.

${ }^{540}$ Justice for Hedgehogs, op. cit, p. 260.

${ }^{541}$ Justice for Hedgehogs, op. cit, p. 262.

542 "Foundations of Liberal Equality", op. cit., p. 262, traduzi.

543 "A igualdade e a vida boa", op. cit., p. 372; no original, "Equality and the Good Life", op. cit., pp. 267.Após mencionar novamente o exemplo da apresentação de skate, em que o atleta pode alcançar resultado superior mesmo que desvie das manobras demandadas, Dworkin afirma: "That will not be true of most people who have more wealth than they should, however. They will do nothing so brilliant or amazing with the surplus over justice that it will compensate for their inability to lead a life good for a just community. Some of them may enjoy their
} 
Dworkin reitera esta visão em Justice for Hedgehogs, ainda que neste trabalho mais recente aparentemente não esteja tão disposto a marginalizar a possibilidade de uma vida criticamente mais valiosa em razão de injustiça ${ }^{544}$. Ele introduz a distinção emtre viver bem (living well) e boa vida (good life): Em poucas palavras, o autor defende

"uma distinção na ética que é familiar na moral: uma distinção entre dever e consequência, entre o certo e o bom. Temos de fazer uma distinção entre viver bem e ter uma vida boa. Estes dois objetivos diferentes estão associados e separados da seguinte maneira: viver bem significa esforçar-se por criar uma vida boa, mas sujeita a certos condicionalismos essenciais para a dignidade humana. Estes dois conceitos - viver bem e ter uma vida boa - são conceitos interpretativos. A nossa responsabilidade ética inclui tentar encontrar definições apropriadas para os doisc conceitos. ${ }^{, 545}$.

Dworkin utiliza a distinção para justificar a responsabilidade de viver uma vida boa ${ }^{546}$ e para explicar de que modo um individuo pode viver bem sem ter uma boa vida ${ }^{547}$, e pode ter uma boa vida sem ter vivido bem: é o caso do Principle Médici, que, diz Dworkin, cometeu diversos crimes para garantir sua bela vida ${ }^{548}$. Os exemplos dados lembram os anteriores: invertem o destino da criança imaginada anteriormente e tratam do financiador, e não do artista financiado. Mas acredito que o objetivo seja o mesmo. No exemplo do príncipe, Dworkin pretende rejeitar a ideia de que

life more than they would in a just community, of course. But that does not mean that their lives are any better in the critical sense", "Foundations of Liberal Equality", op. cit., p. 262. No mesmo parágrafo, sobre os exemplos de Michelângelo e da criança: "These concessions seem required by our sense of ethical possibility. But they are statistically insignificant. On the model of challenge, Plato was nearly right”, p. 262. Veja Mulhal e Swift, Liberals and Communitarians, op. cit., pp. 287-8, 297.

${ }^{544}$ Justice for Hedgehogs, op. cit., cap. 9, pp. 195 e ss. Dworkin diz ainda o seguinte: "We might be able to construct a conception of a good life such that an immoral or base act would always, or almost always, makes the agent's life finally a worse life to lead. But I now suspect that any such attempt would fail [5]", p. 195, acrescentei o itálico. O [5] marca o lugar da nota 5, que tem a seguinte redação: "Though I was once tempted. See Dworkin, Sovereign Virtue, 263-67; and Dworkin, "Foundations of Liberal Equality", op. cit., 190, 195, 258-62", p. 457, acrescentei o itálico. Não é claro, portanto, como Dworkin interpreta "Foundations of Liberal Equality": ele foi tentado (o que parece dizer que resistiu à tentação) pela visão atribuída a Platão, ou a adotou, ainda que em versão menos "hard" que posterior abandonou em Justice for Hedgehogs? A meu ver, a primeira opção é mais adequada porque, apesar de inexistente em "Foundations of Liberal Equality", a distinção entre viver bem e boa vida não modifica a tese mais fundamental de que é possível, independentemente de quão improvável, que uma vida injusta seja mais valiosa em função da injustiça, mas que isso exige habilidade adicional (ou uma hipótese particularmente pobre de vida justa, como seria o caso da criança salva pelos cuidados injustos que recebeu).

545 Justiça para ouriços, op. cit., p. 203; no original, Justice for Hedgehogs, op. cit. cap. 9, p. 195. Tanto a tradução brasileira de Sovereign Virtue quanto a portuguesa de Justice for Hedgehogs traduzem "good life" por "vida boa" (veja "A igualdade e a vida boa", op. cit. e Justiça para ouriços, op. cit., pp. 203 e ss.). Darlei Dall'Agnol, a meu ver, traduz melhor ao preferir "boa vida": "O igualitarismo liberal de Dworkin", op. cit., p. 67, citando "Foundations of Liberal Equality", op. cit., p. 259. Para "viver bem", veja o mesmo trecho da tradução portuguesa. Veja Caio Moysés de Lima, O Império dos Direitos: Lei e Autoridade Política em Ronald Dworkin, op. cit., pp. 74 e ss.

${ }^{546}$ Justice for Hedgehogs, op. cit. cap. 9, pp. 195 e ss.

${ }^{547}$ Caso de alguém que "has been born in great poverty or to a despised race, or is severely crippled, or dies very young", Justice for Hedgehogs, op. cit. cap. 9, p. 200.

${ }_{548}$ Justice for Hedgehogs, op. cit. cap. 9, p. 200. 
"a imoralidade piora sempre e necessariamente uma vida. De facto, em qualquer padrão plausível daquilo que define uma vida boa, o nosso príncipe teve uma vida melhor do que aquela que teria tido se tivesse respeitado escrupulosamente as suas responsabilidades morais. Mas isto não implica que tenha vivido bem. Falhou nas suas responsabilidades éticas; não devia ter cometido os crimes que cometeu e devia ter aceitado a vida menos espetacular que teria tido. Assim, apesar de pensar que melhorou a vida graças aos seus atos imorais, devemos dizer que viveu pior., ${ }^{, 49}$,

A diferenciação entre viver bem e boa vida leva à possibilidade de que indiquem cursos de conduta distintos, hipótese em que Dworkin recorre a noção utilizada por Rawls para dizer que viver bem tem "prioridade lexical" sobre a boa vida ${ }^{550}$. Em conclusão, a ideia que, em "Foundations of Liberal Equality”, Dworkin pretende expressar pela caracterização da justiça como um parâmetro normativo da boa vida é explicada em Justice for Hedgehogs pela distinção entre boa vida ( good life) e viver bem (to live well).

Em sua obra mais recente, Dworkin é particularmente claro sobre a necessidade de integração entre ética e moral ${ }^{551}$. Não se trata somente de dizer que, no exemplo de Dworkin, o respeito às responsabilidades éticas do príncipe exigem dele respeito à moral, cujo conteúdo é por sua vez independente da ética - o autor chama esta visão de "incorporação" e a rejeita ${ }^{552}$. Ao compreender a justiça como parâmetro normativo da boa vida ou ao entendermos que viver bem significa atender à moral, vamos da moral à ética ${ }^{553}$, pois neste caso nossas convicções sobre justiça exigem a adoção de opiniões sobre ética. Por outro lado, ao analisar os dois

${ }_{550}^{549}$ Justiça para ouriços, op. cit., p. 208; no original, Justice for Hedgehogs, op. cit. cap. 9, p. 200.

${ }^{550}$ Justice for Hedgehogs, op. cit. cap. 9, pp. 201-2. "Is ethically irresponsible for you to live less well in order to make your life a better one, and inappropriate for you to take pleasure or pride in your life's goodness when you achieve this at the cost of living badly. We might say (using a term developed by economists that John Rawls made popular among philosophers) that the value of living well is lexically prior to the value of a good life. But the goodness of a life nevertheless has independent value. You should feel glad when your life is good, but not if you cheated to achieve it. You should regret a life that is less good because your luck has been bad or because other have chated you", Justice for Hedgehogs, op. cit. cap. 9, pp. 201-2.pp. 201-2, nota omitida (Veja Justiça para ouriços, op. cit. para “(...) o valor de viver bem é lexicalmente anterior ao valor de uma vida boa", p. 209, nota omitida.). Tratar "viver bem" (living well) como categoria fundamental da ética reforça a noção de que o valor da vida é adverbial, de performance (veja pp. 196-7).

${ }_{551}^{5}$ Justice for Hedgehogs, op. cit. cap. 9, p. 202.

${ }^{552}$ Justice for Hedgehogs, op. cit. cap. 9, p. 202. Na p. 203, Dworkin usa a ciência como analogia explicativa: nela, " (...) we draw a sharp distinction between the intrinsic goal of seeking the truth and our justifying reasons for seeking that true. We think that trying to understand the structure of the universe is part of living well, but do not think - unless we are crude pragmatists or mad - that we identify that structure by asking what view of it would help us to live well", nota omitida. Nesta nota, ele remete o leitor à seção das pp. 152 e ss. (Capítulo 7) em que o autor elabora a separação fundamental, aplicável à ciência mas não à interpretação, entre os motivos que temos para fazer ciência e os padrões de correção desta empreitada: "the truth of the big bang theory does not turn on whether it enchants us" (p. 153). Por outro lado, "Interpretation is dramatically different. In that realm justifying purpose is at the heart of success. (...) In interpretation, we might say, justifying and intrinsic goals merge" (p. 153). No capítulo 9 de Justice for Hedgehogs, após falar de ciência, Dworkin menciona o valor da arte relacionado ao do viver bem: veja discussão no capítulo primeiro desta dissertação.

${ }^{553}$ Justice for Hedgehogs, op. cit. cap. 9, p. 202. 
princípios de dignidade ou o modelo do desafio vamos da ética à moral, pois neste caso nossa visão sobre viver bem ajuda a estabelecer o que é justo ${ }^{554}$. Como Dworkin esclarece ao descrever a opção de integração entre moral e ética, que opõe à incorporação da primeira pela seguinte,

“(...) podemos ver o conteúdo da moral como determinado, pelo menos em parte, pelo caráter independente da responsabilidade ética: podemos supor que, tal como as nossas responsabilidades éticas são parcialmente determinadas pelas nossas responsabilidades morais para com os outros, estas são parcialmente determinadas pelas nossas responsabilidades éticas. De acordo com essa segunda perspectiva, a moral e a ética estão integradas no modo interpretativo que temos analisado nos últimos capítulos" $" 555$.

O autor pretende não só incorporar a moral à ética, mas integrá-las uma a outra, o que exige uma "relação interpretativa bilateral" entre as duas ${ }^{556}$.

Em Dworkin, portanto, a qualidade de uma vida depende da justiça dos recursos que lhe são disponíveis. ${ }^{557}$. Mas o que este argumento de Dworkin sobre a integração entre moral e ética, ou, mais especificamente, a respeito de a justiça ser um parâmetro normativo da boa vida, mesmo suave, nos diz sobre a atitude correta frente às liberdades, bem como a respeito do prejuízo às nossas vidas do gozo de ambiente que seja produto de violação de liberdades? Relembre o leitor que Dworkin integra os valores políticos da liberdade e da igualdade ao apontar a necessidade de um regime de liberdades enquanto direitos à compreensão da justiça distributiva como igualdade de recursos. Isso significa que as liberdades são uma questão de justiça, e, novamente, uma questão de ética porque as circunstâncias justas caracterizam o desafio correto. Ou seja, uma vez que Dworkin integra as liberdades à igualdade, integra também as liberdades à ética, pois, pelo argumento sob análise, esta se integra à justiça/igualdade. Temos aqui outra maneira de reforçar a integração das liberdades à boa vida no pensamento de Ronald Dworkin, desta vez intermediada pela ideia de igualdade: as liberdades fazem parte das circunstâncias, e, portanto, a sua violação tem consequências às vidas dos indivíduos que se beneficiam dela da mesma forma que prejudica a vida de quem

\footnotetext{
${ }^{554}$ Veja a segunda seção deste capítulo, acima. Dworkin, sobre a integração em Justice for Hedgehogs, diz o seguinte: "We can achieve that integration, however, only if we can find some compelling aspect or dimension of living well that is not itself, at least at first glance, a matter of our duties to others but yet both affects and is affected by those duties. I believe that we can find that interpretive lever in the twin, connected ideas of selfrespect and authenticity", op. cit., p. 203 (e então se põe a elaborar os princípios, pp. 203 e ss.).

${ }^{555}$ Justiça para ouriços, op. cit., p. 210 (substituí “;”, por “:” para adequar ao original); para o original, Justice for Hedgehogs, op. cit. cap. 9, p. 202.

${ }_{556}^{5}$ Justiça para ouriços, op. cit., p. 210; Justice for Hedgehogs, op. cit., cap. 9, p. 202 (veja ainda pp. 255 e ss.).

557 "Foundations of Liberal Equality", op. cit., p. 286.
} 
goza de situação de injusta distribuição de recursos (afinal, para Dworkin, a distribuição de recursos não é inteligível salvo como distribuição de conjunto de liberdades, isto é, direitos, a recursos).

Em outras palavras, na obra de Dworkin temos o seguinte panorama acerca da integração entre ética, liberdades e justiça distributiva como igualdade. A justiça ingressa na ética como padrão normativo da boa vida. A liberdade ingressa na igualdade/justiça como linha de base do leilão. Assim, a liberdade ingressa na ética pela igualdade. Mas a liberdade também ingressa na ética diretamente porque (i) a boa vida é livre, já que só com liberdade existe performance e (ii) a liberdade não tem valor intrínseco, especificamente, seu valor depende da capacidade de contribuir à boa vida. Este último caso, a saber, do valor intrínseco da arte e do valor integrado da liberdade, diz mais respeito à ética ingressar na liberdade que o contrário, pois não é só a ética que se define pela presença das liberdades, mas as liberdades é que têm seu valor decorrente da ética do bem viver. Isto significa dizer que, em Dworkin, sendo o valor das liberdades dependente da sua integração à boa vida, a ética faz parte da delimitação das liberdades.

Faço esses comentários como exegese da conclusão de Dworkin sobre o que chama de "tolerância liberal" ou "neutralidade em operação" no modelo do desafio ${ }^{558}$. É tolerante neste sentido, para Dworkin, o estado que não restringe liberdades com base em concepções éticas (apresentei esta visão acima neste capítulo). O autor diz:

“A igualdade liberal é tolerante no seguinte sentido. Distingue dois tipos de razões que a comunidade política pode oferecer como justificativa para negar a liberdade. O primeiro é de justiça: a comunidade deve proibir qualquer conduta quando e porque a melhor teoria da justiça assim o exigir. Deve coibir o roubo, por exemplo, para proteger os direitos das pessoas à segurança de propriedade. O segundo é ético: a comunidade pode pensar que a conduta proibida, embora não contra a justiça, seja humilhante, corruptora ou ruim para a vida de seu autor. Eu poderia pensar, por exemplo, que a vida do homossexual é degradante e, com base nisso, tornar ilícitas as relações homossexuais. A igualdade liberal nega a legitimidade da segunda razão, ética, para tornar condutas ilícitas.". 559

A tolerância liberal explica a razão que um liberal ético, independentemente das suas convicções sobre o bem ( good, ou valor da vida $)^{560}$, tem para não impor suas opiniões sobre

\footnotetext{
558 "Foundations of Liberal Equality", op. cit., pp. 297-305, esp. pp. 300-305. Veja ainda discussão na segunda seção do próximo capítulo. Veja Macleod, Liberalism, Justice, and Markets, op. cit., esp. cap. 7.

559 "A igualdade e a vida boa", op. cit., pp. 394 (modifiquei a tradução para substituir "motivo(s)" por "razão(ões)" para traduzir "reason(s)"); no original, "Equality and the Good Life", op. cit., pp. 282; para "Foundations of Liberal Equality", op. cit., ver p. 301 (Dworkin, aqui, fala em "neutral in its operation" em vez de em "tolerante")..

560 "Foundations of Liberal Equality", op. cit., p. 302.
} 
terceiros. Dworkin exerga imensa relevância nesta questão porque o seu modelo de continuidade ou de integração entre ética e moral aparentemente chancela a visão de que, no exemplo da citação, quem julga a prática de relações homossexuais degradante deva proibi-la pelo direito ou, no exemplo sob análise, quem julga errada a manifestação de opiniões racistas deve torná-las ilegais ${ }^{561}$.

A resposta de Dworkin a este tema é a seguinte:

“A questão. não é se devem fazer campanha pelo que entendem por bem, mas como. A tolerância liberal lhes nega uma arma: não devem empregar a lei, mesmo quando estão em maioria, para proibir ninguém de levar a vida que quiser, ou punir por fazê-lo, só porque acham que as convicções éticas dessas minorias estão profundamente equivocadas. Se as pessoas sentem atração pelo liberalismo ético mesmo as que tenham convicções éticas muito fortes - não terão motivo para resistir a essa única restrição a seu poder de propagar opiniões. Os liberais éticos sabem que não podem melhorar a vida do próximo por meios coercitivos que a tolerância liberal proíbe, pois sabem que não se pode melhorar a vida de niguém contra a firme convicção de que não melhorou. Mesmo achando que a vida de alguém seria melhor se mudasse de convicções, sabem que não podem torná-la melhor se não conseguirem modificar tal pessoa, e da maneira certa. Admitem que essa pessoa leva uma vida melhor em paz com suas próprias convicções arraigadas do que, sob pressão externa, em guerra com elas." ${ }^{, 62}$

Este trecho, de "Equality and the Good Life", aparece um pouco diferente em "Foundations of Liberal Equality". Após negar que a maioria pode restringir condutas por razão ética, Dworkin diz:

"Liberais éticos têm o que parece ser uma razão conclusiva para aceitar esta restrição: eles aceitam uma explicação da justiça que exige igualdade de circunstâncias e de recursos. O direito é claramente parte das circunstâncias das pessoas, e as circunstâncias são claramente desiguais quando o direito proíbe alguns de levar as vidas que acham melhor para eles somente porque outros discordam. (58) Logo, liberais éticos, que aceitam a igualdade de circunstâncias como aquilo que a justiça exige, devem aceitar a tolerância liberal também. A liberdade e a igualdade, para eles, se mesclam como aspectos diferentes do mesmo ideal político. Claro que alguém que acredite que a melhor vida é uma vivida em uma comunidade religiosamente homogênea pensará que é melhor para ele se a sua comunidade for tanto justa quanto homogênea. Mas na concepção de ética do desafio ela é melhor para ele somente se for justa, porque a injusta estragaria a desvantagem, e a homogeneidade não é justa se for coagida" ${ }^{\text {}}{ }^{23}$.

O autor sustenta ainda que a tolerância liberal decorre da ética do desafio de modo que seja coerente, e, na verdade, indispensável a um liberal ético não só que não "lamente", mas

\footnotetext{
561 "Foundations of Liberal Equality", op. cit., p. 302.

562 "A igualdade e a vida boa", op. cit., pp. 395-6; no original, "Equality and the Good Life", op. cit., pp. 282.

563 "Foundations of Liberal Equality", op. cit., 302, traduzi; (58) marca a posição da nota 58, em que Dworkin sustenta que este argumento foi desenvolvido mais pormenorizadamente no artigo publicado como capítulo terceiro de Sovereign Virtue, op. cit. (i.e., "The Place of Liberty", discutido acima nesta dissertação), e reitera os exemplos que menciono a seguir. Ver Mulhall e Swift, Liberals and Communitarians, op. cit., pp. 293-4.
} 
que valorize a neutralidade deste tipo ainda que modos de vida que julgue ruins sejam desta forma permitidos. 564

$\mathrm{O}$ argumento de Dworkin, portanto, consiste em apontar que os liberais éticos, que adotam o modelo do desafio, têm razão para respeitar as liberdades, que são integradas à igualdade, pois este respeito é condição do valor de suas próprias vidas. Um liberal ético que se descubra vivendo em um ambiente que facilite a condução das suas escolhas éticas, mas que é produto de violação da liberdade deve saber que isto não aprimora criticamente a sua vida. A resposta dworkiniana à questão da relação entre respeito às liberdades, entre elas a liberdade de expressão, e a qualidade da vida de quem goza da violação, é clara: o respeito às liberdades, como respeito à justiça, é crucial ao valor da vida de todos, inclusive daqueles que não pretendem exercer as liberdades violadas.

Isto, é claro, se resume às liberdades que efetivamente existem, pois prejudicar o exercício de uma vida em razão da justiça não faz parte, segundo Dworkin, não é vedado pela tolerância liberal: o exemplo que dá é a vida de um colecionador de obras de arte renascentista, certamente dificultada pela igualdade de recursos, que impede que um indivíduo seja rico o suficiente para tanto ${ }^{565}$. A questão, como vimos, reside na origem do prejuízo: viola a

${ }^{564}$ Dworkin diz, em trecho que segue imediatamente o ultimo cotado: "It is crucial to the continuity strategy, moreover, that ethical liberals will not resent this tolerance, or feel that they have in any way compromised or set aside or bracketed their own ethical convictions in deciding not collectively to impose them on a dissenting minority when they have the opportunity to do so. On the contrary, tolerance gives full force to their abstract ethical convictions about how they and others can live best, because the theory of justice that requires tolerance is not a competing department of morality that checks their ethical convictions, but, on the contrary, is drawn from and serves these ethical convictions in the ways we have been exploring. Their substantive convictions, in other words, offer no advice or incentive or motive that could override tolerance if these were somehow given freer reign, because there is nothing these convictions aks or require of them that tolerance forbids. They cannot make their own lives better by ignoring the limits justice sets to their power to have a cultural or social environment more congenial to them, because justice is a parameter of the life good for them. They cannot make other people's lives better by the coercive means liberal tolerance forbids, because on the challenge model, as we discovered, someone's life cannot be improved against his steady conviction that it has not been. Ethical liberals will treat each other's convictions as parameters in the way I described. Even if they think someone's life would be better if he changed his convictions, they know they cannot make it better unless he does change them, and in the right way. They accept that he leads a better life at peace with his own settled convictions than he can live, under external pressure, at war with them.", "Foundations of Liberal Equality", op. cit., p. 303, itálicos no original. Veja ainda p. 305, em que Dworkin, entre outros, reitera a visão de que a tolerância é um teorema, e não um axioma, afirmação discutida acima na primeira seção deste capítulo desta dissertação.

565 "Foundations of Liberal Equality", op. cit., p. 301 e p. 302, n. 58. Dworkin diz que a igualdade liberal não é "neutra in result", ou seja, pode ter como consequência prejuízo à condução de determinadas escolhas éticas. Veja ainda pp. 301-5; na p. 304, Dworkin fala que "liberal equality cannot be neutral in consequences" como sinônimo. Veja pp. 304-5 para sentidos em que a igualdade liberal não é neutra. Veja nota de rodapé na quinta seção do primeiro capítulo, acima, para maiores referências. Veja "The Place of Liberty", op. cit., pp.153-155 
tolerância liberal, componente da justiça, somente se justificado por razão ética ${ }^{566}$. Se a restrição às manifestações preconceituosas sob análise é questão de justiça, novamente, faz parte da questão mais básica desta dissertação, objeto do próximo capítulo. Argumento aqui é hipotético: se discurso de ódio faz parte da liberdade de expressão, proibi-lo ofende a justiça e prejudica a vida dos proibidores. Que ele, entre outros, faz parte será argumentado no próximo capítulo. O que desde já se percebe na obra de Dworkin é restrição ao tipo de razão pertinente à restrição de uma liberdade, inclusive a liberdade de expressão: a razão só pode ser de justiça. É por isso que a questão fundamental à liberdade de expressão é justamente esta: a teoria da justiça distributiva capaz de justificá-la e delimitá-la.

Este é assunto para a primeira seção do próximo capítulo. Gostaria, para concluir esta seção, de explorar os argumentos oferecidos por Dworkin à conexão entre o modelo do desafio e a igualdade.

\section{Subseção 3.2. A ética igualitária}

A teoria política de Ronald Dworkin é conhecidamente igualitária ${ }^{567}$. Em especial, aigualdade ocupa papel fundamental nos seus argumentos, por exemplo, em defesa de direitos a liberdades (veja introdução à dissertação, bem como o capítulo primeiro). Mais recentemente, o autor tem procurado fundamentar sua teoria política em uma concepção de bem, e é objeto deste capítulo analisar este processo. O objeto desta subseção é a relação entre a sua concepção de bem e a igualdade; meu objetivo é saber se as ideias de que o valor da vida é adverbial e de que a vida tem valor objetivo implicam a adesão à igualdade como valor político e à teoria da justiça específica formulada por Dworkin.

Ou seja, existem dois níveis em que esta relação opera: um abstrato e outro mais específico, concreto. O abstrato consiste na conexão entre o modelo do desafio ou o primeiro princípio ético de dignidade, a saber, do respeito próprio, e a igualdade enquanto "conceito" ou "princípio igualitário abstrato" 568 . O nível concreto, por sua vez, consiste na conexão entre o modelo do desafio e a concepção de justiça defendida pelo autor, a saber, a igualdade de

\footnotetext{
566 "Foundations of Liberal Equality", op. cit., pp. 300-1 igualdade de recursos; veja ainda pp. 96 e ss., esp. pp. 97-8, 101).

568 “The Place of Liberty”, op cit., p. 128; veja a seção 1 deste capítulo para esta noção.
}

567 Ripstein, "Liberty and Equality", op. cit., p. 106, n. 20 à p. 93 (comparando Dworkin e Rawls quanto à natureza "comprehensive" do liberalismo do primeiro e comentando a relação entre o modelo do desafio e a 
recursos. Exponho a seguir estes argumentos, dos mais abstratos aos mais concretos. Aponto em nota de rodapé que e por que reorganizei os argumentos formulados por Dworkin e pelo menos em uma ocasião interpretei argumento de forma diferente da pretendida pelo autor.

Em "Foundations of Liberal Equality", Dworkin sustenta que os liberais éticos, que adotam o modelo do desafio, tratam a justiça como questão de recursos, que deverão ser iguais $^{569}$. O autor discute primeiro a relação entre seu modelo de ética preferido e a justiça como recursos, e, só então, a relação com a igualdade. Este argumento é extremamento interessante pelas amplitude das consequências que detecta na visão de que a justiça é parâmetro da boa vida: Dworkin sustenta que aos liberais éticos estão indisponíveis diversos argumentos típicos da teoria da justiça contemporânea, entre eles o rawlsiano sobre a convergência das pessoas sobre o valor de recursos primários à condução de uma vida e o econômico que defenda determinada teoria da justiça pelos seus benefícios de crescimento da geração de recursos ${ }^{570}$. Estes argumentos estão indisponíveis a quem adote a justiça como parâmetro normativo da boa vida porque eles assumem a possibilidade de valorar positivamente eventual acréscimo de recursos como passo à definição da justiça, o que é impossível a quem os valore a partir da própria teoria da justiça, que é, em outras palavras, anterior e condição da valoração e não resultado da valoração do acréscimo. ${ }^{571}$

O ponto de Dworkin é que o modelo do desafio exige o abandono da visão "competitiva" 572 ou de "justiça como acomodação [compromisse] de interesses",573 adotada por estes argumentos indisponíveis. O modo de pensar de um liberal ético é diferente:

\footnotetext{
569 "Foundations of Liberal Equality", op. cit., p. 285.

570 "Foundations of Liberal Equality", op. cit., pp. 286-7.

571 "Foundations of Liberal Equality", op. cit., pp. 286 e ss.. Sobre Rawls, Dworkin diz que "If justice is a parameter and not merely a componente of a good life (...) it is not true that having more primary goods makes, even pro tanto, for a critically better life. There is no 'thin' sense of interests such that justice can be defined in a noncircular way as the distribution that is most in the interests of the worst-off group", p. 286. Sobre o argumento econômico, ele diz: "It cannot (...) be an argument for a theory of justice that a community run on that theory will have more aggregate resources; that would beg the question whether having more is actually in the interests of those who will in fact have more. We will not think that more wealth is in the interests of the majority unless the scheme that provides this is just", p. 287, nota omitida, italic no original (veja ainda pp. 287-8 sobre Thomas Scanlon). Veja geral pp. 275 e ss., especialmente: para Dworkin, "Self-interest and a concern for justice merge, because the later is part of the former", pp. 279-80 (veja p. 181, n. 49 e pp. 285-291). Compare com "Equality of Welfare", op. cit., pp. 30 e ss., esp. pp. 38-42, pp. 45-6, p. 48, 52-3 e p. 63 e também com "Equality of Resources", op. cit., pp. 70.

572 Dworkin fala em "the competitive model the contractarian tradition exploits" ("Foundations of Liberal Equality", op. cit., p. 287) e em seguida menciona Hobbes e Rawls (pp. 287-8). Veja ainda p. 283.
}

573 "Foundations of Liberal Equality", op. cit., p. 288, traduzi. 
"se não podemos testar uma teoria da justiça consequencialmente, perguntando se tem as consequências certas aos interesses das pessoas, podemos testá-la eticamente, perguntando se se encaixa bem nas nossas outras crenças sobre como é apropriado que as pessoas vivam." ${ }^{774}$.

Imediatamente no parágrafo seguinte, ele continua, "liberais éticos devem tratar a questão da justiça como parte da ética. Eles decidem que parcela dos recursos cada um deve ter decidindo quais parâmetros é apropriado que cada um aceitar como definidores a natureza da boa vida para ele״ ${ }^{, 575}$. Dworkin acredita que pensar assim sobre a justiça exige adesão à igualdade porque implica a rejeição de argumentos não-igualitários, como o econômico mencionado acima, que pode justificar desigualdades pela sua suposta relação com aumento de recursos disponíveis ${ }^{576}$. Os outros argumentos não-igualitários cuja rejeição Dworkin enxerga ser necessária a um liberal ético são ainda menos cogentes e menos aceitos: são aqueles que "recorrem à diferença inerente na qualidade ou valor [worth or value] de diferentes pessoas ou grupos." ${ }^{277}$; Dworkin diz que estes argumentos estão "agora felizmente fora de moda"578. E o motivo de serem particularmente indisponíveis a quem adote o modelo do desafio é o seguinte: os liberais éticos

"pensam que é parte da responsabilidade ética de cada pessoa decidir uma identidade ética para ela mesma - para decidir por ele mesmo se é um parâmetro de sua vida que ele é um aristocrata ou talentoso ou se essas propriedades são somente oportunidades ou limitações que enfrenta ao levar uma vida apropriadamente definidada de maneira bastante diferente. ${ }^{.579}$.

Em outras palavras, quem adota o modelo do desafio não pode aceitar teorias nãoigualitárias ou (i) porque elas assumem relação entre interesses dos indivíduos e justiça que é rejeitada pela integração entre justiça e ética ou (ii) porque os argumentos anti-igualitários restantes subtraem do indivíduo e atribuem à política a responsabilidade de interpretar as circunstâncias da vida (por exemplo, ao distribuir mais recursos a um indivíduo simplesmente por pertencer a certa linhagem nobiliárquica). ${ }^{580}$ Dworkin diz que

“obscurece e diminui o desafio total da ética, a força categórica do imperativo de viver bem, localizar a sua fonte em qualquer coisa mais contingente do que sermos pessoas com vidas para viver. Teorias nãoigualitária da justiça, observadas da perspectiva da visão do desafio, diminuem a ética precisamente

\footnotetext{
574 "Foundations of Liberal Equality", op. cit., p. 288, traduzi.

575 "Foundations of Liberal Equality", op. cit., pp. 288-9.

576 "Foundations of Liberal Equality", op. cit., p. 289.

577 "Foundations of Liberal Equality", op. cit., p. 289, traduzi.

578 "Foundations of Liberal Equality", op. cit., p. 289, traduzi.

579 "Foundations of Liberal Equality", op. cit., p. 289, itálicos no original, traduzi.

${ }^{580}$ Dworkin dá o exemplo dos "descendents of Richard Plantagenet", "Foundations of Liberal Equality", op. cit., p. 289; veja em geral pp. 289-90 e também Is Democracy Possible Here?, op. cit., p. 15 para o mesmo exemplo.
} 
desta forma. Elas supõem que pertence à política, em vez de às pessoas, construir os parâmetros da identidade ética." ${ }^{581}$.

Em resumo, Dworkin sustenta que os liberais éticos, que aceitam o modelo do desafio, devem adotar a igualdade porque as razões que teriam para não fazê-lo submetem à apreciação política juízos de interpretação das circunstâncias da vida que a ética liberal atribui ao indivíduo.

A ideia de que as responsabilidades éticas têm origem no simples fato da nossa existência tem, que eu saiba, origem justamente em "Foundations of Liberal Equality", mas foi elaborada novamente em Justice for Hedgehogs no esforço feito por Dworkin de integrar o primeiro princípio ético de dignidade - o do respeito próprio - ao princípio político da igualdade $^{582}$. A meu ver, o argumento é o mesmo, feito, porém, em outro contexto terminológico. Julgo que o argumento continua abstrato, isto é, conecta a visão de ética do autor com a igualdade enquanto conceito, e não à concepção específica de igualdade de Dworkin, a saber, a igualdade de recursos. ${ }^{583}$ Aqui, Dworkin fala da igualdade de modo muito similar, senão idêntico, àquilo que em "The Place of Liberty” de princípio igualitário abstrato.

Como visto, no pensamento mais recente de Dworkin, cada princípio ético de dignidade tem a sua versão política. É importante explorar brevemente estas conexões, pois elas são cruciais ao projeto dworkiniano de integrar ética e moral e à compreensão da fundamentação dos direitos no autor. Dworkin chega ao princípio político da igualdade a partir do respeito próprio ao observar que as circunstâncias que, nas nossas vidas, promovem este respeito estão presentes também nas demais pessoas, eis que não faz sentido respeitar o valor

581 "Foundations of Liberal Equality", op. cit., p. 290, traduzi. Veja Mulhall e Swift, Liberals and Communitarians, op. cit., pp. 293, 297.

${ }^{582}$ Para reiteração do argumento, veja também, Is Democracy Possible Here?, op. cit, pp. 11-17, esp. pp. 15-7.

${ }^{583}$ Logo em seguida do trecho que citei acima Dworkin diz que "Ethical liberals will therefore reject all such theories and endorse equality of resources as the only theory of justice that matches their sense of the charater of the ethical challenge each faces", "Foundations of Liberal Equality", op. cit., p. 290. Eu não acredito que uma coisa siga da outra, isto é, que os motivos que os liberais éticos têm para rejeitar os argumentos não-igualitários implique a aceitação da igualdade de recursos como teoria da igualdade. Isso não significa que os liberais éticos não tenham motivos para adotar a igualdade de recursos - pelo contrário, exploro abaixo os argumentos elaborados por Dworkin neste sentido (altero a ordem dos argumentos em "Foundations of Liberal Equality" justamente para expor antes os que julgo abstratos e, em seguida, os que julgo concretos). O que quero dizer simplesmente é o seguinte: que uma teoria aristocrática da justiça, para ficar no exemplo do autor, exija visões sobre valor da vida que contrariam o modelo do desafio não é per se motivo para quem adota o modelo do desafio adotar a igualdade de recursos. É verdade que Dworkin sustenta simplesmente que "the challenge views supports equality of resources directly, as flowing from people's sense of their own best interests critically understood" (p. 290). Novamente, não discordo. É simplesmente o caso que este é um argumento distinto daquele elaborado pelo autor nas páginas anteriores, e que analisei acima. 
objetivo das nossas vidas sem respeitá-lo também nas vidas dos outros ${ }^{584}$. É por isso que, para o autor, o princípio ético do respeito próprio tem como consequência o princípio político da igualdade. Dworkin endossa aqui o que chama de "Princípio de Kant", definido como o princípio que

“(...) afirma que uma forma correta de respeito próprio - o respeito próprio exigido por esse princípio de dignidade - implica um respeito paralelo pelas vidas de todos os seres humanos. Para me respeitar a mim próprio, tenho de considerer as vidas dos outros como tendo também importância objetiva" ${ }^{, 585}$.

Assim, Dworkin extrai compromisso igualitário do primeiro princípio ético de dignidade: não faz sentido enxergar valor na própria vida sem enxergar valor na vida do outro $^{586}$.

O argumento é muito parecido, senão idêntico ao formulado para conectar o modelo do desafio à igualdade, pois consiste em rejeitar qualquer teoria política que atribua importâncias a circunstâncias particulares de determinados indivíduo, seja porque isto viola a responsabilidade do indivíduo de interpretar estas circunstâncias, seja porque não são elas que atribuem valor objetivo à vida. Em ambos os argumentos de Dworkin, a existência de um indivíduo com uma vida a viver, características que todos compartilham, e não outra, específica de alguns e ausente a outros, é o ponto de partida da reflexão ética e política.

A meu ver, a igualdade é entendida, nestes argumentos, de forma abstrata, isto é, ampla o suficiente para agrupar diferentes teorias, nos termos daquilo que Dworkin chamou de "princípio igualitário abstrato":

"(...) acredito estarmos hoje unidos na aceitação do princípio igualitário abstrato: o governo deve agir para tornar melhor a vida daqueles a quem governa, e deve demonstrar igual consideração pela vida de todos. Qualquer pessoa que aceita esse princípio abstrato aceita a igualdade como ideal político, e embora a igualdade admita concepções distintas, essas concepções são interpretações de tal princípio"587.

Dworkin apresenta a igualdade recursos justamente como uma dessas concepções, e a defende enquanto interpretação deste princípio igualitário abstrato. Além de justificar as credenciais igualitárias da sua concepção de ética, Dworkin aponta razões específicas pelas quais o modelo do desafio oferece razões a quem o adota para adotar também a igualdade de

\footnotetext{
${ }^{584}$ Justice for Hedgehogs, op. cit., p. 255 e ss..

585 Justice for Hedgehogs, op. cit., p. 255; veja ainda outra definição do princípio de Kant na p. 19. Veja Guest, Ronald Dworkin, op. cit., pp. 164-5.

${ }^{586}$ Justice for Hedgehogs, op. cit., p. 19, pp. 255 e ss., pp. 265 e ss.. Veja ainda "Do Liberty and Equality Conflict?", op. cit., pp. 42-3.

587 "O lugar da liberdade", op. cit., p. 169; no original, "The Place of Liberty", op cit., p. 128 (veja ainda "Political Equality", op. cit., p. 184). Veja Macleod, Liberalism, Justice, and Markets, op. cit., cap. 7.
} 
recursos. Eu identifico três argumentos deste tipo - concretos - em "Foundations of Liberal Equality", que apresento abaixo em ordem descrescente de complexidade, o que não corresponde à ordem que figura neste trabalho do autor.

Em primeiro, o autor enxerga no modelo do desafio apoio para uma distinção central à igualdade de recursos (como diz no artigo sob análise, a igualdade liberal), a saber, aquela entre circunstâncias e personalidade ${ }^{588}$. Dworkin separa os "aspectos das circunstâncias que uma pessoa enfrenta" ${ }^{, 589}$ entre recursos impessoais ${ }^{590}$ e recursos pessoais (como talentos ${ }^{591}$ ). Como visto no capítulo primeiro, Dworkin constrói a igualdade de recursos por meio da ideia de um leilão imaginário dos recursos de determinado lugar (o autor imagina uma ilha anteriormente deserta) que, constituído pelos princípios corretos, alcança o custo de oportunidade dos diferentes recursos. Os recursos impessoais são o objeto deste leilão, e, segundo o "teste da inveja" são iguais quando ninguém inveja os recursos de outro. Ocorre que recursos pessoais, como talentos, também são capazes de justificar inveja; o problema que este fato levanta, diz Dworkin, é que recursos deste tipo não podem ser objeto de leilão - o autor então propõe os "seguros hipotéticos" (que distribuem recursos impessoais como compensação a quem tem menos recursos pessoais) como mecanismo de alcançar a igualdade tanto quanto possível em relação ao tipo de recurso que não pode ser redistribuído ${ }^{592}$.

Assim, a igualdade de recursos, ainda que de diferentes maneiras e na medida do permitido pela natureza da cada tipo de recurso ou circunstância, busca torná-los iguais nos termos do teste da inveja. A teoria da justiça de Dworkin, entretanto, enfrenta de outra maneira diferenças em relação à personalidade: elas simplesmente não são objeto da justiça ${ }^{593}$.

\footnotetext{
588“"Foundations of Liberal Equality", op. cit., pp. 226-7 e 293-7. Veja também "Equality of Resources", op. cit., pp. 81 e ss.

589 "Foundations of Liberal Equality", op. cit., p. 293, traduzi

590 "The independente control he exercises over transferable goods which he can use, as he chooses, in leading his life as he wishes" "Foundations of Liberal Equality", op. cit., p. 293.

${ }^{591}$ São as "qualities of physical and mental health and skill, and other talents and capabilites", Foundations of Liberal Equality", op. cit., p. 293. Compare com "Equality of Resources", op. cit., pp. 79-80 e "Do Liberty and Equality Conflict?", op. cit., pp. 46-8.

592 "Foundations of Liberal Equality", op. cit., p. 293 para o resumo que Dworkin oferece das diferentes soluções dadas pela igualdade de recursos aos recursos pessoais e aos impessoais. Veja Ripstein, "Liberty and Equality", op. cit., esp. pp. 98 e ss., Macleod, Liberalism, Justice, and Markets, op. cit., pp. 82 e ss. (em geral, veja caps. 4 e 5 para críticas detalhadas a Dworkin) e Guest, Ronald Dworkin, op. cit., cap. 10, esp. pp. 183 e ss., pp. 196 e ss.

593 "Liberal equality does not count, among the personal resources which affect the equality of someone's circumstances, the preferences, tastes, convictions, predilections, ambitions, attachments and other features of personality that will in fact play an important role when he decide show content he is with the life he leads", "Foundations of Liberal Equality", op. cit., p. 293.
} 
Dworkin descreve - mas não enfrenta - a seguinte questão: por que compensar falta de talentos e não, por exemplo, determinada preferência por bem custoso (que, portanto, talvez não possa ser consumido tanto quanto o indivíduo gostaria, o que o frustra) $?^{594} \mathrm{O}$ ponto crucial do autor neste artigo sob análise, e de fato ponto mais relevante a este trabalho, é saber se e por que liberais éticos, que adotam o modelo do desafio, têm razão para adotar a distinção entre circunstâncias e personalidade e reservar as primeiras como objeto da justiça enquanto igualdade ${ }^{595}$. A razão, diz Dworkin, é a seguinte:

"A igualdade liberal foi concebida [is designed] para os liberais éticos: ela tem o objetivo de fazê-los iguais em suas circunstâncias, e ela entende as circunstâncias de uma pessoa como o conjunto de oportunidades e de limitações que ele encontra ao identificar e perseguir o que ele considera, após reflexões, ser uma vida apropriada para ele. Talentos e deficiências são claramente circunstâncias neste sentido. Mas convicções e preferências claramente não são. Seria incoerente que eu considerasse uma convicção que eu tenho - que a única coisa importante para fazer na minha vida é criar monumentos religiosos, por exemplo - como uma limitação na bondade da vida que posso levar. Se essa é a minha visão sobre o que uma boa vida seria para mim, então devo achar que eu ter essa vida é essencial a levar uma boa vida; não pode ser uma limitação porque eu ficaria pior, e não melhor, sem ela. Logo, a distinção entre deficiências e personalidade é tão pouco arbitrária quanto a própria ética. (...) Logo, novamente um aspecto controverso da igualdade liberal pode ser traçado a uma concepção particular de reflexão ética. A igualdade liberal tem o objetivo de ser contínua com as reflexões dos liberais éticos; ela tem o objetivo de fornecer uma teoria da justiça tal que as pessoas podem usar eticamente, nas suas próprias vidas a partir da sua perspectiva pessoal, bem como publicamente a partir da sua perspectiva política. Se as pessoas não podem considerar as suas próprias convicções e preferências como limitações, não podem aceitar e usar uma teoria da justiça que trata a cegueira e a convicção nos mesmos termos.". ${ }^{596}$

Em outras palavras, se para os liberais éticos, que adotam o modelo do desafio, a justiça é parâmetro da ética, demanda-se da justiça a capacidade de se inserir na reflexão ética, o que, por sua vez, exige uma teoria da justiça que faça a distinção entre circunstâncias e

594 “Foundations of Liberal Equality", op. cit. pp. 293-4; Dworkin dá o exemplo do indidívuo que cultiva o hábito de comer caviar ou que deseja construir catedrais (p. 294, p. 296) e nas pp. 294-5 e 296-7 rebate a defesa de que a linha divisória entre aquilo que deve ser compensado e aquilo que não seja traçada pela separação entre situações involuntárias das voluntárias. Veja ainda "Equality of Welfare", op. cit., pp. 48 e ss. e "Equality of Resources", op. cit., pp. 81 e ss. Contrastando a teoria da igualdade de Dworkin e a concepção dos "luck-egalitarians", Ripstein diz que as diferenças que encontra entre estas concepções indica que a controvérsia entre elas "(...) is not about where to make the 'cut' between choices and circumstances at all, or even about what the appropriate metric of equality is. Both of these questions reflect a deeper issue about the importance of individual choice in relation to equality. For Dworkin, the requirement that the state treat its citizens with equal concern and respect applies against the background of the requirement that each citizen has a special responsibility for his or her own life. For the luck-egalitarian, by contrast, people do not have a responsibility for their lives as a whole but rather for the discrete decisions they make about particular matters", p. 96 (para as diferenças que motivam esta conclusão, veja pp. 94-6; veja pp. 96 e ss. em geral.).

595 "Foundations of Liberal Equality", op. cit., pp. 293-7.

596 "Foundations of Liberal Equality", op. cit., pp. 295-6, nota omitida, itálicos no original, traduzi, mantive entre colchetes palavras do original. Veja Guest: para Dworkin, "our viers about what constitutes the good life cannot be regarded as handicaps (unless we thought them wrong, in which case they would not be our views)", Ronald Dworkin, op. cit., p. 198 (veja pp. 197 e ss. em geral). 
personalidade e que restrinja a igualdade às primeiras porque é incoerente entender a segunda como produto do exercício da capacidade ética de reflexão e, em seguida, julgá-la capaz de justificar compensação. ${ }^{597}$ Dworkin afirma que nenhum esquema de compensação por aspectos da personalidade seria possível (quem poderia sinceramente pedir recursos por fato da sua personalidade, que julga positivo? Os recursos não ajudariam a financiar, em vez de compensar, este fato? Entre outros ${ }^{598}$ ), mas, independentemente disso, são inadmissíveis aos liberais éticos "porque ele não seria um esquema que pudesse desempenhar o papel dinâmico dentro da ética que eles querem que uma teoria da justiça desempenhe. Ninguém poderia identificar os recursos que deveria ter para compensar as crenças erradas que ele não poderia considerer erradas. ${ }^{, 599}$. A igualdade de recursos é desta forma integrada à ética liberal porque fornece a discriminação entre personalidade e circunstância que é necessária ao exercício das responsabilidades que o modelo do desafio atribui ao indivíduo em relação à formação das suas convicções e que, portanto, não atraem intervenção da justiça. Logo, Dworkin estabelece uma conexão entre ética e política liberais, entre o modelo do desafio, que trata a justiça como parâmetro da ética, e a igualdade de recursos, que faz a distinção entre personalidade e circunstâncias que é exigida pela ética liberal em razão de fornecer o tipo de reflexão sobre justiça que decorre da impossibilidade de julgar aspectos da vida próprios da personsalidade como capazes de justificar qualquer esquema de compensação. ${ }^{600}$

$\mathrm{O}$ autor tem outros dois argumentos concretos, que conectam o modelo do desafio à igualdade de recursos ${ }^{601}$. A opção imaginada por Dworkin à igualdade de recursos é o que ele chama de igualdade de bem-estar. Dworkin enxerga no modelo do desafio incompatibilidade com a igualdade de bem-estar e compromisso com a igualdade de recursos porque o processo de alcance da justiça na primeira teoria, ao contrário do que ocorre na segunda, define bem estar dos indivíduos sem recurso à justiça (afinal, utiliza o bem-estar como medida da justiça, e não o contrário), o que é impossível a quem trate a justiça como parâmetro ético e, portanto, a

\footnotetext{
597 "Foundations of Liberal Equality", op. cit., p. 297.

598 "Foundations of Liberal Equality", op. cit., p. 297.

599 "Foundations of Liberal Equality", op. cit., p. 297. Dworkin sustenta que a continuidade entre ética e moral é, então, de primeira pessoa, e não terceira, pois é possível que eu, terceiro, julgue como limitações os aspectos da sua personalidade (pp. 296-7).

${ }^{600}$ Compare com a dimensão de responsabilidade da autenticidade em Justice for Hedgehogs, op. cit., esp. pp. 210-1, mencionada brevemente na segunda subseção da seção anterior.

601 "Foundations of Liberal Equality", op. cit., pp. 280-285 em geral.
} 
utilize para definir quais são os interesses críticos dos indivíduos ${ }^{602}$. Ainda, Dworkin enxerga em versão hedonista do modelo do impacto a possibilidade de elaboração de uma teoria da justiça que, em procedimento de duas etapas, primeiro estabelece quanto cada pessoa tem de prazer sob cada organização econômica, e, num segundo momento, se estabelecem quais instituições são capazes de gerar mais prazer ${ }^{603}$. Antes, o autor imagina este procedimento aplicado a teoria da justiça que trata bem-estar como satisfação de interesses volitivos, ideia rejeitada tanto pelo modelo do desafio quanto pelo modelo do impacto, elaborados por Dworkin como modelos de interesses críticos ${ }^{604}$. Este tipo de procedimento está indisponível ao modelo do desafio porque, para um liberal ético, a definição de interesse crítico, ao contrário do que ocorre em qualquer versão do modelo do impacto, não só a hedonista, é dependente da medida justa de recursos ${ }^{605}$. Como vimos acima, para Dworkin, os liberais éticos pensam sobre justiça de modo a conectá-la à ética, eis que lhes é impossível definir interesses normativos dos indivíduos sem definir qual parcela dos recursos é justo que tenham à sua disposição; logo, estes interesses ou o seu atendimento não podem esgotar o significado da justiça. Ele diz:

“(...) no modelo do desafio (...) a ética e a justiça são dinamicamente inter-relacionadas. As pessoas que veem o seu bem-estar [well-being] naqueles termos se amparam em instintos ou assunções sobre como as suas vidas se conectam e se relacionam com as vidas de seus vizinhos e concidadãos em todas as decisões que tomam acerca de quais das maneiras possíveis de viver seria viver bem para eles. Logo, eles não podem aceitar nenhuma teoria da justiça que pressupõe que bem-estar [well-being] e justiça são duas coisas separadas, como deve [fazer] qualquer teoria que tome o bem-estar [welfare] como métrica da justiça. Eles precisam de uma explicação da justiça que responda à exigência que identificamos, que recursos entrem na ética como parâmetros normativos, e somente uma visão de justiça baseada em recursos pode fazer isso." ${ }^{\prime 606}$.

Em outras palavras, o modelo do desafio é incompatível com qualquer teoria que pretenda definir interesses sem recurso à justiça, e, por tratar a justiça da quantidade de recursos disponível a um indivíduo relevante à definição de seus interesses críticos, entende a justiça em termos de recursos; daí a ligação estabelecida pelo autor entre sua ética liberal e sua teoria política liberal.

\footnotetext{
602 "Foundations of Liberal Equality", op. cit., p. 283.

603 "Foundations of Liberal Equality", op. cit., pp. 282-3.

604 "Foundations of Liberal Equality", op. cit., veja pp. 280 e ss. e pp. 240 e ss.

605 "Foundations of Liberal Equality", op. cit., p. 283.

606 "Foundations of Liberal Equality", op. cit., p. 283, traduzi, acrescentei o "fazer" entre colchetes e mantive entre colchetes as palavras em inglês, que são do original.
} 
Existe ainda um terceiro argumento deste tipo, apresentado por Dworkin logo após este último: qualquer teoria de justiça enquanto bem-estar prejudica o enfrentamento do desafio que caracteriza a vida. O modo de calcular o bem-estar nestas teorias, que é o procedimento em duas etapas descrito acima, "promove prejuízo a desafio de maneira fatal, porque funcionários tentam garantir que as pessoas levem vidas que são igualmente boas, ou em média igualmente boas, independentemente das escolhar de vida que elas tomam por elas mesmas ${ }^{607}$. O prejuízo ao desafio reside na impossibilidade de um indivíduo arcar com as responsabilidades das suas escolhas, pois quaisquer que sejam - por exemplo, se mal sucedidas - poderão ser compensadas dada a necessidade de corrigir o bem-estar do indivíduo, que diminui dado seu insucesso ${ }^{608}$. Em outras palavras, Dworkin liga a sua ética à sua política da seguinte maneria: o modelo do desafio, ao atribuir ao indivíduo a responsabilidade de interpretar as circunstâncias da sua vida, rejeita a igualdade de bem-estar, que neutraliza as consequências das decisões éticas tomadas por ele, e aponta para a igualdade de recursos como a teoria capaz de atender tanto ao requisito de que a justiça é parâmetro da ética quanto à percepção de que o valor da vida reside em performance executada pelo próprio indivíduo, o que inclui as consequências disso decorrentes ao seu bem-estar. ${ }^{609}$ Trata-se fundamentalmente de consequência política da ideia ética defendida pelo autor em Justice for Hedgehogs sob rubrica de "princípio da autenticidade".

É nos termos destes argumentos que Dworkin integra ética e política no seu pensamento. Algumas objeções podem ser levantadas dada a natureza do argumento e as conclusões desta seção. Como vimos, o autor entende que valores políticos como liberdade e igualdade são integrados com o viver bem: na sua ética liberal, o desafio de viver bem precisa ser definido com recurso à política porque a justiça de uma vida é parâmetro de sua qualidade $^{610}$; e também a correta caracterização da justiça depende do modelo do desafio pois aos liberais éticos imaginados por Dworkin não é dado, em razão de sua adesão a este modelo, crer que age com justiça uma comunidade que se arroga a autoridade de interpretar em nome

\footnotetext{
607 "Foundations of Liberal Equality", op. cit., p. 284, traduzi.

608 "Foundations of Liberal Equality", op. cit., p. 284; Dworkin enxerga as seguintes consequências éticas à aplicação do procedimento de dois estágios da igualdade de bem-estar: "an individual has no genuine responsibility for the design of his life. It will be equally good, judged by the right standards, no matter how ethically perceptive or insensitive he has been".

609،"Foundations of Liberal Equality", op. cit., pp. 283-5, veja em geral pp.280-285

610 "Foundations of Liberal Equality", op. cit., pp. 258-262..
} 
dos indivíduos as circunstâncias da vida ${ }^{611}$. Assim se entendem, para o autor tanto a igualdade quanto a liberdade na forma de liberdades que constituem os termos do leilão imaginário que funda a igualdade de recursos, teoria da igualdade defendida por Dworkin.

A alguns a conclusão de Dworkin pode soar contra intuitiva e artificial. Parece contra intuitiva porque, se é difícil concordar que a vida de alguém possa, em qualquer sentido, ser aprimorada pela realização de ato tão desprezível quanto a propaganda de teorias racistas, misóginas etc., tanto mais parece inadmissível que a vida de um indivíduo possa ser piorada por tentar proibir este tipo de atitude. Parece artificial porque resultado de um mecanismo abstrato, de associação de conceitos, desconectado da realidade prática da política.

Estes não são propriamente argumentos. O argumento de Dworkin é abstrato, e a natureza filosófica da teoria da justiça exige que o seja. Que o argumento é abstrato não é argumento que lhe seja levantável porque abstração não é defeito. Distância da prática política tampouco é argumento: a filosofia e as suas abstrações servem à política, mas servi-la significa examente orientá-la e corrigi-la, e não submeter-se a ela como podem querer alguns. Em outras palavras, o condicionamento da filosofia a propósitos práticos é uma questão de orientação, e não de conteúdo: no que diz respeito ao significado, a prática deve curvar-se ao bom argumento, abstrato ou não.

Ainda, há algo a ser acrescentado sobre a natureza contra-intuitiva do argumento, e suspeito que muito da dificuldade contemporânea e brasileira em apreciar as liberdades decorra da falta de apreciação do tipo de problema envolvido na violação de um direito, ideia que Dworkin pretendeu expor ao formular a ideia de "fator de injustiça" ou "moral harm" (veja primeira seção do capítulo primeiro, acima). Acredito que passamos por um processo de tentativa de materialização das violações das liberdades, como se só houvesse ofensa a direito quando um resultado naturalístico (para usar expressão da dogmática) sobrevém, seja ele físico ou psicológico. A ideia de "direito no sentido forte" (e todas as características das liberdades, talvez em especial a lista - exposta no capítulo primeiro - daquilo que não são) garantem uma abstração inerente à noção de liberdades. Não é preciso sofrer para ter direito violado; não é preciso sequer se importar; pode-se, aliás, celebrar violação de um direito. Nada disso importa, nada disso é necessário, nada disso caracteriza o prejuízo que existe no desrespeito a um direito ou a uma liberdade.

\footnotetext{
611 "Foundations of Liberal Equality", op. cit, pp. 275-305.
} 
Isso tudo, naturalmente, coloca em questão a importância dos direitos. A sua aparente desconexão da realidade do sofrimento humano mais elementar parece lhe subtrair o seu fundamento mais óbvio $^{612}$. A este ceticismo a resposta dworkiniana, sem surpresas, é teórica: justiça é questão de igualdade de recursos e não de bem-estar, e direitos a liberdades, entre eles a liberdade de expressão, se fundamentam em concepção de ética e em interpretação de valores políticos como a igualdade e a democracia. Veremos em detalhes no próximo capítulo como o autor constrói essa justificação, que não ignora o sofrimento salvo no sentido relevante a qualquer teoria que trata o bem-estar como padrão de boa vida e de justiça. O ponto importante é que os argumentos de Dworkin - como qualquer argumento - são reféns exclusivamente da sua eventual falta de cogência, o que se mede teórica e argumentativamente. Reclamar uma noção de direitos ou de igualdade mais próxima da realidade e do sofrimento humanos é reclamar noção não mais próxima do mundo concreto da política, mas próxima em outro sentido, sentido ele mesmo que não pode passar sem defesa ou somente com base em intuições sobre, por exemplo, a função da política de amenizar sofrimentos ou prevenir consequências sensíveis. Não sem surpresas, esta defesa deverá ser $\operatorname{argumentativa}^{613}$, o que exige engajamento exatamente no tipo de exercício que, nas mãos de Dworkin, culminou nas conclusões expostas nesta dissertação. O teste final de qualquer intuição ou desconfiança é portanto demandante e indistinto daquele empregado pelo próprio autor. Vejamos um exemplo deste tipo de elaboração teórica antes de passar ao capítulo final desta dissertação.

\section{Seção 4. Conclusão, com um exemplo: autenticidade e obscenidade}

Vimos neste capítulo o significado e execução do projeto dworkiniano de integrar a ética, bem como algumas de suas consequências ao tema das liberdades. Nesta seção, a título de conclusão deste capítulo, e de pavimentação do caminho ao próximo, especificamente dedicado à liberdade de expressão no autor, eu gostaria de explorar as hipóteses de recurso

\footnotetext{
${ }^{612}$ Veja Waldron, The Harm in Hate Speech, op. cit., esp. cap. 5, esp. pp. 105-116, 118 e ss., sobre a distinção entre dignidade e ofensa e a defesa da primeira, aspecto social e não subjetivo dos sentimentos da vítima (p. 106, por exemplo), como fundamento à proibição do hate speech (embora o autor não ache que a ofensa a sentimentos seja irrelevante - veja p. 112, por exemplo - e por vezes simplesmente a considere objeto de argumento não necessariamente contraditório com o seu - p. 114, por exemplo).

${ }^{613}$ Veja Law's Empire, op. cit., esp. cap. 2 para a natureza argumentative do direito e Justice for Hedgehogs, op. cit. (veja ainda Guest, Ronald Dworkin, op. cit. esp. p. 159 e Caio Moysés de Lima, O Império dos Direitos: Lei e Autoridade Política em Ronald Dworkin, op. cit., pp. 13 e ss.).
} 
explícito de Dworkin à autenticidade para justificar direitos, especificamente os direitos envolvidos na publicação de material obsceno. Procuro demonstrar que a visão de Dworkin sobre o tema não é tão coerente quanto se pode esperar, mas que a obra do autor indica critérios que apontam para a seleção da opção interpretativa da autenticidade que é mais generosa à liberdade de expressão ligada à pornografia. Esta é, também, uma seção exegética em que exploro texto a texto por ordem de publicação (salvo algumas referências a capítulo de Freedom's Law), o tema da autenticidade ou similares e os tratamentos aparentemente distintos dispensados por Dworkin ao discurso de ódio e à obscenidade. Não é, entretanto, meu objetivo esgotar a análise da obra de Dworkin sobre esta questão porque na quarta seção do próximo capítulo o direito à pornografia retornará. Uma vez que o objetivo é exegese dos textos do autor, permito-me extensas citações. Começo retomando temas já discutidos nesta dissertação.

Em "The Place of Liberty" (1987), que é o capítulo terceiro de Sovereign Virtue, Dworkin apresenta um dos princípios que formam a baseline na estratégia da ponte, versão do que chama de estratégia constitutiva que liga o princípio igualitário abstrato ao leilão imaginário, próprio da sua teoria da justiça distributiva, a igualdade de recursos. Dworkin, após admitir dificuldades sobre a formulação do princípio e das condutas por ele permitidas ${ }^{614}$ escreve sobre o que chama de "princípio da autenticidade"615.

“(...) qualquer princípio aceitável deve ter certo alcance. A autenticidade tem voz ativa e passiva: os participantes do leilão gostariam de uma oportunidade de formar e ponderar suas próprias convicções; apegos e projetos, e uma oportunidade de exercer influência sobre as opiniões correspondentes de outrem, das quais depende muito seu próprio êxito no leilão. Esperaríamos encontrar, portanto, dentro das amplas dimensões de qualquer princípio da autenticidade que a estratégia da ponte recomende, uma justificativa para permitir uma proteção especial à liberdade de culto religioso [religious commitment], à liberdade de expressão, ao mais amplo acesso à literatura e a outras formas de arte, à liberdade de associação pessoal, social e íntima, e também à liberdade da não expressão, na forma da liberdade contra a vigilânciaa [surveillance] $]^{, 616}$.

Como vimos, autenticidade, além de princípio que regula o leilão imaginário, é o segundo princípio ético da concepção de dignidade defendida por Dworkin. O que eu gostaria de destacar é que o princípio da autenticidade é composto por duas vozes, a saber, uma ativa e outra passiva. Como veremos, é muito parecido com a ideia de responsabilidade moral

\footnotetext{
614 "The Place of Liberty" op. cit., p. 159.

615 "O lugar da liberdade", op. cit., pp. 215 e ss.; no original, "The Place of Liberty", op. cit., pp. 158 e ss.

616 "O lugar da liberdade", op. cit., pp. 217-8, acrescentei entre colchetes palavras do original; "The Place of Liberty" op. cit., p. 160.
} 
oferecida posteriormente pelo autor e por ele entendida como possuidora de um aspecto, digamos, passivo e outro "mais ativo".

Em Freedom's Law, Dworkin compila artigos sobre liberdade de expressão em que defende o direito ao discurso de ódio e à pornografia. Entretanto, o autor sustenta que a pornografia não veicula "idéias": no Adendo ao capítulo 9 ("Addendum: A Response to MacKinnon's Reply" in "MacKinnon's Words"), respondendo a Catharine MacKinnon, o autor diz que

“[Ela] Exige também que eu defenda a tese de que a pornografia gira em torno de [is about] 'idéias'. A verdade é que eu cuidei de rejeitar explicitamente esta opinião: disse que a maior parte dos materiais pornográficos não propõe idéia nenhuma e que seria errado procurar invocar para eles a proteção da Primeira Emenda com base na noção de que eles propõem". ${ }^{617}$

Em outras palavras, o fato de um discurso veicular ideias pode servir de distinção entre os direitos do discurso de ódio político da pornografia, isto é, se o discurso a ser permitido é só aquele que expressa ideias, então se torna difícil defender que pornografia compõe a liberdade de expressão. Mas Dworkin não vê relevância nesta questão. É que a sua defesa da liberdade de expressão acentua um direito individual: imediatamente após o trecho citado acima, Dworkin diz:

"Acrescentei, porém, que todos os cidadãos têm o mesmo direito de contribuir para a formação do que chamei de 'ambiente moral' - até mesmo as pessoas cujos gostos não refletem 'idéias', mas somente 'preconceitos, culturas e estilos de vida' profundamente desgradáveis [verry offensive]."

Com efeito, no capítulo oitavo de Freedom's Law - "Why Must Speech be Free?", de 1992 - após expor o que chama de justificação "instrumental” da liberdade de expressão ${ }^{619}$, o autor defende a ideia de responsabilidade moral como categoria fundamental à compreensão da liberdade de expressão e seus limites:

"O segundo tipo de justificação da liberdade de expressão pressupõe que ela é importante não só pelas consequências que tem, mas porque o Estado deve tratar todos os cidadãos adultos (com exceção dos incapazes) como agentes morais responsáveis, sendo esse um traço essencial ou 'constitutivo' de uma sociedade política justa. Essa exigência tem duas dimensões. Em primeiro lugar, as pessoas moralmente responsáveis fazem questão de tomar suas próprias decisões acerca do que é bom ou mal [sic] na vida e

\footnotetext{
617 “Addendo - resposta à réplica de MacKinnon” em “As palavras de MacKinnon”, op. cit., p. 388, acrescentei palavras do original entre colchetes; no original, "Addendum: A Response to MacKinnon's Reply" in "MacKinnon's Words" op. cit., p. 242.

618 "Addendo - resposta à réplica de MacKinnon” em “As palavras de MacKinnon”, op. cit., p. 388, acrescentei palavras do original entre colchetes; no original, "Addendum: A Response to MacKinnon's Reply" in "MacKinnon's Words" op. cit., p. 242.

619 "Why Must Speech be Free?" op. cit., pp. 199-200.
} 
na política e do que é verdadeiro ou falso na justiça ou na fé. O Estado [Government] ofende [insults] os seus cidadãos e nega a responsabilidade moral deles quando decreta que eles não têm qualidade moral [cannot be trusted] para ouvir opiniões que possam perssuadi-los a [to] convicções perigosas ou desagradáveis. Só conservamos nossa dignidade individual quando insistimos em que ninguém - nem o governante nem a maioria dos cidadãos - tem o direito de nos impedir de ouvir uma opinião por medo de que não estejamos aptos a ouvi-la e ponderá-la.

"Para muita gente, a responsabilidade moral tem um outro aspecto, um aspecto mais ativo: seria a responsabilidade não só de constituir convicções próprias, mas também de expressá-las para os outros, sendo esta expressão movida pelo respeito para com as outras pessoas e pelo desejo ardente de que a verdade seja conhecida, a justiça seja feita e o bem triunfe. O Estado frustra e nega esse aspecto da personalidade moral quando impede que certas pessoas exerçam essas responsabilidades, justificando o impedimento pela alegação de que as convicções delas as desqualificam [make them unworthy participants]. Na mesma medida em que o Estado exerce o domínio político sobre uma pessoa e exige dela obediência política, não pode negar nenhum desses dois aspectos da responsabilidade moral da pessoa, por mais odiosas que sejam as opiniões que esta decida ponderar ou propagar. Não pode fazê-lo do mesmo modo pelo qual não pode negar-lhe o direito de voto. Se o Estado faz isso, abre mão [forteits] de um aspecto substancial da sua reivindicação de poder legítimo. Quando o Estado proíbe a expressão de algum gosto ou atividade social, o mal que ele faz é tão grande quanto o de censurar o discurso explicitamente político; assim como os cidadãos têm o direito de participar da política, também têm o direito de contribuir para a formação do clima moral e estético" ${ }^{620}$.

Deste trecho, gostaria de destacar dois aspectos (outros serão analisados no próximo capítulo). Em primeiro lugar, é importante observar a defesa explícita da dimensão "mais ativa" da responsabilidade moral, isto é, “(...) responsabilidade (...) de expressá-las [as convicções] para outros" ${ }^{621}$. Reside neste ponto a analogia relevante a esta seção guardada pelas ideias de responsabilidade moral em Freedom's Law e autenticidade no capítulo terceiro de Sovereign Virtue. Em "Why Must Speech be Free?”, capítulo oitavo de Fredeom's Law, essa dimensão ativa implica que, para Dworkin, a ideia de responsabilidade moral oferece justificação não só do direito à pornografia possuído pelo consumidor, direito este mais claramente amparado na primeira dimensão de responsabilidade moral, mas também do possuído pelo autor da pornografia ou por aquele que a publica ${ }^{622}$. Em segundo lugar, há aqui

\footnotetext{
620 "Por que a liberdade de expressão?", op. cit., pp. 319-20, acrescentei as palavras do original entre colchetes e o [sic] para indicar que mantive expressão da tradução, mas substitui "de" por "a" para traduzir "to" (mantido entre colchetes); no original, "Why Must Speech be Free?" op. cit., pp. 200-1 (veja também pp. 207-8). Veja ainda Dworkin, "Foreword" in Ivan Hare e James Wiestein (Eds). Extreme Speech and Democracy. Oxford: OUP, 2009 , esp. “(...) freedom of speech is not just instrumental to democracy but constitutive of that practice (...)", p. v. Veja, no capítulo três, seção 3 e subseção 4.1. Veja o comentário de Waldron a Geoffrey Stone e sua defesa da restrição do "hate speech" em The Harm in Hate Speech, op. cit., pp. 152-4.

621 "Por que a liberdade de expressão?", op. cit., p. 320, acrescentei as palavras entre colchetes para esclarecer o significado da citação; no original, "Why Must Speech be Free?" op. cit., p. 200.

${ }_{622}$ Não pretendo aqui endossar a distinção entre direitos do consumidor e direitos do autor. Dworkin por vezes fala mais de um que de outro, e ressalta que a liberdade de expressão é quase que somente um direito do autor ("Introduction" to Dworkin (Ed.) The Philosophy of Law, Oxford: Oxford University Press, 1977 e "Is the Press Losing the First Amendment?", op. cit.). Eric Barendt faz questão da distinção e enxerga em um dos trabalhos de Dworkin sobre pornografia preocupação exclusiva sobre direitos dos consumidores, o que o torna pouco relevante
} 
a explícita defesa de um direito de influenciar "o clima moral e estético" em pé de igualdade com o direito de influenciar o ambiente político. ${ }^{623}$ Que a pornografia não são ideias tampouco discurso político não é motivo relevante, na opinião de Dworkin, para lhe reconhecer menor liberação do que a outros discursos. Este é o estado das liberdades associadas à pornografia em nos capítulos 8 a 10 de Freedom's Law ${ }^{624}$ : um direito (i) tanto do consumidor quando do autor e que goza de (ii) paridade com o discurso político, como o discurso político de ódio. Chego agora a Justice for Hedgehogs.

Como vimos, as ideias dworkinianas de autenticidade e de responsabilidade moral adquiriram, respectivamente em Sovereign Virtue e em Freedom's Law, característica ativa. Já não é este o tom da ideia de autenticidade em Justice for Hedgehogs, publicado em 2011. Como visto acima neste capítulo, a autenticidade é apresentada por Dworkin no capítulo nono de Justice for Hedgehogs como o segundo princípio de dignidade. Trata-se ideia possuidora de duas dimensões, a saber, uma que o autor chama de responsabilidade ${ }^{625}$ e outra, que é a relevante para os meus propósitos, por ele chamada de independência ética ${ }^{626}$. Lembre-se o

à medida dos direitos de liberdade de expressão envolvidos na produção e publicação da pornografia (Freedom of Speech, op. cit., pp. 7, 14-5, 353, 356, 360). Langton faz observação semelhante: após citar a p. 358 de "Do We Have a Right to Pornography", op. cit., ela diz: "Note that Dworkin uses the term pornographer to mean 'consumer of pornography'; I follow his usage for the purposes of this article", "Whose Right? Ronald Dworkin, Women, and Pornographers, op. cit., p. 328, n. 51 (itálico no original?). Este é um tema delicado e interessante mas não julgo necessários elaborá-los. Ficará para outra ocasião.

623 "Por que a liberdade de expressão?", op. cit., p. 320, no trecho citado acima; no original, "Why Must Speech be Free?" op. cit., p. 200. Veja ainda, para "ambiente moral", "As palavras de MacKinnon", op. cit., p. 380; no original, "MacKinnon's Words", op. cit., pp. 237 (veja ainda "Addendum: A Response to MacKinnon's Reply" in "MacKinnon's Words", p. 242 e“Why Academic Freedom?”, op. cit., 247-8). Veja, no próximo capítulo, subseção 4.1.

${ }^{624}$ No capítulo 11, "Why Academic Freedom?", op. cit., o discurso político recebe mais relevo: "People who accept ethical individualism accept consequent responsibilities. The first is the responsibility not to profess what one believes to be false. This duty is protected, in liberal societies, by a right of conscience that forbids forcing people to religious or moral or political declaration against their will. The second is a more positive responsibility of affirmation: it is the duty to speak out for what one believes to be true. According to ethical individualism, we all have that duty as citizens: it is wrong to remain silent when our society must make a collective decision and we believe we have information or opinion it should take into account. We have that responsibility even when we know that our opinion will not be heeded - when the state acts unjustly, for example, and we know we can only bear witness to our anger at what it does in our name. That sense of responsibility, and of the moral damage done when we are prevented from exercising it, is part of the medley of reasons that together make it so important to us, as individuals, that we have a general right of free speech on political matters.", pp. 250-1. Veja, abaixo, subseção 4.3. do capítulo terceiro e conclusão desta dissertação.

${ }^{625}$ Dworkin discute a dimensão de responsabilidade enquanto princípio de dignidade em Justice for Hedgehogs, op. cit., pp. 209-11; esta ideia de responsabilidade não me parece apontar para a mesma questão que a capturada pela ideia de responsabilidade moral defendida em Freedom's Law - esta ideia me parece capturada pela ideia de independência ética, e é por isso que eu a discuto.

${ }^{626}$ Justice for Hedgehogs, op. cit., pp. 209 e ss. 
leitor de que a independência ética, dimensão da autenticidade, requer, em trecho que citei acima, as escolhas importantes da vida de um indivíduo sejam tomadas por ele mesmo. ${ }^{627}$

Julgo evidente a semelhança entre o segundo princípio de dignidade, isto é, a ideia de independência ética e a primeira dimensão da ideia de responsabilidade moral defendida por Dworkin no capítulo oitavo de Freedom's Law: relembremos que, para o autor, a responsabilidade exige das pessoas que elas mesmas formem suas opiniões sobre política, justiça e fé ${ }^{628}$. Relembremos também que o autor expressa as demandas desta dimensão de responsabilidade moral como uma questão de dignidade ${ }^{629}$.

De volta a Justice for Hedgehogs e mais diretamente à liberdade de expressão. Como visto, para Dworkin o direito à liberdade de expressão se funda na independência ética, aspecto da autenticidade, segundo princípio da concepção de dignidade por ele defendida ${ }^{630}$. A diferença que procuro explorar decorre de o autor considerar que a proibição do discurso de ódio de conteúdo político pode violar a independência ética de dois modos, enquanto a proibição da obscenidade só a viola de uma maneira. Os seguintes trechos de Justice for Hedgehogs expõem claramente a distinção:

“(...) a liberdade de expressão, tal como entendida nas democracias ocidentais, abrange mais do que a expressão política, mesmo concebida de forma lata; temos de levar em conta mais do que a liberdade positive para explicar tudo aquilo que abrange - e que não abrange. Embora um Estado possa promover, de várias maneiras, aquilo que coletivamente é considerado válido na literatura, na arte e na música, não pode proibir seus membros de lerem, verem e ouvirem o que quiserem, quando a sua única justificação é que certas opiniões sobre o que vale a pena ser apreciado são ofensivas a si mesmas e podem ser contagiosas. O material sexualmente explícito é protegido por um direito à liberdade de expressão, não porque exprima uma posição política - isto é improvável [far-fetched] -, mas porque os únicos argumentos existentes para o banir são, como afirmei, ofensivos para a independência ética.

"A censura pode não só ameaçar a liberdade positiva, mas também, como disse, violar o direito à independência ética das duas maneiras que distingui. Veja-se como vários fatores interagem quando o governo tenta banir o discurso de ódio. Os juízes de Ohio condenaram um dirigente do Ku Klux Klan pelo crime de promover o ódio aos negros e aos judeus. (10). Assim interpretada, a lei violava o seu direito à liberdade positiva, pois proibia-o de tentar levar outros cidadãos a aderirem às suas opiniões. Violava o seu direito à independência ética, uma vez que o direito de exprimir publicamente [to bear public witness] as suas convicções políticas é essencial [foundational] e qualquer violência que ele defendesse contra outros não era iminente. Violava a sua independência ética de outra maneira se, como parece provável, a acusação fosse motivada não por receio de violência, mas por uma repulsa totalmente justificável em relação ao seu baixo apreço pela importância de certas vidas. O Supremo Tribunal [Supreme Court] anulou a condenação; no entanto, cito esse exemplo não para ilustrar a lei

${ }^{627}$ Justice for Hedgehogs, op. cit., p. 212.

628 "Por que a liberdade de expressão?", op. cit., pp. 319-20, trecho citado acima; no original, "Why Must Speech be Free?", op. cit., pp. 200-1.

629 "Por que a liberdade de expressão?", op. cit., pp. 319-20, trecho citado acima; no original, "Why Must Speech be Free?", op. cit., pp. 200-1.

${ }^{630}$ Justice for Hedgehogs, op. cit. cap. 9; veja, acima, subseção 2.2. deste capítulo. 
constitucional [American constitutional law] mas para mostrar a confluência de aspectos da liberdade positiva e da liberdade negativa em ação, honradamente, para proteger os direitos dos detestáveis". ${ }^{631}$

É curioso observar que, ao mencionar obscenidade, Dworkin sustenta, no trecho citado, que “(...) um Estado (...) não pode proibir seus membros de lerem, verem e ouvirem o que quiserem" ${ }^{632}$ : todos os verbos - ler, ver e ouvir - são passivos. Como se vê, a dimensão mais ativa do direito à liberdade de expressão fica reservada ao discurso político, como o de ódio. É que, para Dworkin, é uma questão ética "fundacional",633 de uma pessoa que ela possa expor sua opinião política. E pornografia não tem conteúdo político, diz ele. Mas não seria igualmente "fundacional" que um indivíduo possa expor a sua opinião sobre questões morais, comportamentais etc.? Esta pergunta a meu ver recebe resposta necessariamente afirmativa à luz tanto da voz ativa do princípio da autenticidade defendido pelo autor no capítulo terceiro de Sovereign Virtue quanto do aspecto "mais ativo" da responsabilidade moral que Dworkin oferece enquanto justificação constitutiva da liberdade de expressão no capítulo oitavo de Freedom's Law.

Vale recapitular a exegese feita acima dada a pluralidade de categorias, conexões e distinções. Muito brevemente, em "The Place of Liberty” (publicado em Sovereign Virtue), o princípio da autenticidade, que compõe a baseline defendida pelo autor para o leilão imaginário caracterizador da igualdade de recursos, é ativo tanto quanto passivo ${ }^{634}$. Já em "Why Must Speech be Free?” (publicado como capítulo oitavo de Freedom's Law), Dworkin defende a liberdade de expressão com base na ideia de responsabilidade moral que, no seu

\footnotetext{
${ }^{631}$ Justiça para ouriços, op. cit., pp. 381-2, mantive entre colchetes palavras do original, o (10) indica posição da nota de rodapé 10 (veja p. 491, n. 10 à p. 381, com o seguinte texto: "Brandenburg v. Ohio, 395 U.S. 444 (1969)", itálicos no original); no original, Justice for Hedgehogs, op. cit. pp. 372-3; O (10) marca a posição da nota 10, p. 482 à p. 373. Veja Guest, Ronald Dworkin, op. cit., p. 177. Veja nota ao capítulo primeiro desta dissertação para discussão sobre o critério de inspiração no juiz Holmes que Dworkin adota para restringir direitos. Veja ainda Is Democracy Possible Here?, op. cit., pp. 152-3 (trecho citado em nota abaixo). Compare com a defesa da liberdade de expressão elaborada por C. Edwin Baker, como descrita e criticada por Waldron em The Harm in Hate Speech, op. cit., cap. 6, esp. pp. 161 e ss. (me parece bastante semelhante com a de Dworkin ou, pelo menos, Waldron a expõe de modo parecido, por exemplo, ao distinguir liberdade de expressão de outras "liberdades" - veja, além das páginas indicadas, pp. 157 e ss.).

${ }_{633}^{63}$ Justiça para ouriços, op. cit., p. 381; no original, Justice for Hehgehogs, op. cit., trecho citado, p. 372.

${ }^{633}$ Justice for Hedgehogs,op. cit., p. 369, para "fundational independence", traduzida como "independência essencial" em Justiça para ouriços, op. cit., p. 378.

634 “The Place of Liberty" in Sovereign Virtue, op. cit. pp. 159-161.
} 
"aspecto" "mais ativo" inclui o direito de influenciar o "clima estético ou moral"635; isso assegura um direito à publicação de pornografia ainda que, para o autor, a pornografia não veicule ideias ${ }^{636}$. A mesma expressão utilizada por Dworkin em “The Place of Liberty" autenticidade - reaparece em Justice for Hedgehogs como segundo princípio de dignidade ${ }^{637}$; este segundo princípio, por sua vez, tem dois aspectos: responsabilidade e independência ética $^{638}$, e é este segundo aspecto que, para Dworkin, justifica o direito à liberdade de expressão. ${ }^{639}$

A independência ética, enquanto segundo princípio da dignidade, recebe tratamento que, à aparência, soa bastante passivo ${ }^{640}$, para utilizar a expressão escolhida por Dworkin para caracterizar os dois aspectos - ativo e passivo - do princípio da autenticidade em Sovereign Virtue (veja discussão acima). A independência ética, para o autor, pode ser violada (i) ou porque a restrição sofrida pelo indivíduo atinge "questões fundamentais éticos [ethical foundation]"641 (ii) ou porque a única justificação possível da restrição é ética ${ }^{642}$. Para Dworkin, a restrição da pornografia viola a independência ética somente pelo motivo apontado em (ii) ${ }^{643}$, enquanto a restrição do discurso político, inclusive de ódio, pode violar nos dois sentidos: quanto ao primeiro, o autor entende ser "fundacional" expressar convicções políticas" ${ }^{644}$. O ponto é que, aparentemente, Dworkin entende que proibição da pornografia viola a independência ética somente porque este tipo de medida se ampara em razões éticas, o que indica que o autor assume que publicação de material não-político, como pornografia, não é "foundational". Em outras palavras, embora existam diversas convergências na justificação

635 "Por que a liberdade de expressão?”, op. cit., pp. 319-20; no original,“Why Must Speech be Free?”, op. cit., pp. 200-1 (veja ainda "Addendum: A Response to MacKinnon's Reply" in "MacKinnon's Words", p. 242 e"Why Academic Freedom?”, op. cit., 247-8).

636 "Pornography and Hate" op. cit, p. 242.

${ }^{637}$ Justice for Hedgehogs, op. cit. cap. 9.

${ }^{638}$ Justice for Hedgehogs, op. cit., pp. 209-214.

${ }^{639}$ Justice for Hedgehogs, op. cit., cap. 17.

${ }^{640}$ Justice for Hedgehogs, op. cit., pp. 209-10, 211-213.

${ }^{641}$ Justice for Hedgehogs, op. cit., p. 368, mantive palavras do original entre colchetes; na tradução, "questões de essência ética", Justiça para ouriços, op. cit., p. 377.

${ }^{642}$ Justice for Hedgehogs, op. cit.., pp. 368 e ss.; veja "Do We Have a Right to Pornography?", in A Matter of Principle, op. cit., e "Reverse Discrimination" in Taking Rights Seriously, op. cit. Veja Yowell, "A Critical Examination of Dworkin's Theory of Rights", pp. 121-123, esp. p. 123 e também p. 135. Estes fundamentos talvez deem razão a Yowell no seguinte trecho: “(...) since 1985 Dworkin ceased to look to the externality of preferences and instead has directed his argument against the respect-denying content of certain motivations for laws, which Hart argued had been his real concern all along", p. 131, itálicos no original. Veja a crítica de Langton a Dworkin em Sexual Solipsism, op. cit., pp. 168-70.

${ }^{643}$ Justice for Hedgehogs, op. cit., pp. 369, 272.

${ }^{644}$ Justice for Hedgehogs, op. cit., p. 373. 
ética do direito à liberdade de expressão nos diferentes pontos da obra de Dworkin, mais recentemente o tema da obscenidade recebeu defesa menos vigorosa do que anteriormente disponível, em que a restrição do discurso político era considerada tão grave quanto a restrição do discurso não-político.

Dois grupos de questões pelo menos demandam enfrentamento. Em primeiro lugar, há encolhimento da autenticidade em Justice for Hedgehogs se comparada com o princípio de mesmo nome em "The Place of Liberty” e com a ideia de responsabilidade moral que Dworkin oferece como interpretação do direito à liberdade de expressão ${ }^{645}$ ? Se sim, qual é preferencial, tanto no sentido de ser valor mais coerente com a obra do autor quanto no sentido de ser mais cogente independentemente da teoria dworkiniana?

Em segundo lugar, há encolhimento dos fundamentos do direito à pornografia enquanto direito à liberdade de expressão? Se sim, como explicar a dimensão "ativa"646 do direito à liberdade de expressão política que, se violado, implica ofensa "fundacional" à independência ética ${ }^{647}$ ? Ainda, o "aspecto" "mais ativo" da responsabilidade moral, que Dworkin menciona ao defender o direito de influenciar o "ambiente moral" não indica que este direito é "foundational", assim como o é, no trecho já citado, "o direito de exprimir publicamente as suas convicções políticas" ${ }^{\text {"648 }}$ ? Por que expressar convicção política, em Justice for Hedgehogs, tem mais proteção do que influenciar o ambiente moral se no artigo publicado em Freedom's Law a responsabilidade moral do sujeito inclui as duas coisas (a expressão política e a não-política) no que se revela tratamento semelhante de coisas substancialmente parecidas?

Algo mudou. A categoria fundamental que justifica direitos a meu ver não mudou, mas o argumento que dela extrai justificação de direitos sofreu enxugamento acentuado: perdeu sua dimensão ativa, positiva, interventiva na sociedade. Cumpre indagar: qual é preferencial? E mais: a versão de Justice for Hedgehogs e a defesa mais acentuada do discurso de ódio político que da obscenidade é coerente?

A meu ver, a ideia de autenticidade oferecida por Dworkin em Justice for Hedgehogs precisa ser entendida como incluindo o direito de influenciar política, moral e esteticamente a

\footnotetext{
645 "Why Must Speech be Free?”, op. cit..

646 "The Place of Liberty", op. cit..

647 Justice for Hedgehogs, op. cit., cap. 17.

${ }^{648}$ Justiça para ouriços, p. 382, de trecho já citado; no original, Justice for Hedgehogs, op. cit., cap. 17, p. 373.
} 
sociedade. Em primeiro lugar a possibilidade de a independência ética ser violada por restrição a direito "fundacional" é inexplicável se a autenticidade tiver somente dimensão passiva. Em segundo lugar, porque a concepção de bem oferecida pelo autor, a saber, o modelo do desafio, abstrato que é, permite que, ao interpretar as suas circunstâncias, o indivíduo julgue que deve intervir para se fazer ouvir. Isso revela que, na verdade, a divisão entre as dimensões é heurística, desprovida de essência. A dimensão ativa é talvez parte da passiva, o que fica claro se notarmos que o direito à liberdade de expressão precisa ser preservado, pois o seu exercício pode ser demandado em razão de reflexão efetuada nos termos da dimensão mais passiva. $\mathrm{Ou}$ seja, o exercício da dimensão ativa é questão a ser definida pelo próprio indivíduo no exercício da sua autenticidade. Isso também indicia que não há justificativa para que o discurso político de ódio goze de mais liberdades que a pornografia: restrições a estes dois tipos de discurso, como diz Dworkin em Freedom's Law, violam direitos da mesma forma, ainda aceitemos a opinião do autor de que pornografia não veicula ideias nem seja propriamente discurso político. ${ }^{649}$

\footnotetext{
${ }^{649}$ Veja, em nota ao próximo capítulo, discussão das críticas de James Weistein a Dworkin.
} 


\section{CAPÍTULO TERCEIRO: A LIBERDADE DE EXPRESSÃO NO PENSAMENTO DE RONALD DWORKIN}

\section{Introdução: Recapitulação}

Neste capítulo, apresento os argumentos formulados por Ronald Dworkin em defesa da sua concepção do direito à liberdade de expressão. Na primeira seção, exploro ponto fundamental à compreensão destes argumentos, a saber, a integração das liberdades, especificamente da liberdade de expressão, na justiça distributiva, interpretada pelo autor nos termos da sua teoria da igualdade de recursos. Este ponto tem diversas consequências a polêmicas em torno da liberdade de expressão e informam, expressamente ou não, diversas opiniões defendidas por Dworkin, notadamente aquela sobre discurso de ódio e pornografia. Nas seções 2 e 3 exploro os diferentes pontos do pensamento do autor em que a liberdade de expressão figura como direito. Na primeira subseção da seção 2, apresento as consequências da independência ética, aspecto do princípio da autenticidade discutido no capítulo anterior, à liberdade de expressão, bem como concluo a exposição do argumento dworkiniano acerca das liberdades na igualdade de recursos - $\mathrm{o}$ argumento foi iniciado na seção 5 do capítulo primeiro como tese sobre as liberdades em geral, e agora retomo a questão com o propósito de delinear a liberdade de expressão a que a igualdade de recursos se compromete. A seção 3 é dedicada à liberdade de expressão na teoria da democracia de Dworkin. A seção 4, que, dividida em subseções, é dedicada à exposição dos argumentos de Dworkin de algumas questões, a saber, ao discurso de conteúdo discriminatório, em especial ao discurso de ódio racial e à pornografia, ao financiamento de campanhas eleitorais, e a liberdades que Dworkin julga próximas mas distintas da liberdade de expressão, isto é, a liberdade de imprensa e a acadêmica.

Diversos temas deste capítuloo já foram expostos ou ao menos mencionados nos capítulos anteriores. Em especial, Dworkin defende a liberdade de expressão como uma questão de princípio, isto é, de direito ${ }^{650}$, o que torna importante as consequências da adoção

\footnotetext{
${ }^{650}$ Dworkin, "Ronald Dworkin replies", op. cit. Frederick Schauer, comentando trabalho de Dworkin, havia entendido a interpretação dworkiniana da liberdade de expressão como questão somente de princípio: veja Schauer. "[Sem título]", in Frederick F. Schauer, Virginia Held, and John L. Hess, The Rights of M.A. Farber: An Exchange, reply by Ronald Dworkin, op. cit.. Dworkin sustenta que a sua visão sobre liberdade de expressão é que ela é, principalmente, mas não só, uma questão de princípio. Veja o texto original, objeto da crítica de
} 
do que o autor chama de "direito no sentido forte"; ainda, o autor recorre ao valor de independência, que compõe a sua teoria ética, especificamente o segundo princípio de dignidade, o da autenticidade, tanto para orientar o seu argumento sobre liberdades quanto para formar a sua teoria da democracia, bastante confortável à liberdade de expressão. O objetivo desta introdução é de recapitular bastante brevemente os dois primeiros capítulos da dissertação de modo iniciar o terceiro capítulo propriamente dito de maneira mais contextualizada.

Nas seções 1 e 2 do capítulo primeiro, apresentei a noção que Dworkin chama de "direito no sentido forte", que, quando possuído pelo indivíduo em relação a determinada ação, significa que lhe é dado agir desta forma independentemente de ser errado fazê-lo, ou de que fazê-lo gere más consequências ao interesse coletivo da sociedade. Na terminologia dworkiniana, um princípio, padrão político de justificação de ação do Estado que descreve um direito, salvo exceções, supera políticas, padrões políticos que descrevem um "objetivo não individualizado", que atende a um interesse geral em vez de um interesse específico de um indivíduo, e que, se beneficia pessoas determinadas, o faz em razão do benefício geral aí decorrente e não do reconhecimento de que determinado recurso, por exemplo, é de sua titularidade. O ponto principal a ser ressaltado é a natureza "individualizada" ou "pessoal" dos direitos, que explica por que não existem "direitos da maioria" (salvo em sentido não forte de direitos) e que ecoa as responsabilidades, também pessoais, que Dworkin defende na elaboração da sua teoria sobre o viver bem.

Também são relevantes o significado objetivo da violação dos direitos, que é uma questão de injustiça que independe da percepção de prejuízo por parte do titular do direito

Schauer: "The Farber Case: Reporters and Informers" in A Matter of Principle, op. cit., esp. pp. 375-7 e também "Is the Press Losing the First Amendment?", op. cit., pp. 385-9. Veja ainda "Why Must Speech be Free?", in Freedom's Law, op. cit., para exposição das visões instrumentais e constitutivas da liberdade de expressão (pp. 199-201) (neste artigo, Dworkin cita Scanlon: veja "Introduction" to Dworkin (Ed.), The Philosophy of Law, Oxford: Oxford University Press, 1977) e "Free Speech, Politics, and the Dimensions of Democracy", op. cit., p. 354 (para a ideia de que a liberdade de expressão tem mais de uma finalidade, mas que é a conexão nãoinstrumental entre ela e a democracia que é o crucial à Primeira Emenda à Constituição dos EUA - veja também p. 372) e "Is Democracy Possible Here?", op. cit., pp. 152-4. Compare com "Why Academic Freedom?" in Freeom's Law, op. cit., p. 250 e veja também pp. 257 e ss. Júlio Cesar Barroso expressou elegantemente a ideia ao dizer que a liberdade de expressão não é um "samba de uma nota só", Júlio César Casarin Barroso Silva. Democracia e Liberdade de Expressão: Contribuições para uma interpretação política da liberdade de palavra, op. cit., p. 106. 
violado, e as consequências do sentido forte de direitos à identificação das hipóteses em que eles podem ser violados. Especificamente, Dworkin critica a especulação quanto às consequências do reconhecimento de um direito, e sustenta que um direito só pode ser restrito quando o seu reconhecimento implicar "clear and presente danger" a outro direito (expressão que o autor empresta de Oliver Wendell Holmes - Veja capítulo primeiro, inclusive nota, para discussão e referências.). Ainda, o autor rejeita o "modelo do balanceamento" e o seu igual compromisso em evitar violação de direito e excesso no seu reconhecimento, como se as duas coisas fossem igualmente graves, e como se os custos de conveniência do exercício, por exemplo, da liberdade de expressão, devessem ser incorporados ao cálculo da extensão dos direitos. Para Dworkin, a instituição de direitos, dado seu fundamento (igualitário, por exemplo), aponta que sua restrição não pode ser tratada como se fosse tão grave quanto o exagero no reconhecimento de um direito. Daí o autor defender outro modelo sobre as restrições aceitáveis a direitos, a saber, aquele que as admite somente se no caso em questão o valor protegido não estiver presente, se houver um direito (no sentido forte) em conflito, ou se o custo da não-restrição for imenso.

Na terceira seção, discuto ponto fundamental ao pensamento de Dworkin, a saber, a integração entre valores políticos, especialmente entre liberdade e igualdade. Esta integração é defendida concretamente pelo autor, ou seja, a partir das suas concepções de igualdade, liberdade, comunidade e ética, e é, portanto, na análise dessas concepções que a viabilidade da integração deve ser aferida. O ponto é particularmente importante porque no restante da dissertação exploro os argumentos de Dworkin sobre a integração entre liberdades, igualdade e ética.

Como mencionei, Dworkin é claro ao não pretender derivar da sua concepção de direitos argumento detalhado sobre a existência desta ou daquela liberdade, salvo no que a ideia de direito no sentido forte é capaz de identificar usos da expressão "direitos" em outros sentidos ou no que se presta a indicar aquilo que as liberdades não são, a saber, (i) direito geral de não restrição, (ii) mero instrumento de interesse coletivo, (iii) dependentes do interesse do titular ou (iv) mercadoria. Estes são temas tratados na seção 4 do capítulo primeiro. O ponto é a necessidade de justificação política dos direitos que independe, ainda que não totalmente, do seu significado. O autor encontra esta justificação na sua teoria sobre ética e igualdade, e entende que as liberdades são integradas a outros conceitos, entre eles à boa vida. 
Dworkin também integra as liberdades à igualdade, que interpreta sob a rubrica de "igualdade de recursos", sua teoria da justiça distributiva. Abordo o tema na última seção do capítulo primeiro. $\mathrm{O}$ argumento do autor neste sentido, por ser orientado à sua concepção de igualdade, é extremamente específico e se reporta ao complexo modelo da ilha deserta, de modo a entender as liberdades como o regramento necessário à compreensão do significado da distribuição de recursos segundo o leilão imaginário realizado entre os habitantes da ilha. $\mathrm{Na}$ subseção 2.2. deste capítulo, retomo o argumento para expor a passagem deste argumento ideal ao "mundo real" conforme Dworkin a compreende ainda em "The Place of Liberty".

O segundo capítulo é quase que integralmente dedicado a análise da teoria ética de Ronald Dworkin e aos argumentos oferecidos pelo autor na execução do seu projeto de fundamentar eticamente uma concepção de liberalismo igualitário. Na primeira seção, exponho a realocação da ideia de neutralidade no pensamento do autor no principal artigo discutido no capítulo, a saber, "Foundations of Liberal Equality". É ainda neste trabalho que Dworkin expõe a sua teoria ética do "modelo do desafio", segundo o qual o valor da vida é adverbial, análogo ao valor da arte. Este é o objeto da primeira subseção da segunda seção, sendo objeto da segunda subseção a exposição, em Justice for Hedgehogs da teoria ética dworkiniana como teoria sobre o valor da dignidade, composto, segundo o autor, por dois princípios, a saber, o do respeito-próprio e o da autenticidade.

A terceira seção avança a partir da concepção de bem de Dworkin em direção à sua teoria política: expõe argumento fundado no modelo do desafio acerca dos prejuízos da violação das liberdades (que, por serem integradas à igualdade, são questão de justiça) à boa vida de quem as viola e de quem sofre as violações. É que, além de integrar as liberdades à boa vida e às liberdades à igualdade, Dworkin integra ética e justiça ao entender que a justa distribuição de recursos é parâmetro da boa vida, isto é, que se vive pior com mais ou menos recursos que o chancelado pela justiça. Se as liberdades compõem a justiça, violar a liberdade de outros ou tê-las violado impacta negativamente a vida de quem as viola ou de quem sofre a violação. Este é o objeto da primeira subseção da terceira seção. O objeto da segunda subseção são os argumentos éticos em defesa da igualdade, ponto importante a um teórico igualitário que pretenda fundar sua teoria política em uma concepção de bem: exponho, então, brevemente argumentos neste sentido presentes na obra de Dworkin. 
Na conclusão, tento ilustrar a fundamentação da política, em especial das liberdades, na ética de Dworkin indicando a importância do valor da autenticidade na defesa que o autor faz da liberdade de expressão, em especial em relação ao tema da pornografia. Aponto para possível inconsistência nos fundamentos elaborados pelo autor para defender os direitos relacionados à publicação de material obsceno, e indico as razões pelas quais os fundamentos mais generosos disponíveis nos artigos colecionados em Freedom's Law são mais convincentes do que os mais restritos disponíveis em Justice for Hedgehogs.

\section{Seção 1: liberdade de expressão e justiça distributiva}

O objetivo desta seção é apresentar o argumento fundamental disponível no pensamento de Dworkin em defesa da sua interpretação do direito à liberdade de expressão. Este argumento consiste na integração das liberdades na teoria da justiça de modo, isto é, na integração entre os valores da liberdade e da igualdade, o que resulta em interpretação generosa das liberdades em razão de interpretação específica da igualdade como questão de recursos. Este argumento interpreta a liberdade de expressão como um direito no sentido forte e nela inclui diversas hipóteses de seu exercício por vezes vedadas por democracias contemporâneas, entre elas o discurso racista de ódio. Em que pesem características específicas destes discursos, a resposta dworkiniana à justiça da sua proibição é conjunta: as liberdades consistem no uso desimpedido dos recursos distribuídos com justiça, o que justifica compreensão de "discriminação" de tal modo que a simples manifestação de ideia racista, misógina ou de conteúdo discriminatório não seja ela mesma discriminatória porque não caracteriza a subtração de recurso a que indivíduo tenha direito ${ }^{651}$. Ainda, tendo o indivíduo

\footnotetext{
${ }^{651}$ A meu ver, o argumento de Waldron tem a forma correta, isto é, procura indicar direito - baseado no que chama de "dignidade" como status social - que seria desrespeitado pelo discurso de ódio. A distinção entre condutas discriminatórias e expressão de ideia de conteúdo discriminatório corresponde aos objetos de dois tipos de lei conforme distinção que Waldron (para descrever argumento de Dworkin a favor da inclusão do discurso de ódio na liberdade de expressão) faz entre "upstream laws" e "downstream laws": veja The Harm in Hate Speech, op. cit., pp. 173 e ss. (esp. pp. 174, 177-181. com quadro explicativo na p. 179). Ele diz: "Dworkin notices that arguments about hate speech often envolve two sorts of laws, not one. On the one hand, there are the hate speech laws themselves - or the proposals for hate speech laws - which would restrict expressions of racial hostility, religious hatred, group defamation, and so on. On the other hand, there are laws in place protecting the people who are supposedly also protected by hate speech laws - I mean laws against violence, laws against discrimination, against blocking access to polling places, laws guaranteeing equal opportunity, laws against racial profiling, laws against various forms of disorderly conduct, and so on. Following Dworkin's metaphor, I am going to call these upstream laws and downstream laws. The downstream laws are the laws against violence, discrimination, and so on, and the upstream laws are laws against hate speech" p. 178, itálicos no original. Veja o seguinte trecho de MacKinnon em Only Words, op. cit.: "The current legal distinction between screaming 'go kill
} 
direito a determinado recurso, lhe é dado usá-lo para expressar suas opiniões, quaisquer que sejam, como preferir, desde que não viole direito de terceiros. Isso atrela a existência de uma liberdade à justiça dos recursos empregados no seu exercício, e explica diversas restrições que Dworkin julga aceitáveis, entre elas as relativas ao financiamento de campanha, ao mesmo tempo que afasta outras restrições e, em geral, proibições por vezes defendidas por outros autores.

A integração das liberdades à igualdade oferece a chave interpretativa das liberdades em geral, e da liberdade de expressão em especial, no pensamento de Ronald Dworkin. Especificamente, explica o porquê de o discurso de ódio, a pornografia e outras hipóteses de exercício de liberdade de expressão comumente restringidas ou simplesmente proibidas, estarem incluídas na concepção do direito à liberdade de expressão defendida pelo autor. Em poucas palavras, a integração da liberdade à igualdade traduz a necessidade de compreender a liberdade enquanto grupo de liberdades na forma de direitos no sentido forte ao uso dos recursos atribuídos a cada indivíduo conforme for distributivamente justo. Para Dworkin, portanto, as liberdades tem seu conteúdo definido pela justiça distributiva:

“(...) proibições ou restrições são concessões [compromises] da liberdade somente se o limite do uso da propriedade ou de outros recursos nas mãos de seu dono devido [rightful] não de acordo com a própria teoria da comunidade sobre distribuição justa, mas de acordo com a melhor ou a mais sólida [soundest] teoria deste tipo" ${ }^{652}$.

Conforme exponho a seguir, isso explica a inclusão do discurso de conteúdo discriminatório na liberdade de expressão. Em poucas palavras, discurso racista, homofóbio, misógino etc., por mais ofensivo que seja, não é discriminatório porque não viola direitos. Isso é diferente de dizer que o conteúdo do discurso não defende discriminação; discurso racista, por exemplo, defende discriminação no sentido de que seu conteúdo é discriminatório, isto é,

that nigger' and advocating the view that African-Americans should be eliminated from parts of the United States needs to be seriously reconsidered, if real equality is ever to be achieved", p. 108 e, também, a sua crítica à "approach of current law" que considera a pornografia como "defamation" ou "offense", mas não "discrimination" (p. 11, veja também pp. 13-5, 29-31, 36, por exemplo). Veja ainda Samantha Ribeiro MeyerPflug. Liberdade de expressão e discurso de ódio, op. cit., p. 263.

652 "Do Liberty and Equality Conflict?", op. cit. p. 53, traduzi, itálicos no original, mantive entre colchetes palavras do original (veja ainda pp. 39 e 55 para liberdade de expressão e veja subseção 2 da próxima seção deste capítulo). E ainda: "Those are among my reasons for thinking that any appealing defense of the morally important liberties must proceed in a different, less conventional way: not by insisting that liberty is more important than equality, but by showing that these liberties must be protected according to the best view of what distributional equality is, the best view of when a society's distribution of property treats each citizen with equal concern." "The Place of Liberty", op. cit., p. 122. Veja "Do Values Conflict?", op. cit., p. 254 e Maria Beatriz Inkis em $O$ Exercício da Cidadania segundo as Teorias Política e Jurídica Propostas por Ronald Dworkin, op. cit., pp. $26-7$. 
no sentido de que as proposições do discurso são inconciliáveis com proposições igualitárias, por exemplo. Neste sentido, e somente neste sentido, é possível dizer que ele é "discriminatório". 653

Mas esse não é o sentido relevante de discriminação, que só é inteligível enquanto categoria capaz de restringir liberdades se entendida como violação de direitos. Ou seja, no sentido relevante à discussão sobre liberdades, um ato é discriminatório não quando o seu conteúdo é discriminatório, mas quando ele próprio subtrai, toma ou impede acesso a bem, recurso, oportunidade a que alguém tenha direito. Não basta que o discurso modifique a realidade, dificulte acesso a recurso; no pensamento de Dworkin, é preciso que o indivíduo supostamente discriminado tenha direito à realidade tal qual ela existia antes do discurso ou ao recurso subtraído pela manifestação ${ }^{654}$. A meu ver, é esta a premissa que a todo tempo Dworkin se reporta nos seus escritos sobre liberdade de expressão e que reflete o seu esforço de integração das liberdades na forma de uma teoria dos direitos no sentido forte dependente de uma teoria da justiça distributiva. Ainda, esta premissa reflete a admissibilidade estreita de limitações a direitos presente, por exemplo, na noção de direitos no sentido forte, na justificação das liberdades na igualdade e na dignidade, que limitam o tipo de justificação suficiente a eventual restrição de direito: como visto, benefício coletivo é incapaz de restringir direitos para Dworkin, o que só pode ocorrer quando houver "clear and presente danger" de

\footnotetext{
${ }^{653}$ Veja os seguintes trechos de Dworkin representativos da sua opinião sobre o significado de discriminação: "She [MacKinnon] also demands that I defend my view that "being discriminated against on the basis of sex is just being "offended." But I said nothing even close to that: on the contrary, I said that distributing pornography, as distinct from using it to sexually harass, does not constitute sexual discrimination."[1994] "Addendum" to [1993] "MacKinnon's Words" in Freedom's Law, op. cit., p. 242; veja ainda pp. 234-6 sobre "sexual harassment laws and university speech codes". E ainda: "People do have a right not to suffer from discrimination, which is different from ridicule or offense. They have a right not to be denied employment just out of prejudice against blacks or women or creationists or people of no imagination or very bad taste, for example", n. 8, p. 380 à p. 360 de [1995] "Why Academic Freedom?", in Freedom's Law, op cit. (veja o mesmo exemplo sobre existência de direito contra discriminação em "The Farber Case: Reporters and Informers", op. cit., p. 375).

${ }^{654}$ Compare com Greenawalt, autor defende visão bem menos demandante à restrição de discurso, em Fighting Words: Individuals, Communities, and Liberties of Speech, op. cit., pp. 6-7, 19 (e também pp. 84-5 e pp. 89 e ss. para discussão sobre liberdade de expressão e discriminação em ambiente de trabalho) e, influenciado por Greenawalt, Barent em Freedom of Speech, op. cit., pp. 75 e ss.. Compare com Dworkin em "Why Academic Freedom?", op. cit., p. 259.

A meu ver, Jeremy Waldron oferece, em The Harm in Hate Speech, op. cit., argumento que, se correto, implica direitos exatamente do tipo que tenho em mente. Acredito que o ponto fundamental deste livro de Waldron - a saber, que o discurso de ódio ofende a dignidade das suas vítimas e que é permissível preservar a aparência da sociedade em que vivemos - tenha a forma correta do tipo de argumento que a teoria da liberdade de expressão de Dworkin exige para que se justifique restrição à libedade de expressão. A meu ver, este argumento não é bem sucedido - fica para outra ocasião explicar por quê. Mas eu gostaria de deixar claro que Waldron oferece precisamente o tipo de argumento que se pode cobrar de um defensor da sua posição
} 
violação de outro direito, e não quando existe interesse de maioria ou especulação sobre exercício de direito. Igualmente, o princípio da segurança, que compõe o princípio da abstração, parte da linha de base do leilão imaginário oferece defesa generosa das liberdades ao limitar as hipóteses em que podem ser restritas. ${ }^{655}$ Nos três pontos - direito no sentido forte, liberdades integradas à justiça distributiva em geral, e argumento específico do princípio da segurança na igualdade de recursos - uma vez existente uma liberdade, sua restrição só é aceitável em circunstâncias muito específicas, a saber, quando o seu exercício viole direito no sentido forte do termo ${ }^{656}$.

Daí o fato de que determinado "discurso é discriminatório" não ser capaz de restringir o exercício da liberdade de expressão. A ideia de que algo é "racista" é ambígua, e atribuição de sentido mais específico revela distinções importantes ao tema das liberdades. Chega a ser tautológico dizer que ninguém tem direito de violar direitos sob pretexto de exercer liberdades; o problema é que muito do que comumente se entende como discriminatório na verdade é simplesmente de conteúdo discriminatório, o que não viola direitos e pode, portanto, perfeitamente consistir em hipótese de regular exercício de liberdade, sem prejuízo de se apontar, por outros motivos, violação efetiva de direitos que então justifique restrição.

Especificamente, isso não significa que discursos de conteúdo discriminatório não possam ser restringidos, ou até mesmo proibidos em ambientes que admitem tratamento diferenciado (como ambientes laborais ${ }^{657}$ etc.). Será, naturalmente, necessário apontar direito violado: o ponto é que esta empreitada é muito mais plausível nessas hipóteses mais restritas do que no ambiente público mais geral. O que é inadmissível é o tipo de proibição que alguns enxergam, por exemplo, na Lei de Racismo no Brasil (Lei 7.716 de 1989), a saber, proibição completa de qualquer discurso de conteúdo discriminatório que diga respeito às hipóteses do caput do artigo $20^{658}$, ocorra ele por meio de privilégio de concessão pública, de charge jornalística $^{659}$ ou por meios mais simplórios, como um tweet ${ }^{660}$.

\footnotetext{
655 “The Place of Liberty", op. cit, p. 149.

${ }^{656}$ A diferença fica por conta de o princípio da abstração e a integração entre liberdade e igualdade serem também argumento a favor de determinadas liberdades, enquanto a ideia de direito no sentido forte é, como diz Dworkin, "hipotética".

657 “MacKinnon's Words", op. cit., pp. 234-5 e "Why Academic Freedom?”, op. cit. (veja discussão abaixo na subseção 4.1.).

658 “Art. 20. Praticar, induzir ou incitar a discriminação ou preconceito de raça, cor, etnia, religião ou procedência nacional. (Redação dada pela Lei no 9.459, de 15/05/97)

Pena: reclusão de um a três anos e multa.(Redação dada pela Lei n 9.459, de 15/05/97)
} 
De volta a Dworkin, a liberdade de expressão em seu pensamento, além de ser um direito de justiça distributiva, é uma liberdade fundada na autenticidade das vidas dos sujeitos necessária à igualdade de recursos, teoria da justiça distributiva defendida pelo autor. Neste sentido, a extensão da liberdade de expressão, como visto, coincide com a extensão dos recursos possuídos pelo sujeito, e é independente do conteúdo do que ele diz ou publica ${ }^{661}$. É

$\S 1^{\circ}$ Fabricar, comercializar, distribuir ou veicular símbolos, emblemas, ornamentos, distintivos ou propaganda que utilizem a cruz suástica ou gamada, para fins de divulgação do nazismo. (Redação dada pela Lei $\mathrm{n}^{\circ}$ 9.459, de 15/05/97)

Pena: reclusão de dois a cinco anos e multa.(Incluído pela Lei no 9.459, de 15/05/97)

$\S 2^{\circ}$ Se qualquer dos crimes previstos no caput é cometido por intermédio dos meios de comunicação social ou publicação de qualquer natureza: (Redação dada pela Lei n ${ }^{\circ} 9.459$, de 15/05/97)

Pena: reclusão de dois a cinco anos e multa.(Incluído pela Lei $\mathrm{n}^{\circ}$ 9.459, de 15/05/97)" disponível em http://www.planalto.gov.br/ccivil 03/leis/17716.htm, acesso em 16.10.2013

${ }_{659}$ Veja a seguinte notícia: "TJ/SC condena jornalistas por racismo em charge", disponível em http://www.conjur.com.br/2013-jun-01/tj-sc-condena-jornalistas-racismo-charge-maioridade-penal, último acesso em 16.10.2013.

${ }^{660}$ Lembremo-nos das frases anti-nordestinas que uma jovem publicou no Twitter após eleição de Dilma Rouseff para a Presidência da República em 2010 (eu discuti o caso brevemente na introdução).

${ }^{661}$ Para as críticas de Dworkin à restrição da liberdade de expressão com base no conteúdo daquilo que é expressado, veja "Equality, Democracy, and Constitution: We the People in Court", Alberta Law Review, Vol. XXVIII, No. 2, 1988-9, pp. 324-46, esp. p. p. 338, “Why Must Speech be Free?”, op. cit., p. 205 (esp. o seguinte trecho sobre a sociedade norte-americana "we are a liberal society committed to individual moral responsibility, and any censorship on grounds of content is inconsistent with that commitment", itálico no original), "Pornography and Hate", op. cit. pp. 217-9 (sendo exemplo de norma que restringe a liberdade de expressão baseada em conteúdo a "British Race Relations Act", p. 218, contrastada pelo autor com o padrão norteamericano sobre o tema) e "Devaluing Liberty", op. cit., p. 8; compare com "Free Speech, Politics, and the Dimensions of Democracy", op. cit., pp. 358 e ss.; para a questão do discurso negacionista do Holocausto, veja "Addendum: A Compelling Case for Censorship?" em "Pornography and Hate", op. cit., pp. 223-6. Como o crucial para da liberdade de expressão em Dworkin é a posição ou circunstâncias do indivíduo, o conteúdo da expressão é relegado a segundo plano. Assim, uma mesma manifestação, mas oriunda de indivíduo distinto, ou ocorrida em circunstância geográfica ou temporal diferentes, pode ser proibida, enquanto a outra, de conteúdo idêntico mas de circunstâncias díspares, pode ser restrita com justiça. Imaginemos uma manifestação que procure incitar a violência contra determinado grupo racial ou étnico. A possibilidade de sua restrição, para Dworkin, é integralmente dependente da sua capacidade efetiva de provocar a violência que pretende, aplicáveis todas as condições à válida restrição de um direito: trata-se da discussão, presente no capítulo primeiro, sobre tipos aceitáveis de restrições a direitos. Acredito que Oscar Vilhena Vieira, em evento na Direito GV ("[Sem título]". Manifestação no Evento "As reações ao filme 'A Inocência dos Muçulmanos': quais os limites à liberdade de expressão?", outubro de 2012, debatedores: Professores José Garcez Ghirardi, Oscar Vilhena Vieira e Salem Hikmat Nasser, organizado pelo CEJUR e realizado nas dependências da Direito GV, São Paulo: 2012.), tenha chegado a conclusão semelhante, apesar de tê-lo feito por caminhos bastante distintos. Vieira tem teoria da liberdade de expressão baseada na natureza do ser humano, e justifica a liberdade de expressão como mecanismo de dar vazão à nossa agressividade (sua inspiração é Freud). Nesta ocasião, Vilhena defendeu a regulamentação da liberdade de expressão desde que insensível ao conteúdo do discurso mas sensível às circunstâncias da manifestação, de modo que, a depender da época e local uma manisfetação possa ser proibida sem que o fosse em outras hipóteses. A meu ver, Dworkin defende as mesmas ideias. Mas Vilhena admite restrições à liberdade de expressão que Dworkin não aceita ao entender que determinadas manifestações - como as anti-semitas - tenham capacidade suficiente de gerar violência na Alemanha a ponto de poderem ser proibidas, o que não ocorre no Brasil. O requisito de Vieira e a sua insensibilidade ao conteúdo são estruturalmente idênticos ao de Dworkin, mas a teoria dos direitos de Dworkin exige, para usar a expressão adotada (mas não inventada) pelo autor, que o "danger" seja muito mais "clear and present" do que Vieira parece exigir (Agradeço ao professor Vieira pela 
por isso que impedir um indivíduo de entrar em um estabelecimento comercial em razão da

disponibilidade de discutir comigo a liberdade de expressão e as suas ideias sobre o tema). Júlio Cesar Casarin Barroso Silva também parece endossar critério análogo acerca da proibição do tipo de discurso que seja suficientemente próximo da violação de direitos de terceiro, mas, a exemplo de Oscar Vilhena, emprega critério a meu ver excessivamente amplo de proximidade, a ponto de cogitar que discursos críticos do sistema de proteção dos direitos humanos talvez possam ser restritos (o autor, de rigor, deixa a questão em aberto), Júlio César Casarin Barroso Silva. Democracia e Liberdade de Expressão: Contribuições para uma interpretação política da liberdade de palavra. Op. cit., esp. pp. 158 e ss. (para críticas a Dworkin a partir de "Why Must Speech be Free?", op. cit., em trecho citado acima nesta dissertação), 182-4, 231, esp. os trechos que seguem: sobre a pornografia, "Em contextos em que as palavras (ou imagens, ou atos expressivos) de ódio têm um vínculo direto com a coação e com a supressão de direitos, a censura poderia ser justificável" (p. 182), "A exigência para a punibilidade do discurso, portanto, é o estabelecimento do vínculo com a privação de direito das mulheres (...)" (p. 183), e, sobre a relação entre pornografia e violência, "Acreditamos que se (e somente se) essa relação causal for provada de modo mais claro poderia ser admissível reprimir um conjunto estreito e bem-delimitado de manifestações pornográficas, como simulação de estupros, por exemplo, mesmo no sistema atual de liberdade de expressão" (p. 184; veja em geral, sobre pornografia seção 4.3. do capítulo IV) e, por fim, sobre violação de direitos humanos, ""(...) uma questão importante que precisa ser incorporada à discussão brasileira sobre o tema da liberdade de expressão é a do status das freqüentes expressões de ódio dirigidas através das ondas de rádio não diretamente contra minorias específicas, mas contra o sistema de proteção aos direitos humanos. Na medida em que essas expressões se vinculam ao clima geral de desrespeito aos direitos humanos pelas forças policiais brasileiras, podem essas expressões ser suprimidas ou penalizadas? Essa questão ainda está em aberto" (p. 231, itálico no original); após crítica a Dworkin, o autor compara este exemplo com a contribuição que programas de rádio deram ao genocídio de Ruanda: veja p. 159-60, e n. 110, p. 160 (veja nota abaixo com comentários de Júlio Silva à lei de racismo).

Veja as críticas de Dworkin à associação entre pornografia e violência: "Do We Have a Right to Pornography?", op. cit., pp. 354-5, 338, 344, 345, "Why Must Speech be Free?", op. cit., pp. 206 e ss, "Pornography and Hate", op. cit., p. 219, "MacKinnon's Words", op. cit., pp. 230-1, "Addendum: A Response to MacKinnon's Reply" in "MacKinnon's Words", op. cit., pp. 239-41; veja ainda "Addendum: A Compelling Case for Censorship" in "Pornography and Hate", op. cit., p. 224 sobre violência e negação do Holocausto: "It is implausible that allowing fanatics to deny the Holocaust would substantially increase the risk of fascist violence in Germany". Veja as críticas de Waldron em The Harm in Hate Speech, op. cit., pp. 176 e ss. e trecho (nas pp. 150 e ss.) sobre direito norte-americano aplicável à liberdade de expressão e sua rejeição a restrições por conteúdo - os dois criticados pelo autor. Veja ainda Eric Barendt, Freedom of Speech, op. cit., pp. 51 e ss. (sobre restrição de discurso com base em conteúdo na jurisprudência dos EUA) e pp. 184 e ss. do trabalho de Júlio César Barroso Silva citado acima.

Catharine MacKinnon, autora feminista defensora da proibição de certos tipos de pornografia, defende os prejuízos causados pela pornografia decorrem do seu conteúdo, e não do seu "contexto"( "Whatever damage is done through such words is done not only through their context but through their content, in the sense that if they did not contain of what they contain, and convey the meanings and feelings and thoughts they convey, they would not evidence or actualize the discrimination that they do", MacKinnon, Only Words, op. cit. p. 14 (veja ainda p. 68). Veja também pp. 29 e ss., esp. pp. 33-35 para exemplo das fotografias dos linchamentos de negros nos EUA, pp. 35 e ss. e p. 91 para pornografia infantil, p. 36 para exemplo de discriminação em ambiente de trabalho e pp. 38 e ss. para caso dos panfletos comunistas julgado pela Suprema Corte dos EUA comparado à pornografia (esp. pp. 40-1 para comparação entre pornógrafos e o estado), pp. 103-4 (sobre violência e "proof of injury") e pp. 1037 sobre ofensa. Excelente artigo de intervenção no debate sobre pornografia é . "Whose Right? Ronald Dworkin, Women, and Pornographers", op. cit., de Rae Langton. Trata-se de trabalho extremamente admirável pela minúcia e detalhe com que se dedica a mostrar por que os argumentos de Dworkin a favor da permissibilidade da discriminação reversa por meio de cotas raciais nas universidades e contra a proibição da pornografia na verdade exigem a proibição de material obsceno de determinado tipo. Veja ainda cap. 7 de Langton, Sexual Solipsism, op. cit. (Abigail Levin tem argumento análogo: The Cost of Free Speech: Pornography, Hate Speech, and their Challenge to Liberalism, op. cit., pp. 34 e ss., pp. 89 e ss.). Análise e crítica do trabalho de Langton exigiriam esforço inadequado ao objeto imediato desta dissertação. 
sua raça é discriminatório, enquanto a expressão da ideia de que deve haver restaurantes separados entre brancos e negros, embora tenha conteúdo discriminatório, não é ela mesma discriminatória $^{662}$. É claro, este diagnóstico depende de que haja o direito de acesso a serviços independentemente da raça ou cor, mas que não haja o direito de viver em um ambiente completamente desprovido de manifestações de determinado conteúdo, inclusive racista.

${ }^{662}$ Assim, outros artigos da Lei 7.716 de 1989, em especial seu artigo $5^{\circ}$, não violam a liberdade de expressão. O dispositivo tem a seguinte redação

"Art. $5^{\circ}$ Recusar ou impedir acesso a estabelecimento comercial, negando-se a servir, atender ou receber cliente ou comprador.

Pena: reclusão de um a três anos.”, disponível em http://www.planalto.gov.br/ccivil 03/leis/17716.htm, acesso em 16.10.2013. Aproveito a oportunidade para agradecer à Luciana Silva Reis e ao Yuri Corrêa da Luz pelas conversas sobre temas variados sobre liberdade de expressão, em especial sobre questões relativas a esta lei.

Compare as minhas observações sobre a lei de racismo com Júlio César Casarin Barroso Silva. Democracia e Liberdade de Expressão: Contribuições para uma interpretação política da liberdade de palavra. op. cit., pp. 160 e ss. Júlio César defende o projeto de lei que criminaliza a homofobia e diz o seguinte sobre a lei vigente:

"Os tipos penais cridaos pela lei 7716 são ostensivamente focados em ações de privação ou tentativa de privação de direitos e liberdades das categorias protegidas. Verbos como 'impedir' e 'obstar' repetem-se uma e outra vez no texto da lei (...) O escopo da lei e do projeto que propõe a criminalização de condutas discriminatórias de fundo homofóbico é claramente o de fazer com que homossexuais não precisem mais, por exemplo, temer a demissão sumária no caso de sua inclinação sexual se tornar pública.

"As implicações diretamente vinculadas à liberdade de expressão estão no final do documento. Se bem que o artigo 20 tenha uma redação mais aberta e ampla, penalizando a conduta de 'induzir ou incitar a discriminação ou preconceito de raça, cor, etnia, religião ou procedência nacional', acreditamos, de acordo com a argumentação que vimos desenvolvendo, que o tipo deve ser interpretado em consonância com o restante do documento legal. A expressão deve ser suprimida caso se resuma a insultos dirigidos contra grupos historicamente privados de direitos. No caso de a expressão apelar para habilidades deliberativas, a punição deve executar-se apenas na medida em que se a expressão esteja relacionada de forma mais ou menos direta com a privação concreta de direitos. É uma distinção deste tipo que nos permitiria punir a incitação à demissão de um homossexual, por exemplo, preservando o direito de crença religiosa em que a homossexualidade é 'pecado', desde que essa crença sirva apenas como guia de conduta dos indivíduos que a abraçam voluntariamente. Isso se torna mais evidente diante do fato de que a lei autoriza o juiz a tomar medidas duras, no caso de incitação ao racismo ser feita 'por intermédio dos meios de comunicação social ou publicação de qualquer natureza'. Nesse caso, o juiz poderá determinar 'o recolhimento imediato ou a busca e apreensão dos exemplares do material respectivo' e/ou 'a cessação das respectivas transmissões radiofônicas ou televisivas'. No nosso entender, a única forma de expressão punível per se no documento é a da fabricação, comercialização, distribuição e veiculação da suástica 'para fins da divulgação do nazismo'. Mas a suástica, convenhamos, não faz nenhuma falta a nossa deliberação pública", pp. 161-2, itálico no oridinal.

A meu ver, a teoria do direito à liberdade de expressão em Dworkin não obsta as normas da lei que Júlio César também defende - e, de fato, outros pontos da teoria dworkiniana as exigem, ainda que talvez não como normas penais, pois caracterizam discriminação, e não somente discurso de conteúdo discriminatório - mas demanda interpretação muito mais restrita do artigo 20 nos termos da ideia de discriminação defendida por Dworkin; por fim, as reflexões sobre liberdade de expressão em Dworkin apontam como clara violação deste direito a norma sobre suástica. Se de fato lhe é dado concordar que do ponto de vista de "deliberação pública", para usar a expressão de Júlio César, nada se perde, não é aí que Dworkin encontra o crucial da liberdade de expressão. Para ele, o que se perde com a proibição do porte de suástica é o respeito aos direitos de autenticidade e de participação exigidos pela igualdade e pela democracia, como discuto abaixo neste capítulo.. Veja a nota anterior. 
Existem direitos ao ambiente em que vivemos, mas é implausível supor que este direito seja tal que justifique não só restrição, mas também proibição, de discursos ditos discriminatórios ${ }^{663}$.

Não é injusto dizer que a integração das liberdades à igualdade no pensamento de Dworkin permite ao indivíduo fazer o que bem desejar com os seus recursos ${ }^{664}$. O ponto é que, ao contrário do que pode parecer, esta afirmação garante liberdade de expressão bastante menor do que aquela disponível de facto aos sujeitos que controlam a esfera pública de sociedades como a nossa, que são desiguais. O importante é perceber que a crítica, por exemplo, à concentração da mídia, à falta de acesso a meios de comunicação por parte de muitas pessoas e grupos etc. possível de ser formulada a partir da teoria da justiça de Dworkin segue a crítica mais básica à má-distribuição de recursos ${ }^{665}$. Isto faz esta crítica ser uma questão de posição distributiva ocupada pelo indivíduo, dos recursos ou "circunstâncias" de que determinado sujeito goza, e não do conteúdo do que ele diz, pois o problema no ambiente público de uma sociedade em que existe propagação de ideias racistas, por exemplo, não é o conteúdo destas ideias propriamente dito, mas que muitas vezes os defensores de ideias contrárias não gozam de recursos para defendê-las. Para Dworkin, problema é mais fundamental do que simples análise do panorama discursivo da sociedade evidencia: está na desigualdade, inclusive racial, na distribuição de recursos, e não no racismo enquanto conteúdo de ideias. As medidas consequentes desta percepção são reformas distributivas e, eventualmente, restrições, mas nunca proibições à defesa e propagação de ideias específicas, pois viola as liberdades suprimir por meio de proibições legais a defesa de opiniões, quaisquer que sejam. Para Dworkin, portanto, o problema é a injustiça mais básica - o fato de a

\footnotetext{
${ }^{663}$ Compare com a crítica de Waldron à associação entre crença religiosa e identidade: The Harm in Hate Speech, op. cit., pp. 131-136, esp. p. 134. Waldron defende a restrição do discurso de ódio, mas se preocupa em delimitar os direitos que indivíduos tenham ao "social environment" (p. 134).

${ }^{664}$ MariaBeatriz Inkis, O Exercício da Cidadania segundo as Teorias Política e Jurídica Propostas por Ronald Dworkin, op. cit., "Liberty é (...) conceituada por Dworkin como 'o direito de fazer o que você quiser com os recursos que são seus por direito'", p. 26, itálico no original, nota omitida (trata-se da n. 26, com referência a Is Democracy Possible Here, op. cit., p. 69). Compare com a crítica de Waldron à distinção defendida por Dworkin entre as obrigações do governo e dos cidadãos: veja The Harm in Hate Speech, op. cit., pp. 92 e ss.,97-100. Como diz Ripstein, "The key idea underlying Dworkin's egalitarianism and his specific account of the relation between liberty and equality is that the state must treat its citizens as equals, not that each person's life must be organized around achieving equality", "Liberty and Equality", op. cit., p. 84 (veja ainda a descrição da teoria de Nozick na p. 83 e também pp. 92-3, 97-8)

${ }^{665}$ Dworkin fala muito pouco sobre o tema, mas veja "Political Equality", op. cit., pp. 201-3, trecho discutido abaixo na subseção 3.1 .
} 
sociedade ter distribuição não-igualitária de recursos - e não o conteúdo - o fato de que a ideia defende sociedade com tal distribuição injusta - de determinada manifestação.

Isto fica claro quando o autor rejeita a ideia de igualdade de influência horizontal como intepretação da igualdade política ${ }^{666}$. Dworkin entende que a objeção que se pode levantar contra este tipo de diferença de poder reside não na diferença em si, mas na sua possível origem distributiva, isto é, no fato de que decorre, como no caso das mulheres, "da combinação de injustiça econômica, estereótipos e outras formas de opressão e preconceito (...) ${ }^{\text {} 667}$. Para o autor, não é a diferença que é injusta, mas a desigualdade inicial que gera a diferença, que é perfeitamente aceitável se se mantiver caso o problema distributivo seja corrigido. Em outras palavras, Dworkin cogita

"uma sociedade na qual a discriminação econômica, social e cultural contra as mulheres tenha sido eliminada. Se o poder de homens e mulheres, em média, for assimétrico em tal sociedade - como talvez seja, em qualquer direção -, este fato, por si só, contaria como falha na organização social?" ${ }^{\text {"668 }}$.

Dworkin responde negativamente, pois a melhor interpretação da queixa sobre as desigualdades de influência na nossa sociedade reside na percepção de que a injustiça da diferença reside na sua origem, e não nela mesma, pois não há nada a reparar numa sociedade que, apesar de justa, tem indivíduos com poder de influência variável. ${ }^{669} \mathrm{O}$ ponto, portanto,da

${ }^{666}$ Veja "Political Equality", op. cit., pp. 195 e ss. Por influência Dworkin entende "the nonconstitutional powers of charisma or reputation or association or skill or threat or bribe or other advantages that give any person influence over the political acts of anyone else" pp. 191-2, e a define em termos de probabilidade, dando um exemplo: "when you learn that I oppose tax reduction and will do everything I can to defeat it, the degree to which you should increase the probability of that decision in virtue of that information states my political influence over the issue", p. 192, nota omitida; a influência é horizontal porque diz respeito à comparação entre a influência entre os cidadãos, e não entre eles e seus representates, pp. 190-1, 194-5.

${ }^{667}$ Veja "Igualdade Política" in Virtude Soberana, op. cit., p. 270; no original, "Political Equality", op. cit., p. 196.

${ }^{668}$ Veja "Igualdade Política", op. cit., p. 270; no original, "Political Equality", op. cit., p. 196

${ }^{669}$ Coisa que Dworkin julga provável: "Political Equality", op. cit., pp. 196-7. Pouco antes, Dworkin trabalha outro exemplo, desta vez de uma pessoa muito rica (Rockefeller): "The main appeal of horizontal equality of influence lies in the conviction that it is unfair that some private citizens have much more influence in politics than others just because they are much richer. But we can explain this intuition in two ways. We can, indeed, explain it as resting on the assumption that any great lapse from equality of influence among private citizens is a serious lapse in democracy. Or we can explain it in a way that does not appeal to equality of influence, as a general idea, at all. We can say, for example, that it is unjust that some people have as much money as a Rockefeller because that violates the distributive principles of equality, and then add that the disproportionate political influence their wealth gives them is particularly deplorable consequence of the injustice because it allows them, among other things, to perpetuate and multiply their unfair advantages.

"These two ways to object to a Rockefeller's political influence are, of course, very different. The first is insensitive to the source of his disproportionate influence; it supposes that aggregate influence, from all sources, must be equal. The second makes no assumptions about aggregate influence; it condemns a Rockefeller's influence only because of the particular source of that influence. We can contrast the two objections by imagining a world in which the first would hold but the second would not. Suppose the distributional goals of equality were 
influência de ideias negativas, não reside nela propriamente dita, mas na sua eventual origem, o que caracteriza como injusta a propagação de determinadas ideias independentemente do seu conteúdo. É a posição ocupada pelo emissor, ou, como Dworkin diz ao discutir igualdade de influência, as questões distributivas que antecedem a influência de um indivíduo, e não o conteúdo das ideias que expressa, que são relevantes e que podem atrair intervenção do direito.

Isto dito, é indispensável reconhecer que à liberdade de expressão não é relevante somente indicar quais direitos de liberdade de expressão existem, mas também que direitos que eventualmente se lhe opõem inexistem ${ }^{670}$. É que direitos, em Dworkin, só cedem, salvo exceções, a outros direitos. É relevante então saber se existem direitos que sejam capazes de modificar a ideia fundamental de liberdades integradas à justiça distributiva e ao consequente tratamento da liberdade de expressão como uma questão de posição distributiva, e não de conteúdo de ideias. Dworkin discute alguns destes direitos. O primeiro é o direito a um

met, but some people still had more influence in politics than others. They might have more influence for a variety of reasons, but I shall assume reasons unobjectionable in themselves, because we are considering whether we should object to unequal influence as such. They might have decided to spend more of their initially equal wealth on political campaigns, for example, than others have. Or they might have invested more in study and training, which made others more likely to consult them or listen to their advice. Or they might have led lives of such conspicuous achievement or virtue that others trust them more or are more ready to follow them. The first form of objection to a Rockefeller's influence would nevertheless apply to such people. We would regard the greater influence of politically motivated or experienced or charismatic people as a defect in political organization, and take whatever steps we could to eliminate or reduce it. But the second form of the objection would lapse unless we had some other reason, quite independent of any assumption that political influence should be equal, for objecting to a situation in which some people are more politically motivated or trained or charismatic than others.", pp. 195-6. Ainda, nas pp. 197-8 Dworkin imagina estratégias "preposterous" (p. 198) que possam corrigir as diferenças de influência que não são superadas pela justa distribuição de recursos - todas elas, diz o autor, inaceitáveis (veja o argumento sobre limite a doação eleitoral, discutido abaixo).

Veja ainda "Introduction: The Moral Reading and the Majoritarian Premise", in Freedom's Law, op. cit, pp. 26 e ss., especialente: "We do not want wealth to affect political decisions, but that is because wealth is unequally and unfairly distributed. We certainly do want influence to be unequal in politics for other reasons: we want those with better views, and who can argue more cogently, to have more influence", p. 27. De Justice for Hedgehogs (op. cit.), veja o seguinte trecho: "We regret some people's influence because it is grounded in wealth, which we think should make no difference in politics. But we do not regret other people's special influence - Reverend King's, for instance - nor think this is a defect in our democracy. On the contrary, we are proud of the power he had", p. 389 (veja em geral pp. 388 e ss. e também Is Democracy Possible Here?, op. cit., p. 142). Veja "Free Speech, Politics, and the Dimensions of Democracy", op. cit., p. 364, pp. 366-7.

Para argumento análogo, veja "Foundations of Liberal Equality", op. cit. pp. 258-9, sobre o modelo do impacto e a justiça como parâmetro soft da boa vida: para este modelo, o que importa é a quantidade de recursos disponíveis, e não a sua justiça (veja discussão no capítulo segundo). Compare com p. 260 sobre o modelo do desafio, que é o preferido de Dworkin: para ele, o relevante é a justiça, não a quantidade absoluta de recursos. Em outras palavras, no pensamento de Dworkin, tanto a quantidade absoluta de recursos quanto a influência política elas mesmas não são injustas, dependendo reparo da situação de eventual violação da justiça distributiva irredutível a qualquer simples desigualdade.

${ }^{670}$ Veja a crítica de Waldron à inclusão do discurso de ódio na liberdade de expressão defendida por Baker: “(...) in the end, what Ed Baker has done, most adeptly, is account for the importance of one of the values rather than dispelling our sense that other values are also at stake”, The Harm in Hate Speech, op. cit., p. 172. 
ambiente desprovido de discurso de conteúdo discriminatório. Talvez existam direitos ao ambiente em que vivemos, mas é implausível supor que este direito é tal que justifique não só restrição, mas também proibição, de discursos ditos discriminatórios. A interpretação da liberdade de expressão disponível na integração entre igualdade e liberdade no pensamento dworkiniano pressupõe concepção de ambiente que, em Dworkin, é expressa através das ideias de "cultura de liberdade" e "cultura de independência". Estes são temas que desenvolvo superficialmente nesta dissertação, pois não é meu objetivo elaborar uma teoria do ambiente a partir do liberalismo igualitário de Dworkin. Mas o autor fez algumas observações sobre o tema, que exponho em partes ao longo deste capítulo e na conclusão desta dissertação. A questão relevante, portanto, é saber quais direitos as pessoas têm em relação ao ambiente em que vivem; veremos que, para Dworkin, a igualdade exige que todos possam contribuir política e moralmente ao ambiente, o que exige a inclusão do discurso de ódio e a pornografia à liberdade de expressão que se reconhece.

O segundo direito, ou melhor, grupo de direitos, é aquele impossível de ser generalizado $^{671}$, entre eles o direito de não ser ofendido ou ridicularizado, de ser "silenciado", entre outros. O argumento de Dworkin contra estes direitos consiste em apontar a impossibilidade de limitar sua concessão porque, concedida a um subgrupo que o reclama, outros, por igualdade, deveriam recebê-lo, o que, por circunstâncias de cada direito, é impossível de se fazer. Discuto em maiores destalhes estes temas na subseção 4.1., abaixo.

Por ora, vale notar que a interpretação da liberdade de expressão oferecida por Ronald Dworkin precisa ser compreendida de maneira bastante distinta daquela pela qual muitas vezes se pretendem estabelecer as fronteiras entre os discursos aceitáveis e os inaceitáveis. A teoria da liberdade de expressão em Dworkin tem como chave teórica as circunstâncias distributivas do emissor, e não o conteúdo daquilo que ele diz ou publica. A posição distributiva caracteriza o conceito da qual a teoria da liberdade de expressão do autor pode ser considerada uma concepção, para utilizar distinção por ele empregada diversas vezes, pois a depender da teoria da justiça distributiva defendida, defende-se maior ou menor extensão da liberdade de expressão que, entretanto, é insensível ao conteúdo da ideia expressa. Se igualdade é de circunstâncias, e se liberdade é questão de igualdade, então é evidente que a liberdade é uma

\footnotetext{
${ }^{671}$ Dworkin caracteriza o argumento em termos de impossibilidade de generalização em "Free Speech, Politics, and the Dimensions of Democracy", op. cit., p. 366 (veja subseções 3.2. e 4.1., abaixo).
} 
questão de circunstância, e não de conteúdo ${ }^{672}$. Por posição entenda-se a situação ocupada pelo indivíduo em relação a terceiros, em contraste com avaliação ética, moral ou política do conteúdo do discurso. O ponto aqui remete ao que Dworkin chama de "independência ética"; o tema foi objeto do capítulo segundo e retorna na primeira subseção da próxima seção.

Apesar de o conceito de liberdade de expressão em Dworkin ser uma questão de posição, e não de conteúdo, ainda assim admite restrições. As principais restrições trabalhadas pelo autor em sua obra são as seguintes: (i) aquelas exigidas ou autorizadas pela justiça distributiva; (ii) as decorrentes dos direitos dos que não querem pornografia em público; (iii) as decorrentes de os direitos legalmente reconhecidos à imprensa não serem direitos morais; (iv) às decorrentes de as empresas não terem direito à liberdade de expressão, (v) e as próprias do processo eleitoral. Alguns destes pontos serão trabalhados abaixo.

Um último ponto merece atenção. Apesar de a literatura, sobretudo a que pretende ver restringida a liberdade de expressão, explorar especificidades de alguns tipos de discurso, notadamente da pornografia, e apesar de sempre que se fala de direitos ser útil dar-lhes concretude, a interpretação da liberdade de expressão em Dworkin admite - e, na verdade, exige - a abordagem geral que ofereço nesta seção. Ou seja, integração da liberdade à igualdade na forma de uma concepção de justiça distributiva é que ela oferece solução conjunta a casos cujas características parecem ser diferentes: discurso de ódio racista, que estimula discriminação no ambiente de trabalho, pornografia, que tem a mesma consequência, mas também pode ter relação com violência sexual etc. A interpretação do direito à liberdade de expressão oferecida por Dworkin não ignora os argumentos específicos formulados por autores e autoras em defesa de proibições seja do discurso de ódio, seja de espécies de pornografia. Mas opõe obstáculo geral decorrente da fundamentação de princípio por ele desenvolvida à liberdade de expressão. Pode-se dizer que, para Dworkin, o argumento que justifica a extensão da liberdade de expressão ao discurso de ódio e à pornografia é o mesmo, ainda que o autor se preocupe em responder a argumentos específicos de adversários intelectuais. Mais que isso, aplicação a contrario sensu dos argumentos em defesa da liberdade de expressão explica por que, para ele, liberdade de imprensa e liberdade acadêmica e discurso corporativo não fazem parte da liberdade de expressão. Novamente, argumentos específicos são aplicáveis, mas a ideia geral de um direito igualitário a uma liberdade de uso de recursos

\footnotetext{
672 “Foundations of Liberal Equality”, op cit., pp. 300-5 (veja discussão no capítulo anterior).
} 
distribuídos está presente. Em outras palavras, a fundamentação da liberdade de expressão em Dworkin desempanha o papel que dela se espera: diz o que faz e o que não faz parte desta liberdade. Não é meu objetivo, nesta dissertação, esmiuçar os argumentos oferecidos pela literatura a favor de opiniões diferentes das de Dworkin, e nem expor pormenorizadamente os debates sobre, por exemplo, discurso de ódio e pornografia em que o autor interveio. Na quarta seção, abaixo, exponho brevemente suas ideias, e espero ser capaz de fazer chegar o leitor a profunda coerência com que Dworkin desenvolve suas reflexões teóricas sobre justiça e ética, bem como seus argumentos sobre liberdade de expressão. ${ }^{673}$

Antes de concluir esta seção e ingressar nas próximas, gostaria de apresentar a estrutura das defesas do direito à liberdade de expressão disponíveis no pensamento de Ronald Dworkin. Cumpre distinguir dois tipos de liberdade, a saber, liberdade positiva e liberdade negativa, ambas decorrentes, para Dworkin, do segundo princípio de dignidade, a saber, da autenticidade $^{674}$ :

"Em primeiro lugar, todas as pessoas devem poder participar de forma correta das decisões coletivas que constituem a sua governação [governance]; em segundo, todas as pessoas devem ser eximidas da decisão coletiva em questões que a sua responsabilidade pessoal exige que sejam decididas por si próprias. Como a responsabilidade tem estas duas dimensões, o mesmo acontece com a liberdade. Uma teoria da liberdade positiva estipula o que significa as pessoas participarem de forma correta. Ou seja, oferece uma conce[p]ção de governo democrático.Uma teoria da liberdade negativa descreve que escolhas deverão estar isentas das decisões coletivas, se a responsabilidade tiver de ser preservada" ${ }^{\text {"675 }}$.

Dworkin esclarece que, em Justice for Hedgehogs, discute liberdade negativa no capítulo 17 , e positiva no capítulo 18 , dedicado à democracia. O que se tem, portanto, é uma

\footnotetext{
${ }^{673}$ Faço esta observação em resposta a crítica efetuada pelo orientador, prof. Ronaldo Porto Macedo Junior, por ocasião da Banca de Qualificação realizada em outubro de 2012. O professor apontou para as especificidades, por exemplo, do discurso de ódio e da pornografia, o que exigiria que fossem analisados separadamente. As especificidades existem, mas não são relevantes porque o direito aos dois tipos de discurso admitem a mesma fundamentação, a saber, aquela oferecida por Dworkin em termos da ética, igualdade e democracia. Isso não significa que não podem receber análise específica, especialmente considerando a importância da literatura em torno, por exemplo, da pornografia. Dworkin aliás faz esse esforço, em "Pornography and Hate", op. cit. e "MacKinnon's Words", op. cit.. O ponto, entretanto, é que este é uma tarefa específica de análise do debate entre Dworkin e as feministas anti-pornografia que não compõe esta dissertação, focada no pensamento de Dworkin.

${ }^{674}$ Justice for Hedgehogs, op. cit., p. 365.

675 Justiça para Ouriços, op. cit., p. 374 (acrescentei a palavra entre colchetes para indicar como consta no original, e acrescentei "p", também entre colchetes, em "concepção"); no original em inglês, Justice for Hedgehogs, op. cit., p. 365. Na p. 364, o autor cita Benjamin Constant e Isaiah Berlin acerca da existência de dois conceitos de liberdade (veja ainda pp. 379 e ss. e, sobre Berlin, veja "Pornography and Hate", op. cit.), autores mencionados também em "Introduction: The Moral Reading and the Majoritarian Premise" in Freedom's Law, op. cit., p. 21. Para aplicação da distinção entre liberdade positiva e negativa à liberdade de expressão, veja trecho citado no capítulo anterior em Justice for Hedgehogs, op. cit. pp. 372-3. Veja Guest, Ronald Dworkin, op. cit., pp. $175-7$.
} 
concepção bipartite de liberdade em que ambas as partes se fundam num princípio ético de dignidade. Se buscarmos nesta e em outras obras de Dworkin os cruzamentos de cada tipo de liberdade com o valor da igualdade e se rastrearmos a integração da ética na liberdade, chegase à seguinte estrutura:

A liberdade de expressão é defendida no pensamento de Ronald Dworkin como liberdade I. negativa ou II. positiva. Enquanto liberdade negativa, ela se fundamenta (I.i) num direito à independência ética (veja subseção 2.2., abaixo) ou (I.ii) numa concepção de justiça distributiva que Dworkin chamou de igualdade de recursos (veja subseção 2.3., abaixo); tanto I.i quanto I.ii, cada um a seu modo, dependem do que Dworkin chamou, em diferentes momentos, de "autenticidade".

Enquanto liberdade positiva (II), a liberdade de expressão é uma questão de democracia, que Dworkin interpreta com mais de uma terminologia, sendo mais relevantes para os meus propósitos (II.i) a ideia de agência e o princípio (nitidamente ético) da independência, que compõe a democracia concebida como ação comunal integrada, de responsabilidade coletiva e de julgamento individual e o princípio da participação (veja subseção 3.1., abaixo) e (II.ii) a "igual cidadania", "dimensão" da democracia que o autor apresenta como questão de direitos. ${ }^{676}$

Cada um desses elementos é considerado separadamente nas subseções das próximas duas seções. Isto não significa que as distinções ora encontradas em Dworkin sejam mais de

\footnotetext{
${ }^{676}$ O seguinte trecho de "Is Democracy Possible Here?" oferece uma visão mais panorâmica dos argumentos de Dworkin em defesa da liberdade de expressão:

"We must now ask the question about the right of free speech that I asked in chapter 3 about the right of religious freedom. What more basic principles or policies justify protection speech in that special way? There is an extensive literature among constitutional scholars and political philosophers devoted to that question, and much of it makes the important point that there is no single answer. Freedom of speech serves a considerable variety of important principles and policies. But two of these are most in point in our discussion now. First, freedom of speech is a crucial part of the rights people must have to protect their personal responsibility under the second principle of human dignity: the responsibility to identify and seek value in their own lives. Second, that freedom is a crucially important condition for the realization of any plausible conception of democracy: it is plainly essential to the partnership conception that I said we should favor. We must therefore ask whether the radical changes in election law that I propose would compromise either of these fundamental reasons for protecting speech.

"Preventing someone from speaking his conscience and conviction to other people is a particularly grave harm. People develop their ethical and moral responsibilities most effectively in conversation and exchange with others. Speaking out for what one believes - bearing witness and testimony - is in any case for most people an essential part of believing; it is part of the total phenomenon of conviction. Identifying oneself to others as a person of particular beliefs or faiths is part of creating one's identity, part of the process of self-creation that is at the center of our personal responsibility. Silencing someone's political speech is a particularly devastating insult because it denies his role as a full partner in self-government. So we should be particularly attentive to the danger of regulating political speech in any way." Op. cit., pp. 152-3.
} 
substância do que por conveniência expositiva. O contrário é o caso, e é justamente por viabilizar explicação estruturada que as aproveito neste capítulo. Trata-se de esforço a meu ver complicado pela natureza integrada da teoria de Dworkin, mas que é necessário dada a relevância da liberdade de expressão à interpretação tanto da ética quanto de valores políticos como a igualdade, a liberdade e a democracia.

\section{Seção 2. A Liberdade de Expressão como Liberdade Negativa}

Nas próximas duas seções, discuto os fundamentos teóricos da liberdade de expressão em Dworkin, seja como liberdade negativa, seja como liberdade positiva, na distinção presente em Justice for Hedgehogs. Na subseção 2.1., recupero brevemente argumento já mencionado anteriormente: a fundamentação de direitos, especialmente o da liberdade de expressão, em aspecto da concepção de bem de Dworkin que ele chamou de "independência ética". Na subseção 2.2., recupero o argumento acerca da integração das liberdades na igualdade de recursos exposto na última seção do capítulo primeiro e exponho a passagem do mundo ideal ao mundo real concebida por Dworkin, e que aponta para delineamento bastante claro da liberdade de expressão: existe perda de liberdade no mundo real quando a liberdade resultante é inferior à que estaria disponível no que chama de uma "distribuição igualitária defensável”. Esses são os dois pontos que pretendo explorar para apresentar a compreensão de Dworkin da liberdade de expressão enquanto liberdade negativa.

\section{Subseção 2.1. Liberdade de Expressão e independência ética}

A defesa de Dworkin da liberdade de expressão com base na ideia de independência ética admite exposição sumária tanto porque reitera pontos já discutidos nesta dissertação (veja acima a ideia "tolerância liberal" como o autor a concebe em "Foundations of Liberal Equality", por exemplo, bem como) quanto porque parte dos trabalhos em que Dworkin defende direitos de independência se insere no esforço que faz de criticar tentativas, por exemplo, de proteger o consumo de pornografia por fundamentos utilitaristas ${ }^{677}$. É que, agora, estes fundamentos não estão mais em jogo porque Dworkin justifica as liberdades ao integrá-

\footnotetext{
677 “Do We Have a Right to Pornography?”, op. cit.. (p. 354, por exemplo). Para crítica, veja Rae Langton, "Whose Right? Ronald Dworkin, Women, and Pornographers", op. cit..
} 
las na sua teoria da justiça distributiva, a igualdade de recursos, que não é utilitarista ${ }^{678}$. Este ponto é extremamente complexo porque diz respeito à comparação de diferentes momentos da obra do autor.

Não é meu objetivo enfrentar esta questão nesta dissertação, embora o tema seja, a meu ver, de imenso interesse teórico. Basta reiterar que, para Dworkin, a independência ética pode ser violada pelo menos de duas formas quando o estado restringe a liberdade de expressão: ou porque trata-se de utilização de julgamentos éticos para restringir liberdade ou porque restringe aspecto fundacional da independência ${ }^{679}$. exemplo do primeiro é a proibição da pornografia e, do segundo, proibição de discurso racista ${ }^{680}$. Estes são temas que, ainda que em outros termos, retornam abaixo nesta dissertação. Por ora vale explorar a delimitação da liberdade de expressão disponível na teoria da justiça distributiva do autor, a saber, a igualdade de recursos.

\section{$\underline{\text { Subseção 2.2. Liberdade de Expressão e igualdade de recursos }}$}

No primeiro capítulo, expus a tentativa de Dworkin de encontrar lugar às liberdades na sua teoria da justiça distributiva, a saber, a igualdade de recursos ${ }^{681}$. A tentativa é importante porque, a depender de como se entendessem as liberdades segundo a teoria da justiça de Dworkin acabariam muito pouco protegidas. $\mathrm{O}$ autor então apresenta argumento que identifica as liberdades como pressuposto do leilão, e não de seu objeto: formam o que ele chama de "baseline", conjunto de regras que estabelecem o que significa possuir os recursos distribuídos. Este expediente preserva as liberdades de inúmeros problemas e - ao mesmo tempo que lhes justifica, poisse fundamentam na igualdade e na autenticidade das negociações dos recursos - lhes delimita, isto é, aponta tanto para o que, por exemplo, a liberdade de expressão inclui quanto para o que ela não inclui (pelo menos não segundo a igualdade recursos).

$\mathrm{O}$ argumento de Dworkin, até este ponto, em que elabora os princípios caracterizadores da linha de base do leilão imaginário, é expressamente ideal; ou melhor, é próprio do que Dworkin chama de "ideal mundo ideal", contrastado com o "mundo real ideal"

\footnotetext{
${ }^{678}$ Yowell, "A Critical Examination of Dworkin's Theory of Rights", op. cit., p. 109 (para a ideia de que, no início da década de 1980, Dworkin adotou "resource egalitarianism" em substituição ao utilitarismo como "theory of legislative justice"; veja ainda pp. 116-20).

${ }^{679}$ Justice for Hedgehogs sop. cit., pp. 368 e ss.; veja ainda “Do Liberty and Equality Conflict?”, op. cit. pp. 50-1.

${ }^{680}$ Justice for Hedgehogs, op. cit., pp. 371 e ss..

681 "The Place of Liberty", op. cit.
} 
e o "real mundo real" 682 . Não pretendo aqui apresentar todas as categorias oferecidas por Dworkin para explicar a passagem entre os mundos, salvo mencionar, em poucas palavras, que o autor formula a noção de "distribuições igualitárias defensáveis", que são distribuições que não alcançam perfeição no ideal igualitário, mas que chegam o mais próximo possível dele, ou seja, são distribuições caracterizadas por situação "em que nenhuma mudança adicional tecnicamente possível pudesse nos aproximar ainda mais do ideal(...)" ${ }^{\prime 683}$. Essas distribuições defensáveis caracterizam o mundo ideal real para Dworkin, em que ninguém seria proibido de utilizar seus recursos da maneira que bem entendesse salvo limitações necessárias à proteção da segurança e à correção de defeitos de mercado. ${ }^{684}$ Em contraste, a rigidez com que Dworkin enxerga a proteção das liberdades no ideal mundo ideal é atenuada quando está em questão o real mundo real, em que não há uma distribuição igualitária defensável.

Surge questão acerca da delimitação das liberdades ser idêntica a depender de se tratar do mundo ideal ou do mundo real, em que a distribuição de recursos não é igualitária. A pergunta é natural considerando que o argumento do autor integra liberdade e igualdade: talvez desigualdade em uma afete a extensão da outra. Pergunta o autor

\begin{abstract}
"Seriam as restrições à liberdade, não obstante, justificadas em uma sociedade de igualdade muito imperfeita? Será que a igualdade de recursos insiste, mesmo aí, que não se deve comprometer a abstração? Ou será que limitar a liberdade de escolha é um meio legítimo de aumentar a igualdade em uma sociedade muito desigual?" 685
\end{abstract}

A questão é que, observa Dworkin, no real mundo real alguns constrangimentos à liberdade parecem capazes de produzir igualdade, ainda que, no ideal mundo ideal, essas restrições fossem vedadas pelos princípios caracterizadores da linha de base do leilão imaginário: dada a situação de desigualdade do real mundo real essas restrições podem ser justificadas. ${ }^{686}$ Para os propósitos desta pesquisa, a categoria fundamental a ser analisada no real mundo real é o "princípio da vitimização" liberdade": "um décifit de liberdade é uma perda de poder, devido a restrições jurídicas, de

${ }^{682 ~ " O ~ l u g a r ~ d a ~ l i b e r d a d e ", ~ o p . ~ c i t ., ~ p p . ~} 235$ e ss.; no original, "The Place of Liberty", op. cit., esp. pp. 172 e ss. Veja Guest, Ronald Dworkin, op. cit., pp. 203-7.

683 "O lugar da liberdade", op. cit. p. 231; no original, "The Place of Liberty", op. cit., p. 169.

684 "The Place of Liberty", op. cit., pp. 171 e 173; veja em geral pp. 169 e ss.. Compare com o real mundo real, discutido a seguir, em que algumas limitações são toleráveis.

685 "O lugar da liberdade", op. cit., p. 237, com alteração (substituí "eqüidade" por "igualdade"); no original, "The Place of Liberty", op. cit., p. 173.

686 "The Place of Liberty", op. cit., pp. 172 e ss., esp. p. 174.

687 "The Place of Liberty", op. cit., pp. 175 e ss. (a tradução brasileira faz opção por "princípo do sacrifício": veja "O lugar da liberdade", op. cit., pp. 240 e ss.) 
fazer ou ter acesso a algo que se teria o poder de fazer ou ter acesso seguindo uma distribuição defensável. Uma comunidade vitimiza um de seus membros, digamos, quando lhe impõe um deficit de liberdade" ${ }^{688} \mathrm{O}$ princípio responde negativamente à suspeita de que a restrição da liberdade protegida pelo princípio da vitimização possa aprimorar a igualdade. ${ }^{69}$ Mais importante aos meus propósitos é observar que Dworkin não considera necessariamente violadoras da liberdade algumas restrições, a saber, aquelas cuja imposição não afeta liberdade igual ou superior à disponível ao sujeito em uma distribuição igualitária defensável. Esta ideia trabalha com a premissa de que situações de desigualdades, próprias do real mundo real, concedem a indivíduos maior liberdade de escolha do que teriam em situações de igualdade. Em outras palavras, não faz parte da liberdade do indivíduo no mundo real acesso a liberdade que existe em razão de desigualdade de distribuição, que inexistiria no mundo ideal. Por esse motivo, não o vitimiza restrição que não afeta a extensão da liberdade que se ampara em distribuição justa de recursos. Sobre o princípio da vitimização, Dworkin diz que:

"Nega que haja violação da liberdade quando ninguém é vitimizado, isto é, quando o valor da liberdade que
os cidadãos retêm é pelo menos igual ao valor da liberdade irrestrita que teriam em uma distribuição
defensável. Como pode uma concepção plausível de liberdade exigir que qualquer um tenha mais poder do
que teria se a liberdade de escolha fosse ilimitada e os recursos distribuídos com justiça?" O exemplo mais claro utilizado por Dworkin é o do financiamento de campanhas políticas $^{691}$, que abordarei em mais detalhes abaixo. O fato de que no real mundo real, em que

688 "O lugar da liberdade", op. cit., p. 240, com modificações (veja o trecho intacto na tradução: "a restrição à liberdade é uma perda de poder, devido a restrições jurídicas, de fazer ou ter acesso a algo que se teria o poder de fazer ou ter acesso após uma distribuição defensável. A comunidade sacrifica um de seus membros, digamos, quando lhe impõe uma restrição à liberdade"); no original, "The Place of Liberty", op. cit., p. 175; veja pp. 175-6 em especial: "it (...) denies that equality can be improved when someone is vitimized", p. 175. O argumento de Dworkin em defesa desta conclusão consiste em sustentar que déficit de liberdade é incomensurável com diminuição de déficit de igualdade (que, por sua vez, é composto pelo déficit de liberdade e de recursos - mas não pela soma destes dois déficits, pois, enquanto o déficit de recursos é monetarizável, o de liberdade não é: veja $\mathrm{p}$. 165); para déficit de igualdade (equity déficit), veja p. 164; para as ideias de déficit de recursos e de liberdade, veja p. 165 (veja pp. 162-172 em geral).

${ }^{689}$ "The Place of Liberty", op. cit., pp. 175-6. Veja comentário crítico de Langton em "Whose Right? Ronald Dworkin, Women, and Pornographers", op. cit..p. 349, n. 94 (inclusive com citação da definição de "liberty deficit" que citei).

690 "O lugar da liberdade", op. cit., p. 240, modifiquei (substituí “quando não se sacrifica ninguém” pela opção feita na citação); no origina, veja "The Place of Liberty", op. cit., p. 175.

691 "The Place of Liberty", op. cit., pp. 176-7. Dworkin considera outros, como o da medicina privada e o do caso Lochner, decidido pela Suprema Corte dos EUA. Utilizo o do financiamento privado de campanha por ser o mais simples e o mais relevante à liberdade de expressão, objeto desta pesquisa. 
vivemos, existe imensa desigualdade ${ }^{692}$ faz com que alguns indivíduos gozem de condições superiores de se expressar politicamente por meio de doações eleitorais do que gozariam em uma situação mais igualitária. A medida da liberdade, em Dworkin, é a da situação mais igualitária, em que se poderia dizer que existe uma distribuição igualitária defensável. Se uma restrição no real mundo real, que é desigual, não avança sobre a liberdade que haveria numa situação igualitária, não há que se falar em vitimização. Impedir uma pessoa extremamente rica de fazer imensas doações eleitorais não a vitimiza porque numa distribuição igualitária defensável ninguém teria tantos recursos à sua disposição. Diz Dworkin: “(...) ninguém em uma comunidade que houvesse alcançado uma distribuição defensável poderia ter o impacto nas decisões políticas, simplesmente em virtude de dinheiro gasto na política, que os ricos podem ter agora nos Estados Unidos (...)." ${ }^{693}$

${ }^{692}$ Dworkin diz que "Neither Britain nor the United States (nor, I believe, any other country), has yet achieved a defensible scheme of distribution", "The Place of Liberty", op. cit., p. 169. Veja Guest, Ronald Dworkin, op. cit., p. 205.

693 "The Place of Liberty", op. cit., p. 176, traduzi; para a tradução brasileira, veja "O lugar da liberdade", op. cit., pp. 241-2 (traduz-se da seguinte forma: "Ninguém em uma comunidade que alcançou uma distribuição defensável exerceria a influência sobre as decisões políticas, somente devido ao dinheiro o gasto com a política, que os ricos têm hoje nos Estados Unidos"). O trecho completo é o seguinte: comentando a versão do "victimization principle" que prefere, o autor diz: "We may test this version of the victimization principle by applying it to our initial sample cases. Is anyone victimized, first, by limits on the amounts a single person can spend promoting a political candidate? No such limits would be imposed in any plausible defensible distribution. People would have as close to equal resources, judged by the opportunity-cost test, as is technically possible, and each would be free to decide how much of his resources to spend addressing his fellow citizens rather than on other goods he might also want. Nevertheles the limits on election expenses that the Supreme Court struck down in Buckley v. Valeo, had they gone into effect, would not have made the value of the freedom that remained less for anyone that the value of the unconstrained freedom he would have had in at least most plausible defensible distributions. For no one in a community that had reached a defensible distribution could have the impact on political decisions, just in virtue of money spent in politics, that the rich can now have in the United States, or even the impact that the rich would still have had if the Supreme Court had left the legislation intact. Disposable wealth would be much more evenly distributed, and though some people would presumably choose to spend a high proportion of their wealth in politics, many others, some of differing political views, would be ready and able to spend a similar proportion of theirs in the same way. The law the Supreme Court struck down therefore victimized no one", pp. 176-7. Dworkin discute este julgado em "Free Speech, Politics, and the Dimensions of Democracy", op. cit., discutido abaixo nas subseções 3.2. e 4.2. Veja Guest, Ronald Dworkin, op. cit., pp. 117, 205-6: comentando a opinião de Dworkin sobre a lei declarada inconstitucional no caso Buckley, Guest diz que "Under an ideal egalitarian distribution, Dworkin thinks that such a restriction would be unjustified. In Chapter 6, I discussed his view that the freedom to be able to influence political thinking is a significant freedom of a properly democratic community. In the ideal society, where there is a genuine equality of resources, no person would be able to amass such an amount of resources as to have a disproportionate political impact. In the real world, unjust differences of income permit some political candidates to make a disproportionate impact. In Dworkin's view, the financial constraints place upon political candidates were justified. Since they did not impose restrictions on freedom that were less than would have been permitted under an ideal egalitarian distribution they were not, therefore, instances of victimization. The constraints come closer to mimicking the just society although in that society there would be no constraints. And why in that society shouldn't a person devote 
Dworkin acentua que os recursos distribuídos no leilão imaginário constituído pela linha de base correta podem ser utilizados pelo seu titular como bem entender, observado o princípio da segurança ${ }^{694}$. A contrario sensu, os recursos que o leilão nega a um indivíduo não podem ser por ele utilizados livremente: não são dele. Se a titularidade jurídica de um recurso numa sociedade desigual não tem apoio em nenhuma distribuição igualitária defensável, a igualdade de recursos rechaça como injusta a atribuição e uso do recurso. O milionário não pode doar imensas somas porque, em termos de justiça, essas imensas somas sequer lhe pertencem. Para Dworkin, a pergunta relevante é a seguinte: como dizer que a restrição da liberdade de expressão aparentemente presente na vedação de doações ilimitadas a campanhas políticas viola a liberdade se o exercício da liberdade de expressão restrito se dá com recursos sobre os quais, à luz de uma distribuição igualitária defensável, sequer há qualquer liberdade ou direito? Pode-se concluir, portanto, nos seguintes termos: a questão para Dworkin não é se alguém pode gastar o seu dinheiro na política (isto é, pode-se sempre gastar o seu dinheiro), mas se o dinheiro gasto na política é seu.

Temos neste ponto argumento convincente acerca dos limites das liberdades, inclusive da liberdade de expressão, com base em teoria da justiça distributiva. Trata-se de especificação da ideia geral expressa há pouco. Ao integrar as liberdades na justiça, Dworkin se compromete com delimitação de direitos individuais (como a liberdade de expressão) que remete à qualidade da distribuição de recursos utilizada para exercê-la, e não o conteúdo das manifestações realizadas. E como este arcabouço teórico compreende o caso da pornografia e do discurso de ódio? Como princípio, parece autorizar tais direitos se o exercício dessas liberdades não empregar recursos vedados pela igualdade. Faz parte do objeto desta pesquisa aprofundar esta ideia e identificar no papel atribuído por Dworkin às liberdades na igualdade de recursos uma proposta sobre discurso de ódio e pornografia ${ }^{695}$. Se fazem parte da liberdade

his money and time to political causes, rather than, say, to sport, or to buying a second house, or having a large family?", p. 206

${ }^{694}$ Por exemplo, veja este trecho: "The principle of abstraction insists that people should in principle be left free, under the baseline system, to use the resources they acquire, including the leisure they provide and protect through their bidding program, in whatever way they wish, compatibly with the principle of security", "The Place of Liberty", op. cit., p. 152 (veja ainda pp. 171, 176 e 183). Compare com o que Dworkin diz sobre parcialidade em "Foundations of Liberal Equality", op. cit.,: "the goods distributed to me under a fair and equal auction are, that is, morally, mine, in a way nothing can be morally mine under welfare egalitarianism or another welfarebased conception of justice. Equality of resources in that way licenses partiality", p. 292

695 "Do minimum-wage laws, or laws censoring racial speech, abolishing private education, or imposing redistributive income or wealth taxes, advance equality of resources? Would they violate liberty on the liberal 
de expressão pelo menos as hipóteses a que o indivíduo teria acesso em situação de igualdade, o problema eventual do discurso de ódio racista ou misógino não reside no conteúdo discriminatório expresso, mas nos recursos empreendidos, o que fica evidenciado se percebermos que a mesma restrição se aplica à expressão não-racista que se dê por meio de recursos desiguais

\section{Seção 3. A Liberdade de Expressão Como Liberdade Positiva: Democracia e Igualdade Política}

A categoria fundamental que precisa ser analisada ao discutir a liberdade de expressão enquanto liberdade positiva no pensamento de Dworkin é a sua concepção de democracia. Ocorre que parte significativa das reflexões do autor sobre este valor político se prestam à crítica de restrição da democracia ao governo da maioria e à compatibilização do regime democrático com a instituição do controle de constitucionalidade e de direitos individuais ${ }^{696}$. Não se trata de questão relevante aos propósitos desta pesquisa, de modo que esta subseção e a próxima pinçam temas específicos mais diretamente relacionados ao tema desta dissertação.

Na primeira subseção, ocupo-me principalmente do que o autor chama de "agência" e dos princípios da democracia, em especial o "princípio da independência", que aponta para "responsabilidade coletiva" mas "julgamento individual” dos indivíduos de uma comunidade. Isto significa que, para Dworkin, uma sociedade democrática não necessariamente pensa

conception? When the answer to the first question is yes, the answer to the second question is no, and vice versa (...) Equality cannot be advanced by putting any citizen in a worse position than he would enjoy if full, genuine equality had been achieved (8). We should take the same view about censoring racial, sexist or pornographic speech. That is a violation of liberty on the liberal conception, and, since it denies some people an equal role in the formation of the community's moral environment, it is a violation of equality as well (9)", "Do Liberty and Equality Conflict?", op. cit., pp. 55-6, notas omitidas. A nota de rodapé 8, pp. 153-4, tem a seguinte redação: “I am here assuming that appealing to equaliy of resources would not justify putting some people, in an unequal society, in a worse position than they are and worse than the position they would have if equality of resources were fully realized, just in order to improve equality on balance or overall. For a defence of that assumption, see 'What is Equality? Part 3: The Place of Liberty' in Iowa Law Review, 73 (1987), 1-54.”; n. 9, p. 154: "This heated and complex issue is discussed at length in my recent book, Freedom's Law: The Moral Reading of the American Constituion (Cambridge, Mass.: Harvard University Press, 1996), part 2."

${ }^{696}$ Por exemplo, "Equality, Democracy, and Constitution: We the People in Court", op. cit., "Constitutionalism and Democracy", European Journal of Philosophy, 3:1, 1995, pp. 2-11 e "The Partnership Conception of Democracy" California Law Review 453, 1998, pp. 453-458, esp .pp. 457-8. Agradeço ao Renan Barbosa Fernandes pois, se não me falha a memória, foi a sua pesquisa que me chamou a atenção a estes três artigos de Dworkin: Controle de Constitucionalidade e Democracia no debate entre Ronald Dworkin e Jeremy Waldron, op. cit., esp. pp. 42 e ss. e n. 50 na p. 42, que traz referência aos dois últimos trabalhos, à introdução a Freedom's Law, op. cit., e a "Political Equality", capítulo 4 de Sovereign Virtue, op. cit. Veja ainda Justice for Hedgehogs, op. cit., cap. 18, esp. pp. 383 e ss. e pp. 395 e ss. 
conjuntamente, e que a democracia enquanto condição da legitimidade da política exige respeito à independência de pensamento dos indivíduos. A esta independência a liberdade de expressão é fundamental.

Na segunda subseção, exploro a relevância da igualdade à concepção dworkiniana de cidadania. Que a noção "igual cidadania” presente na sua concepção de democracia é uma questão de direitos é essencial à inclusão, por exemplo, do discurso de ódio na liberdade de expressão porque outras "dimensões" da democracia são incapazes de excluí-lo; isto mostra a coerência entre "Free Speech, Politics, and the Dimensions of Democracy", capítulo décimo de Sovereign Virtue, a ideia de direitos no sentido forte e a integração das liberdades na igualdade de recursos.

\section{Subseção 3.1. Democracia, agência e independência}

Duas características da teoria da democracia do autor são relevantes a este trabalho. A primeira delas é que Dworkin compreende a democracia como um valor dependente, que produz teste baseado nos "outcomes" da democracia, e não "separada" de outros valores, que produz teste baseado nos seus "inputs". ${ }^{697}$ No caso da democracia, Dworkin a caracteriza como aquela que

"presume que a melhor forma de democracia é a que tiver mais probabilidade de produzir as decisões substantivas que tratem a todos os membros da comunidade com igual consideração. Nesta perspectiva, as principais características da democracia - sufrágio quase universal, liberdade de expressão e tudo o mais - justificam-se porque a comunidade na qual o voto é generalizado e a expressão é livre terá mais probabilidade de distribuir recursos materiais e outras oportunidades e valores de maneira equânime". ${ }^{698}$

Nem tudo nesta definição é feliz e adequada a uma teoria que integra valores. Em especial, o aparente tratamento da democracia como um instrumento da justiça distributiva se compromete com uma conexão unilateral estranha aos propósitos defendidos pelo autor ${ }^{699}$.

\footnotetext{
697 "Igualdade Política", op. cit., pp. 255 e ss.; no original, "Political Equality", op. cit., pp. 185 e ss. Em especial, "A detached conception of democracy (...) supplies an input test: democracy is essentially a matter of the equal distribution of power over political decisions. A dependent conception supplies an outcome test test: democracy is essentially a set of devices for producing results of the right sort”, p. 186. Vejan Renan Fernandes, Controle de Constitucionalidade e Democracia no debate entre Ronald Dworkin e Jeremy Waldron, op. cit., p. 44. 698 "Igualdade Política", op. cit., p. 255; no original, "Political Equality", op. cit., p.186

${ }^{699}$ Veja "Free Speech, Politics, and the Dimensions of Democracy", in Sovereign Virtue, op. cit., p. 354, em especial trecho citado abaixo na próxima subseção. Compare com a rejeição de tentativa de definir democracia pelas consequências entre diferentes modelos: Justice for Hedgehogs, op. cit., pp. 385-6. Veja a crítica de Gargarella a Dworkin em As teorias da justiça depois de Rawls: um breve manual de filosofia política, op. cit., pp. 8-9, n. 7 (não concordo com a leitura que Gargarella faz, mas este trecho de Dworkin lhe daria alguma razão, ainda que não conclusiva, para sustentar o que diz).
} 
Fica clara, no entento, a “dependência” da democracia em relação à liberdade de expressão, entre outros, pois é pelo respeito a estes elementos que o regime democrático se fundamenta. No mais, Dworkin atribui à concepção dependente a indistinção entre justiça distributiva e igualdade política, o que caracteriza o recurso à justiça distributiva para medir a igualdade política $^{700}$, ao contrário da concepção "separada" (detached), que mede a democracia de modo desconectado da justiça distributiva e de demais questões substantivas. ${ }^{701}$

Mais especificamente, Dworkin entende que "a concepção dependente obscurece [blurs] a diferença entre entrada e saída, entre a igualdade política e os outros aspectos da teoria igualitária, inclusive suas finalidades participativas. ${ }^{, 702}$ Dworkin define estas finalidades participativas como "as decorrentes do caráter e da distribuição da própria atividade política"703. O autor dá três exemplos, a saber, consequências participativas simbólicas, agenciais e comunitárias, sendo a primeira mais ligada ao voto e a proibição de desigualdades baseadas em desprezo por indivíduos prejudicados e a terceira a relevância da política na formação de uma "comunidade política coesa e fraterna"704. A segunda é, segundo o próprio autor, a mais relevante à liberdade de expressão. Agência, como consequência participativa de

\footnotetext{
700 "Political Equality", op. cit., pp. 185-6.

701 "Political Equality", op. cit., pp. 188-90.

702 "Igualdade Política", op. cit., 258, acrescentei entre colchetes a palavra do original em inglês para esclarecer como a tradução brasileira traduz "blurs", o que precisa ser entendida sem eventual carga pejorativa, pois trata-se de característica da concepção dependente que não é apontada pelo autor como um defeito; no original; "Political Equality", op. cit., p. 188. Ainda, sobre a distinção entre igualdade política e igualdade distributiva, veja "In this chapter and in the next I discuss one aspect of that question, which might be called the problem of distributional equality. Suppose some community must choose between alternative schemes for distributing money and other resources to individuals. Which of the possible schemes treats people as equals? This is only one aspect of the more general problem of equality, because it sets aside a variety of issues that might be called, by way of contrast, issues about political equality. Distributional equality, as I describe it, is not concerned with the distribution of political power, for example, or with individual rights other than rights to some amount or share of resources. It is obvious, I think, that these questions I throw together under the label of political equality are not so independent from issues of distributional equality as the distinction might suggest. Someone who can play no role in determining, for example, whether an environment he cherishes should be preserved from pollution is poorer than someone who can play an important role in that decision. But it nevertheless seems likely that a full theory of equality, ambracing a range of issues including political and distributional equality, is best approached by accepting initial, even though somewhat arbitrary, distinction among these issues", "Equality of Welfare", $o p$. cit., p. 12 (veja em geral pp. 11-2). Veja ainda "Equality of Resources", op. cit., pp. 70-1, 75-6, 109, "The Place of Liberty", op. cit., pp. 134-5, 148 e 159.

703 "Igualdade Política", op. cit., p. 257; no original, "Political Equality", op. cit., p.187.

704 "Igualdade Política", op. cit., p. 257 (veja ainda pp. 275-7); no original, "Political Equality", op. cit., p. 187 (veja ainda pp. 200-1). Compare as consequências simbólicas com a ideia dworkiniana de "independência ética", discutida acima nesta dissertação. Veja ainda Christopher Wolfe, "The Egalitarian Liberalism of Ronald Dworkin", op. cit., p. 28.
} 
uma concepção de igualdade, exige que o indivíduo tenha o direito de formar e expressar sua opinião, e que, além disso, tenha chance de influenciar outros ${ }^{705}$. Ele diz:

“(...) as exigências da agência ultrapassam a expressão e a dedicação [commitment]. Não ingressamos na política como agentes morais, a não ser quando percebemos que o que fazemos possa assumir importância, e o processo político adequado deve lutar contra obstáculos gigantescos para preservar esse poder em potencial para todos" ${ }^{\text {, }}$.

Após algumas observações sobre formação de distritos eleitorais, o autor considera a exigência que a agência faz de acesso dos cidadãos aos meios deo comunicação: ele diz, após constatar que a relevância do voto em distritos eleitorais ampos é “desprezível” que

“(...) a meta da agência política só se realiza quanto se oferece a todos o acesso suficiente aos meios de comunicação influentes, caso desejem, para que cada pessoa tenha uma oportunidade justa de exercer influência sobre outras, se puder fazê-lo. Poderíamos dizer que isso é o outro lado das liberdades que são as liberdades de expressão e de audiência, julgadas do ponto de vista da agência. Em nossa sociedade desigual, a fonte mais notória de desigualdade de acesso é a desigualdade de riquezas. Se os recursos fossem distribuídos com mais igualdade, haveria incentivo automático para grandes números de cidadãos. Não obstante, se a economia dos meios de comunicação só desse acesso à audiência política àqueles que optam por investir ou trabalhar no ramo, as metas agenciais da democracia exigiriam que $o$ acesso fosse garantido ou concedido de outras maneiras aos cidadãos em geral., ${ }^{, 707}$

Esta afirmação sobre meios de comunicação e sua democratização é bastante abstrata e desconheço ponto da obra de Dworkin em que o autor a elabore a contento. Trata-se de tarefa convidada pela sua teoria da igualdade que, embora pertinente à liberdade de expressão, está além dos objetivos desta dissertação. ${ }^{708}$

\footnotetext{
705 "Igualdade Política", op. cit., p. 278-80; no original, "Political Equality", op. cit., pp. 202-3.

706 "Igualdade Política", op. cit., p. 278, inseri entre colchetes a palavra do original traduzida por "dedicação" (veja p. 278 em geral); no original, "Political Equality", op. cit., p. 202 (veja em geral pp. 201-2).

707 "Igualdade Política", op. cit., p. 279; no original, "Political Equality", op. cit., 202. Veja ainda "A New Map of Censorship", op. cit., e "Foreword", op. cit. e "Free Speech, Politica, and the Dimensions of Democracy", op cit., pp. 374-6.

${ }^{708}$ Antes de finalizar suas reflexões sobre democracia e agência, ao autor considera a objeção de que a ideia de agência traria à sua concepção de democracia a igualdade de influência, noção anteriormente rejeitada ("Igualdade Política", op. cit., pp. 279-80; no original, "Political Equality", op. cit., p. 203; veja seção 1 deste capítulo). Ele esclarece:"(...) the opportunity for influence, and not merely impact, is necessary to agency. But this says nothing about equality of influence. We encountered that latter idea in the course of a very different argument, which we began by assuming that democracy requires equality of power and wondered what that meant. We discovered that it must mean equality of influence, and we grew doubtful about equality of power mainly for that reason. In the present discussion we encounter the idea of influence in a very different context, in the course of building a dependent conception of democracy. The emphasis is now on the opportunity for some influence - enough to make political effort something other than pointless - rather than on the opportunity to have the same influence as anyone else has. We design a dependent conception of democracy so that it permits anyone who wishes it enough leverage or engagement to make it possible for him or her to treat politics as an extension of his moral life. That is a threshold notion, and nothing in it takes equality of influence to be an ideal toward which we should strive", "Political Equality", op. cit., p. 203; na tradução, "Igualdade Política", op. cit, p. 280 (veja ainda "Equality, Democracy, and Constitution: We the People in Court", op. cit., pp. 338-9).
} 
O segundo ponto que eu gostaria de trabalhar nesta subseção são os argumentos oferecidos por Dworkin em defesa de uma concepção da democracia comunal em detrimento de uma concepção estatística, cada qual dependente de uma concepção homônima de ação coletiva $^{709}$. Ação coletiva estatística é aquela praticada por indivíduos separada mas paralelamente, que tem um efeito distinto do que se possa atribuir à ação de cada pessoa mas que não é atribuível aos indivíduos "como um grupo" "710. A ação comunal é distinta, pois ela pode ser atribuída aos indivíduos enquanto grupo: ação comunal é “coletiva no sentido mais profundo de que requer dos indivíduos que assumam a existência de um grupo como uma entidade ou fenômeno separado"711. Os exemplos de Dworkin são a culpa coletiva da Alemanha contemporânea pelas atrocidades nazistas ${ }^{712}$ e uma orquestra ${ }^{713}$. Cada concepção de ação coletiva aponta para uma concepção de democracia: se estatística, consiste em dizer que democracia é o governo do povo considerado estatisticamente, enquanto a democracia comunal exige que se conceba o povo como entidade separada de seus membros e que é responsável pelo governo ${ }^{714}$. Dworkin prefere a concepção comunal tanto por uma razão de moralidade política quanto por uma questão interpretativa da política de países como EUA e Canadá. $^{715}$ Trata-se de razões que, a meu ver, não demandam detalhadamento nesta dissertação ${ }^{716}$ porque o objetivo mais direto do autor é, neste e em outros trabalhos, justificar

\footnotetext{
709 "Equality, Democracy, and Constitution: We the People in Court", op. cit., esp. pp. 328 e ss.; veja ainda "Constitutionalism and Democracy", op. cit., esp. pp. 3 e ss.

${ }^{710 ، " E q u a l i t y, ~ D e m o c r a c y, ~ a n d ~ C o n s t i t u t i o n: ~ W e ~ t h e ~ P e o p l e ~ i n ~ C o u r t ", ~ o p . ~ c i t ., ~ p . ~ 329, ~ i t a ́ l i c o s ~ n o ~ o r i g i n a l, ~ t r a d u z i ; ~}$ o exemplo do Dworkin é o mercado de moeda, pois, neste caso, "the combined effects of the very large number of individual currency transactions was responsible for the higher price of the yen at the last trade", p. 329 (veja ainda p. 336 e "Constitutionalism and Democracy", op. cit., pp. 3-4 para o mesmo exemplo, só que com o marco substituindo o yen e ainda "Introduction: The Moral Reading and the Majoritarian Premise", op. cit., p. 19 para versão com o dólar). Compare com exemplo análogo em "The Partnership Conception of Democracy", op. cit., pp. $455,456$.

711 "Equality, Democracy, and Constitution: We the People in Court", op. cit., p. 329, traduzi.

712 "Equality, Democracy, and Constitution: We the People in Court", op. cit., pp. 329, 335; veja ainda veja Law's Empire, op. cit., cap. 5, esp. pp. 167 e ss.

713 "Equality, Democracy, and Constitution: We the People in Court", op. cit., pp. 329, 335; trata-se de exemplo que empresta de Rawls: n. 9, p. 329: "J. Rawls, A Theory of Justice (Cambridg, Mass: Harvard Univ. Press, 1971) at 523-4 n. 4". Veja Mulhall e Swift, Liberals and Communitarians, op. cit., pp. 294-6 e Ommati, Liberdade de Expressão e discurso de ódio na Constituição de 1988, op. cit., p. 92.

714 "Equality, Democracy, and Constitution: We the People in Court", op. cit., pp. 329-330; veja ainda "Constitutionalism and Democracy", op. cit., pp. 3 e ss. e ainda "Introduction: The Moral Reading and the Majoritarian Premise" op. cit., pp. 19 e ss.

715 "Equality, Democracy, and Constitution: We the People in Court", op. cit., p. 330.

${ }^{716}$ Muito brevemente, Dworkin, em texto muito parecido, senão idêntico ao de "Political Equality", critica a ideia de igualdade de poder que enxerga por trás da ideia de democracia estatística: veja "Equality, Democracy, and Constitution - We the People in Court", op. cit., pp. 331 e ss.
} 
por razões democráticas o controle de constitucionalidade por órgão judicial. Menciono essas características porque elas são necessárias à compreensão da relação traçada pelo autor entre democracia e liberdade de expressão.

Ainda no artigo sob análise, Dworkin insere outra distinção para elaborar a sua concepção de democracia, pois defende uma concepção comunal específica, a saber, a integrada, que contrasta com a monolítica. Para o autor, "a ação comunal depende não da prioridade ontológica da comunidade sobre o indivíduo, mas de certo tipo de atitudes compartilhadas entre os indivíduos" ${ }^{\text {717 }}$. Ele explica o que quer dizer:

"Sempre que agimos com auto-consciência, com o conhecimento [sense] de que o que fazemos é importante e pode ser feito bem ou mal, implicitamente fazemos duas assunções sobre a unidade de ação em jogo. Assumimos, primeiro,uma unidade particular de responsabilidade, que entendo como a pessoa ou grupo cujo crédito ou descrédito, realização ou fracasso, é resultado da ação e, segundo, uma unidade particular de julgamento, que entendo como a pessoa ou grupo cujas convicções sobre o certo ou errado são as apropriadas para que façamos esta avaliação" ${ }^{718}$

A concepção comunal monilítica entende que as duas unidades de ação são coletivas; a integrada entende que a unidade de responsabilidade é coletiva, mas que a unidade de julgamento é individual ${ }^{719}$ (neste ponto, se aproxima da concepção estatística de ação ${ }^{720}$ ). $\mathrm{O}$ exemplo da orquestra é novamente utilizado por Dworkin, pois embora a responsabilidade pelo desempenho seja coletivo, "dos músicos espera que desenvolvam e mantenha a sua própria opinião [sense] sobre realização musical: seu orgulho em relação ao que a orquestra fez é baseado nos seus próprios julgamentos individuais e auto-conscientes sobre mérito musical",721. O contrário é uma comunidade em que vige um "despotismo teocrático": "Tal comunidade julga a si própria"722.

Dworkin defende então uma concepção de democracia comunal integrada, e é no caráter individual da unidade de julgamento que reside a relevância da concepção de

\footnotetext{
717 "Equality, Democracy, and Constitution: We the People in Court", op. cit., p. 335, traduzi. Na p. 336, Dworkin diz que a prioridade da ação coletiva comunal é ética e faz referência (n. 12) ao artigo publicado como capítulo quinto de Sovereign Virtue, op. cit. (sob título de "Liberal Community"). Veja ainda "The Partnership Conception of Democracy", op. cit., pp. 454 e ss. e ainda "Introduction: The Moral Reading and the Majoritarian Premise", op. cit., pp. 21 e ss.

718 "Equality, Democracy, and Constitution: We the People in Court", op. cit., p. 335, traduzi , itálico no original (o trecho é de tradução complicada, e tive de me permitir opções não literais para preservar a legibilidade; também acrescentei palavra do original entre colchetes para indicar como traduzi "sense").

719 "Equality, Democracy, and Constitution: We the People in Court", op. cit., p. 336.

720 "Equality, Democracy, and Constitution: We the People in Court", op. cit., p. 336.

721 "Equality, Democracy, and Constitution - We the People in Court", op. cit., p. 336, traduzi e acrescentei palavra do original entre colchetes para indicar como traduzi "sense"

722 "Equality, Democracy, and Constitution: We the People in Court", op. cit., p. 336, traduzi.
} 
democracia à liberdade de expressão ${ }^{723}$. A ideia aqui é a mesma que o autor expressou pela ideia de independência ética ao defender o princípio da autenticidade, parte da sua concepção de dignidade ${ }^{724}$. No artigo sob análise, ele diz:

"ao menos na nossa culturea, a unidade de julgamento normal ou usual para todas as ações é o indivíduo.
É necessário para o meu respeito próprio, creio eu, que eu faça os meus próprios julgamentos sobre qual
vida levar, como tratar os outros e o que conta como um bom ou mau trabalho na minha profissão. Não
acredito que eu deva (ou possa) fazer estes julgamentos totalmente em privado, sem qualquer consulta a
ou influência de outras pessoas ou da minha cultura como um todo, mas em vez disso, que eu deva me
satisfazer que ao fim ajo com base nas convicções que eu mesmo formei e não me render [bow] ao que
os outros acham certo para mim."

A concepção de democracia de Dworkin consiste, portanto, na ideia de que num regime democrático os cidadãos compartilham responsabilidade pelas decisões políticas tomadas pela comunidade, que é uma questão coletiva, mas que o julgamento permanece uma questão individual $^{726}$. O argumento em favor desta concepção é, diz Dworkin, interpretativo pois busca compreender e justificar as instituições democráticas comumente desenvolvidas que, segundo o autor, "dão aos cidadãos uma parte no coletivo, um stake nele e independência dele" ${ }^{727}$. Esta interpretação é, portanto, desenvolvida em três princípios: da participação, do stake e o da independência, sendo o primeiro e o último os mais relevantes à liberdade de expressão. Em relação ao segundo, o do stake, basta mencionar que uma comunidade o respeita quando adota a igualdade, mesmo que abstratamente. ${ }^{728}$

Por princípio da participação Dworkin entende, em primeiro lugar, a pertinência do um indivíduo a uma comunidade ${ }^{729} \mathrm{e}$, em segundo lugar, a necessidade de os indivíduos

\footnotetext{
723 "Equality, Democracy, and Constitution: We the People in Court", op. cit., pp. 337 e ss.

${ }^{724}$ Justice for Hedgehogs, op. cit., pp. 211 e ss., e "I cannot be free from coercive control in matters of justice and morality, but my dignity requires that I be allowed a role in the collective decisions that exercise that control", $p$. 379.

725 "Equality, Democracy, and Constitution: We the People in Court", op. cit., p. 336, traduzi (acrescentei entre colchetes palavra do original para indicar como traduzi "bow").

726 "Equality, Democracy, and Constitution - We the People in Court", op. cit., p. 337.

727 "Equality, Democracy, and Constitution: We the People in Court", op. cit., p. 337, traduzi, itálicos no original. Mantive a palavra "stake" em inglês porque não encontro correspondente em língua portuguesa (veja o trecho muito parecido em "Introduction: The Moral Reading and the Majoritarian Premise", op. cit., p. 24 traduzido para o português: "Uma comunidade política não pode fazer de nenhum indivíduo um membro moral se não der a essa pessoa uma participação em qualquer decisão coletiva, um interesse nessa decisão e uma independência em relação à mesma decisão" "Introdução: A leitura moral e a premissa majoritária", in $O$ direito da liberdade, op. cit., pp. 37-8, itálicos no original). Veja ainda "Introduction: The Moral Reading and the Majoritarian Premise", op. cit., pp. 24 e ss. e "Constitutionalism and Democracy", op. cit., esp. pp. 4-5 e 9-10. Veja Guest, Ronald Dworkin, op. cit., pp. 117 e ss. (em especial p. 118 para associação entre dignidade, democracia e os três princípios defendidos por Dworkin).

${ }_{728}$ Equality, Democracy, and Constitution - We the People in Court", op. cit., pp. 339-40.

729 "Equality, Democracy, and Constitution: We the People in Court", op. cit., pp. 337-8.
} 
desempenhem um papel na ação coletiva ${ }^{730}$. É nestes termos que o autor entende tanto as regras de sufrágio existentes nas democracias quanto liberdade políticas como a liberdade de expressão, justificados estes direitos por Dworkin de maneira bastante similar à baseada em agência e exposta há pouco ${ }^{731}$; para ele,

"Se cada cidadão deve receber um papel na política que consista em uma chance genuína de fazer a diferença, então, particularmente em uma comunidade política ampla, a ele deve ser permitido voto bem como voz. (...) censura com base no conteúdo violaria a segunda parte do princípio da participação, que estipula que o poder político das pessoas não pode ser reduzido por regulamentações que violam o igual respeito, 732 .

O princípio da independência é aquele que diferencia a democracia comunal integrada da monolítica, e que estabelece a relevância do julgamento individual do cidadão sobre questões políticas, morais e éticas ${ }^{733}$. O ponto do autor não é negar que a reflexão sobre estes temas se dê em contato com outras pessoas, mas somente sustentar que é incompatível com a democracia a utilização "de meios coercitivos ou encobertos ou indiretos de formatar as convicções de seus cidadãos"734. Dworkin enxerga na violação ao princípio da independência prejuízo à integração dos indivíduos à sociedade (no que parecem ser referências aos dois outros princípios) mesmo quando a comunidade assume para si a autoridade para julgar somente alguns temas que deveriam permanecer na esfera individual. ${ }^{735}$ Duas são as consequências deste princípio, segundo Dworkin: primeiro, que liberdades públicas como liberdade de expressão são estruturais à democracia, e, segundo, que é uma questão de democracia a "tolerância liberal", que permite ao cidadão viver conforme suas convicções

\footnotetext{
730 "Equality, Democracy, and Constitution: We the People in Court", op. cit., p. 338.

731 "Equality, Democracy, and Constitution: We the People in Court", op. cit. pp. 338-9.

732 "Equality, Democracy, and Constitution: We the People in Court", op. cit., p. 338; o autor então faz diferenciação entre este argumento e a ideia de igualdade de influência - justamente a diferenciação que faz em "Political Equality", op. cit., ao discutir agência. Veja discussão acima sobre censura com base no conteúdo.

733 "The principle of independence therefore insists that a democratic government must not dictate what its citizens think about matters of political or moral or ethical judgment, but must, on the contrary, provide circumstances that encourage citizens to arrive at beliefs on these matters trough their reflective and finally individual conviction", "Equality, Democracy, and Constitution: We the People in Court", op. cit., p. 340, nota omitida (n. 13, sobre a linha divisória entre questões de julgamento individual e de responsabilidade coletiva) e "Introduction: The Moral Reading and the Majoritarian Premise", op. cit., p. 26. Neste texto, Dworkin fala em "moral independence" (p. 25) e em "personal responsibility" (p. 26), terminologia também utilizada para defender a sua teoria ética: independência faz parte do segundo princípio de dignidade, também chamado pelo autor por vezes de princípio da responsabilidade pessoal (veja pp. 25-6 em geral e capítulo segundo, acima).

734 "Equality, Democracy, and Constitution: We the People in Court", op. cit., pp. 340-1.

735 "Equality, Democracy, and Constitution: We the People in Court", op. cit., pp. 340-1; compare com a ideia de "responsabilidade moral" defendida pelo autor em "Why Must Speech be Free?", op. cit., pp. 200-2, discutida no capítulo segundo, acima, e o argumento dworkiniano, discutido abaixo neste capítulo, acerca do prejuízo à legitimidade política provocado por leis que proíbem o discurso de ódio.
} 
sobre temas são de atribuição de seu julgamento individual ${ }^{736}$ (neste ponto, o autor se refere a "Liberal Community", capítulo quinto de Sovereign Virtue, e a "Foundations of Liberal Equality").

O que se percebe é que, independentemente da terminologia empregada por Dworkin ao defender uma interpretação da democracia - seja ela uma concepção dependente ou uma concepção comunal integradora - as liberdades políticas, em especial a liberdade de expressão, são exigência democrática ${ }^{737} \mathrm{em}$ argumento claramente impactado pela teoria ética do autor ${ }^{738}$. Principalmente as ideias de agência e de independência (e, em menor grau, de participação), refletem concepção de bem viver em que cabe ao indivíduo, e não à sociedade, deliberar sobre questões éticas e morais, e em que lhe é dado tentar influenciar o ambiente em que vive ${ }^{739}$. A liberdade de expressão é, justamente, o instituto mais relevante à realização desde ideal liberal. Antes de discutir questões concretas sobre liberdade de expressão que receberam intervenção de Dworkin, gostaria de apresentar um último ponto acerca das relações traçadas pelo autor entre democracia e o direito objeto desta dissertação.

Subseção 3.2. Democracia, parceria e "equal citizenship"

Dworkin também contrasta a sua visão de democracia à visão "majoritária" deste valor político, segundo a qual há democracia quando "as pessoas se governam a si próprias, e não um grupo mais pequeno, conserva um poder político fundamental" ${ }^{140}$. O problema desta concepção, e o motivo que o autor encontra para rejeitá-la, é que "O governo da maioria não é justo nem valioso em si. Só é justo e valioso quando atende a determinadas condições, entre elas as exigências de igualdade entre os participantes do processo político, por meio do qual se

\footnotetext{
736 "Equality, Democracy, and Constitution: We the People in Court", op. cit., pp. 341-2 (veja ainda pp. 345-6 para os princípios da independência e do stake em relação ao direito ao aborto).

737 "Equality, Democracy, and Constitution: We the People in Court", op. cit., p. 242.

${ }^{738}$ Veja Guest sobre os escritos de Dworkin: "All his earlier work on democracy coheres with Dworkin's second principle of dignity as described in Justice for Hedgehogs, for that principle embodies the importance of moral independence, affirming that a democratic government must not dictate what its citizens should think about politics and ethics (...)", Ronald Dworkin, op. cit., p. 119.

${ }^{739}$ Veja o comentário crítico de Abigail Levin à conexão estabelecida por Dworkin entre democracia, "agência moral independente" e liberdade de expressão e a sua defesa da visão "constitutiva" deste direito: The Cost of Free Speech: Pornography, Hate Speech, and their Challenge to Liberalism, op. cit., pp. 81 e ss. Veja abaixo discussão sobre discurso de ódio e pornografia.

${ }^{740}$ Justiça para ouriços, op. cit., p. 391 (observe que o leitor que se trata de tradução portuguesa); no original,

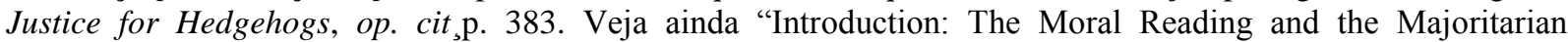
Premise" op. cit., pp. 15 e ss., sobre o que Dworkin chama de "majoritarian premise" e a "constitutional conception of democracy", p. 17 e também Is Democracy Possible Here?, op. cit., cap. 5, esp. pp. 133 e ss.
} 
definirá a maioria”. ${ }^{741}$ Estas condições são elaboradas por Dworkin na interpretação defendida por ele sob o nome de "concepção da parceria", que consiste em dizer que existe democracia quando

"os cidadãos de uma comunidade política governam a si mesmos, num sentido especial mas valioso de auto-governo, quando a ação política é adequadamente vista como ação coletiva por uma parceria em que todos os cidadãos particiam como parceiros livres e iguais, em vez de uma disputa por poder político entre grupos de cidadãos". ${ }^{742}$

Dworkin discutiu democracia nestes termos em diversos textos, e inclusive a apresentou como uma questão de "parceria" nos termos dos três princípios expostos na subseção anterior $^{743}$. Estes princípios garantem direitos fundamentais, entre eles a liberdade de expressão, que são, portanto, incluídos na própria definição de democracia oferecida pelo autor. É assim que ele opera a integração entre liberdades e democracia: a participação do indivíduo no auto-governo exige o reconhecimento de direitos corretamente identificados pelos dois princípios de dignidade discutidos no capítulo anterior. ${ }^{744}$ Isso significa que, para o autor, os direitos oriundos da tolerância liberal, que distingue entre moral e ética e que restringem as razões de fundamentação das decisões às primeiras, fazem parte da democracia porque são necessários à definição da parceria conceitualmente central à ideia de democracia ${ }^{745}$ : para ele, "embora prejudique a minha dignidade submeter-me à autoridade de

741 "Liberdade de expressão, política e as dimensões da democracia", op. cit., p. 510 (veja em geral pp. 509 e ss.); no original, "Free Speech, Politics, and the Dimensions of Democracy", op. cit., pp. 363 (veja pp. 362 e ss.)

742 "The Partnership Conception of Democracy", op. cit., p. 453, traduzi (comentando a concepção de democracia que defende em Freedom's Law, op. cit.); veja ainda: "Citizens have shared responsibility for political decisions in, but only in, a democracy that provides every citizen substantial equality of part and voice in its collective decisions, that recognizes the equal importance of every citizen's fate in deliberating and executing those collective decisions, and that guarantees each individual a sovereign immunity from such collective decisions over certain matter of conscience and faith that, as a matter of self-respect, people must decide for themselves", $p$. 457 (claramente, trata-se das ideias expostas pelo autor nos termos dos três princípios discutidos acima, defendidos também em "Constitutionalism and Democracy", op. cit., pp. 9-10 como uma questão de "liberdade positiva", p. 10). Veja também a democracia como parceria em Justice for Hedgehogs, op. cit., cap. 18, esp. pp. 379-80, 383 e ss. (com referências a trabalhos anteriores de Dworkin na n. 2, p. 483 à p. 383) e "Free Speech, Politics, and the Dimensions of Democracy", op. cit., pp. 356 e ss. e 362 e ss., especialmente o seguinte trecho: "According to the partnership conception, government by 'the people' means government by all the people, acting together as full and equal parterns in a collective enterprise of self-government", p. 358, itálico no original e, por fim, Is Democracy Possible Here?, op. cit., p. 131, pp. 143-7.

743 "Introduction: The Moral Reading and the Majoritarian Premise", op. cit. pp. 24 e ss.

${ }^{744}$ A associação entre democracia como parceria e dois princípios de dignidade é feita por Dworkin em Is Democracy Possible Here?, op. cit., pp. 143 e ss. e, esp. "We need (...) to consider not just the substantive but also the procedural implications of the two principles. What structure of political institutions, and of elections to fill those institutions with officials, do those principles recommend?", p. $144 \mathrm{e} \mathrm{"(...)} \mathrm{I} \mathrm{have} \mathrm{been} \mathrm{talking} \mathrm{about}$ democracy in this book all along. The basic ethical principles of human dignity that I described in chapter 1 are the source of democratic values", p. 155.

${ }^{745}$ Veja Is Democracy Possible Here?, op. cit., pp. 20-1. 
outros quando não tomo parte alguma nas suas decisões, a minha dignidade não é prejudicada quando tomo parte, como um parceiro igual, nessas decisões". ${ }^{746}$ Esta integração entre democracia e o modelo ético de Dworkin foi indicada na última subseção, e a importância dos direitos individuais à concepção de parceria aponta também para a integração entre ela e as liberdades. ${ }^{747}$ Por último, a integração com a igualdade também é evidente na concepção da parceria. Vale aprofundar o ponto.

Dados os objetivos desta dissertação, concentro-me em "Free Speech, Politics, and the Dimensions of Democracy", capítulo décimo de Sovereign Virtue , dedicado à análise política e jurídica de temas extremamente importantes, a saber, liberdade de expressão durante eleições, inclusive sobre financiamento de campanha. Trata-se de trabalho em parte dedicado a questões de direito norte-americanas, nem sempre relevantes a este trabalho. $\mathrm{O}$ tema do financiamento de campanha volta neste capítulo porque o argumento de Dworkin sobre as restrições aceitáveis é parte do seu argumento mais geral sobre os limites das liberdades quando integradas na igualdade de recursos. Por ora, vale expor as "dimensões" da "democracia como parceria", que Dworkin apresenta como três: (i) soberania popular, (ii) igualdade de cidadania e (iii) discurso democrático ${ }^{748}$.

A primeira dimensão consiste em que, entre governantes e governados, estes, e não aqueles, sejam o "senhor",749, e exige liberdade de expressão porque a proibição de publicação de material crítico da atuação dos governantes lhes permite tomar o autoridade que pertence

\footnotetext{
${ }^{746}$ Is Democracy Possible Here?, op. cit., p. 145 (veja em geral pp. 145 e ss., em que Dworkin defende interpretação de "self-government" com base no segundo princípio de dignidade, pois "political arrangements must respect people's personal responsibility for identifying value in their own lives", p. 145; veja também p. 161). Veja ainda Justice for Hedgehogs, op. cit., caps. 9 e 17.

747 "(...) we cannot construct an adequate theory of liberty without relying on other political virtues in our definition. The partnership conception makes a parallel claim about democracy", Is Democracy Possible Here?, op. cit., p. 134 e, para esta concepção, "democracy means that the people govern themselves each as a full partner in a collective political enterprise so that a majority's decisions are democratic only when certain further conditions are met that protect the status and interests of each citizen as a full member in that enterprise", p. 131.

748 "Liberdade de expressão, política e as dimensões da democracia", op. cit., pp. 509 e ss.; no original, "Free Speech, Politics, and the Dimensions of Democracy", op. cit., pp. 362 e ss. A tradução de Sovereign Virtue fala em "concepção co-participativa"; prefiro falar em "parceria", opção feita pela tradução de Justice for Hedgehogs, op. cit.,: veja Justiça para ouriços, op. cit., cap. 18 (p. 400, p. ex.). Entre nós, veja José Emílio Medauar Ommati. Liberdade de Expressão e discurso de ódio na Constituição de 1988, pp. 91-103, esp. p. 95. Veja ainda Júlio César Casarin Barroso Silva. Democracia e Liberdade de Expressão: Contribuições para uma interpretação política da liberdade de palavra. op. cit., "Madison via a liberdade de expressão à luz de seus compromissos com a soberania popular, com a igualdade política e com a função deliberativa da política", p. 139.

749 "Liberdade de expressão, política e as dimensões da democracia", op. cit., p. 510; "Free Speech, Politics, and the Dimensions of Democracy", op. cit., p. 363, no original, "master".
} 
aos governados ${ }^{750}$. As duas outras são ainda mais relevantes à liberdade de expressão. A segunda, da igualdade de cidadania, oferece interpretação igualitária do que significa fazer parte do governo. São, para Dworkin, duas características: o voto e participação, isto é, a igualdade como componente da democracia exige que os indivíduos possam não somente votar, mas também se manifestar publicamente. ${ }^{751}$ Colocada a questão em termos de "opinião pública", a igualdade significa que ao indivíduo não deve ser somente atribuído o direito de compô-la, mas também de influenciá-la ${ }^{752}$, independentemente do tipo de conteúdo expresso.

750 "Free Speech, Politics, and the Dimensions of Democracy", op. cit., p. 365

751 "Liberdade de expressão, política e as dimensões da democracia", op. cit., pp. 511-2; no original, "Free Speech, Politics, and the Dimensions of Democracy", op. cit., p. 364. Após comentar o compromisso da concepção majoritária com o "equal suffrage", Dworkn diz: "The partnership conception insists on equal suffrage too, but it requires that citizens be equal not only as judges of the political process but as participants in it as well.”, p. 364. Após reiterar a sua visão sobre o equívoco que significa interpreter igualdade em termos políticos como igualdade de influência, Dworkin diz: “(...) partership democracy is damaged when some groups of citizens have no or only a sharply diminished opportunity to appeal for their convictions because they lack the funds to compete with rich and powerful donors. No one can plausibly regard himself as a patern in an enterprise of selfgovernment when he is effectively shut out from the political debate because he cannot afford a grotesquely high admission price", p. 364. Entre nós, veja Júlio César Casarin Barroso Silva. Democracia e Liberdade de Expressão: Contribuições para uma interpretação política da liberdade de palavra. op. cit., p. 224.

752 "Citizens play two main roles in a mature democracy. They are, first, the judges of political contests whose verdicts, expressed in formal elections or in referenda or other forms of direct legislation, are normally decisive. 'Public opinion' means the relevant opinions of citizens acting in this capacity. Citizens are also, however, participants in the political contests they judge: they are candidates and supporters whose actions help, in different ways, to shape public opinion and to fix how the rest of the citizens vote. The majoritarian conception of democracy pays exclusive attention to the first of these roles. It insists, in the more sophisticated version I described, that, so far as this is feasible, the informed and reflective opinions of the largest number should be decisive of who is elected to government and of what government once elected does. But it says nothing further about the role that individual citizens and groups must be allowed to play in shaping the opinions of others. The partnership conception recognizes both roles, because it supposes that in a true democrac citizens must play a part, as equal partners in a collective enterprise, in shaping as well as constituting the public's opinion", "Free Speech, Politics, and the Dimensions of Democracy", op. cit., p. 358, itálicos acrescentados.

Similar a esta ideia foi a opinião defendida por Rafael Zanatta, representante do NDIS (Núcleo de Direito, Internet e Sociedade da Faculdade de Direito da USP), na sua manifestação na audiência pública realizada pela Procuradoria Regional Eleitoral de São Paulo em outubro de 2013. Zanatta, convidado da organização do evento, defendeu, entre outros, a participação ativa do cidadão na construção do debate eleitoral - em superação do seu papel de mero receptor - como um dos elementos a serem considerados na regulamentação das campanhas (veja Rafael Zanatta "[Sem título]". Manifestação na Audiência Pública organizada pela Procuradoria Regional Eleitoral de São Paulo intitulada "Liberdade de expressão e de informação no direito eleitoral: coleta de subsídios para a atuação da PRE-SP nas eleições de 2014", outubro de 2013). Com base na fala de Zanatta, pedi posteriormente a palavra e defendi, entre outros, que seja superada, pelo menos quanto aos cidadãos, a limitação temporal trazida pela regra do período eleitoral, e que o direito de tentar influenciar a política, como exercício de aspecto ativo da participação do cidadão no processo eleitoral, que não pode se restringir a ser alvo passivo das propagandas eleitorais, não seja limitado em razão de seu conteúdo e que seja irrestrito, salvo nos casos em que forem utilizados recursos públicos que superem aquilo que é de direito de todos os cidadãos conforme a justiça (defendi ser este o caso das emissoras de televisão que utilizam concessões públicas mas não dos blogs na internet). Trata-se de ideias concretas, aplicáveis ao contexto brasileiro mas que, a meu ver, se inserem confortavelmente na, se é que não são exigidas, pela concepção de liberdade de expressão defendida por Dworkin, especialmente pelas noções - construídas e defendidas pelo autor - de agência, de direito de tentar influenciar o ambiente moral e político, de dimensão ativa da autenticidade (ou independência ou 
Especificamente, Dworkin inclui no direito igualitário de participação, que compõe a democracia como parceria, o direito à expressão de discurso de ódio porque, se decisões políticas são produto, entre outros, do debate a respeito do tema sobre que versam, restringir a atuação de um indivíduo ao seu voto por meio de censura à manifestação da sua opinião prejudica a natureza democrática da decisão tomada ${ }^{753}$. Prefiro comentar este argumento ao discutir os argumentos de Dworkin sobre discurso de ódio e pornografia porque o autor o reitera em diversos outros textos e porque é no contexto da liberdade de expressão especificamente, e não de debate sobre democracia, que o argumento foi questionado com bastante propriedade, embora, a meu ver, sem sucesso ${ }^{754}$. Por ora vale ressaltar que este argumento igualitário em defesa do direito de participação que não se restringe ao direito de voto é apresentando como parte da concepção de democracia de Dworkin, o que significa que viola a igualdade subtrair direito de liberdade de expressão ainda que ao indivíduo não seja negado o direito de votar em condições de igualdade com seus concidadãos. ${ }^{755}$

A liberdade de expressão também faz parte da terceira dimensão da democracia, a saber, do "discurso democrático", que condiciona a existência de autogoverno à existência de

responsabilidade moral), da integração das liberdades na justiça distributiva e da compreensão da liberdade de expressão como um direito igualitário (questões discutidas ao longo desta dissertação). Estas ideias têm diferenças se comparadas com as que nortearam a manifestação de Zanatta e a minha fala (embora haja semelhanças nas concepções de "aspecto ativo" defendidas, elas se contrapõem a coisas diferentes: o aspecto passivo, por exemplo, da autenticidade de Dworkin não se resume a, e não é corretamente caracterizado como, a recepção de influência externa, no caso discutido na audiência, de propaganda eleitoral - em Dworkin, ele diz respeito a exercício de construção pessoal de concepção de bem). Não é meu objetivo pormenorizar possível aplicação da teoria de Dworkin ao direito brasileiro, mas fica a menção a tema que convida reflexão deste tipo.

753 "Free Speech, Politics, and the Dimensions of Democracy", op. cit., pp. 365-7.

${ }^{754}$ Tenho em mente a crítica de Jeremy Waldron: veja The Harm in Hate Speech, op. cit..

${ }^{755}$ Por exemplo, veja "The Curse of American Politics", op. cit., item 4: "First, each citizen must have a fair and reasonably equal opportunity not only to hear the views of others as these are published or broadcast, but to command attention for his own views, either as a candidate for office or as a member of a politically active group committed to some program or conviction. No citizen is entitled to demand that others find his opinions persuasive or even worthy of attention. But each citizen is entitled to compete for that attention, and to have a chance at persuasion, on fair terms, a chance that is now denied almost everyone without great wealth or access to it. Second, the tone of public discourse must be appropriate to the deliberations of a partnership or joint venture rather than the selfish negotiations of commercial rivals or military enemies. This means that when citizens disagree they must present their arguments to one another with civility, attempting rationally to support policies they take to be in the common interest, not in manipulative, slanted, or mendacious pitches designed to win as much of the spoils of politics as possible by any means. These two requirements - of participant equality and civility - are parts of the civic republican ideal I described. But we can now defend them, not just as features of an attractive society that perceptive statesmen have the right to impose on everyone, but as essential conditions of fair political engagement, and hence of self-government, for all." 
"uma estrutura e em um ambiente que incentive a atenção aos méritos do que dizem."756 Este artigo, e, também, Is Democracy Possible Here?, consistem em elaboração sobre temas substantivos a partir do diagnóstico de que o debate político nos EUA não preenche este requisito. $^{757}$

Uma característica fundamental da segunda dimensão, a saber, a da igualdade cidadã, que não é compartilhada pelas duas outras, é que descreve direitos individuais. O ponto é importante porque oferece solução a situações de conflitos entre as dimensões. Especificamente, Dworkin rejeita solução de "balancing",758 pelas razões apontadas no capítulo primeiro: “A igualdade dos cidadãos (...) é uma questão e direito individual, e não poderíamos justificar as violações a esse direito - censurando os racistas com a justificativa de que isso melhoraria o discurso democrático, por exemplo - por intermédio de qualquer calculo agregatório". ${ }^{759}$ Ou seja, medidas que visem a aprimorar o discurso democrático somente são inaceitáveis se interferirem em direito individual necessário à igualdade cidadã, caso do discurso de ódio ${ }^{760}$. Discuto abaixo a abordagem defendida por Dworkin para distinguir as hipóteses em que isso ocorre daquelas em que isso não ocorre, bem como os argumentos que oferece a favor de rejeição de uma terceira, e a relação apontada pelo autor entre esta questão e a regulação do discurso político, especialmente por meio de restrições a doações a campanhas eleitorais.

Concluída esta subseção, está encerrado o esforço de apresentar, neste capítulo, os quatro argumentos de Dworkin em defesa da liberdade de expressão, dois deles acerca deste direito como liberdade negativa e dois deles, como liberdade positiva. A próxima seção,

\footnotetext{
756 "Liberdade de expressão, política e as dimensões da democracia", op. cit., p. 512. O trecho continua da seguinte forma: "If the public discourse is crippled by censorship, or collapses into a shouting or slandering match in which each side tries only to distort or drown out what the others say, then there is no collective selfgovernment, no collective enterprise of any kind, but only vote couting as war by other means" "Free Speech, Politics, and the Dimensions of Democracy", op. cit., p. 365 (veja ainda pp. 364-5 e 384) (na tradução brasileira, veja "Liberdade de expressão, política e as dimensões da democracia", op. cit., pp. 512-3).

${ }^{757}$ Em especial, veja "Free Speech, Politics, and the Dimensions of Democracy", op. cit., pp. 351-3, 369 e ss., pp. 384-5 e Is Democracy Possible Here?, op. cit., pp. 1-23, entre outros.

758 "Free Speech, Politics, and the Dimensions of Democracy", op. cit., p. 367; "Liberdade de expressão, política e as dimensões da democracia", op. cit., pp. 516 e ss. para tradução de "balancing approach" por "abordagem balanceadora".

759 "Liberdade de expressão, política e as dimensões da democracia", op. cit., p. 516; no original, "Free Speech, Politics, and the Dimensions of Democracy", op. cit., pp. 351-3 o outro argumento apontado por Dworkin é o risco de abuso de qualquer exceção (p. 368). Veja ainda "It is absurd to calculate human rights according to costbenefit analysis", op. cit..

760 "Free Speech, Politics, and the Dimensions of Democracy", op. cit., pp. 369-370 (veja ainda pp. 377 e 378 ).
} 
dividida em três partes, é dedicada à análise de argumentos concretos do autor acerca de polêmicas circunscritas envolvendo liberdade de expressão. Parte dos argumentos mais teóricos desenvolvido nesta e em seções anteriores - e, também, nos dois primeiros capítulos poderão ser retomados, afinal, os diferentes pontos do pensamento de Dworkin são interligados e, a meu ver, seus argumentos, por exemplo, sobre discurso de ódio e liberdade de imprensa são convincentes aplicações de suas reflexões teóricas a estes temas concretos.

Em relação à democracia e a nem sempre adequada proliferação de terminologias elaborada acima, julgo que o mais relevante a ressaltar no pensamento de Dworkin sobre o tema é seu esforço de interpretar à luz de sua teoria ética, em particular de sua visão sobre o valor da vida vivida com independência, os valores da igualdade e da liberdade de modo a elaborar teoria democrática integrada a outros valores políticos a que a liberdade da expressão é crucial de diversas maneiras. Algumas destas maneiras, sobretudo nas duas primeiras subseções do próximo capítulo, são retomadas abaixo. Convido o leitor a me acompanhar neste esforço de concretização do direito à liberdade de expressão e de encerramento deste trabalho.

\section{Seção 4. Temas concretos da Liberdade de Expressão}

Nesta seção, analiso a solução dada por Dworkin a alguns temas concretos de liberdade de expressão. Talvez todas estas soluções já tenham sido mencionadas anteriormente nesta dissertação e, se não, talvez o leitor tenha suas opiniões sobre quais conclusões são necessárias dados os argumentos apresentados até este ponto. Por outro lado, o exercício de "aplicação" de uma teoria a um caso concreto é, como diz Dworkin diz, “(...) um novo passo [fresh step] na teoria política"761. A meu ver, os argumentos do autor expostos abaixo são consistentes com a sua teoria e representam boa intepretação das ideias políticas por ele defendidas.

\footnotetext{
761 “Temos direito à pornografia?”, op. cit., p. 531, acrescentei entre colchetes palavras do original; no original, "Do We Have a Right to Pornography?", op. cit., p. 357. Não é desimportante observar que Dworkin diz isso a respeito da concretização de direitos abstratos numa situação que julga conflito de direitos: ele diz que "The process of making an abstract right successively more concrete is not simply a process of deduction or interretation of the abstract statement but a fresh step in political theory", p. 357. Veremos abaixo que os casos que menciono são considerados por Dworkin de outra forma: não se trata, para ele, de hipóteses de conflito de direitos. Mas esta questão (isto é, saber se se trata de caso de conflito de direitos) é, naturalmente, ela mesma uma questão de teoria política. Por isso, apesar das diferenças, acho a afirmação aplicável. Veja ainda Caio Moysés de Lima, O Império dos Direitos: Lei e Autoridade Política em Ronald Dworkin, op. cit., esp. pp. 87 e ss.
} 
A lista de temas tratados abaixo é inferior ao que Dworkin tratou, e extremamente curta frente à potencialidade da teoria do autor se aplicada a questões que ele não tratou ou tratou de maneira (talvez excessivamente) sucinta. Sobre alguns Dworkin fez observações mais elaboradas $^{762}$, em outros defendeu ideias abstratas. Escapa aos objetivos desta dissertação tratar mais detalhadamente destes casos, projeto que fica adiado.

\section{$\underline{\text { Subseção 4.1. Discurso de ódio e pornografia }}$}

A reflexão de Ronald Dworkin sobre a liberdade de expressão é conhecida por incluir argumentos a favor do direito ao discurso de ódio racista e à publicação e consumo de pornografia. Penso que fornecer uma definição prévia detalhada de discurso de ódio é inadequado porque ela depende dos argumentos produzidos no debate, e não o contrário. É possível, entretanto, oferecer uma definição genérica dada pelo próprio autor: discurso de ódio é a expressão de visões “derrogatórias” de grupos étnicos, por exemplo ${ }^{763}$. Esta subseção é dedicada à exposição dos argumentos oferecidos por Dworkin à inclusão deste tipo de discurso no direito na liberdade de expressão.

Em primeiro lugar, é preciso recuperar os sentidos de discriminação que estão e que não estão incluídos na liberdade de expressão. A distinção foi descrita na primeira seção, e a menciono brevemente antes de discutir o principal argumento que Dworkin oferece em defesa do direito à expressão de ódio e à publicação de obscenidade, a saber, o argumento que defende a existência de um direito de tentar influencir o "ambiente moral"; trata-se este do segundo ponto a ser trabalhado nesta subseção. O terceiro consiste no argumento objeto de controvérsia entre o autor e Jeremy Waldron, segundo o qual a violação do direito de tentar influenciar prejudica a legitimidade dos atos políticos tomados acerca dos temas objeto do discurso restrito. De rigor, o terceiro ponto é extensão ou decorrência do primeiro, mas eu os trato separadamente porque podem ser defendidos desta forma.

Estes são, a meu ver, os principais aspectos do argumento positivo dirigido por Dworkin a favor dos direitos de liberdade de expressão relacionados ao discurso de ódio e à

\footnotetext{
762 "The Press on Trial" in Freedom's Law, pp. 192 e ss. para sugestões de alteração do direito norte-americano aplicado à difamação de pessoas públicas.

763 "Free Speech, politics, and the Dimensions of Democracy", op. cit., p. 366; a tradução brasileira fala em "pejorativa" para traduzir "derogatory": veja "Liberdade de expressão, política e as dimensões da democracia", op. cit, p. 514 em trecho citado abaixo. Veja discussão em Waldron, The Harm in Hate Speech, op. cit., pp. 34 e ss. e pp. 56 e ss.
} 
pornografia. Entretanto, o autor criticou defensores de posição contrária, e, em geral, seus argumentos - negativos, desta vez - consistem em apontar a impossibilidade de "generalização" dos direitos pressupostos nas defesas da proibição do tipo de discurso sob análise.

Apresentei na primeira seção deste capítulo o sentido de discriminação relevante a uma discussão sobre direitos em geral e sobre liberdade de expressão em particular e que decorre da integração das liberdades à justiça distributiva no pensamento de Ronald Dworkin: existe discriminação somente se (mas não necessariamente toda vez que) um direito é violado. Isto significa que uma expressão de opinião somente pode ser restrita se a própria expressão violar um direito, e não se a aceitação e a implementação hipotética da opinião for incompatível com (neste caso, violar) a aceitação e implementação de direitos demandados pela justiça. Em outras palavras, que negros tem um direito contra a discriminação racial não significa que propor a discriminação racial seja ela mesma uma hipótese de discriminação: será se o fato de ser proposta violar direito, e não se o conteúdo da proposta for logicamente incompatível com o direito à não-discriminação, este sim exigência da justiça. É premissa dos argumentos de Dworkin que a expressão de discurso de conteúdo discriminatório não é necessariamente discriminatória (veja trechos do autor citados em nota de rodapé na seção 1 deste capítulo).

Este ponto tem implicações aos temas explorados abaixo. Especificamente, respeita a liberdade ampla de expressão como Dworkin a reconhece e, além disso, orienta a exigência de identificação de direito hipoteticamente desrespeitado pela simples exposição de uma ideia. Quanto à primeira questão, Dworkin apresenta a liberdade de expressão como um direito de tentar influênciar o ambiente político, moral e cultural decorrente da igualdade e da democracia. Cada um destes aspectos merece breve explicação.

Vimos que Dworkin rejeita a influência como padrão de interpretação da ideia de igualdade de poder. Mas reconhece o direito de se esforçar para influenciar ${ }^{764}$, o que é uma demanda - a depender da terminologia utilizada - da agência, da independência e/ou da democracia concebida como parceria. Este direito é exposto em termos de influência de "ambiente" nos diversos trabalhos em que o autor discute discurso de ódio e pornografia. $\mathrm{O}$ direito se estende à publicação de material obsceno porque, embora para Dworkin pornografia

\footnotetext{
${ }^{764}$ E não de "succeed in influencing", "MacKinnon's Words", op. cit., p. 238, itálico no original (veja longo trecho citado em nota logo mais).
} 
não consista em ideias tampouco consista em discurso político ${ }^{765}$, é direito do indivíduo buscar influenciar o "ambiente moral e cultural" "766 em que vive. Isso não significa que seu direito de publicação e de exposição de material obsceno seja ilimitado, mas significa que é inadmissível o tipo de proibição que é o tema da controvérsia sobre pornografia. ${ }^{767}$

Dworkin enuncia o argumento de John Stuart Mill de que a verdade tem mais chance de ser encontrada em circunstâncias de liberdade de expressão, mas rejeita o tipo de "especulação"768 que caracteriza este tipo de "argumento instrumental"769 em defesa da liberdade de expressão (veja capítulo primeiro, acima). $\mathrm{O}$ autor prefere um fundamento na "dignidade humana"770, que exige que cada indivíduo seja tratado como "um membro livre e igual da comunidade" ${ }^{, 71}$.Trata-se, naturalmente, do argumento fundado nos dois princípios de dignidade e que instrui a concepção de democracia como parceria. Dworkin acredita que a

\footnotetext{
${ }^{765}$ Veja comentário de Dworkin a opinião que expressara em debate com Catharine MacKinnon em trecho citado na seção 4 do capítulo segundo, e que está em "Addendum: A Response to MacKinnon's reply" a "MacKinnon's Words" in Freedom's Law, op. cit., p. 242 e também "Pornographic images hardly supply 'ideas' to any marketplace of thought", "Foreword", op. cit, p. vii. Veja também Justice for Hedgehogs, op. cit., p. 372, em trecho também citado no capítulo anterior.

766 “A New Map of Censorship", p. 131; veja ainda "MacKinnon's Words" in Freedom's Law, op. cit., p. 237 para "moral environment", traduzido como "ambiente moral" na tradução brasileira: "As palavras de MacKinnon" in O Direito da Liberdade, op. cit., p. 380.

${ }^{767}$ Sobre a legislação anti-pornografia promulgada por cidade norte-americana e criticada por Dworkin, ele diz o seguinte: "the ordinance did not simply regulate the display of pornography so defined, or restrict its sale or distribution to particular areas, or guard against the exhibition of pornography to children. Regulation for those purposes does restrict negative liberty, but if reasonable it does so in a way compatible with free speech. Zoning and display regulations may make pornography more expensive or inconvenient to obtain, but they do not offend the principle that no one must be prevented from publishing or reading what he or she wishes on the ground that its content is immoral or offensive (3). The Indianapolis ordinance, on the other hand, prohibited any "production, sale, exhibition, or distribution' whatever of the material it defined as pornographic', "Pornography and Hate", op. cit., pp. 217-8; (3) marca a posição da n. 3, que faz referência a "Do We Have a Right to Pornography?", op. cit. Veja discussão na seção 1 deste capítulo sobre restrição da liberdade de expressão com base no conteúdo e veja os comentários de MacKinnon à "ordinance": Only Words, op. cit. pp. 91 e ss.

768 "Do We Have a Right to Pornography?", op. cit., pp. 351-3 (“speculative", p. 352). Veja ainda: "Free speech and democracy are connected not instrumentally but in a deeper way, because the dignity freedom of speech protect is an essential component of democracy rightly conceived", "Free Speech, Politics, and the Dimensions of Democracy", op. cit., p. 354 (pouco depois, há nota de rodapé com referência à conexão entre liberdade de expressão e democracia em Freedom's Law, op. cit.: p. 493, n. 2 à p. 354, e referência à defesa de Mill da liberdade de expressão); veja ainda pp. 380-1. Veja ainda "Why Must Speech Be Free?", pp. 199-202, "The Farber Case: Reporters and Informers", op. cit., esp. pp. 375 e ss.; "Why Academic Freedom?", op. cit., esp. pp. 275 e ss., "Is the Press Losing the First Amendment?", op. cit., esp. pp. 385-9; Frederick Schauer. "[Sem título]", op. cit. e Dworkin, "Ronald Dworkin Replies", op. cit.,

769 "A New Map of Censorship", Index on Censorship 2006 35: 130, p. 130; veja ainda "Foreword", op. cit., p. vii e referências na nota anterior. Caio Moysés de Lima discute extensamente a teoria moral de Mill em sua dissertação sobre Dworkin: O Império dos Direitos: Lei e Autoridade Política em Ronald Dworkin, op. cit., esp. cap. III.

770 “A New Map of Censorship”, op. cit., p. 131.

771 “A New Map of Censorship”, op. cit., p. 131, traduzi.
} 
democracia, a igualdade e a dignidade são violadas quando de um indivíduo é subtraído o direito de influenciar o processo político decisório em que é formada a vontade da maioria. Para ele, esta é uma questão de fairness (que traduzo abaixo como “justiça”). Este direito, para Dworkin, é de natureza igualitária. Vimos neste capítulo e nos capítulos anteriores por que e como as liberdades são demandas da igualdade no pensamento do autor. Este ponto diz mais respeito, entretanto, à liberdade positiva, que, como visto, é por ele definida como a liberdade de participar no processo político, de tomada de decisões próprias da comunidade como organização política, e de buscar influenciar o "ambiente moral" em que o indivíduo vive. Para ele,

“(...)pelo fato mesmo de o ambiente moral em que vivemos ser criado em grande medida pelas outras pessoas, as questões de quem terá o poder para moldar esse ambiente e de como este pode ser moldado são fundamentalmente importantes, embora sejam muitas vezes esquecidas pela filosofia política. De todas as respostas a essas perguntas, só uma é compatível com os ideais da igualdade política: ninguém deve ser impedido de influenciar o ambiente moral comum através de suas próprias escolhas, gostos e opiniões e do exemplo de sua vida; o fato de esses gostos e opiniões chocarem aqueles que têm o poder de prender ou calar a pessoa não é motivo suficiente para que ela não possa expressar-se". ${ }^{772}$

772 “As palavras de MacKinnon", op. cit., p. 381; no original "MacKinnon’s Words”, op. cit., pp. 238-9. O trecho continua e vale citá-lo:

"Of course, the ways in which anyone may exercise that influence must be limited in order to protect the security and interests of others. People may not try to mold the moral climate by indimidating women with sexual demands or burning a cross on a black family's lawn, or by refusing to hire women or blacks at all, or by making their working conditions so humiliating as to be intolerable.

"But we cannot count, among the kinds of interests that may be protected in whis way, a right not to be insulted or damaged just by the fact that others have hostile or uncongenial tastes, or that they are free to express or indulge them in private. Recognizing that right would mean denying that some people - those whose tastes these are - have any right to participate in forming the moral environment at all. Of course it should go without saying that no one has a right to succeed in influencing others through his own private choices and tastes. Sexists and bigots have no right to live in a community whose ideology or culture is even partially sexist or bigoted: they have no right to any proportional representation for their odious views. In a genuinely egalitarian society, however, these views cannot be locked out, in advance, by criminal or civil law: they must instead be discreted by the disgust, outrage, and ridicule of other people”, p. 238, itálico no original. Veja a crítica de Abigail Levin a argumento que a autora encontra em trecho de Dworkin similar ao que cito: The Cost of Free Speech: Pornography, Hate Speech, and their Challenge to Liberalism, op. cit., pp. 95-6. Veja ainda, de Dworkin, "Why Must Speech Be Free?", op. cit., "A New Map of Censorship", op. cit., "Foreword", op. cit, e Justice for Hedgehogs, op. cit., cap. 15. Compare ainda com o seguinte trecho sobre a tolerância liberal como defendida pelo autor e exposta no capítulo anterior: "So its version of ethical tolerance is not compromised when a thief is punished who claims to believe that theft is central to a good life. Or when a racist is thwarted who claims that his life's mission is to promote white superiority", "Foundations of Liberal Equality", op. cit., p. 304.

Robert George critica o argumento de Dworkin em defesa do direito à pornografia (como figura em "Do We Have a Right to Pornography?", op. cit.). Ele diz: “(...)among those people whose interests anti-pornography may preserve and advance are those very individuals who would be inclined to use pornography were it freely available. Dignity and beauty in sexual relationships (and a supporting cultural structure) are no less goods for them for anyone else. To the extent that it serves these (truly common) goods, anti-pornography legislation preserves and advances, rather than harms, their interests as well as the interests of everybody else" (Making Men Moral, op. cit., p. 100, itálico no original - veja em geral pp. 98-100). George não está errado ao dizer que a legislação anti-pornografia gera ambiente disponível a todos. Este é o caso, entretanto, em relação à maior parte das restrições não só da liberdade de expressão, mas da liberdade em geral. Que determinado efeito sobre a 
O seguinte trecho também merece ser citado porque é, a meu ver, o que melhor representa as consequências que Dworkin enxerga na violação do direito de influenciar o ambiente político, moral e cultural. Ele diz:

"A democracia justa [fair] exige o que podemos chamar de pano de fundo [background] democrático: ela requer, por exemplo, que cada adulto competente tenha um voto na decisão sobre qual é a vontade da maioria. E ela requer, ademais, que cada cidadão tenha não só um voto, mas uma voz: uma decisão da maioria não é justa [fair] a não ser que todos tenham tido uma oportunidade justa [fair] de expressar as suas atitudes ou opiniões ou medos ou gostos ou pressuposições ou preconceitos ou ideais, não somente na esperança de influenciar os outros, embora esta esperança seja de importância crucial, mas também para confirmar a posição da pessoa como um agente responsável na, em vez de uma vítima passiva da, ação coletiva. A maioria não tem nenhum direito de impor a sua opinião a uma pessoa que é proibida de levantar a voz em protesto ou argumento ou objeção antes de a decisão ser tomada". 773

Observe o leitor a lista obviamente não-exaustiva, e que aponta para a intenção de maior abrangência possível do que que o indivíduo pode expressar: opiniões, atitudes, mas também preconceitos e gostos. Trata-se de argumento de Dworkin orientado à inclusão de discurso não político no direito à liberdade de expressão fundado na dignidade, igualdade e democracia. É que o direito inclui expressão obscena. Entendamos o porquê.

Dworkin, sobre o argumento em análise, diz que "as políticas [policy] e a legislação de uma comunidade" são influenciadas não só por argumentos políticos, mas também "pelo ambiente moral e cultural - a mistura das opiniões, preconceitos, gostos e atitudes das suas pessoas" ${ }^{774}$. Viola o direito sob análise a restrição tanto da manifestação dirigida diretamente ao processo político quanto a manifestação orientada à formação do ambiente moral.

sociedade seja igualitário não é o suficiente para julgar se, no geral, uma medida viola a igualdade. Se Dworkin estiver correto, proibir a distribuição de pornografia viola a igualdade porque subtrai parte do direito de participação do indivíduo, mesmo que ele se beneficie, como esclarece George, de uma das consequencias da proibição. Isso significa que o debate sobre pornografia é dependente de discussão mais geral sobre o que significa e exige a igualdade, isto é, não se circunscreve à disponibilidade geral de parte de seus efeitos.

773 "A New Map of Censorship", op. cit., p. 131, traduzi e inseri entre colchetes palavras do original para indicar como as traduzi (veja ainda "Foreword", op. cit., p. vii para o mesmo texto). Dworkin, em "Foreword" (p. vi, em nota de rodapé), informa que se trata de elaboração de "The Right to Ridicule", op. cit. e "A New Map of Censorship", op. cit. Veja ainda "Why Must Speech Be Free?", op. cit., pp. 199-202. Preciso reconhecer que este argumento de Dworkin não me chamou a atenção antes de eu o ver formulado e criticado por Waldron, que se concentra em "Foreword". Veja, de Waldron, The Harm in Hate Speech, op. cit., esp. cap. 7 (nas pp. 174 e ss., ele faz boa seleção de trechos de Dworkin, alguns dos quais eu cito, embora sua fonte seja "Foreword".).

774 "A New Map of Censorship", op. cit., p. 131, traduzi (veja o mesmo texto em "Foreword", op. cit., p. viii).. Nem todos concordam com a extensão deste argumento à pornografia. Veja os seguintes comentários de James Weistein às teorias da liberdade de expressão de Scanlon e de Dworkin (a transcrevo porque a julgo uma boa exposição do argumento que discuto nesta subseção): "One shortcoming of Scanlon's theory, however, is that it focus on the right of individuals to receive information to effectuate autonomous choice does little to explain the right of individuals to convey messages. Into the breach steps Ronald Dworkin, who generates a theory of speech protection using essentially the same first-order political principle Scanlon employs. But where Scanlon 
Este argumento é, a meu ver, extremamente convincente. Mas ele não exige a conclusão de que as leis aprovadas em processo censurado sejam ilegítimas. A liberdade de expressão é, para Dworkin, condição de legitimidade política da formação da opinião da maioria e das decisões políticas daí decorrentes ${ }^{775}$. Mas isso não significa que qualquer

emphasizes the "autonomous" aspect of the foundational principle that government must treat each individual as "equal, autonomous, rational agents," Dworkin emphasizes the "equal". To Dworkin, government violates the basic command of equal treatment when "it disqualifies some people from [expressing their views] on the ground that their convictions make them unworthy" (18). Democracy in this view is valued not just because it leads to stability, wealth, peace, and good order but because it is the only form of government that does not insult the dignity of some members of society by treating others as more valuable or worthy of respect. Just as denying some people to vote because the government disagrees with whom or what they indend to vote for is contrary to the basic equality principle on which democracy is founded, so, too, is denying some people the chance to shape public opinion because the government finds their ideas to be wrong or offensive. Dworkin thus supplies a moral, noninstrumental reason for democratic self-governance rationale for free speech, thereby firmly grounding it as an individual right. (19)", Hate Speech, Pornography, and Radical Attacks on Free Speech Doctrine, op. cit., pp. 15-6, itálicos e trecho entre colchetes do original (veja ainda pp. 84, 93, 187 e 191, páginas que constam no Index) (a nota 18 tem a seguinte redação: "Ronald Dworkin, "Women and Pornography," New York Review of Books, October 21, 1993.", p. 221). Na nota 19, Weistein formula a sua crítica a Dworkin: "Dworkin does not, however, limit the rationale to the protection of political speech. "The wrong is just as great", he insists, "when government forbids the expression of some social attitude or taste as when it censors explicitly political speech; citizens have as much a right to contribute to the formation of the moral or aesthetic climate as they do to participate in politics." This extension makes his theory more controversial. It is one thing to argue that a right to equal participation in the political process is a precondition for the government's legitimaly exercising power over individuals; it is quite another to argue that government may not legitimaly exercise authority over individuals unless each individual has a right to contribute "to the formation of the moral or aesthetic climate". An obvious connection exists between individuals' ceding political authority to the government on the condition that they retain an equal right to participate in deciding how this political authority shall be exercised. The connection between ceding political power to the government and "the formation of the moral or aesthetic climate" is not so apparent", n. 19, pp. 221-2.

Ao contrário, a mim me parece que a conexão é bastante aparente: que é pressuposta e, com efeito, efetivamente explicitada por Dworkin no argumento sobre o direito de tentar influenciar o ambiente moral e o prejuízo democrático gerado por proibições a certos tipos de expressão por simples razão de conteúdo. (O que talvez se possa dizer é que esta conexão está explícita em trabalhos de Dworkin não discutidos por Weinstein. Não pretendo explorar eventuais alterações este argumento de Dworkin). É que, ainda que se possa diferenciar discurso político de discurso não político (trata-se, pelo menos, de diferença que Dworkin faz: para ele, pornografia não é discurso político), as decisões políticas são produto tanto do ambiente político quanto do ambiente não-político, e, portanto, a restrição de discurso não-político pode ser devidamente considerada uma violação de direito político. Em outras palavras, é possível ter direito político a discurso não-político pois simplesmente não é verdade que a natureza do direito se confunde com o seu objeto (isto é, não é porque o discurso não é político que o direito a ele deixe de sê-lo: existe um direito político ao discurso não-político). A meu ver, esta crítica a Dworkin me parece derivada de má compreensão do argumento democrático a favor da extensão da liberdade de expressão a discurso não político, apesar de Weistein descrevê-lo tão bem no trecho citado acima. Consiste também em cisão entre processo político-decisório e ambiente moral e cultural que é implausível e expressamente negada por Dworkin. Salvo argumento convincente a favor desta cisão, Weistein não me parece capaz de dirigir crítica bem-sucedida a Dworkin. Compare com o que diz George, defensor da restrição da pornografia e crítico da distinção entre discurso político e não-político em Making Men Moral, op. cit., p. 206, n. 8; veja p. 206 em geral.

775 "Foreword" in Ivan Hare e James Weistein (Eds.) Extreme Speech and Democracy, op. cit. p. ix, em trecho citado abaixo (ou "A New Map of Censorship", op. cit., p. 132). E ainda: "Laws and policies are not legitimate unless they have been adopted through a democratic process, and a process is not democratic if government has 
violação da liberdade de expressão torne esta formação ou as decisões dela decorrentes ilegítimas. O ponto aqui é que legitimidade política é uma questão de grau. Waldron cogitou que Dworkin defendesse que legitimidade política é questão de grau ${ }^{776}$; efetivamente, ele confirmou que é esta sua opinião em debate com Waldron na Noruega em $2012^{777}$. Antes disso, ele havia claramente defendido esta opinião. ${ }^{778}$ Coerente com esta posição, Dworkin é muito cuidadoso ao discutir violações à liberdade de expressão: ele deliberadamente evita qualificar de "totalitários" ou "tirânicos" regimes em outros termos politicamente democráticos e que falham, mesmo que muito, no respeito que devem à liberdade de expressão. $^{779}$

O argumento também é compatível com, se é que não emprega, o sentido de discriminação exigido pela integração das liberdades compreendidas negativamente à justiça distributiva: a democracia, para Dworkin, proíbe qualquer intervenção precoce no sistema

prevented anyone from expressing his convictions about what those laws and policies should be.", "The Right to Ridicule", op. cit..

776 Jeremy Waldron, The Harm in Hate Speech, op. cit., pp. 184-192, esp. pp. 186 e ss. Waldron considera algumas interpretações do argumento de Dworkin a depender de a legitimidade ser ou não questão absoluta: sigo a terceira interpretação (pp. 188 e ss.), embora o ponto não seja exatamente que "the enforcement of hate speech laws diminishes (...) the legitimacy of downstream laws without destryong their legitimacy altogether" (p. 188, itálico no original), mas que a própria existência da lei tem esse efeito. Entre nós, veja Júlio César Casarin Barroso Silva. Democracia e Liberdade de Expressão: Contribuições para uma interpretação política da liberdade de palavra. op. cit., pp. 160 e ss. Sobre obrigação política e legitimidade em Dworkin veja Caio Moysés de Lima, O Império dos Direitos: Lei e Autoridade Política em Ronald Dworkin, op. cit., pp. 79 e ss.

777 Ronald Dworkin e Jeremy Waldron. "Session 4: Multiculturalism and Human Rights" debate em The New York Review of Books Foundation and Fritt Ord Foundation, Oslo (Orgs.), Robert Silvers (Chaired). Challenges to Multiculturalism. A Conference on Migration, Citizenship, and Free Speech, 25-26 June 2012 at The House of Literature in Oslo, disponível em http://www.youtube.com/watch?v=DoSbp8pdbM8 (parte 1/2), http://www.youtube.com/watch?v=6wJQ658e-4U (Parte 2/2) e http://www.youtube.com/watch?v=zHioq4mc7c0 (Q\&A), último acesso em 03.12.2013. Dworkin faz essa afirmação na segunda parte, que traz a sua manifestação no debate.

778 "Because legitimacy is a matter of degree, so, on this conception, is democracy", Justice for Hedgehogs, op. cit., p. 384. Veja ainda Law's Empire, op. cit., cap. 5 e "The Curse of American Politics", op. cit., item 4. Waldron cita Dworkin defendendo a ideia em Is Democracy Possible Here, op. cit., p. 97 (veja The Harm in Hate Speech, op. cit., p. 188 - referência completa na p. 269, n. 22).

${ }^{779}$ Veja, por exemplo, o argumento do autor sobre o governo de Margaret Thatcher, ex-primeira-ministra da Inglaterra: "this government's challenge to freedom has nothing to do with totalitarian despotism. It shows a more mundane but still corrupting insensitivity to liberty, a failure to grasp its force and place in modern democratic ideals", "Devaluing Liberty", op. cit., p. 8, primeira coluna (neste pequeno artigo de duas páginas, cada uma tem três colunas). E ainda: "Thatcherism makes intellectual liberty just another commodity, to be enjoyed when there is no particular political or commercial or administrative price to be paid for it, but abandoned, with no evident grief, when the price begins to rise. That is not despotism. But it cheapens liberty and diminishes de nation", p. 9, terceira coluna. Veja ainda "It is absurd to calculate human rights according to a cost-benefit analysis", op. cit., de 2006, para análise mais recente do respeito às liberdades na Inglaterra. Veja a Conclusão desta dissertação para discussão mais extensa de "Devaluing Liberty", em que Dworkin elabora o que chama de "culture of liberty". 
político. Entendamos também este ponto em detalhe. Que o leitor me permita mais uma citação de "A New Map of Censorship" e de "Foreword":

"Podemos e devemos proteger as mulheres, os homossexuais e os membros dos grupos minoritários das consequências específicas e danosas do sexismo, da intolerância e do racismo. Devemos protegê-los contra injustiça [unfairness] e desigualdade em emprego ou educação ou moradia ou na justiça criminal [criminal process], por exemplo, e podemos adotar leis para alcançar esta proteção. Mas não devemos intervir rio acima [further upstream], por meio de proibição de qualquer expressão das atitudes ou de preconceitos que acreditamos que nutrem esta injustiça [unfairness] ou desigualdade, porque se intervirmos cedo demais no processo pelo qual a opinião coletiva é formada, estragamos a única justificação democrática que temos para insistir que todos obedeçam estas leis, mesmo aqueles que as odeiam e delas se ressentem" ${ }^{, 780}$.

Em outras palavras, há um direito de publicar discurso de ódio e pornografia, e o respeito a este direito é exigência da democracia e da igualdade, mas não existe um direito a que a maioria acate as ideias racistas ou misóginas ou homofóbicas e que as incorpore nas decisões tomadas (o que, é claro, assume a existência de direitos dos direitos de negros, mulheres e homossexuais contra a discriminação representada pela adoção política de ideias de conteúdo discriminatório). Dworkin expressa esta ideia em artigo crítico de Catharine MacKinnon, defensora da proibição de certos tipos de pornografia, e, logo após defender o argumento sobre as demandas de liberdade de expressão que decorrem da democracia e da igualdade, diz o seguinte:

“(...) o papel igualitário da Primeira Emenda (...) proíbe a censura dos pervertidos sexuais ou dos neonazistas, não porque alguém pense que as contribuições deles vão impedir a corrupção ou melhorar a qualidade do debate público, mas porque a igualdade exige que todos, por mais excêntricos ou desprezíveis que sejem, tenham a oportunidade de exercer sua influência não só sobre as eleições, mas também sobre as políticas [policies]. Não se deduz daí que o Estado vá, no fim, respeitar igualmente a opinião de todos, nem que as decisões oficiais serão igualmente favoráveis a todos os grupos. O que a igualdade exige é que todas as opiniões tenham a oportunidade de exercer a sua influência, e não que todas triunfem ou mesmo que sejam representadas naquilo que o Estado efetivamente faz". ${ }^{781}$

\footnotetext{
780 "A New Map of Censorship", op. cit., p. 132, traduzi e inseri entre colchetes palavras do original para indicar como as traduzi (veja o mesmo texto em "Foreword", op. cit., p. viii). Veja a mesma ideia em outras palavras: "So in a democracy no one, however powerful or impotent, can have a right not to be insulted or offended. That principle is of particular importance in a nation that strives for racial and ethnic fairness. If weak or unpopular minorities wish to be protected from economic or legal discrimination by law-if they wish laws enacted that prohibit discrimination against them in employment, for instance - then they must be willing to tolerate whatever insults or ridicule people who oppose such legislation wish to offer to their fellow voters, because only a community that permits such insult as part of public debate may legitimately adopt such laws. If we expect bigots to accept the verdict of the majority once the majority has spoken, then we must permit them to express their bigotry in the process whose verdict we ask them to accept." "The Right to Ridicule", op. cit.. (veja ainda "Foreword", op. cit., p. viii). Veja Waldron, The Harm in Hate Speech, op. cit., pp. 173 e ss., especialmente p. 179 para quadro explicativo daquilo que, para Dworkin, são "upstream laws" (que dizem respeito ao "hate speech") e "downstream laws" (que dizem respeito a "discrimination, violence etc.").

781 "As palavras de MacKinnon" in $O$ Direito da Liberdade, op. cit., p. 380 (alterei a tradução citada para alterar "oportunidade de exercer sua influência não só nas eleições, mas na política em geral", que traduz "chance to influence policies as well as elections", pela opção que consta na citação); para o original, veja "MacKinnon's
} 
Ou seja, Dworkin defende que o direito à liberdade de expressão inclui o direito de expressão de opiniões de conteúdo discriminatório, bem como o direito de tentar divulgar e difundir estas opiniões, mas não inclui o direito de que estas opiniões sejam acatadas, mesmo que parcialmente, isto é, de maneira proporcional àqueles que as detêm ${ }^{782}$. Para o autor, o direito de tentar influenciar o ambiente público é incompatível com proibições à manifestação de ideias, mas nada tem a ver com o resultado das decisões políticas tomadas neste ambiente. Ainda, é possível reconhecer inúmeros direitos contra discriminação, mas a legitimidade do reconhecimento institucional destes direitos depende da abertura do processo decisório a opiniões contrárias. Dworkin diz, ao falar de preconceito contra a religião muçulmana, que,

"Se queremos proibir a polícia de profiling pessoas que se parecem ou que se vestem como muçulmanos para revistas [searches] especiais, por exemplo, não podemos também proibir as pessoas de se oporem a esta polícia ao afirmarem, em cartoons ou em outros lugares, que o Islã é comprometido com o terrorismo, independentemente de quão equivocado pensemos que esta opinão é." ${ }^{783}$

Ou seja, muçulmanos têm um direito - de não-discriminação, pode-se acrescentar contra revistas baseadas na percepção de que existe uma relação entre Islã e terrorismo, mas

Words", op. cit., p. 237 (veja em geral pp. 236 e ss.). Trata-se de trecho em que Dworkin critica um dos argumentos de Catharine MacKinnon a favor da proibição da pornografia (veja abaixo para discussão da crítica do autor a este argumento, que diz respeito aos efeitos da pornografia à igualdade). Veja a crítica de Levin ao argumento de Dworkin em trecho similar a este que cito em The Cost of Free Speech: Pornography, Hate Speech, and their Challenge to Liberalism, op. cit., pp. 94-6 e, em especial, "Dworkin is saying that there is no conflict between the First and Fourteenth Amendments, because an unrestricted First Amendment leads unproblematically to the upholding of the Fourteenth Amendment's equal protection clause. However, the charge of the subordination argument is exactly the opposite - unregulated freedom of expression applied systematically in favor of the hate speaker and the pornographer denies minorities and women the equal protection of the laws. In other words, protecting pornography gives rise to the silencing argument - privileging the freedom of expression interests of the speaker over the freedom of expression interests of the minority is an immoral and unjustified reification of the status quo of the powerful, the expense of the relatively powerless", p. 98.

${ }^{782}$ Veja "Addendum: A Response to MacKinnon's Reply", in "MacKinnon's Words", in Freeom's Law, op. cit., p. 242 (na mesma página Dworkin diz que distribuir pornografia não pode ser considerado "discriminação": veja trecho citado em nota acima) e também "MacKinnon's Words", op. cit., p. 238 (em trecho citado em nota acima).

783 "Foreword", op. cit., p. ix, traduzi, mantive entre colchetes palavras do original para indicar como as traduzi, mas deixei de traduzir as palavras em inglês italicizadas que não estão entre colchetes (veja o mesmo texto em "The Right to Ridicule", op. cit.). O contexto do trecho citado é o argumento de Dworkin de que haja mais motivo para proibir ofensas às religiões do que há de proibir ofensas por motivo de raça, por exemplo ("Foreword", p. viii). O contexto politico, por sua vez, são as charges de Maomé: Dworkin, sobre restrições contemporaneamente populares à liberdade expressão, relata que “(...) in 2005 several people called for the punishment of those who publishes cartoons in a Danish newspaper associating the Prophet Mohammed with terrorismo and demanded censorship of these images in other countries", "Foreword", op. cit, p. vi (veja ainda "The Right to Ridicule", op. cit.). Sobre o tema das críticas às religiões, particularmente ao Islã, veja, sobre Salman Rushdie, Eric Barendt, Freedom of Speech, op. cit., pp. 186 e 189 e 1993 (sobre os "Danish Cartoons", veja Waldron em The Harm in Hate Speech, op. cit., pp. 125-6, inclusive com citação e "The Right to Ridicule", op. cit., de Dworkin; para o argumento de Dworkin, veja pp. 173 e ss., esp. p. 174.). 
este direito não inclui a proibição das manifestações que defendem a existência desta relação ou do não reconhecimento do direito contra revistas discriminatórias.

Mas talvez seja possível justificar direito mais extenso de minorias e outros grupos prejudicados por ideias cuja defesa Dworkin inclui na liberdade de expressão. Como mencionei, assumida esta definição de discriminação, o sucesso do argumento de Dworkin é dependente da inexistência de direito que se contraponha com sucesso à liberdade de expressão. Dworkin discute alguns desses direitos ao analisar argumentos a favor da restrição do discurso de ódio e à pornografia. Gostaria de analisá-los para concluir esta subseção.

Embora Dworkin utilize a expressão para criticar somente um dos direitos pressupostos nas críticas à extensão da liberdade de expressão ao discurso de ódio e à pornografia ${ }^{784}$, a mim me parece que a objeção do autor aos direitos enunciados para este propósito é a mesma: tratase de direitos que não podem ser generalizados embora os argumentos que os empreguem, por uma questão de princípio, estejam comprometidos com esta generalização. Ou seja, a crítica de Dworkin consiste em apontar para a impossibilidade de implementação dos direitos enunciados na forma com que a defesa das restrições à liberdade de expressão deve logicamente se comprometer. Por exemplo, para Dworkin a proibição do discurso negacionista do Holocausto precisa se estender a outros discursos igualmente ofensivos, como o racista contra negros. Aparentemente, trata-se de crítica que poderia ser superada pela simples extensão da proibição a outros tipos de discurso, ou ainda talvez seja crítica inaplicável, por exemplo, à legislação brasileira. Ocorre que o ponto de Dworkin, como veremos, não diz respeito a simples inconsistência corrigível por modesta extensão das proibições, mas de incompatibilidade da proibição defendida com a própria ideia do direito à liberdade de expressão. Para o autor, os direitos apontados como fundamento de proibição de certos tipos de discursos se comprometem logicamente com a proibição de discursos em tal extensão que seu resultado é o fim da liberdade de expressão como direito, e não restrição pontual e isolável de algumas hipóteses de seu exercício. Trabalhar mais concretamente pode elucidar o argumento de Dworkin.

Há pelo menos menção a dois destes direitos nos escritos de Dworkin: direito de não ser ofendido(a) ou ridicularizado(a) e direito de não ser silenciado(a). Em relação ao primeiro, o autor entende que ofensa não caracteriza critério capaz de distinguir discursos aceitáveis dos

\footnotetext{
784 “Free Speech, politics, and the Dimensions of Democracy”, op. cit., p. 366 (veja trecho citado abaixo).
} 
inaceitáveis $^{785}$. Vale citar o seguinte trecho, em que Dworkin, após ressaltar que o direito canadense restringe a liberdade de expressão em casos não previstos na Constituição dos EUA, comenta decisão da Suprema Corte do Canadá sobre pornografia em que o tribunal

"admitiu que sua decisão teria o efeito de estreitar ainda mais essa proteção constitucional, mas disse que a 'proliferação de materiais que ofendem gravemente os valores fundamentais de nossa sociedade é uma preocupação substancial que justifica a restrição do pleno exercício da liberdade de expressão'. Trata-se de afirmação incrível. A premissa central que define a liberdade de expressão reza que o caráter ofensivo de idéias, ou o fato de porem em xeque as idéas tradicionais e aceitas, não são motivos válidos de censura; uma vez deixada de lado essa premissa, não se sabe mais o que significa a liberdade de expressão. A Corte acrescentou que certas formas de representação explícita do sexo fazem mal às mulheres porque 'as representações que retratam as mulheres como uma classe de objetos de exploração e abuso sexual têm efeito negativo sobre a noção que o indivíduo tem do seu valor e do seu grau de aceitação na sociedade'. Porém, esse tipo de mal é tão próximo da simples 'ofensa' que também não pode, por si mesmo, constituir uma razão válida para a censura. Toda idéia poderosa e controversa tem potenciais efeitos negativos sobre a auto-estima de alguém. É de presumir que a Suprema Corte canadense não sustentaria a proibição de livros não-pornográficos escritos com a finalidade de negar explicitamente a igualdade entre homens e mulheres, por mais que esses livros fossem persuasivos ou eficazes para atingir sua finalidade", 786

\section{Em outro artigo publicado em Freedom's Law, ele diz:}

"A pornografia, muitas vezes, é grotescamente afrontosa; é ultrajante, não só para as mulheres, mas também para os homens. Porém, não podemos ver aí uma razão suficiente para proibi-la, sob pena de destruir o princípio de que formas de expressão que odiamos são tão dignas de proteção contra quaisquer outras. A essência da liberdade negativa é a liberdade de ofender, e isso não se aplica somente às formas de expressão heróicas, mas também às de mau gosto." 787

Ainda, ao comentar a incompatibilidade de restrições "rio acima" com a liberdade de expressão, Dworkin diz: "Numa democracia, ninguém, independentemente de quão poderoso ou impotente seja, pode ter direito de não ser insultado ou ofendido". ${ }^{788}$ A ideia a meu ver é

785 “Do We Have a Right to Pornography?", op. cit., pp. 346-7. Veja ainda a noção de "bare harm” em "Principle, Policy, Procedure", op cit..

786 "Por que a liberdade de expressão?" in $O$ direito da liberdade, op. cit., p. 331, nota omitida (em geral, veja pp. 330-1); no original, "Why Must Speech Be Free?", op. cit., pp. 206-7. A decisão do tribunal canadense é citada por Dworkin na n. 42 à p. 330, que tem a seguinte redação: "Butler vs. Her Majesty the Queen, decidido em 27 de fevereiro de 1992" (no original, "Why Must Speech Be Free?”, op. cit., n. 24, p. 376 à p. 206). Compare com KATEB, George. "The Freedom of Worthless and Harmful Speech" in YACK, Bernard (Ed.) Liberalism without illusions: essays on liberal theory and the political vision of Judith N. Shklar. Chicago: The University of Chicago Press, 1996, p. 221. Veja comentários de MacKinnon ao direito canadense em Only Words, op. cit., pp. 97 e ss. e críticas de Levin a Dworkin em The Cost of Free Speech: Pornography, Hate Speech, and their Challenge to Liberalism, op cit., pp. 92-3.

787 "Pornografia e ódio", op. cit., p. 351; no original, "Pornography and Hate", pp. 218-9.

788 The Right to Ridicule", op. cit., traduzi (o texto é o mesmo de "Foreword", op. cit., p. xviii). Veja Waldron em The Harm in Hate Speech, op. cit., pp. 126-30, 134-5 sobre a inevitabilidade de certas hipóteses de ofensa religiosa ("(...)offense is likely to be endemic", p. 129 e "The deepest, most troubling feelings are involved, and mutual affront is pretty much the name of the game", p. 129), embora defenda certas restrições que julga distinguíveis do "(...) impossible burder of protecting everyone from offense" (p. 130 e, imediatamente no parágrafo seguinte, resume sua visão: "Religious freedom means nothing if it is not freedom to offend: that is clear. But, equally, religious freedom means nothing if it does not mean that those who offend others are to be 
compatível com a rejeição dworkiniana da noção de "bare harm" em prol do "fator de injustiça" como categoria capaz de explicar a violação de um direito, o que desaloja a simples percepção da ofensa por parte do indivíduo como fato capaz de apontar para a violação de um direito $^{789}$. Paralelamente a esta demanda de explicação normativa do prejuízo provocado pela pornografia, há, como visto no longo trecho citado, o fato de que ideias são mesmo muitas vezes ofensivas, e que adotar este fato como critério de restrição da liberdade da expressão é encerrá-la. A afirmação parece exagerada porque, ainda que adotado este critério, seria permitido o discurso não ofensivo ${ }^{790}$. Mas observe, em primeiro lugar, que esta não seria uma nocão estável, pois seria uma função das percepções das vítimas, o que é incompatível com o reconhecimento de uma faculdade política dos cidadãos fundada em valores da igualdade, da democracia e em visão normativa sobre o que significa uma vida bem vivida - e é nestes termos que, para o autor, as liberdades devem ser defendidas. Em segundo lugar, e independentemente da instabilidade da ideia de ofensa, ela, se não é incompatível com a permissão de todo e qualquer discurso, é incompatível com a interpretação da liberdade de expressão como um direito. Elaboro este ponto abaixo após expor o próximo direito rejeitado por Dworkin e depois de expor crítica do autor comum aos dois direitos. ${ }^{791}$

Em relação ao segundo direito, trata-se de argumento que Dworkin identifica na defesa, por parte de autoras feministas como Catharine MacKinnon, da proibição de certos tipos de pornografia em razão de a distribuição de material obsceno operar silenciamento das

recognized nevertheless as fellow citizens and secured in that status, if need be, by laws that prohibit the mobilization of social forces to exclude them", p. 130).

789 "Principle, Policy, Procedure", op. cit.

${ }^{790}$ Veja, por exemplo, “Do We Have a Right to Pornography?”, op. cit., p. 346, trecho discutido abaixo.

${ }^{791}$ Dworkin aplica mesmo raciocínio em sua crítica à proibição da negação do Holocausto, que é, diz ele, "is a monstrous insult to the memory of all the Jews and others who perished under it", "Addendum: A Compelling Case for Censorship?" in "Pornography and Hate", op. cit., p. 225 (veja em geral pp. 223-6). Apesar disso, não se trata, na opinião do autor, de característica específica da negação do Holocausto - Dworkin menciona trabalhos racistas, que podem, diz ele, ser considerados extremamente insultantes inclusive em razão do histórico norteamericano de escravidão dos negros, e sustenta que "Censorship is often the child of grievance, and people who fell that history has been unjust to them - as many Moslem fundamentalists and other groups as well as blacks do - are unlikely to accept that their positions is not special too", p. 225. Observe que este não é um argumento acerca da excepcionalidade histórica do Holocausto, mas um argumento sobre a inexistência de especificidade na ofensa à memória de suas vítimas. Os dois pontos podem ser associados num argumento que aponte para a necessidade de censura da negação do Holocausto em razão da sua excepcionalidade história, mas o expediente não me parece plausível. Dworkin, de qualquer forma, trabalha com a ofensa caracterizada pela negação, e ela, de fato, não é distinta da ofensa provocada por outros discursos, o que torna convincente a crítica do autor à seletividade de se proibirem certos tipos de "revisionismos" histórico. 
mulheres $^{792}$. O autor, como veremos, também considera este argumento aplicável a outros tipos de discurso. Não é meu objetivo apreciar o sentido do argumento, salvo indicar o modo como Dworkin o interpreta e o defeito fundamental que encontra nesta interpretação: trata-se de direito que não pode ser "generalizado". Em "Free Speech, Politics, and the Dimensions of Democracy”, comentando a relação da "igual cidadania” e o discurso de ódio, Dworkin diz:

"Há quem afirme que a expressão de opiniões pejorativas [derogatory] com relação a grupos raciais, étnicos e sexuais prejudica a igualdade dos cidadãos porque, além de ofender os cidadãos que são seus alvos, também prejudica sua própria capacidade de participar da política como iguais. Diz-se que o discurso racista, por exemplo, "cala" ["silence"] as minorias raciais que são seu alvo. (...) seria um grave mal-entendido da igualdade dos cidadãos, e da concepção de democracia co-participativa [partnership], supor que permitir a livre circulação até de opiniões políticas psicologicamente danosas ofenda a igualdade em questão. A igualdade dos cidadãos não pode exigir que eles sejam protegidos pela [by] censura, mesmo contra as crenças, convicções ou opiniões que dificultem para eles conquistar atenção para suas opiniões em um concurso político justo, ou que prejudiquem sua própria opinião sobre eles mesmo. Não seria possível generalizar um direito a tal proteção - um cristão fundamentalista, por exemplo, não poderia ser protegido de tal forma - sem proibir completamente o discurso e a expressão de opiniões. Precisamos atacar coletivamente o preconceito ou [or] a predisposição, mas não assim". ${ }^{793}$

Dworkin não nega que haja certo direito de não ser silenciado, mas nega que este direito exista na extensão exigida pelo argumento a favor da proibição de alguns tipos de pornografia. Para o autor, faz parte da liberdade de expressão não ser impedido de falar pelo exercício da liberdade de expressão de outra pessoa. ${ }^{794}$ Dworkin discute argumento de Frank

${ }^{792}$ Veja ainda "Why Must Speech be Free?", op. cit., pp. 205 e ss.: Dworkin atribui o argumento a Catharine MacKinnon e a Frank Michelman. Veja crítica de Abigail Levin à objeção de Dworkin a este argumento: The Cost of Free Speech: Pornography, Hate Speech, and their Challenge to Liberalism, op. cit., pp. 84 e ss., 91 e ss. 793 "Liberdade de expressão, política e as dimensões da democracia", op. cit, 514-5, inseri entre colchetes a palavra do original em inglês para indicar como a palavra foi traduzida (inseri o "or" porque a tradução traz "e" em vez de "ou", erro que corrigi na citação que faço); no original, "Free Speech, politics, and the Dimensions of Democracy", op. cit., p. 366. Prefiro traduzir "silencing" por "silenciar", como faz a tradução de $O$ direito da liberdade (veja, por exemplo, "As palavras de MacKinnon", op. cit, p. 371 - em geral, veja pp. 371-3). Dworkin descreve da seguinte forma o argumento de MacKinnon: "pornography should be banned because it "silences' women by making it more difficult for them to speak and less likely that others will understand what they say", "MacKinnon's Words", op. cit., p. 231 (veja em geral pp. 231-2). Ao criticar o argumento de Dworkin sobre o prejuízo da restrição do hate speech à legitimidade das leis, Waldron (The Harm in Hate Speech, op. cit., pp. 18184) faz crítica análoga: "One preliminary response is to wonder whether Dworkin's argument can be kept under control" (p. 182), pois poderia se aplicar tanto ao discurso de ódio quanto a outras hipóteses em que a restrição da liberdade de expressão é nitidamente aceitável - um dos exemplos é a pornografia infantil, p. 182. O argumento não me parece convincente porque não é plausível sustentar que haja direito à liberdade de expressão, fundado ou não na democracia, de violar direito de terceiro - o que ocorre no caso da pornografia infantil mas não, se Dworkin estiver correto, nos casos de discurso de ódio. A questão não me parece distinta da discussão mais geral sobre os limites da liberdade de expressão.

794 "Government must indeed balance negative liberties when it prevents heckling or other demonstrative speech designed to stop others from speaking or being heard", "Pornography and Hate", op. cit. p. 221. Neste ponto, Dworkin crítica argumento sobre o "silencing" provocado pela pornografia defendido por Frank Michelman: "He argues that some speech, including pornography, may be itself 'silencing,' so that its effect is to prevent other people from exercising their negative liberty to speak", p. 221 (pouco depois, Dworkin abre aspas para citar Michelman, e faz referência a artigo seu p. 377, n. 9 à p. 222: "Frank Michelman, Conceptions of Democracy in 
Michelman, segundo o qual seria contraditório proibir a censura pública mas permitir que indivíduos privados se silenciem uns aos outros. ${ }^{795}$ Para Dworkin, entretanto, não faz parte da liberdade de expressão que outros se disponham a ouvir ou compreendam o que alguém diz: este direito de não ser silenciado(a) não existe. ${ }^{796}$ Ele diz que

"não existe contradição nenhuma em insistir em que toda idéia deve ter a possibilidade de ser ouvida, mesmo aquela que tem por consequência fazer com que outras idéias sejam mal compreendidas, desconsideradas ou mesmo silenciadas, na medida em que os que poderiam expressá-las não controlam sua própria identidade pública e portanto não podem ser vistos pelos outros como gostaria de ser. Sem dúvida essas consequências são muito indesejáveis e devem ser combatidas por todos os meios autorizados por nossa Constituição. Porém, nem por isso os atos que têm essas consequiências negativas privam as outras pessoas de sua liberdade de se expressar (...),"797

A meu ver, este ponto é paralelo aos conflitos entre "discurso democrático" e "democracia cidadã", duas das dimensões da democracia elaboradas por Dworkin. Como exponho na próxima subseção, e como mencionei brevemente acima, o fato de que a segunda descreve direitos torna impertinentes à medida do direito à liberdade de expressão eventuais benefícios que traga à qualidade do debate público. Em concreto, o fato de que existe benefício público em discursos de mulheres serem corretamente compreendidos não significa que é possível restringir ou proibir outros tipos de discurso responsáveis pelo entendimento equivocado (ou silenciamento). A liberdade de expressão como direito não inclui o direito de ser corretamente compreendido. Mas por quê? Porque esse direito não pode ser implementado. Desta vez comentando a versão de MacKinnon do argumento do "silenciamento" das mulheres provocado pela pornografia, ele diz:

“(...) esse argumento (...) toma como premissa uma proposição inaceitável: que o direito à liberdade de expressão inclui o direito a viver em circunstâncias que nos encorajem a falar e o direito que outros compreendam e respeitem o que queremos dizer.

"Evidentemente, esses direitos não podem ser reconhecimentos nem impostos por nenhuma sociedade. Atualmente, por exemplo, os criacionistas, os adeptos da teoria da terra plana e os moralistas dogmáticos são ridicularizados em muitas partes dos Estados Unidos; sem dúvida, esse ridículo diminui a vontade

American Constitutional Argument: The Case of Pornography Regulation, Tennesse Law Review, vol. 56, no 291 (1989), pp. 303-4"). Dworkin entende que Michelman aponta contradição entre a proibição da censura pelo estado e a permissão do silenciamento privado; em resposta, Dworkin diz que não é esta a distinção feita pela interpretação da liberdade de expressão que impede a proibição da pornografia. Veja discussão abaixo e Júlio César Casarin Barroso Silva. Democracia e Liberdade de Expressão: Contribuições para uma interpretação política da liberdade de palavra. op. cit., pp. 180 e ss.

795 "Pornography and Hate", op. cit. pp. 221-2. Veja ainda "Why Must Speech be Free?", op. cit., pp. 205 e ss. e "MacKinnon's Words", op. cit., p. 235.

796 "Pornography and Hate", op. cit. pp. 221-2, "MacKinnon's Words", op. cit., pp. 231-2 e "Free Speech, politics, and the Dimensions of Democracy", op. cit., p. 366.

797 "Pornografia e ódio", op. cit., pp. 357-8 (este trecho se insere em contexto em que Dworkin emprega a distinção de Isaiah Berlin entre liberdade negativa e positiva; não me parece necessário empregá-la para expor o argumento do autor contra Michelman). 
que muitos deles têm de sair pregando aquilo em que acreditam, assim como diminui a atenção que os outros prestam ao que eles têm a dizer. É verdade que muitos teóricos da política e da Constituição insistem em que, para que a liberdade de expressão tenha algum valor, ela tem de incluir um direito à oportunidade de se expressar: dizem que uma sociedade em que só os ricos têm acesso aos jornais, à televisão e a outros meios de comunicação pública não garantem o verdadeiro direito à liberdade de expressão. Porém, isso não é a mesma coisa que asseverar que a liberdade de expressão inclui não só a oportunidade de falar ao público como também uma garantia de que sua voz será recebida com simpatia ou mesmo entendida com competência" ${ }^{\text {"798 }}$

Para Dworkin, estes direitos - de não ser ofendido(a) e de não ser silenciado(a) - não existem. Em primeiro lugar, porque não são compatíveis com o reconhecimento da liberdade de expressão. É preciso entender o primeiro ponto considerando que a liberdade de expressão, para Dworkin, é um direito no sentido forte. Propor a proibição de discurso que afeta a imagem de determinados grupos certamente não implica a proibição de todo tipo de expressão, pois nem todo discurso tem esse efeito; mas certamente implica o abandono da ideia de que o direito à liberdade de expressão inclui mesmo discursos dotados de maus efeitos, e que somente pode ser restrito por outros direitos. Vimos acima o argumento de Dworkin contra o uso de "ofensa" como critério definidor dos limites da liberdade de expressão. De sua adoção certamente não se seguirá que nenhum discurso poderá ser feito, pois haverá discurso que ninguém considerará ofensivo. $\mathrm{O}$ argumento do autor não diz respeito à extensão de direito permissível sob o critério por ele rejeitado, mas à sobrevivência da liberdade de expressão como um direito forte. Ou seja, por mais que adotar a ofensa como critério de proibição de

\footnotetext{
798 “As palavras de MacKinnon”, op. cit., pp. 272-3, alterei a tradução para corrigi-la, pois no original constam "right to circumstances that encourage one to speak, and a right that others grasp and respect what one means to say" e "These are obviously not rights that any society can recognize or enforce", traduzidos por "direito a viver em circunstâncias que nos encorajem a falar e o dever das outras pessoas de compreender e respeitar a nossa voz" e por "Evidentemente, esse direito e esse dever não podem ser reconhecidos nem muito menos impostos por nenhuma sociedade"; para o original, veja "MacKinnon's Words", op. cit., p. 232 (na n. 11, p.379 à p. 232, Dworkin cita artigo de Michelman discutido em "Pornography and Hate", op. cit. - veja citação em nota de rodapé acima). Veja ainda: "The 'silencing' argument supposes that everyone - the bigot and the creationist as well as the social reformer - has a right to whatever respectful attention on the part of others is necessary to encourage him to speak his mind and to guarantee that he will be correctly understood; and that is absurd", "MacKinnon's Words", op. cit., p. 235.Veja também "Why Academic Freedom?", op. cit., pp. 259-60 e, de Eric Barendt, Freedom of Speech, op. cit., p. 191. Veja crítica de Langton (Sexual Solipsism, op. cit., pp. 67-8) a trecho de Dworkin similar ao que eu cito (em geral veja cap. 2 do livro de Langton). Veja crítica de MacKinnon em Only Words, op. cit., pp. 103-7 e veja o comentário crítico de Abigail Levin, The Cost of Free Speech: Pornography, Hate Speech, and their Challenge to Liberalism, pp. 96 e ss.: comentando, trecho de Dworkin similar ao que cito, Levin distingue minorias raciais e sexuais dos "flat-earthers" ao sustentar que as opiniões destes, e não daqueles, já foram "tested, debated, investigated, and empirically rejected" (p. 97), o que legitima a ridicularização de suas ideias (neste ponto, Levin se ampara em visão, que atribui a Mill, da liberdade de expressão como meio de se chegar à verdade). $\mathrm{O}$ argumento não me parece convincente: que uma ideia é absurda não é motivo suficiente (e talvez sequer seja relevante) para proibi-la.
} 
discurso não exija a proibição total de qualquer manifestação, exige o abandono da interpretação da liberdade de expressão como um direito. ${ }^{799}$

Em segundo lugar, os direitos de não ser ofendido(a) e de não ser silenciado(a) não existem porque não é possível implementá-los, e isso não é possível porque fazê-lo exigiria o tipo de generalização - aplicação a todos os outros casos de indivíduos ou grupos que também têm dificuldade de se fazer entender em razão da imagem, distorcida ou não, socialmente disponível, ou que são ofendidos por discurso - que é impraticável ${ }^{800}$. Não se deve intervir proibitivamente no debate público para garantir que as mulheres sejam compreendidas porque isso exigiria generalização desta intervenção a todos os casos de pessoas ou grupos que também não são compreendidos em razão de discursos de outros indivíduos. Dworkin dá o exemplo de "dogmáticos religiosos", e é muito plausível que o tipo de raciocínio que se pretende aplicar à pornografia deveria, se aceito, ser aplicado também a estes grupos. Não se deve intervir proibitivamente para proteger indivíduos de ofensa porque fazê-lo em casos supostamente mais graves que outros não oferece critério capaz de distinguir estes casos de outros em que indivíduos ou grupos efetivamente são também ofendidos. ${ }^{801}$

\footnotetext{
${ }^{799}$ Dworkin, ao discutir o "Williams Report", relatório sobre a restrição ou proibição da pornografia na Inglaterra, faz o seguinte comentário:

"The slippery slope argument calls our attention to the fact that if the majority is allowed to have its way, individuals might be prevented from reading some things that are valuable for them to read. But even so it would surely overstate the facts to say that if people were not allowed any sexually explicit literature or art at all, they would lose their liberty altogether.

"The report may mean to say something from this. It may mean that if the suggestion were adopted, that people may not do whatever the majority finds deeply disguisting, even in private, then people would have lost their right to liberty - because they may no longer insist that it is always wrong for the majority to restrict them for that reasons - even if their actual loss of liberty turns out to be not to be very great. I agree that some such right is important (even though I would hesitate to call it a right to liberty as such). But whether people have that right, as a matter of Principle, is exactly what is now in dispute", "Do We Have a Right to Pornography?", op. cit., p. 346, itálico no original nota omitida (à segunda parte do artigo citado e a "What Rights Do We Have?", op. cit.) Veja ainda p. 340, 344 e ss. e pp. 346-7, inclusive nota n. 10 à p. 346 na p. 414 com crítica aHart. Em outras palavras, para o autor, é claro que proibir a pornografia não é incompatível com a permissão de outros discursos, mas pode ser incompatível com o tratamento da liberdade de expressão como direito. A minha sugestão é que o argumento de Dworkin em outros textos seja compreendido nos termos deste trecho citado.

${ }^{800}$ Compare com o argumento de George Kateb em "The Freedom of Worthless and Harmful Speech", op. cit.

${ }^{801}$ Uma crítica evidente pode ser levantada contra esta caracterização do argumento: que não que se trata de simples ofensa no sentido de indignação, "dano psicológico", ou qualquer categoria subjetiva deste tipo, mas prejuízo de outra natureza (veja "Why Must Speech be Free?", op. cit., p. 206). Pode bem ser que o discurso racista e alguns tipos de pornografia tenham efeito deste tipo; o que resta, entretanto, é descrever qual direito é violado por este tipo de discurso e por que o direito existe e se estende aos casos em que é afetado por obscenidade misógina, por exemplo. Em outras palavras, o fato de que o problema que se pretende apontar em determinado tipo de discurso não é devidamente descrito como uma quetão de "ofensa" não dispensa a elaboração de argumento que aponte para a existência de outro problema, desta vez eventualmente capaz de justificar restrição à liberdade de expressão. Os exemplos de direitos que não são "generalizáveis", como diz Dworkin, não
} 
Por fim, é possível levantar uma dúvida acerca do sentido do argumento de Dworkin de que direitos como o de não ser ofendido(a) e de não ser silenciado(a) não existem porque precisariam ser aplicados a outras situações de modo que restaria encerrada a liberdade de expressão. Pelo menos duas interpretações deste argumento são possíveis. A primeira diz respeito ao que o autor chama de "antiga advertência liberal" 802 e parece ser um argumento de encosta escorregadia ${ }^{803}$. Dworkin diz o seguinte:

"É tentador, como eu disse, pensar que se alguma liberdade de expressão deve ser considerada um direito universal, este direito não pode ser absoluto; que aqueles cujas opiniões são muito ameaçadoras ou baixas [base] ou contrárias ao consenso moral ou religioso abandonam [have forfeited] qualquer direito à consideração em que o direito se baseia. Mas esta reserva destruiria o princípio: deixaria espaço somente para a concessão sem sentido de proteção para ideias ou gostos ou preconceitos que aqueles no poder apoiam, ou, em qualquer caso, não temem. Podemos ter o poder de silenciar aqueles que desprezamos, mas o custo disso seria a legitimidade política, que é mais importante do que eles são.

Qualquer tipo de reserva também seria perigosa. O princípio é indivisível, e tentamos dividi-los a nosso risco [at our peril]. Quando cedemos liberdade porque acreditamos que os nossos objetivos imediatos são mais importantes, provavelmente descobriremos que o poder de explorar a cessão não está nas nossas mãos afinal de contas, mas nas dos sacerdotes fanáticos armados com fatwas e moralistas fanáticos com o seu próprio tipo de ódio". ${ }^{804}$

são exaustivos, mas qualquer outro que se pretendam elaborar enfrenta os argumentos positivos lançados anteriormente nesta dissertação em defesa da liberdade de expressão enquanto direito no sentido forte. Waldron, por exemplo, expressamente diz que proibições de discurso de ódio visam a proteger a dignidade de, e não impedir a ofensa a, membros de grupos atingidos: veja The Harm in Hate Speech, op. cit., esp. cap. 5 (em especial, "The distinction is in large part between objective or social aspects of a person's standing in society, on the one hand, ans subjective aspects of feeling, including hurt, shock, and anger, on the other", p. 106 e, após citar o Oxford English Dictionary, diz: "(...) to protect people from offense or from being offended is to protect them from a certain sort of effect on their feelings. And that is different from protecting their dignity and the assurance of their decent treatment in society", p. 107 - veja pp. 107 e ss.). Os argumentos de Waldron a favor desta concepção de dignidade e as exigências que impõe à liberdade de expressão merecem discussão à parte e não compõem o objeto desta dissertação.

802 “As palavras de MacKinnon”, op. cit., p. 383; no original, "MacKinnon's Words", op. cit., p. 239.

${ }^{803}$ A expressão traduz "slippery slope", opção de "Temos direito à pornografia?" (op. cit., pp. 506-7) que sigo, a despeito de outra tradução de trabalho de Dworkin traduzir a expressão de outro modo - veja citação abaixo; para o original, veja "Do We Have a Right to Pornography?", op. cit., p. 341. Veja ainda "Pornography and Hate", op. cit., pp. 218-9, “MacKinnon's Words", op. cit., p. 232, "Why Academic Freedom?”, op. cit.,pp. 259-60 e e "Foreword", op. cit. Veja Levin, The Cost of Free Speech: Pornography, Hate Speech, and their Challenge to Liberalism, op. cit., pp. 96-7 e Langton, "Whose Right? Ronald Dworkin, Women, and Pornographers", op. cit., p. 343 e ss..

804 "Foreword", op. cit., p. ix, traduzi, inseri entre colchetes as palavras em inglês do original para indicar como as traduzi; mantive o "fatwa" como consta no original. Veja ainda: "MacKinnon's is right to emphasize the connectino between the fight over pornography and the larger, more general and importante, argument about the freedom of Americans to say and teach what others think politically incorrect. She and her followers regard freedom of speech and thought as an elitist, inegalitarian ideal that has been of almost no value to women, blacks, and others without powers; they say America would be better off if it demoted that ideal as many other nations have. But most of her constituents would be appalled if this denigration of freedom should escape from universities and other communities where their own values about political correctness are now popular and take root in the more general political culture. Local majorities may find homosexual art or feminist theater just as degrading to women as the kind of pornography MacKinnon hates, or radical or separatist black opinion just as inimical to racial justice as crude racial epithets. 
Assim interpretado, o argumento não é convincente, embora a advertência liberal tenha valor independente da crítica aos direitos sob análise. Ou seja, não é em razão da advertência que os direitos não existem, mas ela mesmo assim merece alguma atenção porque existe o risco de abuso da possibilidade de proibição de certos tipos de discurso. Mas o risco de abuso não explica por que é errado restringir o discurso de ódio e a pornografia: explica somente por que é perigoso, para outras hipóteses de exercício da liberdade de expressão, proibir certos tipos de discurso. Ou seja, trata-se de argumento sobre a necessidade instrumental da permissão de discursos a que supostamente pessoas não têm direito para garantir a permissão de discurso a que indivíduos têm direito. Dworkin como visto, é ele mesmo crítico deste tipo de compreensão instrumental das liberdades, e, a meu ver de maneira coerente com esta posição teórica, mostra ceticismo em relação a argumentos de encosta escorregadia e muito mais confiança na capacidade das instituições de proibir certos tipos de discurso sem descambar para proibições não pretendidas:

\begin{abstract}
"Pode-se dizer que os legisladores ou juízes não têm a capacidade de fazer distinções entre comentários úteis e nocivos, de tal modo que, para proteger os jornais sérios que discutem assuntos sérios, temos que proteger também os membros da Klan e os nazistas que disseminam o ódio e causam sofrimento. Porém, esse argumento, baseado na idéia de uma precaução contra o perigo possível [slippery-slope argument], ignora a capacidade dos advogados de fazem distinções difíceis nesse ramo do direito como fazem em outros. Se a Suprema Corte é capaz de distinguir o discurso político do discurso comercial e decidir que este último goza de uma proteção constitucional muito menor, então é igualmente capaz de distinguir as expressões de racismo ou sexismo de outras formas de comentário político. Poderia, por exemplo, declarar a constitucionalidade de uma lei cuidadosamente formulada de modo que só criminalize formas de expressão que insultem as pessoas por sua raça, religião ou sexo, como faz a Lei de Relações raciais do Reino Unido.
\end{abstract}

\footnotetext{
"This is an old liberal warning - as old as Voltaire - and many people have grown impatient with it. They are willing to take that chance, they say, to advance a program that seems overwhelmingly important now. Their impatient may prove fatal for that program rather than essential to it, however. If we abandon our traditional understanding of equality for a different one what allows a majority to define some people as too corrupt or offensive or radical to join in the informal moral life of the nation, we will have begun a process that ends, as it has in so many other parts of the world, in making equality something to be feared rather than celebrated, a mocking, 'correct' euphemism for tyranny", "MacKinon's Words", op. cit., p. 239. Ainda, “(...) censorship plainly is the enemy, not the friend, of equality in the long run (...). If some people think racial and gender equality are urgent goal, others - and there may well be more of them - think it more urgent that the decline in family values and traditional virtues be halted, and they will be glad of a chance to dictate that university curricula emphasize those virtues and avoid texts that question them, particularly those in which homosexuality and other 'different' styles of life are celebrated. I am only repeating an old liberal warning. But it is a warning that cannot be repeated often enough. Censorship will always prove a traitor to justice", "Why Academic Freedom?", op. cit., p. 258 (veja também p. 260). Veja ainda "Addendum: A Compelling Case for Censorship?" em "Pornography and Hate", op. cit, p. 225-6 e compare com "Free Speech, Politics, and the Dimensions of Democracy", op. cit., pp. 367 e ss.
} 
"Se dou ênfase a esta questão, não é para recomendar um tal curso de ação, mas para demonstrar que a justificação instrumental não nos oferece proteção suficiente contra uma lei desse tipo". ${ }^{805}$

A segunda maneira de interpretar o argumento de Dworkin diz respeito à “indivisibilidade de princípio" por trás da liberdade de expressão, expressão que o autor utiliza ao criticar as restrições à liberdade de expressão sob análise. Em diversos pontos, não é claro se é isto que o autor quer dizer, ou se pretende veicular a "velha advertência liberal" já mencionada, mais próxima de um argumento de encosta escorregadia do que de um argumento de princípio baseado na impossibilidade de se separarem situações semelhantes. Acredito que a melhor interpretação do argumento seja a segunda. A minha sugestão é que a "advertência liberal" seja tratada como argumento separado do argumento de princípio porque este passa sem aquele, e porque aquele não é tão convincente quanto este. A rejeição por parte do autor se funda na impossibilidade de a ofensa ou o silenciamento oferecerem categoria operável de restrição à liberdade de expressão. Sugiro que este argumento de Dworkin seja lido não como um argumento de encosta escorregadia, isto é, como uma previsão empírica acerca da improbabilidade de a autoridade pública deixar de proibir condutas que, pensa-se, devem ser permitidas uma vez que proíba aquelas que se julgam inadmissíveis. O argumento é mais bem lido da seguinte forma: uma vez proibido um caso de ofensa, não existe razão para deixar de proibir outros, ou seja, o ponto é normativo, de coerência, e não sobre os aspectos práticos de que, dadas certas condições políticas, é impossível ou muito difícil restringir o ímpeto proibitivo do governo ou da sociedade. ${ }^{806}$

A meu ver, esta crítica às tentativas de justificar a proibição de discurso de ódio e pornografia é clara em objeção dirigida por Dworkin a outro argumento de Catharine MacKinnon, que consiste em apontar para os efeitos da pornografia à desigualdade social das

\footnotetext{
805 "Por que a liberdade de expressão?", op. cit., p. 326 (inseri entre colchetes a expressão do original); no original, "Why Must Speech be Free?", op. cit, p. 204 (na p. 207, entretanto, Dworkin não demonstra tanto otimismo quanto à capacidade dos tribunais de diferenciarem material obsceno de material não-obsceno). Veja ainda "Do We Have a Right to Pornography?", op. cit., pp. 337 e ss., 340, 341 e pp. 344 e ss. Entre nós, Júlio César Casarin Barroso Silva. Democracia e Liberdade de Expressão: Contribuições para uma interpretação política da liberdade de palavra. op. cit., p. 220, sobre a opinião de Dworkin exposta na citação de "Why Must Speech be Free?".

${ }^{806}$ A meu ver, trata-se do ponto captado por Caio Moysés de Lima ao enxergar no argumento de Dworkin acerca das três hipóteses de restrição permissível de direito a ideia exposta em Law's Empire como "integridade legislativa": veja O Império dos Direitos: Lei e Autoridade Política em Ronald Dworkin, op. cit., pp. 108-9 (Lima cita "Taking Rights Seriously", op. cit., p. 200 e Law's Empire, op. cit., p. 217). Uma autora que enxerga argumento de "slippery-slope" na objeção de Dworkin à proibição da pornografia é Levin: The Cost of Free Speech: Pornography, Hate Speech, and their Challenge to Liberalism, op. cit., pp. 93-4.
} 
mulheres e dizer que o conflito entre a liberdade de expressão dos pornógrafos e o direito à igualdade das mulheres deve ser resolvido em favor do último. ${ }^{807}$ Dworkin critica a comparação entre restrições à pornografia e leis que proíbem “assédio racial ou sexual” (racial or sexual harassment ${ }^{808}$; ele diz o seguinte sobre essas leis:

“(...) embora se possa dizer que essas legislações atendem a um objetivo igualitário de maneira geral, elas costumam ser defendidas de modo muito mais específico e limitado. As leis de assédio sexual não são feitas para proteger as mulheres contra o efeito difuso das opiniões depreciativas a respeito delas que fazem parte da cultura em geral, mas contra as provocações sexuais diretas e o uso aviltante da linguagem no ambiente de trabalho (81). (...) Não quero dizer que essas normas não sejam problemáticas do ponto de vista da liberdade de expressão; elas são. (...) Minha intenção é somente a de afirmar que as restrições da expressão no ambiente de trabalho ou no ambiente acadêmico podem ser justificadas sem fazer apelo a um princípio assustador, segundo o qual a igualdade exige que certas pessoas não sejam livres para expressar seus gostos, preferências ou convicções. Já o argumento de MacKinnon a favor da proibição absoluta[banning] da pornografia pressupõe esse princípio, e portanto a aceitação desse argumento teria conseqüências devastadoras" $\$$ ".

O ponto de Dworkin é que, admitido o uso de proibições a certos tipos de discurso como mecanismo de promoção de igualdade social de grupos, seria logicamente necessário admitir a proibição de diversos discursos além do pornográfico e que, por hipótese, ninguém está disposto a ver proibido. Ou seja, o argumento é de aplicação muito extensa, mas não em razão do abuso no seu emprego, mas exatamente porque a sua única aplicação consistente é indesejável. Observe o leitor que está pressuposta nesta crítica de Dworkin o sentido de discriminação adotado pelo autor: há um direito de não sofrer abuso verbal, mas não existe um direito contra o discurso que provoca, não ele mesmo, mas por outro ato, discriminação, salvo

\footnotetext{
${ }^{807}$ Sobre MacKinnon, Dworkin diz: "She says that the way in which pornography is offensive - that it portrays women as submissive victims who enjoy torture and mutilation - contributes to the unequal opportunities of women in American society, and that therefore contradicts the values meant to be protected by the equal protection clause" da Constituição dos EUA, "MacKinon's Words", op. cit., p. 234 (veja em geral pp. 233-9)

808 "As palavras de MacKinnon", op. cit., p. 376; para o original, veja "MacKinnon's Words", op. cit., p. 234 e o seguinte trecho: "The censorship of pornography, she says, should be regarded as like other kinds of government action designed to create genuine equality of opportunity", p. 234.

809 "As palavras de MacKinnon", op. cit., pp. 377-8, inseri entre colchetes a palavra do original; "(81)" marca a posição da n. 81, p. 377, que tem a seguinte redação: "Ver Barbara Presley Noble, "News Reminders on Harassment", New York Times, 25 (15 de agosto de 1993)" (para o original, veja "MacKinnon's Words", op. cit., n. 13, p. 379 à p. 235). O trecho completo do original contém texto que omiti (indiquei as omissões por (...)) à questão dos "university speech codes" porque o argumento da liberdade de expressão no ambiente de trabalho me pareceu suficiente para ilustrar o ponto. Dworkin diz: "Government prohibits racial or sexual harassment at work - it punishes employers who subject blacks to racial insult or women to sexual pressures, in spite of the fact that these objectionable practices are carried out through speech - and many universities have adopted 'speech codes' that prohibit racial insults in classrooms or on campus", p. 234. Sobre a questão da liberdade de expressão nas universidades, veja "Why Academic Freedom?", op. cit.. Sobre a questão da liberdade de expressão no ambiente de trabalho, veja Kent Greenawalt. Fighting Words: Individuals, Communities, and Liberties of Speech, op. cit. cap. 5, esp. pp. 84-5 e 88 e ss. para liberdade de expressão e discriminação no ambiente de trabalho. Veja ainda Waldron em The Harm in Hate Speech, op. cit., pp. 116-8 e MacKinnon em Only Words, op. cit., esp. cap. II.
} 
se houver, como vimos no capítulo primeiro, "perigo claro e presente" de que o ato discursivo gerará o ato discriminatório. ${ }^{810}$

Dworkin ressalta que este argumento é, num sentido, mais restrito que o do silenciamento porque se limita à proteção de grupos sociais vítimas de "desvantagens persistentes na nossa sociedade" ${ }^{„ 811}$; em outro sentido, porém, trata-se de argumento de alcance muito maior, pois permitiria

“proibir a expressão vívida, visceral ou excessivamente emotiva de qualquer opinião ou convicção que tivesse uma possibilidade razoável de ofender um grupo menos privilegiado. Poderia pôr na ilegalidade as apresentações da peça $O$ mercador de Veneza, os filmes sobre mulheres que trabalham fora e não cuidam dos filhos e as caricaturas ou paródias de homossexuais nos shows de comediantes. Os tribunais teriam de pesar o valor dessas formas de expressão, enquanto contribuições culturais ou políticas, contra os danos que poderiam causar ao status ou à sensibilidade dos groups atingidos. MacKinnon pensa que a pornografia é diferente de outras formas de expressão hostis ou discriminatórias. Porém, o argumento que ela apresenta em favor de sua proibição se aplica a muitas outras coisas." ${ }^{812}$

Mais ainda: vimos acima, na elaboração da concepção de democracia como parceria, que a participação do cidadão na comunidade em vive exige não somente o direito ao voto mas também à $\operatorname{voz}^{813}$. Ocorre que suprimir o direito a voto de quem houver expressado diversas vezes opiniões racistas e sexistas, por hipótese, contribuiria à melhora da situação de negros e de mulheres ${ }^{814}$. A sugestão é absurda e acredito que Dworkin só a mencione para exemplificar restrição inaceitável da igualdade política. $\mathrm{O}$ autor parece insinuar que, se julgamos absurdo a supressão do voto mesmo quando isso aprimoraria a situação de grupos em desvantagem, e se o direito à participação inclui o direito de voz, restringi-lo também é inaceitável ${ }^{815}$. O exemplo serve então para apontar o que a consistência exige do argumento que pretende explorar as consequências do exercício à liberdade de expressão à igualdade, e, ao fazê-lo, procura mostrar por que o argumento precisa ser rejeitado. Trata-se, a meu ver, de questão de coerência, e não de previsão sobre catástrofes por qualquer motivo evitáveis mas que são ainda assim

\footnotetext{
${ }^{810}$ Compare com a decisão do juiz Easterbrook no caso da legislação antipornografia que Dworkin discute em "Pornography and Hate", op. cit., p. 218, pp. 220-1 e com a visão de Baker descrita por Waldron em The Harm in Hate Speech, op. cit., pp. 168-171.

811 “As palavras de MacKinnon”, op. cit., p. 377; no original, "MacKinnon's Words”, op. cit., pp. 235-6.

812 "As palavras de MacKinnon", op. cit., p. 378 (em trecho logo em seguida ao mais longo citado há pouco); no original, "MacKinnon's Words", op. cit., p. 236.

813 "To take a part in the government" (Is Democracy Possible Here?, op. cit., p. 145) significa ter um voto e voz: veja acima argumento sobre leis contra discurso de ódio e deterioração da legitimidade da autoridade política; para a democracia como parceria, fazer parte da opinião pública significa tanto constituí-la quanto formatá-la ("Free Speech, Politics, and Dimensions of Democracy", op. cit., p. 358; veja em geral 364-6).

814 "MacKinnon's Words", op. cit., pp. 236-7.

815 "MacKinnon's Words", op. cit., pp. 236-7.
} 
prováveis. Trata-se daquilo que é normativamente necessário caso se aceite determinado princípio, e não o que provavelmente ocorrerá.

Existem diversos outros pontos que poderiam ser mencionados e, em especial, o debate entre Dworkin e Catharine MacKinnon é mais extenso do que pretendi expor nesta subseção. Não é meu objetivo pormenorizar estas polêmicas. Antes de passar à próxima subseção, gostaria de trabalhar brevemente algunas spectos do argumento de Dworkin acerca da existência de um direito ao consumo de pornografia como o autor o expôs em "Do We Have a Right to Pornography?”. Em primeiro lugar, Dworkin trabalha com premissa oposta àquela que orienta seus trabalhos posteriores sobre direito à liberdade de expressão se estender à publicação em pornografia: o autor defende que restringir distribuição de material obsceno não afeta direito à participação política ${ }^{816}$.

Em segundo lugar, e como mencionado acima, trata-se de argumento desenvolvido pelo autor em crítica de uma teoria utilitarista que incorpore ao cálculo que faz preferências sobre terceiros (que Dworkin chama de "preferências externas"), e não somente as preferências sobre si (o que o autor chamde "preferências pessoais") 817 . O argumento do autor acerca deste direito é, para ele, como qualquer argumento sobre direito, dependente da “justificação de fundo" considerada, que, no caso, é uma teoria utilitarista ${ }^{818}$. Embora a noção

816 "It is an old problem for liberal theory how far people should have the right to do the wrong thing. Liberals insist that people have the legal right to say what they wish on matters of political or social controversy. But should they be free to incite racial hatred, for example? (...)

"Some lawyers and political philosophers consider the problem of pornography to be only an instance of the first problem I mentioned, the problem of freedom to speak unpopular or wicked thoughts. But we should be suspicious of that claim, because the strongest arguments in favor of allowing Mein Kampf to be published hardly seem to apply in favor of the novel Whips Incorporated or the film Sex Kittens. No one, I think, is denied an equal voice in the political process, however broadly conceived, when he is forbidden to circulate photographs of genitals to the public at large, or denied his right to listen to argument when he is forbidden to consider these photographs at his leisure. If we believe it wrong to censor these forms of pornography, then we should find the justification for that opinion elsewhere than in the literature celebrating freedom of speech and press.", "Do We Have a Right to Pornography?", op. cit., pp. 335-6, itálicos no original (veja ainda pp. 351-3). A crítica de James Weistein a capítulo de Freedom's Law, op. cit. descrita em nota de rodapé acima se parece com esta opinião anterior de Dworkin. Veja discussão acima no capítulo segundo sobre outra possível oscilação da opinião de Dworkin sobre o direito de publicar pornografia. Veja em nota acima discussão sobre comentários de Eric Barendt (em Freedom of Speech, op. cit.) sobre as defesas dworkinianas do direito à pornografia.

817 "Temos direito à pornografia?", op. cit., pp. 354 e ss. (e p. 541 para "preferências pessoais"); no original, "Do We Have a Right to Pornography?", op. cit., pp. 359 e ss. (p. 363 para "personal preferences"). Veja ainda "A discriminação compensatória" in Levando os direitos a sério, p. 361, p. ex., para "preferências externas" (no original, "Reverse Discrimination", p. 234, p. ex.).

818 "Temos direito à pornografia", op. cit., esp. pp. 534 e ss. (veja p. 535 para a expressão citada"); no original, "Do We Have a Right to Pornography?", op. cit. pp. 359-372, especialmente pp. 359-60 e 369-372.. Veja Macleod, Liberalism, Justice, and Markets, op. cit., p. 62, n. 8 e Yowell, “A Critical Examination of Dworkin's Theory of Rights", op. cit., pp. 99 e ss., entre outros, 110-16, 121 e ss., 131. 
de direito aqui seja a mesma da exposta anteriormente a título de "direito no seu sentido forte" ${ }^{\sharp 19}$, não é evidente que o argumento de Dworkin seja transferível para um contexto não utilitarista. Por outro lado, o autor, ao discutir o direito à liberdade de expressão aplicada à publicação de material obsceno, faz referência a seu trabalho anterior e parece admitir o tipo de restrição, mas não proibição, que defendera anteriormente, o que é plausível também se consideramos, em primeiro lugar, que o esquema de restrição é elaborado por Dworkin antes e independentemente dos seus argumentos antiutilitaristas ${ }^{820} \mathrm{e}$, segundo, que a independência como direito dos indivíduos é defendida tanto neste trabalho que reage a teorias utilitaristas quanto em outros trabalhos do autor que definem a tolerância a partir da igualdade de $\operatorname{recursos}^{821}$.

Entre estas restrições aceitáveis está, por exemplo, zoneamento de áreas em que divulgação de pornografia é permitida ${ }^{822}$. Ou seja, mesmo na sua reflexão mais recente, embora não as elabore de maneira detalhada, Dworkin não trata o direito à publicação de pornografia como um direito livre de restrições possíveis. É de se indagar se o mesmo raciocínio se aplica ao direito de liberdade de expressão ao discurso de ódio mais nitidamente político e quais restrições à pornografia e ao discurso de ódio são compatíveis com o reconhecimento do direito, defendido por Dworkin, de tentar influenciar o ambiente moral e político. Não é objetivo deste trabalho enfrentar estas questões exegéticas do trabalho de Dworkin. Assim, passo a debate bastante diferente: sobre as implicações da liberdade de expressão ao financiamento de campanha eleitoral.

\footnotetext{
${ }^{819}$ Sobre o direito que julga crucial à definição dos direitos sobre pornografia a serem reconhecido, ele diz, "Someone who appeals to the right of moral independence in order to justify a permissive legal regime of obscenity does not suppose that the community will be better off in the long run (...)", "Do we have a right to pornography?", op. cit., pp. 353-4 (veja em geral pp. 351 e ss. e pp. 359, 363-4). Veja Yowell, “A Critical Examination of Dworkin's Theory of Rights", op. cit., p. 93 (Yowell diz que Dworkin adotou "symbiotic relationship between rights and utilitarianism" e sustenta que "Although Dworkin eventually discards this symbiotic approach, he maintains the concept of rights as trumps"; veja ainda pp. 98-9, pp. 106-8, pp. 110-20).

820 "Do We Have a Right to Pornography?", op. cit., pp. 353-9 para o direito à independência moral e sua aplicação ao caso da pornografia e pp. 359 e ss. para o argumento antiutilitarista.

${ }^{821}$ Veja, por exemplo, "Foundations of Liberal Equality", op. cit., e Justice for Hedgehogs, op. cit., caps. 9 e 17.

${ }^{822}$ “Do We Have a Right to Pornography?", op. cit., p. 357; veja pp. 356-9 em geral e também pp. 364-5. Compare com Barendt, Freedom of Speech, op. cit., pp. 385-91.
} 


\section{Subseção 4.2. Campanha eleitoral}

Dworkin escreveu divesos trabalhos sobre o estado do debate político nos EUA e o processo eleitoral norte-americano. Algumas questões trabalhadas pelo autor tocam a liberdade de expressão, e, nesta subseção, destaco duas para exposiçãos detalhada: as hipóteses em que viola a liberdade de expressão restringir financiamento e gastos de campanhas eleitorais e quem pode ser titular deste direito. A solução à primeira questão está disponível na extensão das liberdades reconhecida pelo argumento dworkiniano que as integra à igualdade: ela coincide com a extensão disponível ao cidadão numa situação de justiça distributiva. Para resolver a segunda questão será preciso relembrar brevemente o fundamento dos direitos na obra do autor, o que justifica a sua recusa em entender que empresas (corporations) tenham direito à liberdade de expressão. Este último ponto é análogo aos que serão objeto da próxima subseção, sobre liberdade de imprensa e liberdade acadêmica, as duas consideradas por Dworkin distintas da liberdade de expressão, que é fundamentalmente questão de direitos.

Dworkin discutiu financiamento de campanha em diversos artigos publicados no The New York Review of Books ${ }^{823}$, mas o mais rigoroso é o trabalho publicado como capítulo décimo de Sovereign Virtue e intitulado "Free Speech, Politics, and the Dimensions of Democracy". Neste texto, Dworkin relaciona sua concepção da democracia como parceria, que ele defende nos termos das três dimensões discutidas acima, e a concepção majoritária de democracia, que ele rejeita, a três soluções acerca da permissibilidade de o Estado intervir no discurso político produzido na sociedade. A primeira é o a "aposta democrática" (democratic wager), e a segunda é a abordagem balanceadora (balancing approach) e a terceira, defendida pelo autor, é a "estratégia minuciosa" (discriminating strategy) (veja referências nas notas a

\footnotetext{
${ }^{823}$ The Curse of American Politics", The New York Review of Books, Volume 43, N. 16, de 17 de outubro de 1996, "Uses and Abuses". Index on Censorship 2002 31: 58, "Keep Corporations Out of Televised Politics". NYRBlog, October 5, 2009, disponível em http://www.nybooks.com/blogs/nyrblog/2009/oct/05/keepcorporations-out-of-televised-politics/ (último acesso em 23.10.2013), "The 'Devastating' Decision", The New York Review of Books, Volume 57, número 3, 25 de fevereiro de 2010, "Ronald Dworkin replies" em Floyd Abrams e Ronald Dworkin, "The 'Devastating' Decision': An Exchange", The New York Review of Books, Volume 57, número 7, 29 de abril de 2010, "The Decision that Threatens Democracy", The New York Review of Books, Volume 57, número 8, 13 de maio de 2010, "More Bad Arguments: The Roberts Court \& Money in Politics", NYRblog, 27 de abril de 2011, disponível em http://www.nybooks.com/blogs/nyrblog/2011/apr/27/more-bad-arguments-roberts-court-money-politics/, ultimo acesso em 05.11.2013, "The Court's Embarrassingly Bad Decisions", The New York Review of Books, Volume 58, número 9, 26 de maio de 2011 e "[Sem título]" em Frank Rich, David Cole, Ronald Dworkin e Russel Baker, "The Election - II", The New York Review of Books, Volume 59, número 17, 8 de novembro de 2012 (existe alguma sobreposição entre os textos destes artigos).
} 
seguir). A primeira é definida da seguinte forma por Dworkin: "ela afirma que a melhor proteção para a democracia é o princípio que proíba o governo de limitar ou controlar qualquer tipo de expressão política com a finalidade de proteger a democracia" ${ }^{\text {824; }}$ a segunda é a “abordagem 'balanceadora' que permitisse regulamentações do discurso político que prejudicariam a democracia em uma de suas dimensões", desde que o resultado fosse globalmente positivo ${ }^{825}$. Por fim, a defendida pelo autor é o "método mais minucioso que combinasse elementos de ambas as estratégias", isto é, das estratégias da aposta democrática e do balanceamento ${ }^{826}$.

Dworkin discute diversas questões à luz das duas concepções de democracia e das três regras acerca da intervenção do estado no discurso político, mas eu gostaria de me concentrar em uma delas: à possibilidade de restrição aos gastos eleitorais de candidatos a cargos eletivos violar a liberdade de expressão. O autor discute o tema em crítica à decisão do caso Buckley, da Suprema Corte dos EUA, que declarou, em 1976, inconstitucional lei de 1974 que pretendera inserir limitação deste tipo no direito norte-americano; nesta decisão, entretanto, o Tribunal julgou permissíveis certas restrições às doações eleitorais. ${ }^{827}$ Para Dworkin, se a

824 "Liberdade de expressão, política e as dimensões da democracia", op. cit., p. 496; no original, "Free Speech, Politics, and the Dimensions of Democracy", op. cit., p. 353 (Dworkin informa que chama a ideia de "democratic wager" "folling the famous judge Learned Hand"); trata-se da "(...) prophylactic technique of forbidding government to attempt to make our political system more democratic through that device. Even though government may regulate and restrict speech for other reasons - to protect national security, for example, or private reputation - it cannot regulate or restrict it for that particular reason.”, p. 353 (veja abaixo citação da continuação deste trecho). Veja "The Curse of American Politics", op. cit., itens 3 e 4. Entre nós, Júlio César Casarin Barroso Silva. Democracia e Liberdade de Expressão: Contribuições para uma interpretação política da liberdade de palavra. Op. cit., p. 194, 218-9.

825 "Liberdade de expressão, política e as dimensões da democracia", op. cit., p. 516; no original, "Free Speech, Politics, and the Dimensions of Democracy", op. cit., p. 367. A tradução também fala em "estratégia de equilíbrio" para traduzir "balancing strategy" (p. 517 da tradução, p. 368 do original), mesma opção de Justiça para ouriços, op. cit. (pp. 268 e ss.; para o original, Justice for Hedgehogs, op. cit., pp. 260 e ss.).

826 "Liberdade de expressão, política e as dimensões da democracia", op. cit., p. 516; no original, "Free Speech, Politics, and the Dimensions of Democracy", op. cit., p. 367.

${ }^{827}$ Veja "The Place of Liberty", op. cit., pp. 123-4, 176-7, "The Curse of American Politics", op. cit., item 2 e "Free Speech, Politics, and the Dimensions of Democracy", op. cit., esp. pp. 352-3, 355, pp. 273-4, 381 e ss. Em "The Place of Liberty", Dworkin diz o seguinte: "In 1974 Congress enacted a statute that limited the amount any one person could lawfully spend to advance the interests of a particular political candidate", op. cit., pp. 123-4, nota omitida. Em "Free Speech, Politics, and the Dimensions of Democracy", Dworkin diz que a decisão de Buckley consiste em dizer que "expenditure caps are unconstitucional", "but another ruling was also part of the Buckley decision - The Court's ruling that permitted Congress to impose limits on the contributions that people might make to political campaigns of others", op. cit., p. 373. Dworkin argumenta que a distinção entre limites a contribuições e limites a gastos não faz sentido (pp. 373-4). "The Curse of American Politics", op. cit., traz descrição de Buckley mais próxima do artigo publicado em Sovereign Virtue, op. cit. do que de "The Place of Liberty". Pouco antes de descrever a decisão como rejeição dos limites a gastos de campanha, o autor diz o seguinte em "The Curse of American Politics", op. cit., "A free society cannot dictate the tone its politicians 
decisão da Suprema Corte é correta depende de qual concepção de democracia e de liberdade de expressão é mais convincente ${ }^{828}$; é por isso que ele apresenta a sua concepção de democracia como parceria e a estratégia minuciosa: para mostrar por que não ofende a democracia limitar a quantidade de dinheiro que um candidato pode gastar em uma campanha eleitoral apesar de esta restrição afetar o discurso político ${ }^{829}$.

Dworkin rejeita a abordagem balanceadora por dois motivos: em primeiro lugar, porque a igualdade dos cidadãos - terceira dimensão da sua concepção de democracia - é uma questão de direitos, que não podem ser submetidos ao tipo de "balanceamento" que a abordagem sugere $^{830}$ e, em segundo lugar, porque a permissão concedida pela estratégia é muito sujeita a abusos. ${ }^{831}$ Ainda, Dworkin rejeita a aposta democrática porque, argumenta, o mau estado da política norte-americana revela que os seus custos são muito altos, e que não vale a pena pagá-lo ${ }^{832}$. A opção do autor é pela estratégia "discriminating”, que apresenta o seguinte critério para a intervenção do governo no discurso político:

adopt or the kind of arguments they offer the public, or what political news or scandal reporters do or do not print, or how carefully television commentators analyze what the candidates have offered or opposed. But a free society can - or so it would seem - limit the amount of money the candidate or anyone else may spend on political campaigns. Every European democracy does this and Europeans are amazed that we do not. But the Supreme Court has held that we may not, that limiting political expenditures by law would be an unconstitutional denial of free speech, in violation of the First Amendment", item 2 (veja ainda "The Decision that Threatens Democracy", op. cit., item 3). A mim me parece que o raciocínio de Dworkin se aplica em geral ao emprego de dinheiro em campanha eleitoral, seja por meio de doação seja por meio de gasto eleitoral. Sobre Buckley, veja Greenawalt, Fighting Words - Individuals, Communities, and Liberties of Speech, op. cit., pp. 139-140; veja também Eric Barent em Freedom of Speech, op. cit., pp. 88-93 (pp. 89-90 para comentário a Buckley) e Yasmin Dawood, "Democracy and the Freedom of Speech: Rethinking the Conflict between Liberty and Equality", op. cit., para discussão de decisões da Suprema Corte dos EUA e do Canadá. Entre nós, Júlio César Casarin Barroso Silva. Democracia e Liberdade de Expressão: Contribuições para uma interpretação política da liberdade de palavra. Op. cit., seção 4.4. do capítulo IV (esp. pp. 190 e ss.) Em especial, veja n. 135, p. 190 para crítica a Dworkin, que, segundo Júlio Silva, utiliza "posicionamento" diferente ao falar de discurso de ódio e de financiamento de campanha ainda que as opiniões que tem sobre os temas não sejam formalmente contraditórias entre si. Acredito que Dworkin esteja justificado porque, no caso do discurso de ódio, existe um direito em jogo, o que não é o caso nos temas de campanha eleitoral discutidos (especificamente, trata-se, portanto, da primeira hipótese de restrição aceitável a direito, como discutido acima no capítulo primeiro desta dissertação). Por isso, Dworkin trata os temas de maneira diferente. Quem também vê contradição em Dworkin é José Emílio Medauar Ommati: veja Liberdade de Expressão e discurso de ódio na Constituição de 1988, pp. 91-103, esp. pp. 96 e ss.

${ }^{828 ، " F r e e ~ S p e e c h, ~ P o l i t i c s, ~ a n d ~ t h e ~ D i m e n s i o n s ~ o f ~ D e m o c r a c y ", ~ o p . ~ c i t . . ~ p . ~ 352-3 ~}$

829 "Free Speech, Politics, and the Dimensions of Democracy", op. cit..

830 "Liberdade de expressão, política e as dimensões da democracia", op. cit., pp. 516-7; no original, "Free Speech, Politics, and the Dimensions of Democracy", op. cit., 367-8; veja discussão na seção 2 do capítulo primeiro desta dissertação. Veja ainda "It is absurd to calculate human rights according to cost-benefit analysis", op. cit..

831 "Liberdade de expressão, política e as dimensões da democracia", op. cit., pp. 516-7; no original, "Free Speech, Politics, and the Dimensions of Democracy", op. cit., 367-8.

832 "Liberdade de expressão, política e as dimensões da democracia", op. cit., pp. 517 e ss.; no original, "Free Speech, Politics, and the Dimensions of Democracy", op. cit., 368 e ss.. 
"a estratégia minuciosa permite regulamentações do discurso político que aprimorem alguma dimensão da democracia quando o defeito que pretendem reparar é substancial e quando a restrição não provocar nenhum dano genuíno à soberania dos cidadãos ou à igualdade entre eles. Assim, permite tetos de gastos em campanha, quando possibilitarem reparar desigualdades significativas entre cidadãos na política, contanto que os tetos sejam suficientemente altos para não amortecer a crítica ao governo, e que não se crie nenhuma desigualdade nova para excluir partidos ou candidatos desconhecidos" $\$ 33$

Mas como saber se determinada regulamentação, em especial, a limitação de gastos eleitorais, viola uma das dimensões da democracia mencionada, em especial a igualdade cidadã? A meu ver, o que a estratégia discriminating faz é transformar a medida da autoridade pública de intervir no discurso política uma função, entre outros, de igualdade, pois a liberdade de expressão é uma questão de justiça distributiva para o autor. Assim, o que Dworkin faz é integrar democracia e igualdade através das liberdades, em especial da liberdade de expressão: viola a democracia violar a liberdade de expressão, mas a liberdade de expressão que existe é aquela chancelada pela justiça distributiva. O argumento, aqui, é aquele já exposto: para Dworkin, existe liberdade de expressão na medida garantida em uma sociedade que tenha justa distribuição de recursos. Mas a nossa sociedade é desigual, então é possível (ou melhor, provável e até inevitável) que parte da liberdade garantida pela atual distribuição não seja questão de direito individual e, portanto, que não viole a liberdade de expressão restringi-la. É por isso que, para o autor, não violam a liberdade de expressão algumas restrições à doação de recursos a campanhas eleitorais e a gastos de campanha: parte dos recursos que, numa sociedade desigual, cidadãos doam e candidatos gastam não lhes é atribuída pela justiça e, portanto, empregá-los para exercer manifestação política não compõe o direito à liberdade de expressão. Por isso, podem ser restritas. É com base neste raciocínio que Dworkin critica a decisão da Suprema Corte dos EUA em Buckley. ${ }^{834}$

833 "Liberdade de expressão, política e as dimensões da democracia”, op. cit., pp. 519-20; no original, "Free Speech, Politics, and the Dimensions of Democracy", op. cit., 370. Para o autor, a estratégia que defende tem "something of the flexibility but not the danger of the balancing strategy", p. 369 (veja ainda p. 377). E ainda, sobre Buckley, "If that holding were overruled in defence of the discriminating strategy, then the First Amendment would permit expenditure ceilings high enough that they do not increase the advantage that incumbentes already have over challengers and do not prevent candidates with no name recognition or groups with novel policies from securing enough public interest to engage the attention of journalist and other broadcasters. Unless those conditions were satisfied, expenditure limits would compromise citizen equality, and they would injure popular sovereignty too, because the public would be denied the ideas that such candidates would offer if they could. The discriminating reading does not permit significant damage to any dimension of democracy", p. 382. Veja ainda "The Curse of American Politics", op. cit., p. 4.

${ }^{834} \mathrm{O}$ argumento é um pouco mais complicado do que isso, entretanto, porque para o autor a dimensão da "popular sovereignty" talvez indique que restringir gastos eleitorais viola a democracia (veja "Free Speech, Politics, and the Dimensions of Democracy", op. cit., pp. 384-5). O argumento de Dworkin é que isso não ocorre, sobretudo na 
Não é difícil entender o argumento dworkiniano de que, numa sociedade igualitária, a restrição à doação eleitoral viola a igualdade. Se a distribuição dos recursos é justa, eles pertencem a quem os recebe, e isso significa que pertencem nos termos do conjunto de liberdades/restrições que descrevem o significado da posse dos recursos (no argumento de Dworkin sobre liberdades na igualdade de recursos, a "baseline" do leilão imaginário) e, portanto, limitação injustificada daquilo que o indivíduo pode fazer com os recursos que têm afeta a sua própria titularidade pois afeta, a exemplo do caso da escultura satírica que o autor dá, o valor que o recurso tem para o indivíduo ${ }^{835}$. Mas numa sociedade desigual, nem todos os recursos que um indivíduo tem à sua disposição são seus segundo a justiça, e este é o critério a partir da qual se mede a liberdade de expressão. Daí não violarem nem a igualdade nem a liberdade de expressão alguns tipos de restrição de contribuições políticas e gastos eleitorais. ${ }^{836}$

Em "The Curse of American Politics", o autor traz uma definição de liberdade de expressão que pretende refletir o fato de que este direito não pode ser absoluto. Ele diz o seguinte: "A liberdade de expressão deve significar a liberdade de falar ou publicar quando negar esta liberdade prejudicaria algum outro direito que a liberdade de expressão protege, ou

\footnotetext{
sua concepcão da democracia como parceria, que tem outras duas concepções (p. 385). Em razão disso, somente menciono este ponto.

Dworkin diz em "Political Equality", op. cit.: "Limits on campaign expenditures are of course appealing when these compensate for unjust differences in wealth; just as both of the arguments I distinguished earlier object to a Rockefeller's disproportionate political influence, so both recommend limits on political expenditure in present circumstances. But if resources were distributed equally, limits on campaign expenditure would be inegalitarian because they would prevent some people from tailoring their resources to fit the lives they wanted though leaving others, who had less interest in politics free to do so (4). Such limits would also be perverse, for they would be protecting equality of influence on behalf of those who put a low value on their influence but who could have had greater influence if they had valued that higher.”, p. 197; (4) marca a posição da nota 4 (p. 485 à p. 197), que tem a seguinte redação: "I assume, in this claim, that wealth remains equal so that no small group of very rich people could dominate politics through political contributions or expenditures. See Chapter 10". O capítulo 10 é justmente "Free Speech, Politics, and the Dimensions of Democracy", op. cit.., do qual o seguinte trecho vale a pena: "In a society of greatly unequal wealth and other resources, some citizens will have much greater opportunity to occupy each of these positions of heightened influence only because they are richer, and that is indeed an insult to citizen equality. But that more general unfairness could not be ended except through a vast redistribution of wealth and what wealth brings. The more specific unfairness that brings influence to the rich only because they can afford large contributions to politicians could be ended or minimized through the simple expedient of expenditure limits", n. 5, p. 493 à p. 364

${ }_{835}$ "The Place of Liberty", op. cit., p. 144.

836 “The Place of Liberty", op. cit., pp. 176-7, em trecho citado acima, na subseção 2.2.
} 
quando atrapalharia [impair] a própria democracia." ${ }^{837}$ Ao fim desta citação, existe uma nota de rodapé muito interessante:

"Constitucionalistas frequentemente colocam o ponto em outra ordem: eles dizem que todas as restrições à expressão são banidas em princípio, e que exceções devem ser justificadas, uma a uma, como especiais. Mas a ampla variedade de atos de expressão que claramente não são protegidos pela Primeira Emenda torna analiticamente mais claro dizer que o discurso protegido é que é especial. O ponto importante, entretanto, é que a proteção não é automática, mas deve ser conectada a alguma razão geral para ou proteger ou eximir o tipo de discurso em questão". 838

$\mathrm{Eu}$ chamo a atenção ao ponto porque ele ressalta, no contexto da liberdade de expressão, o ônus que Dworkin expressamente assume de justificar direitos ${ }^{839}$. Que a liberdade de expressão é um direito igualitário e democrático fundado na dignidade significa que alguns discursos não a compõem; e, ainda, que alguns sujeitos não podem ser titulares da liberdade de expressão.

A meu ver, a diferença entre a visão da aposta democrática sobre a relação entre regulamentação estatal do discurso democrático e liberdade de expressão e a visão de Dworkin, exigida pelas suas concepções dos valores políticos da democracia, igualdade e liberdade, reside no fato de que à concepção da aposta falta definição de direito individual a restringir a extensão da regulamentação. Ou seja, para Dworkin, é possível dizer que não deve haver restrições ao direito - ou a qualquer outro direito - à liberdade de expressão para aumentar o acesso de terceiro a discurso. Dworkin cita Buckley para descrever a aposta que rejeita nos seguintes termos: "Como a Corte disse no caso Buckley, em uma declaração tão explícita quanto qualquer outra registrada, restringir 'a expressão de alguns elementos de nossa sociedade para aumentar a voz relativa de outros é totalmente contrária à Primeira Emenda" " 840 . Na minha opinião, a proposta "discriminating" incorpora exceções a esta regra exatemente ao entender que a proteção que a democracia exige diz respeito aos direitos de expressão, e não à simples expressão. O ponto é coerente com a rejeição dworkiniana da concepção flat de liberdade em defesa de visão interpretativa deste e de outros valores políticos e da defesa de que a liberdade de expressão é, crucialmente, uma questão de direitos

\footnotetext{
837 "The Curse of American Politics", op. cit., item 3, nota omitida, traduzi, acrescentei entre colchetes palavra do original para indicar como a traduzi.

838 "The Curse of American Politics", op. cit., nota 15 ao item 3, traduzi. Compare com "Do We Have a Right to Pornography?", op. cit., pp. 337-8

${ }_{839}^{839}$ Veja "Taking Rights Seriously", op. cit..

840 "Liberdade de expressão, política e as dimensões da democracia", op. cit., p. 497; no original, "Free Speech, Politics, and the Dimensions of Democracy", op. cit., p.353 (o trecho citado é continuação de outro citado em nota de rodapé acima).
} 
individuais. Daí, se o direito à liberdade de expressão inexiste em determinado caso, a regulamentação pública é aceitável, mesmo que ela afete expressão de ideias - o ponto não que é afete expressão, mas que afete direito à expressão. Trata-se de exemplo da primeira hipótese aceitável de restrição a direito como Dworkin a discute em "Taking Rights Seriously", pois no caso de algumas restrições ao emprego do dinheiro na política, os valores que fundamentam a liberdade de expressão não são afetados. O esforço do autor de integrar as liberdades na igualdade de recursos oferece a definição de direitos inexistente na definição do "democratic wager”: é possível limitar doações políticas privadas na nossa sociedade desigual porque o direito à liberdade de expressão se limita aos recursos do indivíduo cuja posse é chancelada pela justiça distributiva. Se a sociedade é desigual, existem pessoas com acesso a mais recursos que a justiça, e a doação deste recurso excedente não caracteriza ato que faça parte da liberdade de expressão.

Por razão similar, para o autor não viola a liberdade de expressão restrição às doações eleitorais feitas por empresas. Aqui, a justificativa de Dworkin é mais simples: direitos, que tem fundamento em interpretação dos valores da liberdade, igualdade e democracia orientada por teoria ética, protegem a dignidade do cidadão, e empresas não têm dignidade porque a sua natureza é orientada ao lucro, e não à condução de uma vida a que a possibilidade de expressão de ideias é fundamental ${ }^{841}$. Especificamente no caso das campanhas eleitorais, Dworkin sustenta que empresas não têm direito à liberdade de expressão ${ }^{842}$ (veremos na próxima subseção argumento análogo aplicado à liberdade de imprensa e à liberdade acadêmica). Ele diz:

“(...) é essencial à legitimidade de qualquer governo que ele trate as opiniões de todos os cidadãos como iguais no processo político. A ninguém deve ser negada uma oportunidade de apresentar as suas opinões políticas da melhor maneira que for capaz aos seus concidadãos. Ninguém deve ouvir do governo que a suas opiniões não são dignas [worthy] de recepção [audience] ou consideração. Mas empresas [corporations] não são cidadãos cuja igualdade política pode ser respeitada ou negada: são entidades artificiais criadas não para formar ou expressar valores mas para ganhar e preservar dinheiro. Ninguém é insultado ou relegado a uma posição de segunda classse porque às empresas não são dados os direitos de pessoas reais". ${ }^{843}$

\footnotetext{
${ }^{841}$ Pouco antes de citar trecho parecido com o que seleciono em nota abaixo sobre "corporations" serem ficções, Guest diz, comentando Dworkin: "The central emphasis always in Dworkin is that democracy embodies the fundamental right to dignity (...) The principles of human dignity therefore do not permit corporate donations to political campaigns", Ronald Dworkin, op. cit., p. 117.

842 "Keep Corporations out of Televised Politics", op. cit., por exemplo, entre outros textos.

843 "Keep Corporations out of Televised Politics", op. cit., traduzi e mantive entre colchetes palavras do original para indicar como as traduzi. Para Dworkin, as restrições ao "corporate electioneering" vigiam nos EUA desde decisão da Suprema Corte em 1907, mas foram recentemente abandonadas por decisão criticada pelo autor: veja
} 
A este argumento sobre a natureza das empresas, Dworkin acrescenta que elas não trazem ao debate político nenhum argumento que as pessoas físicas por trás delas não possam

“The 'Devastating' Decision”, op. cit., para as críticas de Dworkin a decisão recente da Suprema Corte dos EUA (em Citizens United v. Federal Election Comission) que declarou inconstitucional lei que limitada propaganda em televisão paga por empresas ou "unions" e que abandonou a decisão tomada no caso Austin: "The "Devastating Decision", op. cit.. e "The Decision that Threatens Democracy", op. cit.. Deste último o seguinte trecho resume o julgado: Dworkin diz que, na decisão, cinco membros do tribunal - dum total de nove - "declared that corporations and unions have a constitutional right to spend as much as they wish on television election commercials specifically suporting or targeting particular candidates", item 1. Anteriormente, o que se entendia era que "corporations, which are only fictitious persons created by law, do not have the same First Amendment rights to political activity as real people do", op. cit., item 1. Dworkin critica a decisão por ser injustificável sob qualquer teoria defensável da liberdade de expressão ("The Decision that Threatens Democracy", op. cit., esp. item 2); especialmente relevante aos meus propósitos, ele diz: "The opinion announces and perpetuates a shallow, simplistic understanding of the First Amendment, one that actually undermines one of the most basic purposes of free speech, which is to protect democracy. The nerve of his argument - that corporations must be treated like real people under the First Amendment-is in my view preposterous. Corporations are legal fictions. They have no opinions of their own to contribute and no rights to participate with equal voice or vote in politics", "The 'Devastating' Decision", op. cit.. Ainda, ao discutir uma das teorias que justificam a liberdade de expressão, Dworkin diz: "The interests the First Amendment protects, on this second theory, are only the moral interests of individuals who would suffer frustration and indignity if they were censored. Only real human beings can have those emotions or suffer those insults. Corporations, which are only artificial legal inventions, cannot. The right to vote is surely at least as important a badge of equal citizenship as the right to speak, but not even the conservative justices have suggested that every corporation should have a ballot.", "The Decision that Threatens Democracy", op. cit., item 2; veja ainda item 3 (compare com a exposicão na subseção anterior do uso analogia entre voto e voz em crítica a um dos argumentos de Catharine MacKinnon a favor da proibição de certos tipos de pornografia). Veja, por fim, "More Bad Argumentos: The Roberts Court \& Money in Politics", op. cit. e "The Court's Embarrassingly Bad Decisions", op. cit., itens 1 e 3 para defesa da constitucionalidade de lei do estado do Arizona que atribuía mais recursos públicos a candidatos que, ao aceitarem financiamento público, se comprometiam com teto para seus gastos de campanha, se seu adversário que não fizer este compromisso gastar acima de determinado limite (quando da publicação do artigo, a Suprema Corte ainda não havia decidido o caso, embora fatos de uma audiência levassem Dworkin a prever que o tribunal declararia a lei inconstitucional; parece que a previsão se confirmou: veja http://www.supremecourt.gov/opinions/10pdf/10-238.pdf, último acesso em 06.11.2013).

Traduzo "corporations" por empresas, e é uma questão pouco clara na obra de Dworkin se ele julga que outras pessoas jurídicas, como sindicados, devem receber o mesmo tratamento de empresas - o autor, algumas vezes, fala e, "corporations, unions and other groups" ("Free Speech, Politics, and the Dimensions of Democracy", op. cit., p. 352), "rich individuals and corporations" ("Uses and Abuses", op. cit., pp. 58-9), "corporate or union advertising" ("The "Devastating' Decision", op. cit.), "corporations and unions" e "pension and union funds" (ambos em diferentes partes do item 1 de "The Decision that Threatens Democracy", op. cit.), entre outros.

Tramita no STF ADI em que a OAB pede que o tribunal declare inconstitucional a permissão legal de doações eleitorais de empreas; a petição inicial cita Dworkin: CONSELHO FEDERAL DA ORDEM DOS ADVOGADOS DO BRASIL. "Petição Inicial na ADI 4650". AÇÃO DIRETA DE INCONSTITUCIONALIDADE COM PEDIDO DE MEDIDA CAUTELAR. Petição assinada por Ophir Cavalcante Júnior (Presidente do Conselho Federal da $\mathrm{OAB}$ ) e pelos advogados Cláudio Pereira de Souza Neto e Oswaldo Pinheiro Ribeiro Júnior, SETEMBRO DE 2011, p. 25, n. 20 - especificamente, parte da citação acima que extraí de "The 'Devastating' Decision", op. cit.. ao sustentar que pessoas jurídicas são entidades fictícias, e não cidadãos. Veja o seguinte trecho: "Suscitar a liberdade de expressão não é adequado para proteger o suposto direito de as pessoas jurídicas realizarem tais doações. Não há a necessidade de se ponderar igualdade política e liberdade de expressão, pois esta simplesmente não está em questão", p. 24. Veja notícia: Pedro Canário. "STF julgará financiamento de campanhas dia 11 de dezembro", publicada no sítio "Consultar Jurídico", disponível em http://www.conjur.com.br/2013-nov-26/adi-financiamento-campanhas-pautada-11-dezembro, último acesso em 17.12.2013. 
elas mesmas expor. ${ }^{844}$ Os argumentos de Dworkin, portanto inicialmente não dizem respeito aos efeitos ruins decorrentes de se permitir uso político irrestrito dos recursos das empresas: o autor ressalta que muitos outros casos de direito à liberdade de expressão também têm péssimos efeitos, e que isso não é justificativa para proibir manifestações de neonazistas ou que insultam religiões. ${ }^{845}$ Ainda, o autor não defende restrição completa às propagandas políticas financiadas por empresas, mas sim que elas possam bancá-las com fundos especialmente designados para tanto. Daí o autor dizer o seguinte sobre duas decisões da Suprema Corte dos EUA:

"No processo Austin versus Michigan Chamber of Commerce, a Corte obedeceu [upheld] a um estatuto [statute] que proibia as corporações [corporations] de usar seus ativos gerais em apoio ou oposição a candidatos políticos, embora permitisse que usassem fundos segregados que juntassem expressamente para fins políticos" ${ }^{\prime 46}$.

$\mathrm{Na}$ página seguinte, o autor diz, em trecho complicado que vale ser citado

integralmente, que

"A interpretação discriminadora [discriminatory reading], além de uma justificação convincente para Austin, proporciona uma distinção convincente entre este veredicto e um veredicto anterior que, para muitos críticos, pareceu contrária ao espírito de Austin. No processo Bellotti, a Corte declarou inconstitucional um estatuto [statute] de Massachusetts que proibia as corporações [corporations] de gastar qualquer quantia em campanhas pró ou contra iniciativas eleitorais diretas no Estado. Tal restrição impunha uma ameaça muito mais grave à soberania dos cidadãos do que o estatuto mantido em Austin, pois ameaçava privar os cidadãos de informações que, de outro modo, poderiam não lhes estar disponíveis. Muitas iniciativas diretas dizem respeito a complexas questões econômicas, e as corporações quase sempre têm o incentivo que falta aos cidadãos individuais para apresentar determinada faceta da discussão. O estatuto de Bellotti não permitia que essas corporações usassem nem fundos segregados, levantados especificamente para apresentar seu ponto de vista. O estatuto de Austin, pelo contrário, limitava-se às eleições, nas quais os partidos políticos e outros grupos têm grande

\footnotetext{
844 "Keep Corporations out of Televised Politics", op. cit., "The Decision That Threatens Democracy”, op. cit., item 2.

845 "Keep Corporations out of Televised Politics", op. cit. Dworkin também fala da liberdade de imprensa, e observa que a maior parte dos jornais são de propriedade de empresas. Ele fala ainda de indivíduos riquíssimos, como George Soros, que pode gastar seu dinheiro em manifestações políticas, mas, considerando os argumentos de Dworkin em outros textos creio que coerente para ele é dizer que Soros tem direito de liberdade de expressão de utilizar parte de seus recursos para se manifestar, e que essa parte corresponde à permitida pela justiça. Veja por exemplo o seguinte trecho em defesa de uma lei norte-americana sobre campanha eleitoral e o argumento de que ela violava a liberdade de expressão protegida pela Constituicão dos EUA: “That claim confuses a citizens's right to present his opinions and convictions at large, which is of course at the centre of free speech, with the very different idea that he is entitled to spend as much as he wishes in doing so even when the result is to distort democracy by making politicians depend on rich organisations with legislative agendas, rather than on wider public appeal. Contribution and publication restrictions would be illegitimate if they permitted so little expenditure that unknown politicians or unfamiliar groups or interests could not carry their message to the people. But the contribution and expenditure limits under the new law are generous and have no such effect: they are simply to reduce the distortion of the public debate that money has brought in US politics for years. It seems a travesty to appeal to free speech to try to preserve that distortion", "Uses and Abuses", op. cit., p. 59.

846 "Liberdade de expressão, política e as dimensões da democracia", op. cit., p. 532, itálicos no original mas acrescentei entre colchetes palavra do original; no original, "Free Speech, Politics, and the Dimensions of Democracy", op. cit., p. 378.
} 
interesse em oferecer qualquer argumento favorável a seus candidatos e contra os adversários, e ele permitia que as corporações usassem os fundos segregados para marcar uma posição contra ou a favor de um candidato, quando acreditassem que outros não a tivessem marcado com eficiência". ${ }^{847}$

Ou seja, Dworkin elogia as duas decisões, uma que manteve uma lei que permitia doações por empresas a depender da origem dos recursos, e outra, que declarou inconstitucional lei que não fazia essa distinção. Mas o que o autor faz aqui não é distinguir fontes dos recursos ou tipo de decisão - eleição para cargo público ou referendo/plebiscito em razão de interesse das empresas, mas de interesse dos cidadãos refletido na dimensão da "soberania popular", uma das que compõe a concepção dworkiniana da democracia como parceria. Ou seja, empresas não têm direito de liberdade de expressão, mas é positivo para a democracia e para os cidadãos que elas sejam ouvidas em algumas circunstâncias ${ }^{848}$. Quando este é o caso depende do interesse dos cidadãos, e não delas ou de seus representantes.

\section{Subseção 4.3. Liberdade de Imprensa e Liberdade Acadêmica}

Os fundamentos da liberdade de expressão no pensamento de Ronald Dworkin exigem a opinião elaborada pelo autor e expressa acima acerca dos supostos direitos das empresas. Por motivo análogo, o autor sustenta que a liberdade de imprensa e a liberdade acadêmica não são

847 "Liberdade de expressão, política e as dimensões da democracia", op. cit., pp. 533-4, nota omitida, acrescentei entre colchetes palavra do original; no original, "Free Speech, Politics, and the Dimensions of Democracy", op. cit., pp. 379-80. Veja Barendt, Freedom of Speech, op. cit., pp. 91-3.

${ }^{848}$ Compare com o que Dworkin diz sobre grupos econômicos dedicados à imprensa: "Some large news corporations do have great power and influence. But the public looks to the press, and not to other commercial organizations, for information and opinion. Even powerful news conglomerates must be insulated from government control, not because every corporation has the First Amendment rights of ordinary citizens but because democracy needs their independence. "The Decision that Threatens Democracy", op. cit., item 3. Veja ainda Greenawalt: Fighting Words - Individuals, Communities, and Liberties of Speech, op. cit., pp. 139-142, esp. o seguinte trecho: "Business corporations are artificial creations of the state, which receive special privileges in order to promote commerce. Any right of theirs to speak on the wide range of political subjects depends on the public's need to be informed", p. 141. Veja Barendt: "The question of principles is whether restrictions on corporate expenditure really engage freedom of speech at all. Arguably, the free speech principle discussed in Chapter I does not justify the coverage of such expenditure. White J. pointed out his dissent in Bellotti that the arguments from the importance of self-expression as a means to the full development of the individual are clearly irrelevant. A corporation cannot claim a human right as a speaker. On the other hand, the interest of the public in receiving ideas and information is promoted, whether or not a corporation finances their dissemination. Recipients are usually not concerned with the source of the information on which they rely. Further, unless corporations, and other bodies such as trade unions, are free to put over their views effectively, government may be able to dominate public debate through official reports, press releases, and reportrs of politicians' speechs. Corporations also have real interests in disseminating their views about their products and issues of economic and taxation policy.

"Corporations, therefore, should be entitled to claim the benefit of a free speech clause. But it does not follow that their free speech rights are identical to those of individuals", Freedom of Speech, op. cit., p. 92, nota omitida, itálico no original. 
uma questão de direito individual de repórteres e professores às proteções específicas que lhe são concedidas por estas liberdades. Isso não significa que um jornalista não tenha um direito a publicar sua reportagem. Mas isso significa que eventuais proteções adicionais que sejam concedidas em razão da sua condição de jornalista não sejam objeto de direito de sua titularidade. É que, para Dworkin, sendo a liberdade de expressão um direito igualitário, as garantias atreladas, por exemplo, à profissão do jornalista não se prestam a proteger interesse pessoal do repórter, mas de atender a benefício coletivo.

$\mathrm{O}$ autor expressa este ponto por meio da distinção entre princípios e políticas. Para Dworkin, a liberdade de expressão é, principalmente, uma questão de princípio: trata-se de direito individual de quem publica e que se caracteriza por liberdade fundada na igualdade e na democracia interpretadas por meio de uma teoria ética. Para o autor, as garantias dos repórteres, entretanto, são uma questão de política porque se fundamentam na capacidade que têm de servir ao interesse coletivo, da mesma forma que a concessão de subsídios econômicos pelo Estado é capaz de trazer benefícios coletivos. ${ }^{849}$

Dworkin diz o seguinte ao comentar o caso Farber, em que um juiz ordenou a um jornalista que entregasse suas anotações acerca de reportagens que fizera sobre alguns homicídios para que o juízo verificasse se alguma informação era relevante à defesa do indivíduo acusado pelos crimes ${ }^{850}$ :

“(...) o cerne da Primeira Emenda é uma questão de princípio. Os cidadãos individualmente têm o direito de expressar-se livres da censura governamental; nenhuma autoridade pode limitar o conteúdo do que dizem, mesmo acreditando que tem boas razões de política para fazê-lo e mesmo que esteja certo. Muitos norte-americanos acharam que era de interesse nacional censurar os que se opunham à guerra no Vietnã. Sem dúvida, era do interesse da comunidade de Skokie, Illinois, que o Partido Nazista Americano fosse impedido de marchar pela cidade. Mas, como questão de princípio, os que protestavam contra a guerra tinham o direito de falar, e os nazistas, direito de marchar, protegidos pela Constituição, e assim decidiram os tribunais"

"Repórteres, colunistas, noticiaristas, autores e romancistas têm o mesmo direito de livre expressão que outros cidadãos, a despeito to grande poder da imprensa (...) Mas os jornalistas, como questão de princípio, não têm nenhum direito maior que o dos outros à liberdade de expressão.

"Existem, porém, razões de política que podem justificar normas especiais que reforçam a capacidade de investigar dos repórteres. Se suas fontes confidenciais forem protegidas da revelação, mais pessoas que temem ser expostas falarão com eles, e o público pode beneficiar-se. Há uma necessidade específica de sigilo, por exemplo, e um interesse público especial em ouvir o que os informantes podem dizer, quando o informante é um funcionário que denuncia corrupção ou má conduta ou quando a informação diz respeito a um crime. ${ }^{851}$

\footnotetext{
849 "The Farber Case: Reporters and Informers", in A Matter of Principle, op. cit., p. 375.

850 "The Farber Case: Reporters and Informers", op. cit.,

851 "O caso Farber: repórteres e informantes", in Uma questão de princípio, op. cit., pp. 559-60; no original, "The Farber Case: Reporters and Informers", op. cit., p. 376. Veja ainda "Is the Press Losing the First Amendment?", in A Matter of Principle, op. cit.,
} 


\section{Em resumo, diz Dworkin,}

“A posição especial da imprensa é justificada não porque os repórteres tenham direitos especiais, mas porque se acredita que a comunidade como um todo irá beneficiar-se de seu tratamento especial, exatamente como os produtores de trigo podem receber um subsídio não porque têm direito a ele, mas porque a comunidade irá beneficiar-se com isso". ${ }^{852}$

A relevância fundamental da distinção entre princípio e política, especialmente quando utilizada para explicar a extensão dos direitos dos repórteres fundamentados por um ou pela outra, diz respeito à hipótese em que existe conflito entre a liberdade de expressão e outro interesse: para Dworkin, princípios somente perdem de políticas em situações excepcionais. ${ }^{853}$ Por isso, se o sigilo das anotações de um jornalista é uma proteção específica - é só sua e não dos cidadãos em geral - que lhe é garantido pela lei, trata-se de instituição justificava por política, e não por princípio, e, se esta regra entra em conflito com um direito - no caso trabalhado por Dworkin, o direito a um julgamento justo - fica justificada a ordem judicial que determinou a entrega do material utilizado para escrever as reportagens ${ }^{854}$.

A conclusão do autor é esta, mas talvez mais relevante do que o resultado defendido é o modo de compreender o caso - especificamente, a ideia de que o conflito entre sigilo das anotações e de fonte de um jornalista e o direito de um réu de ter acesso às provas pertinentes à sua defesa não é um conflito entre direitos descritos por diferentes princípios, mas um conflito entre um interesse coletivo descrito por um argumento de política e um direito individual descrito por um argumento de princípio. Que este vença é consequência necessária, mas o ponto aqui é a compreensão mais fundamental de que os direitos juridicamente reconhecidos à imprensa não correspondem a direitos morais segundo a filosofia política de Dworkin ${ }^{855}$. Para ele,

852 “O caso Farber: repórteres e informantes”, op. cit., pp. 560-1; no original, "The Farber Case: Reporters and Informers", op. cit., pp. 376-7.

853 "The Farber Case: Reporters and Informers", in A Matter of Principle, op. cit., pp. 375-6, e, sobre o argumento acerca dos prejuízos ao trabalho dos reporters em razão da limitaçao do sigilo de fonte exigido pela decisão no caso Farber: "(...)this argument of policy, however strong or weak as an argument of policy, must yield to the defendant's genuine rights to a fair trial, even at some cost to the general welfare", p. 377.

${ }^{854}$ The Farber Case: Reporters and Informers", op. cit., pp. 277-8.

855 "A law awarding farmes a subsidy for not growing corn, for instance, creates a legal right that matches no prior political right", Justice for Hedgehogs, op. cit., p. 331; veja em geral pp. 227 e ss.

Pouco antes de citar versão expandida do trecho de Justice for Hedgehogs que selecionei, Caio Moysés de Lima explica a relação complexa entre razões de política para reconhecimento de direito e seu tratamento como questão de princípio: "Merece atenção especial o caso dos direitos criados pela legislação por razões de política pública. Nesse sentido, a explicação acima poderia parecer insuficiente, porque os direitos previstos na legislação não 
"Sem dúvida, é valioso para o público que os repórteres tenham acesso a informações confidenciais. Mas não é uma questão de direitos de ninguém. A questão levantada pelo caso Farber não é a questão difícil de como conciliar direitos conflitantes; trata-se de até que ponto a eficiência dos repórteres, valorizada pelo público, deve, não obstante, ser sacrificada para assegurar que o direito a um julgamento justo não seja comprometido." ${ }^{, 556}$

O argumento de Dworkin sobre a liberdade acadêmica é mais complexo e talvez aponte para a necessidade de revisar a visão do autor sobre a liberdade de imprensa. Mas mais importante do que analisar especificamente a concepção de liberdade acadêmica de Dworkin ${ }^{857}$ é compreendê-la na sua relação com o que o autor chama de cultura de independênca). Este é um tema para a conclusão da dissertação porque a meu ver são mais adequados ao encerramento deste trabalho. Por ora, vale apontar a semelhança entre a liberdade de imprensa e a liberdade acadêmica no pensamento do autor: ambas se caracterizam por benefícios a seus titulares que não são estendidos aos demais cidadãos, e, portanto, não podem se justificar por supostamente se tratarem de direitos individuais; não são, portanto, questão de liberdade de expressão, que é justificada por direitos. Dworkin diz o seguinte sobre liberdade de expressão e liberdade acadêmica:

"A liberdade de expressão é um direito moral - e, nos Estados Unidos, também um direito legal - de todos. Porém, não garante para todos o que a liberdade acadêmica garante aos acadêmicos. Exceto em circunstâncias muito especiais, a liberdade de expressão não é o direito de se falar o que se quiser quando se ocupa um cargo mantido e sustentado por outras pessoas. (...) A liberdade de expressão, em

expressam exigência de justiça, mas são apenas instrumentos para a promoção da utilidade geral. Os subsídios outorgados por lei a um certo ramo da indústria, por exemplo, não decorrem do ideal de igual consideração e respeito, mas, possivelmente, da necessidade de fortalecer aquele ramo industrial para o benefício da economia nacional como um todo. Ora, os direitos criados pela legislação são, nesse caso, direitos genuínos, mas não parecem expressar propriamente princípios de justiça.

"Essa aparente dificuldade exige uma nova distinção, nesse caso entre as razões que justificaram a decisão legislativa e as razões decorrentes dessa decisão. Os direitos previstos na legislação para implementar uma política econômica, por exemplo, embora criados por razões de política pública, passam a existir, dali em diante, como princípios. Tais direitos não são, evidentemente, direitos fundamentais, porque não correspondem a direitos morais de fundo. Não obstante, são direitos legais genuínos, porque, enquanto em vigor, podem ser invocados como 'trunfos' contra o interesse geral.", O Império dos Direitos: Lei e Autoridade Política em Ronald Dworkin, op. cit., p. 97, itálico no original. Veja ainda "Hard Cases", op. cit. pp. 95-6, em trecho citado em nota no capítulo primeiro.

856 "O caso Farber: repórteres e informantes", op. cit., p. 558; no original, "The Farber Case: Reporters and Informers", op. cit., pp. 375.

${ }^{857}$ À concepção do autor é importante a distinção entre limitar um valor e reconhecer que o valor se aplica mas deve ceder ("Why Academic Freedom?", op. cit., p. 247; veja, acima, capítulo primeiro desta dissertação); no caso, Dworkin entende que muitas vezes as questões polêmicas consideradas relevantes à liberdade acadêmicas não lhe dizem respeito (p. 255), e oferece a distinção entre insulto deliberado e insulto negligente (“(...) though intentional insult is not covered by academic freedom, negligente insult must be", p. 255) e um "conter-factual test" ( "Whould the speaker have said what he did if he did not believe it would cause distress?" (veja pp. 255 e ss.)) como teste da relevância do valor (pp. 254-57) - veja pp. 257 ss. para casos em que existe conflito e talvez haja necessidade de "compromise", seja em razão de "policy" (pp. 257 e ss.) ou "principle". Dworkin é claro ao dizer que este "conter-factual test" é relevante à liberdade acadêmica, e não à liberdade de expressão (p. 255-6), que para ele inclui o direito de ofender (veja acima, bem como "Foreword", op. cit., entre outros). 
essência, é o direito de ter alguma possibilidade de dizer algo, e não o direito de dizê-lo e continuar sendo sustentado e auxiliado por aqueles que consideram falsa ou indesejável a ideia pregada.

"Sob esse aspecto, a liberdade acadêmica, pela qual certas instituições têm de continuar sustentando e apoiando certas pessoas independentemente do que estas possam falar, escrever ou ensinar, é mais forte do que o direito geral de liberdade de expressão. Sob outros aspectos, porém, não é tão evidente que seja um direito, pois ninguém tem o direito moral de ocupar o posto ao qual está ligada essa proteção suplementar. Ninguém tem o direito de exigir que uma determinada forma de faculdade ou universidade seja criada ou permaneça em funcionamento. Ninguém tem o direito intrínseco de ocupar uma cátedra acadêmica ou administrativa entre as que já existem. Por sso, talvez seja mais adequado não considerar que a liberdade acadêmica seja derivada de um direito mais geral à liberdade de expressão; ou, melhor ainda, não considerar nem sequer que ela seja um direito sob qualquer aspecto." ${ }^{„ 558}$

Acredito que estas aplicações das ideias sobre liberdade de expressão desenvolvidsa por Dworkin sejam extremamente coerentes: se direitos são uma questão de dignidade, empresas não têm direitos - à liberdade de expressão ou a qualquer outra coisa; se direitos são igualitários, não é com base neles que se justificam as instituições da liberdade de imprensa e acadêmica, que garantem proteções específicas a repórteres e a acadêmicos. Isto não exclui nem que o interesse coletivo justifique estas instituições, nem que direitos individuais de terceiros o façam, nem que, por motivos instrumentais, a liberdade de imprensa, por exemplo, desde que não entre em conflito com direito moral, seja poupada de restrições permissíveis em outros $\operatorname{casos}^{859}$. Mas isso exclui a ideia de que a liberdade de imprensa ou a liberdade acadêmica garantam direitos individuais de titularidade de repórteres e professores.

Antes de encerrar esta subseção, gostaria de esclarecer dois pontos. Em primeiro lugar, destas restrições da extensão da liberdade de expressão não decorre que Dworkin recomende, por exemplo, modelos de financiamento de pesquisa que orientem o conteúdo do que é estudado: pelo contrário, ele criticou medida neste sentido adotada pelo Governo Thatcher ${ }^{860}$. Que professores não tenham direito a determinada instituição definitivamente não significa que esta instituição não seja boa e muito menos que viole direito de terceiro.

Em segundo lugar, os argumentos de Dworkin são voltados à extensão de direitos morais no sentido forte descrito no primeiro capítulo desta dissertação. Eles não dizem respeito a direitos jurídicos, e, portanto, os argumentos do autor definitivamente não exigem que não se reconheça, sob o direito brasileiro, direito jurídico e interesse processual, por exemplo, de professores e de suas associações para contestar medidar que violem a liberdade acadêmica

\footnotetext{
858 "Por que a liberdade acadêmica?" in Uma questão de princípio, op. cit., pp. 395-6; no original, "Why Academic Freedom?", op. cit., p. 247.

${ }_{859}^{85}$ A meu ver, é o que o autor faz em "Devaluing Liberty", op. cit.. Veja abaixo.

860 "Devaluing Liberty", op. cit., p. 8, segunda e terceira colunas. veja nota na subseção 4.1., acima.
} 
(sob a forma, por exemplo, da autonomia universitária constitucionalmente garantida: veja artigo 207, caput, da Constituição Federal). 


\section{CONCLUSÃO}

Ronald Dworkin, em sua extensa obra, elaborou interpretação convincente da liberdade de expressão enquanto um direito no sentido forte exigido pela democracia e pela igualdade integradas a uma teoria do bem viver. Apresentei nesta dissertação os aspectos centrais desta interpretação. Para o autor, as liberdades, entre elas a liberdade de expressão, são direitos, e, embora possam ser justificadas parcialmente pelos possíveis benefícios que traz ao interesse coletivo, são, principalmente e antes de tudo, prerrogativas do indivíduo exigidas pela sua independência, aspecto da autenticidade de sua vida que instrui a definição da justiça e da igualdade e da democracia. A liberdade de expressão é um conjunto de direitos no sentido forte justificado por meio de interpretação e de integração dos valores políticos da liberdade, igualdade e democracia orientada por uma concepção de ética. Esta definição de liberdade de expressão concentra-se no indivíduo que a exerce: é um direito do indivíduo. Direitos a liberdades, para Dworkin, como visto, são fortes: ter um direito significa que a distribuição e bens e liberdades que é concedida em seus termos é livre do exercício de comparação entre interesses pertinente a decisões políticas que não envolvam direitos" ${ }^{861}$. Em "Devaluing Liberty”, de 1988, ele diz que

"se aceitamos a ideia de liberdade como um ideal, insistimos que certas questões são, entretanto, em princípio isentas de balanceamento [balancing] e de regulação desta maneira; que o governo não pode censurar as opiniões ou regular as convicções dos gostos dos indivíduos, ou o que dizem ou ouvem ou leem ou escrevem, mesmo quando acredita, independentemente de com quão boas razões, que a censura ou a regulação seria no interesse nacional geral" ${ }^{162}$.

O argumento de Dworkin é muito parecido, se é que não idêntico, ao que desenvolve em "Taking Rights Seriously" e que foi exposto no capítulo primeiro: a titularidade de direitos significa justamente a retirada do tema político em questão dos processos ordinários de decisão em que o interesse público é critério suficiente para justificar uma ação política. Para Dworkin,

861 "Devaluing Liberty", op. cit., p. 7, primeira e segunda colunas, traduzi; veja as primeiras duas seções do capítulo primeiro desta dissertação, acima, dedicadas sobretudo a "Taking Rights Seriousy", op. cit... "Devaluing Liberty" é artigo que foi publicado como início de A Bill of Rights for Britain, op cit. . Foi também publicado como último capítulo da edição de 1997 de Freedom 's Law (a tradução brasileira é da edição de 1996 e, portanto, não traz o capítulo; nesta dissertação, utilizo o original de 1996 e cito "Devaluing Liberty" à parte). Trata-se de artigo em que Dworkin critica o estado das liberdades na Inglaterra sob o governo Thatcher.

862 "Devaluing Liberty", op. cit., p. 7, segunda coluna, traduzi e mantive entre colchetes a palavra do original para indicar como a traduzi. Traduzi "balancing" como em "Liberdade de expressão, política e as dimensões da democracia", op. cit., p. 516 (no original, "Free Speech, Politics, and the dimensions of democracy", op. cit., p. 367). 
direitos são questão de "dignidade" e "igualdade", e não de atribuição "contingente" 863 de bem ou recurso a indivíduo qualquer em razão de benefício coletivo daí derivado: como o impacto da violação do direito na dignidade ou igualdade de seu titular nada tem a ver com as consequências do respeito ao direito, não pode se submeter aos critérios de atribuição e de restrição de distribuição de bens ou recursos que se orientem pelo atendimento do interesse público. Ou seja, direitos são fortes e reconhecem titularidade excepcional a recurso e, portanto, precisam receber justificação específica. Parte significativa do esforço desta dissertação se concentrou na exposição da justificativa oferecida por Dworkin ao direito à liberdade de expressão. Vimos que esta justificativa se concentra nos valores da igualdade e da democracia orientados por uma teoria ética: trata-se de justificativas de princípio, e não de política, para utilizar a distinção empregada pelo autor inclusive para delimitar o direito à liberdade de expressão.

Em "Devaluing Liberty" a questão é um pouco mais complexa: o autor acrescenta às ideias de princípio da dignidade e de igualdade justificativa das liberdades nitidamente de política ao rol daquelas capazes de interpretar a ideia de direitos. Trata-se de uma "justificativa prática: que a democracia não pode trabalhar bem a longo prazo a não ser que cidadãos privados tenham acesso a toda fonte possível de informações, livres de censura por parte de políticos cujos interesses podem residir na sua ignorância". ${ }^{864} \mathrm{O}$ que temos aqui não é exatamente novo, pois Dworkin havia reconhecido que argumentos instrumentais podem justificar direitos em alguns casos. ${ }^{865}$ Talvez seu objetivo seja, como indica seu texto, apontar convergências entre essas três justificativas - dignidade, igualdade e democracia interpretada em termos práticos - na proteção que são capazes de oferecer às liberdades. O autor diz que as três compartilham dois "princípios": (i) que a liberdades como liberdade de expressão e de consciência são direitos humanos fundamentais e (ii) regramento específico sobre as hipóteses em que a exceção às liberdades é aceitável - trata-se do que Dworkin chama de "cultura de liberdade". ${ }^{866}$ Para ele,

\footnotetext{
863 “Temos direito à pornografia?", op. cit., p. 523; no original, "Do We Have a Right to Pornography?", op. cit., p. 352. Veja ainda "Why Academic Freedom?", op. cit., pp. 259-60.

864 "Devaluing Liberty", op. cit., p. 7, segunda coluna, traduzi. Veja ainda "Taking Rights Seriously", op. cit., p. 199, n. 1.

${ }^{865}$ Compare "Hard Cases", op. cit. pp. 95-6, sobretudo trecho citado no capítulo primeiro.

866 "Devaluing Liberty", op. cit., p. 7, primeira e segunda colunas.
} 
"A cultura de liberdade (...) identifica como especiais, entre instituições sociais e políticas, aquelas instituições e práticas por meio das quais informações, ideias, convicções, opiniões, fantasias, imaginários [imaginings] e outras características das mentes das pesssoas são criadas, coletadas e disseminadas. Ela atribui a este conjunto especial de instituições um lugar honrado e protegido, que o governo pode invadir somente quando é evidente e necessário - somente quando, no famoso slogan de Oliver Wendell Holmes, o perigo posto pela liberdade é tanto claro quanto presente - e então somente de maneiras que interfiram minimamente com as liberdades que a cultura de liberdade protege". ${ }^{867}$

Novamente, nada de novo porque, como expus no capítulo primeiro, as reflexões sobre direitos no sentido forte levam Dworkin a certos critérios bastante rígidos de exceção de direitos - exatamente, aliás, ao critério de Holmes citado neste trecho. É preciso avançar no texto para perceber o significado da ideia de cultura de liberdade e o que de diferente ela tem em relação à noção de direito à liberdade de expressão no sentido específico discutido acima nesta dissertação.

Por cultura de liberdade entende Dworkin a atitude da sociedade em que as liberdades são capazes de se desenvolver. $\mathrm{O}$ autor a define nos seguintes termos nos seguintes termos:

“(...) a essência da liberdade não são fronteiras precisas ou testes mecânicos, mas uma atitude: de que a liberdade de convicção, pensamento e expressão é tão crucial que questões difíceis devem ser decididas em favor da liberdade tanto quanto possível, que uma cerca deva ser construída a certa distância do coração da liberdade de expressão, que o governo deve suportar o ônus de demonstrar que qualquer interferência com qualquer parte do sistema de informação é realmente necessária". ${ }^{868}$

Esta presunção, como vimos acima, não faz parte da teoria da liberdade de expressão de Dworkin enquanto direitos, o que é coerente com a fundamentação das liberdades na igualdade e na dignidade pois em razão desta fundamamentação o autor rejeita um direito geral à liberdade ao mesmo tempo em que assume o ônus de oferecer razões para tratar direitos com tanta deferência ${ }^{869}$. Isso não significa que tenhamos em "Devaluing Liberty" contradição ou mudança de ideia do autor. O motivo é o seguinte. A cultura de liberdade é mais ampla que o direito à liberdade de expressão por pelo menos duas razões. Em primeiro lugar, trata das liberdades em geral, e não especificamente da liberdade de expressão. Em segundo lugar, inclui mais que os direitos de expressão reconhecidos por Dworkin, isto é, não se restringe a hipóteses em que existe um direito no sentido forte, embora Dworkin faça uso da ideia (ainda que não sob a mesma terminologia) para descrever o que entende por cultura de liberdade. Ao

\footnotetext{
867 "Devaluing Liberty", op. cit., p. 7, terceira coluna, itálico de "cultura" no original, traduzi, mantive entre colchetes a palavra do original para indicar como a traduzi e deixei "slogan" como consta no original (mas o italicizei porque é palavra estrangeira).

868 "Devaluing Liberty", op. cit., p. 7, terceira coluna, itálico no original, traduzi. Veja ainda Justice for Hedgehogs, op. cit., pp. 370-1.

${ }^{869}$ Por exemplo, "Devaluing Liberty", op. cit., p. 7, segunda coluna.
} 
que parece, a ideia de cultura de liberdade exige tratamento de direito a liberdades mesmo quando são justificadas por argumento de política; isso não é incompatível com a interpretação da liberdade de expressão principalmente como questão de direito subjetivo porque Dworkin não rejeita a possibilidade de argumentos instrumentais justificarem liberdades ${ }^{870}$. Em outras palavras, a cultura de liberdade inclui o respeito às liberdades como direitos e também outras, que compõem o "sistema de informação", inclusive as liberdades de imprensa e acadêmica que, como vimos no capítulo terceiro, não são questão de direitos individuais.

O que talvez demande elaboração é que a ideia de políticas, a que o autor relega a liberdade de imprensa, por exemplo, convida exatamente o tipo de juízo "casuístico" que ele rejeita ao falar da cultura de liberdade: logo após a citação acima sobre atitude e sistema de informação, ele diz que "Este é o espírito com que a cultura de liberdade aborda questões sobre se da imprensa deve ser exigido que divulgue o produto de seu trabalho ou fontes confidenciais" $"$ " Para o autor, perguntar a razão de cada liberdade separadamente - por exemplo, sigilo de fonte jornalística, benefícios de originalidade da liberdade acadêmica ${ }^{872}-$ é inadequado:

"estas questões são injustas com a liberdade, porque o valor da liberdade não pode ser medido aos pedaços [piecemeal], em quotas de informação sacrificada ou imaginação prejudicada ou criatividade diminuída. Quando a liberdade é julgada desta forma, medindo os custos da sua concessão caso-a-caso contra algum ganho em eficiência administrativa ou militar ou diplomática ou apoio popular, ela sempre deverá perder. Pois a liberdade, medida desta forma contra os objetivos imediatos da política ordinária, sempre parecerá especulativa e marginal; ela sempre parecerá acadêmica, abstrata e dispensável”.

O problema é que a ideia de política parece convidar exatamente o tipo de interpretação caso-a-caso que a cultura de liberdade rejeita e, se isto for verdade, a atitude em relação às liberdades que Dworkin defende precisaria se restringir aos direitos às liberdades ou a terceiro tipo de argumento (além de argumentos de princípios, que não explicam tudo na cultura de liberdade, e de políticas, que seriam incompatíveis com ela). É por isso que a "justificativa prática" mencionada acima é tão importante: ela aponta que a cultura de liberdade exige que se trate também como direito, isto é, que o preserve da "política ordinária" mesmo as liberdades que não se fundamentam em direito subjetivo de um cidadão. Isso não significa que os dois tipos de liberdade exigem tratamento idêntico porque, não sendo questão de princípio, por

\footnotetext{
${ }^{870}$ Veja Schauer, "[Sem título]", op. cit. e Dworkin, "Ronald Dworkin replies", op. cit..

871 "Devaluing Liberty", op. cit., pp. 7-8.

872 "Devaluing Liberty", op. cit., p. 8, primeira coluna, traduzi, acrescentei entre colchetes a palavra do original para indicar como a traduzi.
} 
exemplo, a liberdade de imprensa, diz Dworkin, deve ceder frente a direito fundamental (no exemplo trabalhado em "The Farber Case: Reporters and Informers", ao direito a um julgamento justo). Mas isso não impede e, portanto, a meu ver em "Devaluing Liberty" não há nada que contradiga à tese geral, explorada nesta dissertação, de que a liberdade de expressão é um direito individual, que se elabore atitude mais geral que merecem as liberdades sejam elas questão de direito ou não. A minha sugestão é que a cultura de liberdade em Dworkin exige tratamento da liberdade de imprensa idêntico ao oferecido pelo autor em "The Farber Case: Reporters and Informers" quando conflita com direito individual (o direito vence e a liberdade de imprensa deve sofrer restrição), mas (talvez) diferente porque rejeita a análise casuística em prol de uma análise mais global, orientada a uma regra de longo prazo, nos casos em que conflita com interesse coletivo (questão de política).

Entre políticas e princípios, o que fica claro é que, no pensamento de Ronald Dworkin, destaca-se a pluralidade dos argumentos em favor das liberdades, ainda que, por razões éticas que orientam as teorias da igualdade e da democracia do autor, elas devam ser interpretadas crucialmente como direito subjetivo de quem delas se beneficia ${ }^{873}$. Além da pluralidade de justificações das liberdades, Dworkin comumente apresenta seus argumentos em defesa de direitos específicos de maneira não exaustiva. Isto significa que o oferecimento de um argumento a favor de determinadas liberdades não quer dizer que inexistam nem outros argumentos a favor de outras liberdades nem outros argumentos a favor desta mesma liberdade $^{874}$. Por exemplo, ao considerar de que modo a teoria da justiça distributiva por ele preferida, a saber, a igualdade de recursos, oferece argumentos a favor de determinadas liberdades, Dworkin é claro ao afirmar que a igualdade política - por ele distinguida da justiça distributiva - é também capaz de oferecer defesa das liberdades que existem ${ }^{875}$. Em trabalho anterior, Dworkin apontou como, numa sociedade regida por considerações utilitaristas - isto é, que adote o utilitarismo como o que o autor nomeou de background theory - existe um direito igualitário à independência que não exclui nem outros direito nesta mesma sociedade

\footnotetext{
${ }^{873}$ Veja, por exemplo, “Why Must Speech Be Free?”, op. cit., p. 201. Veja Schauer, “[Sem título]”, op. cit. e Dworkin, "Ronald Dworkin replies", op. cit.. Para argumentos de policy a favor da liberdade, veja "The Place of Liberty", op. cit., pp. 160-1 e "Why Must Speech Be Free?", op. cit., pp 201 e ss. Veja Barendt, Freedom of Speech, op. cit., pp. 100-8.

${ }^{874}$ Veja Yowell em “A Critical Examination of Dworkin's Theory of Rights”, op. cit., p. 120.

875 "The Place of Liberty", op. cit. p. 148; veja ainda p. 159, em que a igualdade de recursos é entendida pelo autor como abrangendo uma teoria da justiça distributiva (uma questão de "private ownership") e uma teoria da democracia (veja ainda pp. 134-5).
} 
nem outros direitos (ou, quem sabe, estes mesmos direitos à independência) em sociedades que adotem outra teoria de fundo ${ }^{876}$.

É importante, entretanto não confundir a pluralidade de argumentos com outra pluralidade, esta rejeitada no pensamento do autor. Que as liberdades têm, para Dworkin, diferentes defesas não significa que a sua existência tenha fundamentos distintos e conflitantes entre si. A defesa da pluralidade das justificações das liberdades no pensamento de Ronald Dworkin não é caracterizada por qualquer adesão à pluralidade de valores. Aliás, como visto no primeiro capítulo, o pensamento do autor é marcado pela defesa da unidade de valores, isto é, pela tese de que valores não conflitam entre si. Assim, ainda que Dworkin em determinado ponto ofereça argumento igualitário a favor de determinada liberdade ${ }^{877} \mathrm{e}$, em outro ponto, fundamente outra liberdade (a de expressão, por exemplo) na justiça distributiva e, ainda, esta mesma liberdade na democracia e na igualdade política, isto não significa que estas defesas sejam contraditórias entre si, ou, ao menos, que seja necessário fazer esforço de concessão entre os diferentes valores - igualdade, justiça distributiva e democracia - a que cada uma delas recorre. Espero que esta dissertação tenha sido capaz de pelo menos indiciar a capacidade que os diferentes argumentos de Dworkin têm de se integrar uns aos outros, sobretudo se atentarmos aos valores da autenticidade e da independência, sob esta ou outra terminologia, que orientam as teorias da igualdade e democracia do autor.

Ou seja, faz parte de fato do pensamento do autor que estes valores se integram entre $\mathrm{si}^{878}$. Mais que isso, compõe o pensamento do autor que as liberdades, desprovidas de valor

876 "What Rights Do We Have" in Taking Rights Seriously, pp. 272 e 277-8, por exemplo. O argumento de Dworkin é "hipotético": "Do We Have a Right to Pornography?", pp. 365, 367, 368 and p. 370; veja ainda, op. cit., pp. 359-60. 370 e ss. para a relação entre direitos e "background theory". Veja ainda "The Place of Liberty", op. cit., p. 134 (veja n. 9, p. 481 à p. 134). Veja Yowell em "A Critical Examination of Dworkin's Theory of Rights", op. cit., pp. 114 e ss., 130, 131, entre outros e Langton em Sexual Solipsism, op. cit., pp. 168-9.

${ }^{877}$ Veja "What Rights Do We Have" in Taking Rights Seriously para defesa do direito à não discriminação racial como um direito à igualdade; veja ainda "The Place of Liberty" in Sovereign Virtue, p. 481, n. 9 à p. 134 para observações de Dworkin sobre suas obras anteriores e pp. 153-4, e, especialmente, pp. 161-2 para a defesa, nos termos da igualdade de recursos, de direito bastante similar ao de independência defendido anteriormente pelo autor.

${ }^{878}$ Veja Yowell: “The principle-policy distinction also lay behind the conception of rights as trumps against collective justifications, particularly utilitarianism. (...) In Law's Empire Dworkin calls rights trumps against various conceptions of equality. But this trumping is now revealed to be at a surface level of political conflict in the theory of resource egalitarianism - at a deeper level equality and liberty are unified and 'cannot conflict,' because the principles of liberty are necessary assumptions of an ideal distribution of resources. In TRS [i.e., Taking Rights Seriously, op. cit.] Dworkin made similar claims that equality was the source of both collective goals and the rights that serve as limitations on those goals, but he acknowledged that 'the promise of unity in political theory is indistinct in these essays' and 'must be defended, it at all, elsewhere.' (228) The unity was 
intrínseco, rementem-se a uma concepção de bem capaz de instruir a interpretação dos diferentes valores políticos empregados por Dworkin para defender as liberdades. É nesse sentido que o liberalismo de Dworkin pode ser corretamente compreendido como um liberalismo que se fundamenta numa concepção de ética ${ }^{879}$. O liberalismo do autor entretanto também é igualitário; em que pesem as diferentes defesas das liberdades, Dworkin elabora o seu pensamento em função daquilo que chama de "princípio igualitário abstrato": por exemplo, o autor é claro ao dizer que a sua defesa das liberdades na justiça distributiva não começa na igualdade de recursos, mas neste princípio abstrato que, portanto, instrui também a sua visão de igualdade política e de democracia ${ }^{880}$.

Por fim, pretendo apresentar esboço de reflexão sobre o ambiente público exigido pela teoria liberal de Ronald Dworkin e, em especial, pelo destaque dado à liberdade de expressão no seu liberalismo igualitário. Seguindo boa lição de Jeremy Waldron (The Harm in Hate Speech $)^{881}$, acredito que haja proveito em compreender o caso da liberdade de expressão enquanto uma questão de ambiente público (Waldron, na defesa da regulamentação do discurso de ódio, recorre à noção de bem público para expor o tipo de prejuízo decorrente do abuso da liberdade de expressão ${ }^{882}$ ). A defesa da liberdade de expressão em Dworkin, a meu ver, pode ser compreendida enquanto defesa de um ambiente liberal propício ao desenvolvimento dos indivíduos segundo a ética liberal oferecida pelo autor: desenvolvimento autêntico, livre de medidas paternalistas excessivamente intrusivas e de outras restrições inadmissíveis no livre uso dos recursos devidamente possuídos pelos indivíduos.

Que eu saiba, o texto em que Dworkin desenvolveu em maior pormenor este ideal público, além do já citado "Devaluing Liberty”, é o artigo "Why Academic Freedom?",

apparentely found in resource egalitarianism", pp. 125-6, itálicos no original, notas omitidas; o "228" indica a posição da nota 228 , que tem a seguinte redação: "TRS, xv", itálico no original, sendo, portanto, referência a "Introduction" in Taking Rights Seriously, op. cit.. (O trecho que omito menciona a atribuição das questões de princípio aos tribunais, a integração entre liberdade e igualdade em "The Place of Liberty", op. cit., e comparação entre os princípios do leilão imaginário e as diferentes versões das teorias dos direitos de Dworkin que Yowell enxerga nos trabalhos do autor).

${ }^{879}$ Veja "Foundations of Liberal Equality", op. cit.

${ }^{880}$ Veja "The Place of Liberty", op. cit., pp. 147-8.

${ }^{881}$ Waldron, The Harm in Hate Speech, op. cit., cap. 4, esp. pp. 92-104 (veja também pp. 4-5, 16, 46-7, 81, 151 5).

${ }^{882}$ Veja ainda a crítica de Eric Barendt ao argumento que diz que ao Estado é dado proibir a pornografia para proteger o "Moral Tone of Society" (Freedom of Speech, op. cit., pp. 363 e ss.): “(...) it may be said that broad antipornography rules cannot be justified by recourse to moral tone argument, because the commitment to free expression on sexual matters itself represents an integral aspect of a liberal community's morality", p. 364 
publicado em Freedom's Law. Neste texto, Dworkin apresenta o que chama de "cultura de independência" como proteção ao ideal de individualismo ético e julga a liberdade acadêmica e a liberdade de expressão como instituições que contribuem a que ela não degenere numa cultura de conformidade ${ }^{883}$. O fundamento ético da cultura de independência é exposta pelo autor nos seguintes termos: a liberdade acadêmica é "uma parte importante, de um elemento estrutural da cultura de independência de que precisamos para levar o tipo de vida que queremos levar" $" 884$.

Dworkin distingue, de um lado, cultura de independência (ou "cultura de responsabilidade intelectual individual" ${ }^{885}$ ) e individualismo ético e, de outro, cultura de conformidade, que ocorre se "(...) a verdade não é adquirida pelos indivíduos isolados através de atos de convicção independentes, mas está embutida em tradições monolíticas, nos fiats do clero, da junta ou do voto da maioria; e onde toda discordância em relação a essa verdade é um ato de traição" 886 . A inclusão do "voto da maioria" pode parecer dessarazoada, especialmente pela companhia de que goza e os exemplos que Dworkin dá de cultura de conformidade ("a cultura de conformidade, do Irã de Khomeini, da Espanha de Torquemada, dos Estados Unidos de Joe McCarthy") ${ }^{887}$, mas não é desarrazoada se nos lembrarmos que o que é coletivo na teoria da democracia de Dworkin: a responsabilidade, e não o julgamento. Em Dworkin, a ideia de que o julgamento sobre a verdade, inclusive política, seja individual é uma característica do que o autor chama de "cultura de independência", que é uma consequência política do individualismo ético ${ }^{888}$, que exige as instituições e o ambiente em que ao indivíduo é dado não se expressar como não pensa, e expressar-se como pensa ${ }^{889}$, e que tem consequências ao significado do regime democrático.

Articulando os diferentes pontos do pensamento de Dworkin, especialmente "Equality, Democracy, and Constitution: We The People in Court" (e outros trabalhos citados no capítulo terceiro, acima) e "Why Academic Freedom?", pode-se dizer que, para o autor, a cultura de

883 "Why Academic Freedom?", op. cit. p. 250. Compare com George Kateb. "The Freedom of Worthless and Harmful Speech", op. cit., pp. 235 e ss.

884 "Por que a Liberdade Acadêmica?", op. cit., pp. 399-400; no original, "Why Academic Freedom?", op. cit., p. 250.

885 “"Por que a Liberdade Acadêmica?”, op. cit., pp. 396; no original, “Why Academic Freedom?”, op. cit., p. 248.

886 "Por que a Liberdade Acadêmica?", op. cit., pp. 403, itálico da tradução citada; no original, "Why Academic Freedom?", op. cit., p. 252.

887 “Por que a Liberdade Acadêmica?", op. cit., pp. 403; no original, “Why Academic Freedom?”, op. cit., p. 252.

${ }^{888 ، " W h y ~ A c a d e m i c ~ F r e e d o m ? ", ~ o p . ~ c i t ., ~ p . ~ 250, ~ v e j a ~ c a p . ~} 2$ desta dissertação, sobretudo subseção 2.2. acima

889 "Why Academic Freedom?", op. cit., pp. 250-1. 
independência sofre quando o voto majoritário é utilizado como critério de verdade, ou como mecanismo de julgamento coletivo em prejuízo do individual (por exemplo, se pretende justificar censura daquilo que destoe da visão compartilhada sobre a verdade) mas não sofre quando a opinião majoritária é critério de decisão política que não impeça a formação e expressão de juízos que lhe sejam contrários. Vale relembrar uma observação de Dworkin sobre "responsabilidade" (um dos aspectos da autenticidade, segundo princípio de dignidade por ele defendido em Justice for Hedgehogs): não se trata de dizer que vivemos sem influência de outros ou do meio em que estamos inseridos, mas que nada disso pode prejudicar o fato de sermos nós mesmos, individualmente, responsáveis pelas opiniões que temos e pela condução das nossas vidas ${ }^{890}$. Podemos decidir coletivamente, e podemos nos deixar influenciar por outros, mas é irresponsável recorrer irrefletidamente à opinião de terceiro sobre como viver nossas vidas, o que inclui saber o que é verdade na política e na moral, pois esta é uma responsabilidade "pessoal" 891.

As especificidades desta reflexão sobre cultura de liberdade e individualismo ético aplicadas à liberdade acadêmica e a distinção que Dworkin traça entre ela e a liberdade de expressão foram brevemente mencionadas no capítulo anterior, mas seus detalhes não fazem parte do objeto desta dissertação. Vale relembrar a proximidade entre a teoria da democracia de Dworkin, formada, entre outros, pelo princípio da independência, e a noção de cultura de independência, fundada pelo autor na teoria ética por ele desenvolvida e que expus no capítulo anterior. Esta teoria justifica a liberdade de expressão como liberdade negativa. Mas também informa a teoria da democracia de Dworkin e a sua visão sobre a independência dos cidadãos e os direitos de liberdade de expressão que exige. Em outras palavras, a liberdade de expressão (entre outros ${ }^{892}$ ) é(são) fundamental(is) à cultura de independência ${ }^{893}$. Isso não significa que Dworkin enxergue as liberdades como instrumentais à cultura de independência. Como visto no capítulo primeiro, em Dworkin as liberdades integram o ideal de boa vida, e é este ideal que informa a visão política da cultura de independência, que é o compartilhamento de "atitude" em relação à responsabilidade sobre a formação de juízos sobre a verdade que transcendem,

\footnotetext{
${ }^{890}$ Justice for Hedgehogs, op. cit., cap. 9, esp. pp. 209 e ss.

891 "Why Academic Freedom?", op. cit., p. 250.

892 "Liberal public education, freedom of speech, conscience, and religion, and academic freedom are all parts o four society's support for a culture of independence and of its defense against a culture of conformity.", "Why Academic Freedom?", op. cit., p. 252.

893 "Why Academic Freedom?", op. cit., p. 252
} 
mas não passam sem, os direitos individuais de liberdade de expressão (neste ponto, utilizo a palavra "atitude" para descrever a cultura de independência porque Dworkin a utiliza para descrever ideia similar, a saber, a "cultura de liberdade”, citada há pouco).

É esta atitude de respeito às liberdades e de independência na busca da verdade sobre as questões relevantes à condução de uma vida bem vida que se extrai das reflexões de Ronald Dworkin sobre a liberdade de expressão. Trata-se, a meu ver, de tema que merece elaboração e detalhadamento maiores do que os oferecidos pelo autor. Mas que as liberdades como direitos merecem lugar de destaque no regime democrático, e que diversas instituiçõos públicas, entre elas a liberdade de expressão, são essenciais à independência dos cidadãos é um excelente começo também porque situa o tema corretamente: a liberdade de expressão são, fundamentalmente, direitos que caracterizam o respeito ao cidadão exigido pela igualdade e pela democracia e que integram o exercício da sua responsabilidade pessoal de viver bem.

Por fim, relevante lição teórica é extraída das reflexões de Dworkin sobre liberdade de expressão: as liberdades são um tema da teoria da justiça e precisam ser enfrentadas nestes termos. Ou seja, é impossível discutir de maneira proveitosa quais liberdades existem e quais são os seus limites sem a interpretação do valor político da justiça. Se Dworkin estiver certo, esta interpretação é uma teoria da igualdade e, se sua opinião for correta, trata-se de uma teoria da igualdade de recursos. Independentemente deste compromisso teórico específico, o ponto mais geral é o ônus interpretativo da justiça que qualquer argumento sobre liberdade de expressão - ou sobre qualquer liberdade - precisa incorporar. 


\section{REFERÊNCIAS}

\section{$\underline{\text { Livros e artigos }}$}

BARENDT, Eric. Freedom of Speech. $2^{\text {nd }}$ Ed. OUP: Oxford, 2007.

BURLEY, Justine (Ed.). Dworkin and His Critics - with replies by Dworkin. Malden: Blackwell Publishing, 2005.

DALL'AGNOL, Darlei. “O igualitarismo liberal de Ronald Dworkin”. KRITERION, Belo Horizonte, $n^{\text {o }} 111$, Jun/2005, p. 55-69.

DAWOOD, Yasmin. "Democracy and the Freedom of Speech: Rethinking the Conflict between Liberty and Equality" in Canadian Journal of Law and Jurisprudence Vol. XXVI, No. 2 (July 2013).

DWORKIN, Ronald. Taking Rights Seriously. London: Gerald Duckworth \& Co. Ltd, 2005 (terceira impressão), publicado inicialmente em 1977. Tradução brasileira: DWORKIN, Ronald. Levando os Direitos a Sério. Tradução Nelson Boeira. Revisão da tradução Silvana Vieira. São Paulo: Martins Fontes, 2001

(Ed.). The Philosophy of Law. Oxford: Oxford University Press, 1977.

. "Ronald Dworkin replies" in Frederick F. Schauer, Virginia Held e John L. Hess, "The Rights of M. A. Farber: An Exchange", The New York Review of Books, edição de 7 de dezembro de 1978.

. A Matter of Principle. London/Cambridge(Massachusetts): Harvard

University Press, 1985. (Tradução brasileira: DWORKIN, Ronald. Uma questão de princípio. $2^{\mathrm{a}}$ Ed. Tradução Luís Carlos Borges. Revisão técnica Gildo Sá Leitão Rios. São Paulo: Martins Fontes, 2005).

- Law's Empire, Oxford/Portland: Hart Publishing, 2008; publicado inicialmente em 1986. (Tradução para o português: DWORKIN, Ronald. O império do direito. Tradução Jefferson Luiz Camargo, revisão técnica Gildo Sá Leitão Rios. $2^{\mathrm{a}}$ Ed. São Paulo: Martins Fontes, 2007).

. "Devaluing Liberty". Index on Censorship, 1988, 17: 7. . "Equality, Democracy, and Constitution: We The People In Court". Alberta Law Review, Vol. XXVIII, No. 2, 1988-9.

. “A Harmful Precedent". Index on Censorship 1991 20: 2. 
. Life's Dominion - an Argument about Abortion, Euthanasia, and

Individual Freedom. New York: Vintage Books, edição vintage, 1994. . "Foundations of Liberal Equality" in DARWALL, Stephen (Ed.) Equal

Freedom: Selected Tanner Lectures on Human Values. Ann Arbor: The University of Michigan Press, 1995 (aulas dadas em 1988).

. "Constitutionalism and Democracy". European Journal of Philosophy,

3:1, pp. 2-11, 1995.

. Freedom's law: the moral reading of the American Constitution.

Cambridge (Mass.): Harvard University Press, 1996. (Tradução para o português:

DWORKIN, Ronald. $O$ direito da liberdade: a leitura moral da Constituição norteamericana. Tradução Marcelo Brandão Cipolla, revisão técnica Alberto Alonso Muñoz. São Paulo: Martins Fontes, 2006).

. “Do Liberty and Equality Conflict?" In BAKER, Paul (Ed.) Living As

Equals. Oxford: Oxford University Press, 1996.

. "The Curse of American Politics", The New York Review of Books,

Volume 43, N. 16, de 17 de outubro de 1996.

. "Forked tongues, faked doctrines". Index on Censorship, 3:148, 1997.

. "The Partnership Conception of Democracy". 86 California Law Review

4531998.

. Sovereign Virtue: The Theory and Practice of Equality,

Cambridge/London: 2001 (terceira impressão). (Tradução para o português: DWORKIN,

Ronald. A virtude soberana: teoria e prática da igualdade. Tradução Jussara Simões;

revisão técnica e da tradução Cícero Araújo e Luiz Moreira. São Paulo: Martins Fontes, 2005).

. "Do Values Conflict? A Hedgehog's Approach". Vol. 43:2 Arizona Law

Review, 2001, pp. 251-259.

. "Uses and Abuses". Index on Censorship 2002 31: 58

. "A New Map of Censorship". Index on Censorship 2006 35: 130.

. Justice in Robes. Cambridge/London: Cambridge University Press,

2006. (Tradução para o português: DWORKIN, Ronald. Justiça de Toga. Tradução 
Jefferson Luiz Camargo, Revisão da tradução Fernando Santos e Revisão técnica Alonso Reis Freire. São Paulo: WMF Martins Fontes, 2010)

analysis", The Guardian, 24 de maio de 2006, disponível em http://www.theguardian.com/commentisfree/2006/may/24/comment.politics, último acesso em 02.11.2013.

. "The Right to Ridicule", The New York Review of Books, Volume 53, número 5, 23 de março de 2006.

. Is Democracy Possible Here? Principles for a new political Debate.

Princeton/Oxford: Princeton University Press, 2008.

. "Keep Corporations Out of Televised Politics". NYRBlog, October 5,

2009, disponível em http://www.nybooks.com/blogs/nyrblog/2009/oct/05/keepcorporations-out-of-televised-politics/ (último acesso em 23.10.2013)

. "Foreword" in HARE, Ivan e Weinstein, James (Eds). Extreme Speech and Democracy. Oxford: OUP, 2009.

. "The 'Devastating' Decision", The New York Review of Books Volume 57, número 3, 25 de fevereiro de 2010.

. "Ronald Dworkin replies" em Floyd Abrams e Ronald Dworkin, "The 'Devastating' Decision': An Exchange", The New York Review of Books Volume 57, número 7, 29 de abril de 2010.

. "The Decision that Threatens Democracy”, Volume 57, número 8, 13 de maio de 2010.

."More Bad Arguments: The Roberts Court \& Money in Politics", NYRblog, 27 de abril de 2011, disponível em http://www.nybooks.com/blogs/nyrblog/2011/apr/27/more-bad-arguments-roberts-courtmoney-politics/, ultimo acesso em 05.11.2013.

. “The Court's Embarrassingly Bad Decisions”, Volume 58, número 9, 26 de maio de 2011.

. "[Sem título]" em Frank Rich, David Cole, Ronald Dworkin e Russel Baker, “The Election - II”, Volume 59, número 17, 8 de novembro de 2012. 
. Justice for Hedgehogs, London/Cambridge: The Belknap Press of Harvard University Press, 2011. (Tradução para o português: DWORKIN, Ronald. Justiça para Ouriços. Tradução Pedro Elói Duarte, Revião Joana Portela, Coimbra: Almedina, 2012).

ELEFTHERIADIS, Pavlos. Legal Rights. Oxford: Oxford University Press, 2008. . "Human Rights for Liberals" (October 9, 2009). Global Justice, Forthcoming; Oxford Legal Studies Research Paper No. 41/2009. Available at SSRN: http://papers.ssrn.com/sol3/papers.cfm?abstract_id=1486080.

FERNANDES, Renan Barbosa. Controle de Constitucionalidade e Democracia no debate entre Ronald Dworkin e Jeremy Waldron, 130f. Trabalho de Conclusão de Curso, Orientador: prof. Ronaldo Porto Macedo Junior Faculdade de Direito da Universidade de São Paulo: São Paulo, 2013

FINNIS, John. Natural Law and Natural Rights, Oxford: Clarendon Press, Oxford University Press, 1980.

. "Liberalism and Natural Law Theory", 45 Mercer L. Rev. 687 1993-1994.

FURQUIM, Lilian de Toni. O Liberalismo Abrangente de Ronald Dworkin. 235f. Tese de Doutorado, Faculdade de Filosofia, Letras e Ciências Humanas, Universidade de São Paulo. Orientador: Cícero Araújo. São Paulo, 2010.

GARGARELLA, Roberto. As teorias da justiça depois de Rawls: um breve manual de filosofia política. Trad. Alonso Reis Freire, revisão da tradução Elza Maria Gasparatto, revisão técnica Eduardo Appio. São Paulo: WMF Martins Fontes, 2008.

GEORGE, Robert. P. Making Men Moral: Civil Liberties and Public Morality. Oxford: Clarendon Press, 1993.

GUEST, Stephen. Ronald Dworkin. $3^{\text {nd }}$ Ed. Stanford: Stanford Law Books, 2012.

GREENAWALT, Kent. Fighting Words - Individuals, Communities, and Liberties of Speech. Princeton: Princeton University Press, 1995.

INKIS, Maria Beatriz. O Exercício da Cidadania segundo as Teorias Política e Jurídica Propostas por Ronald Dworkin. 107f. Dissertação de Mestrado, Universidade Presbiteriana MacKenzie, orientador: Gianpaolo Poggio Smanio. São Paulo: 2009. 
KATEB, George. "The Freedom of Worthless and Harmful Speech" in YACK, Bernard (Ed.) Liberalism without illusions: essays on liberal theory and the political vision of Judith $N$. Shklar. Chicago: The University of Chicago Press, 1996.

KYMLICKA, Will. Contemporary Political Philosophy. 2a edição Oxford: Oxford University Press, 2002.

LANGTON, Rae. "Whose Right? Ronald Dworkin, Women, and Pornographers". Philosophy \& Public Affairs, Vol. 19, No. 4 (Autumn, 1990), pp. 311-359

- Sexual Solipisism: Philosophical Essays on Pornography and

Objectification. Oxford: Oxford University Press, 2009.

LEVIN, Abigail. The Cost of Free Speech: Pornography, Hate Speech, and their Challenge to Liberalism. Basingstoke: PALGRAVE MACMILLAN, 2010.

LIMA, Caio Moysés de. O Império dos Direitos: Lei e Autoridade Política em Ronald Dworkin. 184f. Dissertação de Mestrado - Departamento de Filosofia, Faculdade de Filosofia, Letras e Ciências Humanas, Universidade de São Paulo. Orientador: Rolf Nelson Kuntz. São Paulo, 2011.

MACEDO Jr., Ronaldo Porto. Do xadrez à cortesia: Dworkin e a teoria do direito contemporânea. São Paulo: Saraiva, 2013.

MacKINNON, Catharine. Only Words. Cambridge (Mass.): Harvard University Press, 1993.

MACLEOD, Colin. Liberalism, Justice, and Markets: a Critique of Liberal Equality. Oxford: Clarendon Press, 1998.

MEYER-PFLUG, Samantha Ribeiro. Liberdade de expressão e discurso de ódio. Prefácio de Ives Gandra da Silva Martins e apresentação de Ney Prado. São Paulo: Editora Revista dos Tribunais, 2009.

MULHALL, Stephen; SWIFT, Adam. Liberals and Communitarians. 2nd Ed. Oxford: Blackwell Publishers Ltd., 1996

OMMATI, José Emílio Medauar. Liberdade de Expressão e discurso de ódio na Constituição de 1988. Editora Lumen Juris: Rio de Janeiro, 2012

POTIGUAR, Alex Lobato Igualdade e Liberdade: a luta pelo reconhecimento da igualdade como direito à diferença no discurso de ódio. 155f. Dissertação de Mestrado, Faculdade de Direito, Universidade de Brasília. Orientador: Alexandre Bernardino Costa. Brasília, 2009. 
RIPSTEIN, Arthur "Liberty and Equality" in Arthur Ripstein (Ed.). Ronald Dworkin. New York: Cambridge University Press, 2007.

SCHAUER, Frederick. "[Sem título]", in Frederick F. Schauer, Virginia Held, and John L. Hess, The Rights of M.A. Farber: An Exchange, reply by Ronald Dworkin, The New York Review of Book, edição de 7 de dezembro de 1978.

SILVA, Júlio César Casarin Barroso. Democracia e Liberdade de Expressão: Contribuiçães para uma interpretação política da liberdade de palavra. Tese de Doutorado. Faculdade de Filosofia, Letras e Ciências Humanas, Universidade de São Paulo. Orientador: Álvaro de Vita. São Paulo, 2009.

TOLSTÓI, Leon. War and Peace. Trad. Louise Maude e Aylmer Maude, Foreword de Christopher Hong, Cambridge World Classics (edição kindle), 2010

WALDRON, Jeremy. The Harm in Hate Speech. Cambridge (Mass.): Harvard University Press, 2012.

WILLIAMS, Bernard. "Conflicts of Liberty and Equality" in In the Beginning Was the Deed. Princeton: Princeton University Press, 2005.

WOLFE, Christopher. Natural Law Liberalism. New York: Cambridge University Press, 2009, edição paperback (inicialmente publicado em 2006).

. "The Egalitarian Liberalism of Ronald Dworkin" in Christopher Wolfe (Ed.) Liberalism at Crossroads: An Introduction to Contemporary Liberal Political Theory and Its Critics. $2^{\text {nd }}$ Ed. Oxford: Rowman \& Littlefield Publishers, Inc., 2003.

YOWELL, Paul. “A Critical Examination of Dworkin's Theory of Rights”. The American Journal of Jurisprudence, Vol. 52, pp. 93-137, 2007.

$\underline{\text { Leis, projetos e processos }}$

BRASIL. Constituição da República Federativa do Brasil. 1988. Disponível em http://www.planalto.gov.br/ccivil_03/constituicao/constituicao.htm

. Lei n. 7.716, de 5 de janeiro de 1989. Lei ordinária federal. Disponível em http://www.planalto.gov.br/ccivil_03/leis/17716.htm

. Câmara Municipal de São Paulo. Projeto de Lei 01-00002/2013 do Vereador Conte Lopes (PTB), Publicado DOC 06/02/2013, p. 75 
. "Reincidência e Recepção pela CF/88 1" in Informativo 700. Secretaria de Documentação (SDO), Coordenadoria de Jurisprudência Comparada e Divulgação de Julgados - CJCD do Supremo Tribunal Federal, Brasília: abril de 2013 . Acórdão no Recurso Extraordinário 453.000-RS. Inteiro Teor. Relator Min. Marco Aurélio, Plenário do Supremo Tribunal Federal, 04/04/2013.

. Acórdão na Apelação Criminal, N. 2012.016841-9, Lages, TJ/SC, Des. Jorge Schaefer Martins, $4^{a}$ Câmara Criminal, julgado em 23/05/2013.

CONSELHO FEDERAL DA ORDEM DOS ADVOGADOS DO BRASIL. "Petição Inicial na ADI 4650". AÇÃO DIRETA DE INCONSTITUCIONALIDADE COM PEDIDO DE MEDIDA CAUTELAR. Petição assinada por Ophir Cavalcante Júnior (Presidente do Conselho Federal da OAB) e pelos advogados Cláudio Pereira de Souza Neto e Oswaldo Pinheiro Ribeiro Júnior, SETEMBRO DE 2011, pp. 24-5.

\section{Noticias e outros}

CANÁRIO, Pedro. "STF julgará financiamento de campanhas dia 11 de dezembro", publicada no sítio "Consultar Jurídico", disponível em http://www.conjur.com.br/2013-nov26/adi-financiamento-campanhas-pautada-11-dezembro, último acesso em 17.12.2013.

CONSULTOR JURÍDICO, TJ-SC condena jornalistas por racismo em charge, $1^{\circ}$ de junho de 2013, disponível em http://www.conjur.com.br/2013-jun-01/tj-sc-condena-jornalistasracismo-charge-maioridade-penal, último acesso em 04.12.2013

DWORKIN, Ronald e WALDRON, Jeremy. "Session 4: Multiculturalism and Human Rights" debate em The New York Review of Books Foundation and Fritt Ord Foundation, Oslo (Orgs.), Robert Silvers (chaired). Challenges to Multiculturalism. A Conference on Migration, Citizenship, and Free Speech, 25-26 June 2012 at The House of Literature in Oslo, disponível em http://www.youtube.com/watch?v=DoSbp8pdbM8 (parte 1/2), http://www.youtube.com/watch?v=6wJQ658e-4U

(Parte

2/2)

$\mathrm{e}$ http://www.youtube.com/watch?v=zHioq4mc7c0 (Q\&A), último acesso em 03.12.2013, videos do "StiftelsenFrittOrd (http://www.youtube.com/user/StiftelsenFrittOrd?feature=watch) 
MALAFAIA, Silas. "PR SILAS MALAFAIA FALA SOBRE A MARCHA PARA JESUS E A PARADA GAY / PT 1", disponível em http://www.youtube.com/watch?v=vy5VIxQwlcM\&feature=player_embedded, último acesso em 11.12.2013, disponibilizado por "Dionaldo Henrique" (http://www.youtube.com/user/Dionaldo22?feature=watch).

TERRA, "SP: estudante é condenada por ofensas a nordestinos no Twitter", 17 de maio de 2012, disponível em http://noticias.terra.com.br/brasil/sp-estudante-e-condenada-porofensas-a-nordestinos-no-

twitter,133cdc840f0da310VgnCLD200000bbcceb0aRCRD.html, último acesso em 04.12 .2013

TRIBUNAL DE JUSTIÇA DE SANTA CATARINA, "JORNALISTAS SÃO CONDENADOS POR CHARGE QUE INCORRE EM DISCRIMINAÇÃO RACIAL”, disponível em http://app.tjsc.jus.br/noticias/listanoticia!viewNoticia.action?cdnoticia=28062, último acesso em 17.12.2013.

VIEIRA, Oscar Vilhena. "[Sem título]". Manifestação no Evento "As reações ao filme 'A Inocência dos Muçulmanos': quais os limites à liberdade de expressão?", outubro de 2012, debatedores: Professores José Garcez Ghirardi, Oscar Vilhena Vieira e Salem Hikmat Nasser, organizado pelo CEJUR e realizado nas dependências da Direito GV, São Paulo: 2012.

ZANATTA, Rafael. "[Sem título]”. Manifestação na Audiência Pública organizada pela Procuradoria Regional Eleitoral de São Paulo intitulada "Liberdade de expressão e de informação no direito eleitoral: coleta de subsídios para a atuação da PRE-SP nas eleições de 2014", outubro de 2013. 